Digitized by the Internet Archive in 2007 with funding from Microsoft Corporation 

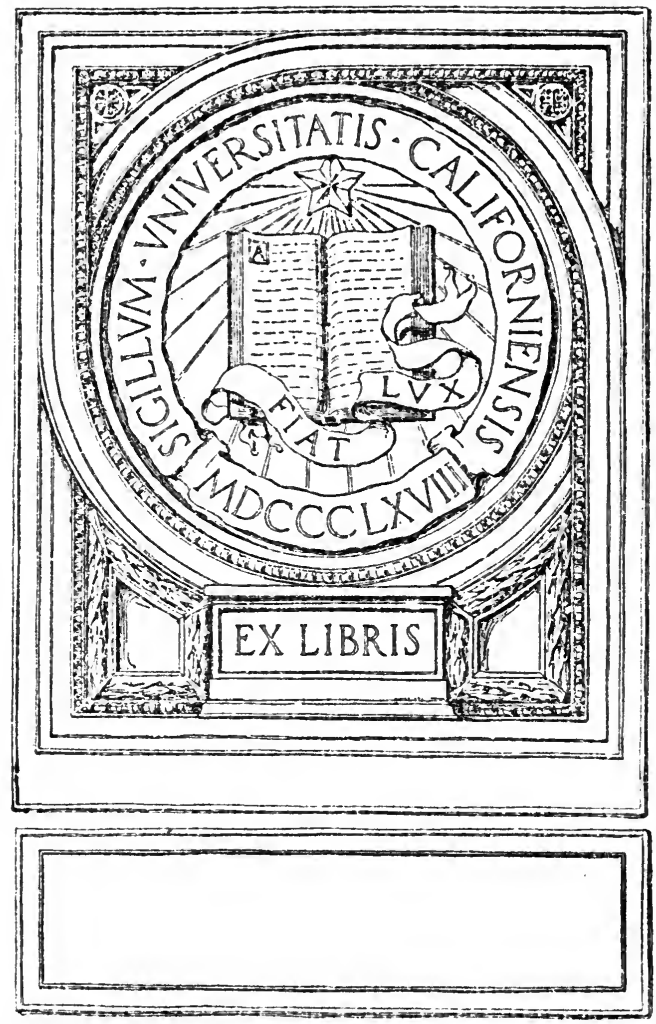


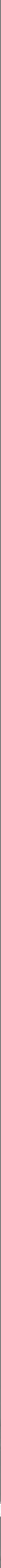





\title{
THE
}

\section{TAXATION OF CORPORATIONS} AND

\section{PERSONAL INCOME}

IN NEW YORK

\author{
BY \\ HENRY M. POWELL \\ OF THE NEW YORK BAR
}

\section{Revised Edition}

NEW YORK

CLARK BOARDMAN CO., LTD. 
COPYRIGHT, 1919;

BY HENRY M. POWELL

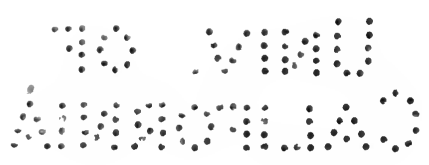




\section{PREFACE}

In June, 1918, the author in his preface to "The New York Franchise Tax on Manufacturing and Mercantile Corporations," made the statement in calling attention to the adoption by the states of the federal plan of income taxation, that "we may therefore look forward to the extension of the principle of net income taxation as a permanent feature of our state revenue system." At that time, there had been in successful operation for more than a year, in the State of New York, the act taxing manufacturing and mercantile corporations on net income based on their return to the United States Treasury Department. This law has now been extended by the New York Legislature of 1919 so as to apply to all business corporations, including personal service corporations, and the rate has been increased from three to four and one-half per cent.

The same Legislature acting upon the recommendations of the Joint Legislative Committee on Taxation, headed by Senator Frederick M. Davenport and Assemblyman Franklin W. Judson, passed a law taxing personal incomes modeled on the federal plan (Article 16 of the Tax Law), which, together with Articles 9 and $9 \mathrm{a}$ governing the taxation of public service corporations, banks, insurance companies and business corporations, forms the subject of the present volume. Parts I, II and III cover the taxation of corporations and the remedy by certiorari. Part IV treats of the tax on personal incomes. These subjects may not appear at first glance to be closely related, and yet, the general scheme of both New York acts is taken from the federal income tax laws. In their state administration they are closely allied by reason of the fact that the common remedy of certiorari is applied generally to the corporation taxes as well as to the personal income tax. So, too, in their method of collection, they are similar.

It was for these reasons that the author combined the revised 
edition of his former work on the taxation of corporations with a commentary on the substantive and case law on the taxation of personal incomes. It is true that there have been no adjudications on the New York Income Tax Act, which has just gone into effect, but the federal law is replete with rules, regulations and decisions, which have been made use of in Part IV of the present volume. The State Comptroller's rules and regulations have also been made a part of the book under the appropriate chapter, and decisions in recent cases affecting the Corporation Income Tax Law are a supplementary feature.

The difficulty of accurately presenting a book on a complex subject like the Income Tax within thirty days after the end of the legislative session will be apparent to the professional if not to the lay reader. If errors and omissions appear in the book, under these circumstances, it is hoped that the reader will be merciful in his criticism, particularly since an effort has been made to publish the book in time to make it useful to lawyers, corporation managers and others, before the time expired to file the annual state tax reports.

June 30, 1919.

Henry M. Powell.

51 Chambers Street, New York City. 


\section{TABLE OF CONTENTS}

PART I. THE CORPORATION TAX (ARTiCle 9)

CHAPtER

I INTRODUCTORY

II The System of Taxing Stock Corporations for State Purposes . . . . . . . . . . . . . . 7

III Organization Tax Paid by Domestic Corporations . 11

IV License Paid by Foreign Corporations . . . . 14

V Annual Franchise Tax on Capital Stock (\$182) • 23

VI Taxation of Foreign Corporations $(\$ \$ 181,182)$. 45

VII Tax on Transportation, Transmission, Heat, Iight, Power and Water Companies Based on Gross Earnings . . . . . . . . . . . . . 50

VIII Tax on Insurance Companies Based on Gross PremIUMS . • . . . . . . . . . . . . . 56

IX Tax on Trust Companies, Savings Banks, Investment Companies and Foreign Bankers . . . . 61

$\mathrm{X}$ Reports to be Filed and Statement of Tax . $\quad 65$

PART II. THE BUSINESS CORPORATIONS TAX (ARTICLE 9-a)

XI Amendments of 1919 to Article 9-a . . . . . . 77

XII Subjects of Taxation . . . . . . . . . . . . . 81

XIII What is Net Income . . . . . . . . . . 84

XIV Foreign Corporations . . . . . . . . . . 91

XV Reports of Corporations. Segregation of Assets. 99

XVI Exemption from Personal Property Tax. Fixtures 121

XVII Temporary Provisions for Crediting Corporations with Taxes Paid. School Taxes . . . . . 125

XVIII Apportionment of Tax Between State, Cities, Towns and Villages . . . . . . . . . . . 132

XiX Franchise Tax on Business Corporations (Text of THE LAW) . . . . . . . . . . . . . 135 
PART III. REMEDIES, CERTIORARI, COLLECTION CHAPTER

XX Remedies • • • . • . . . . . . • . . . 155

XXI Powers of Tax Commission and Comptroller.

Penalties. Collection. Secrecy. Limitations . 163

XXII Certiorari . . . . . . . . . . . . . . 171

PART IV. THE TAX ON PERSONAL INCOMES

XXIII Brief Analysis of the Law . . . . . . . . 185

XXIV Constitutionality . . . . . . . . . . . 190

XXV Residence for Personal Income Taxation. . . 198

XXVI Payment and Information at the Source. Withholding. Rules and Regulations of State Comptroller

XXVII Exemption of Intangible Personal Property from Local Taxation . . . . . . . . . . . . . 214 XXVIII Estates and Trusts . . . . . . . . . . 217

XXIX Table of Parallel Sections in Federal and State Income Tax ACts . . . . . . . . . . 222

XXX Text of New York Income Tax ACt with Corresponding Federal Regulations . . . . . . . . 226

\section{FORMS}

Form 101-Certificate to be Filed by Withholding Agent Under $\S 366$ of the Tax LaW . . . . . 345 Affidavit by Corporation That Has Discontinued BusiNESS . . . . . . . . . . . . . . . . . . 346

Forms in Certiorari Proceedings . . . . . . . 347

Reports by Corporations Under Articles 9 and 9a . 354 et seq. TABle of CASES . . . . . . . . . . . . . . . . 365 Index to Corporation Taxes . . . . . . . . . 373 Index to Tax on Personal Income . . . . . . . 382 


\title{
PART I
}

\section{THE CORPORATION TAX}

\author{
(Article 9 of the Tax Law.)
}

EXCEPT REMEDIES, CERTIORARI, AND CERTAIN ADMINISTRATIVE PROVISIONS CONTAINED IN PART III. 



\section{CHAPTER I.}

\section{INTRODUCTORY.}

The Legislature of the State of New York in January, 1919, passed a concurrent resolution creating a Joint Legislative Commission consisting of three assemblymen and three senators assisted by experts and counsel, upon whom devolved the duty to investigate the general subject of taxation and to devise means to raise taxes that would take the place of the revenue that would be lost through the adoption of the Prohibition Law.

This special committee headed by Senator Frederick M. Davenport and Assemblyman Franklin W. Judson, after holding public hearings in various parts of the State of New York and after studying the available tax propositions, introduced towards the end of the Legislative session, a series of bills intended to relieve the financial straits in which the State of New York found itself. The first of these bills, which became Chapter 627 of the Laws of 1919, introduced an entirely new scheme of taxation into the state system and imposed a personal income tax at a graded rate of one, two and three per centum on individual incomes in excess of $\$ 1,000$ for single persons and $\$ 2,000$ for married persons. The rate of one per centum applied to all persons whose income was $\$ 10,000$ or less. The rate of two per centum applied to such part of the personal income as exceeded $\$ 10,000$ and did not exceed $\$ 50,000$, the rate of three per centum attached to so much of the income as exceeded $\$ 50,000$. The second bill which was enacted and is known as Chapter 628 of the Laws of 1919, was an amendment to the tax law in relation to the franchise tax on business corporations. This class of corporations had already been taxed under Chapter 726 of the Laws of 1917 as amended by the Laws of 1918. The new act broadened the tax so that it applied practically to all business cor- 


\section{CÓRPóration tax (ART. 9)}

porations and increased the rates from three to four and one-half per centum upon the net income of such corporations.

The work of the Davenport committee, which resulted in the passage of these two bills, was perhaps a corollary or a sequel to the labors of the Joint Legislative Committee on Taxation, sometimes known as the Mills Committee, appointed by the New York Legislature in 1915, to examine generally the subject of taxation.

Among other things, the Mills Committee devoted its attention to

"A. An investigation of the personal property tax, the causes of its failure and possible remedies or substitutes, involving a study of systems tried elsewhere;

B. The reform of taxation of general business corporations, including mercantile, manufacturing and miscellaneous, involving a study of the principal methods of taxing general business corporations in the principal states of the Union." (See page 4 of report of Joint Legislative Committee on Taxation.)

The Mills Committee made its report to the Legislature of 1916 and in its conclusions, the Committee recommended, among other things, as a result of its investigations, " 1 , abolition of the present tax on personal property; 2, the withdrawal of general business corporations from the provisions of Section 182 of the Tax Law; and 3, the imposition of an income tax on individuals and general business corporations, including manufacturing corporations." (See page $20 \%$ of the Joint Legislative Committee's report.)

In the year this report was made, various conferences held by other bodies, municipal and civic, adopted reports proposing a plan basing the taxation of business corporations on the reports made by such corporations to the Federal Government, and suggesting a division of the tax between the State and localities.

In June, 1917, the law now known as Chapter 726 of the Laws of 1917, which carried out many of those recommendations, was approved by the Governor.

The principal feature of the law of 1917 was a franchise tax on 
manufacturing and mercantile corporations, based on their net income as reported to the United States Treasury Department, amounting to three per cent. of such net income. If the corporation's business was entirely transacted within the State, the tax would be equal to three per cent. of such net income. If only a portion of the company's business was transacted within the State, the tax would be in proportion to the tangible property within and without the State. The tax was payable in advance, and based on the Federal Income Tax for the preceding fiscal or calendar year.

Administrative features were added for making the reports of corporations, for the computation of the tax, providing for failure to report, for revision and re-hearing of a tax in case of error or illegality, for review by certiorari, and for the collection of a tax by the State in case of neglect or failure to pay the same; there was also provision for the deposit of revenue collected by the State and the division or apportionment between the State and the several counties of the State; for secrecy by officials, and penalties for violation thereof; and for the exemption from personal property taxation, and from the State Franchise Tax under Section 182 of the corporations subject to tax under this law.

By Chapters 271, 276, 292 and 417 of the Laws of 1918, various amendments were made to Chapter 726 of the Laws of $191 \%$, which are more fully treated hereafter. The Act of 1917 is in itself designated as Article 9-a. It specifically excepts certain classes of corporations from the method of taxation therein provided for. (Chap. 41\%, L. 1918.) The excepted corporations are still subject to taxation under Article 9. It is therefore essential to review the general system of franchise taxation under Article 9 , in order to grasp the bearing of the new law.

Article 9 of the tax law up to the time of the enactment of the 191\% law imposing a franchise tax on manufacturing and mercantile corporations based on net income, contained a complete system for the taxation of corporations for state purposes. It also included the statutory provisions for the organization and license taxes which respectively provide for the amount to be paid by a 
domestic corporation upon receiving its charter for the exercise of its franchise in the state, and for the tax to be paid by a foreign corporation as a license fee to do business in the state. By Chapter 726 of the laws of 1917, manufacturing corporations which were theretofore exempted (section 183 of the tax law, Article 9) from taxation on their capital stock, and the greater number of mercantile and miscellaneous corporations, theretofore taxable on their capital stock under section 182 of Article 9, were now taxable on net income under Article 9-a. These mercantile and miscellaneous corporations now taxable under Article 9-a were hereafter to be exempted from taxation under Article 9.

It is patent then, that no very clear idea can be obtained from the new provisions of the tax law contained in Article 9-a taxing general business corporations (formerly denominated manufacturing and mercantile corporations) on their net income without considering Article 9, which is entitled in the Consolidated Laws "Corporation Tax."

The chapters immediately following therefore treat of Article 9 with the exception of that portion devoted to the administrative procedure, certiorari and collection. This procedure is in the main common to the entire system of state taxation and is treated in Part III of the book. 


\section{CHAPTER II.}

\section{The System of Taxing Stock Corporations for State Purposes.}

The present system of taxing corporations for state purposes dates from the year 1880. Until that time the largest part of the revenue of the state was derived from a direct tax on land assessed and collected by the various counties of the state.

Annual franchise tax.-By Chapter 542 of the Laws of 1880 a general scheme of state taxation of stock corporations, excepting certain specified corporations, was inaugurated. A tax was imposed by this law on all stock corporations, resident and foreign, excepting savings banks, life insurance companies, foreign insurance companies and companies carrying on manufacturing and mining within the state, the basis of computing the tax in each case being the value of the capital stock.

Organization tax.-To this law, in 1886 (Chapter 143), was added an organization tax, to be paid by every domestic stock corporation, with the exception of banking and building loan associations upon the organization of the company, the basis of computation being the par value of the authorized capital stock.

This act did not apply to literary, scientific, medical and religious associations or corporations.

License tax.-By Chapter 240 of the Laws of 1895 a tax similar to the organization tax, and known as a license tax, was required to be paid by every foreign corporation upon its commencing business within the state, for the privilege of carrying on such business, to be computed on the basis of the capital stock employed within the state. 
Additional franchise tax based on gross earnings.-Chapter 361 of the Laws of 1881 provided for an additional annual franchise tax on transportation and transmission companies, based on gross earnings within the state. This tax was in 1896 also imposed on elevated and surface railroads not operated by steam; and on water, gas, electric, steam heating, light and power companies at a higher rate. The latter companies were, however, relieved from the payment of the annual franchise tax on capital stock.

Franchise tax on insurance companies, trust companies, banks.-Chapter 361 of the Laws of 1881 imposed an annual franchise tax on insurance companies, based on gross premiums or earnings, for business done in the state. Chapter 679 of the Laws of 1886 amended the Law of 1881 by reducing the amount of tax on the premiums of fire and marine insurance companies and exempting them from payment of the tax on capital stock.

In 1901 the annual franchise tax was also extended to trust companies and savings banks, to be computed on the basis of surplus and undivided profits.

The entire system of state taxation on stock corporations is based on the theory of an annual tax to be paid by each stock corporation for the privilege of exercising its corporate franchise or carrying on its business in the state, whether the corporation be foreign or domestic, and whether the tax be computed on the basis of capital stock net income or gross earnings.

In 1906 and 1907 the method of computing the franchise tax and the license tax under sections 181 and 182 of the Tax Law was materially changed. While the basis of the tax remained capital stock employed in the state, the value of the capital stock and the rate of the tax were fixed by certain arbitrary rules. Heretofore, the value of the capital stock employed within the state had been in most cases determined by the value of the property itself. People ex rel. Commercial Cable Co. v. Morgan, 178 N. Y. 433 (1904). The method of ascertaining the amount of the capital stock employed in the state by means of the property or gross assets in the state is now incorporated in the statute, and very little 
is left to the discretion of the taxing authorities in making an assessment.

Power of the State to tax corporations.-The inherent power of the state to tax, apart from any statutory provisions or constitutional limitations, is necessarily dependent upon whether the person, property or business is within its jurisdiction. State Tax on Foreign Held Bonds, 15 Wall. 300 (319).

In the case of a domestic corporation, except in so far as it may be restrained by the constitution of the United States, the power of the state to tax as to mode, form and extent is unlimited. (Ibid.).

In respect to foreign corporations its power is limited by the property located, or business done, within its borders.

The State of New York has proceeded to exercise its powers to tax corporations for state purposes by levying a tax on their franchises or business. While this is the general scheme of corporate taxation for state purposes, the basis on which the tax is computed, and the rate or amount of the tax, differ in various classes of corporations. In some cases the basis on which the tax is computed, depends upon the value of the capital stock or property of the corporation. In other cases it depends on earning power, and in a third class, on surplus or undivided profits. In a number of the classes of corporations named below, a combination of these methods of computation is used in estimating the tax or taxes to be paid.

Corporations subject to franchise tax and basis thereof.The following classification will show the various taxes paid by corporations to the state for the privilege of exercising their corporate franchises or business in the state.

1. Domestic corporations, paying an incorporation or organization tax based on the amount of the authorized capital stock.

2. Foreign corporations, paying a license fee or business tax based on the amount of the capital stock used within the state represented by property in the state. 
3. Domestic and foreign corporations, taxable under Article 9, paying an annual tax based on the value of capital stock employed within the state.

4. Domestic and foreign business corporations, taxable under Article 9-a, with the exception of the corporations named in the other classifications, paying an annual franchise tax based on net income returned to the United States Treasury Department.

And the following special classes of corporations:

5. Transportation, heating, power, lighting, water and transmission companies, paying an annual tax based on gross earnings.

6. Elevated and surface railroads not operated by steam, paying an annual tax based on gross earnings.

\%. Insurance companies, paying an annual tax based on gross premiums or earnings.

8. Trust companies, paying an annual tax based on capital stock, surplus and undivided profits.

9. Investment companies, paying an annual tax based on face value of capital stock, surplus and undivided profits.

10. Savings banks, paying an annual tax based on surplus and undivided earnings.

11. Foreign bankers, which class includes corporations, paying an annual tax on net earnings or interest earned. 


\section{CHAPTER III.}

The Organization Tax to be Paid by Domestic CorporaTIONS.

Defined.-The organization or incorporation tax is the charge to be paid by every domestic stock corporation except banking, building, mutual loan, accumulating fund and co-operative associations, and is paid for the privilege of receiving its charter or exercising its corporate franchise in the state.

The basis of the tax.-The basis of the tax is the authorized capital stock. In this respect, it differs from the license tax or initial tax paid by a foreign corporation for the privilege of coming into the state to do business, which is based on that part of its issued capital stock represented by the proportion which the property or assets in the state bear to its entire property or assets.

Rate of tax.-The rate or amount of the tax is one-twentieth of one per cent. on the authorized amount of capital stock, but in no case shall this tax be less than ten dollars. Prior to 1901, the rate for the organization tax was the same as for the license tax to be paid by a foreign corporation on coming into the state to do business, viz., one-eighth of one per cent. The Comptroller's Report of 1900 recommended a reduction of the organization tax, and by Chapter 448, Laws of 1901, it was reduced to one-twentieth of one per cent., the present rate.

In many states the rate paid by domestic and foreign corporations is the same, but there is no unconstitutionality in imposing a different rate on foreign corporations coming into the state. Horn Silver Mining Co. v. N. Y., 143 U. S. 305.

When the organization tax is payable, how paid, and to whom.-The organization tax is payable at the time the certifi- 
cate of incorporation is filed with the secretary of state. A check for the amount of the tax should be sent to the state treasurer, and the receipt for the same should be annexed to the certified copy certificate of incorporation or duplicate of original when filed in the office of the clerk of the county in which the principal office is situated.

The present statute reads as follows:

Organization tax.-Every stock corporation incorporated under any law of this state shall pay to the state treasurer a tax of onetwentieth of one per centum upon the amount of capital stock which the corporation is authorized to have and a like tax upon any subsequent increase. Provided, that in no case shall such tax be less than ten dollars. Such tax shall be due and payable upon the incorporation of such corporation or upon the increase of its capital stock. Except in the case of a railroad corporation, neither the secretary of state nor county clerk shall file any certificate of incorporation or article of association, or give any certificate to any such corporation or association until he is furnished a receipt for such tax from the state treasurer, and no stock corporation shall have or exercise any corporate franchise or powers, or carry on business in this state until such tax shall have been paid. And in case of a decrease of capital stock, upon which the tax required by law has been paid, and a subsequent increase thereof, a tax shall be-paid only upon so much of such increase as exceeds the amount of capital stock upon which a tax has been before paid. In case of the consolidation of existing corporations into a corporation, such new corporation shall be required to pay the tax hereinbefore provided for only upon the amount of its capital stock in excess of the aggregate amount of capital stock of said corporations. This section shall not apply to state and national banks or to building, mutual loan, accumulating fund and co-operative associations. A railroad corporation need not pay such tax at the time of filing its certificate of incorporation, but shall pay the same before the public service commission shall grant a certificate, as required by the railroad law, authorizing the construction of the road as proposed in its articles of association, and such certificate shall not be granted by the public service commission until it is furnished with a receipt for such tax from the state treasurer. If the board of railroad commissioners or public service commission shall have heretofore granted, or the public service commission shall hereafter grant, such certificate and upon an appeal from the determination of such board of railroad commis- 
sioners or public service commission, such certificate has been or may hereafter be denied the state treasurer shall refund the amount of tax so paid to the railroad corporation or corporations by which such tax was paid, upon proof of payment being presented and appropriation being made therefor. (Sec. 180, former sec. 180, Tax Law, as amended by ch. 369, L. 1897, ch. 448, L. 1901, ch. 524, L. 1906, ch. 472, L. 1910, ch. 91, L. 1911, ch. 317, L. 1915, and ch. 493, L. 1917.)

Source: Ch. 143, L. 1886, as amended by ch. 668, L. 1892.

Tax on re-organization of corporations. - No organization tax is due on the re-organization of a manufacturing corporation under the Business Corporation Law. Matter of Consol. Kansas City Smelting Co., 13 App. Div. 50 (1897). But where railroad corporation property and franchises have been foreclosed and sold, and a new corporation formed under a re-organization act (Chapter 430, of Laws of 18\%4, as amended), an organization tax is payable. People ex rel. Schurz v. Cook; same v. Mertens, 110 N. Y. 443. The law imposing this tax does not impair the obligation of contracts. Ibid.

Consolidated corporations.-Before the amendment of 1892 (Chapter 668, Laws of 1892), consolidated corporations were required to pay the organization tax. After this amendment no tax was required from a consolidated corporation except upon the excess stock.

Organization tax payable by corporations with shares without designated monetary value.-The organization tax payable under section one hundred and eighty of the tax law by any corporation issuing such shares without designated monetary value shall be at the rate of five cents on each such share which the corporation is authorized to issue, and a like tax upon any subsequent increase thereof. (Chap. 351, L. 1912.)

Note: The amendment of 1917 to Section 180 making the organization tax in each case not less than $\$ 10.00$, applies also to corporations having shares without designated par value. (Rept. of Atty. General [1912], 291.) 


\section{CHAPTER IV.}

\section{License Tax; Foreign Corporations.}

License tax defined.-The license tax is the fee or tax paid by a foreign corporation for the privilege of exercising its corporate franchise, or for carrying on its business, in its corporate or organized capacity within the state.

History.-This tax corresponds very closely to the organization tax to be paid by domestic corporations for the privilege of receiving its charter, or exercising its corporate franchise in the state. The organization tax, or tax on incorporation of domestic corporations, has existed in this state since 1886, but it was not until 1895 that a foreign corporation was required to pay any fee or tax for the privilege of exercising its corporate franchise in the state. The Comptroller of the state, in his report for the year 1895, in order to bring within the jurisdiction of the state certain corporations organized under the laws of other states, but practically domestic, as far as their business was concerned, recommended that foreign corporations be taxed on the basis of the capital stock employed in the state. By Chapter 240 of the Laws of 1895, a foreign corporation was required to pay a license fee or a tax of one-eighth of one per centum "for the privilege of exercising its corporate franchise or carrying on its business in such corporate or organized capacity in the state ... computed upon the basis of the amount of its capital stock employed within the state" during the first year. This has practically remained the law to this date. The amendment of 1901 included manufacturing corporations, and the amendment of 1906 changed the method of computing the amount of capital stock employed within the state. 
'The present law reads as follows:

License tax on foreign corporations.-Every foreign corporation, except banking corporations, fire, marine, casualty and life insurance companies, co-operative fraternal insurance companies, and building and loan associations, doing business in this state, shall pay to the state treasurer, for the use of the state, a license fee of oneeighth of one per centum for the privilege of exercising its corporate franchises or carrying on its business in such corporate or organized capacity in this state, to be computed upon the basis of the capital stock employed by it within this state, during the first year of carrying on its business in this state, which first payment shall not be less than ten dollars; and if any year thereafter any such corporation shall employ more than eight thousand dollars of its capital stock within this state on which a license fee has not been paid then a license fee at the rate of one-eighth of one per centum shall be due and payable upon any such increase. The measure of the amount of capital stock employed in this state shall be such a portion of the issued capital stock as the gross assets employed in any business within this state bear to the gross assets wherever employed in business. For purposes of taxation, the capital of a corporation invested in the stock of another corporation shall be deemed to be assets located where the physical property represented by such stock is located. The amount of capital upon which such license fees shall be paid shall be fixed by the state tax commission, which shall have the same authority to examine the books and records in this state of such foreign corporations, and the employees thereof, as it has in the case of domestic corporations, and the comptroller shall have the same power to issue his warrant for the collection of such license fees as he now has with regard to domestic corporations. No action shall be maintained or recovery had in any of the courts in this state by such foreign corporation after thirteen months from the time of beginning such business within the state, without obtaining a receipt from the comptroller for the payment of the license fee upon the capital stock employed by it within this state during the first year of carrying on its business in this state. (Former sec. 181, Tax Law, as amended by L. 1910, ch. 340, L. 1915, ch. 317, L. 1917, oh. 490.)

Source: Ch. 240, L. 1895, without change of substance.

Recent Amendments.-The amendment of 1915 gave the assessing power to the state tax commission instead of the comptroller, but gave the state comptroller the power to collect the tax. The 1917 amendments fixed the minimum tax at $\$ 10.00$ and gave the tax de- 
partment the power to levy a license tax on foreign corporations, irrespective of whether they had complied with the provisions of the General Corporation Law, or not. There was some question as to whether the tax department had such power.

When the license tax should be paid.-The tax should be paid at any time between the twelfth and thirteenth month after the corporation has commenced to do business in the state. People ex rel. Dutilh-Smith Co. v. Miller, 90 App. Div. 545 (1904).

Change in computing amount of capital stock.-While the basis of the tax remains the same as in the past, viz., "Capital stock employed within the state," the method of computing the tax, as in the case of a domestic corporation, has been materially changed by the amendment of 1906. (Ch. 474.) Formerly it was the amount of capital employed within the state, regardless of the share stock. People ex rel. Consolidated Ginseng Co. . Kelsey, 182 N. Y. 526; affirming 105 App. Div. 175 (1905); People ex rel. National Enameling Co. v. Miller, 112 App. Div. 880 (1906). Now, it approximates very closely to the organization tax paid by the domestic corporation upon its incorporation, except that the tax is computed on the issued share stock and not on the authorized stock, as in the organization tax paid by domestic corporations. The use of the words "issued capital stock" in the amendment of 1906 clearly shows that the par value of the issued stock was to be the basis of taxation rather than the appraised value. People ex rel. Elliott-Fisher Co. v. Sohmer, 148 App. Div. 514 (1911). Affirmed 206 N. Y. 634.

The purpose of the legislature in passing the law authorizing the payment of a license tax by foreign corporations (Sec. 181) as evidenced by the recommendation of the Comptroller in his report for the year 1895, was to impose upon foreign corporations a tax similar to the organization tax imposed upon domestic corporations, and thus do away with any favor that the former may have enjoyed. Despite this fact the courts felt obligated to follow former decisions and to declare that the tax was not to be computed upon the par value of the stock of the foreign corpora- 
tion, but rather upon the amount of capital employed in the state. (See Ginseng case supra.)

The decision in this case caused the Comptroller to ask for an amendment to Section 181, and in 1906 there was added to the section the words: "The measure of the amount of capital stock employed . . ." etc. So the tax is now computed on par value. Elliott-Fisher Co. v. Sohmer, supra.

Foreign corporations not citizens.-Foreign corporations are not citizens within the meaning of the fourteenth amendment to the United States Constitution, guaranteeing equal privileges to citizens of other states. Nor are they citizens within the meaning of section 2, article 4, of the United States Constitution, entitling citizens of each state to all privileges and immunities of citizens of the several states, and the right of a state to exclude foreign corporations is well settled. A state may impose on a foreign corporation a tax for the privilege of doing business in the state measured by the amount of capital employed in such business within this state. People ex rel. Parke, Davis \& Co. v. Roberts, 91 Hun, 158 (1895) ; aff'd 149 N. Y. 608, 171 U. S. 658.

The United States Supreme Court has held that a license tax imposed on a drummer or sales agent was unconstitutional. Carson v. Maryland, 120 U. S. 502 (1887) ; Robbins v. Shelby County Taxing District. Id. 489, but there is a distinction between a license $\operatorname{tax}$ on a sales agent or drummer sent here to make sales and a tax on a corporation bringing property into the state and carrying on business. People ex rel. Southern Cotton Oil Co. v. Wemple, 61 Hun, 83 (1891); aff'd 131 N. Y. 64.

When foreign corporations carry on business or employ capital in the state.-In order that corporations shall be liable to pay the license tax under section 181 of the Tax Law they must (1) carry on business in the state, and (2) employ capital in such business. These are also conditions precedent before foreign corporations are liable to taxation for the annual franchise tax under section 182 of the Tax Law, and are discussed under that head. 
Foreign corporations to file certificate before doing business.-Section 15 of the General Corporation Law requires every foreign stock corporation, with the exception of moneyed corporations, to file a certificate with the secretary of state, giving certain information as to business, capital and officers, before it can do business in the state. Failing to do this it subjects itself to certain disabilities, such as being unable to maintain an action in the courts of the state upon any contract made by it in the state.

If it files such certificate, however, it may be considered as prima facie evidence that it is doing business in the state, as has been held in the case of corporations assessed for local purposes. People ex rel. Armstrong Cork Co. v. Comm'rs, 157 N. Y. 159 (1898). The failure to file the certificate does not, on the other hand, imply that the corporation is not engaged in business in the state.

Failure to pay license tax bar to action.-The last paragraph of section 181 requires every foreign corporation to pay the license fee or tax within thirteen months after beginning to do business in the state. No action can be maintained in any court of the state after this time, if the fee has not been paid. The provisions of this section should not be confused with section 15 of the General Corporation Law (above referred to) requiring every foreign corporation doing business in the state to file a certificate with the secretary of state before it can maintain an action upon any contract made by it in the state. A corporation may undoubtedly be engaged in business in the state without having capital employed in such business, and while the doing of business in the state would subject it to the provisions of section $\mathbf{1 5}$ of the General Corporation Law, it need not pay the license fee under section 181 of the Tax Law required of a corporation engaged in business and employing its stock in the state. A number of the decisions hold that a complaint by a foreign corporation, which alleges that it is doing business in the state must also affirmatively show that it has filed a certificate under section 15 of the Corporation Law. Welsbach v. Norwich Gas. Co., 96 App. 
Div. 52, affirmed without opinion, 180 N. Y. 533; Wilson McNeill Co. v. Standard Oil Co., 110 App. Div. 888; Wood \& Sellick Co. v. Ball, 114 App. Div. 744 (1906); aff'd 190 N. Y. 219. The general requirements of section 15 of the General Corporation Law have been confounded with the provisions of section 181 of the Tax Law. This would seem to be so from the case of Reedy Elevator Co. v. American Grocery Co., 24 Misc. 678 (Appellate Term), holding that compliance with section 181 is a jurisdictional fact and must be set forth in an application for attachment. In Kinney v. Reid Ice Cream Co., 57 App. Div. 208, it was held that if it be shown in the pleadings that the foreign corporation has been engaged in business for more than a year, having capital employed in such business, and has not paid the license tax under section 181 of the Tax Law, a demurrer to the pleadings will lie, and that the assignee of the foreign corporation, defaulting in this respect, is in no better position than the corporation itself. The court said in this case: "We see no reason why the rule applied in the cases cited in reference to section 15 of the General Corporation Law should not apply to section 181 of Chapter 908 of the Laws of 1896." This case was followed by Halsey v. Jewett Dramatic Co., 114 App. Div. 420 (1906). The dissenting opinion in the last named case, by Judge Houghton, is valuable, in that it points out the distinction in the objects of section 15 of the General Corporation Law and section 181 of the Tax Law. While it would be necessary affirmatively to allege the filing of the certificate under the former section, it is not necessary to allege the payment of the tax under section 181 of the Tax Law, as a part of the pleading.

In the case of Wood $\&$ Sellick $v$. Ball, which was affirmed in 190 N. Y. 217-218, the court points out the distinction between the Welsbach case and Parmele v. Haas, 171 N. Y. 5r9. In the Parmele case the payment of the license fee was a condition subsequent. The corporation was permitted to carry on business in the state and after carrying on business for a certain length of time, must then pay the license tax. There was no express prohibition against doing business without paying the license tax, but 
a penalty was imposed through withholding the right to sue unless the license fee was paid within the statutory period. It was, therefore, held that it was not absolutely necessary to allege compliance with the section of the Tax Law before commencing an action. This is in accordance with the general rule that performance of a condition subsequent which continues in force a right already acquired, need not be pleaded, while performance of a condition precedent by which the right itself is acquired in the first instance must be pleaded. On the other hand, section 15 of the Corporation Law which led to the result in the Welsbach case, is a condition precedent to the right of a foreign stock corporation to do business. It was, therefore, held in Wood \& Sellick v. Ball, that compliance with section 15 of the General Corporation Law should be alleged and proved by a foreign corporation in order to establish a cause of action in the courts of this state.

Whatever the rule may be as to section 15 of the General Corporation Law, it would seem to be well settled by the case of Parmele v. Haas, and of Wood v. Ball, supra, that it is unnecessary affirmatively to plead compliance with section 181 of the Tax Law; that the matter covered by this section is no part of an affirmative case and that the corporation will be presumed to have complied with the section unless the contrary is shown. The Welsbach case, supra, does not seem to affect the decision in Parmele $v$. Haas, since the complaint in the former case showed upon its face that the plaintiff company was engaged in business within the state. Consequently, the presumption that it has complied with the law did not arise.

In Emmerich v. Sloane, 108 App. Div. 330 (1905), the court distinguished section 15 of the General Corporation Law from section 181 of the Tax Law, saying that the requirements of the latter law were not to be strictly construed, since they were mere revenue regulations for the benefit of the state, which the latter had the right to waive; that if the tax under section 181 were paid before the commencement of the action, the certificate might be obtained thereafter. 
Correspondence school corporation engaged in interstate business.-A foreign corporation engaged in the business of a correspondence school, soliciting business within the state through agents, but having no office here, the contracts being closed at the home office outside of the state, and the instruction being given from that office by mail, through text book and letter, is engaged in interstate commerce and may bring an action without paying the license tax under Section 181. People ex rel. International Text Book Co. v. Tone, 220 N. Y. 313 (191\%) ; reversing 162 App. Div. 930.

Foreign corporation, shipping goods into the state, not doing business, and may commence action.-A foreign corporation shipping goods into the state on orders addressed to the home office, is not doing business within the state, and therefore not subject to the above limitations as to commencement of action. Harvard Co. v. Wicht, 99 App. Div. 507 (1905) ; Novelty Manufacturing Co. v. Connell, 88 Hun, 254 (1895). Nor does this tax apply to a foreign corporation, which sold no goods here but received from its agents abroad reports of orders, which these agents transmitted for execution to another corporation outside of the state. People ex rel. Dutilh-Smith Co. v. Miller, 90 App. Div. 545 (1904).

Not applicable to foreign corporations in business less than thirteen months. - A foreign corporation not having employed its capital in the state for a period of thirteen months may sue out a writ of attachment without first obtaining the receipt required by section 181, Tax Law. Reedy Elevator Co. v. American Grocery Co., 82 N. Y. St. Rep. 619. The provisions of the Tax Law of 1896, that the tax must be paid within thirty days after December 1, 1901, by a foreign corporation engaged in business for more than thirteen months previous to that date does not bar the corporation from maintaining an action, if the tax has been paid prior to the commencement of the action. Dunbarton Flax Spinning Co. v. G. \& J. R. Co., 87 App. Div. 21 (1903). The amendment of 1910 makes this point clear, because the action may 
be commenced after thirteen months from the time the corporation has begun business in the state, provided the tax has been paid.

Corporation not within jurisdiction until license fee paid. -While corporations are not "citizens," they have been deemed "persons" within the meaning of the 14th amendment, by which no state shall "deprive any person of life, liberty or property without due process of law, nor deny to any person within its jurisdiction the equal protection of the law;" but a foreign corporation that has not paid its state license fee, was held to be not within the "jurisdiction," although a "person," until it complied with the prerequisite. Phila. Fire Ins. Co. v. N. Y., 119 U. S. 110 (1886). Nor is there any doubt about the right of the state to impose a tax on a foreign corporation for the privilege of doing business in the state. Ducat v. Chicago, 10 Wall. 410, except that the power of the state to exclude a foreign corporation should be subject to the limitation that freedom of interstate commerce is not to be impaired. International Text Book Co. v. Tone, supra, citing Western Union Tel Co. v. Kansas, 216 U. S. 27.

Measure of the amount of capital stock employed in the state.-This subject applies to the annual tax as well as to the license tax and is, therefore, treated under that head in the next chapter. 


\section{CHAPTER V.}

\section{Annual Franchise Tax on Capital Stock.}

Besides paying a tax upon its organization, or when it begins to do business in the state, an annual franchise tax "for the privilege of doing business or exercising its corporate franchise in this state" must be paid every year, under section 182 Tax Law, by each of the following classes of corporations doing business in the state:

Corporations subject to capital stock tax under section 182.-

1. Corporations only engaged in the purchase, sale and holding of real estate for themselves.

2. Holding corporations whose principal income is derived from holding the stocks and bonds of other corporations.

3. Steam surface railroad corporations;

4. Canal corporations;

5. Steamboat corporations;

6. Ferry corporations;

7. Express corporations;

8. Navigation corporations;

9. Pipe line corporations;

10. Transfer and baggage corporations;

11. Telephone and telegraph corporations;

12. Palace car and sleeping car corporations.

Corporations exempt from capital stock tax under section 182.-The following corporations are excepted from the provisions of the annual franchise tax, payable under section 182:

1. Manufacturing, mercantile, laundering, mining and miscellaneous corporations now classed as "business corporations" and 
paying a franchise tax on the amount of net income returned to the United States Treasury Department under section 209, Article 9-a of the Tax Law.

2. Banks, savings banks, and institutions for savings.

3. Title guaranty companies;

4. Insurance companies;

5. Surety companies;

6. Trust companies.

7. Elevated and surface railroads, liable under section 185, Tax Law.

8. Water, lighting and power companies liable under section 186, Tax Law.

9. Agricultural and horticultural associations and corporations.

The present provisions of the statute read as follows:

Certain corporations exempt from tax on capital stock.-Banks, savings banks, institutions for savings, title guaranty, insurance or surety corporations, every trust company incorporated, organized or formed, under, by or pursuant to a law of this state, and any company authorized to do a trust company business, solely or in connection with any other business, under a general or special law of this state, laundering corporations, manufacturing corporations to the extent only of the capital actually employed in this state in manufacturing, and in the sale of the product of such manufacturing, mining corporations wholly engaged in mining ores within this state, agricultural and horticultural societies or associations, and corporations, joint stock companies or associations owning or operating elevated railroads or surface railroads not operated by steam, or formed for supplying water or gas for electric or steam heating, lighting or power purposes, and liable to a tax under sections one hundred and eighty-five and one hundred and eighty-six of this chapter, shall be exempt from the payment of the taxes prescribed by section one hundred and eighty-two of this chapter. But such a laundering, manufacturing or mining corporation shall not be exempted from the payment of such tax, unless at least forty per centum of the capital stock of such corporation is invested in property in this state, and used by it in its laundering, manufacturing or mining business in this state. (Former sec. 183, Tax Law, as amended by ch. 785, L. 1897, ch. 558, L. 1901, and ch. 474, L. 1906.)

Source: Ch. 542, L. 1880, as amended by ch. 361, L. 1881. 
NoTE: The italicized portions of the above Section remain parts of the existing tax law, but laundering, manufacturing and mining corporations are no longer exempt from state taxation. While they are not taxable under the above section, they must pay an annual franchise tax on net income under Article 9-a of the Tax Law (see Part II of this book). They are, however, exempt from the local personal tax to which they were formerly subject.

The statute covering the annual franchise tax on capital stock under Section 182 of the Tax Law and the method of appraisement under Section 193 are given below:

Franchise tax on corporations.-For the privilege of exercising its corporate franchises in this state every corporation, joint stock company or association, and for the purpose of doing business in this state, every foreign corporation, joint stock company or association shall pay to the state treasurer annually, in advance, an annual tax to be computed upon the basis of the amount of its capital stock, employed during the preceding year within this state, and upon each dollar of such amount. The measure of the amount of capital stock employed in this state shall be such a portion of the issued capital stock as the gross assets employed in any business within this state bear to the gross assets wherever employed in business. For purposes of taxation, the capital of a corporation invested in the stock of another corporation shall be deemed to be assets located where the physical property represented by such stock is located. If the dividends upon the capital stock amount to six, or more than six per centum upon the par value of the capital stock, during any year ending with the thirty-first day of October, the tax shall be at the rate of one-quarter of a mill for each one per centum of dividends made or declared upon the par value of the capital stock during said year. If such dividend or dividends amount to less than six per centum on the par value of the capital stock, and

1. The assets do not exceed the liabilities, exclusive of capital stock, or

2. The average price at which such stock sold during said year, did not equal or exceed its par value, or

3. If no dividend was declared,

Then each dollar of the amount of capital stock employed in this state, determined as hereinbefore provided, shall be taxed at the rate of three-fourths of one mill. If such dividend or dividends amount to less than six per centum on the par value of the capital stock, and 
1. The assets exceed the liabilities, exclusive of capital stock, by an amount equal to or greater than the par value of the eapital stock, or

2. The average price at which such stock sold during said year is equal to or greater than the par value,

Then the amount of capital stock, determined as hereinbefore provided to be employed in this state, shall be taxed at the rate of one and one-half mills on each dollar of the valuation of the capital stock employed in this state, but such valuation shall not be less than

1. The par value of such stock.

2. The difference between the assets and liabilities, exclusive of capital stock.

3. The average price at which such stock sold during said year.

If such corporation, joint-stock company or association shall have more than one kind of capital stock, and upon one of such kinds of stock a dividend or dividends amounting to six, or more than six percentum upon the par value thereon has been made or declared, and upon the other no dividend has been made or declared, or the dividend or dividends made or declared thereon amount to less than six percentum upon the par value thereof, then the tax shall be at the rate of one-quarter of a mill for each one percentum of dividends made or declared upon the capital stock upon the par value of which the dividend or dividends made or declared amount to six or more than six percentum, and in addition thereto a tax shall be charged upon the capital stock,

1. Upon which no dividend was made or declared, or

2. Upon which the dividend or dividends made or declared did not amount to six per centum upon the par value,

At the rate as hereinbefore provided for the taxation of capital stock. upon which no dividend was made or declared, or upon which the dividend or dividends made or declared did not amount to six percentum on the par value.

All corporations not taxable under the preceding paragraphs of this section shall be taxed in an amount not less than would be produced by an assessment of one and one-half mills on each one dollar of the actual value of its capital stock, determined to be employed in this state as hereinbefore provided, or one and one-half mills upon each dollar of such capital stock at the average price at which said stock sold during the said year. (Sec. 182, former sec. 182, Tax Law, as 
amended by ch. 558, L. 1901, ch. 474, L. 1906, ch. 734, L. 1907, and oh. 333, L. 1916.)*

Source: Ch. 542, L. 1880, as amended by ch. 361, L. 1881.

Recent Amendments. - The amendment of 1916 struck out the words "doing business" before the words "exercising its corporate franchise" and made it clear that the tax was to apply to domestic corporations "exercising their corporate franchises in the state" and foreign corporations "doing business in this state." This was in line with the case of People ex rel. Lehigh \& N. Y. R. Co. v. Sohmer, 217 N. Y. 443, reversing 169 App. Div. 430 (1916).

* Note: For amount of franchise tax payable by corporations incorporated under Chap. 351 L. 1912, providing for shares of capital stock without nominal or par value, see end of this chapter.

Value of stock to be appraised.-If the dividend or dividends amount to less than six per centum on the par value of the capital stock, or no dividend is declared the president, treasurer or secretary of the company liable to pay a tax under the provisions of section one hundred and eighty-two of this chapter, shall, under oath, between the first and fifteenth days of November in each year, estimate and appraise the capital stock of such company at its actual value.

And shall forward the same to the tax commission with the report provided for in the last section. If the tax commission is not satisfied with the valuation so made and returned it is authorized and empowered to make a valuation thereof, and settle an account upon the valuation so made by it, and the taxes, penalties and interest to be paid the state. (Sec. 193, former sec. 190, Tax Law, as amended by ch. $474, L$. 1906, ch. 734, L. 1907, and ch. 317, L. 1915.)

Source: Ch. 540, L. 1880, as amended by ch. 361, L. 1881.

"Business" corporations no longer taxed under section I82. -The principal application of section 182 to business corporations has now been greatly limited by Article 9-a, which takes away from section 182 mercantile, and business corporations generally, except the realty and hołding corporations exempted from the franchise tax on income under section 210. Manufacturing,laundering and mining corporations exempted under section 183, are now taxed on net income under Article 9-a.

Method of assessment under section 182:-Section 182 of the Tax Law must be taken in connection with section 193 (for- 
mer section 190) which it supplements. People ex rel. N. Y. \& E. R. Ferry Co. v. Roberts, 168 N. Y. 14 (1901).

By Chapter 474, Laws of 1896 and Chapter 734, Laws of 190\%, the provisions governing the annual franchise tax (Sections 182, 193 Tax Law) were materially amended in the following particulars :

1. The franchise tax was declared to be payable in advance.

2. A rule was provided in the statute itself, by which the amount of capital stock employed within and without the state could be easily determined.

3. A method was provided in the statute for determining the amount of capital stock employed within the state represented by stock in other corporations, owned by the company taxed.

4. Corporations paying less than 6 per cent. dividends, or paying no dividends, were re-classified in two divisions, so that a different rate applied to them as they fell into one or. the other classification.

The arrangement under section 182 is confusing and does not lend itself easily to any accurate grouping or classification of corporations. The evident intent of the statute was to group corporations into classes according to the amount of dividend paid, and vary the rate on that basis. In the case of corporations paying dividends of less than six per cent., there is also a variation of the rate, depending upon the market price of the stock or the value of the net assets. The following general classification seems to be called for by the statute:

(1) Corporations paying dividends of six per cent. or more, which are taxed at the rate of one-quarter of a mill for each per cent. of dividend declared on the par value of the capital stock, without reference to the market price of the stock or the value of the assets. There is no change here from the law prior to the amendment of 1906 .

(2) Corporations paying no dividend, which are taxed at the rate of three-quarters of a mill on the appraised value of the capital 
stock. There is no minimum valuation here, and under the appraisement provided by section 193 (formerly 190), the tax may be nominal.

(3) Corporations paying dividends of less than six per cent., which are subdivided into two classes:

(a) Corporations paying dividends of less than six per cent., whose assets exceed the liabilities by an amount equal to or greater than the capital stock, or in which the average price of the stock sold during the year was par or over, and not included in the classification provided for in subdivision (b) infra, of corporations paying at the three-quarter mill rate. In either case, the capital stock is taxed at the rate of one and one-half mills on the appraised value, but such appraised value shall not be

less than the par value of the stock or

less than the difference between the assets and liabilities, or

less than the average price at which the stock sold during the year.

The minimum valuation here is the par value of the stock.

(b) The second subdivision of corporations paying dividends of less than six per cent., is that class of corporations in which the average price of the stock sold during the year was less than par, or whose assets do not exceed the liabilities exclusive of capital stock. In either case, the tax to be paid is three-quarters of a mill on the appraised value of the capital stock. There is no minimum valuation in this class, and under the appraisement provided for by section 193 (formerly section 190) the tax may be nominal. It may have been intended by the framers of the amendment of 1906 to take into account a minimum valuation of par for this class of corporations, but the statute did not clearly express it, and after the amendment of section 193 (formerly section 190), it was decided by a divided court of four to three in People ex rel. N. Y. Mail \& Transportation Co. v. Gaus, 198 N. Y. 250 , that the valuation referred to in this part of section 182 by 
the words "each dollar of the amount of capital stock employed in this state" was the appraised valuation provided by section 193 (formerly 190).

(4) There is yet another group or class of corporations, consisting of all corporations not taxable under the preceding classifications. An example of this class would be corporations paying dividends of less than six per cent., where there was no stock sold during the year, and hence no market price, and where the assets exceed the liabilities, but not by an amount equal to or greater than the capital stock. This class is taxable at the rate of one and onehalf mills on the actual (or appraised) value of the capital stock. This group was added by the drag-net clause of the amendment of $190 \%$.

Ambiguity as to rate decided in taxpayer's favor.-If a corporation, paying dividends of less than six per cent. falls under one alternative subdivision, in the second paragraph of section 182 , requiring it to pay the rate of three-quarters of a mill, and also an alternative subdivision of the third paragraph or class of section 182, providing for the rate of one and one-half mills, the practice had been to assess the tax at the higher rate. For example, if the average market price of the stock of such a corporation was below par, but the assets exceeded the liabilities by more than the capital stock, it fell at the same time under an alternative subdivision of the second class, paying the three-quarters mill rate, and also of the third class paying the one and one-half mill rate. The legality of this practice was questioned on the general theory that revenue laws should be strictly construed, and that any ambiguity in the Tax Law should be resolved in favor of the public. Brown v. Commonwealth, 98 Va. 366; San Francisco F. L. Co. v. Banbury, 106 Cal. 129; Cooley on Taxation, 3rd Ed. 459.

In People ex rel. American Bank Note Co. v. Sohmer, 157 App. Div. 1 (1913), affirmed 210 N. Y. 621, this question was raised, and the court held that since the reading of the statute disclosed an inconsistency under the general principles of interpretation, the taxpayer was entitled to the most favorable reading, and that the 
common stock of the corporation should therefore be taxed at the three-quarter mill rate. This decision is in line with the opinion in People ex rel. N. Y. Mail \& N. T. Co. v. Gaus, 198 N. Y. 255, interpreting another phase of the same statute, and holding that "the benefit of the doubt and uncertainty as to the meaning of the statute must be given to the relator and not to the state."

Measure of the amount of capital stock employed in the state and method of computing franchise tax in any given case.-The amount of the franchise tax to be paid under section 182 of the Tax Law in any given case depends upon the following facts:

In the case of all corporations having property or assets within and without the state, it depends upon the amount of gross assets or capital employed within the state. This amount bears the same relation to the total issued capital that the gross assets in the state bear to the total gross assets.

In the case of corporations paying dividends of six per cent. or more, it depends upon the amount of issued capital stock at par employed within the state and the rate of dividend.

In the case of corporations paying no dividend, it depends upon the actual value of the amount of capital stock, which may be nominal, and the tax may be nothing. So also in the case of corporations paying dividends of less than six per cent., whose assets do not exceed the liabilities, or whose average market price is below par. In this case, too, the tax may be nominal.

In the case of corporations paying dividends of less than six per cent., when the assets exceed the liabilities by an amount equal to or greater than the capital stock, or when the average market price is above par (and not coming under the three-quarter mill rate supra), it depends upon the value of the net assets, the market price of the stock and the par value of the capital stock, whichever of these values is highest. The minimum appraisement is here the par value of the capital stock. 
If all the corporation's assets are in the state, the amount of the capital stock employed in the state will equal the issued capital stock. The value of the capital stock in this instance and the rate at which the franchise tax is computed will depend upon the conditions set forth in the illustrations hereinafter mentioned.

\section{Illustrations.}

Corporations paying dividends of $6 \%$ or more; rate $1 / 4$ of a mill for each $I \%$ of dividend, at par.-If a corporation whose entire capital stock of $\$ 100,000$ is invested in this state, paid a dividend of eight per cent., it would be subject to a franchise tax under section 182 of the Tax Law of one-fourth of a mill for each one per cent. of dividend, or two mills on $\$ 100,000$, of capital stock, viz., $\$ 200$. Under section 182 this rate is on the par value of the issued capital stock without regard to the market price or to the actual ralue of the assets.

If the corporation's capital is $\$ 100,000$, all of which is issued, and it is engaged in business within this state and also without the state, and if the assets within the state of $\$ 120,000$ and its assets without the state are $\$ 30,000$, the proportion of capital stock within the state subject to taxation under section 182 of the Tax Law would be 120,000/150,000, or four-fifths of $\$ 100,000=\$ 80,000$. If the dividend declared on the capital stock was eight per cent., the tax under section 182 would be at the rate of one-fourth of a mill for each per cent. of dividend or two mills on $\$ 80,000$, viz., $\$ 160$.

Corporations paying no dividend. Rate $3 / 4 \mathrm{mill}$ at appraised value.-If we take the case of the corporation mentioned with $\$ 100,000$ of capital, but paying no dividend, it would be subject to a franchise tax at the rate of three-fourths of a mill on the appraised value of the capital stock employed within the state at its actual or appraised value under sections 182 and 193 (formerly 190), of the Tax Law. There is no minimum valuation here and under the appraisement provided for by section 193, the tax may 
be nominal; for instance, if the gross assets are $\$ 150,000$ and the liabilities $\$ 90,000$, making the net assets $\$ 60,000$, and the average market price of the stock $\$ 80$, the tax to be paid would be appraised at a valuation of $\$ 80$ per share, which would mean that the valuation would be $\$ 80,000$ at three-fourths of a mill or $\$ 60$ for the tax. But if the assets were $\$ 150,000$ and the liabilities $\$ 160,000$, with no market price (no stock sold), the tax would be three-fourths of a mill on a net valuation of zero, and the tax would be nothing.

Corporations paying dividends of less than six per cent., where the assets do not exceed the liabilities, or where the average market price of the stock does not equal or exceed par. Rate $3 / 4$ mill on appraised valuation.-The first case presented under this subdivision is hardly a practical or even a legal proposition, for it presents the hypothesis of an insolvent corporation paying dividends, for instance:

If we take the corporation having a capital stock of $\$ 100,000$ all issued and employed within the state, paying a dividend of less than six per cent.; if it had gross assets of $\$ 100,000$ and liabilities $\$ 110,000$, or if its market price was not equal to or greater than par, it would pay a franchise tax of three-fourths of a mill on the actual or appraised value of the capital stock employed within the state. This is a possible case under this subdivision as the law is framed, but not at all probable.

If we take the case of the corporation mentioned in the last paragraph, with a capital stock of $\$ 100,000$, all issued and employed in the state, paying a dividend of less than six per cent. and with the market price of the stock at $\$ 80$, it will only pay a tax of three-fourths of a mill on the appraised value of its capital stock employed within the state. If the gross assets were $\$ 150,000$, and the liabilities $\$ 90,000$, an appraisement of $\$ 60,000$ might be justified, though less than the market price, in which event the tax would be $\$ 45$.

A corporation having part of its assets within and part without the state is taxed under the same rules, except that in each 
case it would be taxed on the proportion of the capital stock represented by the gross assets within the state.

Corporations paying dividends of less than six per cent. showing a surplus, or with market price above par. Rate $I \frac{1}{2}$ mills.-The next subdivision brings into consideration those corporations paying less than six per cent. (not coming under the three-quarter mill rate supra), whose assets exceed the liabilities by an amount equal to or greater than the capital stock, i.e., corporations with a surplus, or whose market price is equal to, or above par.

If we take the case of the corporation mentioned, having a capital stock of $\$ 100,000$, all employed within the state and paying dividends of less than six per cent., with gross assets of $\$ 220,000$ and liabilities of $\$ 100,000$, the net assets would be $\$ 120,000$, and if the average market price for the stock were $\$ 110$, in this case, the rate would be $11 / 2$ mills, to be computed not on the $\$ 100,000$ of capital stock at par value, or at the market price of $\$ 110$, but on $\$ 120,000$, the net assets, which under the third paragraph of section 182 are deemed to be the value of the capital stock employed within the state.

If we take the same corporation paying a dividend of less than six per cent. with the same net assets of $\$ 120,000$, but with the market price of the stock at $\$ 125$, making the value of the capital stock employed within the state $\$ 125,000$, the rate of $11 / 2$ mills would then be computed on this latter amount, which is higher than either the par value of the capital stock or the net value of the assets.

If we take the same corporation paying dividends of less than six per cent., with gross assets of $\$ 200,000$ and liabilities of $\$ 100,000$, making the net assets exactly $\$ 100,000$ or par, the rate of $11 / 2$ mills would be computed on that figure, provided the market price is not less than par.

Again taking the case of the corporation with $\$ 100,000$ of capital, all employed within the state, and paying less than six per cent., if the average selling price of the stock was at $\$ 120$ during the year, 
and if the gross assets were $\$ 150,000$, and the liabilities $\$ 70,000$, making the net assets $\$ 80,000$, or less than par, in this case the rate would be $11 / 2$ mills, to be computed on the capital stock of $\$ 100,000$, at $\$ 120$, or on $\$ 120,000$, making the tax $\$ 180$.

The same figures in the last paragraph might be applied to the case of a corporation whose capital was partly employed within and partly without the state, the only difference in this case being that the tax would be based on the proportion of the capital stock represented by the amount of the gross assets within the state.

Drag net clause. Rate $\mathrm{I}^{\mathrm{I}} / 2$ mills.-The next subdivision includes all corporations not coming under any other paragraph. An example of this class would be one whose assets exceed the liabilities, but by an amount less than the par value of the capital stock.

For example, we will take a corporation whose capital stock is $\$ 100,000$, all issued and employed in the state. The gross assets are $\$ 150,000$ and the liabilities are $\$ 70,000$, with a dividend of four per cent. declared, but no stock sold during the year. It manifestly does not come under subdivision 1 , paying dividends of six per cent. or more, nor does it come under subdivision 2, of section 182, because its assets exceed its liabilities by an amount not equal to or greater than the capital stock, nor was its market price below par, because the stock was not sold during the year. Neither does it come under subdivision 3, of section 182, because its assets did not exceed its liabilities by an amount equal to or greater than the capital stock at par, nor was its market price above par, there being no stock sold. It therefore comes under subdivision 4 , and pays a tax, in this case, of $1 \frac{1}{2}$ mills under the last paragraph of section 182 on the actual value of the capital stock, or on $\$ 80,000$, viz., $\$ 120$.

Corporations having more than one kind of capital stock.A class of cases, for which no illustrations have yet been furnished, is the fourth or last class but one, mentioned in section 182, viz., that of a corporation paying dividends on two kinds of stock, or 
paying no dividend on one kind of stock, and paying dividends of six per cent. or more, or less than six per cent. on the other kind of stock. Take for example, a corporation having a capital stock of $\$ 100,000$, divided into $\$ 40,000$ of preferred and $\$ 60,000$ of common stock, which pays a dividend of eight per cent. on the preferred and four per cent. on the common, with the common stock selling at $\$ 60$ and the net assets, $\$ 120,000$. It will pay a tax on the par value of $\$ 40,000$ of preferred stock at the rate of two mills, making the tax $\$ 80$. The common stock will pay a tax of $3 / 4$ mill on $\$ 60,000$, at a valuation of $\$ 120,000$ for the $\$ 100,000$ of capital stock, or at $6-5$ of $\$ 60,000$, making the valuation of the common stock $\$ 72,000$, and the tax will be $\$ 54$. The entire tax to be paid by this corporation will be $\$ 134$.

The provision in the statute covering this subdivision has evident reference to the ordinary case of preferred and common stock. People ex rel. N. Y. C.\& H. R. R. Co. v. Gaus, 200 N. Y. 328 (1911).

Annual franchise tax payable in advance.-The amendment of 1906 makes the annual franchise tax payable in advance, but the basis of the tax is computed on the capital stock employed during the preceding year, unless the capital stock was increased prior to October 31st, when it seems the tax will be payable on the increased amount, because payable in advance. People ex rel. N. Y. C. \& H. R. R. Co. v. Gaus, 200 N. Y. 328 (1911). In People ex rel. Mercantile S. D. Co. v. Sohmer, 158 App. Div. 110 (1913), where there had been a distribution of profits of $\$ 880,250$ on $\$ 300,000$ of outstanding capital stock, and the stock reduced at the end of the year to $\$ 100,000$, the court held that it was the capital stock on which the dividends were paid within the year, and not the amount outstanding at the end of the year on which no dividends were paid, that determined the rate of dividend and the basis of the tax. If the corporation ceases to do business before the end of the fiscal year, it escapes taxation for the ensuing year. If the corporation was organized during the preceding year and only in business for a portion of the year, on October 31st it 
will pay on the average capital, irrespective of the time employed, because the tax is payable in advance.

Average capital and average market price.-Where section 182 of the Tax Law requires the actual capital to be ascertained, the rule for determining it, is to take it for the entire fiscal year and divide it by the number of days. The same general principles were applied prior to the amendment of 1906 in ascertaining the average value of the capital employed during the year. If the capital was employed for less than a year, the tax was based on its average employment for the year. People ex rel. Brooklyn Rapid Transit Co. v. Morgan, 57 App. Div. 335, aff'd 168 N. Y. 672; People ex rel. Mutual Trust Co. v. Miller, 177 N. Y. 51 (1903); People ex rel. Rees' Sons v. Miller, 90 App. Div. 592 (1904); People ex rel. Cohen \& Co. v. Miller, 94 App. Div. 564 (1904). Since the amendment of 1906 , it would seem that where the capital stock has been increased during the year the capital employed at the end of the preceding fiscal year, viz., the capital stock outstanding on October 31st, would govern the amount on which the tax was payable. People ex rel. N.Y. C. \& H. R. R. Co. v. Gaus, supra. The average price of stock is to be determined from the different sales irrespective of the amount sold on the various sales. People ex rel. Amer. B'k Note Co. v. Sohmer, $15^{r}$ App. Div. 1 (1913).

How intrinsic value is ascertained; debts to be deducted.Where the various provisions of section 182 require the intrinsic or actual value to be ascertained, it should be determined by deducting the liabilities from the assets. People ex rel. Lorena Co. v. Morgan, 55 App. Div. 265 (1900); People ex rel. J. B. Co. v. Roberts, 37 App. Div. 1 (1899). If the good will of the business has any value that is to be added to the net assets so ascertained. People ex rel. Wiebusch \& Hilger Co. v. Roberts, 19 App. Div. 574; aff'd 154 N. Y. 101 (1897). Under the law, prior to 1906, the comptroller was not required to ascertain the intrinsic or actual value of the stock in cash unless such intrinsic value exceeded the market value. People ex rel. Brooklyn El. R. R. Co. v. Roberts, 90 Hun, 537 (1895). This was so even though the as- 
sessment made by the comptroller, based on such average price, was more than the par value of the stock and thus indirectly assessed on surplus, for the dividends over six per cent. may be accumulated in the form of surplus, which, if profits had been declared, would have increased the assessment. People ex rel. Colonial Trust Co. v. Morgan, 47 App. Div. 126 (1900). Under the present statute, if the dividends are six per cent. or more, the intrinsic value need not be ascertained, and no appraisement is necessary under section 193 (former sec. 190) of the Tax Law.

What debts not deducted.-A foreign corporation cannot deduct its general indebtedness arising from its business done throughout the country generally, but only the specific indebtedness arising out of the business done in this state. People ex rel. Nat'l Enameling Co. v. Miller, 112 App. Div. 880 (1906). In an earlier case (People ex rel. Hyde \& Sons $v$. Miller, 90 App. Div. 599 [1904]; aff'd 179 N. Y. 564) it was held that only that part of the total indebtedness should be deducted, which the assets within the state bore to the total assets of the company.

Actual value not "book value"; good-will._-Book value" does not govern the valuation to be made where intrinsic value is to be ascertained. Where a corporation's entire business is in New York and has been acquired from a firm of similar name doing business in New York, together with the good-will of that firm, the value of the good-will and name of the firm is part of the capital employed in the state. J. B. Co. v. Roberts, supra. The right to tax the good-will was upheld in People ex rel. Johnson Co. v. Roberts, 159 N. Y. 70 (1899), and in the Wiebusch case, supra.

No unequal taxation because lesser dividends pay higher tax.-Where the dividends are less than six per cent. and the price of the stock above par there is no unequal or unjust taxation, because the corporation is obliged to pay a larger tax than for paying a dividend of six per cent. or over. People $v$. President, $\& c ., D$. \& H. Canal Co., 54 Hun, 598 (1889); see, also, People ex rel. 
N. Y. C. \& H. R. R. Co. v. Knight, 173 N. Y. 255 (1903) ; People ex rel. Hyde \& Sons v. Miller, 90 App. Div. 599 (1904); aff'd 179 N. Y. 564.

Stock dividends.-Whether the payment of a stock dividend shall be considered a distribution of profits or an adjustment of capital depends upon the circumstances in each case. If it is paid out of surplus profits, it will be considered a dividend and taxed accordingly. People ex rel. Pullman Co. v. Glynn, 130 App. Div. 332 (1909), affirmed, $198 \mathrm{~N}$. Y. 605. If it is a distribution of the capital not representing profits, it will not be considered the basis for computing the tax. People ex rel. North American Trust Company v. Knight, 96 App. Div. 120. Where stock is surrendered equal in amount to the dividend paid it will be considered a depletion of capital stock and not a payment of dividend. People ex rel. Port Morris Land \& Improvement Co. v. Glynn, $205 \mathrm{~N}$. Y. 578 (1912), modifying 148 App. Div. 908 ; but if a corporation having issued $\$ 300,000$ of capital stock and having purchased with $\$ 200,000$ thereof, the good-will, business and lease of another company and invested the remaining $\$ 100,000$ in securities, afterwards realized $\$ 1,050,000$ for its lease, and divides this amount among its shareholders representing the $\$ 300,000$ of capital stock, which is then reduced to $\$ 100,000$, under such circumstances, the sum of $\$ 850,000$ will be considered as a stock dividend and not as a distribution of capital. People ex rel. Mercantile S. D. Co. v. Sohmer, 158 App. Div. 110 (1913).

Distribution of amount realized in condemnation proceedings not to be construed as dividends. - Where a corporation distributes the greater part of an award it has received in condemnation proceedings, among its stockholders, and thereafter does no business, the comptroller in assessing the franchise tax should not consider such award so distributed as dividend. People ex rel. Jerome Park Villa Site \& Imp. Co. v. Roberts, 41 App. Div. 21 (1899).

United States securities.-The property of a corporation invested in United States securities is taxable under section 182; 
the tax is not on the property, but on the corporate franchises. Home Ins. Co. v. N. Y., 134 U. S. 594 (1890).

Patent rights.-The tax on that part of a corporation's capital invested in patent rights is not contrary to the United States Constitution. The tax is on the franchise or business, no matter how the corporate capital is invested. People ex rel. Edison $E$. Illum. Co. v. Wemple, 61 Hun, 53 (1891); see, also, Home Ins. case, supra. And if the entire capital is invested in patent rights, the rule is not otherwise. People ex rel. U. S. Aluminum Plate Co. v. Knight, 174 N. Y. 475 (1903); rev'g 67 App. Div. 333.

Trade marks.-The same rule applies to the case of a foreign corporation doing business in this state, having part of its capital invested in a trade mark. People ex rel. Spencerian Pen Co. $v$. Kelsey, 105 App. Div. 133 (1905).

How good-will and patents may be valued.-In estimating the value of the good-will it is not improper to assume that it is worth the price paid for it. People ex rel. Keochl \& Co. v. Morgan, 96 App. Div. 110 (1904). This rule also appears to be true in the case of patents. People ex rel. Automatic Vending Co. v. Kelsey, 101 App. Div. 325 (1905); particularly if the company has been paying dividends of six per cent. on its entire authorized capital stock. Ibid.

Realty corporations.-There has been a lack of uniformity in the law in cases affecting the taxation of corporations investing their capital in real estate. For example, it has been held that the capital of a corporation invested in unproductive real estate, like swamp land, was not "capital employed within the state" and, therefore, not taxable. People ex rel. Niagara $R$. Hydraulic Co. v. Roberts, 30 App. Div. 180 (1898); aff'd 157 N. Y. 676. And in an earlier case, it was held that the franchise tax did not apply to real estate bought with the surplus of the corporation and not used in the business. People ex rel. Singer Mfg. Co. v. Wemple, 150 N. Y. 46 (1896). A more recent case to the same effect is that of People ex rel. Fort George Co. v. Mil- 
ler, 179 N. Y. 49 (1904), in which the Court of Appeals by a divided court of four to three held that the capital stock of a corporation invested in unimproved New York City land was not employed in business in the state.

On the other hand, in People ex rel. Wall \& H. St. Realty Co. v. Miller, 181 N. Y. 328 (1905); a realty corporation incorporated for the purpose of, and actively engaged in, leasing and managing a large office building, with the right to acquire and sell both real and personal property and to carry on any other business which could be conveniently conducted, was held to be taxable on this property as "capital employed."

The Court of Appeals in the last named case, by a divided court, of four to three, in its prevailing opinion, distinguishes the three cases cited in the last paragraph from the one then before it on the ground that the company in that case was found to do a realty business, and was not exempt by reason of its business from the franchise tax. The dissenting opinion, in this case, which is concurred in by two of the judges who wrote the prevailing opinion in the Fort George case, points out that there is no material difference between the three cases above cited and that of the Fort George Company, and that if the court is to stand on the doctrine of stare decisis, the Wall Street Realty Co. would be exempt from taxation on similar grounds. The Wall Street Realty Co. case was followed in People ex rel. Hubert Apt. Assn. v. Kelsey, 110 App. Div. 618 (1906) aff'd 184 N. Y. $5 \% 3$.

The amendment of 1906 bases the amount of "capital stock employed" on the gross assets wherever employed, and realty companies would hence seem to be taxable thereunder whether the capital was productively or unproductively invested.

In People ex rel. Fifth Ave. Bldg. Co. v. Williams, 198 N. Y. 242 (1910), it was said:

"This court is now committed to the doctrine that corporations organized for the purposes of buying, selling, leasing, renting and owning real estate, and of erecting buildings or other structures thereon are taxable under the Tax Law as it now stands. * * * From the moment when the relator began to use its money to 
purchase real estate for the purposes of its incorporation it employed its capital in this state within the purview of the statute."

Realty although unproductive is capital employed.-It matters not whether the capital stock of a realty company be employed in business. If it be employed at all, it is sufficient. People ex rel. Waclark R. Co. v. Williams, 198 N. Y. 54 (1910) ; rev'g 134 App. Div. 83.

In People ex rel. Coney Istand Jockey Club v. Sohmer, 140 N. Y. Supp. $50 \%$ (1913), the words "capital" and "capital stock" as well as the words "employed" in reference to capital, are defined. In that case it was held that a domestic corporation incorporated "for improving the breed of horses" and owning two tracts of land, one of which was paid for out of the capital stock, the other of which was paid for out of profits, is subject to a franchise tax under section 182 of the Tax Law, although it claimed it was not exercising its franchise under its certificate of incorporation, and that its capital was simply lying dormant. When the company used its capital to purchase real estate, it was employing its capital in the state. "Using" is employing. Citing People ex rel. Fifth Ave. Bldg. Co. v. Williams, 198 N. Y. 238 (1910); People ex rel. Vandervoort v. Glynn, 194 N. Y. 387; People ex rel. 14th St. Realty Co. v. Kelsey, 110 App. Div. 797 (1909). The fact that one of the two tracts of land was paid for out of the capital stock and the other out of profits is immaterial. Both are capital. The words "capital stock" and "capital" are practically equivalent within the meaning of the provisions of the franchise tax. By "capital stock" is meant the value of the net assets, and since surplus forms part of the capital, it must be taken into account in valuing the capital stock. People ex rel. Commercial Cable Co. v. Morgan, 178 N. Y. 433 (1904); People ex rel. Wiebusch \& Hilger Co. v. Roberts, 154 N. Y. 101 (1897).

Real estate; property without the state.-Real estate employed in business within the state may be taxed, even though it results in double taxation. This does not make the law uncon- 
stitutional. People ex rel. Postal Tel. Co. v. Campbell, 70 Hun, 507 (1893). If the real estate is not within the state, the capital so invested is not taxable here. People ex rel. American Surety Co. v. Campbell, 74 Hun, 101 (1893); aff'd 143 N. Y. 625. The same rule applies to United States bonds deposited in other states. Ibid.

Nor will freight cars permanently outside of the state be taxed as capital employed within the state. People v. Compbell and Roberts, 88 Hun, 545 (1895).

Outstanding accounts of domestic corporations.-Outstanding accounts, representing property of a domestic corporation invested outside of the state, which has never come within the state, have been held to be capital employed without the state. People ex rel. Rees v. Miller, 90 App. Div. 591 (1904). This decision has been modified, but does not seem to have been overruled, on the point cited in People ex rel. Williams $v$. Sohmer, 151 App. Div. 764 (1912).

Joint stock company taxable.-Joint stock companies were held liable to taxation under the law as amended. The insertion of words "or organized" in Chapter 361 of the Laws of 1881 indicated that the legislature did not intend to confine the third section of Chapter 542 of the Laws of 1880 to bodies which were strictly incorporated. People ex rel. Platt $v$. Wemple, 117 N. Y. 136; aff'g 52 Hun, 434 (1889). The legislature amended this section by making it applicable to a "corporation, joint stock company or association, incorporated, organized or formed." (Chap. 353, L. 1889, now included in sec. 182 Tax Law.)

Amount of franchise tax payable by corporations with shares without nominal or par value under chap. 35I, L. I9I2.-The franchise tax upon any corporation issuing such shares of stock payable under sec. 182 of the tax law shall be determined by taking as a base such portion of net assets of the corporation as its gross assets employed in any business within this state, bear to its entire gross assets wherever employed in business, and the rate of such franchise tax shall be fixed in the manner provided in said sec. 182 of the tax law. For this purpose the rate of dividends shall be computed by dividing 
the total amount of dividends which have been paid during the year by the amount of net assets of the corporation upon the first day of such year. (Stock Corp. L., sec. 21 am'd ch. 501, L. 1917, in accordance with the recommendation of the Tas Commission of 1915.)

Note.-After ascertaining the total amount taxable as above, if there are several classes of stock, the preferred having preference in payment of principal, it would appear that the value of the common may be determined by deducting the proportionate share of the par value of the preferred from such amount. 


\section{CHAPTER VI.}

Principles Determining Taxation of Foreign Corporations Under Sections 181 and 182 of the Tax Law.

The same principles of taxation apply to domestic and foreign corporations in determining the amount of capital stock employed within the state for the purposes of the annual franchise tax. If there is no property or business done in the state there is no basis for the tax.

Requirements for taxation of foreign corporation.-Two concurring conditions are necessary for the taxation of foreign corporations under sections 181 and 182 of the Tax Law:

1. Foreign corporations shall be doing business in the state;

2. Its capital, or some part thereof, shall be "employed within this state."

People ex rel. Chicago Junc. Ry. Co. v. Roberts, 154 N. Y. 1 (1897) ; rev'g 90 Hun, 474.

See also People ex rel. Harlin \& H. Co. v. Campbell, 139 N. Y. 68 (1893).

Interstate commerce.-A railroad incorporated in another state, having terminal facilities and real estate here, employing workmen and keeping money in bank in this state, incidental to its business, of forwarding and receiving passengers between New York and other states, is engaged in interstate commerce and not taxable on its capital employed here. People ex rel. Pa. R. R. $v$. Wemple, 65 Hun, 252 (1892) aff'd 138 N. Y. 1. But a railroad employing its capital in cab service, beginning and ending in this state, for which a separate charge is made, is taxable thereon, 
since it is not a part of the interstate commerce of a railroad company. The tax is not on the property of the company, but on its privilege of exercising its corporate franchises. People ex rel. Penn. R. R. v. Knight, 67 App. Div. 398 (1901); aff'd 171 N. Y. 354 (1902) ; aff'd in 192 U. S. 21 (1904).

A more recent case, People ex rel. International Elevator Co. v. Roberts, 116 App. Div. 30 (1906), intimates that the franchise tax may be imposed on a corporation engaged in interstate commerce, provided part of its business is done in the state.

Good-will; United States copyrights ; patents.-Good-will of a foreign corporation carrying on business in this state and nowhere else is subject to a franchise tax under sections 181 and 182 of the Tax Law. People ex rel. Johnson Co. v. Roberts, 159 N. Y. 70 (1889). In the last named case it was held that the copyrights were not taxable, but a later case overruled so much of the decision as was applicable to the taxation of copyrights and clearly upheld the right of the state to impose a franchise tax on a corporation owning letters patent or copyrights. People ex rel. U. S. Aluminum Printing Co. v. Knight, 174 N. Y. 475 (1903); see, also, People ex rel. Edison El. Ill. Co. v. Wemple, 61 Hun, 53 (1891).

Some of the business corporations in the cases above cited are now taxed under Article 9-a of the Tax Law on net income on a somewhat different basis, but the rules laid down in these cases continue to apply to corporations now taxable under Sections 181 and 182 of the Tax Law.

\section{When Foreign Corporations Have Been Held to Be Doing Business or Employing Capital Within the State.}

Selling western mortgages.-A foreign corporation having an office in New York for the sale of mortgages on western real estate, depositing the proceeds of sale in New York, and sending the funds to the home office for re-investment, is doing business within the state. People ex rel. N. E. Loan \& Invest. Co. v. Roberts, 25 App. Div. 16 (1898). 
A foreign corporation is doing business when it becomes a special partner in a limited partnership within this state, and is liable to taxation on the amount of its capital contributed to the partnership. People ex rel. Badische Anilin \& Soda Fabrit Co. v. Roberts, 152 N. Y. 59 (1897) ; O’Brien, J., dissenting.

\section{When Foreign Corporations Are Not Doing Business or Employing Capital in the State.}

Foreign corporation carrying on business through brokers. -A foreign corporation carrying on business through brokers in this state, consigning goods to them for sale at a price fixed by it, or in fulfillment of orders approved by it, was held not to be carrying on business here, although the proceeds of sale were deposited in bank in New York to its credit. People ex rel. Southern Cotton Oil Co. v. Roberts, 25 App. Div. 13 (1898). The court said in this case that "the goods consigned to commission merchants were in their possession and control, and their disposition in accordance with the directions of the relator was a part of their business, not the business of the relator. A commission merchant has ordinarily a right to sell in his own name (Story's Agency, Secs. 33 and 34). As to the public he is the dealer."

In another case, People ex rel. Washington Mills v. Roberts, 8 App. Div. 201 (1896), it was held that where a foreign corporation solicited orders through agents in the state, which were filled from the factory in the home office, and leased offices, kept samples and a bank account in New York State, it was not taxable here. This case was followed in People ex rel. H. P. Smith $v$. Roberts, 27 App. Div. 455 (1898). The court held in these cases that the business of soliciting orders in the state was not taxable, and that the bank account and samples were not taxable, but merely incidental to the business of soliciting orders.

Newspaper advertising agency forwarding printed matter. -A case on the same lines is that of People ex rel. A. M. Kellogg Newspaper Co. v. Roberts, 30 App. Div. 150 (1898). This was a foreign corporation with a home office at Chicago, Illinois, which 
was engaged in forwarding printed matter from its home office to be used by New York newspapers, and had an office in New York for soliciting advertisements. These advertisements were forwarded to Chicago and the collections made thereon were deposited in a New York bank and credited to the Chicago office. It was held not to be capital employed in the state.

An earlier and frequently cited case in which the right of a foreign corporation to maintain an office and salaried agent here, was maintained, was People ex rel. Harlin \& Hollingsworth Co. v. Campbell, 139 N. Y. 68 (1893). The business of this corporation was manufacturing and equipping railway and steamship cars in the State of Delaware, where all its business was transacted and manufacturing done. While the maintenance of a New York office might be doing business, there was no capital employed by the corporation which would subject it to a tax under the statute.

Telephone companies leasing telephones to local companies. -In People v. American Bell Telephone Co., 117 N. Y. 241 (1889), reversing 50 Hun, 114, it was held that where a Massachusetts company leased to certain corporations in this state, under contracts executed in Boston, telephones which were delivered to lessees in that city, at its office, the local companies supplying poles, wires, plant, agents, etc., but the lessor company supplying much of the capital of the local companies, that the lessor company was not carrying on business in this state within the act.

Cases which seem to be overruled by the amendment of I906.-Under the law prior to 1906 a foreign corporation investing its capital in the stock of another corporation, domestic or foreign, was not engaged in business in the state, even if the corporation in whose stock its capital was invested was so engaged in business. People ex rel. Chicago Junc. Ry. Co. v. Roberts, 154 N. Y. 1 (1897) ; People ex rel. Edison Co. v. Kelsey, 101 App. Div. 205 (1905); People v. American Bell Telephone Company, 117 N. Y. 241 (1889).

The present statute expressly declares that "for the purposes of taxation the capital of a corporation invested in the stock of an- 
other corporation shall be deemed to be assets located where the physical property represented by such stock is located."

This also changes the rule in the case of a domestic corporation investing its capital in the stock of another corporation, domestic or foreign. Such a corporation investing its capital in the stock of a foreign corporation was formerly not taxable, but if its capital was invested in the stock of a domestic corporation it was held to be taxable. People ex rel. Edison Electric Light Company v. Campbell, 138 N. Y. 543 (1893); same v. same, 148 N. Y. 690 (1896). Under the present law such corporations are taxable only if the physical property represented by such stock is located in the state. 


\section{CHAPTER VII.}

Annual Tax on Transportation, Transmission, Heat, Light, Power and Water Companies Based on Gross Earnings.

The law imposing an additional franchise tax on transportation and other companies (Chapter 361, Laws of 1881) was amended in 1894 (Chapter 562) by excluding interstate earnings. Prior to this amendment there had been a decision on the state's right to tax gross earnings derived from the carriage of interstate passengers. People ex rel. Dunkirk, etc., Ry. Co. v. Campbell, 74 Hun, 210 (1893). This decision of the Supreme Court appears to be in line with Maine v. Grand Trunk Ry., 142 U. S. 21\%, in which the Supreme Court held that the tax was on the franchise and not on interstate commerce. The amendment of the law obviated this question.

The present law, section 184 Tax Law, reads as follows:

Additional franchise tax on transportation and transmission corporations and associations.-Every corporation and joint-stock association formed for steam surface railroad, canal, steamboat, ferry, except a ferry company operating between any of the boroughs of the City of New York under a lease granted by the city, express, navigation, pipe line, transfer, baggage express, telegraph, telephone, palace car or sleeping car purposes, and every other transportation corporation not liable to taxation under section one hundred and eightyfive or one hundred and eighty-six of this chapter, shall pay for the privilege of exercising its corporate franchises or carrying on its business in such corporate or organized capacity in this state, an annual excise tax or license fee which shall be equal to five-tenths of one per centum upon its gross earnings within this state, which shall include its gross earnings from its transportation or transmission business originating and terminating within this state, but shall not include earnings derived from business of an interstate character. (Former sec. 184, Tax Law, as amended by ch. 734, L. 1907, ch. 334, L. 1914.) 
Source: Ch. 361, L. 1881, secs. 6 and 11, as amended by ch. 562, L. 1894, without change of substance.

Recent Amendments.-The amendment of 1914 exempted ferry companies operating between the boroughs of New York City from the additional franchise tax.

Additional tax in nature of license fee.-The additional franchise tax is to be considered in the nature of a license fee. In People ex rel. Cornell Steamboat Co. v. Sohmer, 206 N. Y. 651 (1912), Cullen, C. J., said: "I doubt whether in the true sense of the term it is to be considered a tax, but should not rather be deemed a compensation exacted for the privilege which the state might refuse." This tax is imposed on transportation corporations as distinguished from general corporations.

Constitutionality of tax on gross receipts of transportation or transmission companies.-It is to be observed that the above $\operatorname{tax}$ is a license tax on earnings within the state. In Osborne $v$. Mobile, 16 Wall. 479 (1872), the United States Supreme Court has upheld the right of a state or municipality to impose a license tax. It must, however, be for the transacting of business within the state. Such business is intra-state and not inter-state commerce. Pacific Express Co. v. Seibert, 142 U. S. 339 (1892); Postal Telegraph Co. v. Charleston, 153 U. S. 692 (1894). A state tax on gross freight receipts has been upheld, although partly derived from interstate business. State Tax on railway gross receipts (Reading R. R. v. Pa.), 15 Wall. 284 (1872).

On the other hand it has been held by the New York Court of Appeals that a corporation organized under the General Railroad Law of New York, engaged in the transportation of grain from ports outside of the state to ports in the state, and vice versa, owning a grain elevator, warehouse and short railroad track used in its business, cannot be taxed on its gross receipts derived from the storage and handling of interstate trade, because under section 184 of the Tax Law it is in no event to "include earnings derived from business of an interstate character." People ex rel. C. T. R. Co. v. Miller, 178 N. Y. 194 (1904), reversing 84 App. Div. 174, Cullen, Vann and Martin, JJ., dissenting. 
United States mail carriers not taxable if they carry interstate mail.-Gross earnings of a railroad company derived from carrying United States mail are not taxable where the mail carried includes not only domestic but also interstate and foreign letters and packages, and it is impossible to ascertain the proportion of mail which originates and terminates in the state. People ex rel. N. Y. Cent. \& Hud. Riv. R. R. v. Morgan, 168 N. Y. 1 (1901).

Meaning of "gross earnings" in this section.-The term "gross earnings from its transportation or transmission business" covers all receipts of a corporation specified in section 184 growing out of employment of its capital, whether employed in the transportation or transmission business or otherwise. People ex rel. N. Y. Cent. \& Hud. R. R. v. Roberts, 32 App. Div. 113 (1898).

Section 185 of the present Tax Law, imposing a franchise tax on elevated railroads or surface roads not operated by steam, reads as follows:

Franchise tax on elevated railroads or surface railroads not operated by steam.-Every corporation, joint-stock company or association owning or operating any elevated railroad or surface railroad not operated by steam shall pay to the state for the privilege of exercising its corporate franchise or carrying on its business in such corporate or organized capacity within this state, an annual tax which shall be one per centum upon its gross earnings from all sources within this state and three per centum upon the amount of dividends declared or paid in excess of four per centum upon the actual amount of paid-up capital employed by such corporation, joint-stock company or association. Any such railroad corporation whose property is leased to another railroad corporation shall only be required under this section to pay a tax of three per centum upon the dividends declared and paid in excess of four per centum upon the amount of its capital stock, except that where the property leased is operated by a receiver and the gross earnings are not included in the gross earnings of the lessee for the purpose of taxation under this section, then such receiver shall be required to pay the tax upon gross earnings as hereinbefore provided. (Former sec. 185, Tax Law, as amended by ch. 474, L. 1906, ch. 710, L. 1917.) 
Recent Amendments. -The amendment of 1917 added the exception as to property leased and operated by a receiver.

Corporations operating elevated railroads or surface railroads not operated by steam, which formerly paid a tax on capital stock as well as on gross earnings are exempted from the payment of the former tax by section 183, Tax Law.

Under section 35 of the Rapid Transit Act (Chapter 616, Laws of 1900), a corporation operating a subway is exempt from taxation on its rolling stock and equipment but not on its real estate used in connection with the road. It was held in People ex rel. Interborough Rapid Transit Company $v$. Williams, 200 N. Y. 93 (1910), that while this exemption relieved the company from taxation on the interest acquired and the property used in carrying out. the contracts for the equipment and operation of the subway road, it did not exempt the subway from the payment of any franchise tax whatever. The wording of section 185 whereby any "elevated or surface railroad" was made subject to a tax upon its gross "income from all sources," was held not broad enough to cover the earnings from the subway operated by the elevated road, although the subway was one of the sources of income of the elevated road. It was intimated by the court that the subway might be taxable under sections 182 and 184, and in the case of People $v$. Sohmer, 207 N. Y. 272, decided in 1913, it was held that the exemption under 183, of corporations operating elevated railroads or surface railroads not operated by steam, and taxable under 185, did not apply to subways, but that the latter are taxable under sections 182 and 184.

Sec. 186. Franchise tax on water works companies, gas companies, electric or steam heating, lighting and power companies.Every corporation, joint-stock company or association formed for supplying water or gas, or for electric or steam heating, lighting or power purposes, shall pay to the state for the privilege of exercising its corporate franchises or carrying on its business in such corporate or organized capacity in this state, an annual tax which shall be five-tenths of one per centum upon its gross earnings from all sources within this state, and three per centum upon the amount of dividends declared or paid in excess of four per centum upon the 
actual amount of paid-up capital employed add: in this state by such corporation, joint-stock company or association add: which amount of capital employed in this state shall be found by dividing the gross receipts from all sales made in this state, by the gross sales wherever made and multiplying the aggregate paid in capital stock by the percentage so found. The term "gross earnings" as used in this section means all receipts from the employment of capital without any deduction. (Present and former sec. 186, Tax Law, as amended by ch. 734, L. 1907, and ch. 548 L. 1919.)

Recent Amendments.-The amendment of 1919 provides for the method of finding the amount of capital employed in the state.

These companies which formerly paid a tax on capital stock under Chapter 542, Laws of 1880, are exempted from paying a tax on capital stock under section 183, Tax Law.

The amendment of 1907 to section 186 defined the term "gross earnings" and provided for taxing "gross earnings from all sources," adding the words that it meant "all receipts from the employment of capital without any deduction." In People ex rel. Westchester L. Co. v. Gaus, 199 N. Y. 147, the court refused to place an interpretation on this amendment that would permit any deduction for the cost of raw material converted into gas and electric current for the replacement of capital, which the relator in that case held was not an employment of capital. This case was followed in People ex rel. Genesee Light \& Power Co. v. Sohmer, 162 App. Div. 20\%, aff'd 212 N. Y. 598, where no deduction was allowed in the case of an electric company which bought some of its current, later resold by it, from another company. The relator then sought to have the section declared unconstitutional but the court held in People ex rel. Genesee Light \& Power Co. $v$. Saxe (1917), 179 App. Div. 48\%, aff'd 223 N. Y. 690, that there was no unfair discrimination, as the law applied equally to all corporations of the same class.

The amendment of 1907 to section 186 probably grew out of the decision in People ex rel. Brooklyn Union Gas Co. v. Morgan, 114 App. Div. 266 (1906), which held that the value of certain investments in raw materials, such as coal and oil used in making 
gas by a gas company, should be deducted before computing the $\operatorname{tax}$; that, otherwise, the tax would be on gross receipts and not on gross earnings. The present statute obviates the necessity of any such distinction. 


\section{CHAPTER VIII.}

\section{Annual Tax on Insurance Companies, Based on Gross Premiums.}

\section{Premiums received on business done in the state defined.-}

The tax is computed on the basis of premiums received on business done at any time in the state and is for the privilege enjoyed and not on the property in the state in the case of a foreign fire insurance company. People ex rel. Conn. Mutual Life Ins. Co. v. Kelsey, 116 App. Div. 97 (1906), aff'd 188 N. Y. 541.

Franchise tax on insurance corporations.-An annual state tax for the privilege of exercising corporate franchises or for carrying on business in their corporate or organized capacity within this state equal to one per centum on the excess of the gross amount of premiums charged, over the deductions hereinafter provided, during the preceding calendar year for business done at any time in this state, shall be paid annually into the treasury of the state on or before the first day of June. The gross amount of premiums subject to deduction shall include all premiums charged during such preceding calendar year on all policies, certificates, renewals, policies subsequently cancelled, insurance and reinsurance executed, issued or delivered during such preceding and all prior calendar years. The excess of the gross amount of premiums taxable shall be found by deducting from the total amount of premiums charged, including reinsuranoe premiums charged, for business done in this state under all such policies, certificates, renewals, policies subsequently cancelled,-insurance and reinsurance executed, issued or delivered during such preceding and all prior calendar years, the amount of premiums paid for reinsurance in corporations taxed under this section, unearned premiums returned on cancellation of policies, premiums on policies not taken and all the so-called dividends made to policy holders, but not including deferred dividends paid in cash to policy holders on maturing policies; provided, however, that in the case of life insurance companies the 
word "charged" wherever it appears shall bo understood to mean the amount of premiums received. Such tas shall bo paid by the cortporation which charges the premium provided it is one of the corporations hereinafter described:

1. Every domestic insurance corporation, incorporated, organized or formed under, by, or pursuant to a general or special law;

2. Every insurance corporation, incorporated, organized or formed under, by, or pursuant to the laws of any other state of the United States, and doing business in this state, except a corporation doing a fire insurance business or a marine insurance business;

3. Every insurance corporation, incorporated, organized or formed under, by, or pursuant to the laws of any state without the United States, or of any foreign country, except such a corporation doing a life, health or casualty insurance business, and doing business in this state; but the tax on gross premiums of a corporation so incorporated, organized or formed and doing a fire or marine insurance business within the state shall be equal to five-tenths of one per centum. This section does not apply to a fraternal beneficiary society, order or association, a corporation for the insurance of domestic animals, a town or county co-operative insurance corporation, nor to any corporation subject to the supervision of or required by or in pursuance of law to report to the superintendent of banks; but this section does apply to an individual, or partnership, or association of underwriters known as Lloyds in so far as corporations doing the same kind of insurance business are subject to its provisions. The taxes imposed by this section shall be in addition to all other fees, licenses or taxes imposed by this or any other law, except that in assessing taxes under the reciprocal provision of section thirty-three of the insurance law, credit shall be allowed for any taxes paid under this section. The term "insurance corporations" as used in this article shall include a corporation, association, joint-stock company or association, person, society, aggregation or partnership by whatever name known doing an insurance business in this state. (Present and former sec. 187, Tax Law, as amended by ch. 494, L. 1897, ch. 118, L. 1901, ch. 94, L 1905, ch. 796, L. 1917, and ch. 625, L. 1919.)

Source: Sec. 5, ch. 361, L. 1881, as amended by ch. 425, L. 1895; sec. 1, ch. 679, L. 1886, as amended by ch. 418, L. 1895.

Recent Amendment.-The amendment of 1919 provides the method for finding the excess of the gross amount of premiums taxable. 
No deductions for the two per cent. annual tax payable to superintendent of insurance.-Under subdivision 2, section 187, as amended by Chapter 118, Laws of 1901, the tax imposed is in addition to all other fees, licenses and taxes, and a foreign marine insurance company cannot deduct the annual tax of two per cent. payable to the superintendent of insurance under section 34, Insurance Law. People v. Thames \& Mersey Marine Ins. Co., 176 N. Y. 531 (1903). Section 34 reads as follows:

Taxation of foreign corporations. - "The capital of an insurance corporation incorporated under the laws of any state or country outside of the United States, to the extent employed in the transaction of business in this state, and as determined and certified as prescribed by section twenty-seven of this chapter, shall be subject to taxation the same as the capital of a like domestic insurance corporation, to be levied, assessed and collected, as prescribed by law, at such place in the state as it shall have its principal office. Upon satisfactory proof to the superintendent of insurance that any foreign insurance corporation has neglected or refused to pay any tax levied and assessed under the laws of this state, he shall revoke any certificate of authority granted by him to such corporation to do business in this state, and it shall thereafter be precluded from doing business herein. Every health, or casualty insurance corporation incorporated by or organized under the laws of any government outside of the United States engaged in the transaction of the business of health or casualty insurance in this state, under a certificate of authority from the superintendent of insurance shall annually on or before the first day of March, pay to the superintendent of insurance a tax of two per centum on all premiums received in cash or otherwise by its attorneys or agents in this state during the year ending on the preceding thirty-first day of December for business done at any time in this state on risks resident therein. Every life insurance corporation incorporated by or organized under the laws of any government outside of the United States engaged in the transaction of the business of life insurance in this state, under a certificate of authority from the superintendent of insurance shall annually, on or before the first day of March, pay to the superintendent of insurance a tax of one per centum on all premiums received in cash or otherwise by its attorneys or agents in this state during the year ending on the preceding thirty-first day of December, for business done at any time in this state on risks resident therein. If any such corporation shall neglect or refuse to pay such tax, the superintendent shall collect the same out of the interest on the 
stocks or securities deposited in the insurance department. The agent of every corporation, association or individual not incorporated by the laws of this state to effect insurance against marine risks shall annually, on or before the first day of February, pay to the superintendent of insurance a tax of two per centum upon the amount of all premiums upon insurance against marine risks which have been received by such agent or any person for him or have been agreed to be paid for any such insurance effected or agreed to be effected or procured by him, within this state, for the year ending the thirty-first day of December preceding. In ascertaining the amount of premiums upon which said two per centum tax is to be levied, there shall be deducted from the premiums aforesaid, on account of reinsurances, such portion of the premiums upon said reinsurances as may have been paid to companies that are subject to the payment of the tax hereby provided for, but no credit or deduction shall be allowed on account of such reinsurances where any part of the risk insured against is reinsured in a corporation authorized to effect insurances against fire, or in the fire insurance branch of a corporation authorized to effect insurance against both marine and fire risks." (Former sec. 34, Ins. Law, as amended by ch. 725, L. 1893, ch. 708, L. 1904, ch. 634, L. 1910, and ch. 766, L. 1911.)

Amendment of 1905.-Chapter 94 of the Laws of 1905 amended section $18 \%$ of the Tax Law and materially changed the method of computing the tax on insurance companies. Prior to the passage of this law it had been held that a tax of one per cent., imposed under section 187 of the Tax Law, on the gross premiums of domestic insurance companies applied only to first year premiums on new policies and not to renewal policies. People ex rel. Provident S. L. A. Society v. Miller, 179 N. Y. 227 (1904) ; reversing 88 App. Div. 218, Vann and Bartlett, JJ., dissenting. By the amendment of 1905 a tax was imposed not only on premiums collected on new policies but also on the gross amount of premiums received during the preceding calendar year on all policies, all renewal premiums, insurance and re-insurance executed, issued and delivered in all years prior to such preceding calendar year. See also People ex rel. Conn. Mutual Life Ins. Co. v. Kelsey, 116 App. Div. 97 (1906).

A somewhat different question was raised in People ex rel. Continental Insurance Co. v. Miller, 177 N. Y. 515 (1904), in which 
the court held that the premiums refunded to policy holders of domestic fire insurance companies are not to be taxed under section 187 , since no "business is done" after the cancellation of the policy. 


\section{CHAPTER IX.}

Annual Franchise Tax on Trust Companies, Savings Banks, Investing Companies and Foreign Bankers.

Relieved from all other taxes.-Trust companies were intended to be relieved by section 188 (former sec. 18\%-a), Tax Law, from taxation on personal property for all other purposes from the date of the passage of the act, March 21, 1901. Binghamton Trust Co. v. Binghamton, 72 App. Div. 341 (1902).

Franchise tax on trust companies.-Every trust company, incorporated, organized or formed under, by or pursuant to a law of this state, and any company authorized to do a trust company's business solely or in connection with any other business, under a general or special law of this state, shall pay to the state annually for the privilege of exercising its corporate franchise or carrying on its business in such corporate or organized capacity, an annual tax which shall be equal to one per centum on the amount of its capital stock, surplus and undivided profits. (Sec 188, former sec. 187-a, Tax Law, added by ch. 132, L. 1901, and amended by ch. 535, L. 1901.)

Apportionment of tax.-The basis of the tax is the average amount of capital, surplus and undivided profits during the preceding year. This is more equitable to both the trust company and state than if a special date was fixed upon which same should be taken, for such a date might find the trust company with either an unusually large or an unusually small amount of surplus and undivided profits. If the trust company has not been doing business during the entire fiscal year, the tax must be apportioned accordingly. People ex rel. Mutual Trust Co. v. Miller, 177 N. Y. 51 (1903) ; see People ex rel. Bklyn R. T. Co. v. Morgan, 57 App. Div. 335; People ex rel. Lincoln Trust Co. v. Glynn (1909), 132 A. D. 546, aff'd 198 N. Y. 501, holding also that the method of 
taxing trust companies had not been changed by the 1906 amendment to section 182, making tax payable in advance.

Sec. 188-a. Taxation of investment companies.-Every investment company incorporated, organized or formed under, by or pursuant to the banking law of this state and actually exercising the powers conferred by both subdivisions two and four of section two hundred and ninety-three of the banking law, shall annually pay to the state, for the privilege of exercising its corporate franchise or carrying on its business in such corporate or organized capacity, a tax of an amount equal to one and one-half mills for every dollar face value of its capital, and in addition thereto a tax equal to one per centum of its surplus and undivided profits.

This section was added by Chapter 707, Laws of 1917, as a substitute for the tax on personal property (from which these investment companies are now exempt under Article I, Section 4, Subdivision 14, of the Tax Law). It applies only to the so-called Morris Plan Companies.

Franchise tax on savings banks.-Every savings bank incorporated, organized or formed under, by or pursuant to a law of this state, shall pay to the state annually for the privilege of exercising its corporate franchises or carrying on its business in such corporate or organized capacity, an annual tax which shall be equal to one per centum on the par value of its surplus and undivided earnings. (Sec. 189, Tax Law, formerly sec. 187-b, added by ch. 117, L. 1901.)

Purchase of state bonds; credit to be given.-Every corporation, company or association required by section one hundred and eightyseven, one hundred and eighty-eight or one hundred and eighty-nine of this chapter, to pay to the state an annual tax equal to a percentage of its gross premiums, capital stock, surplus, undivided profits or undivided earnings, or one or more, for the privilege of exercising its corporate franchise or carrying on its business in such corporate or organized capacity, which shall own any of the bonds of the state of New York, shall have credited to it annually to apply upon or in lieu of the payment of such tax an amount equal to one and one-half per centum of the par value of all such bonds of the state, bearing interest at a rate not exceeding three per centum per annum, owned by such corporation, company or association, and registered in its name or registered in the name of a public department, a public officer or officers of this state, or of any state, or of the United States, in trust for such corporation, company or association, on the thirtieth day of June prior to the date when such tax shall become due and 
payable; provided, however, that there shall in no case be credited to any such corporation, company or association an amount in excess of the amount due to the state from such corporation, company or association for taxes payable to the state under this chapter for the fiscal year for which such credit is given; and further provided that any such credit so allowed under this section shall not bear interest. (Section 190 of the Tax Law, as amended by ch. 357 of the Laws of 1913, and ch. 794, L. 1913.) The latter amendment of 1913 eliminated the former, so there is no change in the statute.

Source: Former Sec. 187c, Tax Law, as added by ch. 550, L. 1907, and am'd by ch. 228, L. 1908.

Exception.-Bonds registered with an officer of the Dominion of Canada in trust for policy holders are not entitled to the exemption from taxation provided for in this section. (Report Atty. Genl. [1914], 129.)

Bonds, etc., forming surplus not to be valued above par.Bonds and securities in which surplus may be invested are to be assessed at market value, if below par, and at face value if above par. People ex rel. Bank for Savings $v$. Miller, 177 N. Y. 461 (1904).

Tax upon foreign bankers.-Every foreign banker doing business in this state, shall annually pay to the treasurer a tax of five per centum on the amount of interest or compensation of any kind earned and collected by him on money loaned, used or employed in this state by such banker.

The term, doing a banking business, as used in this section means doing such business, as a corporation may be created to do under article three of the banking law, or doing any business which a corporation is authorized by such article to do. The term, foreign banker doing a banking business in this state, as used in this section includes:

1. Every foreign corporation doing a banking business in this state, except a national bank.

2. Every unincorporated company, partnership or association, of two or more individuals, organized under or pursuant to the laws of another state or country, doing a banking business in this state.

3. Every other unineorporated company, partnership or association, of two or more individuals, doing a banking business in this state, if the members thereof, owning more than a majority interest therein, 
or entitled to more than one-half 'of the profits thereof, or who would, if it were dissolved, be entitled to more than one-half of the net assets thereof, are not residents of this state.

4. Every non-resident of this state, doing a banking business in this state, in his own name and right only. (Section 191, former sec. 188, Tax Law, as amended by ch. 500, L. 1900.) 


\section{CHAPTER X.}

Reports to be Filed with the Tax Commission-Statement of Tax and Payment Thereof Under article 9.

Section 192 of the Tax Law provides for the making of reports by the various classes of corporations hereinbefore referred to, liable to taxation under Article 9 of the Tax Law. It reads as follows:

Reports of corporations.-Corporations liable to pay a tax under this article shall report as follows:

1. Corporations paying franchise taX.-Every corporation, association or joint stock company liable to pay a tax under section one hundred and eighty-two of this chapter shall, between first of November and fifteenth of December in each year, make a written report to the tax commission of its condition at the close of its business on October thirty-first preceding, stating the amount of its authorized capital stock, the amount of stock paid in, and date and rate per centum of each dividend declared by it during the year ending with such day, the entire amount of the capital of such corporation, and the capital employed by it in this state during such year. Upon written application the state tax commission may, in its discretion, extend the time in which to make the report, but not beyond the fifteenth day of February succeeding.

2. Transportation AND tRANSMission CORPORATIONS.-Every transportation or transmission corporation, joint stock company or association liable to pay an additional tax under section one hundred and eighty-four of this chapter, shall also, on or before August first in each year, make a written report to the tax commission of its condition at the close of its business on June thirtieth preceding, stating the amount of its gross earnings from all sources and the amount of its gross earnings from its transportation or transmission business originating and terminating within this state.

3. Elevated AND SURFACE RAILBOAd CORPoBATIONs.-Every corporation, joint stock company or association liable to pay a tax under section one Htundred and eighty-five of this chapter, shall, on or before 
August first of each year, make a written report to the tax commission of its condition at the close of its business on June thirtieth preceding, stating the amount of its gross earnings from business done in this state, the amount of dividends of every nature declared or paid during the year ending June thirtieth, the authorized capital of the company and the amount of capital stock actually issued and outstanding.

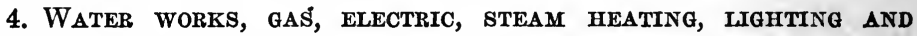
POWER CORPORATIONS. - Every corporation, joint stock company or association liable to pay a tax under section one hundred and eighty-six of this chapter, shall, on or before December first of each year, make a written report to the tax commission of its condition at the close of its business on October thirty-first preceding, stating the amount of its gross earnings from business done in this state, the amount of dividends of every nature declared or paid during the year ending with October thirty-first, the authorized capital of the company and the amount of capital stock actually issued and outstanding.

5. Insuranice CORPORATIONS.-Every insurance corporation liable to pay a tax under section one hundred and eighty-seven of this chapter, shall, on or before March first in each year, make a written report to the tax commission of its condition at the close of its business on December thirty-first preceding, stating the gross amount of all premiums referred to in section one hundred and eighty-seven of this chapter, received during the preceding calendar year on business done thereby in this state during the year ending with such day, and at all times prior thereto, whether the premiums were in money or in the form of notes, credits or other substitutes for money. ( $S u b d$. 5, amended by ch. 118, L. 1901, and ch. 94, L. 1905.)

6. Foreign baNKers.-Every foreign banker liable to pay a tax under section one hundred and eighty-eight of this chapter shall, on or before February first in each year, make a written report to the tax commission of the condition of his business on December thirtyfirst preceding, stating the amount of tax for which he is liable under this article, and giving in detail the facts required by the last preceding section for the purpose of ascertaining and computing the same.

7. Trust companies.-Every company liable to pay a tax under section one hundred and eighty-eight of this chapter shall on or before August first in each year, make a written report to the tax commission of its condition at the close of business on June thirtieth preceding, separately stating the amount of its capital stock, the amount of its surplus, and the amount of its undivided profits, and containing such other data, information or matter as the tax commis- 
sion may require. (Added by ch. 132, L. 1901, and re-enacted by ch. 172, L. 1902.)

8. SAvings BANKS.-Every savings bank liable to pay a tax under section one hundred and eighty-nine of this chapter, shall on or before August first in each year make a written report to the tax commission of its condition, at the close of business on June thirtieth preceding, stating the par value of its surplus, and undivided earnings and containing such other data, information or matter as the tax commission may require.

9. Investment compaxies.-Every investment company liable to pay a tax under section one hundred and eighty-eight-a of this chapter shall, on or before August first in each year, make a written report to the tax commission of its condition at the close of business on June thirtieth preceding, separately stating the amount of its capital stock, the amount of its surplus, and the amount of its undivided profits, and containing such other data, information or matter as the tax commission may require. (Former sec. 189, Tax Law, added by ch. 117, L. 1901, ch 317, L. 1915, ch. 707, L. 1917.)

Source: Ch. 361 of L. 1881, sec. 1; ch. 361 , L. 1881, sec. 5, as amended by ch. 425 , L. 1895 ; ch. 361 , L. 1881, sec. 7 ; ch. 409 , L. 1882, sec. 322 , as amended by ch. 196, L. 1894; ch. 679, L. 1886, sec. 2. Subds. 7, 8 and 9 of the above section are new.

Recent Amendments. - The amendment of 1915 required the reports to be made to the state tax commission, instead of comptroller. The amendment of 1917 extended the time for making the report.

The time when taxes are payable by the various classes of corporations required to make reports under the various provisions of the foregoing section, is fixed by section 197 (former 194) of the Tax Law (infra).

Prospective character of section 192.-When a corporation organized in February, 1880, made a report under section 192 (formerly 189) in November, 1880, and paid a tax in January, 1881, such report and payment were proper, even though the corporation had not been in existence one year. This construction does not give the act a retroactive effect, as the tax was for the prospective fiscal expenditures for the year commencing October 30, 1880. People v. Spring Valley Hydraulic Gold Co., $92 \mathrm{~N}$. Y. 383 (1883). 
The above act is prospective in character. The tax imposed is not for the past but for the future engagements of the franchises. People v. Albany Ins. Co., 92 N. Y. 460 (1883).

Further requirements as to reports of corporations.-Every report required by this article shall have annexed thereto the affidavit of the president, vice-president, secretary or treasurer of the corporation, association or joint stock company or of the person or one of the persons, or the members of the partnership making the same, to the effect that the statements contained therein are true. Such reports shall contain any other data, information or matter which the tax commission may require to be included therein, and he may prescribe the form in which such reports shall be made and the form of oath thereto. When so prescribed such form shall be used in making the report. The commission may require at any time a further or supplemental report under this article, which shall contain information and data upon such matters as the commission may specify. (Sec. 194, former sec. 191, Tax Law, amended ch. 317, L. 1915.)

Source: See source to sec. 192, Tax Law, supra; same references.

Recent Amendments.-The amendment of 1915 substitutes commission for comptroller.

Powers of tax commission to examine into affairs of corporation.-In case any report required by any of the preceding sections of this article shall be unsatisfactory to the commission, or if any such report is not made as herein required, the commission is authorized to make an estimate of the dividends paid by such corporation and the value of the capital stock employed by it, from any such report or from any other data, and to order and state an account according to the estimate and value so made by it for the taxes, percentage and interest due the state from such corporation, association, joint stock company, person or partnership. The commission shall also have power to examine or cause to be examined in case of a failure to report or in case the report is unsatisfactory to it, the books and records of any such corporation, joint stock association, company, foreign banker, person or partnership, and may hear testimony and take proofs material for its information, either personally and may appoint a commissioner by a written appointment under its official seal for that purpose. Every commissioner so appointed shall be authorized to make such examination and take such testimony and hear such proofs and report the proofs and testimony so taken and the result of his examination so made and the facts found by him to the com- 
mission. The commission shall, therefrom, or from any other data which shall be satisfactory to it, order and state an account for the tax due the state, together with the expenses of such examination and the taking of such testimony and proofs. Such expenses shall be fixed and adjusted by the commission. (Sec. 195, former sec. 192, Tax Law, amended ch. 317, L. 1915.)

Source: L. 1880, ch. 542, sec. 1, as amended by L. 1881, ch. 361 and secs. $11,12,13$, as added by L. 1882, ch. 151, and amended by L. 1885 , ch. 501, and L. 1894, ch. 562; L. 1882, ch. 409, secs. 322, 323, as amended by L. 1895, ch. 196.

Recent Amendments.-The amendment of 1915 substitutes commission for comptroller.

(This and subsequent sections are more fully treated in a later chapter.)

Comptroller not bound by corporation's report; burden on relator.-The comptroller is not bound by the report of the officers of a corporation as to the value of the stock, but may act as an assessor, and fix the value of the capital stock employed within the state of New York, according to information obtained or on his judgment, and his decision will not be disturbed unless clearly shown to be erroneous. People ex rel. Am. Axe \& Tool Co. v. Roberts, 82 Hun, 313 (1894), aff'd 147 N. Y. 69.

Evidence of comptroller's dissatisfaction with treasurer's appraisement.-The fact that the comptroller makes a new appraisement, and rejects that made by the treasurer of a corporation, is sufficient evidence of dissatisfaction with the company's appraisement. People ex rel. Metropolitan S. Co. v. Kelsey, 101 App. Div. 248 (1905).

Notice of statement of tax; interest.-Upon auditing and stating every account for taxes or other charges under this article, the commission shall forthwith send notice thereof in writing to the person, partnership, company, association or corporation against whom the same is made, which notice may be mailed to the post-office address of such person, partnership, association, company or corporation. All accounts so audited and stated shall bear interest upon the total amount found due thereon to the state, for taxes, percentage, interest and other charges, from the expiration of thirty days after sending 
such notice until payment thereof shall be made, and shall be added thereto and collected therewith by the comptroller. (Sec. 196, former sec. 193, Tax Law, ch. 317, L. 1915.)

Source: L. 1880, ch. 542, secs. 15, 16, as added by ch. 501, L. 1885, without change of substance.

Recent Amendments.-The amendment of 1915 substituted commission for comptroller and added the words at the end of the section as to the collection by the comptroller.

Payment of tax and penalty for failure.-A tax imposed by section one hundred and eighty-two or one hundred and eighty-six of this chapter, shall be due and payable into the state treasury on or before the fifteenth day of January in each year. A tax imposed by section one hundred and eighty-four of this chapter on a transportation or transmission corporation, or by section one hundred and eighty-five, on elevated railroads or surface railroads not operated by steam shall be due and payable into the state treasury on or before the first day of August in each year. A tax imposed by section one hundred and eighty-seven of this chapter on an insurance corporation shall be due and payable into the state treasury on or before the first day of June in each year. A tax imposed by section one hundred and eighty-eight, one hundred and eighty-eight-a or one hundred and eighty-nine shall be due and payable into the state treasury on or before the first day of September in each year. A tax imposed by section one hundred and ninety-one of this chapter on a foreign banker shall be due and payable into the state treasury on or before February first in each year. If such tax in any case is not paid within thirty days after the same becomes due, or if the report of any such corporation is not made within the time required by this article, the corporation, association, joint stock company, person or partuership, liable to pay the tax, shall pay into the state treasury in addition to the amount of such tax, a sum equal to five per centum thereof, and one per centum additional for each month the tax remains unpaid, which sum shall be added to the tax and paid or collected therewith. Every corporation, association, joint stock company, person or partnership failing to make the annual report required by this article, or failing to make any special report required by the commission, within any reasonable time to be specified by the commission, shall forfeit to the people of the state the sum of one hundred dollars for every such failure, and the additional sum of ten dollars for each day that such failure continues. Such tax shall be a lien upon and bind all the real and personal property of the corporation, joint stock company or as- 
sociation liable to pay the same from the time when it is payable until the same is paid in full. (Sec. 197, former sec. 194, Tax Law, as amended in 1901, chs. 118, 132 and 558, ch. 317, L. 1915 and 707, L. 1917.)

Source: L. 1881, ch. 361 , secs. 4, 5, 6, 7; L 1882, ch. 409, sec. 322 , as amended by L. 1895 , ch. 196 ; L. 1886 , ch. 679 , sec. 1 , as amended by L. 1895, ch. 418 .

Recent Amendments.-The amendment of 1915 substitutes commission for comptroller. The amendment of 1917 inserts the reference to section one hundred and eighty-eight-a (investment companies).

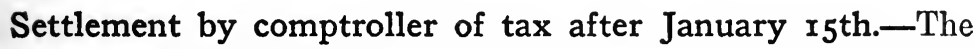
comptroller may settle an account for a tax imposed by section 182, Tax Law, after the 15th day of January in the year in which the tax becomes due. People ex rel. F. A. Stokes Co. v. Roberts, 90 Hun, 533 (1895).

Lien of tax on real and personal property.-The precise time at which the lien attaches does not appear to be fixed by the statute. Section 197 of the Tax Law provides that the tax is due and payable on or before the various dates mentioned therein. It also appears that such tax may be settled after the dates mentioned (People ex rel. Stokes Co. v. Roberts, supra). It is not unreasonable to suppose that it runs from the time mentioned in section 196, viz., from the day the tax is audited and stated, and notice thereof sent to the corporation or person chargeable therewith. This is on the theory applied in the local taxation of real and personal property, when a tax is presumed to be due at the time it is fixed and extended on the tax rolls. Lathers $v$. Keogh, 109 N. Y. 583 (1888) ; Burr v. Palmer, 53 App. Div. 358 (1900).

Priority in payment of state tax from insolvent estate.State taxes are entitled to a priority in payment out of the funds of an insolvent corporation by a receiver appointed in proceedings to foreclose a mortgage on the company's property. Central Trust Co. v. N. Y. C. \& H. R. R. Co., 110 N. Y. 250 (1888). In a recent case where the property of an insolvent corporation was operated by the receiver pendente lite, and franchise taxes were 
levied during the time of such operation, it was held that the plaintiff who bought the property at a foreclosure sale "subject to all taxes which might be levied thereon at the time of the sale," had taken the property subject to such lien, and that the state's taxes were paramount to all prior encumbrances. N. Y. Terminal Co. v. Gaus, 204 N. Y. 512 (1912).

In the Matter of Carnegie Trust Co., 206 N. Y. (1912), 398, the court said that while it entertained no doubt as to the wisdom of adopting the doctrine that the state may claim priority in respect to the payment of taxes, "there is one limitation and that pertains to claims in which a prior specific lien has been obtained by the creditors" citing Wise v. Wise Co., $153 \mathrm{~N}$. Y. $50 \%$.

In the latter case taxes assessed upon the personal property of a corporation became due subsequent to the levy of an attachment and execution by creditors. The corporation was insolvent and a receiver appointed. The receiver of taxes sought to have his claim satisfied in preference to the judgment on the theory that the sovereign from most ancient times was entitled to priority of payment over all claims by subjects. The court did not sustain this contention, but held there was no authority for preferring such claims over specific prior liens-distinguishing Central Trust Co. v. N. Y. C. (supra).

The Federal Court in construing this very section (sec. 197) and having before it the question of whether the state has a priority of payment out of a fund in court for distribution, in the case of Central Trust Co. v. Third Ave. R. Co., 186 Fed. 291 (1911) says: "We think it fair to suppose the legislature intended to make the tax a lien on the property in its then condition," i. e., at the time the lien accrued, and therefore subject to the mortgage.

In Sweet v. The All-Package Grocery Stores Co., U. S. District Court for the Southern District of New York, reported in the N. Y. Law Journal of April 25, 1919, Judge Hand held: that, while as a matter of general administrative procedure the state courts have decided that a tax or other indebtedness to the state is entitled to payment prior to all claims not based on a specific lien, the federal courts will not grant such a priority under the Bankruptcy Law 
unless such a lien exists; that there is no essential difference between a license fee to begin business (181) and a license fee to continue business (182) excepting that under the provisions of section 197 a lien is imposed in the latter case. The court in this case quotes with approval the three cases mentioned above. 



\section{PART II}

\section{THE BUSINESS CORPORATIONS TAX}

BEING THE FRANOHISE TAX ON CORPORATIONS BASED ON NET INCOME UNDER ARTICLE 9-A OF THE TAX LAW. 



\section{CHAPTER XI.}

Amendments of 1919 to Article 9-a.

The franchise tax on manufacturing and mercantile corporations passed in June, 191\%, by the Legislature of the State of New York, and known as Chapter 726 of the laws of that year, imposed a tax of $3 \%$ based on their net income returned to the Treasury Department under the Federal Income Tax Act. This law was amended in 1918 principally to settle doubtful portions deemed unconstitutional, and by Chapter 628 of the Laws of 1919, it was again amended. The important changes in Chapter 628 are given below.

I. Business corporations taxed.-It brought within its provisions, by changes in the title and body of the act, all business corporations with the exception of those expressly exempted under Section 210 of the act.

2. Entire net income taxed.-Under Paragraph 3 of Section 208, it clearly outlined that the entire net income of the corporation was to be taxed and defined it thus:

"3. The term "entire net income" means the total net income before any deductions have been made for taxes paid or to be paid to the government of the United States on either profits or net income or for any losses sustained by the corporation in other fiscal or calendar years whether deducted by the government of the United States or not."

3. Foreign corporations' return.-It added to the first paragraph of Section 211 the following sentence:

"Any corporation not organized under the laws of any state within the United States shall state the facts in relation to its entire net income as though organized under the laws of this state." 
The purpose of this addition was to apportion the $\operatorname{tax}$ on the basis of the entire income earned by a foreign corporation doing business outside of the United States in the proportion that the income earned by it in the state bore to the entire income. In its return to the Treasury Department such foreign corporation may only return and be taxed on the income earned by it within the United States.

4. Stock in other corporations to be allocated.-It added subdivision 5 to Section 211. This subdivision included among the bases of the apportionment of income earned within the state by a corporation having assets elsewhere, the value of stock in other corporations owned by it, as allocated by the process set forth in Section 214. It reads as follows:

" 5 . The average total value for the fiscal or calendar year of the stock of other corporations owned by the corporation, and the proportion of the average value of the stock of such other corporations within the state of New York, as allocated pursuant to section two hundred and fourteen of this chapter."

5. Segregation required.-It added to the eighth paragraph of Section 211 a provision for the segregation of assets where there was no income, in the following words:

"Corporations having no net income shall, however, complete the segregation of assets in every case."

The purpose of this amendment was to enable the Tax Commission properly to allocate or apportion the minimum tax under the method of computation provided in Section 214 of the act.

6. Merged and consolidated corporations.-By more appropriate words in Section 214-a, referring to merged and consolidated corporations, it sought to prevent evasions of the law. The amended section, showing in the brackets the words omitted, and the new words by italics, are given below:

Sec. 214-a. Taxation of [merged or consolidated] corporations aoquiring assets or franchises of other corporations. If any corporation taxable under this article shall [take over] acquire either directly, indirectly or by merger or consolidation the major portion of 
the assets or the franchise of another corporation or of corporations exercising any franchise or franchises or doing any business in this state during [the] any year [ending with the thirty-first day of October, such corporation shall make a consolidated report for all the corporations so merged or consolidated as though the merged or consolidated corporation had existed and done business as an entity throughout the year for which the report is made and shall be taxed for the year to ensue upon the basis of such report and as hereinbefore provided in this article], it shall include in its oun next annual return, in addition to its own entire net income, so much of the entire net income of the corporation or corporations whose assets or franchises it acquired as shall not have been used or included in measuring a franchise tax to this state, and shall not be taxed upon such combined entire net incomes for the year to ensue and as hereinbefore provided. The provisions for a minimum tax shall be applied only when under such provisions a tax will result in excess of the amount which would be produced by a tax on entire net income as hereinbefore provided and then in lieu thereof.

7. Rate now $4 \frac{1}{2} \%$. - The rate of tax in Section 215 was increased from 3 to $4 \frac{1}{2} \%$.

8. Comptroller may refund under I9I9 law.-The last paragraph of Section 219-j as it heretofore existed was omitted and a provision was inserted for the refunding by the Comptroller out of the current revenues in his hands, of excess taxes paid by a corporation by reason of a credit given by the Tax Commission under this section. A more convenient administrative arrangement for charging or crediting such taxes was provided in the 1919 law, which is given in full at the end of Chapter XVII infra.

9. Fixtures defined.-It amended Section 219-1 by more clearly defining personal property as applied to manufacturing corporations. Differences resulting in construing the original section as changing the definition of real estate, had led to much litigation in connection with the assessment of buildings by local assessors. The amended section with the omitted words shown in brackets and the new words by italics, is given below:

Sec. 219-1. Personal property defined. The term "personal prop. erty," for the purposes of the exemption from assessment and taxa- 
tion thereon locally as granted by section two hundred and nineteen-j of this chapter, shall include [such] any movable machinery and equipment [affixed to the building as would not pass between grantor and grantee as a part of the premises if not specifically mentioned or referred to in the deed, or as would, if the building were vacated or sold, or the nature of the work carried on therein changed, be moved, except] used for trade or manufacture and not essential for the support of the building, structure or superstructure, and removable without material injury thereto. The term "personal property," as used in such section, shall not include boilers, ventilating apparatus, elevators, [gas, electric and water] plumbing, heating, lighting and power generating apparatus, [and] shafting other than counter-shafting, equipment for the distribution of heat, light, power, gases and liquids, nor any equipment consisting of structures or erections to the operation of which machinery is not essential. An owner of a building is entitled to the same exemption under this section as a lessee [and every assessment of real property made subsequent to June fourth, nineteen hundred and seventeen, shall be subject to the provisions of this section as amended hereby].

Sec. 15. This act shall not affect any action or proceeding now pending.

Sec. 16. This act shall take effect immediately.

10. Administrative changes.-An amendment to Section 219-a changed the date from November 1st to December 1st in each year when the Tax Commission shall audit and state the account of each corporation liable to a tax under Article 9-a. There were slight verbal changes in Sections 209, 211, 214, 219-b and 219 - $d$ to carry out the purpose expressed in Section 208 that the tax was to be based on the entire income, and the second paragraph of Section 211 contained a statement that deductions for losses in prior years should be specified in the report. Section 219-j was amended by Chapter 138 of the Laws of 1919 providing for a refund by the Comptroller to corporations paying excess taxes. 


\section{CHAPTER XII.}

Subjects of Taxation.

I. Business corporations taxed.-Article 9-a added as a new article to the Tax Law by Chapter 726 of the Laws of 1917, amended by Chapter 276 of the Laws of 1918, imposed a tax on manufacturing and mercantile corporations based on net income, and Chapter 628 of the Laws of 1919 extended the scope of the law so that it applied practically to all business corporations and exempted only Realty Companies, Holding Companies, Public Service and Public Utility Corporations, Banks, and Insurance Companies (Section 210).

2. Personal service corporations now taxable under Article 9-a.-There had been some duplication of assessments by local assessors and the State Tax Commissioners under the 1917 and 1918 laws. This duplication occurred more often with Hotel corporations and Contracting companies who rendered personal service and at the same time supplied merchandise or material.

The case of People ex rel. McCord v. Cantor pending in the Supreme Court, New York County, raises such an issue as to the right to tax such corporations for local purposes prior to the 1919 amendments to Article 9-a. The present law places all of these personal service corporations, whether engaged in purely personal service or of a mixed character, under Article 9-a.

The state may now tax on the basis of net income varied forms of personal service corporations engaged in business including Accounting, Advertising, Assaying, Auto-Garage, Bonding, Chemical Laboratory, Collection, Custom House, Brokerage, Dredging, Engineering, Hotel, Insurance, Brokerage, Investment, Laundry, Pattern Publication, Restaurant, Safe Deposit, Salvage and Wrecking, 
Shipping Agent, Steamship Agent, Storage Warehouse, Taxicab, Theatre Ticket, Trucking, etc., Corporations.

3. Exceptions from tax.-Section 210 of the Tax Law as amended in 1918, containing the classes of corporations exempt from the franchise tax on net income, reads as follows:

Sec. 210. Corporations exempted from article.-Corporations wholly engaged in the purchase, sale and holding of real estate for themselves, holding corporations whose principal income is derived from holding the stocks and bonds of other corporations and corporations liable to a tax under section one hundred and eighty-four to one hundred and eighty-nine inclusive of this chapter, banks, savings banks, institutions for savings, title guaranty, insurance or surety corporations shall be exempt from the payment of the taxes prescribed by this article.

Realty corporations are only exempted from Article 9-a if they purchase, sell or hold real estate for themselves. They are then taxable under Article 9. If they engage in construction work or act as agents for others, they will be taxable under Article 9-a.

Holding corporations are defined as those whose principal income is derived from holding the stocks and bonds of other corporations. If the income is partly derived from holding the securities of other corporations and in part from other sources, that from which the greater source of revenue is derived determines the basis of the tax. If there is no net income, in cases of mixed corporations of this character, then the basis of determining the tax will depend upon the source from which the larger amount of gross revenue is received.

The term "holding corporations" has been construed by the State Tax Commission to mean that class of corporations whose activities are confined to holding stocks and bonds for purposes of control in a permanent manner and not such as are engaged in selling various stocks and bonds and replenishing a stock of such securities from time to time. In other words, "holding corporations" are not defined to be merely such as derive their principal income from hold- 
ing stocks and bonds, but such as are actually holding companies. (N. Y. State Tax Bulletin, May, 1919.)

The exemption by specific mention, as well as by mention of section numbers, is a double expression of intention. The specific exemptions of banks, savings banks, institutions for savings, title guaranty, insurance or surety corporations also fall within the exemptions of insurance corporations, trust companies and savings banks, covered by Sections 187 to 189 .

The following are the exceptions made by reference to section numbers of the Tax Law:

Section 184.-Corporations formed for steam surface railroad, canal, steamboat, ferry, express, navigation, pipe line, transfer baggage express, telegraph, telephone, palace or sleeping car purposes, and every other transportation corporation not included in Sections 185 and 186.

Section 185.-Railroads, elevated or surface, not operated by steam.

Section 186.-Waterworks, gas, heat, light and power, electric or steam companies.

Section 18\%.-Domestic insurance corporations and insurance corporations formed in other states of the United States, and doing business in this State, except fire and marine insurance companies; and those formed under the laws of foreign states and countries (except life, health, or casualty companies) and Lloyds underwriters; this section does not include fraternal benefit orders, domestic animal insurance companies, town and county co-operative insurance companies, and companies required to report to the superintendent of banks.

Section 188.-Domestic trust companies and any company authorized to do trust company business, solely or in connection with any other business under general or special law.

Section 189.-Savings banks formed under the laws of this State. 


\section{CHAPTER XIII.}

\section{What Is Net InCOME.}

\section{The Present Law:}

Sec. 209. Franchise tax on corporations based on net income. -For the privilege of exercising its franchise in this state in a corporate or organized capacity every domestic corporation, and for the privilege of doing business in this state, every foreign corporation, except corporations specified in the next section, shall annually pay in advance for the year beginning November first next preceding an annual franchise tax, to be computed by the tax commission upon the basis of its entire net income for its fiscal or the calendar year next preceding, as hereinafter provided, which entire net income is presumably the same as the entire net income upon which such corporation is required to pay a tax to the United States.

The amendments of rgr8-Constitutionality.-The amendments of 1918 struck out the clause in the Act of 191\%, which made the income upon which foreign and domestic manufacturing and mercantile corporations are required to pay a federal income tax, the essential basis for the computation of this annual franchise tax. It was the purpose of those who drew the law, to make the income tax report of these corporations to the United States, the basis for the State franchise tax. The amendments of 1918 aimed to avoid the objection that the State had deputized its tax assessing powers to the federal internal revenue authorities.

The State Tax Commission in its 1918 annual report, recommended the addition of the word "presumably," which change would relieve the Commission from the absolute necessity of taking the figures of the United States Treasury Department as the amount of the net income.

The same idea was carried out by adding to the end of Subdivision 2, Section 211, calling for the report of the corporation to 
be made to the State Tax Commission, the italicized words shown at the end of the following paragraph:

"2. The amount of its net income for its preceding fiscal or the preceding calendar year as shown in the last return of annual net income made by it to the United States treasury department, and if the corporation shall claim that such return is inaccurate, the amount claimed by it to be the net income for such period."

The amendments of I9r9.-While the 1918 amendments were designed to make the law constitutional, the amendments of 1919 were intended to clarify the construction placed upon Section 209 . Under the former section many corporations contended that the net income upon which "the corporation was required to pay a tax to the United States" meant the total net income returned to the Treasury Department, less the excess profits tax. The Legislature of 1919, therefore, inserted the word "entire" before the words "net income" in the several places where they occurred in the statute, and in Section 208 of the new law, under the heading of "Definitions," added the new paragraph defining net incomes, supra.

The excess profits deduction.-The confusion that had arisen in relation to the construction of the statute was largely due to the fact that the original New York law provided that the tax be based on the net income "upon which such corporation is required to pay a tax to the United States." Both the federal income tax and the federal excess profits tax are based on a report of "net income on which corporations are required to pay a tax to the United States." In the case of the federal income tax, the excess profits tax is deducted before calculating the amount upon which the corporation is required to pay a tax to the United States. This is done in accordance with Section 29 of the federal income tax law of September 8th, 1916, as amended by the act of October 3d, 1917, which reads as follows:

In assessing income tax, the net income embraced in the return shall also be credited with the amount of any excess profits tax imposed by act of Congress and assessed for the same calendar or fiscal year upon the taxpayer. 
The excess profits tax, however, is determined on the whole amount of net income returned by the corporation. The state tax commission has made a ruling that the net income which the New York law required to be returned as the basis of the tax, is the "total net income required by answer No. 8 in form No. 1031, of the federal corporation income tax return, from which the excess profits tax has not been deducted."

The corporations' contention.-Attorneys representing corporations, which, under this ruling, would be obliged to pay heavy taxes on their entire net income including the charge represented by the excess profits tax, objected to this decision of the state tax department on the ground that it was not a fair construction of the statute. They contended that at the time the state income tax law was passed on June 4th, 1917, it was the intention of the New York Legislature to create a tax burden falling equally upon all corporations directly proportionate to their net income or profits. The tax was to be paid by each corporation "upon the basis of its net income for its fiscal or calendar year next preceding, as hereinafter provided, upon which income such corporation is required to pay a tax to the United States." Although the word "income" was not repeated before the word "tax," it was the income tax of the United States to which the statute had reference and to no other tax. They argued that the federal law of September 8th, 1916, provided that in arriving at the net income, the federal income tax should be deducted; that there was at that time no excess profits tax payable to the federal government; that the federal act of October $3 \mathrm{~d}, 1917$, was passed and amended the income tax act of 1916 , by providing for an excess profits tax in addition to the income tax; that the amended federal act provided that in arriving at the taxable net income the income tax should not be deducted, but that the excess profits tax should be deducted. That the federal tax therefore ceased to be imposed upon the same net income; that in order to continue the imposition of the New York tax upon an equal (net income) basis, the state law was amended so that the corporation might report its actual net income, viz., the income after 
the deduction of the excess profits tax. This was the true net income on which the corporation paid a tax to the United States. To carry out this purpose, the New York amendment was to be "construed as having been in effect $* * *$ as of the date of the original enactment of the New York law." Hence federal income taxes were to be deducted under the 1917 state law, and excess profits taxes were to be deducted under the 1918 New York law. This in each case would result in net income from the corporation's standpoint.

Massachusetts and Connecticut laws.-Two recent decisions of sister states, on this question, are worthy of notice. The first is the opinion of the Attorney-General of Connecticut, dated March 1st, 1918, in relation to the Connecticut income tax law of 1915 , and the other is a decision of the Supreme Court of Massachusetts, in American Printing Co. v. Commonwealth of Massachusetts, construing the net income tax on corporations, reported in $120 \mathrm{~N}$. E. 686. Both decisions permit a deduction of the excess profits tax. The Massachusetts income tax law is almost identical with the Connecticut law and the Connecticut law is similar in language to the New York law. In both cases it was required that every corporation should render to the tax commission "a true copy of the last return made to the collector of internal revenue, of the annual net income $* * *$ and such other information as may be requested by the United States treasury department for the purpose of ascertaining the total amount of net income taxable under the United States income tax act; the net income of such corporation after making the deduction authorized." "The laws of each of these states requires a tabulation of all the particulars by which the United States arrives at the net income subject to the tax, and appropriates it as part of its own method of computing the net income. No opportunity for correction or change is permitted either by the corporation or by the tar commission of those states. The treasury department ruling is binding on that point. The main points of difference are: (1) that the Massachusetts and Connecticut laws are income tax laws and based on net income; (2) that 
the wording of the Massachusetts and Connecticut acts is essentially different, being based on' "net income taxable under the United States income tax act." (3) The New York law uses the result of the federal return as far as the total net income is concerned, for the purpose of information and assessment, but reserves to itself the right to ascertain what is net income in case of inaccuracy or error, while the Connecticut and Massachusetts laws leave no discretion in the tax commissioner but oblige him to accept the net income as determined under the federal rules and regulations.

The State's Contention.-The New York Legislature adopted as the basis for the franchise tax on manufacturing and mercantile corporations the figure "reported" as "net income" to the federal government in the returns made to that government, subject to correction by the State Tax Commission for inaccuracies or errors which could have been corrected by the federal authorities themselves.

The definition of "net income" for purposes of this state franchise tax is found in Sections 211 and 214, which explain the provisions of Section 209. "Net income" means "entire net income" of the corporation.

The sole purpose of the state legislation of 1918 amending Article 9 -a so as to make the net income, taxable under the state law, "presumably" the same as the net income taxed by the United States and permitting corrections by the state tax commission for fraud, evasion or errors, was not to require the state tax commission to accept in every instance as a matter of law the figure showing the net income reported to the United States by deducting the income taxes paid and crediting the excess profits taxes paid to the federal government, but simply to protect the constitutionality of our statute by making the assessment of net income under the state law a proceeding separate from the assessment of net income under the federal laws.

- The amendments of 1918 did not cut away the basis of assessment. The state franchise tax was still to be computed on the "net income" of the corporation for the "preceding" year as "re- 
turned" to the federal government. Errors or inaccuracies of fact could be changed (such changes as the federal administrative authorities themselves could make), but the underlying method of arriving at net income found in the federal laws which set forth specifically the deductions permitted from gross income, was still retained by the state law. Whatever was "net income" and was reported as such under federal laws was basically the "net income" under the state law.

The state was not taxing income at all, but was assessing a state franchise privilege by a single tax on the value of the exercise of the corporate franchise within the state for the previous year, with no concern of the amount of tax a corporation had paid to the federal government whose jurisdiction to tax was a matter wholly apart from the state's right to tax that corporation.

The court's ruling.-The issue was finally presented to the Appellate Division of the Third Department, in People ex rel. Barcalo Manufacturing Company v. Knapp and People ex rel. American Broom \& Brush Company v. Knapp, et al., etc., in April, 1919, and decided in favor of the State. Justice Woodward saying in the opinion of the Court:

"The rule seems entirely simple. The presumption is that the 'entire net income' returned by the corporation to the United States treasury department is the real net income of the corporation. If the corporation, in its return to the State, finds that it has erroneously stated any fact in its report to the United States it is privileged to state the amount claimed by it to be the net income, and the state tax commission is authorized to make corrections for 'fraud, evasion or errors' so that the actual 'entire net income' for the year involved shall be made to appear, and upon this basis the tax of 3 per cent. is imposed for the privilege of exercising corporate franchises in this state.

"In the cases now before us, the state tax commissioners have followed the statute literally; they have taken the 'entire net income' of the corporations involved, as returned to the United States treasury department, and no questions of fraud or evasion are involved. The relators contend, not that there is anything wrong with their returns to the United States, but that in some manner the United States statutes operate to change the law as it appears from a literal read- 
ing, and that the so-called excess profits taxes assessed for and as of the year 1917 should be deducted from the incomes of these corporations before the computation of the state franchise tax is made, and that the income taxes paid to the federal government during the year 1917 by the American Broom and Brush Company, should be deducted from its income before such computation by the state tax commission is made.

"But, why? This is not an income tax; it is a franchise tax. It is a tax for the privilege of doing business in a corporate form in the State of New York, and the only relation of the federal act to the statute of New York is the basis for the computation of the state tax. It provides for a 3 per cent. tax upon the basis of the 'entire net income' of the corporation as shown by its report to the United States government, unless such income is erroneously stated, when the actual 'entire net income' as determined by the Tax Commission becomes the foundation of the assessment."

Entire net income for 1918 , in the light of the above decision, would seem to include the $\$ 2,000$ exemption allowed each corporation under the 1918 Federal Act, but would permit a deduction for so much of the income derived from obligations of the United States as may be exempt under the Federal Act, and also for all income from state, municipal, farm loan bonds and dividends on stocks of corporations. 


\section{CHAPTER XIV.}

\section{Foreign Corporations.}

\section{Doing business in this State.}

That capital be employed within the State in order to subject a foreign corporation to assessment of the income tax under the Act of 1917 and the amendatory legislation since enacted is of consequence only in regard to the apportionment of the earnings of a corporation doing business in this and in other States according to the ratio of its realty, stocks of merchandise, and accounts receivable located here to the totals of those items of assets wherever located. See Section 214.

"Business is a very comprehensive term, and embraces everything about which a person can be employed."

Flint v. Stone Tracy Co. 220 U. S. 10\%; People ex rel. Hoyt v. Tax Commissioners, 23 N. Y. 244. There is a difference between "engaged in business" sufficiently to confer by service of process jurisdiction on a court and "doing business" in the sense that confers jurisdiction on the Tax Commission to assess a tax.

In Tanza v. Susquehanna Coal Co., 220 N. Y. 259, it was held of a corporation having its principal office and its coal yards in Pennsylvania, and a sales office in New York, orders obtained by which were subject to the confirmation of the Philadelphia office to which all payments by the customers were made, that the company was doing business within this state in such a sense and to such a degree as to subject it to the jurisdiction of our courts. This was on the authority of International Harvester Co. v. Kentucky, 234 U. S. 579 and Green v. Railway Co., 205 U. S. 530.

But in International Text Book Co. v. Tone, 220 N. Y. 313, it was held that a correspondence school fulfilling its contracts by 
transmitting information through the mails was doing nothing in New York except in furtherance of interstate commerce in maintaining division agencies here, and could not be subjected to a license tax by reason of maintaining those agencies.

\section{Doing local business in connection with interstate com- merce.}

Transporting freight, communication by telegraph or telephone, and sales, purchases and shipments of goods between states are operations of interstate commerce. As such they are beyond the reach of restrictions, exactions, license taxes, business taxes, and occupation taxes. No state can interfere with the enforcement by a foreign corporation of its sales contracts with citizens of the state for goods to be shipped from outside the state. A license tax may not be exacted for the operation of an interstate ferry. Savage v. Atlanta Home Ins. Co., 55 App. Div. 20. Keeping an office to show samples is not "doing business" in a state, since using samples like employing salesmen is a means of carrying on interstate commerce. Cheney Bros. v. Massachusetts, 246 U. S. 147; McCall v. California, 136 U. S. 104; Crenshaw v. Arkansas, 227 U. S. 389 ; International Text Book Co. v. Begg, 217 U. S. 92.

Selling goods through a commission house is not doing business although the commission merchants are in effect a substitution for a selling agency given up to escape a tax on capital employed in this state. People ex rel. So. Cotton Oil Co. v. Roberts, 131 N. Y. 64, 25 App. Div. 13. On the other hand, keeping a sales office with a resident manager is local business falling within the taxing power of the state. Sending machines into a state, to sell, try, rent; buying, exchanging and selling machines of another make; keeping a mechanic to make repairs, and a stock of parts and supplies, is doing business. Datton Adding Machine Co. v. Virginia, 246 U. S. $498 ; 118 \mathrm{Va} .563$. Various operations, such as hiring laborers to dig ditches, and build and paint foundations in installing an electric signal system, repairing and selling second hand motor cars, keeping a stock of type setting machine parts for repair orders, 
keeping a garage and service station, keeping an office from which solicitors from retailers of orders to be filled by jobbers are sent, keeping an office under a provision in the corporate charter for distributing in dividends the proceeds of a foreign mining and smelting business, have been held to be "doing business" locally and subject to state taxation,-General Railway Signal Co. v. Virginia, 246 U. S. 500, 118 Va. 301; Locomobile Co. v. Massachusetts, 246 U. S. 146, 38 S. C. R. 298, 228 Mass. 117; Lanston Monotype Case, 246 U. S. 147; Northwestern Consolidated Milling Case, 245 U. S. 644, 38 S. C. 297 ; Champion Copper Co. v. Mass., 246 U. S. 147, 38 S. C. R. 297; White Co. v. Mass., Idem., but state taxation for the privilege of doing a local business based on the total capitalization of the foreign corporation and with no provision for a maximum tax to prevent an arbitrary and unreasonable result, disproportionate to the local business done and capital employed or invested locally is invalid because it is a direct burden upon interstate commerce and an interference with it. Statutes of Massachusetts, Oklahoma and Texas have been condemned in the Federal Supreme Court on this ground. In Looney $v$. Crane, 245 U. S. 178, a foreign corporation had a capital and surplus account all told of $\$ 25,000,000$, and had only $\$ 300,000$ employed in Texas in a warehouse and the goods therein. It was taxed $\$ 1 \%, 000$ for the privilege of doing business in Texas in lieu of $\$ 200$ under the previous statute. In International Paper Co. v. Massachusetts, 246 U. S. 135, a tax of $\$ 5,500$ on a foreign corporation which had only $2 \%$ of its assets and did only $14 \%$ of its business in the State was pronounced unconstitutional, because the law under which it was imposed did not contain, as did a former act held valid, a restriction to a maximum tax of $\$ 2,500$. A tax on gross earnings even has been upheld, when expression of the intention to avoid burdening interstate commerce as such is embodied in a statutory provision that it should be in lieu of all other taxes whether on property or otherwise. Cudahy Packing Co. v. Minn., 246 U. S. 450; Myer v. Wells Fargo \& Co., 223 U. S. 298. 


\section{Local business taxed in proportion to goods and accounts here located.}

On the face of it, the New York Income Tax Law of 1917 does not, even in any extreme instance, present any unconstitutional interference with interstate commerce. No constitutional obstacle will be encountered in levying a tax, the apportionment of which as to local business done here is based upon stocks of goods, either manufactured here or sold here, and bills receivable for such stock of goods, with the item added of services rendered under the heading of bills receivable. This last factor in the apportionment, will cover the cases of corporations engaged, for instance, in construction work, or engineering contracting, organized in another State but deriving income within this State. The credits and accounts receivable, carried on the books of such a corporation, would not proceed from stocks of material or goods manufactured in New York or sold in Nèw York, or carried in New York warehouses. Such corporations do not make or sell their materials, they put them together and leave them in a permanent location. Their profits could not be credited to the manufacture or sale of tangible personal property, but would fall logically and accurately within the description of "services performed" under an engineering or construction contract. The item of bills receivable for services performed would also apply to a commission business for which an office is maintained within the State.

\section{The Wisconsin income tax case.}

The Wisconsin Income Tax Law of 1911 (Section 1087 M. 1) undertook to tax non-residents "upon income derived from sources within the State," with a proviso that any person engaged in business within and without the State shall be taxed only upon the proportion of the income derived from business transacted and property located within the State.

In U. S. Glue Co. v. Oak Creek, 161 Wis. 211, it was held that income of a domestic corporation from goods owned by it purchased outside the State and shipped either from the seller, or from a factory in Wisconsin, to its branch houses in other states, and thence 
sold and delivered to customers outside the State, is a separable class of income, and that such business is transacted and located without the State. The incidental management from the home office in Wisconsin and the accounting for the proceeds to it, does not make it taxable in Wisconsin.

In the same case, the point was raised and decided as to the constitutionality of taxing income derived from goods sold to customers outside the State from branch offices maintained outside the State, from the standpoint of levying a tax upon transactions in interstate commerce. The court held "the manufacture, the management, and the conduct of the business at the home office are the controlling features in the process of disposing of the article and constitute the source out of which the income issues, and give it a situs within the State under the Income Tax Law."

The reasoning of the court was in substance as follows: That the income tax is not a tax on property as such, but is a tax on the income under the amendment of the Constitution of Wisconsin; that the income tax law did not seek to reach property or an interest in property as such, but to reach incomes having either a situs within the State or a source within the State; that income is the net result of many combined elements, of which the manufacture, the management and conduct of the business at the home office are essential and controlling, and that the different elements are not absolutely separable, and that it is no objection to taxing income produced in part from the profits of business conducted through branch offices in other states, and dealings at the branch offices with customers in other states, that it came from property of itself non-taxable.

This case distinguished the Philadelphia \& S. S. Co. v. Pennsylvania, $122 \mathrm{U}$. S. 326, where a tax levied on the gross receipts of a steamship company for interstate freight was held to be a tax upon interstate commerce, and therefore invalid, and it relied for the distinction on Flint $v$. Stone Tracy Co., 220 U. S. 10\%, to the effect that it is no valid objection to the standard of measuring a privilege tax, that there is included within the standard, as part of it, property which as such, could not be directly taxed. 
For the affirmance in the United States Supreme Court on June 3d, 1918, Justice Pitney, in writing the opinion, quoted from Postal Telegraph Cable Co. v. Adams, 155 U. S. 688, 695-696, as follows :

"But property in a State belonging to a corporation, whether foreign or domestic, engaged in foreign or interstate commerce, may be taxed, or a tax may be imposed on the corporation on account of its property within a State, and may take the form of a tax for the privilege of exercising its franchises within the State, if the ascertainment of the amount is made dependent in fact on the value of its property situated within the State (the exaction, therefore, not being susceptible of exceeding the sum which might be leviable directly thereon), and if payment be not made a condition precedent to the right to carry on the business, but its enforcement left to the ordinary means devised for the collection of taxes."

In another portion of his opinion, in pointing out the distinction between a tax which is a direct burden on interstate commerce, and one which is an indirect burden, he says:

"The correct line of distinction is so well illustrated in two cases dectded at the present term that we hardly need go further. In Crew Levick Co. v. Pennsylvania, 245 U. S. 292, we held that a state tax upon the business of selling goods in foreign commerce, measured by a certain percentage of the gross transactions in such commerce, was by its necessary effect a tax upon the commerce, and at the same time a duty upon exports, contrary to sections 8 and 10 of Article I of the Constitution, since it operated to lay a direct burden upon every transaction by withholding for the use of the State a part of every dollar received. On the other hand, in Peck \& Co. v. Lowe, Collector, decided May 20th last, ante, p. - we held that the Income Tax Act of October 3d, 1913, Chap. 16, Sec. 2, 38 Stat. 166, 172, when carried into effect by imposing an assessment upon the entire net income of a corporation approximately three-fourths of which was derived from the export of goods to foreign countries, did not amount to laying a tax or duty on articles exported within the meaning of Art. I, Sec. 9, cl. 5, of the Constitution.

"The distinction between a direct and an indirect burden by way of tax or duty was developed, and it was shown that an income tax laid generally on net incomes, not on income from exportation because of its source or in the way of discrimination, but just as it was laid on other income, and affecting only the net receipts from exportation 
after all expenses were paid anc losses adjusted and the recipient of the income was free to use it as he chose, was only an indirect burden. "The difference in effect between a tax measured by gross receipts and one measured by net income, recognized by our decisions, is manifest and substantial, and it affords a convenient and workable basis of distinction between a direct and immediate burden upon the business affected and a charge that is only indirect and incidental. A tax upon gross receipts affects each transaction in proportion to its magnitude and irrespective of whether it is profitable or otherwise. Conceivably it may be sufficient to make the difference between profit and loss, or to so diminish the profit as to impede or discourage the conduct of the commerce. A tax upon the net profits has not the same deterrent effect, since it does not arise at all unless a gain is shown over and above expenses and losses, and the tax cannot be heavy unless the profits are large. Such a tax, when imposed upon net incomes from whatever source arising, is but a method of distributing the cost of government, like a tax upon property, or upon franchises treated as property; and if there be no discrimination against interstate commerce, either in the admeasurement of the tax or in the means adopted for enforcing it, it constitutes one of the ordinary and general burdens of government, from which persons and corporations otherwise subject to the jurisdiction of the States are not exempted by the Federal Constitution because they happen to be engaged in commerce among the States.

"And so we hold that the Wisconsin income tax law, as applied to the plaintiff in the case before us, cannot be deemed to be so direct a burden upon the plaintiff's interstate business as to amount to an unconstitutional interference with or regulation of commerce among the States. It was meâsured not by the gross receipts, but by the net proceeds from this part of plaintiff's business, along with a like imposition upon its income derived from other sources, and in the same way that other corporations doing business within the State are taxed upon that proportion of their income derived from business transacted and property located within the State, whatever the nature of their business. Judgment affirmed."

This opinion has been quoted here at length because it is the last word emanating from the Supreme Court of the United States, on this subject, and also because it is directly concerned with an income tax very similar in its application to that of the New York franchise tax on the net income of corporations. 


\section{Connecticut income tax case.}

The Connecticut Income Tax Law, which is substantially like the New York statute, imposes a tax of two per cent. on the net income of miscellaneous corporations based on their return made to the United States Treasury Department. It affects practically the same class of corporations that is comprehended under the New York Law. The Connnecticut Law was passed in 1915, constituting Part 4, Chapter 292 of the Public Acts of 1915, and was amended by Chapter 298 of the Public Acts of 191\%. This law came before the Connecticut courts in the case of Underwood Typewriter Co. v. Chamberlain, 102 Atlantic, 600 (December, 1917). In that case, the appellant, Underwood Typewriter Company, a Delaware corporation, had its principal office in Wilmington, Delaware; its main office was in New York City, where it contended that it was engaged in interstate commerce; its manufacturing plant was in Hartford, Connecticut, the larger part of its property and assets was located beyond the limits of Connecticut, but a large part of its tangible personal property and real estate was located in Connecticut and was used there for manufacturing purposes. The appellant's contention was that the State of Connecticut, under the guise of a franchise or privilege tax, could not impose a tax upon a foreign corporation, measured by its income from interstate commerce, although nearly one-half of its real estate and tangible personal property was located in Connecticut. While this was the question presented by the complaint, the State of Connecticut raised by demurrer, the point that plaintiff had voluntarily paid the tax demanded, and that if one pays an alleged unconstitutional tax on demand, the amount cannot be recovered. The latter point was decided in favor of the contestant without involving the decision of the question as to the validity of the law, the court holding that the plaintiff's payment of the tax under protest was not a voluntary payment but a payment under duress.

In view of the decision of the United States Supreme Court in U. S. Glue Co. v. Town of Oak Creek, cited supra, it may be doubted whether the main ground of appeal has not been covered by the decision of the Federal Court of last resort. 


\section{CHAPTER XV.}

Reports of Corporations, Segregation of Assets.

\section{Domestic corporations.}

Under Section 211, every corporation taxable under Article 9-a, is required to transmit to the State Tax Commission, a report of its taxable condition. Under Section 209, every domestic corporation except those expressly specified in Section 210, is taxable, and if it be assumed that those corporations, not dissolved, are exercising or capable of exercising their corporate franchises, it is incumbent on them to file reports. The word "taxable" is used in the statute in the sense of liable to taxation. The law will infer (in the absence of proof to the contrary) that capital invested in business yields an income, and that a domestic corporation is a "stock" corporation. McLean, Receiver of Taxes v. Julien Elec. Co., $28 \mathrm{Abb}$. N. C. 349 . It has also been held in connection with the construction of a similar term such as "corporation deriving an income or profit," that it applies to every moneyed or stock corporation organized for the purpose of acquiring income or profit, and does not apply to financial condition.

In connection with Federal reports it has been held that the duty to make returns depends upon corporate or associational existence and not upon the receipt of income.

Treasury Decision 2090, December 14, 1914.

Article 9-a provides for the payment of a tax by a "domestic corporation for the privelege of exercising its franchise in this state in a corporate or organized capacity," and this does not mean actively engaged in business, nor does it mean that the corporation need be in receipt of a gross or net income, for, under the last paragraph of Section 214 there is a minimum tax of $\$ 10$ irrespective of whether the corporation earns anything or not. In the imposition of the federal capital stock tax, it has been held that 
corporations discontinuing active business and simply holding the title to property and distributing the income, are not "doing business."

In 1916, by Chapter 333, Laws of New York, there was an amendment to the New York Franchise Tax Law (Article 9), as it applied to domestic corporations, the words "exercising its corporate franchises" being substituted for the words "doing business" in the act, to make it clear that the tax was to apply to domestic corporations irrespective of whether they were actively engaged in business or not. This followed the decision in People ex rel. Lehigh \& N. Y. R. R. Co. v. William Sohmer, 217 N. Y. 443.

Corporations discontinuing business on or before October 31st in any year are not liable for taxation because the tax is payable in advance for the year beginning November 1st. No tax is refundable if a corporation ceases to do business during the year. In this respect it follows the capital stock tax under the Federal law (See Art. 1, Regulator 38, Capital Stock Tax).

\section{Foreign corporations.}

Respecting foreign corporations, Section 211 provides that "every corporation taxable under this article, as well as foreign corporations having officers, agents or representatives within the State" shall transmit to the Tax Commission, a report. Section 209 provides that "for the privilege of doing business in this State, every foreign corporation, except corporations specified in the next section" (210), shall pay an annual franchise tax.

"Doing business" as a general rule means maintaining an office and employing capital, but the statute evidently contemplates the making of a report by a foreign corporation in cases beyond this, namely, where there is a resident agent or representative within the State, and where no capital may be employed otherwise than in furnishing material or rendering services. N. Y. Terra-Cotta Co. v. Williams, 102 App. Div. 1, aff'd 184 N. Y. 579. Consequently not only foreign corporations liable to taxation, viz., those that are engaged in business within this State, but those which, while not engaged in business, have officers, agents or representatives within the State, must file a report under this article. 
Under Section 15 of the Stock Corporation Law, "no foreign stock corporation other than moneyed corporations, shall do business in this State without having first procured from the Secretary of State its certificate that it has complied with all the requirements of law to authorize it to do business in this State." Clearly, every foreign corporation obtaining such certificate must also file a report under Article 9-a of the Tax Law.

When report is to be-made.

Under Section 211, reports must be filed on or before July 1st in each year or within thirty days after making the corporate Federal Tax Reports for any fiscal or calendar year. Blank forms are sent to corporations by the State Tax Department during the month of June. The non-receipt of a blank form does not excuse a corporation from making a report. If a corporation has neglected or failed to make its Federal report, it will not be excused from making a report (Section 213) to the New York State Tax Commission, but it must (even though the time limited therefor has expired), either file its Federal Report and make a State Tax Report under this Article within thirty days thereafter, or else compute its income and then make and file the State report. Under I. T.-Mim. 2129 the time for filing corporation reports for 1918 has been extended to June 15, 1919, which extends the time for filing the New York reports until July 15, 1919. T. D. 2856, June 7, 1919, permits a further extension until July 15 for "corporations other than personal service corporations having a fiscal year ending Jan. 31, Feb. 28, or March 31, 1919." This would extend the time for filing the state return, in the case of these corporations, until August 15, 1919.

The time for filing State reports may be extended on application to the State Tax Commission, under Section 217, for good cause shown, and it may be assumed that such extension would preclude a default and bar the penalties under the law.

\section{Form of report.}

The form of report under the amendments of 1918 showed several important changes. The State was no longer concluded by 
the corporation's return to the United States Treasury Department in case of fraud, error or evasion and "if the corporation shall claim that the return made to the United States Treasury Department was inaccurate, the amount claimed by it to be the net income for such period" shall be specified in its report to the State Tax Commission. The 1919 amendments provided that the "entire net income" was to be returned without deduction for Federal Taxes or losses in previous years. The underlying method of arriving at net income employed by the Federal system as to deductions from gross income was still retained.

The duplication of accounts receivable for goods sold and for goods manufactured or shipped within the State is now avoided by more appropriate language. Due to the inapt phraseology of the 1917 statute, corporations were obliged to duplicate their outstanding accounts within and without the State, but as the general result of the apportionment of assets was approximately the same, there was no great disadvantage in this. This defect has been cured and it is now possible for a manufacturing corporation to apportion its outstanding accounts receivable for goods manufactured by it, and if it sell goods not manufactured by it, they may be classified under subdivision (b).

Through an oversight, subdivision 5 of Section 211 had been entirely omitted from the 1918 amendment. This subdivision covering the average value of shares of stock of other corporations within and without the State has now been included in the 1919 Act.

This omission in the 1918 Law was not fatal, since Section 213 points out the Commission's power to call for such other facts as it may require, for the purpose of making the computation required by Article 9-a.

Subdivision 6 of Section 214, furthermore points out the method of allocating within and without the State, the shares of stocks of other corporations owned by the reporting company, viz., "The value of the share stock of another corporation owned by a corporation liable hereunder, shall for the purposes of allocation of assets be apportioned in and out of the State in accordance with 
the value of the physical property in and out of the State representing such share stock." This is substantially in accordance with the rule laid down in Section 182 of the Tax Law, applicable to corporations taxable under Article 9. Under this rule a corporation owning stock of the New York Central Railroad Co., must first ascertain where the physical property represented by that stock is located, and apportion its stock within and without the State accordingly. If it is not in possession of this information, it may obtain it from the State Tax Commission. The reporting corporation must return in its report all the stock of other corporations, that it owns, and not an amount equal to 10 per cent. of the aggregate of real and tangible personal property. If the corporation owns 100 shares of railroad company stock, whose actual average monthly value throughout the year was $\$ 90$ per share and 40 per cent. of the railroad company's physical property was in the State, it must allocate in the column of total assets wherever located, opposite the item of average total value of shares of stocks, the amount $\$ 9,000$, and in the corresponding column of assets in New York State, the amount $\$ 3,600$ (40 per cent. of the total of $\$ 9,000)$. The amount apportioned to these respective items of only 10 per cent. of the real and tangible personal property, will be filled in by the State Tax Commission.

\section{Segregation of assets.}

Section 209 provides for "an annual franchise tax to be computed by the Tax Commission upon the basis of its entire net income for its fiscal or calendar year next preceding, as hereinafter provided, which entire net income is presumably the same as the entire net income upon which such corporation is required to pay a tax to the United States."

The sections to which the words "hereinafter provided" have reference, are Sections 211 and 214, Section 211 calling for the facts to be stated in the report and Section 214 showing the method of computation on the basis of the facts so reported. The law evidently contemplates that a corporation transacting an interstate business as distinguished from an intrastate business, shall have 
the benefit of the apportionment of the net income referred to.

Much of the confusion that has arisen in connection with the segregation of assets has been occasioned by the difficulty of fixing the situs of accounts for merchandise sold by a corporation doing an interstate business, having no warehouse or factory in the State of New York. Such corporations, while maintaining an agency or offices outside of the State, will, as a rule, carry their outstanding accounts on the books of the New York office, although much of the business arises from sales made by agencies or offices maintained outside of the State. Some of the goods never come within the State at all. A few examples will suffice to show the difficulty of segregating assets in such cases:

Cotton converting company: In the City of New York there are a large number of so-called cotton converting corporations who will contract with mills in the South or New England, for a certain quantity of unfinished goods to be woven, shrunk or converted. They will order these goods at the mills in the South or New England, and send them down to a bleachery to have them dyed and finished. Very often an office is maintained at such places and orders received, or else travelling agents will sell these goods and the orders are filled and shipped from the agencies outside of the state. The goods are insured at the places located outside of the state, in the name of the corporation and under the law they own these goods which are located outside of the state at the time of sale, and the bills and accounts receivable for them are located outside of the state and not in the state.

Cotton converting corporation selling from New York office: A domestic corporation selling all its merchandise from its New York office is engaged in the business of buying, selling and converting cotton goods. Its merchandise is manufactured outside the state and is all delivered from outside the state. None of it comes to New York State. All the sales are made from the New York office, where buyers come and make their purchases from samples. The corporation pays a nominal rent for space in the warehouses or mills outside the State where its goods are kept 
and it carries insurance on the merchandise there held. Its state tax is computed by allocating to New York State all of the bills and accounts receivable and by segregating outside the state all of the tangible personal property excepting furniture and fixtures.

Coal company: Another instance is that of a coal company buying and selling coal at wholesale with a New York City office, another sales office at Boston, Mass., and one in Virginia near the coal mines, where it maintained a stock of coal continuously and a general shipping and distributing office in charge of a manager, and where the entire business for the distribution of coal was centered. All orders were billed there, none of the coal coming into New York State, most of the sales being passed on in New York City where the principal financial office was maintained. This company owned no mining property of any kind and all of the coal was located, and most of it was sold by its agents outside of the state, the prices being fixed, in most instances, from the New York office. The difficulty in segregation here is where to allocate coal in transit and the outstanding accounts represented by the sales made outside of the state, made through the New York office from a stock of coal located outside of the state. If the strict letter of law be followed, all of the accounts will be located outside of the state. If, on the other hand, the fact that in some cases the price was fixed from the New York office, be made controlling, most of the accounts will be allocated to New York. The contracts being accepted or closed outside of the state, and the goods being located there, the accounts would seem to be properly allocated there. The fact that the price may be fixed in New York should not be a determining factor.

Import corporation: A corporation engaged in trade with the East Indies, buying crude rubber, spices, pepper, gums, chemicals, etc., maintaining its principal financial office in New York City, but having a shipping and distributing agency on the Pacific Coast with clerks in charge where the goods were inspected and distributed. Most of the contracts were consummated outside of the state by the acceptance of offers there made. Nearly all of the 
sales were made outside of the country and only a small portion of the goods were maintained or stored in New York State. The doubtful question in this case is how much of the outstanding accounts can be allocated as goods in transit sold from the New York office, since only a relatively small portion of the goods came either into the state for storage, or selling purposes, or remained on the Pacific Coast for like purposes, most of the goods being shipped directly from outside of the country to places outside of the state. The financial business of the company was conducted here, although much of the financing was done through the offices of London Banks having agencies in the East Indies.

Commission merchant maintaining office in New York: A corporation was engaged in the commission business with an office in New York City and also in New Jersey, where the President of the corporation resided, all of the goods being sold and shipped from factories outside of the state, the business being practically a one-man concern. The New York office had a few office fixtures, these being the entire tangible property. Under these circumstances and because the business was entirely a commission business, all of the outstanding accounts were allocated to New York City, the corporation being a domestic corporation. All sales were, however, made outside of the state.

Contracting company: A corporation engaged in selling structural steel and erecting the same in connection with contract work. The goods were made in Pittsburgh and sold outside of the State from a warehouse where they were kept, the contract being accepted there. The outstanding accounts for the merchandise when sold by corporations doing an interstate business, are allocated or segregated to the state where the sales are made. If the goods are in transit from New York, they are segregated in New York.

Minimum tax provision: A further important change in the method of taxation based on the report, is that calling for the amount of the corporation's issued capital stock in paragraph (1) of Section 211. 
Under the minimum tax clause in paragraph (6) of Section 214, it is provided "that every domestic corporation exercising its franchise in this State and every foreign corporation doing business in this State, other than those exempted by Section 210 of this chapter, shall be subject to a minimum tax of not less than ten dollars and not less than one mill upon each dollar of the apportionment of the face value of its issued capital stock apportioned to this State, which shall be determined by dividing the amount of the real and tangible personal property in this State by the entire amount of the real and tangible personal property as shown in the report, and multiplying the quotient by the face value of the issued capital stock. If such a corporation has stock without par value, then the base of the tax shall be on such a portion of its paid in capital as its real and tangible personal property in this State bears to its entire real and tangible personal property."

The minimum tax provision questioned.-The last sentence of this paragraph provides that a corporation organized with stock without par value is taxed on the actual value of the property while a corporation organized with stock of par value is taxed on the face value of the issued capital stock. For example, a corporation with a capital issued stock of $\$ 1,000,000$ par value, all employed in the state, having no net income for the taxable year, must pay under the minimum tax provision a tax of $\$ 1,000$, although the actual value of its property in the state is only worth $\$ 350,000$. If it had been organized with stock without par value, then the amount of the tax paid would only be $\$ 350$. We have, therefore, in the same paragraph of the law two different methods of assessment or taxation. If the corporation with stock of par value is assessed on the higher basis, may this not be deemed a violation of the fourteenth amendment of the federal constitution guaranteeing equal protection of the laws for all persons within the jurisdiction? There are two classifications for a corporation and for the same property in which a different tax would be exacted dependent upon administrative provisions under which the corporation is organized. The tax in question being a franchise or busi- 
ness tax should be uniform on all the same classes or subjects. Under Section 182 (Article 9) corporations paying no dividends, with stock of par value, are taxed in the same manner as corporations with stock of no par value. Has the State the right to change the tax dependent purely on administrative classification by a corporation, irrespective of the character of the business, or the class of corporation?

The taxation of department stores according to the number of departments was held unconstitutional in Missouri because it was unwarranted class legislation violative of the natural rights of the citizen. State ex rel. Ashbrook, 154 Mo. 375 (1900). The Court said in that case: "To have made the act apply to all merchants of a given avoirdupois or to those employing clerks of a designated stature, or to those doing business of a special architectural design, would have been as natural and as reasonable classification for the purposes in view as the classification made by the act."

Bells Gap Company case: On the other hand in the muchquoted case of Bells Gap Co. v. Pa., 134 U. S. 32, a tax arbitrarily placed on the face value of corporate stocks as to non-residents, regardless of actual value, and on actual value as to residents, was sustained. This was held not to be a discrimination on the ground that the face value of stocks as to non-residents expressed the actual value.

Illustration of report: The following form is an example of a report of a corporation doing business and having tangible assets within and without the State, operating a factory without the State, capitalized at $\$ 1,000,000$, with a net income of $\$ 20,000$ per annum, and with assets segregated as follows:

\section{TOTAL SEGREGATED ASSETS WHEREVER LOCATED.}

(a) Average monthly value of bills and accounts receivable for personal property manufactured by it........

(b) Average monthly value of bills and accounts receiv$\$ 140,000$ able for personal property sold by the corporation from merchandise owned by it at the time of acceptance of order but not manufactured by it..... 
(c) Average monthly value of bills and accounts receivable for services performed, based on orders received at offices maintained by the corporation, excluding bills and accounts receivable on orders filled from a stock of merchandise or other property maintained

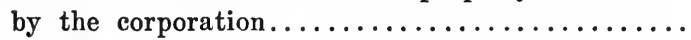
Average monthly value of all real property wherever

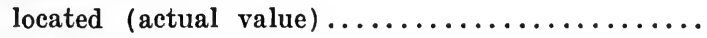
Average monthly value of all its tangible personal property wherever located (actual value) .........

Total None 40,000

260,000

Average total actual value of shares of stocks of other corporations owned by this corporation......

$\$ 480,000$

None

\section{ASSETS SEGREGATED TO NEW YORK STATE ONLY.}

(a) Average monthly value of bills and accounts receivable for personal property manufactured by it within

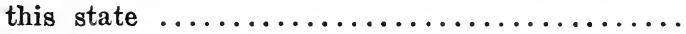

None

(b) Average monthly value of bills and accounts receivable for personal property sold by it from merchandise owned by it and located in this state at the time of acceptance of the order, but not manufactured by it within this state..............

(c) Average monthly value of bills and accounts receiv$\$ 21,000$ able for services performed, based on orders received at offices maintained by the corporation within this state, excluding bills and accounts receivable arising from sales made from a stock of merchandise or other property at a place of business maintained by the corporation within this

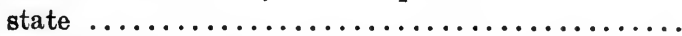

Average monthly value of its real property within this State as detailed in this report (actual value)..... Average monthly value of its tangible personal property in New York State as detailed in this report (actual value)

Total $\$ 96,000$

Average total actual value of shares of stocks of other corporations owned by it and allocated to this State by rule below. 
If this company paid a tax based on its net income only, the computation would be as follows:

$$
20,000 \times \frac{96,000}{480,000} \times \frac{45}{1000}(41 / 2 \%)=\$ 180 .
$$

which is less than one mill upon each dollar of the apportionment of the face value of its issued capital stock, apportioned as above stated, as will be seen by the following computation, in which the apportionment is based on the monthly average of "real and tangible personal property" in this State as compared with the total "real and tangible personal property" as shown in the report.

$$
1,000,000 \times .001 \text { (one mill) } \frac{75,000}{300,000}=\$ 250 \text {. }
$$

Since $\$ 250$ is greater than $\$ 180$, and since the tax can be no less than $\$ 250$ under the rule laid down in the statute above quoted, this would be the amount payable under Article 9-a as amended.

In U. S. Glue Co. v. Town of Oak Creek, decided by the U. S. Supreme Court June 3d, 1918, and affirming 161 Wisconsin 211, the Supreme Court of the United States has just passed upon a method of apportionment analogous to that printed in the foregoing pages. While the direct question before the court in this case was the right to tax a corporation engaged in interstate commerce, under a general Income Tax Law, for a portion of its business transacted within the state, the method of apportionment under the Wisconsin statute was before the court and we may conclude that it came within its approval in the judgment of affirmance.

The method of apportionment as set forth in the opinion of the court, is referred to as follows:

"In order to determine what part of the income of a corporation engaged in business within and without the State (other than that derived from rentals, stocks, bonds, securities, etc.), is to be taxed as derived from business transacted and property located within the State, reference is had to a formula prescribed by another statute 
(see 1770b, subs. 7, par. [e] of Wisconsin Stats.) for apportioning the capital stock of foreign corporations, under which the gross business in dollars of the corporation in the State, added to the value in dollars of its property in the State, is made the numerator of a fraction of which the denominator consists of total gross business in dollars of the corporation both within and without the State, added to the value in dollars of its property within and without the State. The resulting fraction is taken by the income tax law as representing the proportion of the income which is deemed to be derived from business transacted and property located within the State. This formula was applied in apportioning plaintiff's net 'business income' for the year 1911, and upon the portion thus attributed to the State, plus the income from rentals, stocks, bonds, etc., the tax in question was levied."

\section{General instructions for making reports.}

An officer having knowledge of the facts, preferably the chief fiscal officer of the company, may make a report under Article 9 -a. Section 213 requires that the report shall be verified by the President, Vice-President, Secretary or Treasurer; it is not necessary that two officers verify the return; verification by one officer is sufficient.

Receivers, trustees in bankruptcy and assignees, under the federal income tax law must make returns and pay taxes for corporations whose property they are operating, and it would seem that they should also make a report under Article 9-a of the Tax Law. That there is some warrant for such action in connection with the State Tax, see Central Trust Co. v. N. Y. C. and H. R. R. Co., 110 N. Y. 250.

Under the form of report required by the amendment of 1918 , the amount of issued capital stock is called for, evidently, for the purpose of computing the minimum tax where no income is earned and where the company would otherwise not be taxable. The 1919 form of report also calls for the amount of authorized capital stock as an administrative regulation. Issued and authorized stock had often been returned indiscriminately.

The purpose of ascertaining the amount of indebtedness as called for in the State tax form, is not clear. This is another 
administrative regulation. This information is required by the Connecticut Law taxing miscellaneous corporations on their income. (Part IV, Chap. 292, Public Acts of 1915 of Connecticut, as amended by Chap. 298, Public Acts of 191\%.) It is also required by the Wisconsin Income Tax Law. (Chap. 650, Laws of 1911, as amended.) The Connecticut Law accepts the income return made to the United States Treasury Department as a basis of taxation, but it also calls for facts on which to base an assessment on substantially similar lines. The Wisconsin Statute, which is a general Income Tax Law, makes its own assessment on independent lines, irrespective of the report to the Treasury Department. Since the amendment of 1918, the New York Statute permits the corporation to return its own income if it contends that the amount determined by the United States Treasury Department be not correct. This does not mean that the net income is to be determined de novo, but that there may be a re-computation in case of error.

The New York Law makes no specific requirements for any method of bookkeeping for ascertaining the net income, and it is to be assumed that, as in the case of the Wisconsin Income Tax Law and also under the Federal Statute, any method of bookkeeping which fairly attains the result, will be acceptable.

Under the United States Treasury decision, Article 183, Regulation 33 of January 5th, 1914, it is held that "the books of a corporation are assumed to reflect the facts as to its earnings, income, etc. Hence they will be taken as the best guide in determining the net income upon which the tax imposed by this act is calculated. Except as the same may be modified by the provisions of the law, wherein certain deductions are limited, the net income disclosed by the books and verified by the annual balance sheet, or the annual report to stockholders, should be the same as that returned for taxation."

The nature of the business and how transacted, should be stated with some particularity in the report, as the question may arise as to whether the company may segregate its assets in and out of the State. 
Under item 13 of the report, calling for the locality where the company maintains a store, warehouse or factory as a place of business, the corporation may state any regular office or permanent agency established by it outside of the State.

The fact that a corporation did no business or received no income during the year in question, does not relieve it from making a return. Every question should be answered. If there is no amount or no information to be given opposite a question, the word "none" should be written in.

If the entire business of a corporation is not transacted within the State, to entitle it to an apportionment of income, and a segregation of assets, it must maintain a definitely organized branch establishment. The mere sale of goods, wares and merchandise without the State, does not entitle it to a segregation of assets or property or accounts receivable for such property as located outside of the State.

Determining factors are whether the company maintains a store, warehouse, office, factory or salesroom in another State. Has it received a license to do business in any other State? Can it show possession of goods subject to local taxation in other States, or any other facts tending to establish a permanent business without the State?

The consent by a corporation to a tax on its entire income, should only be executed where the corporation's entire income is due to property located, and business transacted, within the State. Many corporations have executed this consent and placed themselves in the class of corporations whose entire property is located within the State, which may lead to unnecessary explanation for future assessments.

Corporations transacting business, and owning tangible property, within and without the State, and having no net income, but subject to a minimum tax of one mill (.001) on the face value of their issued capital stock, should not execute the consent but should fill out the statement of segregation of assets in order that such minimum tax may be determined as provided in paragraph 6, Section 214. Such corporations having a net income but 
less than the minimum tax of one mill (.001) on the face value of its issued capital stock, should for the same reason, not sign the consent but fill out the segregation statement.

\section{How to ascertain average monthly values.}

Under the State Tax Law, as it existed prior to 191\%, the method for averaging capital employed in the State, was to take it for the entire period under consideration, and divide it by the number of days in that period. People ex rel. B. R. T. Co. v. Morgan, 57 App. Div. 335, affirmed 168 N. Y. 672; People ex rel. Mutual Trust Co. v. Miller, $17 \%$ N. Y. 51; People ex rel. Rees' Sons v. Miller, 90 App. Div. 591; People ex rel. Cohn \& Co. v. Miller, 94 App. Div. 564. This rule might be applied to each month, and the aggregate for the twelve months so averaged then divided by twelve.

Under the United States Treasury Department regulations, invested capital for a taxable year (or where the tax is computed upon the basis of a period less than a year, for such period) is the average invested capital for the year or period averaged monthly according to the following rules:

(a) Add the capital for each of the several months during which no change occurs, and the average capital [ascertained as provided in subdivision (b)] for each month in which a change occurs and divide the total by the number of months in the year or period.

(b) To ascertain the capital for any month in which a change occurs multiply the capital as of the first day of the month by the number of days it remains constant and the capital after each change by the number of days (including the day on which the change occurs) during which it remains constant, add the products, and divide the sum by the number of days in the month.

Under the heading "Segregation of Assets," item "(a) average monthly value of bills and accounts receivable for personal property manufactured by it," may include accounts for personal property manufactured by a corporation and then shipped to a branch outside of the State, sold and delivered from this branch 
to customers outside of the State. See U. S. Glue Co. v. Town of Oak Creek, 161 Wisc. 211. In such case, the corporation may be taxable in two jurisdictions.

Under the item "(b) personal property sold by the corporation from merchandise owned by it at the time of the acceptance of order, but not manufactured by it;" viz., goods which were made up for it after it accepted the order, a corporation may have on its books accounts for goods sold which were not in existence at the time of the acceptance of the order, and hence could not reasonably go under (b), but might be fairly expected to go under "(c) services performed based on orders received at offices maintained by the corporation, excluding bills and accounts receivable on orders filled from a stock of merchandise or other property maintained by the corporation." Item (c) would include the value of services rendered by a so-called personal-service corporation under the 1919 amendment, viz., accounts receivable by an advertising corporation, engineering company, trucking company, etc.

Item (c) might also include accounts for services performed in the State, by a company maintaining a factory or warehouse outside of the State; for instance, a corporation engaged in the automobile business, having a factory outside of the State, might have a repair shop or service station within the State, where services are rendered and work is done. In connection with such services, supplies and parts might also be sold. These last should be separated from the services rendered.

The item of average monthly value of all real property includes the actual value. In New York State, the Tax Law provides (Section 6), that all real estate shall be assessed at the "full value" thereof, and there is a legal presumption that assessors, being public officers, do their duty. People ex rel. Manhattan $R$. R. Co. v. Commissioners, 146 N. Y. 304, 165 N. Y. 305 . There is no presumption in relation to the assessments in other States, and consequently the assessed value of real estate outside of the State of New York, may or may not be at actual value.

The provision in the form as to the item of the average monthly 
value of its tangible personal property, is that it shall be made at "its actual value where located," which may be construed as its ordinary market value. This may be accepted even though smaller than the book value where nothing else appears to cast a doubt on the corporation's figures. People ex rel. A. G. Hyde \& Sons v. O'Donnel, 116 App. Div. 161; aff'd 188 N. Y. 551.

The cost may be taken as the basis in the absence of satisfactory proof as to the market or actual value. People ex rel. John Turl's Sons v. O'Donnell, N. Y. Law Journal, June 27th, 1905. See also People ex rel. Journeay \& Burnham Co. v. Roberts, 37 App. Div. 1.

The last item in the segregation of assets is the "average total actual value of shares of stocks of other corporations owned by this corporation."

In connection with this item and the apportionment of property called for by it, it should be remembered that only the shares of stock should be segregated to this State if the physical property represented by it, is within the State, or vice versa.

Under the amended law, while the segregation of this item shall be given in full, in its computation for the purpose of arriving at the tax due in each case, this item shall not exceed 10 per cent. of the real and tangible personal property segregated to this State, or in case of the segregation of shares of stock outside of New York State, it shall not exceed 10 per cent. of the aggregate real and tangible personal property set up in this report.

\section{Computation of tax.}

I. If the entire business of the corporation be transacted within the State, the tax will be $4 \frac{1}{2}$ per cent. of the entire net income. The tax will not be less than $\$ 10$ or less than one mill on the dollar $(1 / 10 \%)$ on the face value of the issued capital stock, viz., if the income is $\$ 200$ and the face value of the issued capital stock is $\$ 1,000$, the tax will be $\$ 10$. If the income is $\$ 200$ and the face value of the issued capital stock is $\$ 20,000$, the $\operatorname{tax}$ will be $\$ 20$.

II. If the corporation has no income for the fiscal or calendar 
year under consideration, and if its entire property is apportioned within the State as determined by the rules laid down in the statute and heretofore explained, the tax will be one mill upon each dollar of the face value of its issued capital stock, but not less than $\$ 10$, viz., if the face value of the issued capital stock is $\$ 1,000$ the tax will not be less than $\$ 10$, which in this case, coincides with one mill on the face value of $\$ 1,000$, the issued capital stock. But if one mill on the face value of the issued capital stock is more than $\$ 10$, viz., if the face value of the issued capital stock is $\$ 20,000$, the tax will be $\$ 20$ in the case mentioned; and if the face value of the issued capital stock is $\$ 100,000$ the tax will be $\$ 100$.

The expression in the statute, that the tax shall be "not less than $\$ 10$ and not less than one mill upon the apportionment of the face value of its issued capital stock apportioned to this State" means that the tax shall not be less than $\$ 10$ and also that the tax shall not be less than the sum arrived at by the apportionment pointed out in the provisions in the amended statute of 1918.

The method of apportionment in determining the minimum tax of one mill on the face value of the issued capital stock under the last or proviso clause in Section 214, is not identical with the method of apportionment used in the body of Section 214 in determining the amount of tax based on net income. In the former case, the bills receivable and stock in other corporations are not to be considered at all in making the apportionment, but only the real and tangible personal property.

Phrases similar to that used in Section 214 of the amended law, that the tax shall be "not less than $\$ 10$ and not less than one mill upon each dollar of the apportionment," etc., have been passed upon by the courts as meaning that it shall not be less than the greater sum.

In Commonwealth v. P.R.R. Co., $94 \mathrm{~Pa} .474$, the court said in this connection:

"The Act of Assembly does not say so. It requires an appraisement to be made between the lst and 15th days of November, of the stock of non-dividend paying corporations, or those paying less than 
six per cent., said stock is to be appraised at its cash value, 'not less, however, than the average price which said stock sold for during said year.' If the Legislature intended to have the stock appraised at its average price during the year, it was very easy to have said so. We find nothing in the act from which such intent can be gathered with any reasonable certainty. On the contrary, the use of the words 'not less, however, than average price which said stock sold for during said year,' necessarily implies the power to appraise the stock at more than its average price during the year. The construction of the Act contended for by the company would expunge the words above quoted, or render them nugatory. It is our duty to give them effect if consistent with other portions of the statute. They mean just this: That if the stock of the company is lower when the appraisement is made in November than it was during the previous year, it shall be appraised at not less than the average selling price for the year. On the other hand, if it is higher in November, it may be appraised at its increased value. If it be objected to this view that the advantage is all on the side of the State, we may safely concede it to be so. The object of the Act was to raise revenue, and it appears to have been drawn with care, and in the interests of the State.

"We are of opinion that the learned judge of the court below ruled the law correctly, and his judgment is accordingly affirmed."

III. If the entire business be not transacted within the State, the tax shall be based on such proportion of the entire net income at $4 \frac{1}{2}$ per cent., as the aggregate of items mentioned in subdivisions 1, 2 and 3 of Section 214 of the Tax Law, bears to the aggregate of items mentioned in subdivisions 4,5 and 6 of Section 214, with this proviso: That, in the case of the ownership of stocks in other corporations, owned by the corporation, referred to in subdivisions 3 and 6 in said section, such stocks shall in neither case exceed 10 per cent. of the real and tangible personal property segregated to this State under 3, or of the aggregate real and tangible personal property set up under 6 .

IV. Under this state of facts, in the case of a corporation whose net income for the fiscal or calendar year was $\$ 100,000$ on the basis of $\$ 200,000$ of assets segregated in New York State, as shown in the form of report, and $\$ 800,000$ of total segregated assets wherever located, the tax apportioned to this State would be 


$$
\frac{200,000}{800,000}
$$

$\nabla$. If the same corporation has an issued capital stock of $\$ 5,000,000$, the tax would be $\$ 1,250$ instead of $\$ 1,125$, since in no case can it be less than .001 of the issued capital stock. The same tax would be due, if the corporation had no income.

$$
\frac{200,000}{800,000} \times \frac{5,000,000}{1} \times .001=\$ 1250 .
$$

VI. If such a corporation has stock without par value, then it may take the paid in capital as the base, which, let us assume is $\$ 6,000,000$ and the computation would appear as follows:

$$
\frac{200,000}{800,000} \times \frac{6,000,000}{1} \times .001=\$ 1500 .
$$

It will thus be seen that the same corporation may pay a tax of either $\$ 1,200$ or $\$ 1,500$, dependent upon whether it has a stock issue to the extent of the face value of $\$ 5,000,000$, or whether it has stock without par value, which had a paid in capital or actual value of $\$ 6,000,000$ at the time of its issuance.

Consolidated or merged corporations.-Under an amendment in 1918 to Article 9-a, which added a new section known as 214-a to the law taxing manufacturing and mercantile corporations, provision was made for the taxation of a corporation taking over by merger or consolidation the assets or franchise of another corporation. This section was again amended in 1919 so that it would apply to a corporation that took over not only by merger or consolidation, but by acquisition or transfer, directly or indirectly, the whole or major part of the assets of another company. In such case, the corporation receiving the benefit of the additional assets or franchises must return in addition to its own income, so much of the income of the corporation whose assets or franchises it acquired, as had not been used in measuring a franchise tax to 
the State in the past. It had been found that many corporations without merger or consolidation, but by trades and transfers, took over the whole or part of the assets of another corporation, and by blending or changing the names of the companies involved, escaped taxation. 


\section{CHAP'TER XVI.}

Exemption from Personal Property Tax and from Seotion 182.-Fixtures.

Section 219-j of the Act as amended in 1918, provided that "after this article takes effect, corporations taxable thereunder shall not be assessed on any personal property or capital stock, as provided for in Section 12 of this Chapter." The words "corporations taxable thereunder," refer to corporations taxable under Section 209 of Article 9-a, viz., foreign and domestic business corporations except those exempted under Section 210. Foreign corporations doing business in the State are taxed under Section 7 of the Tax Law, paragraph I, "on the capital invested in such business as personal property." Domestic corporations are taxable "upon their capital stock" under Section 12 of the Tax Law. The words "capital stock" in Section 12 of the Tax Law have been defined as referring to the capital of the company and not the shares of the stockholders. People ex rel. Union Trust Co. $v$. Coleman, $126 \mathrm{~N}$. Y. 433. It denotes the property owned by the corporation and not the par or actual value of the shares of the stockholders. People ex rel. Second Avenue Railroad Co. v. Barker, 72 Hun, 126. While no reference is made in the statute to foreign corporations assessed under Section 7, being exempt from local taxation, the intendment is clear.

It is also provided in Section 219-j that "after this article takes effect, corporations taxable thereunder shall not be required to pay the Franchise Tax imposed under Section 182 of this Chapter, or to make the reports called for under Sections 27 and 192 of this Chapter."

Section 27 provides for the report to be made by a domestic corporation to local assessors as to its capital stock, real estate, etc., 
and Section 192 provides for the report by a domestic or foreign corporation to the State Tax Commission as to the rate and date of dividends, etc., for the purposes of Section 182.

Only corporations taxable under 9-a exempt.-Chap. 271 of the Laws of 1918, changed the language of the 1917 law by striking out the words "manufacturing and mercantile" and substituting for that phrase, the expression "corporations taxable thereunder," and chapter 628 of the Laws of 1919 made the act apply to all business corporations.

The amendments of 1919 therefore make the exemption from local personal property taxation and from taxation under Section 182 of the Tax Law apply to all business corporations taxable under Article 9-a. Those corporations that are exempt from taxation under Article 9-a, such as realty corporations, holding companies, public service and public utility corporations and all of the corporations taxable under Sections 184 to 189 of the Tax Law, are still liable to the personal property tax under Section 12.

A curious feature in connection with the exemption of business corporations from the personal property tax, is that it has apparently revived the liability to assessment of the owner or holder of stock in an incorporated company. Heretofore, subdivision 16, Section 4 of the Tax Law provided, under the heading of "Exemption from Taxation," that the "owner or holder of stock of an incorporated company liable to taxation on its capital, shall not be taxed as an individual for such stock." Since business corporations are no longer liable to taxation on their capital, the exemption appears to fall.

\section{Fixtures, when exempted from taxation.}

The Income Tax Law passed in 1917, provided that personal property should, for the purpose of the exemption under Section $219-j$, include machinery and equipment affixed to the building which would not pass as part of the premises as between grantor and grantee unless specifically mentioned in the deed, and such as would be moved, if the building were vacated or sold, or the nature of the work changed, carried on therein. This did not 
extend to boilers, ventilating apparatus, elevators, shafting and apparatus for generating power by gas, electricity and water. Chapter 417 of the Laws of 1918, struck this provision from Section 219-j of the law, where it stood in the act as passed in 191\%, and segregated it in a new section called Section 219-1. The provision of the former law was repeated with the addition "that the owner of the building is entitled to the same exemption under this section, as a lessee." The amendment of 1918 also provided that every assessment of real property made after June 4, 1917, should be subject to the provisions of this section.

Under a recent decision, it has been held that this section modifies the law embodied in Section 2, subdivision 6, of the Tax Law, under which the term "real property" includes in addition to the land itself, all articles and structures, substructures and superstructures erected upon, under or above, or affixed to the same.

The question of the taxation of machinery and fixtures as real estate when attached to a building had up to this time depended not on whether machinery and fixtures could be removed from the building without material injury thereto, but on whether they were annexed and essentially necessary to the character of the business for which the building was used. This principle was laid down in People ex rel. National Starch Co. v. Waldron, 26 App. Div. 527, and reaffirmed in a number of later cases, among them Herkimer County Light \& Power Co. v. Johnson, 37 App. Div. 257; People ex rel. Federal Telephone \& Telegraph Co. v. Longwell, 131 N. Y. Supp. 361; People ex rel. N. Y. Edison Co. v. Feitner, 99 App. Div. 274; aff'd without opinion, 181 N. Y. 549.

In a recent case before Judge Delehanty in the Supreme Court, New York County, he expressed the opinion that the effect of the amendment to Chapter 726 of the Laws of 1917 was to remove all removable machinery from taxation either as real estate or as personal property. He said in this connection, "Prior to the passage of the Emerson Act, 'real estate' for the purpose of taxation was defined by subdivision 6 , Section 2, of the Tax Law, as 'the land itself above and under water, all buildings and other articles and structures, substructures and superstructures, erected 
upon, under or above, or affixed to the same,' etc., and under the decisions of this State it has been held that pursuant to said section quoted machinery installed in a building and affixed to the realty is taxable as real estate (N. Y. Edison Co. v. Wells, 135 App. Div. 644, and cases there cited). But the situation in this respect is now changed. The Legislature by the Emerson Act has defined what shall constitute 'personal property' for the purpose of taxation of mercantile and manufacturing corporations and has made such exempt from local taxation. The language used in the statute is in nowise uncertain or doubtful of meaning, and in my opinion the plain intent thereof was to exempt from personal property tax such machinery and equipment affixed to the building as could be removed therefrom without material injury thereto, except, of course, boilers, etc., expressly precluded. This is obvious from the context of the statute quoted; otherwise why an enumeration of machinery and equipment not exempt from taxation?" People ex rel. Gen. Chemical Co. v. Cantor, 105 Misc. 62.

This case is now being appealed to the Appellate Division, Supreme Court, but since the trial of the case, the Legislature has amended the section in dispute and removed the element of doubt as to the character of machinery subject to real estate taxation, by making removable machinery used for trade or manufacture, exempt from personal property assessment and by striking out the paragraph as to real estate assessments made subsequent to June, 191\%. The amendment also provides that the act shall not affect pending litigation. 


\section{CHAPTER XVII.}

Temporary Provisions for Crediting Corporations with Personal Taxes Paid in 1917 and 1918.-School Taxes.

Temporary provisions.-The intent to relieve corporations paying the income tax from assessment of personal property and on their capital stock as it was expressed in the Act of 1917, presented obscurity in its application because of difference between the various taxing districts as to the beginning and the end of the fiscal year. The income tax is payable in advance each year on a report made as of November 1, as to the income of the previous year. Under the General Tax Law, assessment rolls outside of New York City are made up before August, closed in September, then equalized by the County Board of Supervisors, and the collector's warrant is by Section 59, to be attached on or before December 15th, or some other date not later than April 15th, if the latter date be adopted by a special resolution of the Board of Supervisors. Speaking generally, there are tax districts in which the tax year runs not only from July to July, but from every month between January and December. By Section 2\%, corporations must report as to their capital stock paid in on June 1st, or within 30 days afterward. The new law took effect at once on its approval by the Governor on June 4th, 191\%, and in making up assessment rolls between then and August 1st, 191\%, assessors outside of New York City had before them corporation reports which prematurely claimed immunity from personal payment to be made January 1st, 1918, in advance for the year beginning November 1st, 191\%. The claim was of immunity from a personal property tax for 1917 not then completely assessed or due and was based on an income tax for the year beginning Norember 1st, 1917, not payable until January 1st, 1918. Amendatory legisla- 
tion added to Section 219-j of the law by Chapter 271 of the Laws of 1918 , sought to cure the confusion so created. There was a serious question as to the constitutionality of the 1917 Act in denying to corporations taxed for the same year the equal protection of the law.

The amendment excepted from the immunity from the personal tax, levies for the fiscal year ending December 31st, 1917, in taxing districts in which the calendar year and the tax year are the same, i. e., "coterminous." In districts in which local taxes are leried for a twelre-month beginning in 1917 and ending in 1918, corporations taxable under Article 9-a are not to be assessed on any personal property or capital stock except the levy for the year 191\%-1918. It was also provided by the amendment that corporations omitted from the assessment rolls in 1917, through prematurely crediting them with an income tax which they expected to pay for the year 1918, should be restored to the rolls and be tared on the raluation of their omitted property at the rate per cent., leried on property generally listed on the roll.

Provision is made for five days notice as to valuation of omitted property, and for an opportunity to be heard. The taxes thus put back on property omitted prematurely from the assessment rolls made up in the summer of 1917, "shall be deducted from the aggregate of taxation, otherwise to be levied on such taxing, for the current year, before such tax is levied." In other words, the town, village and city authorities are to deduct from the 1918 levy the amount of taxes corporations would hare been assessed if they had not been omitted prematurely from the rolls.

The amending act not only confers authority on the assessors to place on the assessment rolls personal property of corporations omitted, but specific authority to make a retroactive tax levy on the omitted property is giren and to make assurance thoroughly certain it is declared that the amended law shall be read and interpreted as though the amendment were in the act when it was passed in 191\%. There is thus a difference from the general authority giren assessors to place omitted property on the assessment roll in the following year at the valuation made or to be 
made for the preceding year under Tax Law Section 34. That section applied to corporations (People ex rel. Brooklyn City Railroad v. Assessors of Brooklyn, 92 N. Y. 430) ; but it did not authorize assessment of omitted property without notice or after completion of the roll of the current year. Overing v. Foote, $65 \mathrm{~N}$. Y. 263.

The case where corporations begin paying income taxes on January 1st, 1918, but are still assessed on personal property and capital for a tax covering some portion of the year 1918, is provided for by the amending legislation of 1918 .

The Act of 1917 provided that the obligation to pay taxes on personal property or capital stock assessed in 1916, and in 191\%, before the act took effect, whether payable in that year or not, should not be impaired, and the omission to mention specifically assessments after June 4th, 1917, no doubt led to omission from the assessment rolls.

The amended act drops the phrases "after this act takes effect, manufacturing and mercantile corporations shall not be assessed on any personal property," etc., and "after this act takes effect manufacturing and mercantile corporations shall not be assessed or taxed on their capital stock as provided for in Section 12 of this chapter."

In their place, is substituted a clearer expression of intent. The phrasing is now: "After this article takes effect, corporations taxable thereunder shall not be assessed on any personal property or capital stock, except for taxes levied for the fiscal year ending December thirty-first, nineteen hundred and seventeen, in taxing districts in which the fiscal year is coterminous with the calendar year, and where taxes are required by law to be levied for local purposes for a fiscal year beginning in nineteen hundred and seventeen and ending in nineteen hundred and eighteen."

The amending act substitutes the phrase "as specifically provided for in this section whether such taxes have been or may hereafter be assessed" for the confusing expression of the act as passed in 1917. The only personal tax assessment now specifically provided for in Section $219-\mathrm{j}$ refers to those made for a year ending 
with 1917 or made in 1917 , and covering a period lapping over into 1918.

As the law now stands, a corporation which shall submit to the Tax Commission, proof that it has paid a tax on its personal property to local assessors for a tax period covering any part of the year ending December 31st, 1918, will be entitled to credit to that extent on account of its income tax payment. The credit can be assigned to another corporation. Such credits are to be deducted from the apportionment made to the same locality for local purposes from the revenue derived from the income tax.

Comptroller may refund under I9I9 law.-Chapter 138 of the Laws of 1919 omitted the last paragraph of Section 219-j. This paragraph had reference to the administrative features for charging or crediting taxes against the various taxing districts of the State. There was added to this section in lieu of the omitted paragraph, the following:

Upon receipt of notice from the tax commission of any credit under this article the comptroller may refund to the corporation, out of the current revenues in his hands received under this article, the amount of such excess paid by the corporation, without interest, and shall charge the amount or amounts of such excess against the state treasury and the taxing district or districts in the proportions that such excess was originally credited or paid. In case the amount of current revenues credited to any taxing district under this article is not equal to the charge against any such taxing district on account of such refund, further revenues credited to such taxing district shall first be applied by the comptroller to the liquidation of such charge.

Payment of personal taxes for the year 1917-18 is not a contract with the State.-In the City of Buffalo, personal tax assessments were made for the fiscal year beginning July, 1917, and ending July, 1918. Under the reading of Section 219-j, as it existed in 191\%, corporations thus assessed were entitled to a credit on their franchise tax payments by virtue of Section $219-j$ of Chapter 726 of the Act of $191 \%$, in the full amount of the personal property tax paid.

After the amendment to Section $219-\mathrm{j}$ in 1918 , by which corporations were only entitled to a credit "for the amount of such 
part of the taxes so paid locally as the portion of the year nineteen hundred and eighteen for which such taxes shall have been paid bears to the entire calendar year," a Buffalo corporation claimed that its payment of taxes in $191 \%$ for 1918 was in the nature of a contract with the State of New York, and that the amendment of 1918 was invalid insofar as it attempted to interfere with or impair the obligation of this contract. Upon application by the Iroquois Door Company of Buffalo, for a credit for the franchise tax assessed and determined against it by the State Tax Commission under the provisions of Section 219-j, Article 9 -a of the Tax Law, for the year beginning November 1st, 1917, on account of taxes paid locally on personal property, the Tax Commission having considered the facts on the application, determined that this corporation was entitled to a credit of only onehalf of the taxes paid by it for city purposes for the fiscal year of the City of Buffalo ending June 30th, 1918. Thereafter, the Iroquois Company appealed to the Appellate Division of the Supreme Court and by unanimous decision, the court sustained the Tax Commission. Judge Cochran, in writing the opinion in People ex rel. Iroquois Door Co. v. Knapp, 173 New York Supplement, 641, said :

"I can discover no element of a contract in the Act of 1917. Such legislation was not personal to the relator. It was part of the General Tax Law of the state. Its provisions were applicable to all corporations falling within its purview. The state, by that legislation was not entering into a contract with the relator or any other corporation. It was merely exercising its taxing power. Inadvertently, an unjust discrimination in the matter of taxation was made in favor of the relator and certain other corporations. When it was discovered that an unfair discrimination had been made in favor of the relator and other corporations, such unfairness was corrected by the Act of 1918. I do not see that it makes any difference whether or not the relator had in the meantime paid the franchise tax contemplated by the Act of 1917. Unless there was a contract with the relator, which very clearly there was not, the state, by virtue of its taxing power, could correct a manifest injustice and prevent the relator from escaping in part a single taxation, which was the effect of the Act of 1917 as applied to the relator. The relator has given up 
or yielded no advantage, nor has it been prejudiced in any particular, nor is it in any different position than it would have been if the Act of 1917 had originally been enacted as it was subsequently amended in 1918. It is urged that the statute (Sec. 219-d) contemplates the assignability of the credit to another corporation liable to pay taxes under Article 9-a, and that this indicates a contractural obligation on the part of the state. As between the state and the original owner of the credit the assignability thereof is permitted as a privilege or favor, and is not granted as a right. It is not necessary to decide what the effect of the amendment of 1918 might be on a credit previously assigned. That question does not exist in this case."

Exemptions of corporations from local taxes on personal property assessed for school purposes.-Issue has arisen as to whether manufacturing and mercantile corporations taxable under Article 9-a are exempt from taxation for local school purposes in the several school districts where personal property of such corporations is found, and in an opinion handed down by AttorneyGeneral Lewis on December 18th, 1917, reported in the State Department Reports, No. 81, February 1st, 1918, it was held that such corporations are not relieved from school taxes so levied. The Attorney-General holds in his opinion that:

"It would seem that if the Legislature intended that such exemption should apply to taxes payable under the provisions of sections 410-413, or article 33-a of the Education Law, it would have mentioned such provisions as well as sections 12 and 182 of the Tax Law, inasmuch as such provisions of the Education Law are left intact, and without change as to the right of the school districts to assess and tax the personal property of such corporations within their districts. I think it more reasonable, more consistent and more in harmony with the general scheme of the legislation to hold that the legislature intended that the school districts should not be included within the exemption provided in section 219-j. No reference is made in section 219-j to such districts and no part of the taxes provided by the act are to be paid to them. This seems significant, particularly as the provisions in the Education Law for taxing such corporations for their personal property within each district are preserved to the respective districts.

"If it should be held that the personal property of such corporations is exempt, under section 219-j, from the payment of school 
taxes, then it follows that the above mentioned sections of the Education Law, which clearly give the right to trustees of school districts to tax all such corporations for their personal estate for school purposes, are repealed by implication so far as such provisions apply to the taxation of personal property of such corporations for school purposes. Repeals by implication are not favored by the courts.

" 'When both the latter and former statute can stand together, both will stand unless the former is expressly repealed or the legislative intent to repeal is very manifest.' People ex rel. Kingsland v. Palmer, 52 N. Y. 83; Hawkins v. Mayor, 64 id. 18; Watson v. City of Kingston, 114 id. 94."

If the opinion of the Attorney-General is sustained by the courts, this peculiar situation will arise-that in country districts where the school authorities levy their own taxes, manufacturing or mercantile corporations will be taxed on their personal property for school purposes, while in cities where the school estimates are included in the general city budget, there will be no machinery for levying school taxes on such personal property. 


\section{CHAPTER XVIII.}

Apportionment of Tax Between State and Cities, Towns and Villages.

Two-thirds of the tax collected, together with all interest and penalties, is paid to the State, the other third is paid to the localities, as provided by Section 219-h of the Tax Law. The onethird paid to the localities is disbursed through the agency of county treasurers as follows:

(1) If the corporation has no tangible personal property within the State, such payment shall be made to the county treasurer of the county in which is located the principal financial office of the corporation.

(2) If the corporation has tangible personal property in but one city or town of the State, as shown by its report under Section 211, such payment shall be made to the county treasurer of the county in which the city or town is located.

(3) If the corporation has tangible personal property in more than one city or town of the State, as shown by its report under Section 211, such payment shall be made to the county treasurers of the counties in which such cities or towns are located in the proportion that the average monthly value of its tangible personal property in the cities and towns of such county, as shown by the report, bear to the average monthly value of its total tangible personal property within the State.

It is to be noted that the proportion distributed among the localities, under the amendment of 1919 (Chapter 628), is not dependent upon the amount of real property plus tangible personal property, located in the city, town or village, but is dependent on the amount of tangible personal property so located. If a corporation owns real estate, the place where such real estate is lo- 
cated receives the benefit in the payment of a tax in full on such property, and under the 1917 law, the town, city or village in which such real estate was situated, also received a greater proportion of the State Income Tax than localities in which there was no real estate. There was no change in substance in the 1919 law from the 1918 Act, but the words "real property and" were omitted because found to be unnecessary to the sense.

A concrete example under paragraph 3 of Section 219 -h is that of a corporation having $\$ 4,000$ of tangible personal property in the town of Canaan, Columbia County, $\$ 8,000$ tangible personal property in the city of Hudson, Columbia County, $\$ 8,000$ of tangible personal property in New York City, and $\$ 12,000$ of real estate in New York City. The aggregate amount of property, real and personal, within the State would be $\$ 32,000$, of which $\$ 12,000$ of personalty is located in Columbia County and $\$ 8,000$ of personalty is located in New York City. If the corporation's State Income Tax was $\$ 2, \% 00$, and all of its business was transacted in the State, one-third of this amount, or $\$ 900$, would go to the localities, to be distributed in the proportion of $4-20: 8-20: 8-20$, which is the same as $4: 8: 8$, or as $1: 2: 2$.

Under the 1917 law, the distribution would be as 4-32: 8-32: 20-32, or as $1: 2: 5$, and New York City would have received a larger proportion by reason of the location of real estate there. This inequality is now removed.

Under the 1919 Act, the county treasurer of Columbia County would receive $12-20$ or $\$ 540$ of the $\$ 900$ apportioned under the law to the localities, and the City Chamberlain of New York would receive the balance, $8-20$ or $\$ 360$. Of the $\$ 540$ paid to the county treasurer of Columbia County, $\$ 180$ or $4-20$ would go to the town of Canaan and $\$ 360$ or $8-20$ would go to the city of Hudson.

(4) In making such payment to a county treasurer, the State comptroller shall indicate the portion to be credited to any city or town within the county, on account of the location of its principal financial office, and if such principal office or property is located in a village, shall indicate such village. If located in a city or town outside of a village, the whole of said portion shall 
be paid to such city or town; if such principal office or property is located in a village, there shall be paid to such village, such part of the entire amount credited to the town as the entire amount of taxes raised by said village or portion thereof in said town, during the preceding calendar year for village and town purposes, bears to the aggregate amount so raised by the town and village during the preceding calendar year for town and village purposes.

If in the example given under subdivision 3 of this section of the law, the town of Canaan contained a village which raised three-fourths of the taxes raised by the town and village together for village and town purposes, the village would receive $\$ 135$, or three-fourths of the sum of $\$ 180$, which was the entire amount credited to the town.

(5) As to any county wholly included within a city, such payment shall be made to the chamberlain or chief fiscal officer, and be paid to the general fund for city purposes. As to any county not wholly included in a city, the county treasurer shall within ten days after the receipt thereof, pay to the chief fiscal officer of a city or the chief fiscal officer of a village or to the supervisor of a town, the portion of money received by him from the State comptroller, to which such city, village or town is entitled, which shall be credited by such officer to general city, village or town purposes. 


\section{CHAPTER XIX.}

Franohise Tax on Business Corporations.

(Article 9-a of the Tax Law.)

Ohapter 726, Laws of 1917, as amended by Laws of 1918 and 1919.

[Text of the Law]

(1919 Amendments in Italics.)

Section

208. Definitions.

209. Franchise tax on corporations based on net income.

210. Corporations exempted from article.

211. Reports of corporations to tax commission.

212. Reports by corporation on basis of fiscal year.

213. Reports to be sworn to; forms.

214. Computation of tax.

214-a. Taxation of corporations acquiring assets or franchises of other corporations.

215. Rate of tax.

216. Penalty for failure to report.

217. Powers of tax commission.

218. Revision and readjustment of accounts by tax commission.

219. Review of determination of tax commission by certiorari and regulations as to writ.

219-a. Audit and statement of tax.

219-b. Notice of tax.

219-c. When tax payable.

219-d. Corrections and changes.

219-e. Warrant for the collection of taxes.

219-f. Action for recovery of taxes; forfeiture of charter by delinquent corporations.

219-g. Deposit of revenues collected.

219-h. Disposition of revenues collected.

219-i. Secrecy required of officials; penalty for violation.

219-j. Exemption from certain other taxation.

219-k. Limitation of time.

219-1. Personal property defined. 
$\S 208$. Definitions. As used in this article:

1. The term "corporation" includes a joint-stock company or association;

2. The words "tangible personal property" shall be taken to mean corporeal personal property, such as machinery, tools, implements, goods, wares and merchandise, and shall not be taken to mean money, deposits in bank, shares of stock, bonds, notes, credits or evidences of an interest in property and evidences of debt;

3. The term "entire net income" means the total net income before any deductions have been made for taxes paid or to be paid to the. Government of the United States on either profits or net income or for any losses sustained by the corporation in other fiscal or calendar years whether deducted by the Government of the United States or not.

[Source:-Ch. 726, L. 1917, as am'd by Ch. 417, L. 1918, and by Ch. 628, L. 1919. The 1918 amendment eliminated the definitions of "manufacturing corporation" and "mercantile corporation," contained in former paragraphs 3 and 4. The 1919 amendment added the present paragraph 3.]

$\S 209$. Franchise tax on corporations based on net income. For the privilege of exercising its franchise in this state in a corporate or organized capacity every domestic corporation, and for the privilege of doing business in this state, every foreign corporation, except corporations specified in the next section, shall annually pay in advance for the year beginning November first next preceding an annual franchise tax, to be computed by the tax commission upon the basis of its entire net income for its fiscal or the calendar year next preceding, as hereinafter provided, which entire net income is presumably the same as the entire net income upon which such corporation is required to pay a tax to the United States.

[SouRCE:-Ch. 726, L. 1917, as am'd by Ch. 276, L. 1918, and by Ch. 628, L. 1919. The 1918 amendment added the words "presumably the same as the income upon which," and the 1919 amendment prefixed the words "entire net" to income.]

$\S 210$. Corporations exempted from article. Corporations wholly engaged in the purchase, sale and holding of real estate for themselves, holding corporations whose principal income is derived from holding the stocks and bonds of other corporations and corporations liable to a tax under sections one hundred and eighty-four to one hundred and eighty-nine inclusive of this chapter, banks, savings banks, institutions for savings, title guaranty, insurance or surety 
corporations shall be exempt from the payment of the taxes prescribed by this article.

[Source:-Ch. 726, L. 1917-no change.]

$\S 211$. Reports of corporations to tax commission. Every corporation taxable under this article as well as foreign corporations having officers, agents or representatives within the state shall annually on or before July first, or within thirty days after the making of its report of entire net income to the United States treasury department for any fiscal or calendar year, transmit to the tax commission a report in the form prescribed by the tax commission specifying: 1 . The name and location of the principal place of business of such corporation, the state under the laws of which organized, and the date thereof; the amount of its issued capital stock and the kind of business transacted. Any corporation not organized under the laws of any state within the United States shall state the facts in relation to its entire net income as though organized under the laws of this state.

2. The amount of its entire net income for its preceding fiscal or the preceding calendar year as shown in the last return of annual net income made by it to the United States treasury department. If the corporation shall claim that the return made to the United States treasury department was inaccurate, the amount claimed by it to be the net income for such period shall be specified. If any deduction has been allowed for losses sustained by the corporation in prior years the amount so allowed and deducted shall be specified.

3. The average monthly value for the fiscal or calendar year of its reäl property and tangible personal property in each city, village or portion of a town outside of a village within the state, and the average monthly value of all its real property and tangible personal property wherever located.

4. The average monthly value for the fiscal or calendar year of bills and accounts receivable for (a) personal property sold by the corporation from merchandise manufactured by it within this state; (b) personal property sold by the corporation from merchandise owned by it and located within the state at the time of the acceptance of the order, but not manufactured by it within this state; and (c) services performed, based on all orders received at offices maintained by the corporation within this state; excluding bills and accounts receivable arising from sales made from a stock of merchandise or other property located at a place of business maintained by the reporting corporation within this state. Also the average total monthly value for the fiscal or calendar year of bills and accounts receivable for 
(a) personal property sold by the corporation from merchandise manufactured by it within and without the state, (b) personal property sold by the corporation from merchandise owned by it at the time of the acceptance of the order but not manufactured by it; and (c) services performed, based on orders received at offices maintained by the corporation, excluding bills and accounts receivable on orders filled from a stock of merchandise or other property maintained by the reporting company.

5. The average total value for the fiscal or calendar year of the stock of other corporations owned by the corporation, and the proportion of the average value of the stock of such other corporations within the state of New York, as allocated pursuant to section two hundred and fourteen of this chapter.

6. If the corporation has no real or tangible personal property within the state, the city, village or portion of a town outside of a village in the state in which is located the office in which its principal financial concerns within the state are transacted.

7. Such other facts as the tax commission may require for the purpose of making the computation required by this article.

8. Any corporation taxable hereunder upon its entire net income may omit from its report the statements required by subdivisions four and five by incorporating in its report a consent to be taxed upon its entire net income. Corporations having no net income shall, however, complete the segregation of assets in every case.

[SouRCE:-Ch. 726, L. 1917, as am'd by Ch. 417, L. 1918 and by Ch. 628, L. 1919.

The 1918 amendment added the limitation of time as to transmitting the state report within 30 days after filing report with the Treasury Department. The amount of issued capital stock was to be returned. It also permitted corporations to return net income on basis other than that determined by the U. S. Treasury Department, where that was inaccurate. There were changes in subdivision 4 avoiding duplication of accounts receivable and a more definite statement of accounts receivable for services rendered.

The 1919 amendment added subdivision 5 and the words italicized in subdivisions 1, 2 and 8.]

$\S 212$. Reports by corporation on basis of fiscal year. A corporation which reports to the United States treasury department on the basis of its fiscal year, may report to the tax commission upon the same basis, except as provided in section two hundred and fourteen-a of this chapter. 
[SOURCE:-Ch. 726, L. 1917, as am'd by Ch. 628, L. 1919. The words italicized were added in 1919.]

$\S 213$. Reports to be sworn to; forms. Every report required by this article shall have annexed thereto the affidavit of the president, vice-president, secretary or treasurer of the corporation to the effect that the statements contained therein are true. Blank forms of the report shall be furnished by the tax commission, on application, but failure to secure such a blank shall not release any corporation from the obligation of making a report herein required. The commission may require a further or supplemental report under this article to contain further information and data necessary for the computation of the tax herein provided.

[Source:-Ch. 726, L. 1917-no change.]

$\S 214$. Computation of tax. If the entire business of the corporation be transacted within the state, the tax imposed by this article shall be based upon the entire net income of such corporation for such fiscal or calendar year as defined in section two hundred and eight of this chapter, subject, however, to any correction thereof for fraud, evasion or error, as ascertained by the state tax commission.

If the entire business of such corporation be not transacted within the state, the tax imposed by this article shall be based upon a proportion of such entire net income, to be determined in accordance with the following rules:

The proportion of the entire net income of the corporation upon which the tax under this article shall be based, shall be such portion of the entire net income as the aggregate of

1. The average monthly value of the real property and tangible personal property within the state.

2. The average monthly value of bills and accounts receivable for (a) personal property sold by the corporation from merchandise manufactured by it with"n this state; (b) personal property sold by the corporation from merchandise owned by it and located within the state at the time of the acceptance of the order, but not manufactured by it within this state; and (c) services performed within this state, excluding bills and accounts receivable arising from sales made from a stock of merchandise or other property located at a place of business maintained by the reporting corporation without this state.

3. The proportion of the average value of the stocks of other corporations owned by the corporation, allocated to the state as provided by this section, but not exceeding ten per centum of the real and tangible personal property segregated to this state under this article, bears to the aggregate of 
4. The average monthly value of all the real property and personal property of the corporation, wherever located.

5. The average total value of bills and accounts receivable for (a) personal property sold by the corporation from merchandise manufactured by it within and without this state; (b) personal property sold by the corporation from merchandise owned by it at the time of acceptance of the order but not manufactured by it; and (c) services performed both within and without this state, based on orders received at offices maintained by the corporation, excluding bills and accounts receivable on orders filled from a stock of merchandise or other property maintained by the corporation.

6. The average total value of stocks of other corporations owned by the corporation, but not exceeding ten per centum of the aggre. gate real and tangible personal property set up in this report.

Real property and tangible personal property shall be taken at its actual value where located. The value of share stock of another corporation owned by a corporation liable hereunder shall for purposes of allocation of assets be apportioned in and out of the state in accordance with the value of the physical property in and out of the state representing such share stock.

It is further provided that every domestic corporation exercising its franchise in this state and every foreign corporation doing business in this state, other than those exempted by section two hundred and ten of this chapter, shall be subject to a minimum tax of not less than ten dollars and not less than one mill upon each dollar of the apportionment of the face value of its issued capital stock apportioned to this state, which shall be determined by dividing the amount of the real and tangible personal property in this state by the entire amount of the real and tangible personal property as shown in the report, and multiplying the quotient by the face value of the issued capital stock. If such a corporation has stock without par value, then the base of the tax shall be on such a portion of its paid in capital as its real and tangible personal property in this state bears to its entire real and tangible personal property.

[SouRce:-Ch. 726, L. 1917, as am'd by Ch. 417, L. 1918 and by Ch. 628, L. 1919. The 1918 amendment added the words "Subject, however, to any correction, * * *" \&c., to the end of the first sentence. It also changed the computation of the tax to correspond to the 1918 amendments in the form of report in Section 211. In subdiv. 6 , it added the words of limitation at the end "but not exceeding ten percentum * * *." It also added the minimum tax provision contained in the last paragraph of Section 214. 
The 1919 amendments added the words italicized.]

\$ 214-a. Taxation of corporations acquiring assets or franchises of other corporations.-If any corporation taxable under this article shall acquire either directly, indirectly or by merger or consolidation the major portion of the assets or the franchise of another corporation or of corporations exercising any franchise or franchises or doing any business in this state during any year, it shall include in its own next annual return, in addition to its own entire net income, so much of the entire net income of the corporation or corporations whose assets or franchises it acquired as shall not have been used or included in measuring a franchise tax to this state, and shall be taxed upon such combined entire net incomes for the year to ensue and as hereinbefore provided. The provisions for a minimum tax shall be applied only when under such provisions a tax will result in excess of the amount which would be produced by a tax on entire net income as hereinbefore provided and then in lieu thereof.

This section shall be construed as having been in effect as of the date of the original enactment of article nine-a of the tax law, as added by chapter seven hundred and twenty-six of the laws of nineteen hundred and seventeen.

[Source:-Added by Ch. 292-L. 1918. See Chapter XI., supra, for 1918 part omitted.]

$\S 215$. Rate of tax. The tax imposed by this article shall be at the rate of four and one-half per centum of the entire net income of the corporation or portion thereof taxable within the state, determined as provided by this article.

[Sou $\mathrm{RCE}:-C h .726, L .1917$, as am'd by Ch. 628, L. 1919. The rate of tax was changed from three to four and one-half per centum.]

$\S 216$. Penalty for failure to report. Any corporation which fails to make any report required by this article shall be liable to a penalty of not more than five thousand dollars to be paid to the state, to be collected in a civil action, at the instance of the tax commission; and any officer of any such corporation who makes a fraudulent return or statement with intent to defeat or evade the payment of the taxes prescribed by this article shall be liable to a penalty of not more than one thousand dollars, to be collected in like manner. All moneys recovered as penalties, for a failure to report or for making fraudulent reports shall be paid to the state comptroller.

[SouRCE:-Ch. 726, L. 1917-no change.]

$\S 217$. Powers of tax commission. The tax commission may for good cause shown extend the time within which any corporation is 
required to report by this article. If any report required by this article be not made as herein required, the tax commission is authoriżed to make an estimate of the net income of such corporation and of the amount of tax due under this article, from any information in its possession, and to order and state an account according to such estimate for the taxes, penalties and interest due the state from such corporation. If the tax imposed upon any corporation under this article is based upon an estimate as provided in this section, the tax commission shall notify such corporation of a time and place at which opportunity will be given to the corporation to be heard in respect thereof. Such notice shall be mailed to the postoffice address of the corporation. All the authority and powers con: ferred on the tax commission by the provisions of section one hundred and ninety-five of the tax law shall have full force and effect in respect of corporations which may be liable hereunder.

[Source:-Ch. 726, L. 1917-no change.]

$\S 218$. Revision and readjustment of accounts by tax commission. If an application for revision be filed with the commission by a corporation against which an account is audited and stated within one year from the time any such account shall have been audited and stated, the commission shall grant a hearing thereon and if it shall be made to appear upon any such hearing by evidence submitted to it or otherwise, that any such account included taxes or other charges which could not have been lawfully demanded, or that payment has been illegally made or exacted of any such account, the commission shall resettle the same according to law and the facts, and adjust the account for taxes accordingly, and shall send notice of its determination thereon to the corporation and state comptroller forthwith.

[Source:-Ch. 726, L. 1917-no change.]

$\S 219$. Review of determination of tax commission by certiorari and regulations as to writ. The determination of the commission upon any application made to it by any corporation for revision and resettlement of any account, as prescribed by this article, may be reviewed in the manner prescribed by and subject to the provisions of section one hundred and ninety-nine of this chapter.

No certiorari to review any audit and statement of an account or. any determination by the commission under this article shall be granted unless notice of application therefor is made within thirty days after the service of the notice of such determination. Eight days' notice shall be given to the commission of the application for such w:it. The full amount of the taxes, percentage, interest and 
other charges audited and stated in such account must be deposited with the state comptroller before making the application and an undertaking filed with the commission, in such amount and with such sureties as a justice of the supreme court shall approve, to the effect that if such writ is dismissed or the determination of the commission affirmed, the applicant for the writ will pay all costs and charges which may accrue against it in the prosecution of the writ, including costs of all appeals.

[Source:-Ch. 726, L. 1917, as am'd by Ch. 417, L. 1918. The 1918 amendment added the words "and regulations as to writ" to the begin. ning of the section and struck out the vords "and two hundred" before the last three words of the first paragraph. It also added the entire last paragraph.]

§ 219-a. Audit and statement of tax. On or before the first day of December in each year the tax commission shall audit and state the account of each corporation known to be liable to a tax under this article, for its preceding fiscal or the preceding calendar year, and shall compute the tax thereon and forthwith notice the same to the state comptroller for collection. The tax commission shall determine the portion of such tax to be distributed to the several counties and the amounts to be credited to the several cities or towns thereof, when the same is collected, and shall indicate such determination in noticing such tax to the state comptroller. If the corporation has real property or tangible personal property located in a village, or if it has no real or tangible personal property in the state but the office in which its principal financial concerns within the state are transacted is located in a village, the tax commission shall indicate such facts to the state comptroller, with the name of the village in which such office or property is located.

[Source:-Ch. 726, L. 1917, as am'd by Ch. 628, L. 1919. The 1919 amendment changed the date of auditing and stating the tax from November lst to December 1st.]

$\S 219-b$. Notice of tax. Every report required by section two hundred and eleven of this chapter shall contain the post-office address of the corporation and lines or spaces upon which the corporation shall enter its entire net income. Notice of tax assessment shall be sent by mail to the post-office address given in the report, and the record that such notice has been sent shall be presumptive evidence of the giving of the notice and such record shall be preserved by the tax commission.

[SoURCE:-Ch. 726, L. 1917-no chañge.] 
§ 219-c. When tax payable. The tax hereby imposed shall be paid to the state comptroller on or before the first day of January of each year, or within thirty days after notice of the tax has been given as provided in section two hundred and nineteen-b of this chapter if such notice is given subsequent to the first day of December of the year for which such tax is imposed. If such tax be not so paid, or in the case of additional taxes, if not paid within thirty days after notice of such additional tax has been given as provided in section two hundred and nineteen-d of this chapter and such notice of additional tax is given subsequent to the first day of December of the year for which such additional tax is imposed, the corporation liable to such tax shall pay to the state comptroller, in addition to the amount of such tax, or additional tax, ten per centum of such amount, plus one per centum for each month the tax or additional tax remains unpaid. Each such tax or additional tax shall be a lien upon and binding upon the real and personal property of the corporation liable to pay the same from the time when it is payable until the same is paid in full.

[Source:-Ch. 726, L. 1917, as am'd by Ch. 271, L. 1918, and by Ch 628, L. 1919. The 1918 amendment added the alternative provision in the first sentence limiting the time of payment to thirty days after notice. It also changed the second sentence as to additional taxes. The 1919 amendment eliminates the provision in the 1918 amendment as to waiver of penalty for taxes for the year beginning Nov. 1, 1917.]

$\S 219$-d. Corrections and changes. If the amount of the net income for any year of any corporation taxable under this article as returned to the United States treasury department is changed or cor. rected by the commissioner of internal revenue or other officer of the United States or other competent authority, such corporation, within ten days after receipt of notice of such change or correction, shall make return under oath or affirmation to the tax commission of such changed or corrected net income, and shall concede the accuracy of such determination or state wherein it is erroneous.

The tax commission shall ascertain from such return and any other information in the possession of the commission, the entire net income of such corporation for the fiscal or calendar year for which such change or correction has been made by such commissioner of internal revenue or other officer or authority. All the authority conferred on the tax commission by the provisions of section one hundred and ninety-five of this chapter is hereby granted to it in respect to the ascertainment of such entire net income. The tax commission shall thereupon reaudit and restate the account of such cor- 
poration for taxes based upon the entire net income for such fiscal or calendar year, such reaudit to be according to the entire net income so ascertained by the tax commission. The proceedings and determination of the tax commission in the making of such reassessment may be revised and readjusted and reviewed in the manner provided by sections two hundred and eighteen and two hundred and nineteen of this chapter, as in the case of an original assessment of the tax. If from such reassessment it appears that such corporation shall have paid under this article an excess of tax for the year for which such reassessment is made, the tax commission shall return a statement of the amount of such excess to the comptroller, who shall credit such corporation with such amount. Such credit may be assigned by the corporation in whose favor it is allowed to a corporation liable to pay taxes under this article, and the assignee of the whole or any part of such credit on filing with the commission such assignment shall thereupon be entitled to credit upon the books of the comptroller for the amount thereof on the current account for taxes of such assignee in the same way and with the same effect as though the credit had originally been allowed in favor of such assignee. If from such reassessment it appears that an additional tax is due from such corporation for such year, such corporation shall, within thirty days after notice has been given as provided in section two hundred and nineteen-b of this chapter by the tax commission, pay such additional tax.

[SOURCE:-Ch. 726, L. 1917, as am'd by Ch. 276, L. 1918 and by Ch. 628, L. 1919.

The 1918 amendment added the last fourteen words to the first paragraph of section 219-d, and all the part of the second paragraph beginning "ascertain from such return" to and including "as in the case of an original assessment of the tax." It changed the word "computation" to "reassessment."

The 1919 amendment prefixed the word "entire" to income, wherever it occurs in the second paragraph.]

$\S 219-e$. Warrant for the collection of taxes. If the tax imposed by this article be not paid within thirty days after the same becomes due, unless an appeal or other proceeding shall have been taken to review the same, the comptroller may issue a warrant under his hand and official seal directed to the sheriff of any county of the state commanding him to levy upon and sell the real and personal property of the corporation owning * the same, found within his coun-

* So in the original; probably intended for "owing." See also Section 380 Tax Law. Part IV infra. 
ty, for the payment of the amount thereof, with the added penalties, interest and the cost of executing the warrant, and to return such warrant to the comptroller and pay to him the money collected by virtue thereof by a time to be therein specified, not less than sixty days from the date of the warrant. Such warrant shall be a lien upon and shall bind the real and personal property of the corporation against whom it is issued from the time an actual levy shall be made by virtue thereof. The sheriff to whom any such warrant shall be directed shall proceed upon the same in all respects, with like effect, and in the same manner as prescribed by law in respect to executions issued against property upon judgments of a court of record, and shall be entitled to the same fees for his services in executing the warrant, to be collected in the same manner.

[SOURCE:-Ch. 726, L. 1917-no change.]

$\S 219$-f. Action for recovery of taxes; forfeiture of charter by delinquent corporations. Action may be brought at any time by the attorney-general at the instance of the comptroller, in the name of the state, to recover the amount of any taxes, penalties and interest due under this article. If such taxes be not paid within one year after the same be due, and the comptroller is satisfied that the failure to pay the same is intentional he shall so report to the attorney-general, who shall immediately bring an action in the name of the people of the state, for the forfeiture of the charter or franchise of any corporation failing to make such payment, and if it be found that such failure was intentional, judgment shall be rendered in each action for the forfeiture of such charter and for its dissolution if a domestic corporation and if a foreign corporation for the annulment of its franchise to do business in this state.

[Source:-Ch. 726, L. 1917-no change.]

$\S 219$-g. Deposit of revenues collected. The state comptroller shall deposit all taxes, interest and penalties collected under this article in responsible banks, banking houses or trust companies in the state which shall pay the highest rate of interest to the state for such deposit, to the credit of the State comptroller on account of the franchise tax. And every such bank, banking house or trust company shall execute and file in his office an undertaking to the state, in the sum, and with such sureties, as are required and approved by the comptroller, for the safe keeping and prompt payment on legal demand therefor of all such moneys held by or on deposit in such bank, banking house or trust company, with interest thereon on daily bararices at such rate as the comptroller may fix. Every such undertaking shall have indorsed thereon, or annexed thereto, the approval 
of the attorney-general as to its form. The state comptroller shall on the first day of each month make a verified return to the state treasurer of all revenues received by him under this article during the preceding month, stating by whom and when paid, and shall credit himself with all payments made to county treasurers since his last previous return pursuant to section two hundred and nineteen-h of this chapter.

[SoUrce:-Ch. 726, L. 1917-no change.]

$\S 219$-h. Disposition of revenues collected. The state comptroller shall on or before the twenty-fifth day of each month pay into the state treasury to the credit of the general fund all interest and penalties and two-thirds of all taxes received by him under this article during the preceding calendar month, as appears from the return made by him to the state treasurer. The balance of all taxes collected and received by him under this article from any corporation, as appears from the return made by him to the state treasurer, shall, on or before the twenty-fifth day of April, July, October and January, for the quarter ending with the last day of the preceding month, be distributed and paid by him to the treasurers of the several counties of the state and disposed of by such treasurers, in accordance with the following rules:

1. If the corporation has no tangible personal property within the state, such payment shall be made to the county treasurer of the county in which is located the office at which its principal financial concerns within the state are transacted;

2. If the corporation has tangible personal property, as shown by its report pursuant to section two hundred and eleven, in but one city or town of the state, such payment shall be made to the county treasurer of the county in which such city or town is located;

3. If the corporation has tangible personal property in more than one city or town of the state, as shown by its report pursuant to section two hundred and eleven, such payments shall be made to the county treasurers of the counties in which such cities or towns are located in the proportion that the average monthly value of the tangible personal property of such corporation in the cities and towns of such county bears to the average monthly value of all its tangible personal property within the state;

4. In making such payment to a county treasurer, the state comptroller shall indicate the portion thereof to be credited to any city or town within the county on account of the location therein of its principal financial office or property as determined by the preceding 
subdivisions, and if such principal financial office or property is located in a village shall indicate the village in which it is located; if such principal financial office or property is located in a city or in a town outside of a village, the whole of such portion shall be paid to such city or town as hereinafter provided; if such principal financial office or property is located in a village, there shall be paid to such village as hereinafter provided such a part of the entire amount credited to the town as the entire amount of taxes raised by said village, or portion thereof in said town, during the preceding calendar year for village and town purposes bears to the aggregate amount so raised by the town and village during the preceding calendar year for town and village purposes;

5. As to any county wholly included within a city such payment shall be made to the chamberlain or other chief fiscal officer of such city and be paid into the general fund for city purposes;

6. As to any county not wholly included within a city, the county treasurer shall within ten days after the receipt thereof pay to the chief fiscal officer of a city or to the chief fiscal officer of a village or to the supervisor of a town the portion of money received by him from the state comptroller to which such city, village or town is entitled, which shall be credited by such officer to general eity, village or town purposes.

[SouRce:-Ch. 726, L. 1917, as am'd by Ch. 417, L. 1918 and by Ch. 628, L. 1919.

The 1918 amendment changed the date of payment from the 10th to 25th day of each month, all the interest and penalties to be retained by the state, and the basis of apportionment of the tax in subdivs. 1, 2 and 3 was to be tangible personal property. The basis of apportionment between town and village was changed as shown in the last sentence of subdiv. 4.

The 1919 amendment eliminates the superfluous words "real property and" at the end of subdiv. 3.]

\section{$\S 219-\mathrm{i}$. Secrecy required of officials; penalty for violation.}

1. Except in accordance with proper judicial order or as otherwise provided by law, it shall be unlawful for any tax commissioner, agent, clerk, or other officer or employee to divulge or make known in any manner the amount of income or any particulars set forth or disclosed in any report under this article. Nothing herein shall be construed to prohibit the publication of statistics so classified as to prevent the identification of particular reports and the items thereof, or the publication of delinquent lists showing the names of taxpayers who have failed to pay their taxes at the time and in the manner 
provided by section two hundred and nineteen-c together with any relevant information which in the opinion of the comptroller may assist in the collection of such delinquent taxes; or the inspection by the attorney-general or other legal representatives of the state of the report of any corporation which shall bring action to set aside or review the tax based thereon, or against whom an action or proceeding has been instituted in accordance with the provisions of sections two hundred and sixteen or two hundred and nineteen-f of this article.

Reports shall be preserved for three years, and thereafter until the stäte tax commission orders them to be destroyed;

2. Any offense against the foregoing provision shall be punished by a fine not exceeding one thousand dollars or by imprisonment not exceeding one year, or both, at the discretion of the court and if the offender be an officer or employee of the state he shall be dismissed from office and be incapable of holding any public office in this state for a period of five years thereafter.

[SOURCE:-Ch. 726, L. 1917-no change.]

\$ 219-j. Exemptions from certain other taxation. After this article takes effect, corporations taxable thereunder shall not be assessed on any personal property or capital stock, as provided for in section twelve of this chapter, except for taxes levied for the fiscal year ending December thirty-first, nineteen hundred and seventeen, in taxing districts in which the fiscal year is coterminous with the calendar year; and where taxes are required by law to be levied for local purposes for a fiscal year beginning in nineteen hundred and seventeen and ending in nineteen hundred and eighteen, such corporations shall not be assessed on any personal property or capital stock, as provided for in section twelve of this chapter, except for taxes levied for such fiscal year.

If, in any taxing district, by reason of the provisions of this section as originally enacted by chapter seven hundred and twentysix of the laws of nineteen hundred and seventeen, the assessment of the personal property or capital stock of any such corporation has been omitted from the assessment-roll for the fiscal year specifically referred to in the first paragraph of this section, the assessors of such district shall enter the same in the assessment-roll first prepared after this act goes into effect, at the valuation of such fiscal year, or if not then valued, at such valuation as the assessors shall determine for such year. Before finally fixing such valuation the assessors shall give to such corporation a notice of at least five days and an opportunity to be heard with reference thereto. Such property shall be 
taxed at the rate per centum of the fiscal year in which it was omitted from the assessment-roll. The whole amount of tax so imposed on the personal property or capital stock of such corporations shall be deducted from the aggregate of taxation otherwise to be levied on such taxing district for the current year, before such tax is levied.

After this article takes effect corporations taxable thereunder shall not be required to pay the franchise tax imposed by section one hundred and eighty-two of this chapter, or to make the reports called for in sections twenty-seven and one hundred and ninety-two of this chapter, except that, for the purpose of assessing the personal property or capital stock of such corporations as specifically provided in this section, such corporations may be required to make the report called for in such section twenty-seven. Nothing herein shall be construed to impair the obligation to pay franchise taxes due on or before the fifteenth day of January, nineteen hundred and seventeen, or taxes on personal property or capital stock assessed as specifically provided in this section, whether such taxes have been or may hereafter be assessed. But if any corporation taxed under this article shall have paid or shall hereafter pay taxes on personal property or capital stock assessed as specifically provided in this section, for any part of the calendar year nineteen hundred and eighteen, such corporation shall be entitled to credit, with interest, as hereinafter provided, for the amount of such part of the taxes so paid locally as the portion of the year nineteen hundred and eighteen for which such taxes shall have been paid bears to the entire calendar year. And if, in any taxing district, by reason of the provisions of this section as originally enacted by chapter seven hundred and twenty-six of the laws of nineteen hundred and seventeen, any such corporation shall have paid or shall hereafter pay taxes on personal property or capital stock for the year ending December thirty-first, nineteen hundred and eighteen, such corporation shall be entitled to credit, with interest, as hereinafter provided, for the amount of taxes so paid locally.

Such credits shall be granted by the tax commission on the submission of satisfactory proofs that the corporation is entitled thereto. The tax commission shall forthwith notify the corporation and the comptroller of any credit so granted. Such credit may be used by the corporation entitled thereto in the payment of taxes charged against it under this article, or such credit or any part thereof may be assigned by the corporation in whose favor it is allowed to a corporation liable to pay taxes under this article, and the assignee of the whole or any part of such credit on filing with the comptroller such assignment shall thereupon be entitled to credit upon the books 
of the comptroller for the amount thereof on the account for taxes of such assignee in the same way and with the same effect as though the credit had originally been allowed in favor of such assignee.

Upon receipt of notice from the tax commission of any credit under this article the comptroller may refund to the corporation, out of the current revenues in his hands received under this article, the amount of such excess paid by the corporation, without interest, and shall charge the amount or amounts of such excess against the state treasury and the taxing district or districts in the proportions that such excess was originally credited or paid. In case the amount of current revenues credited to any taxing district under this article is not equal to the charge against any such taxing district on account of such refund, further revenues oredited to such taxing district shall first be applied by the comptroller to the liquidation of such charge.

[Source:-Ch. 726, L. 1917, as am'd by Ch. 271, L. 1918, and by Ch. 138, L. 1919.

The 1918 amendment struck from 219-j the provision as to exemption of fixtures and segregated it to a new section (219-l). Most of Seotion 219-j, us it now stands, was added by the amendment of 1918, with the exception of the last paragraph as to a refund by the comptroller, which was added by the amendment of 1919.]

$\S 219-\mathrm{k}$. Limitation of time. The provisions of the code of civil procedure relative to the limitation of time of enforcing a civil remedy shall not apply to any proceeding or action taken to levy, appraise, assess, determine or enforce the collection of any tax or penalty prescribed by this article.

[Source:-Ch. 726, L. 1917-no change.]

$\S 219-1$. Personal property defined. The term "personal property," for the purpose of the exemption from assessment and taxation thereon locally as granted by section two hundred and nineteen-j of this chapter, shall include any movable machinery and equipment used for trade or manufacture and not essential for the support of the building, structure or superstructure, and removable without material injury thereto. The term "personal property," as used in such section, shall not include boilers, ventilating apparatus, elevators, plumbing, heating, lighting and power generating apparatus, shafting other than counter-shafting, equipment for the distribution of heat, light, power, gases and liquids, nor any equipment consisting of structures or erections to the operation of which machinery is not essential. An owner of a building is entitled to the same exemption under this section as a lessee. 
[Source:-Added by Ch. 271, L. 1918, and am'd by Ch. 628, L. 1919.

The 1919 amendment struck out the woords in the first paragraph of 1918 law beginning "affixed to the building" and ending "be moved except" and also the injunction as to assessments of real property made subsequent to June 4, 1917.]

Note.-§ 15 of Chapter 628, L. 1919, provided that "This Act shall not affect any action or proceeding now pending."

Note.-The 1919 amendments take effect May 14, 1919, but shall not affect any action or proceeding pending on that date. 


\section{PART III}

REMEDIES

\section{CERTIORARI}

\section{COLLECTION}

AND VARIOUS ADMINISTRATIVE SECTIONS COMMON TO ARTICLES 9, 9-A AND 16 OF THE TAX LAW. 


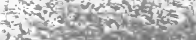

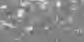
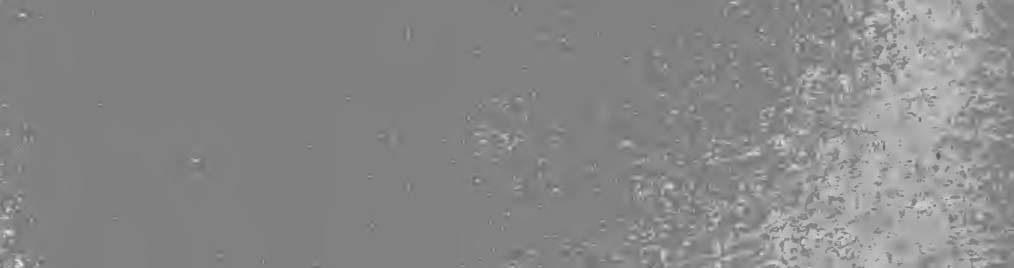


\section{CHAPTER XX.}

\section{Remedies.}

The administrative provisions for the revision and collection of corporation franchise taxes and personal income taxes, whether assessed by the State Tax Commission or by the State Comptroller are similar in character and scope and are therefore treated together. Indeed, the State Comptroller originally levied, as well as collected, all the State corporation taxes and the power was taken away from him by Chapter 317 of the Laws of 1915, which established the State Tax Department and defined its powers and duties transferring thereto certain powers of the Comptroller. Thus under the Laws of 1919, the State Comptroller, who is now authorized to assess as well as to collect the personal income tax under Article 16, is in a measure coming into his own again.

Section 198, Article 9, Sections 218 and 219-d, Article 9-a, respectively, provide the procedure for the revision of an erroneous or illegal corporation tax, and Section 374, Article 16, for an erroneous or illegal personal income tax. The various statutory provisions in each case and the practice covering them are substantially similar.

Revision of corporation taxes under Article 9:-Section 198 of the Tax Law providing for a revision of an illegal or erroneous tax stated against a corporation under Article 9 of the Tax Law, is given below:

Revision and readjustment of accounts by tax commission.-If an application be filed with the commission by the party against whom the account is stated or by the attorney-general within one year from the time any such account shall have been audited and stated, the commission may at any time, upon notice thereof sent to the person, partnership, company, association or corporation against whom it is 
stated, revise and readjust such account, and if it shall be made to appear upon any such application by evidence submitted to it or otherwise, that any such account included taxes or other charges which could not have been lawfully demanded, or that payment has been illegally made or exacted of any such account, the commission shall resettle the same according to law and the facts, and charge or credit, as the case may require, the difference, if any, resulting from such revision or resettlement upon the accounts for taxes of or against any such person, partnership, company, association or corporation. Such credit, whether allowed before or after the passage of this chapter, may be, by the person, partnership, company, association or corporation in whose favor it is allowed, assigned to a person, partnership, company, association or corporation liable to pay taxes under article nine of this chapter and the assignee of the whole or any part of such credit on filing with the commission such assignment shall thereupon be entitled to credit on the books of the commission for the amount thereof on the current account for taxes of such assignee in the same way and with the same effect as though the credit had originally been allowed in favor of such assignee. The commission shall forthwith send written notice of its determination upon such application to the applicant, and to the attorney-general, which notice may be sent by mail to its post-office address. (Sec. 198, former sec. 195, Tax Law, as amended by ch. 642, L. 1903, ch. 734, L. 1907; and by ch. 317, L. 1915.)

Source: L. 1880, ch. 542, sec. 19, as added by L. 1889, ch. 463.

(Recent Amendments.-The amendment of 1915 substituted the word "commission" for "comptroller" where it formerly occurred.)

Similar provisions under Articles 9-a and r6.-Sections 218 and 219-d, containing the statutory provisions for the revision of a tax under the Business Corporations Tax Law (Article 9-a) will be found in the last Chapter of Part II (supra). Section 374 (Article 16) covers a similar provision in the Personal Income Tax Law, and will be found in Part IV infra.

Revision and readjustment of tax.-Under Section 198, Article 9, or under Section 218 of the Tax Law, which is contained in Article 9-a, a corporation dissatisfied with the tax settled against it by the State Tax Commission may make an application, "within one year from the time any such account shall have been audited and stated," for a correction and revision thereof, and it is further 
provided under Section 218 that "the Commission shall grant a hearing thereon."

It will be noticed that under this section, it makes it mandatory upon the Commission to grant a hearing, whereas under Section 198 of Article 9, the Commission was not obliged to comply with the request. Written application for revision must be made, for the section requires the application to be filed.

The auditing and stating of an account by the Tax Commission refers to its determination on the original return filed by the corporation, the entry of the tax, the assessment upon the books of the Tax Commission and notice thereof to the corporation assessed.

Under the practice in the State of Pennsylvania, it has been held that "an 'account' or 'settlement' is a physical, tangible thing, a paper with figures and writing upon it, signed by the AuditorGeneral and State Treasurer, indorsed, copied into a ledger and filed away in its appropriate place. Whether such a settlement has been made against a given corporation, for a tax of a given year, is therefore a question of fact to be ascertained by looking in the proper place for the settlement." Hardenbergh's Opinions and Decisions under Acts of Pennsylvania, p. 31.

The settlement of taxes against corporations by the AuditorGeneral and State Treasurer, being a purely ministerial act, may be made by clerks acting respectively under the direction and by the authority of the Auditor-General and State Treasurer. Seo Phila. \& Read. R. R. Co. v. Com., 104 Pa. 86; Hamilton Wheel Co. v. Com., 12 W. N. C. 328.

Revision of personal income tax.-Under Section 374, Article 16, providing for the revision of a personal income tax, the application must be filed within one year from the time of the filing of the return. Since the personal income tax is self-assessed by the taxpayer, the filing of the return marks the period when the time begins to run. No notice is required unless there be a recomputation, when it would seem that the comptroller must send notice of the recomputation. The granting of the application for 
a revision appears to be mandatory as is the case of business corporation taxes under Article 9-a.

Form of application for revision.-The statute does not set forth any formal requirements to be contained in an application of this character, but it would seem that the following may be used as a precedent. This form of application may be modified to suit the law and facts in cases arising under Articles 9 and 16.

In the Matter

of

The Application of the.

Company for a Revision and Readjustment of the Account Heretofore Au-

dited and Stated by the State Tax Commission of the State of New York, for Taxes under Article 9 -a of the Tax Law.

To the Honorable State Commission of the State of New York:

The application of the............................ respectfully shows:

(1). That it is a domestic corporation duly organized and existing under the Laws of the State of New York [or, if a foreign corporation, say: that it is a foreign corporation organized and existing under the Laws of the State of............. transacting business in the State of New York].

(2). That for the year beginning November 1st, 191\%, it was engaged in the business of [allege the facts] in the State of New York, and in other places outside of said State as will more particularly be referred to hereafter: that part of its capital, including tangible property is employed in the State of New York, but that the greater part of its tangible property consisting of [state nature thereof] is employed outside of said State as will more particularly be referred to hereafter.

(3). That on or about the..... day of......., 191\%, it made a written report to the State Tax Department, as required 
by Article 9-a of the Tax Law, such report being in the form prescribed by said department: that a copy of said report is hereto annexed, made a part hereof, and marked Exhibit A.

(4). That thereafter the State Tax Commission audited and stated the account for taxes to be paid by your petitioner for the year beginning November 1st, 191\%, and sent notice thereof to it.

(5). That the said account so audited and stated imposed a tax of $\$ . . . \ldots \ldots$.... upon said corporation.

(6). That said account was erroneous and illegal in that [here set forth in detail the facts upon which it is claimed that the account was erroneous or illegal].

(7). That in consequence of the fact that said tax was erroneous and illegal, it cannot be lawfully demanded, and the said tax is wholly without warrant or authority either in fact or law.

WHEREFORE, the said company makes application for a revision and readjustment of such account, so audited and stated, so that your petitioner shall be given credit for [here state credit claimed]. That upon such hearing your petitioner will present evidence to corroborate such facts as will support its claim for such credit, to wit: [here set forth facts to be adduced], and your petitioner prays that the Tax Commission shall resettle such tax according to the law and the facts, and adjust the account of the taxes accordingly, and that it shall thereafter send notice of its determination to the State Comptroller; and the said company prays for such other and further relief as may be proper.

.Company.

By.................

President (or other officer).

\section{Attorney.}

Office and P. O. Address.........
(Verification in usual form.)

Verification.-The failure to verify a petition for resettlement is no ground for assuming that facts therein stated are insufficient on certiorari. When the comptroller has granted an application 
for a resettlement of a tax on a petition properly signed, but not verified, the court, on certiorari, cannot assume that in this respect there was not sufficient proof before the comptroller. People $v$. Campbell \& Roberts, 88 Hun, 544.

Revision and resettlement of tax.-Upon the revision or resettlement of an account, the commission shall, under Section 218, Article 9-a, resettle the same according to law and the facts, and adjust the account for taxes accordingly. Under Article 9, Section 198, "the Commission shall resettle the same according to law and the facts, and charge or credit, as the case may require, the difference, if any, resulting from such revision or resettlement."

It is reasonable to assume that the Commission has the same power to credit a business corporation's account with taxes or other charges unlawfully or erroneously demanded, or with an illegal payment, under Section 218, that it has under Article 9 with respect to the corporations affected thereby.

Credit for excess taxes; refund.-Before the enactment of Article 9-a, corporations could assign the difference resulting from a revision or resettlement of a franchise tax under Article 9 (Section 198, Tax Law). There is no similar provision in Article 9-a, but under Section 219- $d$ thereof, business corporations are permitted to assign an excess of tax to a corporation liable to pay taxes, after the amount of annual net income of the assignor corporation has been corrected by the Commissioner of Internal Revenue. There is therefore some ground for believing that the right to assign a credit for excess taxes under Article 9-a would be recognized. Some warrant may be found for this opinion in the general powers of the Commission under Section 218 to "adjust the account." Article 9-a, section 219-j, now provides for a refund of excess taxes paid.

Refund under Article I6 (Section 377).-Articles 9 and 9-a provide for an assignment and credit of excess taxes paid. There is no provision in Article 9 for a refund, and there was none in 9-a until Chapter 138 of the Laws of 1919 added a paragraph to Section 219-j, under which the Comptroller may refund to a cor- 
poration out of the current revenues in his hands, the amount of excess taxes paid without interest.

Under the fourth paragraph of Section 37\%, the following provision is made for a refund under the Personal Income Tax Law (Article 16) :

"4. If the amount of tax as computed shall be less than the amount theretofore paid, the excess shall be refunded by the comptroller out of the proceeds of the tax retained by him as provided in this article.

General rules applying to rehearing.-It is for the corporation on application for a hearing to establish the fact that the conclusion of the Commission was erroneous. People ex rel. Am. Axe \& Tool Co. v. Roberts, 82 Hun, 313.

On application for a revision, if a corporation fails to show ground for a readjustment, the Commission cannot increase the amount of the tax as originally fixed. Under Section 198 Tax Law, as amended by Laws of 1915, Chapter 31\%, the Commission, on a readjustment or revision charged or credited the taxpayer with the difference. Section 218 of Article 9-a provides that the Commission shall adjust the account, and the words "charge or credit" do not appear. Probably the difference in language between the 1915 Law and the present one was the result of the ambiguity created by the use of the terms "charge or credit," which words evidently referred to the state of the account between the State and the taxpayer. A tax, if illegal and already paid, is to be credited; if the tax is unpaid and diminished, it is to be charged. People ex rel. Eppens Co. v. Roberts, 51 App. Div. 152.

Application may be properly made for revision of a tax imposed upon and paid by a corporation exempted from any taxation under the act, even if the tax was voluntarily paid. People ex rel. Edison Elec. Ill. Co. v. Wemple, 141 N. Y. 471.

On application for a revision of the tax under Section 218, it would appear that the petitioner is not obliged to present further testimony or offer witnesses for examination. The corporation may rely on the accounts already presented. People ex rel. Studebaker Co. v. Knight, 66 App. Div. 150. 
When comptroller's determination binding.-The determination of an assessing officer that a corporation is exempt as a manufacturing corporation is not binding on his successor upon application to secure an exemption from taxation for a subsequent year. People ex rel. N. Eng. Dressed Meat \& Wool Co. v. Roberts, 155 N. Y. 408 (1898). But the comptroller cannot, of his own motion, change the amount of a license fee fixed by him or his predecessor. The same is in the nature of a judicial decision. People ex rel. Spencerian Pen Co. v. Kelsey, 105 App. Div. 133 (1905). 


\section{CHAPTER XXI.}

Powers of Tax Commission and Comptroller; Penalties; Collection of Taxes; Secrecy; Limitations.

Section 217 of Article 9-a provides, that if the corporation fails or neglects to make a report under the Law, the Tax Commission may estimate the net income of such corporation and compute the amount of tax due, and may audit and state the account according to such estimate. It must notify the corporation by mail, of such estimate made, and give it an opportunity to be heard with respect thereto. All the authority and powers conferred under Section 195 of the Tax Law, upon the State Tax Commission, shall have full force and effect in respect to corporations liable under this section.

Section 195 of the Tax Law reads as follows:

"Powers of Tax Commission to examine into affairs of corporations. In case any report required by any of the preceding sections of this article shall be unsatisfactory to the commission, or if any such report is not made as herein required, the commission is authorized to make an estimate of the dividends paid by such corporation and the value of the capital stock employed by it, from any such report or from any other data, and to order and state an account according to the estimate and value so made by it for the taxes, percentage and interest due the State from such corporation, association, joint-stock company, person or partnership. The commission shall also have power to examine or cause to be examined, in case of a failure to report or $_{i}$ in case the report is unsatisfactory to it, the books and records of any corporation, joint-stock association, company, foreign banker, person or partnership, and may hear testimony and take proofs material for its information, and may appoint a commissiener by a written appointment under its official seal for that purpose. Every commissioner so appointed shall be authorized to make such examination and take such testimony and hear such proofs and report the proofs and 
testimony so taken and the result of his examination so made and the facts found by him to the commission. The commission shall, therefrom, or from any other data which shall be satisfactory to it, order and state an account for the tax due the State, together with the expenses of such examination and the taking of such testimony and proofs. Such expenses shall be fixed and adjusted by the commission."

General powers of tax commission.-In addition to the powers conferred on the Tax Commission by Section 195, its general powers and duties are defined by Sections 171 and 171-a.

Section 171 of the Tax Law defines the powers of the Tax Commission, and among them are the following:

Third. Make such reasonable rules and regulations, not inconsistent with law, as may be necessary for the exercise of its powers and the performance of its duties under this chapter, and prescribe the form of blanks, reports, assessment rolls, and other records relating to the assessment of property for taxation, and furnish such forms to assessors and other officers at the expense of the State. Local assessors shall follow the forms so prescribed, and the commission shall enforce their use.

Fourth. On and after April fifteenth, nineteen hundred and fifteen, assess, determine, revise, readjust and impose the corporation taxes under article nine of this chapter.

Seventh. Take testimony and proofs, under oath, with reference to any matter within the line of its official duty. Any member of such commission may be designated for that purpose.

Eighth. Require from all State and local officers such information as may be necessary for the proper discharge of its duties.

The power to compel testimony is given under the following section :

Section I7I-a. Administer oaths and compel testimony:-The members of the tax commission, their deputies, secretary or other officer or employee duly designated and authorized by the commission for that purpose shall have power to administer-oaths and take affidavits in relation to any matter or proceeding in the exercise of the powers or duties of the commission under this article. The commission shall have power to subpœna and require the attendance of witnesses and the production of books, papers and documents pertinent to the investigations and inquiries which it is authorized to conduct, and to exam- 
ine them in relation to any matter which it has power to investigate and to issue commissions for the examination of witnesses who are out of the State or unable to attend before the tax commission or excused from attendance.

A justice of the supreme court either in court or at chambers shall have power summarily to enforce by proper proceedings the attendance and testimony of witnesses and the production and examination of books, papers and documents called for by the commission's subpœnas. Any person who shall testify falsely in any material matter pending before the commission shall be guilty of and punishable for perjury. The officers who serve the commission's summons or subpœnas and witnesses attending in response thereto, shall be entitled to the same fees as are allowed to officers and witnesses in civil cases in courts of record.

Commission cannot punish for contempt.-Under Section 171a, it is to be noted that while the Commission has power to subpoena and require the attendance of witnesses and the production of books, papers and documents, it has no power to punish for contempt. The obedience to the Commission's mandate, however, is obtained by recourse to the Supreme Court, a justice of which is by this section expressly authorized to enforce the Commission's mandate. A person who testifies falsely before the Commission is guilty of perjury.

Powers similar to those given to the Tax Commission under Section 21\%, and the power to examine the taxpayer's books and take testimony are given to the State Comptroller under Section 373 (Part IV, infra) of Article 16.

To enforce the powers of the Commission, the statute provides for the imposition of penalties for failure to file reports.

Penalty for failure to report.-Section 216 of the Tax Law reads as follows:

"Any corporation which fails to make any report required by this article shall be liable to a penalty of not more than five thousand dollars to be paid to the State, to be collected in a civil action, at the instance of the tax commission; and any officer of any such corporation who makes a fraudulent return or statement with intent to defeat or evade the payment of the taxes prescribed by this article shall be liable to a penalty of not more than one thousand dollars, to be col- 
lected in like manner. All moneys recovered as penalties, for a failure to report or for making fraudulent reports, shall be paid to the state comptroller."

It is to be noted that the amount of the penalty under this section is to be determined by the Supreme Court; the only limitation is that the penalty imposed shall in no event be more than five thousand dollars. The statute is silent as to the name of the officer of the state by whom the action is to be instituted. It is clear, however, that it should be brought by the attorney-general under his broad powers, in the same manner as he is authorized to insti. tute proceedings for the recovery of the tax under Section 219-f, at the instance of the comptroller. There is a wide departure in the method of prescribing the penalty for a delinquent corporation under Article 9, as prescribed in Section $19 \%$ and for such a corporation under Section 21\%. Under the former, a definite schedule of penalties, based upon the tax payable, in addition to a certain determined and determinate additional penalty is prescribed for corporations subject to Article 9, while Section 217 prescribes that a delinquent business corporation must pay a penalty to be fixed in a civil action in an amount to be not more than five thousand dollars.

\section{Action for recovery of taxes; forfeiture of charter of delin-} quent corporations.- Under the provisions of Article 9-a actions can be instituted for the recovery of taxes against delinquent corporations by the attorney-general, who also has the power conferred upon him, in a proper case, to institute proceedings for the forfeiture of the franchise of any such corporation. Section 219-f of Article 9-a is quite similar to Section 203 which gives the attorneygeneral similar powers over such delinquent corporations as are still affected by such article. It reads as follows:

"Action may be brought at any time by the attorney-general at the instance of the comptroller, in the name of the state, to recover the amount of any taxes, penalties and interest due under this article, if such taxes be not paid within one year after the same be due, and the comptroller is satisfied that the failure to pay the same is intentional he shall so report to the attorney-general, who shall immedi- 
ately bring an action in the name of the people of the state, for the forfeiture of the charter or franchise of any corporation failing to make such payment, and if it be found that such failure was intentional, judgment shall be rendered in each action for the forfeiture of such charter and for its dissolution if a domestic corporation and if a föreign corporation for the annulment of its franchise to do business in this state."

(The above provision follows Section 203, Article 9, in all substantial respects.)

The penalties referred to in the above section are the penalties provided for in Section 219-c, as amended in 1918, and not the penalty referred to in Section 216 for the failure of the corporation to make its report, which latter penalty is enforceable at the instance of the Tax Commission and not at the instance of the comptroller.

Interest uncollectible as part of penalty.-The statute prescribing the penalty (Section 219-c) does not provide for the payment of interest on the tax. It follows that the interest is no part of the penalty, and cannot be collected. People $v$. Gold \& Stock Tel. Co., 98 N. Y. $6 \%$.

Warrant for the collection of taxes.-Generally before proceeding to collect the tax by action (although the statute does not make it an absolute prerequisite) the comptroller resorts to the summary method of issuing a warrant to the sheriff of any county, in conformity with Section 219-e, commanding him to levy upon and sell the real and personal property of the corporation within his county, for the payment of the tax with penalties, interest and cost of executing the warrant, and to return such warrant to the comptroller, and to pay to him the money collected by virtue thereof by the time therein specified, which is not less than sixty days from the date of the warrant. The warrant is a lien on and binds all of the corporation's property from the time the actual levy is made. The sheriff to whom the warrant is directed, proceeds upon the same in all respects as prescribed by law in regard to executions issued against property upon judgments of a court of record; he is 
entitled to the same fees for his services in executing the warrant, to be collected in the same manner.

(Note: See footnote to Section 219-e, chap. XIX, supra.)

Warrant for unpaid personal income tax.-Substantially the same provision exists for the issuance of a warrant by the comptroller under Section 380 of the Tax Law, upon the return of an unpaid personal income tax which may be in arrears for sixty (instead of thirty) days with this additional feature, that

"The sheriff shall within five days after the receipt of the warrant, file with the clerk of his county a copy thereof, and thereupon the clerk shall enter in the judgment docket, in the column for judgment debtors, the name of the taxpayer mentioned in the warrant, and in appropriate columns the amount of the tax or portion thereof and penalties for which the warrant is issued and the date when such copy is filed, and thereupon the amount of such warrant so docketed shall become a lien upon the title to and interest in real property or chattels real of the person against whom it is issued in the same manner as a judgment duly docketed in the office of such clerk."

There is also an added provision that in the comptroller's discretion a warrant may issue to an agent not a sheriff, who will be entitled to actual expenses but no fees; and there is a further provision that if the warrant is returned unsatisfied, the comptroller may have the same remedies to enforce the claim for taxes against the taxpayer as if the people of the State had recovered judgment against the taxpayer for the amount of the tax.

Is there a personal liability for a personal income tax against a non-resident?-In addition to the method above described for collecting a personal income tax by a sheriff's levy on the real and personal property of the delinquent, there is the further provision in the Personal Income Tax Act:

"Section 381. Action for the Recovery of Taxes. Action may be brought at any time by the attorney-general of the state at the instance of the comptroller, in the name of the state, to recover the amount of any taxes, penalties and interest due under this article."

Whatever remedies the state is entitled to pursuant to collect a tax against a resident, it is doubtful if a personal liability may be 
imposed upon a non-resident's property not employed in business in the state, or having a permanent situs here. While a sheriff or marshal may make a levy on "capital invested" by a non-resident in the state, it was intimated in Foster Pump Works v. the Mayor, 100 App. Div. 515, affirmed on opinion below, that distress and sale would not lie against a non-resident's general property in the state.

As far as a non-resident is concerned, Chapter 627 of the Laws of 1919, does not impose a tax upon him individually, i. e., it does not attempt to tax him personally nor does it pretend to tax him on his business. In the case of non-residents employed here, the state has provided for withholding the tax at the source and it may be inferred that as to non-residents having property or capital employed here, it was intended to enforce the tax against the property or capital employed in the state.

In the City of New York v. McLean, 170 N. Y. 374, the court said at page 383 :

"Legislative power ceases at the line of the state and judicial power must also cease at that point. Jurisdiction relates to subject-matter, to person and to property. Hence the rightful exercise of it must be founded upon the person being within the state if a personal determination is involved, or the property must be within its territory if that is the subject of the controversy (Brown on Jurisdiction, Sections 2 and 5 ).

The attempt to give a tax the force of a judgment against the general property of a non-resident in this state was overruled in Matter of Maltbie $v$. Lobsitz Mills, 223 N. Y. 230, and Matter of Maltbie v. N. Y. \& Philadelphia Coal \& Coke Co. 223 N. Y., 633.

Limitation of time.-Section $219-\mathrm{k}$ of the act expressly removes from the code provisions relative to the limitation of time of enforcing a civil remedy, any proceeding or action taken to levy, appraise, assess, determine or enforce the collection of any tax or penalty prescribed in Article 9-a. This provision is similar in substance and language to that contained under Article 9 of the Tax Law in relation to the franchise tax on corporations affected thereby. 
No limitation for action under personal income tax law.Section 381 of the Tax Law to which reference has already been made, fixes no limitation within which an action may be brought to enforce the collection of a personal income tax.

Secrecy required of officials; Penalty for violation.-Section 219-i provides that it is unlawful for any tax commissioner or any of his agents or employees to make known in any manner the amount of income or any particulars set forth in the reports required under this article. This does not prohibit the publication of statistics, when so classified as to prevent the identification of particular reports, nor does it prohibit the publication of delin. quent lists, showing the names of taxpayers who have failed to pay their taxes, together with any relevant information which in the comptroller's opinion may assist in the collection of such delinquent taxes, or the inspection by the attorney-general or other legal representative of the State of the corporation's report, under the circumstances set forth in said section. The reports are to be preserved for at least three years and thereafter until the Commission orders their destruction; any offender against the provisions of this section shall be subject to fine or imprisonment or both, and if he be an officer or employee of the State, he shall be dismissed from office and be incapable of holding any public office in this State for a period of five years thereafter.

The provisions contained in Section 219-i, as to secrecy and for the punishment of an offense against such provisions, are in substance the same as those contained in paragraphs 232, 233, 234 and 235 of the Federal Income Tax Law, Act of September 8th, 1916, as amended by the Act of October 3d, $191 \%$.

Reference in paragraph 1 of Section 219-i, as to the publication of statistics, refers to the usual powers given to the Tax Commission under Section 171 of the Tax Law. The reference to publication of the delinquent lists as an aid to the collection of the taxes, is taken from the Wisconsin Income Law. Under the Wisconsin Income Tax Law, the assessment and the tax rolls, and all proceedings and evidences taken before the County Board of Review, shall be open to public inspection under such conditions as the Tax Commission may permit. 


\section{CHAPTER XXII.}

\section{Certiorari.}

The general purpose of a writ of certiorari is to correct errors of a judicial or quasi-judicial character. The determination of the State Tax Commission, or of the Comptroller, may be placed in the latter category. Under our system of State and local taxation, the corporation or person aggrieved is no longer confined to the common law remedy of certiorari, which was somewhat limited in its scope, but special statutory provisions now regulate this proceeding.

Ever since Chapter 542 of the Laws of 1880, and coincident with the introduction of our system of State taxation of business corporations, there have been provisions in the statute for reviewing the determination of the State Comptroller, and later on, of his successor, the State Tax Commission, as to any determination affecting corporations taxable under Article 9. These provisions have now been repeated either by reference to existing statutes or by additional sections in Article 9-a and again in Article 16. The practice under these provisions has been passed on by the courts in a long line of cases, which are referred to below with the idea of their application to the new law.

The provisions governing certiorari proceedings for business corporations generally, before the passage of the so-called State Income Tax Laws (Articles 9 and 16), are contained in Sections 199 and 200 of the Tax Law under Article 9. Section 219 of Article 9-a and Section 375 of Article 16 are repetitions of Section 200, and provide for a certiorari to review the determination of the State Tax Commission or the State Comptroller respectively as to a tax imposed under Article 9-a or Article 16. The requirements are almost identical in this respect with Section 200, in that notice of the application must be made within thirty days after 
service of notice of the determination, and a further similar requirement is contained as in Section 200, that eight days' notice shall be given to the Commission or the Comptroller (as the case may be), of the application for such writ. So also must the full amount of taxes, percentage, interest and other charges, audited and stated in said account, be deposited with the State Comptroller before making the application, and an undertaking filed with the Commission or the Comptroller (as the case may be) in such amount, and with such sureties as a justice of the Supreme Court shall approve. The forms of petition, the writ and the undertaking are given in another portion of this book. Section 219 further provides that the determination may be reviewed in the manner prescribed by and subject to the provisions of Section 199 of this chapter, to which reference has already been made.

Certiorari under Corporation Tax (Article 9).-Section 199 of the Tax Law reads as follows:

"Review of determination of tax commission by certiorari.The determination of the commission, upon any application made to it by any person, partnership, company, association or corporation for a revision and resettlement of any account, as prescribed in this article, may be reviewed both upon the law and the facts upon certiorari by the supreme court at the instance of any person, partnership, company, association or corporation affected thereby, and in the name and on behalf of the people of the state. For the purpose of such review, the commission shall return, on such certiorari, the accounts and all the evidence before it on such application, and all the papers and proofs upon the original statement of such account and all proceedings thereon. If the original or resettled accounts shall be found erroneous, or illegal, either in point of law or of fact, by the supreme court, upon any stuch review, the accounts reviewed shall then be corrected and restated, and from any determination of the supreme court upon any such review an appeal to the court of appeals may be taken by either party."

[The text of the law in certiorari for Arts. 9-a and 16 is given in Part II and Part IV.]

Taxes to be deposited with State comptroller.-Under the 1918 amendment, Section 200 of the Tax Law (as amended by L. 
1915, ch. 317), which was entitled "regulations as to such writ of certiorari," has been incorporated in the second paragraph of Sec. tion 219 , above quoted, and differs from Section 200 only in that under that section the full amount of the taxes, percentages and charges credited were to be deposited with the State treasurer, whereas under Article 9-a, they are to be deposited with the State comptroller.

Code provisions applicable.-The right to the writ being expressly conferred by statute (Section 199, Tax Law) its issuance is provided by Section 2120 of the Code. It can only be issued out of the Supreme Court (Code, Section 2123). The application for the writ must be made by, or in behalf of, the corporation aggrieved by the determination to be reviewed; it must be founded upon an affidavit, or a verified petition, which must be accompanied by other written proof; and must show a proper case for the issuance thereof. It can be granted only at a term of the Appellate Division of the Supreme Court or at Special Term (Code, Section 212\%). If granted at Special Term, it is invariably granted in the case of a corporation in the judicial district where its principal office is located. In the case of an individual (resident), in the district where he resides, and in the case of a non-resident at his place of business or occupation in the State, eight days' notice of the application for the writ must be given by Section 199 of the Tax Law, as now amended, and copies of the papers upon which the application is to be made, served therewith. (Code, Section 2128). The writ must be directed to the members of the tax commission whose determination is sought to be reviewed, by their names (Code, Section 2129) or to the comptroller, in person (if under Article 16). It must be served, except where different directions respecting the mode of service thereof, are given by the court granting it, upon the chairman of the Tax Commission. (Code, Section 2130, subd. 3; Code, Section 20\%1) or upon the comptroller (Article 16). The writ must be made returnable, within twenty days after the service thereof, at the office of the Clerk of 
Albany County, wherein the determination to be reviewed was made. (Code, Section 2132.)

After the writ has been issued, the time to make a return thereof may be enlarged, or any other order may be made, or proceeding, taken in the cause, as a similar proceeding may be taken in an action brought in the Supreme Court and triable in the county where the writ is returnable (Code, Section 2133). The clerk with whom the writ is filed and the person upon whom the writ is served must make and annex to the writ or to the copy served, a return, with a transcript annexed and certified by him, of the record or proceedings, and a statement of the other matter, specified in and required by the writ. The return under Articles 9 or 9-a must be filed in the office of the clerk of Albany County, where the writ is returnable (Code, Section 2134). In the case of the Personal Income Tax (Article 16) presumably the comptroller must file a like return, although the new law divides the State into districts for convenience of administration under Section 372 (Article 16). If the return is defective the court may direct a further return (Code, Section 2135). The cause must be heard at a term of the Appellate Division of the Supreme Court, Third Department. Either party may notice it for hearing at any time after the return is complete (Code, Section 2138). It must be heard upon the writ and return, and the papers upon which it was granted (Code, Section 2138), except where the chairman of the commission (or the comptroller) whose duty it is to make the return, dies, absconds, removes from the State or becomes insane, after the writ is issued, and before making a return, or after making an insufficient return; and it appears that there is no other person from whom a sufficient return can be procured by means of a new writ; then the court may, in its discretion, permit affidavits or other written proofs relating to the matters not sufficiently returned, to be produced, and may hear the cause accordingly. The court may also, in its discretion, permit either party to produce affidavits or other written proof relating to any alleged error of fact, or any other question of fact, which is essential to the jurisdiction of the commission to make the determinations to be reviewed where the facts, in 
relation thereto, are not sufficiently stated in the return, and the court is satisfied that they cannot be made to appear, by means of an order for a further return (Code, Section 2139). The final orders upon the hearing may annul or confirm wholly or partly, or may modify, the determination reviewed (Code, Section 2141). Such final order must be entered in the office of the clerk where the writ was returnable. But before it can be enforced, an enrollment thereof must be final. For that purpose, the clerk must attach together and file in his office, the papers upon which the cause was heard; a certified copy of the final order; and a certified copy of each order, which in any way involves the merits or necessarily affects the final order (Code, Section 2144).

General provisions.-In certiorari proceedings as comprehended by Section 199 of the Tax Law, it is only a hearing on the merits which is to be had in the Appellate Division, and incidental motions should be heard at Special Term. People ex rel. McNeary $v$. McLean, 64 Hun, 205. But this case has been criticised in People ex. rel. Joline $v$. Willcox, 129 App. Div. 267, which holds that applications to modify writs are entertained by the Appellate Division. And a motion under Code, Section 1348, to quash a writ of certiorari may be heard by the Appellate Division, and Section 2138 does not limit the jurisdiction of that branch of the court to a hearing on the issues. People ex rel. Joline v. Willcox, supra, criticising People ex. rel. Miller v. Peck, 73 App. Div. 89. In reviewing a decision by the commission (or the comptroller), the court is not governed by the same rules as are applicable on an appeal from a judgment entered in an ordinary action of law. People v. Campbell, 88 Hun, 544.

The relator.-Under Section 199 of the Tax Law, any person, partnership, company, association or corporation affected is given the right to review. That section must be construed in conjunction with Article 9-a, Section 219 of the Tax Law, and Section 325 (Article 16).

Time limitation for making application for writ.-Within thirty days after service of the notice of the determination of the 
commission (or the comptroller), the application for the writ must be made and the commission (or comptroller) must receive eight days' notice of such application (Tax Law, Sections 219, 375). This provision is to be read together with Code, Section 2128, which provides that where notice is given, the person served may produce affidavits or other written proofs, upon the merits, in opposition to the application.

The objection that the application for the certiorari was not made within thirty days after service upon relator of the notice of determination, as required by the statute, cannot be raised for the first time on appeal. People ex rel. H.\&H. Co. v. Campbell, 139 N. Y. 68.

Prior to the Tax Law of 1896 it was held in People ex rel. American Contracting Co. $v$. Wemple, 60 Hun, 225; followed, People ex rel. Brush El. Mfg. Co. v. Wemple, 129 N. Y. 543, 549, that the thirty days' limit of time, prescribed by Section 17 of Chapter 501, Laws of 1885, for the application for a writ of certiorari, did not apply to the issuing of such writ under Section 20 of Chapter 463, Laws of 1889, but it would now seem that under the language of Section 199 of the Tax Law, the thirty days' limit of time applies to any determination by the commission under this article.

When the application to the comptroller for revision and readjustment has been signed but not verified, the court on the certiorari proceeding cannot assume in this respect that there was not sufficient proof before the commission. People v. Campbell \& Roberts, 88 Hun, 545. Section 798 of the Code provides that where a notice must be given, or a paper served, within a specified time, if the service is made through the postoffice, three days shall be added to the time specified.

\section{Application for revision as prerequisites to the writ.-The} Tax Law (Sec. 199) provides that the determination upon any application made to the commission for a revision and resettlement of any account may be reviewed and this language clearly makes the application for revision and resettlement a prerequisite 
because it is only the determination upon any application for revision and resettlement that may be reviewed.

Unless the corporation aggrieved first makes application for a revision or resettlement under Section 199 of the Tax Law, the writ of certiorari cannot be sustained. People ex rel. Edison Co. $v$. Wemple, 11 Supp. 246.

The statute contemplates but one revision by the comptroller or the commission and after it has been made, the power is spent and a refusal to make a second revision cannot be reviewed by certiorari. People ex rel. Am. Surety Co. v. Campbell, $64 \mathrm{Hun}, 41 \%$, cited in People ex rel. Edison Co. v. Wemple, 69 Hun, 367-369. Where the comptroller (or commission) denies a revision or readjustment upon an application therefor, certiorari is the proper remedy. People ex rel. Edison Co. v. Wemple, 61 Hun, 53.

Petition.-Where the relator signed the petition and was named in the affidavit of verification, it is sufficient, although he did not sign the verification. People $v$. Campbell, 88 Hun, 544.

The writ when the commission's term has expired.-In Matter of Tiffany \& Co., $80 \mathrm{Hun}, 486$, it was held that a writ is properly directed to the successor of the comptroller who made the determination and that the former comptroller is not a necessary party. By analogy it would seem that the writ is properly directed to the succeeding chairman of the commission.

Containing unauthorized directions. - When the writ contains a direction to the commission to return the grounds of its refusal to revise a tax, such provision may be stricken out on motion as unauthorized under the statute. People ex rel. N. Y. Realty Co. v. Miller, 92 App. Div. 116.

Return.-Where the return states that the principal business of the corporation was the owning of, and the licensing of parties to use various patents relating to electricity; that its principal income was derived from royalties upon its patents; that its capital was largely represented by its ownership of bonds and stocks in other companies, and further, that the relator furnished but little, if any, light or ran or operated wire to any extent; it was held that the 
return did not deny the relator's statement that it manufactured and furnished electricity to its customers. People ex rel. Edison Company v. Campbell, 88 Hun, 52\%. The return of the commission is conclusive as to the facts. People ex rel. Edison Co. v. Campbell, 88 Hun, 530 ; reversed on other grounds in 148 N. Y. 759. The return of the commission should state the facts upon which it bases its determination and should show the whole case, so that the court may determine whether the action of the commission was erroneous or illegal and if so, that the court may make the proper determination. People ex rel. Staten Island R. R. Co. v. Roberts, 4 App. Div. 334.

Where allegations in the petition are denied by the return and no evidence is given in support of such allegations so denied, they will not be considered. People ex rel. Hubert Apartment Ass'n v. Kelsey, 110 App. Div. 617; citing on this point, People ex rel. Lester v. Eno, 176 N. Y. 513; aff'd 184 N. Y. 573.

The statute nowhere authorizes or requires the commission to return, in obedience to the writ, the grounds of its refusal to revise or readjust the tax imposed upon a corporation. If the writ contains such a provision it may be stricken out on motion as unauthorized. People ex rel. N. Y. Realty Co. v. Miller, 92 App. Div. 116.

It seems that the return of the commission to a certiorari should set forth the items of its appraisal, instead of simply giving the total, and making the evidence a part of the return. People ex rel. Union Pacific Tea Co. v. Roberts, 145 N. Y. 375.

Further return.-A further return by the commission cannot be had when its return contains all the evidence and proceedings before it, including its decision. People ex rel. Wiebusch \& H. Co. v. Roberts, 18 Misc. 530; reversed on other grounds, 19 App. Div. 574 .

The court, under Section 2135 of the Code, empowering it to direct a "further return" to a writ of certiorari may order concededly irrelevant matter to be stricken out. People ex rel. Joline v. Willcox, 134 App. Div. 563. 
Burden of proof.-Unless it clearly and conclusively appears that the valuation was erroneous, the decision of the commission is conclusive and will not be set aside. People ex rel. Roebling's Sons' Co. v. Wemple, 138 N. Y. 582 ; People ex rel. Am. Contracting Co. v. Wemple, 60 Hun, 225; citing People ex rel. Osgood v. Tax Comm'rs, 99 N. Y. 154; People ex rel. West F. I. Co. v. Davenport, 91 N. Y. 574; People ex rel. Dann v. Williams, 36 N. Y. 441; People ex rel. Central Park, etc. R. R. Co. v. Tax Comm'rs, 21 N. Y. St. Rep. 358; People ex rel. P. R. R. Co. v. Tax Comm'rs, 104 N. Y. 240 ; affirmed 129 N. Y. 558; People ex rel. Bklyn. El. R. R. Co. v. Roberts, 90 Hun, 537; People ex rel. Am. Axe \& Tool Co. v. Roberts, 82 Hun, 313; People ex rel. Edison El. Co. v. Campbell, 88 Hun, 530; affirmed on this point in 148 N. Y. 759; People ex rel. Stokes v. Roberts, 90 Hun, 533 ; People ex rel. Western Co. $v$. Campbell, 145 N. Y. 587; People ex rel. Seth Thomas Clock Co. v. Wemple, 133 N. Y. 323.

The burden rests upon the relator to show error or mistake in reviewing the determination of the commission. People ex rel. Bklyn. El. R. R. Co. v. Roberts, 90 Hun, 537; People ex rel. Western Elec. Co. v. Campbell, 80 Hun, 466; People ex rel. A. C. \& D. Co. v. Wemple, 129 N. Y. 558; People ex rel. Osgood et al. v. Comm's, 99 N. Y. 154; People ex rel. Am. Axe \& Tool Co. v. Roberts, 82 Hun, 314; People ex rel. Roebling's Sons' Co. v. Wemple, 138 N. Y. 582 ; People ex rel. Gramercy Co. v. Roberts, 91 Hun, 146.

The determination and appeal therefrom.-When the Appellate Division reverses a determination of the commission, not as to the amount of the corporation's property held within the State, but as to the taxable character of a part of it, a question of law is presented, reviewable by the Court of Appeals. People ex rel. Commercial Cable Co. v. Morgan, 178 N. Y. 433; reversing 86 App. Div. $57 \%$.

In reviewing the decision of the commission, the Appellate Division is not governed by the same rules as are applicable on an appeal from a judgment entered in an ordinary action of law. Peaple v. Campbell, 88 Hun, 544. 
It is the duty of the commission upon an application for revision and readjustment to make its determination upon the evidence taken at the original hearing and to send written notice of such determination to the corporation, as required by Section 196, notwithstanding the corporation refuses to produce additional evidence where the commission declines to make a revision and readjustment unless further examination is had. People ex rel. Studebaker v. Knight, 66 App. Div. 150.

Under the provision of Section 199, that "the commission shall return on such certiorari, the accounts and all the evidence before it on such application," if the relator, instead of producing witnesses, furnishes affidavits which are received without objection by the commission and considered by it as evidence, the objection cannot be raised on appeal that such evidence was not competent. People ex rel. Harlan \& H. Co. v. Campbell, 139 N. Y. 68.

Where the determination of an assessment against a foreign corporation is reversed, the Appellate Division will not undertake to modify the same, but will remand the case to the commission for further proceedings. People ex rel. Nat. E.\&S. Co. v. Miller, 112 App. Div. 880.

When remitted to commission for re-assessment.-On appeal to the Appellate Division, if the commission has adopted an erroneous method of appraisement, the matter should be remitted to it for reassessment and not corrected by the court, as testimony may be presented which might change the result. People ex rel. Nat'l Enameling Co. v. Miller, supra.

Statute of limitations.-The statute of limitations does not apply to proceedings to review the comptroller's determination under Chapter 542, Laws of 1880. People ex rel. Edison Elec. Light Co. v. Campbell, 88 Hun, 52\%.

Costs.-Section 2143 of the Code of Civil Procedure provides that costs not exceeding fifty dollars and disbursements may be awarded by the final order, in favor of or against either party, in the discretion of the court. 
The provision with respect to costs contained in Section 294 of the Tax Law are not applicable to certiorari proceedings to review the determination of the commission, but apply only in cases under the special statutory writ of Section 290 of the Tax Law. And vice versa Section 2143 of the Code does not apply to such cases. People ex rel. Niagara Falls Co. v. Russell, 57 Hun, 53.

\section{Estoppel as to matters of record.}

On appeal to the Court of Appeals from the Appellate Division, the corporation may be estopped from asserting that certain property is a liability instead of an asset; for instance, if it alleges the issuance of preferred "debenture stock," referred to in its certificate of incorporation, as a liability instead of an asset. People ex rel. Cohn \& Co. v. Miller, 180 N. Y. 16 ; affirming 94 App. Div. 564.

Refund of tax, when declared illegal on certiorari; interest.

There is no provision by which the commission may refund a deposit of a tax declared illegal on certiorari. Recourse must therefore be had to the Legislature. In re Waterman Co. v. Gilman, 33 Misc. 569. It seems that interest should be allowed by the State on a refund. People ex rel. Knickerbocker Trust Co. v. Kelsey, 114 App. Div. 319; Matter of O'Berry, 179 N. Y. 285.

Refund and credit before certiorari.-A refund of the whole or part of a tax under Section 219-d, Article 9-a, and under Section 37\%, Article 16, as well as the credit to be allowed corporations for excess payment of taxes, cover taxes paid or accounts stated by the state tax commission or the comptroller before certiorari proceedings have been instituted to correct the erroneous or illegal assessments. 


\title{
PART IV
}

\section{TAX ON PERSONAL INCOMES}

\author{
(Article 16 of the Tax Law.)
}

WITH THE TREASURY REGULA'TIONS AND DECISIONS GOVERNING LIKE PROVISIONS OF THE FEDERAL INCOME TAX ACT 



\section{CHAPTER XXIII.}

Brief Analysis of the Personal Income Tax.

The tax levied upon personal incomes introduced in this state in 1919 by Chapter $62 \%$ of the laws of that year, marks an innovation in New York State's fiscal policy.

In general, it may be said that the New York law has copied the Federal Income Tax Act, substituting "taxpayer other than a resident" for "non-resident alien" and "January 1, 1919," for "March 1, 1913." The remedial procedure and method of collection in the New York Corporation Tax Laws (Arts. 9 and 9-a) are substituted for the Federal procedure. Remedies and collections are treated in full under Part III.

Under this act all single persons residing in the state having incomes of $\$ 1,000$ or more and married persons having incomes of $\$ 2,000$ or more will pay the state on or before March 15th, next, a tax based on the following graduated scheme:

Rate of Tax.-1\% of incomes up to and including $\$ 10,000$. $2 \%$ of amount of net income in excess of $\$ 10,000$ but not exceeding $\$ 50,000$. $3 \%$ of the amount of net income in excess of $\$ 50,000$.

Payment.-This tax, like the Federal Tax, is self-assessed and payable at the time of the making of the return, which is coincident with that of making the federal income tax return, except that it is payable in one instalment. Provision is made for an exemption of $\$ 200$ for each dependent.

Non-residents.-Non-residents (individuals) of the state are taxed at the same graduated rates upon the income from all property owned and from every business, trade, or profession carried on in the state, without the personal exemption.

First assessment for I9r9.-The tax shall first be levied, collected and paid in the year 1920 upon and with respect to the tax- 
able income for the calendar year 1919, or for any taxable year ending during the year 1919 .

\section{Exemptions :}

(a) The tax is imposed on single persons receiving more than $\$ 1,000$ and on married persons earning more than $\$ 2,000$. Provision is made for an exemption of $\$ 200$ for each dependent.

(b) Proceeds of life insurance policies.

(c) Return premiums of insurance.

(d) The value of property acquired by gift, bequest, devise or descent (but not the income therefrom).

(e) Interest on government obligations, federal farm loan securities, war finance corporation bonds, interest on obligations of New York State, or of any municipal corporation or political subdivision thereof; income from securities on which the tax on investment has been paid under Section 331 of the New York Tax Law.

(f) Amounts received through accident or health insurance, or under workmen's compensation acts, compensation for personal injuries or sickness, plus damages received by suit or agreement on account of such injuries or sickness, or through war risk insurance or any law for the benefit or relief of injured or disabled members of the United States military or naval forces.

(g) Salaries received by federal employees including those in the military and naval forces.

(h) Income received by officers of a religious denomination or by any institution for moral or mental improvement, religious, bible, tract, charitable, benevolent, fraternal, missionary, hospital, infirmary, educational, scientific, literary, library, patriotic, historical or cemetery purposes, or for the enforcement of laws relating to children or animals.

Determination of net income.-The determination of net income under the law is arrived at by deducting from the gross income reported, the amount of the deduction allowed under the law. 
The ascertainment of gain or loss through the exchange of property or through merger or consolidation or through reorganization, the computation of net income through inventory, the definition of gross income and the various deductions allowed for business expense, interest, taxes, losses, bad debts, depreciation, depletion, contribution and the items not deductible for personal expenses, permanent improvements, restoration of property, premiums for life insurance covering the life of officer or employee, are substantially the same as those under the federal law.

Deduction of non-residents.-Non-residents of the state are only allowed such proportion of deduction as the income arising from sources within the state bears to the total income. The proper apportionment and allocation of deductions with respect to sources of income within and without the state shall be determined under rules and regulations prescribed by the comptroller.

\section{Returns.}

Partnerships.-Partnerships must file a return stating the items of gross income, allowable deductions and the names and addresses of individual partners, with the distributive share of each, the partners being taxed in their individual capacity on their proportionate share in the business.

Estates and trusts.-Estates and trusts are taxed practically the same as under the provisions of the Federal Income Tax Law, except that a non-resident estate shall be deemed one where the estate belongs to a person not a resident of the state at the time of his death, and shall be taxed in the same manner as individual non-residents. The return of income by estates and trusts must be made by the fiduciary. Where income is received during periods of administration or in settlement of the estate, or accumulated for the benefit of unascertained persons or persons with a contingent interest, or for future distribution under the terms of the will or trust, the tax shall be assessed against the estate or trust instead of against the beneficiary.

In the case of income which is distributed to the beneficiary periodically and in case of income collected by a guardian of an 
infant, to be held or distributed as the court may direct, and in the case of income of an estate during the period of administration or settlement, the tax shall not be paid by the fiduciary but there shall be included in computing the net income of each beneficiary, his distributive share whether distributed or not. In such cases the income of a beneficiary of such estate or trust not a resident, shall be taxable only to the extent, derived from sources within the state.

Information returns and withholding agents.-A withholding agent, under paragraph 10 of Subdivision 350, includes "All individuals, corporations, associations and partnerships, in whatever capacity acting, including lessees, or mortgagors of real or personal property, fiduciaries, employers, and all officers and employees of the state, or of any municipal corporation or political subdivision of the state, having the control, receipt, custody, disposal or payment, of interest, rent, salaries, wages, premiums, annuities, compensations, remunerations, emoluments or other fixed or determinable annual or periodical gains, profits and income taxable under this article, and shall make return of complete information concerning such rent, salaries, wages, etc., and shall deduct and withhold $2 \%$ from all "salaries, wages, commissions, annuities, emoluments, and other fixed or determinable annual or periodical gains, profits and income, of which he shall have control, receipt, custody, disposal or payment, if the amount paid or received or to be paid or received in any year equals or exceeds $\$ 1,000$, unless there shall be filed with the withholding agent before the time to return any payment, a certificate prescribed by the comptroller, to the effect that the person entitled to such salary, wage, commission, etc., is a resident and setting forth his residence in the state.

A withholding agent is required to make a return on or before March 15th, and shall at the same time be compelled to pay the tax withheld to the comptroller.

Corporations and partnerships are made liable for the tax and indemnified against claims and demands by individuals or partnerships. 
Income withheld shall be included in the return of the recipient of such income, and that the amount withheld shall be credited to the amount of the income tax in each case.

Administration of the law by the comptroller.-The State Comptroller shall administer the law dividing the state into convenient tax districts. No district to be less than a county.

Powers of comptroller: revision and readjustment.-The comptroller may in his own discretion, where an incorrect return is filed, revise the same on his own motion. He may make examinations of the books and records of the taxpayer and take testimony.

Revision and readjustment. Certiorari.-The taxpayer has the same rights of revision and to the review of the courts by certiorari as under Articles 9 and 9-a of the Tax Law.

Penalties.-A person failing to make a return or making a false or fraudulent return is guilty of a misdemeanor and is liable to a fine of not exceeding $\$ 1,000$ or imprisonment not exceeding one year, or both. Penalties are provided for delay in making returns. 


\section{CHAPTER XXIV.}

\section{Constitutionality.}

There are few restrictions on taxation in the New York Constitution, but a provision that has given the courts some concern and that on its face does not appear to have any direct bearing on taxation, is what is known as the "Home Rule" provision which reads as follows:

"Article 10, Section 2. All county officers whose election or appointment is not provided for by this constitution, shall be elected by the electors of the respective counties or appointed by the boards of supervisors or other county officers as the legislature shall direct. All city, town and village officers whose election of appointment is not provided for by this constitution, shall be elected by the electors of such cities, towns and villages, or of some division thereof, or appointed by such authorities thereof as the legislature shall designate for that purpose. All other officers whose election or appointment is not provided for by this constitution, and all officers whose offices may hereafter be created by law, shall be elected by the people, or appointed, as the legislature may direct."

This provision was in 1903 invoked in People ex rel. Metropolitan Street Railway Co. v. Tax Commissioners, 174 N. Y. 417 Aff'd 199 U. S. 1, where the constitutional right of the legislature to pass the special franchise tax was involved. The point was raised that as the special franchise tax was required to be assessed by the State Tax Commission appointed by the Governor, this was taking away from the local tax assessors the right of valuation, since they were constitutional officers under this provision.

The Court of Appeals decided in this case that the special franchise tax act was constitutional on the ground that special franchises gave the state tax commission the power to assess a new form of property, and that while some real estate in the street was 
assessed therewith, it was only incidental to the new form of taxation.

Judge Vann, in the opinion of the court, said that:

"Home rule, as understood and practiced in the past, giving to localities the right to govern themselves, but not to hamper the government of the state, should be carefully protected from open attack or indirect invasion. Shadows, however, should give way to substance, and the right to create a new system of taxation and bring in property of a new character, hitherto untaxed, with some other property incidental thereto and worthless without it, cannot, as we think, be denied upon principle and should not be withheld from the legislature unless required by some controlling decision of the court."

The same provision as that contained in the New York Constitution (Article $\mathrm{X}$ ) has been embodied in the Wisconsin Constitution and its interpretation came before the Wisconsin Supreme Court in the case of State ex rel. Daniels v. Hussy, 143 Wisc. 649. In that case there was involved the validity of an act of the Wisconsin legislature which authorized a reassessment of the entire property of any town, city or village by the state tax commission, if it should be found that the original assessment had not been legally made, and public interests required a reassessment.

All the New York cases including the special franchise tax case, were reviewed in the Daniels suit, and the court held that a reassessment by a state officer, of an illegal assessment made by local officers, was no deprivation of home rule.

The same section again came up for review before the Wisconsin Courts in State ex rel. Bolens v. Frear, 148 Wisc. 456 . In this case the new Wisconsin Income Tax Law (Chapter 658 of the Laws of 1911), was attacked on the ground that it took away from the local assessor the power to tax personal property and turned over to a new officer called "Assessor of Incomes" appointed by the state tax commission, the power to tax property in the form of incomes.

The court held that the new office was neither a county, city, town or village office, nor an office existing at the time of the adoption of the constitution, or essential to the existence or efficiency 
of either of said municipal divisions of the state, but rather an entirely new office whose election or appointment might be provided for by the legislature in its discretion.

The "Home Rule" provision contained in the present state constitution was taken from the same section and article of the constitution of 1846, with the change of but a single word. At the time of the adoption of the constitution of 1846, assessors were local officers exercising the functions of their offices in the various towns or villages, or in the several wards of cities. They had been recognized as local officers by the first constitution of this state, which provided that

"Town clerks, supervisors, assessors, constables and collectors and all other officers heretofore eligible by the people, shall always continue to be so eligible."

In 1915 there was submitted to the voters of New York, a proposed constitution which failed of adoption, and which contained among its provisions a new Article $\mathrm{X}$, providing for a different form of assessing by assessors who might be either elected or appointed by such authorities as designated by law. Sections 2 and 3, Article $\mathrm{X}$, of the proposed Constitution read as follows:

"The legislature shall prescribe how taxable subjects shall be assessed, and provide for officers to execute laws relating to the assessment and collection of taxes; any provision of Section 2 of Article 13 of this constitution to the contrary notwithstanding." (Section 2, Article 13, is the number of the "Home Rule" provision in the proposed constitution.)

"Section 3. For the assessment of real property, heretofore locally assessed, the legislature shall establish tax districts, none of which, unless it be a city, shall embrace more than one county. The assessors therein shall be elected by the electors of such districts or appointed by such authorities thereof as shall be designated by law. The legislature may provide that the assessment roll of each larger district shall serve for all the lesser tax districts within its boundaries. No such tax district larger than a town, except a city, shall be established until the law providing therefor shall have been adopted by a vote of a majority of the electors voting thereon in such proposed district at an election for which provision shall be made by law. The legislature may, however, provide for the assessment by state author- 
ities of all the property of designated classes of public service corporations."

In submitting these changes to the electorate, the framers of the proposed article stated:

"That these sections vest complete and unhampered power in the legislature to deal effectively with the subject of taxation to the end that property now notoriously escaping taxation may be made to bear a fair and just share of the burdens of government."

There evidently was a realization here that the "Home Rule" provision did not permit the taxation of property unless the same was assessed by local assessors. In a recent case, People ex rel. Town of Pelham v. Pelham, 215 N. Y. 374, in which a law transferring the duties of village collector to a town collector, was declared unconstitutional, the "Home Rule" provision was again upheld in these words:

"Local functions, however, cannot be transferred to a state officer. The legislature has the power to regulate, increase or diminish the duties of the local officer but it has been steadfastly held that this power is subject to the limitation that no essential or exclusive function belonging to the office can be transferred to an officer appointed by central authority."

Is the tax on incomes an assessment on a new form of property?-In the Metropolitan Street Railway Company case, supra, the special franchise tax law was upheld because it conferred the power to assess a new form of property. Will it be held that the income tax act brings in property of a new character? As far back as 1778 , the state raised some of its revenue by means of an income tax (Chapter 17, Laws of 17\%8). Under this provision of the New York law, the local assessors were required to assess

"each and every person within their respective districts, whom they shall know or suspect to have gained by trade merchandise, traffic or manufactory, one thousand pounds or upwards since the twelfth day of September in the year of our Lord, One thousand seven hundred seventy-six"

a tax of fifty pounds over and above the one penny half-penny to be assessed upon his personal estate for over one thousand pounds so gained. 
While the Home Rule Provision is essentially the same in the Wisconsin constitution as in that of New York, the history of local assessors' duties and powers in this state differs somewhat from that of the western state in that at a very early period in New York's history, the power was conferred upon local assessors to tax incomes. Our Courts have jealously guarded this provision of the constitution, but it is not easy to predict what position they may take on this doubtful point in view of the opinion in the New York special franchise tax case, People ex rel. Metropolitan Street Railway Co. v. Tax Commissioners, supra. If the New York Courts hold that the personal income tax has taken away the local assessors' powers and transferred them to a state official and that this is an infringement of the "Home Rule" provision, such a decision would undoubtedly annul the entire law.

Is the New York income tax contrary to the federal constitution?-There seems to be little doubt that New York may levy a tax upon inhabitants or residents of the state based on the entire net income whether derived from property, business or occupations. In so far as non-residents are concerned, it may levy a tax based on net income from sources within the state, provided it does not contravene the federal constitution. In general, it may be said that the State of New York cannot prevent the citizens of a sister state from doing business in this state on any other basis than that accorded to her own citizens. The federal constitution has guaranteed this in the 4th amendment under which the citizens of each state are entitled to all the privileges and immunities of every other state. The federal government does not grant a non-resident alien a personal exemption of $\$ 1,000$ or $\$ 2,000$, as the case may be. The State of New York has copied this provision in its income tax law and denied the citizens of other states residing beyond its jurisdiction, the personal exemption, although all the income of such citizens may be derived from sources within the state. There is a distinction between the right of the United States to tax a nonresident alien and that of the state to tax a citizen of another state. The federal government can prevent aliens from coming into this 
country and deport them. Chae Chang Ping v. U. S., 130 U. S. 581; U. S. ex rel. Turner v. Williams, 194 U. S. 279 ; Fong Yue Ting v. U.S. 149 U.S. 968 . The United States government may prescribe terms under which aliens may do business here or prevent them from doing business here altogether.

The New York State income tax law, in computing the amount of net income of a non-resident, does not permit the deduction of all losses, although the non-resident may have sustained losses in other states to such an extent as to reduce his entire income from all his property so that were he a resident of the State of New York he would not be required to pay any income tax at all. On the other hand, losses of a non-resident may be presumed to be deducted at his domicile. People v. Barker, 141 N. Y. 586.

The next point of inquiry is what is meant by sources within the state, and whether in taxing the income from salaries, occupations and professions of a non-resident we are taxing income from sources within the state.

It has been held in State $v$. Wisconsin Tax Commission, 161 Wisc. 111, that in the Wisconsin Act of 1911, imposing a tax on such part of the non-resident's income derived from sources within the state or within its jurisdiction, that the expression "derived from sources within the state" and the expression "or within its jurisdiction" are considered identical. In so far as a non-resident is taxed on income from property within the state, or on the earnings from a business representing capital employed within the state, the question is no greater than taxing the property itself. In both of these cases the tax is derived from tangible property permanently located in the state or from money or capital invested in business, capable of being permanently located or having a situs in the state. The moot point in the New York income tax law is the situs of the income derived from the non-resident's salary or earnings from professions or occupations carried on in the state. Can these be said to be from sources within the state? In taxing foreign corporations this difficulty of situs is more apparent than real. A foreign corporation doing business within the state has a situs here and must obtain a certificate permitting it to do business in 
the state. New York State recognizes the apportionment of an income in such cases under a rule permitting a segregation of the tangible property, and accounts accruing from business within and without the state. In the case of inheritance taxes, the right as well as the property is within the state. Blackstone $v$. Miller, 188 U. S. 189.

The right of the federal government to tax non-resident aliens on income is not entirely analogous and it has never been absolutely settled according to some legal writers (see Black on Income Tax) that the United States has this power over the income of nonresident aliens. In connection with earnings from salaries, occupations and professions, we not only encounter the question raised by the due process of law section of the federal constittion, but also the limitation on the taxing power of the state in connection with interstate commerce. The federal courts have repeatedly held that an agent delivering goods, or a drummer or commercial traveller making sales in the state, cannot be taxed as such. May not the contract for personal services of a non-resident in his occupation be considered in the sense of a sale of a commodity, and is not the state's exaction of the tax an interference with commerce? A lawyer may write his brief in New Jersey and render his bill from his New York office. An architect or designer may formulate his plans or complete his designs at his home in Connecticut, and may be entitled to his fees or salary at his New York office. Professional advice may be given over the telephone in New Jersey and bills rendered at the New York office.

The Comptroller of the State of New York has already recognized the necessity of apportioning the income derived by a nonresident from employment in the state, by, promulgating regulations in explanation of the new law under which a non-resident salesman, drummer or other employee may apportion his earnings on the basis of business transacted and time employed in the state. (See Regulations, infra.)

The question of interstate commerce as applied to the imposition of the state income tax on non-residents, is vitally important in relation to occupation and labor. The federal constitution grew 
out of the necessity for freedom of commerce between the different states, and a limitation on occupations and labor between these equal sovereignties not only involves the legal question of jurisdiction, but matters of great economic concern.

It is important to bear in mind that the state income tax is a comparatively new revenue feature of the several states. Wisconsin's law, which has been in effect since 1911, and received the approval of the state and federal courts, taxes residents on all income derived from property located and business transacted within the state, and also on income from personal service contracts, mortgages, stocks, bonds and securities. A non-resident is taxable on all the income derived from property located and business transacted within the state, and not on income derived from personal service, land contracts, mortgages, stocks, bonds and securities.

The Massachusetts income tax law taxes only residents. It does not tax non-residents on income.

Oklahoma and Missouri have provisions taxing non-residents like the New York law, and in Oklahoma the case of Shaffer $v$. Howard has been carried to the United States Supreme Court, but was dismissed on a jurisdictional point. In the lower court, $250 \mathrm{Fed}$. Rep., page 874, the non-resident provision was sustained, one of the Justices dissenting and writing an opinion. The case involved in Oklahoma was not a clear-cut case of income arising from occupations or professions, but one of net income arising from property or capital invested in the state.

The Missouri statute contains a provision permitting the deduction from the income tax of taxes paid on real estate, personal property, etc., thus making the act, in its administration, of little value, as an income tax measure. 


\section{CHAPTER XXV.}

\section{Residenoe for Personal Income Taxation.}

The income tax is imposed under Section 351 of the Tax Law on every resident of the state "upon and with respect to his entire net income"; and upon individual non-residents the tax is "upon and with respect to the entire net income as herein defined, except as hereinafter provided, from all property owned and from every business, trade, profession or occupation carried on in this state by natural persons not residents of the state."

Under subdivision 7, Section 350 of the law, there is this definition of a resident.

“7. The word 'resident' applies only to natural persons and includes for the purpose of determining liability to the tax upon or with reference to the income of any taxable year commencing with the year 1919, any person who shall at any time on or after January 1st, and not later than March 15 th of the next succeeding calendar year, be or become a resident of the state."

It will thus be seen that residents are taxed upon their entire income while non-residents are taxed on income from property located, and professions, business, etc., carried on within the state.

Under subdivision 3 of Section 359 of the law entitled "Gross Income Defined" in the case of taxpayers other than residents, gross income includes only the gross income from sources within the state but shall not include annuities, interest on bank deposits, interest on bonds, notes or other interest bearing obligations or dividends from corporations except to the extent to which the same shall be a part of income from any business, trade, profession or occupation carried on in this state subject to taxation under this article."

Since there is therefore this essential difference between the taxation of residents and non-residents, one being taxed on income 
from all sources, the other being taxed substantially on income from sources within the state, it will be important to inquire:-

1. What constitutes residence for the purposes of the New York State Income Tax Act?

2. What is meant by "sources within the State?"

What is a resident?-While the New York law simply states that a resident means "an individual person who shall between January 1st and March 15th, be or become a resident," it has not attempted to define what circumstances or conditions will fix residence for the purpose of personal income taxation. Hence we must look to the laws of this state and of other states, and to the federal law, for light as to the meaning of residence for the purposes of taxation.

Residence under Federal income tax law.-Under Subdivision 1, Par. A of the Act of October 3d, 1913, "residence" is held to be that place where a man has his true fixed and permanent home and principal establishment, and to which whenever he is absent, he has the intention of returning; and indicates permanency of occupation as distinct from lodging or board, or temporary occupation."

Under the federal income tax act, "residence" is used more in the sense of domicile, the word "home" being referred to in that statute. "Domicile" is, in law, in some way connected with the "home" or principal residence or abiding place of a person. Story on Conflict of Law, Section 41.

David Dudley Field, in Section 280 of his International Code, defines "domicile" as the "seat or permanent residence-the home." It has been said, however, by legal writers that domicile is something more than residence. Residence is preserved by the actdomicile by the intention.

This idea is expressed in Bouvier's Law Dictionary where he defines residence as generally transient in its nature; it becomes a domicile when it is taken up animo manendi.

In the federal law the distinction between residents and nonresident aliens is not analogous to the two classes under the state 
law, because the federal law distinguishes between resident aliens and non-resident aliens. Resident aliens are taxed substantially in the same way as residents. Whether a person is a transient alien or a resident alien is to be determined under the federal law by his intention with regard to his stay (Article 311 Federal Income Tax). This is further explained in Article 312 where it is stated that the alien's intentions with regard to his residence are to be determined by his own statements where unequivocal; otherwise, by conduct, acts or other surrounding circumstances which may contradict his statements. The fact that an alien's family is abroad does not necessarily indicate that he is a transient rather than a resident.

Residence under New York transfer (inheritance) tax law. - Under the state law, the situation is more complex because we have to deal with citizens of equal sovereign states; to one, he owes allegiance as a citizen of that state, and in the other he may have property rights.

Under the most recent decisions under our New York Transfer Tax Law, it has been held that residence may be used in a statute in the sense of domicile. Matter of the Estate of Hetty Green, 99 Misc. 582, Aff'd in 179 App. Div. 890.

Surrogate Fowler, in the learned opinion in the case above referred to, said on the question of domicile, among other things:

"If $I$ am in error in assuming that the Appellate Division, in Matter of Martin, intended to hold that the Taxable Transfer Act means by "resident" one domiciled here, then that act operates on two classes of successions: (1) those derived from residents and (2) those derived from non-residents. Residence results from facts alone, not from intention. In law residence is something other than domicil. That it is competent for the legislature of the State of New York to tax successions from residents of the state, irrespective of their domicil, I do not doubt and have so stated before in Matter of Morgan, 96 Misc. Reports, 455 . If a person whose domicil is not in this state voluntarily enter this state, and actually reside here, those taking in succession from her have no valid ground of complaint if she has been subjected to many taxes from which a non-resident, by the usage of nations, would have been exempt. Chapter 551, Laws of 1916, recently 
enacted, attempts to prescribe what constitutes a residence for the purpose of the Taxable Transfer Act. Chapter 551, Laws of 1916, purports to amend Section 243 of the Taxable Transfer Act (Laws of 1909, Chap. 62). The relevant portion of Chapter 551, Laws of 1916, is as follows:

"Section 243. Definitions. . . . For any and all purposes of this article, and for the just imposition of the transfer tax, every person shall be deemed to have died a resident, and not a non-resident, of the State of New York, if and when such person shall have dwelt or shall have lodged in this state during and for the greater part of any period of twelve consecutive months in the twenty-four months next preceding his or her death; and also, if and when by formal written instrument executed within one year prior to his or her death or by last will he or she shall have declared himself or herself to be a resident or a citizen of this state, notwithstanding that from time to time during such twenty-four months such person may not have sojourned outside of this state, and whether or not such person may or may not have voted or have been entitled to vote or have been assessed for taxes in this state; and also if and when such person shall have been a citizen of New York sojourning outside of this state. The burden of proof in a transfer tax proceeding shall be upon those claiming exemption by reason of the alleged non-residence of the deceased. The wife of any person who would be deemed a resident under this section shall also be deemed a resident and her estate subject to the payment of a transfer tax as herein provided, unless said wife has a domicil separate from him."

The legislature in the act referred to in the above case, laid down certain qualifications under which a person was to be deemed a resident if he came within the provisions set forth. The Court, however, said in rendering the opinion in this case:

"I cannot, however, agree with the contention of the state comptroller that the legislature by the amendment above quoted intended that a person who dwelt or lodged here for a period of six months and one day of the twenty-four months immediately preceding such person's death is to be deemed a resident of this state for the purpose of the transfer tax."

Residence under Ohio tax law.-Under a similar statute to that referred to in the above case, John D. Rockefeller, a former citizen of Cleveland, Ohio, moved to New York, establishing there a home, a residence and a right to vote which he exercised in New 
York City. In June, 1913, he returned to Ohio where he retained a home and where it was his custom to spend the summer season. He remained there with his family after the tax listing day-February $3 \mathrm{~d}, 1914$, when under the laws of Ohio he was prima facie liable for a personal tax. The Court held in that case that notwithstanding his stay in Ohio, he was still to be deemed a resident of New York since his intention to return to New York was of controlling importance, and that if there was any doubt as to the meaning of the tax statute, it must be construed and the doubt resolved in favor of the person assessed. People ex rel. Rockefeller v. O'Brien, 224 Fed. Rep. 541.

Residence as determined in personal tax cases in New York. -Residence for the purpose of taxation in the State of New York may be determined from the facts as well as the intention. A mere sojourning in a place does not constitute residence for purposes of taxation (Frost v. Brisbin, 19 Wend 11). The Court in the latter case said "there must be a settled, fixed abode, and the intention to remain permanently at least for a time, for business or other purposes, to constitute a residence within the legal meaning of that term.

Jacobs, in the Law of Domicile, says: "Residence implies an established abode, fixed permanently for a time, for business or other purposes, although there may be an intent in the future at some time or other to return to the original domicile."

Facts determining residence.-Nor does the question of voting determine the residence although that may be one of the circumstances upon which residence for purposes of taxation may be predicated (In Re Crilly, 13 App. Div. 247). In the Crilly case, a person hired a house in the City of New York for residence while temporarily engaged in business, as superintendent of the business of a firm in the City of New York, and remained in the city on tax day although he alleged that for the past fifteen years he had been a resident of Pennsylvania doing business in the City of Philadelphia and paid taxes during that period and voted there, and although these facts may have indicated his domicile in the State of Pennsylvania, they did not disprove his residence for the 
purpose of taxation in New York. The question of residence is not determined upon the payment of personal taxes, irrespective of circumstances under which the assessment was made, and where it appears that a person assessed by the City of New York went before the Tax Commissioner and asserted that he was a resident of New Jersey, stating: "I live some of my time in the City of New York and am quite willing to pay something for the maintenance of the City," the payment of the tax cannot be taken to establish residence for tax purposes. (People ex rel. Strong $v$. O’Donnell, 47 Misc. 226.)

In Bartlett $v$. City of New York, 5 Sanford 44, the person assessed had a home in Westchester County, where he lived with his family for more than half the year, but the Court held that that was not inconsistent with his residence in the City of New York for the remainder of the year including tax day.

In Douglass $v$. Mayor, 2 Duer 110, the plaintiff resided in the City of New York for several years during the winter and spring, and in Flushing in the summer and autumn. Although he had two residences, the court held that he was liable to taxation in the place where he resided on tax day.

The mere temporary stay and rental of an apartment for a brief period during the year in New York City, does not establish a residence for the purpose of taxation in the face of acts and statements showing a contrary intention. The facts in each case must determine the liability for taxation. (People ex rel. Lord $v$. Feitner, 78 App. Div. 28\%.)

Presumption as to residence.-The presumption as to the continuance of residence once established, is covered by Section 8 of the New York Tax Law which provides that "when a person shall have acquired a residence in the tax district and shall have been taxed therein, such residence shall be presumed to continue for the purpose of taxation until he shall have acquired another residence in this state or shall have removed from this state.

In People ex rel. Wright v. O’Rourke, 32 App. Div. 66, it was held that:

"As a general rule a person does not gain a new residence except by some change in the place of his abode, accompanied by an intent 
to acquire such new residence. A change of abode without such intent, is generally insufficient, and a general intent without actual change is equally insufficient."

In People ex rel. Bradley Martin v. Feitner, 33 Misc. 358; Aff'd 60 App. Div. 630, it was held:

"Where a person does not renounce his citizenship in this country and continues to pay personal taxes without protest for a number of years, the mere statement that he has changed his residence to a foreign country will be disallowed on the facts and in view of the statutory presumption contained in Section 8 of the Tax Law, that a person's residence is presumed to continue until he acquires another residence."

There appeared in the above case to be no change in the habits or domicile of the person assessed, but in People ex rel. Astor $v$. Tax Commissioners, 33 Misc. 347, where a person maintained a residence and a home in a foreign country and gave up his house in New York, the mere fact that he had paid tax assessments in 1896, 1897 and 1898 in New York, raised no presumption that he was a resident.

The fact that a person spends a part of the winter months in New York, cannot be said to establish a residence here where he votes in Rhode Island and pays personal taxes there. People ex rel. Lorillard v. Barker, 70 Hun. $39 \%$.

Change of residence to another state.-A person may make a change of residence from one state to another because he believes the assessment unjust or excessive and his motives for making the change of residence are immaterial. People ex rel. Gould v. Barker, 14 Misc. 586.

Change of residence by residents.-In many of the New York cases the question arose as to the determination of which of two places in different parts of the state, should be deemed the legal residence for the purpose of taxation, and where the fact as to the change of residence from one town to another was not made clear, the courts have held that where the principal business was located was to be deemed the taxable residence. Matter of Nichols, 5 N. Y., page 64 , 


\section{CHAPTER XXVI.}

Payment and Information at the Source-Withholding.

What kind of income must be withheld.-The first paragraph of Section 366 which covers deductions or payments of income at the source, provides for the amount and kind of income to be withheld by withholding agent. Under paragraph 10, Section 350 of the law, occurs the definition of withholding agent, as follows:

"The words withholding agent include all individuals, corporations, associations and partnerships, in whatever capacity acting, including lessees, or mortgagors of real or personal property, fiduciaries, employers, and all officers and employees of the state, or of any municipal corporation or political subdivision of the state, having the control, receipt, custody, disposal or payment of interest, rent, salaries, wages, premiums, annuities, compensations, remunerations, emoluments or other fixed or determinable annual or periodical gains, profits and income taxable under this article."

In the first paragraph of Section 366, we find explicit directions for the kind of income that is required to be deducted and withheld at the source, viz.:

"Salaries, wages, commissions, gratuities, emoluments, perquisites and other fixed and determinable annual or periodical compensation of whatever kind and in whatever form paid or received, earned for personal services and taxable under this article."

Rent, interest, annuities and premiums are not mentioned in this paragraph, nor is such income paid for personal services.

The statutory definition of a withholding agent in paragraph 10 , Section 350 , is somewhat misleading since the withholding agent only deducts certain kinds of income. The kinds of income to be deducted are specifically set forth in the first paragraph of Section 366, which is headed "Information and Payment at the Source." This section is divided into five paragraphs. The first paragraph 
provides for the kind of income that is to be withheld or deducted at the source. The third paragraph provides for a return to be made by withholding agents for all of such income required to be deducted under the first paragraph. The second paragraph provides for the return of complete information by withholding agents, of all interest, rent, salaries, wages, premiums, annuities, compensation, remuneration, emoluments or other fixed or determinable annual or periodical gains, profits and income except interest coupons payable to bearer, of any taxpayer taxable under this article, of $\$ 1,000$ or more. The fourth and fifth paragraphs include administrative provisions for procedure similar to those in the federal act, in connection with such returns by the withholding agent or by the recipient.

Since the first paragraph of Section 366 is the only paragraph in the law which specifies the income that is required to be deducted and withheld at the source, it is here stated in full:

"Sec. 366. Information and payment at source. Every withholding agent shall deduct and withhold two per centum from all salaries, wages, commissions, gratuities, emoluments, perquisites and other fixed and determinable annual or periodical compensation of whatever kind and in whatever form paid or received, earned for personal services and taxable under this article, of which he shall have control, receipt, custody, disposal or payment, if the amount paid or received or to be paid or received in any taxable year on account of any individual equals or exceeds one thousand dollars, unless there shall be filed with the withholding agent, before the time when he is required to make return and payment thereof, a certificate in such form as shall be prescribed by the comptroller to the effect that the person entitled to such salary, wage, commission, gratuity, emolument, perquisite or other compensation is a resident and setting forth his residence address within the state."

Note: The form of certificate is given in the Forms, following Part $I V$, infra.)

It may be said generally that only net income paid to an employee for salary, wages or commissions for personal service shall be withheld where it exceeds $\$ 1,000$, if the employee resides without the state. Rent and income from business are not mentioned in this paragraph, nor is this class of income paid in return for per- 
sonal service. Hence, such income is not required to be deducted at the source. Taxes on profits made by a partner in a partnership doing business within the state need not be withheld, nor would it seem that any part of the payments made on account of such profits, should be withheld, whether such payments be made at a fixed period or not.

Interest and annuities are not deducted because not included in the gross income of a non-resident, except to the extent to which the same shall be part of a business carried on in the state.

Under paragraphs 1 and 3 of Section 366, the tax on salaries, wages and compensation paid for personal service are to be deducted by employers. No distinction is made as to the kind of employment, whether it be to a railroad president who receives $\$ 50,000$ a year, or to a stenographer who receives $\$ 1,500$ per year. The third paragraph of this section provides for the return of all deductions made under the first paragraph.

The final sentence of paragraph 3 , provides that

"Every such individual corporation or partnership is hereby made liable for such tax and is hereby indemnified against the claims and demands of any individual, corporation or partnership for the amount of any payments made in accordance with the provisions of this section."

Amount of tax to be deducted.-The statute requires $2 \%$ to be deducted from all salaries, wages, commissions, etc., where it equals or exceeds $\$ 1,000$, unless the recipient of the income is a resident and files a certificate to this effect. The tax is imposed, at a graded rate of 1,2 and $3 \%$ on incomes respectively exceeding $\$ 1,000$, $\$ 10,000$, and $\$ 50,000$. The original bill introduced in the legislature called for a flat rate of $2 \%$ and in the closing days of the session, the tax was fixed at a progressive rate of 1,2 and $3 \%$. Through an oversight, however, the withholding provision in the original bill was retained instead of a deduction of 1,2 and $3 \%$, to conform to the tax rate in Section 351 .

If the withholding agent only returns the proper amount of the tax instead of the $2 \%$ deduction provided in Section 366 , it is not believed that any penalty can attach for conforming to the spirit, 
if not the letter of the law. On the other hand, the deduction of a larger tax than the statute evidently intended, may be an illegal exaction from non-residents in the state. In other words, if a resident of New Jersey earns a salary of $\$ 20,000$, the withholding agent need not deduct $\$ 400$. He only deducts $\$ 100$ for the first $\$ 10,000$ and $\$ 200$ for the remainder-in the aggregate, $\$ 300$.

Note: See Comptroller's Regulations, infra.

Under Section 366 the comptroller has issued the following regulations:

\section{STATE OF NEW YORK. OFFICE OF STATE COMPTROLLER, ALBANY, N. Y.}

\section{DEDUCTING AND WITHHOLDING AT SOURCE}

RULES AND REGULATIONS OF THE STATE COMPTROLLER, IN RELATION TO TAXES IMPOSED UPON AND WITH RESPECT TO INCOMES BY CHAPTER 627 OF THE LAWS OF IgIg

\section{Foreword}

The following regulations, articles 261 to 269, relative to deducting and withholding at source, are promulgated in advance of the formulation of a complete set of rules and regulations because of the immediate importance of the subject.

June 11, 1919

(Signed) EUGENE M. TRAVIS,

\section{DEDUCTING AND WITHHOLDING AT SOURCE}

Art. 261. Deducting and withholding tax at source. Under the opinion of the attorney-general (Income Tax Letter No. 1, May 29, $1919)$, deducting and withholding is required of one per cent (1\%) on the first $\$ 10,000$ and of two per cent $(2 \%)$ on all sums in excess of $\$ 10,000$ from all salaries, wages, commissions, gratuities, emoluments, perquisites and other fixed and determinable annual or periodical compensation earned for personal services in a business, trade, profession or occupation carried on within the state, if the aggregate amount thereof in any calendar year on account of any individual equals or exceeds $\$ 1,000$, unless there shall be filed with the withholding agent a certificate of residence, on Form 101, to the effect that 
the recipient is a resident of the state and setting forth his residence address within the state.

Art. 262. Deducting and withholding in rgrg. Withholding agents shall deduct and withhold, as set forth in Article 1, in respect of personal service compensation paid or credited to the payee at any time on or after January 1, 1919, except that if the employee left the service of the withholding agent prior to May 14, 1919 (the date of the enactment of chapter 627 of the laws of 1919), and was fully paid prior to that date, no duty or obligation in respect to such payments rests on the withholding agent, unless the status of employer and employee is again created during 1919 and further payments of compensation for personal services are made or credited in 1919. In other words, the provisions for deducting and withholding are effective from January 1, 1919, except as stated in this article.

Art. 263. Fixed or determinable annual or periodical income. Only income earned for personal services is subject to deducting and withholding. The statute specifies that every withholding agent shall deduct from all salaries, wages, commissions, gratuities, emoluments and perquisites. But other kinds of personal service income may be included if fixed or determinable annual or periodical. Income is fixed when it is to be paid in amounts definitely predetermined. It is determinable whenever there is a basis of calculation by which the amount to be paid may be ascertained. The income need not be paid annually or at an annual rate. It may be paid periodically. The word "periodical" is used in apposition to "annual" and means from time to time, whether or not at regular intervals. That the length of time during which the payments are to be made may be increased or diminished in accordance with someone's will or with the happening of an event, does not make the payments any the less determinable or periodical.

The following shall be deemed to be fixed and determinable annual or periodical compensation within the meaning of section 360 of the tax law:

Any payment made by way of salary, wage, commission, gratuity, emolument, perquisite or otherwise for personal services rendered, if the amount thereof shall be

(a) determined prior to, concurrent with or subsequent to the rendering of the service, and is

(b) based on personal services rendered by the hour, week, month, year or other period of time,

whether such personal service consists of

(c) the performance of specified or unspecified duties, or of 
(d) work done on or in connection with one or more of certain articles or parts thereof;

irrespective of whether payment be made

(e) in cash,

(f) in board or lodging, or both,

$(\mathrm{g})$ in the stock of a corporation,

(h) by promissory note or other obligation, or

(i) in property, service or otherwise.

If payment shall be made otherwise than in cash, it shall be considered and treated as payment in cash to the fair market value (determinable usually by understanding or agreement existing between the payor and the payee) of such medium, other than cash, as may be employed.

Fees for professional services are not subject to withholding unless contracted for or paid on an annual or periodical basis.

Art. 264. Year, for purposes of deducting and withholding. Deducting and withholding of personal service compensation by withholding agents shall be on the basis of a calendar year, irrespective of the basis of reporting adopted by the payee-taxpayer. Personal service compensation shall be deemed to have been paid by the withholding agent and received by the payee-taxpayer only if and to the extent actually paid or credited to the payee and thus made reducible to possession by him. Commissions and all other forms of personal service compensation determined and paid or credited to a payee-taxpayer after the close of a calendar year, shall, for the purpose of deducting and withholding the tax and of returning information with respect thereto, be treated as payments made in the calendar year when paid or credited, but for such purposes only. The approved method of accounting employed by the payee-taxpayer shall govern in so far as he may be called upon to account for such payments for income tax purposes.

Art. 265. Income not subject to deducting and withholding. Deducting and withholding from income is not required in the following cases:

(a) In respect of personal service compensation income when there shall have been filed with the withholding agent a resident's certificate on Form 101, to the effect that the person receiving the compensation is a resident of this state and setting forth his residence address within the state.

(b) If of a character other than compensation for personal services.

(c) Where the personal services are rendered entirely without the state, by a non-resident, whether payment be made from within 
or without the state, irrespective of the status of the withholding agent. The occasional entry into the state of a non-resident employee who performs the duties for which he is employed entirely without the state but enters the state for the purpose of reporting, receiving instructions, accounting, etc., incidental to his duties without the state, shall not be deemed to take such employee out of the class of those rendering their services entirely without the state.

(d) Where the personal services are rendered within the state, if rendered for, and delivery of payment is made without the state by, a non-resident individual or partnership having no office or place of business or paying agent within the state, or a foreign corporation that (1) is not registered in New York and (2) has no office or place of business or paying agent within the state. (Nothing in sub-paragraph "d" shall be construed to relieve the recipient from liability to make return and pay the tax on such income.)

Art. 266. Income of a non-resident for services performed partly within and partly without the state. In case a non-resident receives compensation for personal services rendered or performed partly within and partly without the state, the withholding agent shall deduct and withhold on the entire amount of compensation, as set forth in Article 1, unless the withholding agent files with the comptroller, with his return (Form 103) of sums deducted and with. held, a certificate on Form 102, setting forth

(1) that the employee is a non-resident (stating his address); (If the withholding agent has not personal knowledge of the place of residence of the employee, he may state it upon information and belief, provided he submits with his certificate the affidavit of the employee stating such residence.)

(2) that part only of the payments made were for services performed within the state, and

(3) the amount in dollars and cents of such part. If brought into question, the burden of proof will be on the withholding agent to show that no greater portion than that set forth in his affidavit of the payments made was for services performed in this state.

In apportioning such income of a non-resident, the following rules shall be observed by the withholding agent:

(a) If the non-resident is a salesman, drummer, agent or other employee through whose services receipts or remuneration inure directly to the employer, the deducting and withholding shall attach to the portion of the entire salary which the vol- 
ume of business transacted by the employee within the state of New York bears to the total volume of business transacted within and without the state by such employee.

(b) If the nature of the employment of the non-resident is such that receipts or remuneration for services rendered do not inure directly to the employer, as in the case of clerks, bookkeepers, laborers or other like classes of employees, the deducting and withholding shall attach to the portion of the personal service compensation income of such employee which the time employed within the state bears to the time employed both within and without the state.

(c) If it is not possible to apportion the income as above provided, because of the peculiarities of the service of the employee, the apportionment shall be made in accordance with the facts and the tax deducted and withheld accordingly. In such a case a full statement of the facts shall be made to the comptroller.

Art. 267. Form of residence certificate. Form 101, shall be used by residents of the state of New York for the purpose of claiming the benefit of such residence for income tax purposes. Withholding agents shall retain, preserve and keep available for examination and inspection by the comptroller or his authorized representative all residence certificates for a period of one year next following the close of the calendar year for which such certificates shall have been given. Blanks (Form 101) will be furnished by the comptroller on the application of withholding agents. Withholding agents may, if they choose to do so, use blanks acquired from other sources, provided, however, that the form and wording thereof shall comply exactly with Form 101.

Art. 268. Revocation and renewal of residence certificates. An employee who has filed a certificate of residence on Form 101, and who thereafter changes his residence, shall notify his employer of such change. Any employer who has reasonable ground for believing that may revoke the certificate of residence theretofore filed by such eman employee has changed his residence, after notice to the employee, and, in default of a new certificate of residence, shall deduct and withhold from the compensation of such employee for the entire calendar year, as provided in Article I.

A certificate of residence shall be effective only for the calendar year in which it is filed.

Art. 269. Deducting and withholding where residence is established. When a withholding agent shall have deducted and withheld from the personal service compensation of an employee and such employee shall thereafter, before return of the amount so withheld 
is made by the withholding agent but not later than March 15 in the year following, file with the withholding agent a residence certificate on Form 101, the withholding agent shall thereupon pay over to the employee the entire amount of income so deductcd and withheld for such calendar year.

Pursuant to the authority conferred by chapter 627 of the laws of 1919, the foregoing regulations (Articles Numbered 261-269 inclusive) in relation to "Deducting and Withholding at Source," are hereby made and promulgated.

(Signed) EUGENE M. TRAVIS, Comptroller.

Albany, N. Y.,

June 11, 1919.

Opinions of Attorney General on Salaries to be Taxed and on withholding. - Attention is called to the following:

Letter No. 2, of May 29, 1919, as to sources within the State, holding that it includes rent for property, and profits for commerce carried on, within the state. Whether earnings or salary paid to a nonresident are from "sources within the state" depend on the work done, rather than the person paying it. Services performed without the state are not taxable.

Letters No. 3 and No. 4, dated May 29th, and June 2, respectively, refer to withholding agents and are covered in substance by the above regulations of the Comptroller.

Wages of mariners.-Attorney General's letter No. 7, dated June 12 , 1919, holds that a mariner's wages derived from a vessel owned by a resident of the state is from a source within the state, even if the vessel never reaches a New York port.

U. S. railroad employee's wages exempt.-Attorney General's letter No. 6, dated June 10, 1919, holds that the gross income of employees of railroads, telegraphs, telephones and cables under federal control are not taxable "for the time the lines might remain in the control of the United States." 


\section{CHAPTER XXVII.}

\section{Exemption of Intangible Personal Property from Local TAXation.}

Section 352 of the Personal Income Tax Law provides: "The taxes imposed by this article are in addition to all other taxes imposed by law, except that money on hand, on deposit or at interest, bonds, notes and choses in action and shares of stock in corporations other than banks and banking associations, owned by any individual or constituting a part of a trust or estate subject to the income tax imposed by this article, and from which any income is derived, shall not after July thirty-first, nineteen hundred and nineteen, be included in the valuation of the personal property included in the assessment-rolls of the several tax districts, villages, school districts and special tax districts of the state."

It was evidently the intention of the framers of the new Personal Income Tax Law to exclude intangible property from local taxation. That would be in accord with the legislative intent to exempt corporations from taxation on personal property for local purposes in the act which was passed in 1917, Sections 210 and 219-j, Article 9-a. It was finally decided only to exempt intangible property and to leave the tangible property for taxation by the local assessors. In order that there might be no question as to the meaning of intangible property, the present act specifically describes by name, the character of intangible property to be exempted. Statutory provisions have been nullified in the past by holding money, mortgages or securities as tangible property, although generally deemed intangible. In the closing hours of the legislative session, the words "and from which any income is derived" were inserted after the enumeration of the classes of in- 
tangible property to be exempted, thus injecting an element of confusion into the statute.

Money on hand and choses in action represented by outstanding accounts when used in a going business yield an income although no interest may be derived from either class, but if the property is used productively, there is a presumption that income will be derived therefrom. (McLean v. Julian Electric Co., $28 \mathrm{Abb}$. N. C. 349.)

In the same way it may be said that notes taken in payment of accounts in a going business, yield an income whether they bear interest, or not. The business in which these various kinds of intangible property were used, is undoubtedly productive in character, but whether it is income producing, is another matter. Of course, in the case of money on hand or on deposit not used in a productive business, no such question will arise. As to shares of stock in corporations other than banks and banking associations, which pays no dividends, the question occurs which receives some significance from the provision of the law imposing a tax on business corporations. Section 219-j provided that "after this article takes effect, corporations taxable thereunder shall not be assessed on any personal property or capital stock as provided for in Section 12 of this chapter."

The words "corporations taxable thereunder" refer to corporations taxable under Section 9-a and it exempted all of such corporations from taxation on their personal property (or capital stock), upon which they have heretofore paid the tax either under Section 12 in the case of domestic corporations, or under Section 7 in the case of foreign corporations.

There had up to that time been effective the following provision in Subdivision 16, Section 4 of the tax law, under the head of "Exemption from Taxation," viz.: "Owner or holder of stock of an incorporated company liable to taxation on its capital shall not be taxed as an individual for such stock."

Since a business corporation was therefore no longer "liable to taxation on its capital," the exemption to the individual owner of the stock may be said to have been repealed and the present pro- 
vision exempting such stock "from which any income is derived" by implication makes stock paying no dividends liable to taxation. This same rule would have seemed to apply equally to residents and to non-residents, although non-residents are in no event taxed on the income from "annuities, interest on bank deposits, interest on bonds, notes or other interest-bearing obligations or dividends from corporations, except to the extent to which the same should be a part of income from any business, trade, profession or occupation carried on in this state, subject to taxation under this article."

Opinion of Attorney General on income from mortgages, Etc.-Tax letter No. 8 dated June 19, 1919, holds that the income from mortgages and secured debts, not being specifically exempted as is the income from "investments" remains subject to the income tax and may not be excluded in the computation of gross income. 


\section{CHAPTER XXVIII}

\section{Estates and Trusts.}

Estates and Trusts.-The wording and the application of the New York State Act differs from that of the federal law because of the difference made in the State law between taxpayers who are residents and those "other than residents." Those who drew the State law avoided skillfully a difficulty by which the drafters of the federal act were not hampered. On the face of the state law there is no attempt to extend the taxing power of the state over persons not under its jurisdiction as to income having neither origin, situs nor destination within this state. This clear intent is carried out and marks one of the few differences in the literal text of the two statutes.

"Net income" of an estate or trust. Exemptions and deductions.-To each of the four separate subdivisions as to which the state law follows the literal text of the federal law as to imposing a tax on the income of estates (meaning estates of decedents) and of any kind of property held in trust there is applied the same exception or exclusion which is provided for individuals who are not residents of the State. The exception appears twice in substantially identical language, first at the end of subd. 3 of section 365, and again at the end of subd. 4 of the same section.

The exception or exclusion reads as follows:

In such cases, the estate or trust shall be allowed the same exemptions as are allowed to single persons under section 362, and in such cases an estate or trust created by a person not a resident and an estate of a person not a resident shall be subject to tax only to the extent to which individuals other than residents are liable under section 359 , subd. 3 .

The provision of Section 359 is as follows: 
In the case of taxpayers other than residents, gross income includes only gross income from sources within the state, but shall not include annuities, interest on bank deposits, interest on bonds, notes or other interest bearing obligations or dividends from corporations, except to the extent to which the same shall be a part of income from any business, trade, or occupation carried on in this state subject to taxation under this article.

It should be noted in this connection that as to trusts and estates receiving income under the first paragraph of Section 365, subdivisions (a), (b) and (c), viz., during the period of administration or settlement, for interest accumulated in trust, for the benefit of unascertained persons, or persons with contingent interest, or for future distribution, that those not resident are to receive the same exemptions as resident single persons, i. e., $\$ 1,000$. For guidance as to income distributed to beneficiaries under subdivision (d) of the same paragraph, we may turn to paragraph 4 and also to the directions imposed on fiduciaries in Section 369, which in effect gives the beneficiary a deduction of $\$ 1,000$, if single, and $\$ 2,000$, if married, subject nevertheless to the clause as to the amount of income taxable to a taxpayer other than a resident, in the last part of paragraph 4, Section 365, and also subject to the intendment in Section 362, that the personal exemptions in this case apply only to resident taxpayers.

In addition to the deductions allowed to individuals which are allowed to estates and trusts under the provisions quoted in full above, there is also deducted under Section 365 subd. 2 income set aside for the United States, a state, territory, or political division of the United States, the District of Columbia, and corporations the purposes of which are religious, charitable, scientific or educational and societies for the prevention of cruelty to children or to animals, when no part of the income inures to the benefit of any private stockholder or individual.

The state statute, like the federal act, taxes the incomes of decedent's estates as they accrue during administration, income of trusts accumulating for persons not born, or not ascertained, or whose identity is to be fixed by a contingency; income held for future distribution and income of trusts distributable periodically. 
The income of an infant collected by a guardian is the subject of a specific separate clause, meant to cover the case when he holds it, and also when he is to distribute it under the court's direction.

Non-resident estates and trusts.-The essential feature of the state statute is that the provisions as to taxing incomes of estates and trusts, reduce,-other than resident,- to a very modest residuum of practical enforcibility. The clear intent is to reach with the income tax levy only such revenues of trusts and decedent's estates as are derived from carrying on a trade or business within the State of New York. That is because annuities and interest receipts of all kinds, speaking generally, are excluded from the operation of the tax on persons, estates and trusts other than residents (subd. $3, \S 359$; subd. $3, \S 365$ ), and because also it is hardly possible to conceive of a trustee, executor, or administrator as carrying on or even continuing within the state a profession or a personal occupation. Practically then, the question of the liability of a non-resident decedent's estate or a trustee not a resident of the State to pay the State income tax will arise only in instances where an executor exercises power given him by a will to continue in this State a trade or business in which the decedent was engaged before his death, or where one in control of a business, sees fit to put it in the hands of a trustee. An administrator who continues the trade, business or occupation of his decedent, does so at his own risk, and on his own account in so far as liability to pay the state income tax is concerned. That is an indisputable inference from familiar principles of substantive law.

Exception as to sums invested in business.-One exception ought to be noted from the expression of a general intention to exclude accruals of interest from the operation of the state income tax levy as to persons, estates or trusts other than those resident in the state, whether it be from bank deposits, bonds, notes or debentures, or corporation dividends. If the interest accrued be part of the income from a trade or business carried on in the state it is taxable against an estate or a trust not a resident. The meaning or application of this will no doubt come up for discussion and 
decision in relation to money left invested in a business by an executor, trustee, administrator, or guardian.

Some interesting questions may grow out of the form in which the fund is carried on the books of the business in question, i. e., whether as a loan to the business or in the form of a contribution to the capital which is still employed in the business after notice given of a future withdrawal. In the latter case, it might be a puzzle whether to call the earnings of the fund interest or profits, but in either event it would, according to the letter and the intent of the law, be taxable.

Executor's or trustees domicile no longer controlling.-The form in which the state statute has been cast tends at least to render academic and immaterial rules evolved in the past as to determining jurisdiction over a decedent's estate or over a trust estate by the location of the fiduciary's residence or by the situs of personal assets either for safe-keeping or for investment or for any other purpose, permanent or casual. The legislative intent is put clearly at the end of the third subdivision of Section 359 of the State Law, the last of ten important clauses into which the section is divided. As to estates, trusts, and infants' incomes held by guardians, the intention is expressed twice in Section 365 to limit the levy on non-residents to incomes derived from business carried on in New York.

The old maxim, mobilia personam sequuntur, and the distinctions between residence and domicile, upon the exposition of which much judicial learning has been lavished, as varying states of the facts have arisen, need not vex the administration of the State Income Tax Law as to the tax on the income of trusts and estates, if the intent, once expressed in the statute be kept to the fore, that the only income sought to be taxed is that derived from a business carried on in this State.

The suggestion that individuals may "die technically in New Jersey" in order that their estates escape the income tax levy in New York will not be pushed to the point of ferryboat trips to the Jersey shore in rigore mortis. As a practical matter, the state 
law leaves taxpayers, whether they be residents or not, at liberty to die. where they please. If they had been residents prior to death, their estates will be subject to income tax on annuities, on bond and note interest, and interest accruing from any obligation to pay money except securities expressly exempted, as well as on every other variety of income not exempted, including business revenues. If they are not residents, the levy is limited to income receipts from business carried on in the state.

The special provisions of the law as to estates and trusts were needed to make it clear that the income derived from a decedent's property is not made immune from levy during the time needed for administration, settlement and distribution of the estate. They were also necessary to the clear or unambiguous expression of the intent to levy on the income in addition to the succession or inheritance taxes which have been collected during many years, out of the principal funds passing to beneficiaries.

The "fiduciary," which the law defines so as to cover specifically guardians, executors, administrators, and trustees as well as generally any person or corporation acting in a fiduciary capacity for any person or estate, must make the return and pay the tax. In one case only is the fiduciary not to pay the tax, and that is in a case where any income has during the administration or settlement period been paid or credited to any heir, legatee, or beneficiary. In such a case, it is the apparent intent of the law,-although the application is far from clear, that the beneficiary shall personally pay the tax. 


\section{CHAPTER XXIX.}

\section{COMPARATIVE TABLE SHOWING PARALLEL SECTIONS IN STATE AND FEDERAL INCOME TAX LAWS.}

\section{State Law}

350-1 new

2 same as, excepting new: "or whose income is in whole or in part subject to a tax imposed by this article, and does not include corporations."

3 same as

4 same as

5 adds after "any person" the words: "whether individual or corporate."

6 adds part beginning: "the term received. ..."

7 new.

8

9 lst half new.

10 wording new-taken partly from: new. new.

\section{same as} excepting Jan. 1st, 1919, substituted for March lst, 1913. same as same as same as, excepting comptroller for commissioner, and adds last clause: "and conforming so far as may be to forms and methods prescribed by U. S. Commissioner.

\author{
Federal Law
}

in section $I$.

in section $\mathbf{I}$.

in section 200 .

in section 200 .

in section 200 .

section 20I, in part.

in section $I$.

section $22 \mathrm{I}-\mathrm{a}$.

section 202-a.

section 202-b, lst sentence.

section 202-b, 2nd sentence with changed dates.

section 203 . 
357 analogous to

358- 1 same as, excepting comptroller for commissioner.

358- 2 same as, excepting comptroller for commissioner.

359- 1 same as, excepting salaries of Federal officials not included.

359-2, a same as, excepting adds: "and contracts"

359-2, b, c same as

359-2, d, excepting new: "obligations of State of New York," and does not include

1. "obligations of all States, etc."

2. provision for statement of ownership of bonds

359-2, e same as, excepting new: "or through War Risk Insurance Act. . . ."

359-2, f new

359-2, $\mathrm{g}$ new

359,3 same as, excepting "State" for "United States," "taxpayer other than a resident" substituted for "non-resident alien individual," and differences in wording of latter part.

360,1 same as

360,2 same as, excepting new: "in the case of a resident such a proportion of the total, etc." "not a resident" for "non-resident alien individual" "state" for "United States"

360, 3 same as, excepting "or third," "by the authority of any foreign government," without the federal distinction as to residence.

360,4 same as

360,5 same as, excepting "taxpayer other than a resident of the state" substituted section 212-a.

section 212-b.

section 2I2-b, last sentence.

section 213-a.

section $213, b-I$.

section 213, b-2, 3 .

section $213, b-4$.

section $213, b-6$.

section 2r3-c.

section 2I4, a-I.

section 214, a-2.

section 214, a-3.

section 214, a-4.

section 214, a-5. 
for "non-resident alien individual," and "State" for "U. S."

360, 6 same as, excepting same substitution as in $\mathbf{a}-\mathbf{5}$

360,7 same as

360,8 same as

360, 9 same as, excepting: Jan. 1st, 1919, for March 1st, 1913 , and comptroller for commissioner, etc.

360-10 same as, excepting: "incorporated by or associations" ... under the laws of this state; "comptroller" substituted for "commissioner, with approval of the secretary."

"Taxpayer other than a resident" substituted for "non-resident alien"

360-11 same as, excepting "taxpayer other than a resident" substituted for "nonresident alien individual," "state for United States," comptroller for commissioner.

361- 1 same as

361- 2 same as

361- 3 same as

361- 4 same as

362 new: "to any resident taxpayer."

362- 1 same as

362- 2 same as

362- 3 new

363 new

364 same as, excepting new: "Taxpayers who are mem. bers of partnerships-may be required to make a return stating gross income," etc., and "personal exemption allowed only to individual partners."

365 same as, excepting new: "and in such cases an es- section 214, a-6.

section $214, a-7$.

section $214, a-8$.

section 2 I4, a-ro.

section 2 I4, a-II.

section 2 r 4-b.

section 2 I5-a.

section $2 \mathrm{I} 5-\mathrm{b}$.

section $215-c$.

section 2 r $5-d$.

section $216-c$.

section $216-d$.

section $2 \mathrm{I} 8 \mathrm{-a}$ and $\mathrm{d}$.

section 2 rg. 
tate or trust created by a person not a resident. ..."

366- 1 new, but see

366- 2 new

366- 3 same as, excepting: "March 15th" for "March 1st" and new: "shall at the same time pay the tax to the comptroller."

366- 4 same as

366- 5 same as

367 same as, excepting new : "taxpayers other than residents shall not be entitled to deductions unless ..." etc., "taxpayer" substituted for "individual."

368 same as

369 same as, excepting "taxpayer" substituted for "individual," "comptroller" for "commissioner."

370 same as, excepting "comptroller" substituted for "commissioner."

371 new.

372 new.

373 new.

374 new.

375 new.

376 new.

377 new.

378 new.

379 new.

380 new.

381 new.

382 new.

383 new.

384 new.

385 new. section 22 .

section $22 \mathrm{I}-\mathrm{C}$.

section 22I-d.

section 22I-e.

section 223.

section 224 .

section 225 .

section 226 . 


\section{CHAPTER XXX}

\section{Text of the Individual Income Tax Law of New York State together with Treasury Decisions and Regulations per- taining to similar provisions of the Federal Income Tax Law.}

(Note: Words added or substituted or other instances where the State Law differs from the Federal, are denoted by italics. The italics are the author's. Where the date March 1st, 1913, or similar dates, occur in the T. D.'s and Regulations, one may substitute, for state purposes, the date January 1st, 1919. In general where the Federal Law refers to "non-resident alien individual" the State Law employs the phrase "taxpayer other than a resident of the state." There have been included in the annotations some T. D.'s and Regulations which in terms apply only to corporations, but which, it is believed, will have some illustrative force (For comparison between State and Federal Law see table preceding this chapter.)

Definitions.

SEc. 350. Definitions. For the purpose of this article and unless otherwise required by the context:

\section{Comptroller defined.}

1. The word "comptroller" means the state comptroller.

(Source: New.)

Taxpayer defined.

2. The word "taxpayer" includes any person, trust or estate subject to a tax imposed by this article, or whose income is in whole or in part subject to a tax imposed by this article, and does not include corporations.

(Source: Fed. Rev. Act 1918, § 1.)

Under the federal law a taxpayer is any person, trust or estate subject to tax, and three chief classes of persons are recognized, to wit: individuals, partnerships and corporations. Corporations include associations, joint stock companies and insurance companies, but not partnerships properly so called. (Reg. 45, Rev. Art. 1501.) 
The state law expressly excludes corporations from the definition of taxpayer under this article.

\section{Military and naval forces defined.}

3. The words "military or naval forces of the United States" include the marine corps, the coast guard, the army nurse corps, female, and the navy nurse corps, female, but this shall not be deemed to exclude other units otherwise included within such words.

(Source: Fed. Rev. Act 1918, \& 1.)

\section{Taxable year and fiscal year defined.}

4. The words "taxable year" mean the calendar year, or the fiscal year ending during such calendar year, upon the basis of which the net income is computed under this article. The words "fiscal year" mean an accounting period of twelve months, ending on the last day of any month other than December.

(Source: Fed. Rev. Act 1918, § 200.)

The return of a taxpayer is made and his income computed for his taxable year, which may be either the calendar year or his fiscal year. No fiscal year will, however, be recognized unless before its close it was definitely established as an accounting period by the taxpayer, and the books of such taxpayer were kept in accordance therewith. If a taxpayer has an accounting period, which is a fiscal year within the meaning of the statute, he must make his return on that basis. If he has no such fiscal year, he must make his return on the basis of the calendar year. (From Reg. 45, Rev. Art. 25.)

\section{Fiduciary defined.}

5. The word "fiduciary" means a guardian, trustee, executor, administrator, receiver, conservator, or any person, whether individual or corporate, acting in any fiduciary capacity for any person, trust or estate.

(Source: Fed. Rev. Act 1918, § 200.)

Fiduciary is a term which applies to all persons that occupy positions of peculiar confidence toward others, such as trustees, executors and administrators, and a fiduciary for income tax purposes is a person who holds in trust an estate to which another has the beneficial title or in which another has a beneficial interest or receives and controls income of another, as in the case of receivers. A committee of the property of an incompetent person is a fiduciary. (Reg. 45, Rev. Art. 1521.) 


\section{Fiduciary distinct from agent.}

There may be a fiduciary relationship between an agent and a principal, but the word "agent" does not denote fiduciary. A fiduciary relationship cannot be created by a power of attorney. An agent having entire charge of property with authority to effect and execute leases with tenants entirely on his own responsibility and without consulting his principal, merely turning over the net profits from the property periodically to his principal by virtue of authority conferred upon him by a power of attorney, is not a fiduciary within the meaning of the statute. In cases where no legal trust has been created in the estate controlled by the agent and attorney, the liability to make a return rests with the principal. (Reg. 45, Rev. Art. 1522.)

\section{"Paid," "paid or accrued," "received" defined.}

6. The word "paid" for the purposes of the deductions and credits under this article, means "paid or accrued" or "paid or incurred," and the terms "paid or incurred" and "paid or accrued" shall be construed according to the method of accounting upon the basis of which the net income is computed, under this article. The term "received" for the purpose of the computation of net income under this article, means "received or accrued" and the term "received or accrued" shall be construed according to the method of accounting upon the basis of which the net income is computed under this article.

(Source: Fed Rev. Act 1918, § 200. Words in italics new.) See also Deductions.

\section{What may be deducted as "paid."}

"Paid" or "actually paid" within the meaning of this title does not necessarily contemplate that there shall be an actual disbursement in cash or its equivalent. If the amount involved represents an actual expense or element of cost in the production of the income of the year it will be properly deductible even though not actually disbursed in cash, provided it is so entered upon the books of the company as to constitute a liability against its assets, and provided further that the income is also returned upon an accrued basis. If, in the course of its business, a corporation credits the accounts of individuals, firms or corporations with the amount of any expenses, interest, rentals, wages, etc., due them, thereby making them subject to the personal drawings of such creditors or if expenses actually incurred are vouchered in definite amounts, the amount so credited or vouchered may be treated as paid, and if the amounts so credited or vouchered are expenses incurred concurrently with and in the production of the income of the year, they may be allowably deducted therefrom. This ruling must not be construed to allow as a deduction any accrued charges 
which if paid in cash or otherwise, would not be deductible. (Article 126, Regulations 33, Rev., Jan. 2d, 1918.)

Amounts which accrue on the books monthly or at other stated periods to meet fixed annual or other charges;

and

Reserves maintained to meet liabilities, the amount of which and date of payment or maturity of which is not definitely determined or determinable at the time the liability is incurred;

may be deducted from gross income as coming under this definition of "paid" or "paid or incurred."

But such amounts deductible must approximate as nearly as possible the actual liabilities for which the accruals are made. Where such deductions are made on an accrual basis the income also must be returned on an accrual basis, and the same practice is to be consistently followed year after year.

Sinking funds or reserves set up to meet additions, betterments, shrinkage in values, losses from bad debts, or other capital obligations, will in no event be allowed as deductions. (T. D. 2433, Jan. 8, 1917.)

No particular bookkeeping or accounting system required.-Any system of accounting which is not consistent with the purpose and intent of the rules set out in this title, and with the general rules set out in these regulations for the ascertainment of net income, will not be accepted as a correct basis for making returns. (Art. 128, Reg. 33, Rev., Jan. 2, 1918.)

\section{Resident defined.}

7. The word "resident" applies only to natural persons and includes for the purpose of determining liability to the tax imposed by this article upon or with reference to the income of any taxable year, commencing with the year nineteen hundred and nineteen, any person who shall, at any time on or after January first and not later than March fifteenth of the next succeeding calendar year, be or become a resident of the state.

(Source: New. See also chapter on Residence, supra.)

Resident aliens.- "Residence," as used in Subdivision 1, Paragraph A of the Act of October 3, $1913^{*} * *^{*}$, is held to be-

"That place where a man has his true, fixed and permanent home and principal establishment, and to which whenever he is absent, he has the intention of returning; and indicates permanency of occupation as distinct from lodging or boarding, or temporary occupation."

For the purposes of the income tax,-it is held that where for business purposes or otherwise, an alien is permanently located in the United States; has there his principal business establishment and is there permanently occupied or employed, even though his domicile may be without the United States he will be held to be within the definition of- 
"Every person residing in the United States, though not a citizen thereof ***" (T. D. 2242, September 17, 1915.)

\section{Aliens temporarily living in the United States.}

For the purposes of the income tax,-it is held that $*^{*} *$ aliens who are physically present in the United States, but only temporarily resident or employed therein (as for a season or other similarly definite term, and with the expectation or intention of leaving the United States upon the termination of employment or accomplishment of the purpose which necessitated presence in the United States), are within the class of-

"Persons residing elsewhere * * * . (T. D. 2242, September 17, 1915.)

\section{Non-resident alien individual.}

Articles 312 to 315 inclusive, Reg. 45, Rev., define a "non-resident alien individual" for purposes of the federal income tax. Briefly it means an individual $(a)$ whose residence is not within the United States and $(b)$ who is not a citizen of the United States. * * * Any alien living in the United States who is not a mere transient is a resident of the United States. Whether he is a transient or not is determined by his intentions with regard to his stay. * * * The best evidence of his intention is afforded by the conduct, acts, and declarations of the alien. ${ }^{*}{ }^{*} \mathbf{A}$ mere floating intention, indefinite as to time, to return to another country is not sufficient to constitute him a transient. * * * Aliens employed in the United States are prima facie regarded as non-residents.

\section{Dividend defined.}

8. The word "dividend" means any distribution made by a corporation out of its earnings or profits to its shareholders or members, whether in cash or in other property or in stock of the corporation.

(Source: Fed. Rev. Act 1918, § 201. For additional provisions of federal statute see Comparative Table, supra.)

Dividends.-Dividends for the purpose of the statute comprise any distribution in the ordinary course of business, even though extraordinary in amount, made by a domestic or foreign corporation to its shareholders out of its earnings or profits. * * * The mere declaration of a dividend is not a distribution. * * * Although interest on State bonds and certain other obligations is not taxable when received by a corporation, upon amalgamation with the other funds of the corporation such income loses its identity and when distributed to stockholders in dividends is taxable to the same extent as other dividends. (Reg. 45, Rev. Art. 1541.)

Dividends paid in property.-Dividends paid in securities or other property (other than its own stock), in which the earnings of a corporation have been invested, are income to the recipients to the amount of the fair market value of such property when receivable by the stockholders. 
A dividend paid in stock of another corporation is not a stock dividend. Where a corporation declares a dividend payable in stock of another corporation, setting aside the stock to be so distributed and notifying the stockholders of its action, the income arising to the recipients of such stock is its fair market value at the time the dividend becomes payable. See Article 53. Scrip dividends are subject to tax in the year in which the warrants are issued. (Reg. 45, Rev. Art. 1544.)

Dividends paid in Liberty Bonds.-In an opinion of the AttorneyGeneral to the Secretary of the Treasury (T. D. 2512, June 8, 1917) on the question of whether stockholders of a corporation receiving a dividend declared payable and distributable in bonds issued under the act of Congress approved April 24, 1917, will have to pay an income tax, it is said that such tax is payable. The said act of Congress provides as to the bonds thereby authorized, that

"The principal and interest thereof shall be exempt both as to principal and interest from all taxation except estate or inheritance taxes imposed by authority of the United States or its possessions, or by any state or local taxing authority' * * * but at tax levied upon one's net income or annual gain cannot be evaded because the income or gain happens to be liquidated by the delivery of a certain number of those bonds or other nontaxable securities. Such a tax is upon the income itself as an entirety and not upon the specific articles into which this income is finally transmuted. When these bonds, therefore, are used as a medium of payment, whether in the discharge of a private debt or a corporate dividend, the profit or gain to the recipient is nevertheless subject to income tax."

Nor is a corporation owning Liberty Bonds exempt to that extent from excise, franchise and other corporation taxes of the United States or several states, the doctrine of Flint $v$. Stone Tracy Co., 220 U. S. 107, being followed. In that case, the court said:

"It is well settled by the decisions of this court that when the sovereign authority has exercised the right to tax a legitimate subject of taxation as an exercise of a franchise or privilege, it is no objection that the measure of taxation is found in the income produced in part from property which of itself considered, is non-taxable. The measure of taxation is the income of the corporation from all sources." (T. D. 2512, June 8, 1917.)

But the income derived by an individual from the interest paid on Liberty Loan Bonds does not constitute taxable income, whether bonds have been received as a dividend or otherwise. (Letter to Lee Higginson \& Co., Boston, signed by Dep. Com. L. F. Speer, June 30, 1917.)

Determination of cash value to the shareholder of a dividend paid in Liberty Bonds.- "Where a corporation distributed Liberty Bonds among its stockholders as a dividend:

"If the corporation bought the Liberty Bonds at 99.25 and the market value thereof when received by the stockholder was 94.25 , should the stockholder make return of the dividend at 99.25 or at 94.25 ?" 
In reply you are advised that, for the purposes of the income tax, income should be predicated on the cash value of the Liberty Bonds at the time of their receipt by the stockholders. (Letter to Ropes, Gray, Boyden \& Perkins, Boston, Mass., signed by Deputy Commissioner L. F. Speer, and dated November 12, 1918.)

Stock dividends.-A dividend paid in stock of the corporation is income to the amount of the earnings or profits distributed, as shown by the transfer of surplus to capital account on the books of the corporation, usually equal to the par value of the stock distributed. But stock distributions made out of surplus other than earnings or profits accumulated since February 28, 1913, when there are no such earnings or profits, are not dividends within the meaning of the statute and are free from tax as dividends. Stock dividends paid from earnings or profits accumulated after February 28, 1913, received by a fiduciary and retained as an accetion to the estate under the terms of the will or trust, are income to the estate. (Reg. 45, Rev. Art. 1545.)

Misapprehension exists as to the effect of the decision of the Supreme Court in the case of Towne vs. Eisner (245 U. S. 418), handed down January 7, 1918. In this opinion it was held that under the Act of October 3, 1913, a stock dividend declared by a corporation January 2, 1914, was not properly regarded as income. It does not necessarily follow, however, that no stock dividends are to be held taxable under the provisions of the Acts of September 8, 1916, and October 3, 1917.

The Act of October 3, 1913, which was the only Act before the Court in the case, contained no provision expressly providing for treating stock dividends as income, and the decision of the Court was to the effect that the Act was not to be construed as taxing such dividends. The Court did not decide that such dividends cannot be income within the meaning of the Sixteenth Amendment, but expressly recognized that the word "income" may have a different meaning in the Statute from the meaning in the Constitution.

The Act of September 8, 1916, contains an express provision taxing stock dividends declared and paid out of earnings accrued since March 1, 1913. In the absence of a decision as to the legal effect of these express provisions contained in the later Acts, the Bureau of Internal Revenue naturally will continue to be governed by the express provisions of the later Acts in reference to stock dividends. (Statement issued to Collectors and Agents, signed by Commissioner Daniel C. Roper, and dated Jan. 10, 1918.)

Stock dividends under the Act of September 8, rgr6.-(Decision. Macomber v. Eisner, Collector, U. S. District Court, Southern District of New York, Jan. 23, 1919.) [Comment: This is a suit for the recovery of tax paid under the Act of September 8, 1916, on a "stock dividend" received by the plaintiff. The contention of counsel for the plaintiff, Murray, Prentice \& Howland, of New York, is that the provision of the taxing Act by which so-called "stock dividends" are in terms stated to be income, to be taxable as such to the same extent as are cash dividends, is unconstitutional, because to tax "stock dividends" is to tax capital or prin- 
cipal, and such a tax may not be imposed except as other direct taxes are laid, that is, by apportionment among the several states according to population. Judge Mayer, of the United States District Court, Southeru District of New York, on January 23, 1919, overruled the demurrer of the Government to the complaint upon the authority of Towne v. Eisner, 245 U. S. 418, and Peabody v. Eisner, 247 U. S. 347. It is understood that the Government will immediately appeal from this decision to the United States Supreme Court and that the case will be advanced on the docket so that speedy adjudication may be looked for, perhaps during the present term. Mr. Charles E. Hughes and Mr. George Welwood Murray presented the case for the plaintiff. Inasmuch as a like provision relative to "stock dividends" appears in the Act of September 8, 1916, as amended by the Act of October 3, 1917, and also in the Revenue Bill (The Revenue Act of 1918) now pending before Congress, the final judgment in Macomber v. Eisner will be controlling for the Revenue Acts of 1916, 1917 and 1918. The question as to the liability of "stock dividends" to tax under the Act of October 3, 1913, was disposed of in Towne v. Eisner above cited, where the decision by the Supreme Court on January 7, 1918, was against the Government's contention. Counsel in the Macomber case were also counsel in the Towne case.

The opinion in the above case consists merely of an endorsement on the demurrer, as follows:

Demurrer overruled on the authority of Towne $v$. Eisner, $245 \mathrm{U}$. S. 418. See also Peabody v. Eisner, 247 U. S. 347.

January 23, 1919.

JULIUS M. MAYER,

U. S. D. J.

Distribution in liquidation.-So-called liquidation or dissolution dividends are not dividends within the meaning of the statute, and amounts so distributed, whether or not including any surplus earned since February 28, 1913, are to be regarded as payments for the stock of the dissolved corporation. Any excess so received over the cost of his stock to the stockholder, or over its fair market value as of March 1, 1913, if acquired prior thereto, is a taxable profit. A distribution in liquidation of the assets and business of a corporation, which is a return to the stockholder of the value of his stock upon a surrender of his interest in the corporation, is distinguishable from a dividend paid by a going corporation out of current earnings or accumulated surplus when declared by the directors in their discretion, which is in the nature of a recurrent return upon the stock. (Reg. 45, Rev. Art. 1548.)

Distribution from depletion or depreciation reserve.-A reserve set up out of gross income by a corporation and maintained for the purpose of making good any loss of capital assets on account of depletion or depreciation is not a part of its surplus out of which ordinary dividends may be paid. A distribution made from such a reserve will be considered a liquidating dividend and will constitute taxable income to a stockholder only to the extent that the amount so received is in excess of the 
cost or fair market value as of March 1, 1913, of his shares of stock. No distribution, however, will be deemed to have been made from such a reserve except to the extent that the amount paid exceeds the surplus and undivided profits of the corporation. In general, any distribution made by a corporation other than out of earnings or profits accumulated since February 28, 1913, is to be regarded as a return to the stockholder of part of the capital represented by his shares of stock, and upon a subsequent sale of such stock his profit will be the excess of the selling price over the cost of the stock or its fair market value as of March 1, 1913, after applying on such cost or value the amount of any such capital distribution. (Reg. 45, Rev. Art. 1549.)

Interest on exempt bonds on distribution as dividend.-Interest on State, municipal, and United States bonds received by corporations is not taxable to the corporation. Upon amalgamation with other funds of the corporation such income loses its identity. When distributed to stockholders as a dividend, the entire amount of the dividend is subject to inclusion in returns of income for the purposes of the income tax. (Art. 4, Reg. 33, Rev., Jan. 2, 1918.)

Scrip dividends. - The dividend paid by the corporation [in 1914] is income to the stockholder for $1914^{*} *^{*}$. The dividends must be included in the return and at the face value of the scrip.

For income tax purposes this transaction is held to be a payment in cash of the dividend, and an investment of the cash in the scrip. (Extract from letter to Oudin, Kilbreth \& Schackno, signed by Deputy Commissioner L. F. Speer, and dated Jan. 19, 1915.)

Dividends paid by a foreign corporation.-Dividends declared and paid by a foreign corporation which derives its entire income from business done wholly within the United States and pays, under the provisions of the Federal income-tax law, a tax upon its net income, should be treated in the same manner as dividends from domestic corporations. (T. D. 2090, Dec. 14, 1914.)

Income from private banks considered as dividends. ${ }^{*} *$ * Income which the members of the association receive from the bank because of their investments therein will be considered dividends, ** * . (T. D. 2152, Feb. 12, 1915.)

Taxes paid by bank for owners of bank stock considered as dividends.-Taxes assessed against the stockholders of a bank and paid by the bank in behalf of the stockholders do not constitute an allowable deduction from the gross income of the bank, but do constitute an allowable deduction in the return of the individual $*^{*} *$. The amount of taxes so paid should be included in his return as income, the said amount being considered as an additional dividend to the amount of the taxes paid. (T. D. 2135, Jan. 23, 1915.)

Dividends paid on life insurance policies.-Dividends paid on life insurance policies that have not matured, whether such dividends are drawn in cash by the insured or applied to the reduction of the annual premium 
due, are not considered items of taxable income under the law, and should be excluded from a return of income.

Dividends from paid-up policies, however, are considered income to the recipient, and must be included in the annual return of income $*^{*} *$. They are considered the same as dividends or net earnings from corporations subject to a like tax and may *** . (T. D. 2137, Jan. 30, 1915.)

\section{Foreign country and United States defined.}

9. The words "foreign country" or "foreign government" mean any jurisdiction other than one embraced within the United States. The words "United States" include the states, the territories of Alaska and Hawaii and the District of Columbia.

(Source: Italicized portions new. Other, Fed. Rev. Act 1918, \& 1.) Withholding agent defined.

10. The words "withholding agent" include all individuals, corporations, associations and partnerships, in whatever capacity acting, including lessees, or mortgagors of real or personal property, fiduciaries, employers, and all officers and employees of the state, or of any municipal corporation or political subdivision of the state, having the control, receipt, custody, disposal or payment, of interest, rent, salaries, wages, premiums, annuities, compensations, remunerations, emoluments or other fixed or determinable annual or periodical gains, profits and income taxable under this article.

(Source: Wording new Sense taken from Fed. Rev. Act 1918, §§ 200 and 221-a.)

Guardians, trustees, executors, administrators, receivers, conservators, and all persons, corporations, or associations acting in any fiduciary capacity hereinafter referred to as fiduciary agents, who hold in trust an estate of another person or persons, shall be designated the "source" for the purpose of collecting the income tax. (T. D. 2231, July 16, 1915.)

An effort has been made to meet the views of certain departments that withholding should occur from the aggregate amounts received by an individual from the various disbursing officers within a department; but, after further and careful consideration of both the law and the administrative features involved, it has been determined that each disbursing officer must be governed by the amounts paid by him alone, and that it is not incumbent upon him to ascertain and take into consideration amounts that may have been paid by other disbursing officers.

This view is in full accord with the provision of the income-tax law which makes "all officers and employees of the United States having the control, receipt, custody, disposal, or payment," etc., personally liable for 
the normal tax of 1 [8] per cent on amounts passing through their hands, subject to the character and amount of income and the exemptions fixed by law.

All rulings heretofore made on the subject, by letter or otherwise, that are in conflict herewith, are hereby overruled and superseded. (T. D. 2135, Jan. 23, 1915.)

All persons, firms, etc., mentioned above are referred to in these regulations as "debtors" or "withholding agents," and the word "source" is to apply to the place where the income originated and is payable. (Art. 31, Reg. 33, Jan. 5, 1914.)

Tax-exempt corporations required to withhold.-While the organizations enumerated in section 11 of this title are themselves exempt from the tax on any income received by them, they are not exempt from the requirements of the title with respect to the withholding of the normal tax on bond interest * * * paid to foreign corporations or bond interest paid to individuals on bonds having a tax free covenant or from furnishing information in accordance with the provisions of this title as amended by section 1205 of Title XII of the act of October 3, 1917. (Art. 81, Reg. 33, Rev., Jan. 2, 1918.)

\section{Persons liable to the tax; rate of tax; and first taxable year.}

SEC. 351. Imposition of income tax. A tax is hereby imposed upon every resident of the state, which tax shall be levied, collected and paid annually upon and with respect to his entire net income as herein defined at rates as follows: One per centum of the amount of net income not exceeding ten thousand dollars; two per centum of the amount of net income in excess of ten thousand dollars but not in excess of fifty thousand dollars; three per centum of the amount of net income in excess of fifty thousand dollars. A like tax is hereby imposed and shall be levied, collected and paid annually, at the rates specified in this section, upon and with respect to the entire net income as herein defined, except as hereinafter provided, from all property owned and from every business, trade, profession or occupation carried on in this state by natural persons not residents of the state. Such tax shall first be levied, collected and paid in the year nineteen hundred and twenty upon and with respect to the taxable income for the calendar year nineteen hundred and nineteen, or for any taxable year ending during the year nineteen hundred and nineteen.

(Source: New.)

* See also § 350, supra. Definition of Resident, and Chapter on Residence. Net Income. 


\section{Certain persorid property exempt.}

SEC. 352. Exemption of certain personal property from taxation. The taxes imposed by this article are in addition to all other taxes imposed by law, except that money on hand, on deposit or at interest, bonds, notes and choses in action and shares of stock in corporations other than banks and banking associations, owned by any individual or constituting a part of a trust or estate subject to the income tax imposed by this article, and from which any income is derived, shall not after July thirty-first, nineteen hundred and nineteen, be included in the valuation of the personal property included in the assessment-rolls of the several tax districts, villages, school districts and special tax districts of the state.

(Source: New. See Chapter XVII, Part IV, supra.)

\section{Ascertainment of gain and loss.}

SEc. 353. Ascertainment of gain and loss. For the purpose of ascertaining the gain derived or loss sustained from the sale or other disposition of property, real, personal or mixed, the basis shall be first, in case of property acquired before January first, nineteen hundred and nineteen, the fair market price or value of such property, as of January first, nineteen hundred and nineteen, and, second, in case of property acquired on or after that date, the cost thereof; or the inventory value, if the inventory is made in accordance with this article.

(Source: Fed. Rev. Act 1918, §202-a. Note: Federal law has March 1st, 1913-where the State law has January 1st, 1919.)

Method of determining value as of March I, r913.-No method of determining this value can be stated by the department which will adequately meet all circumstances. What that value was is a question of fact to be established by any evidence which will reasonably and adequately make it appear. (Art. 4, Reg. 33, Rev., Jan. 2, 1918.)

Determination, in the case of stock, of "fair market price or value" as of March I, I913.- "In case of the sale of stock traded in on the exchange, shall the opening price on March 1st, or the closing price, or the average price for the day, be taken as the basis?"

Under paragraph (c) of Section 2 and paragraph (4) of Section 5, Act of September 8, 1916, in case of property acquired prior to March 1, 1913, "the fair market price or value of such property as of March 1, 1913, shall be the basis for determining the amount of gain or loss" upon sale or other disposition of the property. 
"The fair market price or value as of March 1 " is held to be the fair market price or value as of the entire day of March 1 , which, in the case of variation between "opening and closing price" for the day, would mean the average price for the day. This, however, would be conditioned upon showing that the exchange quotation represented the fair market price or value of the stock, as it is this "fair market price or value" which is to control, however that fact may be ascertained. (Letter to The Corporation Trust Company, signed by Commissioner W. H. Osborn, and dated November 21, 1916.)

Basis for determining gain or loss from sale.-For the purpose of ascertaining the gain or loss from the sale or exchange of property the basis is (a) its fair market price or value as of March 1, 1913, if acquired prior thereto, or $(b)$, if acquired on or after that date, its cost or its approved inventory value. In both cases proper adjustment must be made for any depreciation or depletion sustained. What the fair market price or value of property was on March 1, 1913, is a question of fact to be established by any evidence which will reasonably and adequately make it appear. (Reg. 45, Rev. Art. 1561.)

Sale of property acquired by gift or bequest.-In the case of property acquircd by gift, bequest, devise or descent the basis for computing gain or loss on a sale is the fair market price or value of the property at the date of acquisition or as of March 1, 1913, if acquired prior thereto. For the purpose of determining the profit or loss from the sale of property acquired by bequest, devise or descent since February 28, 1913, its value as appraised for the purpose of the federal estate tax, or in the case of estates not subject to that tax its value as appraised in the State court for the purpose of State inheritance taxes, should be deemed to be its fair market value when acquired. (Reg. 45, Rev. Art. 1562.)

\section{Gain or loss from exchange of property.}

SEC. 354. Exchange of property. When property is exchanged for other property, the property received in exchange shall for the purpose of determining gain or loss be treated as the equivalent of cash to the amount of its fair market value, if any; but when in connection with the reorganization, merger or consolidation of a corporation a taxpayer receives, in place of stock or securities owned by him, new stock or securities of no greater aggregate par or face value, no gain or loss shall be deemed to occur from the exchange, and the new stock or securities received shall be treated as taking the place of the stock, securities or property exchanged.

(Source: Fed. Rev. Act 1918, § 202-b, lst sentence.)

Exchanges of property.-Gain or loss arising from the acquisition and subsequent disposition of property is realized when as the result of a 
transaction between the owner and another person the property is converted into cash or into property $(a)$ that is essentially different from the property disposed of and $(b)$ that has a market value. In other words, both (a) a change in substance and not merely in form, and (b) a change into the equivalent of cash, are required to complete or close a transaction from which income may be realized. By way of illustration, if a man owning ten shares of listed stock exchanges his stock certificate for a voting trust certificate, no income is realized, because the conversion is merely in form; or if he exchanges his stock for stock in a small, closely held corporation, no income is realized if the new stock has no market value, although the conversion is more than formal; but if he exchanges his stock for a liberty bond, income may be realized, because the conversion is into independent property having a market value. The property received in exchange may be real estate, personal property, or a chose in action. The exchange of a so-called convertible bond for stock pursuant to such a privilege granted in the bond will produce income if the stock received in exchange has a fair market value in excess of the cost or fair market value as of March 1, 1913, of the bond. (Reg. 45, Rev. Art. 1563.)

Determination of gain or loss from exchange of property.- $-(a)$ The amount of income derived in the case of an exchange of property, as of stock for a bond, is the excess of the fair market value at the time of exchange of the bond received in exchange over the original cost of the stock exchanged for it, or over the fair market price or value of such stock as of March 1, 1913, if acquired before that date. The amount of income derived from a subsequent sale of the bond for cash is the excess of the amount so received over the fair market value of such bond when acquired in exchange for the stock. (b) On the other hand, if the property received in exchange is substantially the same property or has no market value, then no gain or loss is realized, but the new property is to be regarded as substituted for the old and upon a sale of the new property the amount of income derived is the excess of the amount so received over che cost or fair market value as of March 1, 1913, of the old. (Art. 1564.)

Exchange for different kinds of property.-(a) If property is exchanged for two different kinds of property, such as bonds and stock, the bonds having a market value and the stock none, the value of the bonds is to be compared with the cost or fair market value as of March 1, 1913, of the original property, as the case may be. If the market value of the bonds is less than such cost or value, the difference represents the cost of the stock. If the market value of the bonds is greater than such cost or value, the difference is taxable income at the time of the exchange and whenever sold the entire proceeds of the stock will be taxable. (b) If property is exchanged for two different kinds of property, such as bonds and stock, neither having a market value, the cost or fair market value as of March 1,1913 , of the original property should be apportioned, if possible, between the bonds and stock for the purpose of determining gain or loss on subsequent sales. If no fair apportionment is practicable, no profit on any subsequent sale of any part of the bonds or stock is realized until out of 
the proceeds of sales shall have been recovered the entire cost or fair market value as of March 1, 1913, of the original property. (Art. 1565.)

Exchange of property and stock.-(a) Where property is transferred to a corporation in exchange for its stock, if the previous owner of the property receives 50 per cent or more of the stock of the corporation, so that an interest of 50 per cent or more in such property remains in him, then no gain or loss is realized by such owner from the transaction. For the purpose of ascertaining the gain or loss from the subsequent sale by the stockholder of any stock so received for such property the stock is to be considered as substituted for the property, and the cost of the property or (if acquired prior thereto) its fair market value as of March 1, 1913, is the basis for determining the amount of such gain or loss. For the purpose of ascertaining the gain or loss from the subsequent sale by the corporation of any such property the cost of the property to the former owner or (if acquired prior thereto by him) its fair market value as of March l, 1913, is the basis for determining the amount of such gain or loss. As to the invested capital of the corporation, see section 331 of the statute and article 941. "Owner" includes "owners." This article applies to the incorporation of a business previously conducted by an individual or by a partnership. (b) If, however, the exchange of property and stock involves less than 50 per cent of the stock of the corporation, the exchange constitutes a closed transaction, and the former owner of the property realizes a gain or loss if the stock has a market value and such market value is greater or less than the cost or (if acquired prior thereto) the fair market value as of March 1, 1913, of the property given in exchange. (c) Where a corporation dissolves and distributes its assets in kind and not in cash no taxable income is received from the transaction by its stockholders, because they merely exchange an indirect interest for a direct interest in the same property. As to cash distributions, see article 1548 . For the purpose of ascertaining the gain or loss from the subsequent sale of any property so received upon dissolution see article 1564 (b). (Art. 1566.)

Exchange of stock for other stock of no greater par value.-In general, where two (or more) corporations unite their properties by either $(a)$ the dissolution of corporation $B$ and the sale of its assets to corporation $\mathbf{A}$, or (b) the sale of its property by $\mathbf{B}$ to $\mathbf{A}$ and the dissolution of $\mathbf{B}$, or (c) the sale of the stock of $\mathbf{B}$ to $\mathbf{A}$ and the dissolution of $\mathbf{B}$, or $(d)$ the merger of $\mathrm{B}$ into $\mathrm{A}$, or $(e)$ the consolidation of the corporations, no taxable income is received from the transaction by $A$ or $B$ or the stockholders of either, provided the sole consideration received by $\mathrm{B}$ and its stockholders in $(a),(b),(c)$ and $(d)$ is stock or securities of $\mathrm{A}$, and by $\mathbf{A}$ and $\mathrm{B}$ and their stockholders in $(e)$ is stock or securities of the consolidated corporation, in any case of no greater aggregate par or face value than the old stock and securities surrendered. If the stock so received has no nominal or par value the limitation on aggregate par value is inapplicable. (Art. 1567.) 
Determination of gain or loss from subsequent sale.-The new stock and securities received as described in the preceding article take the place of the old stock and securities. For the purpose, therefore, of ascertaining the gain derived or loss sustained from the subsequent sale of any stock of A or of the consolidated corporation so received, the original cost to the taxpayer or the fair market value as of March 1, 1913, of the stock of $B$ or $A$ in respect of which the new stock was issued, less any untaxed distribution made to the taxpayer by $A$ out of the former capital or surplus of $\mathrm{B}$, or by the consolidated corporation out of the former capital or surplus of $\mathbf{A}$ or $\mathbf{B}$, is the basis for determining the amount of such gain or loss. Similarly, the cost after reorganization, merger or consolidation of the assets of A or of the consolidated corporation is the sum of the cost (or the fair market value as of March 1, 1913) of the assets of A and of B for the purpose of ascertaining the gain or loss upon a subsequent sale. The new invested capital of $\mathrm{A}$ or of the consolidated corporation is to be determined as if $\mathrm{A}$ and $\mathrm{B}$ were rendering a consolidated return as affiliated corporations. (Art. 1568.)

\section{Gain through exchange.}

SEc. 355. Gain through exchange. When in the case of any such reorganization, merger or consolidation the aggregate par or face value of the new stock or securities received is in excess of the aggregate par or face value of the stock or securities exchanged, a like amount in par or face value of the new stock or securities received shall be treated as taking the place of the stock or securities exchanged, and the amount of the excess in par or face value shall be treated as a gain to the extent that the fair market value of the new stock or securities is greater than the cost of the stock or securities exchanged, if acquired on or after January first, nineteen hundred and nineteen, and its fair market price or value as of January first, nineteen hundred and nineteen, if acquired before that date.

(Source: Fed. Rev. Act 1918, § 202-b, 2nd sentence.)

Exchange of stock for other stock of greater par value.-If in the case of any reorganization, merger or consolidation the aggregate par or face value of the new stock or securities received is in excess of the aggregate par or face value of the stock and securities exchanged, income will be realized from the transaction by the recipients of the new stock or securities to an amount limited by $(a)$ the excess of the par or face value of the new stock or securities over the par or face value of the old and $(b)$ the excess of the fair market value of the new stock or securities over the cost or fair market value as of March 1, 1913, of the old. In other words, 
the taxable profit will be $(a)$ or $(b)$, whichever is less. Upon a subsequent sale of the new stock or securities their cost to the taxpayer will be the cost or fair market valie as of March 1, 1913, of the old stock and securities, plus the profit taxed on the exchange. (Art. 1569.)

Readjustment of partnership interests.-When a partner retires from a partnership, or it is dissolved, he realizes a gain or loss measured by the difference between the price received for his interest and the cost to him or (if acquired prior thereto) the fair market value as of March 1, 1913, of his interest in the partnership, including in such cost or value the amount of his share in any undistributed partnership net income earned since February 28, 1913, on which the income tax has been paid. If, however, the partnership distributes its assets in kind and not in cash, the partner realizes no gain or loss until he disposes of the property received on distribution. See article 1566. Whenever a new partner is admitted to a partnership, or any existing partnership is reorganized, the facts as to such change or reorganization should be fully set forth in the next return of income, in order that the Commissioner may determine whether any gain or loss has been realized by any partner. (Art. 1570.)

\section{Use of inventories.}

SEc. 356. Inventory. Whenever in the opinion of the comptroller the use of inventories is necessary in order clearly to determine the income of any taxpayer, inventories shall be taken by such taxpayer upon such basis as the comptroller may prescribe, conforming as nearly as may be to the best accounting practice in the trade or business and most clearly reflecting the income, and conforming so far as may be to the forms and methods prescribed by the United States commissioner of internal revenue under the act of congress known as the revenue act of nineteen hundred and eighteen.

(Source: Fed. Rev. Act 1918, § 203.)

Need of inventories.-In order to reflect the net income correctly, inventories at the beginning and ending of each year are necessary in every case in which the production, purchase or sale of merchandise is an income-producing factor. The inventory should include raw materials and supplies on hand that have been acquired for sale, consumption or use in productive processes, together with all finished or partly finished goods. Title to the merchandise included in the inventory should be vested in the taxpayer and goods merely ordered for future delivery and for which no transfer of title has been effected should be excluded. The inventory should include merchandise sold but not shipped to the customer at the date of the inventory, together with any merchandise out upon consignment, but if such goods have been included in the sales of the taxable year they should 
not be taken in the inventory. It should also include merchandise purchased, although not actually received, to which title has passed to the purchaser. In this regard care should be exercised to take into the accounts all invoices or other charges in respect of merchandise properly included in the inventory, but which is in transit or for other reasons has not been reduced to physical possession. (Reg. 45, Rev. Art. 1581.)

Valuation of inventories.-Inventories should be valued at (a) cost or $(b)$ cost or market whichever is lower. Whichever basis is adopted must be applied to each item and not merely to the total of the inventory; that is, if for instance basis $(b)$ is adopted, the value of each item in the inventory will be measured by market if that is lower than cost, or by cost if that is lower than market. A taxpayer may, regardless of his past practice, adopt the basis of cost or market, whichever is lower, for his 1918 inventory, provided a disclosure of the fact and that it represents a change is made in the return. Thereafter changes can be made only after permission is secured from the Commissioner. But see article 1585 for inventories by dealers in securities. Inventories should be recorded in a legible manner and properly computed and summarized, and should be preserved as a part of the accounting records of the taxpayer. Goods taken in the inventory which have been so intermingled that they can not be identified with specific invoices will be deemed to be the goods most recently purchased. (Art. 1582.)

Inventories at cost.-Cost means:

(1) In the case of merchandise purchased, the invoice price less trade or other discounts except strictly cash discounts approximating a fair interest rate, which may be deducted or not at the option of the taxpayer provided a consistent course is followed. To this net invoice price should be added transportation or other necessary charges incurred in acquiring possession of the goods.

(2) In the case of merchandise produced by the taxpayer, $(a)$ the cost of raw materials and supplies entering into or consumed in connection with the product, $(b)$ expenditures for direct labor, $(c)$ indirect expenses incident to and necessary for the production of the particular article, including in such indirect expenses a reasonable proportion of management expenses, but not including any cost of selling or return on capital whether by way of interest or profit. In any industry in which the usual rules for computation of cost of production are inapplicable, costs may be approximated upon such basis as may be reasonable and in conformity with established trade practice in the particular industry. (Art. 1583.)

Inventories at market.-Market means the current bid price prevailing at the date of the inventory for the particular merchandise, and is applicable to goods purchased and on hand and to basic materials in goods in process of manufacture and in finished goods on hand, exclusive, however, of goods on hand or in process of manufacture for delivery upon firm sales contracts at fixed prices entered into before the date of the inventory. Where no open market quotations are available the taxpayer must use such evidence of a fair market price at the date or dates 
nearest the inventory as may be available to him, such as specific transactions in reasonable volume entered into in good faith, or compensation paid for cancellation of contracts for purchase commitments. The burden of proof will rest upon the taxpayer in each case to satisfy the Commissioner of the correctness of the prices adopted. It is recognized that in the latter part of 1918, by reason among other things of governmental control not having been relinquished, conditions were abnormal and in many commodities there was no such scale of trading as to establish a free market. In such a case, when a market has been established during the succeeding year, a claim may be filed for any loss sustained in accordance with the provisions of section 214 (a) (12) or section 234 (a) (14) of the statute. (Art. 1584.)

Inventories by dealers in securities.-A dealer in securities, who in his books of account regularly inventories unsold securities on hand either (a) at cost or (b) at cost or market value whichever is lower, may make his return upon the basis upon which his accounts are kept; provided that a description of the method employed shall be included in or attached to the return, that all the securities must be inventoried by the same method, and that such method must be adhered to in subsequent years, unless another be authorized by the Commissioner. For the purpose of this rule a dealer in securities is a merchant of securities, whether an individual, partnership or corporation, with an established place of business, regularly engaged in the purchase of securities and their resale to customers, that is, one who as a merchant buys securities and sells them to customers with a view to the gains and profits that may be derived therefrom. If such business is simply a branch of the activities carried on by such person, the securities inventoried as here provided may include only those held for purposes of resale and not for investment. Taxpayers who buy and sell or hold securities for investment or speculation, and not in the course of an established business, and officers of corporations and members of partnerships, who in their individual capacities buy and sell securities, are not dealers in securities within the meaning of this rule. (Art. 1585.)

T. D. 2609, issued under date of December 19, 1917, authorizes dealers in merchandise and dealers in securities to make their income-tax and excess-profits tax returns upon the basis of inventories taken "at cost or at market price, whichever is lower."

The legality of this authorization having been questioned, the matter was referred to the Attorney General, who advises that the general principle at issue is involved in cases pending in the Supreme Court of the United States and that an early decision may be reasonably expected. Pending this decision returns made upon the basis of T. D. 2609 will be tentatively accepted.

If the ruling of the Attorney General should be adverse to the principle enunciated in the Treasury decision referred to, dealers in merchandise or in securities who shall have made returns on the basis of inventories taken at a value other than cost will be required to make 
amended returns upon the basis of inventories taken at cost. In making their returns in the first instance, for the taxable year 1917, dealers in merchandise or in securities will be required to indorse upon or attach to such returns a statement specifying the basis upon which the inventories were taken, whether at cost or market price. (T. D. 2649, Feb. 16, 1918.)

\section{Net income defined.}

SEc. 35\%. Net income defined. The term "net income" means the gross income of a taxpayer less the deductions allowed by this article.

(Source: Fed. Rev. Act 1918, § 212-a.)

Meaning of net income.-The tax imposed by the statute is upon income. In the computation of the tax various classes of income must be considered: (a) Income (in the broad sense), meaning all wealth which flows in to the taxpayer other than as a mere return of capital. It includes the forms of income specifically described as gains and profits, including gains derived from the sale or other disposition of capital assets. It is not limited to cash alone, for the statute recognizes as income-determining factors other items, among which are inventories, accounts receivable, property exhaustion and accounts payable for expenses incurred. See sections 202, 203, 213 and 214 of the statute. (b) Gross income, meaning income (in the broad sense) less income which is by statutory provision or otherwise exempt from the tax imposed by the statute. See section 213 and articles 71-86. (c) Net income, meaning gross income less statutory deductions. The statutory deductions are in general, though not exclusively, expenditures, other than capital expenditures, connected with the production of income. See sections 214 and 215 and the articles thereunder. (d) Net income less credits. See section 216 and articles 301-307. Though taxable net income is wholly a statutory conception it follows, subject to certain modifications as to exemptions and as to some of the deductions, the lines of commercial usage. Subject to these modifications statutory "net income" is commercial "net income." This appears from the fact that ordinarily it is to be computed in accordance with the method of accounting regularly employed in keeping the books of the taxpayer. (Reg. 45, Rev. Art. 21.)

\section{Computation of net income.}

Sec. 358. Computation of net income. 1. The net income shall be computed upon the basis of the taxpayer's annual accounting period (fiscal year or calendar year as the case may be) in accordance with the method of accounting regularly employed in keeping the books of such taxpayer; but if no such method of accounting has been so employed, or if the method employed does not clearly 
reflect the income, the computation shall be made upon such basis and in such manner as in the opinion of the comptroller does clearly reflect the income. If the taxpayer's annual accounting period is other than a fiscal year as defined in this article, or if the taxpayer has no annual accounting period or does not keep books, the net income shall be computed on the basis of the calendar year.

2. If a taxpayer changes his accounting period from fiscal year to calendar year, from calendar year to fiscal year, or from one fiscal year to another, the net income shall, with the approval of the comptroller, be computed on the basis of such new accounting period, subject to the provisions of section three hundred and seventy.

(Source: Fed. Rev. Act 1918, \& 221-b. See also \& 350-4-Definition of taxable year.)

Computation of net income.-Net income must be computed with respect to a fixed period. Usually that period is twelve months and is known as the taxable year. Items of income and of expenditures which as gross income and deductions are elements in the computation of net income need not be in the form of cash. It is sufficient that such items, if otherwise properly included in the computation, can be valued in terms of money. The time as of which any item of gross income or any deduction is to be accounted for must be determined in the light of the fundamental rule that the computation shall be made in such a manner as clearly reflects the taxpayer's income. If the method of accounting regularly employed by him in keeping his books clearly reflects his income, it is to be followed with respect to the time as of which items of gross income and deductions are to be accounted for. If the taxpayer does not regularly employ a method of accounting which clearly reflects his income, the computation shall be made in such manner as in the opinion of the Commissioner clearly reflects it. (Reg. 45, Rev. Art. 22.)

Bases of computation.-Approved standard methods of accounting will ordinarily be regarded as clearly reflecting income. A method of accounting will not, however, be regarded as clearly reflecting income unless all items of gross income and all deductions are treated with reasonable consistency. See section 200 of the statute for definitions of "paid," "paid or accrued," and "paid or incurred." ( $\$ 350-6$ of State law.) All items of gross income shall be included in the gross income for the taxable year in which they are received by the taxpayer, and deductions taken acordingly, unless in order clearly to reflect income such amounts are to be properly accounted for as of a different period. See section 213 (a) of the statute. A taxpayer is deemed to have re- 
ceived items of gross income which have been credited to or set apart for him without restriction. See article 53. On the other hand, appreciation in value of property is not even an accrual of income to a taxpayer prior to the realization of such appreciation through conversion of the property. The return of income shall in every case be made on the basis clearly reflecting the income, including such items of income and deductions as properly would have been included in the return for the preceding taxable year had the present basis been used, but which were not so included, and excluding such items of income and deductions as would have been excluded from the return for the preceding taxable year had the present basis been used, but which were in fact included. A separate statement shall be attached to the return showing in detail all such items and the reasons why they were excluded or included in the return for the preceding taxable year. If in the opinion of the Commissioner the net effect of such items upon the net income for the taxable year indicates that the returns for any previous years did not approximately reflect the true income for such years, amended returns for such years may be required. (Reg. 45, Rev. Art. 23.)

Methods of accounting.-It is recognized that no uniform method of accounting can be prescribed for all taxpayers, and the law contemplates that each taxpayer shall adopt such forms and systems of accounting as are in his judgment best suited to his purpose. Each taxpayer is required by law to make a return of his true income. He must, therefore, maintain such accounting records as will enable him to do so. See section 1305 of the statute and article 1711. Among the essentials are the following:

(1) In all cases in which the production, purchase or sale of merchandise of any kind is an income-producing factor inventories of the merchandise on hand (including finished goods, work in process, raw materials and supplies) should be taken at the beginning and end of the year and used in computing the net income of the year;

(2) Expenditures made during the year should be properly classified as between capital and income, that is to say, that expenditures for items of plant, equipment, etc., which have a useful life extending substantially beyond the year should be charged to a capital account and not to an expense account; and

(3) In any case in which the cost of capital assets is being recovered through deductions for wear and tear, depletion or obsolescence any expenditure (other than ordinary repairs) made to restore the property or prolong its useful life should be charged against the property account or the appropriate reserve and not against current expenses. (Art. 24.)

Accounting period.-The return of a taxpayer is made and his income computed for his taxable year, which means his fiscal year, or the calendar year if he has not established a fiscal year. The term "fiscal year" means an accounting period of twelve months ending on the last day of any month other than December. No fiscal year will, however, be 
recognized unless before its close it was definitely established as an accounting period by the taxpayer and the books of such taxpayer were kept in accordance therewith. The taxable year 1918 is the calendar year 1918 or any fiscal year ending during the calendar year 1918. See section 200 of the statute. A taxpayer having an existing accounting period which is a fiscal year within the meaning of the statute not only needs no permission to make his return on the basis of such a taxable year, but is required to do so, regardless of the former basis of rendering returns. A person having no such fiscal year must make return on the basis of the calendar year. The first return under the present statute of a taxpayer who has heretofore made return on a basis different from his accounting period will necessarily overlap his next previous return. (Art. 25.)

Change in accounting period.-If a taxpayer changes his accounting period, and not merely his taxable year to conform with his existing accounting period, he shall as soon as pussible give to the collector for transmission to the Commissioner written notice of such change and of his reasons therefor. The Commissioner will not approve a change of the basis of computing net income unless such notice is given at a time which is both $(a)$ at least thirty days before the due date of the taxpayer's return on the basis of his existing taxable year and ( $b$ ) at least thirty days before the due date of his return on the basis of the proposed taxable year. If the change in the basis of computing the net income of the taxpayer is approved by the Commissioner, the taxpayer shall thereafter make his returns upon the basis of the new accounting period in accordance with the requirements of section 226 of the statute and his net income shall be computed as therein provided. (Art. 26.)

Returns when accounting period changed. - No return can be made for a period of more than twelve months. A separate return for a fractional part of a year is, therefore, required wherever there is a change, with the approval of the Commissioner, in the basis of computing net income from one taxable year to another taxable year or wherever a taxpayer making his first return of income does so on the basis of a fiscal year. The periods to be covered by such separate returns in the several cases are stated in the statute. The requirements with respect to the filing of a separate return and the payment of tax for_a part of a year are the same as for the filing of a return and the payment of tax for a full taxable year closing at the same time. The tax on net income computed on the basis of the period for which a separate return is made shall be paid thereon at the rate for the calendar year in which such period is included, and the credits for personal exemption and dependents shall be such proportion of the full credits as the number of months in such period bears to twelve months. (Art. 431, Reg. 45 Rev.)

(See also $\S 370$ of State Law, page -, infra.)

\section{Gross income defined: what it includes.}

Sec. 359. Gross income defined. The term "gross income": 
1. Includes gains, profits and income derived from salaries, wages or compensation for personal service, of whatever kind and in whatever form paid, or from professions, vocations, trades, businesses, commerce, or sales, or dealings in property, whether real or personal, growing out of the ownership or use of or interest in such property; also from interest, rent, dividends, securities, or the transaction of any business carried on for gain or profit, or gains or profits and income derived from any source whatever. The amount of all such items shall be included in the gross income for the taxable year in which received by the taxpayer, unless, under the methods of accounting permitted in this article, any such amounts are to be properly accounted for as of a different period; but*

(Source: Fed. Rev. Act 1918, § 213-a. See also § 350-8, supra-Dividends.)

Income accruing prior to March I, 1913.-Property held by the taxpayer on March 1, 1913, is capital. Included in this capital are all claims, whether evidenced by writing or not, and all interest which had accrued thereon before that date. Interest accruing on or after that date is taxable income. Where an interest-bearing claim contracted prior to March 1, 1913, is paid in whole or in part after that date, any gain derived from the conversion of the claim into money is taxable. The amount of such gain is the excess of the proceeds of the claim (both principal and interest), exclusive of any interest accrued since February 28, 1913, already returned as income, over the fair market value of the claim as of March 1, 1913 (both principal and interest then accrued). In the case of an insurance policy its surrender value as of March 1, 1913, may be used as a basis for the purpose of ascertaining the gain derived from the sale or other disposition of such policy. Where services were rendered prior to March 1, 1913, but paid for thereafter, the amount received is taxable income to the extent of the excess of such amount over the fair market value on March 1, 1913, of the principal of the claim and any interest which had then accrued. A claim for the purpose of this article means a right existing unconditionally on March 1, 1913, and then assignable, whether presently payable or not. Interest does not, of course, include dividends on corporate stock. (Art. 87.)

Note: For March 1, 1913, where it occurs in the Federal statute and regulations, read January 1, 1919, in the New York Law.

Compensation for personal services.-Where no determination of compensation is had until the completion of the services, the amount received is income for the calendar year of its determination. Commis-

* Note: See (2) infra for what gross income does not include. 
sions paid salesmen, compensation for services on the basis of a percentage of profits, commissions on insurance premiums, tips, retired pay of federal and other officers, and pensions or retiring allowances paid by the United States or private persons, are income to the recipients; as are also marriage fees, baptismal offerings, sums paid for saying masses for the dead, and other gifts and contributions received by a clergyman, evangelist or religious worker for services rendered. The salaries of federal officers and employees are subject to tax. (Not, however, under the State law.) (Reg. 45, Rev. Art. 32.)

Commissions on insurance premiums include commissions on renewal premiums. (Art. 4, Reg. 33, Rev., Jan. 2, 1918) ; and commission retained by the agent on his own life insurance policy. (T. D. 2137, Jan. $30,1915$.

Special compensation (bonus) when compensation for services rendered, must be included in the personal return of the employee. (T. D. 2152, Feb. 12, 1915.)

Salaries paid by corporations themselves exempt, are subject to income tax. (T. D. 2090, Dec. 14, 1914.)

Services paid on a percentage of net profits is income to employee. (Art. 4, Reg. 33, Jan. 4, 1918.)

Compensation paid other than in cash.-Where services are paid for with something other than money, the fair market value of the thing taken in payment is the amount to be included as income. If the services were rendered at a stipulated price, in the absence of evidence to the contrary such price will be presumed to be the fair value of the compensation received. Compensation paid an employee of a corporation in its stock is to be treated as if the corporation sold the stock for its market value and paid the employee in cash. When living quarters such as camps are furnished to employees for the convenience of the employer, the ratable value need not be added to the cash compensation of the employee, but where a person receives as compensation for services rendered a salary and in addition thereto living quarters, the value to such person of the quarters furnished constitutes income subject to tax. Premiums paid by an employer on life, accident or health policies in favor of his employees as additional compensation of such employees are income to the employees. (Art. 33.)

Compensation paid in notes.-Promissory notes received in payment for services, and not merely as security for such payment, constitute income to the amount of their fair market value. A taxpayer receiving as compensation a note regarded as good for its face value at maturity, but not bearing interest, may properly treat as income as of the time of receipt the fair discounted value of the note at such time. Thus, if it appears that such a note is or could be discounted on a six or seven per cent basis, the recipient may include such note in his gross income to the amount of its face value less discount computed at the prevailing rate for such transactions. If the payments due on a note so accounted for are met as they become due, there should be included as income in re- 
spect of each such payment so much thereof as represents recovery for the discount originally deducted. (Art. 34.)

Gross income from business.-In the case of a manufacturing, merchandising or mining business, "gross income" means the total sales, less the cost of goods sold, plus any income from investments and from incidental or outside operations or sources. In determining the gross income subtractions should not be made for depreciation, depletion, selling expenses or losses, or for items not ordinarily used in computing the cost of goods sold. Gross income includes all amounts received by the taxpayer as allowances for amortization, from whatever source and by whatever name called. The allowance for amortization authorized by the statute must be taken by way of explicit deduction from gross income. (Art. 35.)

Long term contracts.-Persons engaged in contracting operations, who have uncompleted contracts, in some cases perhaps running for periods of several years, will be allowed to prepare their returns so that the gross income will be arrived at on the basis of completed work; that is, on jobs which have been finally completed any and all moneys received in payment will be returned as income for the year in which the work was completed. If the gross income is arrived at by this method, the deduction from gross income should be limited to the expenditures made on account of such completed contracts. Or the percentage of profit from the contract may be estimated on the basis of percentage of completion, in which case the income to be returned each year during the performance of the contract will be computed upon the basis of the expenses incurred on such contract during the year; that is to say, if one-half of the estimated expenses necessary to the full performance of the contract are incurred during one year, one-half of the gross contract price should be returned as income for that year. Upon the completion of a contract if it is found that as a result of such estimate or apportionment the income of any year or years has been overstated or understated, the taxpayer should file amended returns for such year or years. (Art. 36.)

State contracts.-Any profit received from a State or political subdivision thereof by an independent contractor is taxable income. Where warrants are issued by a city, town or other political subdivision of a State, and are accepted by the contractor in payment for public work done, the face value of such warrants must be returned as income. If for any reason the contractor upon conversion of the warrants into cash does not receive and can not recover the full face value of the warrants so returned, he may allowably deduct from gross income for the year in which the warrants are converted into cash any loss sustained. (Art. 37.)

Gross income of farmers.-All gains, profits and income derived from the sale or exchange of farm products, whether produced on the farm or purchased and resold, shall be included in the return of income for the year in which the products were actually marketed and sold, 
unless an inventory is used. In case of the sale of machinery, and of animals purchased as draft or work animals or solely for breeding purposes and not for resale, any excess over the cost thereof reduced by all sums theretofore deducted for depreciation shall be included as gross income in preparing the taxpayer's return. Where farm produce is exchanged for merchandise, groceries or mill products, the market value of the article or product received in exchange is to be returned as income. Rents received in crop shares shall be returned as of the year in which the crop shares are reduced to money or a money equivalent. If a farmer is engaged in producing crops which take more than a year from the time of planting to the time of gathering and disposing, the income therefrom may be computed upon the crop basis; but in any such case the entire cost of producing the crop must be taken as a deduction in the year in which the gross income from the crop is realized. When live stock purchased is sold, its cost is to be deducted from the sales price in ascertaining the amount of gain or profit to be returned for tax purposes. If, however, an inventory is used, the cost price of the article sold must not be taken as an additional deduction in the return of income, as such cost price will be reflected in the inventory. As herein used the term "farm" embraces the farm in the ordinarily accepted sense, and includes stock, dairy, poultry, fruit and truck farms, also plantations, ranches and all land used for farming operations. All individuals, partnerships or corporations that cultivate, operate or manage farms for gain or profit, either as owners or tenants, are designated farmers. A person cultivating or operating a farm for recreation or pleasure, the result of which is a continual loss from year to year, is not regarded as a farmer. A farmer need not include in his return the value of farm produce consumed by himself and family. (T. D. 2665, Mar. 8, 1918, as amended by S. B. C., Minn., 1836, Mar. 18, 1918.) (Art. 38.)

Sale of stock and rights.-When shares of stock in a corporation are sold from lots purchased at different times and at different prices and the identity of the lots can not be determined, the stock sold shall be charged against the earliest purchases of such stock. The excess of the amount realized on the sale over the cost of the stock, or its fair market value as of March 1, 1913, if purchased before that date, will be the profit to be accounted for as income. In the case of stock received as a stock dividend, whether or not paid out of earnings or profits accrued since February 28, 1913, and in the case of stock in respect of which any such dividend was paid, the cost of each share of such stock shall be ascertained as specified in article 1547. Where common stock is received as a bonus with the purchase of preferred stock or bonds, the total purchase price shall be fairly apportioned between the stock and securities purchased for the purpose of determining the portion of the consideration attributable to each class of stock or securities and so representing its cost, but if that should be impracticable in any case, no profit on any subsequent sale of any part of the stock or securities will be realized until out of the proceeds of sales shall have been recovered the total cost. See article 
1565. The entire amount realized from the sale of rights to subscribe for stock is income. (Art. 39.)

Sale of patents and copyrights.-A taxpayer disposing of patents or copyrights by sale should determine the profit or loss arising therefrom by computing the difference between the selling price and the value as of March 1, 1913, if acquired prior to that date, or between the selling price and the cost, if acquired subsequently to that date. The profit or loss thus ascertained should be increased or decreased, as the case may be, by the amounts deducted on account of depreciation of such patents or copyrights since February 28, 1913, or since the date of acquisition if subsequently thereto. (Art. 40.)

Sale of good will.-Any profit or loss resulting from an investment in good will can be taken only when the business, or a part of it, to which the good will attaches is sold, in which case the profit or loss will be determined upon the basis of the cost of the assets, including good will, or their fair market value as of March 1, 1913, if acquired prior thereto. If nothing was paid for good will acquired after February 28, 1913, no deductible loss is possible, although, on the other hand, upon the sale of the business there may be a profit. It is immaterial that good will may never have been carried on the books as an asset, but the burden of proof is on the taxpayer to establish the cost or fair market value on March 1, 1913, of the good will sold. (Art. 41.)

Sale of personal property on installment plan.-Dealers in personal property ordinarily sell either for cash, or on the personal credit of the buyer, or on the installment plan. Occasionally a fourth type of sale is met with, in which the buyer makes an initial payment of such a substantial nature (for example, a payment of more than 25 per cent) that the sale, though involving deferred payments, is not one on the installment plan. In sales on personal credit, and in the substantial payment type just mentioned, obligations of purchasers are to be regarded as the equivalent of cash, but a different rule applies to sales on the installment plan. Dealers in personal property who sell on the installment plan usually adopt one of four ways of protecting themselves in case of default: $(a)$ through an agreement that title is to remain in the seller until the buyer has completely performed his part of the transaction; $(b)$ by a form of contract in which title is conveyed to the purchaser immediately, but subject to a lien for the unpaid portion of the purchase price; (c) by a present transfer of title to the purchaser, who at the same time executes a reconveyance in the form of a chattel mortgage to the seller; or $(d)$ by conveyance to a trustee pending performance of the contract and subject to its provisions. The general purpose and effect being the same in all of these plans, it is desirable that a uniformly applicable rule be established. The rule prescribed is that in the sale or contract for sale of personal property on the installment plan, whether or not title remains in the vendor until the property is fully paid for, the income to be returned by the vendor will be that proportion of each installment payment which the gross profit to be realized when the property is paid for 
bears to the gross contract price. Such income may be ascertained by taking that proportion of the total payments received in the taxable year from installment sales (always including payments received in the taxable year on account of sales effected in earlier years as well as those effected in the taxable year) which the gross profit to be realized on the total installment sales made during the taxable year bears to the gross contract price of all such sales made during the taxable year. Where a change is made to thĩs method of computing net income the taxpayer's balance sheet should be adjusted conformably as of the date when the change is effected. If for any reason the vendee defaults in any of his installment payments and the vendor repossesses the property, the entire amount received on installment payments, less the profit already returned, will be income of the vendor for the year in which the property was repossessed, and the property repossessed must be included in the inventory at its original cost to himself, less proper allowance for damage and use, if any. If the vendor chooses as a matter of consistent practice to treat the obligations of purchasers as the equivalent of cash, such a course is permissible. (Art. 42.)

Sale of real estate in lots. - Where a tract of land is purchased with a view to dividing it into lots or parcels of ground to be sold as such, the entire fair market value as of March 1, 1913, or the cost, if acquired subsequently to that date, shall be equitably apportioned to the several lots or parcels and made a matter of record in the books of the taxpayer, to the end that any gain derived from the sale of any such lots or parcels may be returned as income for the year in which the sale was made. This rule contemplates that there will be a measure of gain or loss in every lot or parcel sold, and not that the capital invested in the entire tract shall be extinguished before any taxable income shall be returned. The sale of each lot or parcel will be treated as a separate transaction and the gain or loss will be accounted for accordingly. (Art. 43.)

Sale of real estate involving deferred payments.-Deferred payment sales of real estate ordinarily fall into two classes when considered with respect to the terms of sale, as follows:

(1) Installment transactions, in which the initial payment is relatively small (generally less than one-fourth of the purchase price) and the deferred payments usually numerous and of small amount. They include $(a)$ sales where there is immediate transfer of title when a small initial payment is made, the seller being protected by a mortgage or other lien as to deferred payments, and $(b)$ agreements of purchase and sale which contemplate that a conveyance is not to be made at the outset, but only after all or a substantial portion of the agreed installments have been paid.

(2) Deferred payment sales not on the installment plan, in which there is a substantial initial payment (ordinarily not less than one-fourth of the purchase price), deferred payments being secured by a mortgage or other lien. Such sales are distinguished from sales on the installment plan 
by the substantial character of the initial payment and also usually by a relatively small number of deferred payments.

In determining how these classes shall be treated in levying the income tax, the question in each case is whether the income to be reported for taxation shall be based only on amounts actually received in a taxing year, or on the entire consideration made up in part of agreements to pay in the future. (Art. 44.)

Sale of real estate on installment plan.-In the two kinds of transactions included in class (1) in the foregoing article, installment obligations assumed by the buyer are not ordinarily to be regarded as the equivalent of cash, and the vendor may report as his income from such transactions in any year that proportion of each payment actually received in that year which the gross profit to be realized when the property is paid for bears to the gross contract price. If the return is made on this basis and the vendor repossesses the property after default by the buyer, retaining the previous payments, the entire amount of such payments, less the profit previously returned, will be income to the vendor and will be so returned for the year in which the property was repossessed, and the property repossessed must be included in the inventory at its original cost to himself (less any depreciation as defined in articles 161 and 162). If the taxpayer chooses as a matter of settled practice consistently followed to treat the obligations of the purchaser as equivalent to cash and to report the profit derived from the entire consideration, cash and deferred payments, as income for the year when the sale is made, this is permissible. If so treated the rule prescribed in article 46 will apply. (Art. 45.)

Deferred payment sales of real estate not on installment plan.-In class (2) in the next to the last article the obligations assumed by the buyer are much better secured because of the margin afforded by the substantial first payment, and experience shows that the greater number of such sales are eventually carried out according to their terms. These obligations for deferred payments are therefore to be regarded as equivalent to cash, and the profit indicated by the entire consideration is taxable income for the year in which the initial payment was made and the obligations assumed. If the buyer defaults and the seller regains title to the land by agreement or process of law, retaining payments previously made, he may deduct from his gross income as a loss in the year of repossession any excess of the amount previously reported as income over the amount actually received, and must include such real estate in his inventory at its original cost to himself (less any depreciation). (Art. 46.)

Annuities and insurance policies.-Annuities paid by religious, charitable and educational corporations under an annuity contract are subject to tax to the extent that the aggregate amount of the payments to the annuitant exceeds any amounts paid by him as consideration for the contract. An annuity charged upon devised land is income taxable to the annuitant, whether paid by the devisee out of the rents of the land or from 
other sources. The devisee is not required to return as taxable income the amount of rent paid to the annuitant, and he is not entitled to deduct from his taxable income any sums paid to the annuitant. Where an insured receives under life insurance, endowment or annuity contracts sums in excess of the premiums paid therefor, such excess is income for the year of its receipt. See article 72 . Distributions on paid-up policies which are made out of earnings of the insurance company subject to tax are in the nature of corporate dividends and are income of an individual only for the purpose of the surtax. (Art. 47.)

Note: There is no surtax under the New York Law, and dividends are taxed to residents as incomes.

Rent and royalties. - When improvements made by a lessee become part of the real estate, the value of such improvements upon the expiration of the existing term of the lease is income to the lessor. In general, sums paid by a tenant for the use of property, although to another than the landlord, are properly to be regarded as rent and constitute income of the landlord. See further article 109. Royalties on patents are income. (Art. 48.)

Rent not paid in money.-Amounts expended by tenants for taxes and necessary repairs under agreement, in addition to a stipulated cash rental, are items of taxable income, and as such should be reported in the return of the landlord. A corresponding amount may be deducted by the landlord. (Art. 4, Reg. 33, Rev., Jan. 2, 1918.)

Board, lodging or other consideration received in lieu of rental is considered income equal in amount to the indebtedness in payment of which it is received, and should be included in any return of annual net income its recipient is required to render under the provisions of the income-tax law. (T. D. 2135, Jan. 23, 1915.)

Compensation for loss.-In the case of property which has been lost or destroyed in whole or in part through fire, storm, shipwreck or other casualty, or where the owner of property has lost or transferred title by reason of the exercise of the power of requisition or eminent domain, including cases where a voluntary transfer or conveyance is induced by reason of the fact that a technical requisition or condemnation proceeding is imminent, the amount received by the owner as compensation for the property may show an excess over the value of the property on March 1, 1913, or over its cost, if it was acquired after that date (after making proper provision in either case for depreciation to the date of the loss, damage or transfer). The transaction is not regarded as completed at this stage, however, if the taxpayer proceeds immediately in good faith to replace the property, or if he makes application to establish a replacement fund as provided in the following article. In such a case the gain, if any, is measured by the excess of the amount received over the amount actually and reasonably expended to replace or restore the property substantially in kind, exclusive of any expenditures for additions or betterments. The new or restored property effects a replacement in kind only to the extent that it serves the same purpose as the property which it replaces without 
added capacity or other element of additional value. Such new or restored property shall not be valued in the accounts of the taxpayer at an amount in excess of the cost or value at March 1, 1913, if acquired before that date (after making proper provision in either case for depreciation to the date of the loss, damage or transfer), of the original property, plus the cost of any actual additions and betterments. If the taxpayer does not elect to replace or restore the property, the transaction will then be deemed to be completed and the income shall be measured by the excess of the amount of the compensation received over the cost of the property or its actual value at March 1, 1913, if acquired before that date (after making proper provision in either case for depreciation to the date of the loss, damage or transfer). Articles 49 and 50 have no application to property which is voluntarily sold or disposed of. (Art. 49.)

Replacement fund for loss.-In any case in which the taxpayer elects to replace or restore the lost, damaged or transferred property, but where it is not practicable to do so immediately, he may obtain permission to establish a replacement fund in his accounts in which the entire amount of the compensation so received shall be held, without deduction for the payment of any mortgage, and pending the disposition thereof the accounting for gain or loss thereupon may be deferred for a reasonable period of time, to be determined by the Commissioner. In such a case the taxpayer should make application to the Commissioner on form 1114 for permission to establish such a replacement fund and in his application should recite all the facts relating to the transaction and undertake that he will proceed as expeditiously as possible to replace or restore such property. The taxpayer will be required to furnish a bond with such surety as the Commissioner may require for an amount not less than the estimated additional income and war profits and excess profits taxes assessable by the United States upon the income so carried to the replacement fund. See section 1320 of the statute. The estimated additional taxes, for the amount of which the claimant is required to furnish security, should be computed at the rates at which the claimant would have been obliged to pay, taking into consideration the remainder of his net income and resolving against him all matters in dispute affecting the amount of the tax. Only surety companies holding certificates of authority from the Secretary of the Treasury as acceptable sureties on federal bonds will be approved as sureties. The application should be executed in triplicate, so that the Commissioner, the applicant and the surety or depositary may each have a copy. (Art. 50.)

Forgiveness of indebtedness.-The cancellation and forgiveness of indebtedness is dependent on the circumstances for its effect. It may amount to a payment of income or to a gift or to a capital transaction. If, for example, an individual performs services for a creditor, who in consideration thereof cancels the debt, income to that amount is realized by the debtor as compensation for his services. If, however, a creditor merely desires to benefit a debtor and without any consideration therefor cancels the debt, the amount of the debt is a gift from the creditor to the debtor 
and need not be included in the latter's gross income. If a stockholder in a corporation which is indebted to him gratuitously forgives the debt, the transaction amounts to a contribution to the capital of the corporation. If, however, a corporation to which a stockholder is indebted forgives the debt, the transaction has the effect of the payment of a dividend. (Art. 51.)

When included in gross income.-Gains, profits and income are to be included in the gross income for the taxable year in which they are received by the taxpayer, unless they are included when they accrue to him in accordance with the approved method of accounting followed by him. See articles 21-24. Lands which are received as compensation for services in one year, the title to which is disputed and in a later year adjudged to be valid, constitute income to the grantee in the former year. On the other hand, a person may sue in one year on a pecuniary claim or for property, but money or property recovered on a judgment therefor rendered in a later year would be income in that year, assuming that it would have been income in the earlier year if then received. This is true of a recovery for patent infringement. Bad debts or accounts charged off because of the fact that they were determined to be worthless, which are subsequently recovered, whether or not by suit, constitute income for the year in which recovered, regardless of the date when the amounts were charged off. See articles 111 and 151. In view of the unusual conditions prevailing at the close of the year 1918 it is recognized that many items of gross income, such as claims for compensation under cancelled contracts, together with claims against contracting departments of the Government for amortization and other matters, while properly constituting gross income for the taxable year 1918 were undecided and not sufficiently definite in amount to be reported in the original return for that year. In every such case the taxpayer should attach to his return a full statement of such pending claims and other matters, and when the correct amount of such items is ascertained an amended return for the taxable year 1918 should be filed. (Art. 52.)

Where the service and payment period is divided by the end of the taxable year, the compensation for the period so divided at the end of the year will be accounted for as income for the year in which payment is actually received. Where the service is compensated by fee, or is of such nature that no part of the fee or compensation becomes due until the completion of the service, the entire amount received should be income to be accounted for as for the year of receipt.

A person having a salary by the year and in addition commissions on sales, the salary to be paid at the time commissions are determined, and the determination of commissions is in the succeeding calendar year, the entire amount of salary and commissions should be accounted for as income of the calendar year of receipt. (Art. 4, Reg. 33, Rev., Jan. 2, 1918.)

Compensation for services as trustees.-If no determination was made of the amount due the trustee of an estate as compensation for his services over a period of years until the trust was terminated, the amount allowed 
him should be returned in full, subject to allowable deductions, as income for the year in which paid; and should not be prorated over the length of tìme during which he served as trustee. (T. D. 2135, Jan. 23, 1915.)

Rent is returnable as income in year received.-This office is in receipt of your letter of February 18, 1915, and in reply thereto you are advised that the amount of rental received from a piece of real property should be included in any personal annual return of net income the landlord may be required to render for the year in which received, and deduction may be claimed on account of any expense incurred in the maintenance of the said property, or its use, for rental purposes, including amounts paid for repairs, insurance, fuel, light and water, and janitor and elevator service, if any, and in addition thereto an amount representing a reasonable allowance for the wear and tear of the property arising from its use for rental púrposes may be claimed as a deduction, but no claim for depreciation should be made on account of any amount of expense of restoring property or making good the exhaustion thereof for which a deduction is claimed elsewhere in the return. (Letter to The Corporation Trust Company signed by Acting Commissioner David A. Gates, and dated February 26, 1915.)

A landlord should include in his return of annual net income the rents actually paid to him within the year; $*^{*} *$ The rent paid on January 5, 1915, for the months of November and December, 1914, belongs to the year 1915 for * * * the purposes of return by the landlord * * * " (Extract from letter to Wm. S. Lare, signed by Deputy Commissioner L. F. Speer, and dated February 9, 1915.)

Accrued interest on bonds purchased between interest dates.-Interest accrued to the time of purchase (advanced by purchaser) is not to be accounted for as income by the purchaser. Only the amount of interest assignable to the portion of the interest period subsequent to the purchase has a status of income for the purposes of return and tax by purchaser.

The amount of accrued interest so advanced by the purchaser is taxable income to be accounted for in the return of the vendor. (Art. 4, Reg. 33, Rev., Jan. 2, 1918.)

Interest coupons exchanged for new bonds.-Coupons from bonds for interest thereon, exchanged for other bonds are held to be the equivalent of payment of the interest coupons and purchase of the new bonds with the cash. The amount of the coupons to be accounted for as income for the calendar year in which the exchange is made. (Art. 4, Reg. 33, Rev., Jan. 2, 1918.)

Scrip payment of interest.-The foregoing holds true for scrip payment of interest [i. e., the scrip is gross income]. (Art. 4, Reg. 33, Rev., Jan. 2, 1918.)

Property acquired by gift.-The value of property acquired by gift is not subject to income tax, but all gains, profits, or income derived therefrom are subject to tax and if the property so acquired is subsequently sold at a price greater than the appraised value at the time the property 
was acquired by gift, the gain in value is held to be income and subject to tax under the provisions of the Federal income tax law. (T. D. 2090, Dec. 14, 1914.)

Legacies.-The general policy of the law and rule of interpretation require that legacies in all cases, unless clearly inconsistent with the intention of the testator, should be held to be vested rather than contingent. Where there is a vested interest the income from such interest, whether distributed or not, is subject to the tax; and when in the hands of fiduciaries they are required to account for and pay the tax thereon. (T. D. 2090, Dec. 14, 1914.)

Interest on bonds received by legatee.-A legatee is required to return as income the full amount of interest received by him on a bond, notwithstanding the fact that a part of the first coupon, payable after he had received it, had been added to the bond and included in the gross estate of the decedent, thereby becoming subject to the estate-tax law. (T. D. 2570, Nov. 6, 1917.)

Income not reduced to possession.-Income which is credited to the account of or set apart for a taxpayer and which may be drawn upon by him at any time is subject to tax for the year during which so credited or set apart, although not then actually reduced to possession. (See also letter to Certified Audit Co. of America, signed by Dep. Com. Speer, dated April 30, 1918.) To constitute receipt in such a case the income must be credited to the taxpayer without any substantial limitation or restriction as to the time or manner of payment or condition upon which payment is to be made. A book entry, if made, should indicate an absolute transfer from one account to another. If the income is not credited, but is set apart, such income must be unqualifiedly subject to the demand of the taxpayer. Where a corporation contingently credits its employees with bonus stock, but the stock is not available to such employees until the termination of five sears of employment, the mere crediting on the books of the corporation does not constitute receipt. The distinction between receipt and accrual must be kept in mind. Income may accrue to the taxpayer and yet not be subject to his demand or capable of being drawn on or against by him. (But see $\S 350$ subd. 6 State Law-Definition of "received."

Examples of constructive receipt.-Where interest coupons have matured, but have not been cashed, such interest payment, though not collected when due and payable, is nevertheless available to the taxpayer and should therefore be included in his gross income for the year during which the coupons matured. This is so if the coupons are exchanged for other property instead of eventually being cashed. Dividends on corporate stock are subject to tax when set apart for the stockholder, although not yet collected by him. See section 201 of the statute and articles 1541-1549. The distributive share of the profits of a partner in a partnership or of a stocktiolder in a personal service corporation is regarded as received. See section 218 of the statute and articles 321-335. Interest credited on sav- 
ings bank deposits, even though the bank nominally have a rule, seldom or never enforced, that it may require so many days' notice in advance of cashing depositors' checks, is income to the depositor when credited. An amount credited to shareholders of a building and loan association, when such credit passes without restriction to the shareholder, has a taxable status as income for the year of the credit. Where the amount of such accumulations does not become available to the shareholder until the maturity of a share, the amount of any share in excess of the aggregate amount paid in by the shareholder is income for the year of the maturity of the share. (Art. 54.)

\section{Gross income defined: does not include.}

2. Does not include the following items which shall be exempt from taxation under this article:

\section{(Source: Fed Rev. 'Act 1918-§ 213-b.)}

What excluded from gross income.-Gross income excludes the items of income specifically exempted by the statute and also certain other kinds of income by statute or fundamental law free from tax. Such tax-free income should not be included in the return of income and need not be mentioned in the return, unless inforination regarding it is specifically called for, as in the case, for example, of interest on municipal bonds. See article 402. The exclusion of such income should not be confused with the reduction of taxable income by the application of allowable deductions. See section 212 of the statute and article 21. (Art. 71.)

\section{Proceeds of life insurance policies.}

(a) The proceeds of life insurance policies and contracts paid upon the death of the insured to individual beneficiaries or to the estate of the insured.

(Source: Fed. Rev. Act 1918-§ 213-b, 1.)

(b) The amount received by the insured as a return of premium or premiums paid by him under life insurance, endowment or annuity contracts, either during the term or at the maturity of the term mentioned in the contract or upon surrender of the contract.

(Source: Fed. Rev. Act 1918-§ 213-b, 2.)

Proceeds of insurance.-(a) Upon the death of an insured the proceeds of his life insurance policies, whether paid to his estate or to individual beneficiaries, directly or in trust, are excluded from the gross income of the beneficiary. See article 541. (b) During his life only so much of the amount received by an insured under life, endowment or annuity contracts as represents a return, without interest, of premiums paid by him therefor is excluded from his gross income. (But where he receives an amount in excess of premiums paid for the insurance, such 
excess has a taxable status and is to be accounted for as for the calendar year of its receipt. (Art. 4, Reg. 33, Rev., Jan. 2, 1918.) (c) Whether he be alive or dead, the amounts received by an insured or his estate or other beneficiaries through accident or health insurance or under workmen's compensation acts as compensation for personal injuries or sickness are excluded from the gross income of the insured, his estate and other beneficiaries. Any damages recovered by suit or agreement on account of such injuries or sickness are similarly excluded from the gross income of the individual injured or sick, if living, or of his estate or other beneficiaries entitled to receive such damages, if dead. See further article 294. Since June 25, 1918, no assessment of any federal tax may be made on any allotments, family allowances, compensation, or death or disability insurance payable under the War Risk Insurance Act of September 2, 1917, as amended, even though the benefit accrued before that date. (Art. 72.)

Dividends paid on life insurance policies that have not matured, whether such dividends are drawn in cash by the insured or applied to the reduction of the annual premium due, are not considered items of taxable income under the law, and should be excluded from a return of income. (T. D. 2137, Jan. 30, 1915.)

Dividends on paid-up policies are in the nature of corporate dividends. (Art. 4, Reg. 33, Rev., Jan. 2, 1918.)

Life insurance annuities shall not be included as income. (Signed by Deputy Commissioner L. F. Speer, and dated Feb. 17, 1914.)

Payment of deferred dividends in so far as they represent portions of actual premiums received are proceeds of insurance policy within the meaning of law." (Letter to R. L. Cox-signed by Speer, dated Mar. 5, 1914.)

\section{Property acquired by gift, etc.}

(c) The value of property acquired by gift, bequest, devise or descent (but the income from such property shall be included in gross income).

(Source: Fed. Rev. Act 1918-§ 213-b, 3.)

Gifts and bequests.-Money and real or personal property received as gifts, or received under a will or under statutes of descent and distribution, are exempt from tax, although the income therefrom derived from investment, sale or otherwise is not. An amount of principal paid under a marriage settlement is a gift. Neither alimony nor an allowance based on a separation agreement is taxable income. (Art. 73.)

Where the monthly salary of an officer or employee is paid for a limited period after his death to his widow in recognition of the services rendered by her husband, no services being rendered by the widow, it is held that such payment is a gratuity and exempt from taxation under the income tax law. Such a payment would not, however, be an allowable deduction 
as an expense of carrying on business in the return of the person, firm, or corporation paying same. (T. D. 2090, Dec. 14, 1914.)

\section{Interest upon obligations of the United States and of New York.}

(d) Interest upon the obligations of the United States or its possessions; or securities issued under the provisions of the federal farm loan act of July seventeen, nineteen hundred and sixteen; or bonds issued by the war finance corporation; or the obligations of the state of New York or of any municipal corporation or political subdivision thereof; or investments upon which the tax provided for in section three hundred and thirty-one of this chapter has heretofore been paid since June first, nineteen hundred and seventeen, during the period of years for which such tax shall have been paid.

(Source: 1st part from Fed. Rev. Act 1918-\$ 213-b, 4-portions in italics are new. The federal law exempts interest upon the obligations of a State, Territory, or any political subdivision thereof. * * * See Comparative Table-ante.)

Interest upon United States obligations.-Although interest upon the obligations of the United States is in general exempt from tax, in the case of such obligations issued after September 1, 1917, which include Treasury certificates of indebtedness, war savings certificates and the liberty bond issues (except the first liberty loan $3 \frac{1 / 2}{2}$ per cent bonds), the interest is exempt from tax only if and to the extent provided in the acts authorizing the issue thereof, as amended and supplemented. Interest credited to postal savings accounts upon moneys deposited in postal savings banks on or before September 1, 1917, is exempt from income tax, while interest credited upon deposits made subsequently to September 1, 1917, is liable to tax. Interest on the first liberty loan $3 \frac{1}{2}$ per cent bonds is entirely exempt from tax, but that absolute exemption does not extend to the bonds of the first liberty loan converted. (Art. 77.)

Liberty bond exemption from normal tax in 1918.-The Second Liberty Bond Act of September 24, 1917, as amended by the Third Liberty Bond Act of April 4, 1918, and by the Fourth Liberty Bond Act of July 9, 1918, provides:

"SEc. 7. That none of the bonds authorized by section one, nor of the certificates authorized by section five, or by section six, of this act, shall bear the circulation privilege. All such bonds and certificates shall be exempt, both as to principal and interest from all taxation now or hereafter imposed by the United States, any State, or any of the possessions of the United States, or by any local taxing authority, except (a) estate or inheritance taxes, and (b) graduated additional income taxes, com- 
monly known as surtaxes, and excess-profits and war-profits taxes, now or hereafter imposed by the United States, upon the income or profits of individuals, partnerships, associations, or corporations. The interest on an amount of such bonds and certificates the principal of which does not exceed in the aggregate $\$ 5,000$, owned by any individual, partnership, association, or corporation, shall be exempt from the taxes provided for in subdivision (b) of this section."

Accordingly, in addition to the interest on first liberty loan $31 \frac{1}{2}$ per cent bonds, which is entirely free from tax, all interest on first liberty loan converted 4 per cent bonds, first liberty loan converted $41 / 1$ per cent bonds, first liberty loan second converted $41 / 1$ per cent bonds, second liberty loan 4 per cent bonds, second liberty loan converted $41 / 4$ per cent bonds, third liberty loan $4 \frac{1}{4}$ per cent bonds, and fourth liberty loan $4 \frac{1}{4}$ per cent bonds, together with all interest on United States certificates of indebtedness and war savings certificates, is exempt from the normal tax. Such interest in excess of the interest on not exceeding $\$ 5,000$ principal amount of such bonds and certificates may, however, be subject to surtax and to the war profits and excess profits tax and may accordingly require to be included in gross income. (Art. 78.)

Dividends and interest from federal land bank and national farm loan association.-As section 26 of the Federal Farm Loan Act of July 17 , 1916, provides that every federal land bank and every national farm loan association, including the căpital and reserve or surplus therein and the income derived therefrom, shall be exempt from taxation, except taxes upon real estate, and that farm loan bonds, with the income therefrom, shall be exempt from taxation, the income derived from dividends on stock of federal land banks and national farm loan associations and from interest on such farm loan bonds is not subject to the income tax. See also section 231 (13) of the statute. (Art. 75.)

Dividends from federal reserve bank.-As section 7 of the Federal Reserve Act of December 23, 1913, provides that federal reserve banks, including the capital stock and surplus therein and the income derived therefrom, shall be exempt from taxation, except taxes upon real estate, such exemption attaches to and follows the income derived from dividends on stock of federal reserve banks in the hands of the stockholders, so that the dividends received on the stock of federal reserve banks are not subject to the income tax. Dividends paid by member banks, however, are treated like dividends of ordinary corporations. (Art. 76.)

Where a municipality purchases a public utility subject to a mortgage the mortgage retains its original character, even though the municipality assumes the mortgage indebtedness and pays the interest thereon. Therefore, the indebtedness secured by such mortgage is not an obligation of the municipality within the meaning of Paragraph $B$ of the income tax law. (T. D. 2090, Dec. 14, 1914.)

Political subdivisions.-The term "political subdivision" denotes any division of the State made by proper authorities thereof acting within their constitutional powers for the purpose of carrying out a portion of those 
functions of the State which by long usage and the inherent necessities of government have always been regarded as public. Political subdivisions of a State, within the meaning of the exemption referred to in Article 83, include special assessment districts so created, such as road, water, sewer, gas, light, reclamation, drainage, irrigation, levee, school, harbor, port improvement and similar districts and divisions of a State." (Art. 84, Reg. 33, Rev., Jàn. 2, 1918, as amended by T. D. 2715, May 20, 1918.)

Returns of income from exempt securities. - Where the entire income of an individual is from tax-exempt bonds and where the amount of income other than that from tax-exempt securities is less than the amount of income for which a return is required, no return of income is to be made. Interest from securities which is exempt from tax under section 4 [Sec. 213] of the Income Tax Law is not to be included in returns of income. (Art. 26, Reg. 33, Rev., Jan. 2, 1918.)

Amounts received through accident insurance, etc.

(e) Any amount received through accident or health insurance or under workmen's compensation acts, as compensation for personal injuries or sickness, plus the amount of any damages received whether by suit or agreement on account of such injuries or sickness, or through the war risk insurance act or any law for the benefit or relief of injured or disabled members of the military or naval forces of the United States.

(Source: Fed. Rev. Act 1918-§ 213-b, 6-Portions in italics new.)

The Attorney General has advised upon the basis of recent decisions of the Supreme Court (Doyle v. Mitchell Brothers Company (247 U. S. 179), decided May 20, last; Lynch v. Hornby, Lynch v. Turrish and Southern Pacific Company v. Lowe, decided June 3, last) and it is accordingly held that the proceeds of an accident insurance policy received by an individual on account of personal injuries sustained by him through accident are not income taxable under the provisions of Title I of the Act of September 8, 1916, as amended by Title XII of the Act of October 3, 1917, and of Title I of the Act of October 3, 1917.

It is held upon similar principles that an amount received by an individual as the result of a suit or compromise for personal injuries sustained by him through accident is not income taxable under the provisions of said Titles.

Such provisions of Treasury Decisions and of Regulations No. 33 (Revised) as are inconsistent herewith are hereby revoked. (T. D. 2747, July 12, 1918.)

Reimbursement of expenses incident to an accident.-Amounts received from a railroad company by way of reimbursement for expenses incident to an accident are not subject to the income tax. (T. D. 2135, Jan. 23, 1915.) 
Accident insurance paid on death of the insured.-The proceeds of accident insurance policies paid upon the death of the person insured to the beneficiaries is to be treated like the proceeds of life insurance policies. (T. D. 2135, Jan. 23, 1915.)

\section{Salaries of United States officials.}

(f) Salaries, wages and other compensation received from the United States of officials or employees thereof, including persons in the military or naval forces of the United States.

(Source: New)

Compensation of soldiers and sailors.-A person of either sex in active service in the military or naval forces of the United States may exclude from gross income his or her compensation received from the United States up to the amount of $\$ 3,500$ in any taxable year, except that this exemption does not apply to compensation received either before or after the present war. The date of the termination of the war for the purpose of the statute will be fixed by proclamation of the President. The military and naval forces of the United States include, among others, army contract surgeons and the individuals named in section 1 of the statute. A person is in active service if he is actually serving in such forces, not necessarily in the field or in the theatre of war, and is not merely on the retired or reserve list. Accordingly, if such a person receives compensation from the United States of $\$ 3,500$ or less and has no other income of an amount sufficient in itself to require him to render a return of income, he need make no return. Members of draft boards are not as such entitled to this exemption. (Art. 86.)

(Note: The State Law sets no maximum limit.)

Income received by officer of religious, charitable, etc., institution.

(g) Income received by any officer of a religious denomination or by any institution, or trust, for moral or mental improvement, religious, bible, tract, charitable, benevolent, fraternal, missionary, hospital, infirmary, educational, scientific, literary, library, patriotic, historical or cemetery purposes, or for the enforcement of laws relating to children or animals, or for two or more of such purposes, if such income be used exclusively for carrying out one or more of such purposes; but nothing herein shall be construed to exempt the fees, stipends, personal earnings or other private income of such officer or trustee.

(Source: New.) 


\section{Gross income: taxpayers other than residents.}

3 . In the case of taxpayers other than residents, gross income includes only the gross income from sources within the state, but shall not include anuuities, interest on bank deposits, interest on bonds, notes or other interest-bearing obligations or dividends from corporations, except to the extent to which the same shall be a part of income from any business, trade, profession or occupation carried on in this state subject to taxation under this article.

(Source: Fed. Rev. Aot, 1918-\$ 213-c-The wording differs slightly.) See note at beginning of this chapter.)

Gross income of non-resident alien individuals.-In the case of nonresident alien individuals "gross income" means only the gross income from sources within the United States. This includes interest on bonds, notes or other interest-bearing obligations of residents, corporate or otherwise, dividends from resident corporations, amounts received representing profits on the manufacture or disposition of goods within the United States, rentals and royalties from property and income from business carried on in the United States, interest on deposits in banks located within the United States, income from capital otherwise invested in the United States, and income from services rendered or labor performed within the United States.

(Art. 91.)

Royalties received by non-resident aliens.-Royalties paid to nonresident aliens under an agreement of purchase of certain patent rights, the payment being based upon the quantity of goods produced by the use of such patents, are held to be income accruing to non-resident aliens by réason of property owned or business carried on within the United States; and

(T. D. 2137, January 30, 1915.)

Income of non-resident alien individuals not subject to tax.-Salaries, wages, commissions and rents paid by domestic business enterprises to non-resident alien employees for services rendered entirely in a foreign country or for property located in a foreign country are not subject to tax as income from a source within the United States. Dividends on stock and interest on notes of corporations organized in the United States, but doing no business and owning no property therein, paid to non-resident alien individuals or corporations, are not subject to the tax. The tax does not apply to charter money or freight payments received by a foreign owner in regard to a vessel operated between the United States and foreign ports, if the person receiving the income maintains no regular agency in the United States and is not doing business in the United States. Compensation received by non-resident alien munitions inspectors and purchäsing agents from foreign governments is not subject to the tax. (Art. 92.) 
Gross income: Subtraction for redemption of trading stamps.Where a taxpayer, for the purpose of promoting his business, issues with sales trading stamps or premium coupons redeemable in merchandise or cash, he should in computing the income from such sales subtract only the amount received or receivable which will be required for the redemption of such part of the total issue of trading stamps or premium coupons issued during the taxable year as will eventually be presented for redemption. This amount will be determined in the light of the experience of the taxpayer in his particular business and of other users engaged in similar businesses. The taxpayer shall file for each of the five preceding years, or such number of these years as stamps or coupons have been issued by him, a statement showing $(a)$ the total issue of stamps during each year, $(b)$ the total stamps redeemed in each year, and $(c)$ the percentage for each year of the stamps redeemed to the stamps issued in such year. A similar statement shall also be presented showing the experience of other users of stamps or coupons whose experience is relied upon by the taxpayer to determine the amount to be subtracted from the proceeds of sales. The Commissioner will examine the basis used in each return, and in any case in which the amount subtracted in respect of such stamps or coupons is found to be excessive an amended return or amended returns will be required. (Art. 88.)

\section{Deductions allowable in computing net income: ordinary and necessary expenses.}

SEc. 360. Deductions. In computing net income there shall be allowed as deductions:

1. All the ordinary and necessary expenses paid or incurred during the taxable year in carrying on any trade or business, including a reasonable allowance for salaries or other compensation for personal services actually rendered, and including rentals or other payments required to be made as a condition to the continued use or possession, for purposes of the trade or business, of property to which the taxpayer has not taken or is not taking title or in which he has no equity.

(Source: Fed. Rev. Act 1918-\$ 214, a-1. For meaning of "paid" and "paid or incurred" see § 350-6.

Business expenses.-Business expenses, whether subtracted from total receipts in computing gross income or deducted from gross income in computing net income, include all items entering into what is ordinarily known as the cost of goods sold, together with selling and management expenses, except such classes of items as are treated in articles 121 to 268. Among the items to be treated as business expenses are material, labor, supplies and repairs in the case of a manufacturer, while a merchant would include 
his purchases of goods bought for resale. In either case the amount to be taken as a deduction in any year should be determined by taking into consideration the inventory at the beginning and end of the year. Other items that may be included as business expenses are reasonable compensation for the services of officers and employees, advertising and other selling expenses, together with insurance premiums against fire, storm, theft, accident or other similar losses in the case of a business, and rental for the use of business property. A taxpayer is entitled to deduct the necessary expenses paid in carrying on his business from his gross income from whatever source. (Art. 101.)

Cost of materials.-Taxpayers carrying materials and supplies on hand should include in expenses the charges for materials and supplies only to the amount that they are actually consumed and used in operation during the year for which the return is made, provided that the cost of such material and supplies has not been taken into account in determining the net income for any previous year. If a taxpayer carries materials or supplies on hand for which no record of consumption is kept or of which physical inventories at the beginning and end of the year are not taken, it will be permissible for the taxpayer to include in his expenses and deduct from gross income the total cost of such supplies and materials as were purchased during the year for which the return is made, provided the net income is clearly reflected by this method. (Art. 102.)

Repairs. - The cost of incidental repairs which neither materially add to the value of the property nor appreciably prolong its life, but keep it in an ordinarily efficient operating condition, may be deducted as expense, provided the plant or property account is not increased by the amount of such expenditures. Repairs in the nature of replacements, to the extent that they arrest deterioration and appreciably prolong the life of the property, should be charged against the depreciation reserve. (Art. 103.)

Professional expenses.-A professional man may claim as deductions the cost of supplies used by him in the practice of his profession, expenses paid in the operation and repair of an automobile used in making professional calls, dues to professional societies and subscriptions to professional journals, the rent paid for office rooms, the expense of the fuel, light, water, telephone, etc., used in such offices, and the hire of office assistants. Amounts expended for books, furniture and professional instruments and equipment of a permanent character are not allowable as deductions. (Art. 104.)

The form or method of fixing compensation is not decisive as to deductibility. While any form of contingent compensation invites scrutiny as possible distribution of earnings of the enterprise, it does not follow that payments on a contingent basis are to be treated fundamentally on any basis different from that applying to compensation at a flat rate. Generally speaking, if contingent compensation is paid pursuant to a free bargain between the enterprise and the individual made before the services are rendered, not influenced by any consideration on the part of the em- 
ployer other than that of securing on fair and advantageous terms the services of the individual, it should be allowed as a deduction even though in the actual working out of the contract it may prove to be greater than the amount which wonld ordinarily be paid.

(b) In the case of excessive payments by individuals or partnerships, the amounts disallowed should ordinarily be treated as partnership shares and would thus be free from the excess-profits tax to the recipient, but, of course, still subject to the income tax, except that payments for property should be treated by the individual or partnership as a capital expenditure and by the recipient as part of the purchase price.

Compensation on whatever basis fixed, representing only the price paid for services pursuant to a fair bargain made in advance between the individual and the business enterprise, is deductible in determining the taxable net income of the enterprise. Payments nominally as compensation for services, which in fact include amounts paid as dividends, waste of corporate assets, payments for property or for anything other than services, are deductible only to an amount not in excess of compensation for like services in similar enterprises.

Compensation greater than that ordinarily paid for like services in similar enterprises must be shown to represent payment for services only. In the case of compensation fixed after services are rendered and not in accordance with any contract or any custom or practice amounting virtually to a contract, reasonableness is ordinarily the controlling test of deductibility. (T. D. 2696, April 10, 1918.)

(3) In any event the allowance for compensation paid may not exceed what is reasonable in all the circumstances. It is in general just to assume that reasonable and true compensation is only such amount as would ordinarily be paid for like services by like enterprises in like circumstances. The circumstances to be taken into consideration are those existing at the date when the contract for services was made, not those existing at the date when the contract is questioned. See article 32. (Art. 105-Reg. 45, Rev.)

Commissions paid to salesmen.-Commissions paid to salesmen as a part of the expense of conducting business are allowable deductions to the payer of the commission. (T. D. 2090, Dec. 14, 1914.)

Commissions paid real estate agents.-A commission paid to a real estate agent for collecting rents and management of property is a legitimate business expense and constitutes an allowable deduction in computing net income. (T. D. 2090, Dec. 14, 1914.)

Allowances to minor children.-The father is legally entitled to the service of his minor children. As a rule, allowances which he gives them, whether said to be in consideration of service or otherwise, are not allowable deductions, in his return of income nor are they income to the children. (Art. 8, Reg. 33, Rev., Jan. 2, 1918.) 
Paying salary to self.-Wages or salary drawn by a taxpayer from his own business are more in the nature of a charge out of profits than a charge against profits. If such could be deducted they would merely be added to his income, the effect of which would be to take money out of one pocket and put it in another. Therefore, no deduction can be claimed. (Question 49, 1918 Income Tax Primer.)

Bonuses to employees.-Gifts or bonuses to employees will constitute allowable deductions from gross income when such payments are made in good faith and as additional compensation for the services actually rendered by the employees, provided such payments, when added to the stipulated salaries, do not exceed a reasonable compensation for the services rendered. Donations made to employees and others, which do not have in them the element of compensation or are in excess of reasonable compensation for services, are considered gratuities and are not deductible from gross income. (Art. 107.)

Bonuses which may be otherwise deductible are not so when left with the company to secure it against loss.-If a corporation pays its employees a salary in the form of weekly stated amounts, together with a certain percentage of the profits, and if such percentage of the profits is in no way based upon interest in the business and makes a total which is no more than a fair compensation, is such payment or percentage of the profits allowably deducted from gross income of the corporation in the event that there is an agreement to the effect that the so-called bonuses are to be left on deposit with the company to secure the company against such losses as may be by contract charged to the employees at a percentage of the profits received under the contract.

In reply, you are informed that under the conditions set out in the foregoing paragraph, the bonuses or percentages of profits "left on deposit with the company to secure it against loss," are not deductible. (Letter to Greenbaum, Wolff \& Ernst, New York, N. Y., signed by Acting Deputy Commissioner S. H. Boyd, and dated November 30, 1917.)

(See also § 359-1, supra-Bonus as taxable income.)

Donations deductible.-Donations made by a corporation for purposes connected with the operation of the property, when limited to charitable institutions, hospitals, or educational institutions, conducted for the benefit of its employees or their dependents, shall be a proper deduction as ordinary and necessary expenses. Such deduction should, however, be reduced by any amount repaid to the corporation by the employees.

Donations which legitimately represent a consideration for a benefit flowing directly to the corporation as an incident of its business are allowable deductions from gross income in ascertaining net income subject to the income tax; for example, a street railway corporation donates a sum of money to an organization intending to hold a convention in the city in which it operates, with the expectation that the holding of such convention will augment its income through a greater number of people using the cars. In such case the donations would be an allowable deduction, the 
reduction to be reduced by any portion of the donation which may be returned to the corporation. (Art. 134, Reg. 33, Rev., Jan. 2, 1918.)

Pensions.-Amounts paid for pensions to retired employees or to their families or others dependent upon them, or on account of injuries received by employees, and lump sum amounts paid as compensation for injuries, are proper deductions as ordinary and necessary expenses. Such deductions are limited to the amount not compensated for by insurance or otherwise. No deduction shall be made for contributions to a pension fund held by the corporation, the amount deductible in such case being the amount actually paid to the employee. When the amount of the salary of an officer or employee is paid for a limited period after his death to his widow or heirs in recognition of the services rendered by the individual, such payments may be deducted. Salaries paid by employers during the continuance of the war to employees who are absent in the military or naval service or are serving the Government in other ways at a nominal compensation, but who intend to return at the conclusion of the war, are allowable deductions. (Art. 108.)

Spending money.-So-called "spending or treating money" actually advanced by corporations to their traveling salesmen to be used by them as a part of the expense incident to selling the product of such corporations, is an allowable deduction in a return of income by such corporation. The deduction of such expenditures is conditioned upon a satisfactory showing that all the allowance claimed as a deduction was actually expended for and was an ordinary and usual expense incurred in selling the product or merchandise of the corporation. (Art. 133, Reg. 33, Rev., Jan. 2, 1918.)

Business insurance.-Premiums paid in advance, covering a period of several years, are to be taken as a deduction on the basis of one of two methods: When the books are kept on a cash basis, the entire amount is deductible in the year in which the premium is paid. Where the books are kept on an accrual basis the premium is to be prorated over the period covered by the insurance. (Art. 8, Reg. 33, Rev., Jan. 2, 1918.)

Reserves for insurance.-Funds set aside by a corporation for insuring its own property are not a proper deduction, but if such funds are set aside, or a reserve therefor is set up, any loss actually sustained and charged to such funds or reserves may be deducted. (Art. 144, Reg. 33, Rev., Jan. 2, 1918.)

Lobbying expenses and campaign contributions.-Sums of money expended for lobbying purposes, the promotion or defeat of legislation, the exploitation of propaganda, and contributions for campaign expenses are held not to be an ordinary and necessary expense in the operation and maintenance of the business of a corporation, and are therefore not deductible from gross income in arriving at the net income upon which the income tax is computed. (Art. 143, Reg. 33, Rev., Jan. 2, 1918.)

Rentals.-Where a leasehold is acquired for a specified sum, the purchaser may take as a deduction in his return an aliquot part of such 
sum each year, based on the number of years the lease has to run. Taxes paid by a tenant to or for a landlord for business property are additional rent and constitute a deductible item to the tenant and taxable income to the landlord, the amount of the tax being deductible by the latter. The cost of erecting buildings or permanent improvements on ground leased by a taxpayer is additional rental and is therefore a proper deduction from gross income, provided such buildings and improvements under the terms of the lease revert to the owner of the ground at the expiration of the lease. In such a case the cost will be prorated according to the number of years constituting the term of the lease. The lessee will not be permitted to deduct from gross income any depreciation with respect to such buildings, but the cost of incidental repairs necessary to keep them in an efficient condition for the purposes of their use may be deducted. If, however, the life of the improvement is less than the life of the lease, depreciation may be taken by the lessee instead of treating the cost as rent. (Art. 109.)

Rent for residential property.-In the case of a professional man who rents a property for residential purposes but receives there clients, patients, or callers in connection with his professional work (the place of business being elsewhere), no part of the rent is deductible as business expense. (Art. 8, Reg. 33, Rev., Jan. 2, 1918.)

Expenses of farmers.-A farmer who operates a farm for profit is entitled to deduct from gross income as necessary expenses all amounts actually expended in the carrying on of the business of farming. The cost of ordinary tools, of short life or small cost, such as hand tools, including shovels, rakes, etc., may be included. The cost of feeding and raising live stock may be treated as an expense deduction, in so far as such cost represents actual outlay, but not including the value of farm produce grown upon the farm or the labor of the taxpayer. Where a farmer is engaged in producing crops which take more than a year from the time of planting to the process of gathering and disposal, expenses deducted may be determined upon the crop basis, and such deductions must be taken in the year in which the gross income from the crop has been realized. If a farm is operated for recreation or pleasure and not on a commercial basis, and if the expenses incurred in connection with the farm are in excess of the receipts therefrom, the entire receipts from the sale of products may be ignored in rendering a return of income, and the expenses incurred, being regarded as personal expenses, will not constitute allowable deductions. The cost of farm machinery and farm buildings represents a capital investment and is not an allowable deduction as an item of expense. Amounts expended in the development of farms, orchards and ranches prior to the time when the productive state is reached may be regarded as investments of capital. The amount expended in purchasing draft or work animals or live stock either for resale or for breeding purposes is regarded as an investment of capital. The purchase price of an automobile, even when wholly used in carrying on farming operations, is not deductible, but it is regarded as an investment of capital. The cost of gasoline, repairs and 
upkeep of an automobile if used wholly in the business of farming is deductible as an expense; if used partly for business purposes and partly for the pleasure or convenience of the taxpayer or his family, such cost may be apportioned according to the extent of the use for purposes of business and pleasure or convenience, and only the proportion of such cost justly attributable to business purposes is deductible as a necessary expense. (Art. 110.)

When charges deductible.-Each year's return, so far as practicable, both as to gross income and deductions therefrom, should be complete in itself, and taxpayers are expected to make every reasonable effort to ascertain the facts necessary to make a correct return. See articles 21-24 and 52. The expenses, liabilities or deficit of one year can not be used to reduce the income of a subsequent year. A person making returns on an accrual basis has the right to deduct all authorized allowances, whether paid in cash or set up as a liability, and it follows that if he does not within any year pay or accrue certain of his expenses, interest, taxes or other charges, and makes no deduction therefor, he can not deduct from the income of the next or any subsequent year any amounts then paid in liquidation of the previous year's liabilities. A loss from theft or embezzlement occurring in one year and discovered in another is deductible only for the year of its occurrence. Any amount paid pursuant to a judgment or otherwise on account of damages for personal injuries, patent infringement or otherwise, is deductible from gross income when the claim is put in judgment or paid, less any amount of such damages as may have been compensated for by insurance or otherwise. If subsequently to its occurrence, however, a taxpayer first ascertains the amount of a loss sustained during a prior taxable year which has not been deducted from gross income, he may render an amended return for such preceding taxable year, including such amount of loss in the deductions from gross income, and may file a claim for refund of the excess tax paid by reason of the failure to deduct such loss in the original return. (Art. 111.)

\section{Deductions allowable: interest paid or accrued.}

2. In the case of a resident of the state such a proportion of the total interest paid or accrued during the taxable year on indebtedness, as the net income of the taxpayer taxable under this article bears to his total income from all sources; or in case of an individual not a resident of the state, the same proportion of interest paid or accrued within the taxable year on indebtedness which the amount of such gross income, as herein defined, bears to the gross amount of his income from all sources within and without the state.

(Source: New, but see Fed. Rev. Act 1918-§ 214,a-2.)

Interest.-Interest paid or accrued within the year on indebtedness may be deducted from gross income. But interest on indebtedness in- 
curred or continued to purchase or carry securities, such as municipal bonds, the interest upon which is exempt from tax, is not deductible. However, this exception does not apply to obligations of the United States issiued after September 24, 1917, which include the liberty bonds of the second and subsequent issues, and interest on indebtedness incurred to purchase such obligations is deductible pursuant to the general rule. See articles 77-80. Interest paid by the taxpayer on a mortgage upon real estate of which he is the legal or equitable owner, even though the taxpayer is not directly liable upon the bond or note secured by such mortgage, may be deducted as interest on his indebtedness. (Art. 121.)

Interest on capital.-Interest calculated as being a charge against income on account of capital or surplus invested in the business, but which does not represent a payment on an interest-bearing obligation, is not an allowable deduction from gross income; that is to say, the interest which the money might earn if otherwise invested is not a deductible charge against income. (Art. 122.)

Interest on indebtedness incurred for the payment of dividendpaying stock is deductible.-Interest upon a note the proceeds of which are used to purchase dividend-paying stock allowable as a deduction. (Letter of inquiry from Harris, Forbes \& Company, New York, N. Y., and telegram of reply thereto signed by Commissioner Daniel C. Roper, and dated Nov. 19, 1917.)

\section{Deductions allowable: taxes.}

3. Taxes other than income taxes paid or accrued within the taxable year imposed, first, by the authority of the United States, or of any of its possessions, or, second, by the authority of any state, or territory, or any county, school district, municipality, or other taxing subdivision of any state or territory, not including those assessed against local benefits of a kind tending to increase the value of the property assessed or, third, by the authority of any foreign government.

\section{(Source: Fed. Rev. Act 1918-§ 214, a-3.)}

Taxes.-Federal taxes (except income, war profits and excess profits taxes), State and local taxes (except taxes assessed against local benefits of a kind tending to increase the value of the property assessed), and taxes imposed by possessions of the United States or by foreign countries (except the amount of income, war profits and excess profits taxes allowed as a credit against the $\operatorname{tax}$ ), are deductible from gross income. See section 222 of the statute and articles $381-384$ as to tax credits. Postage is not a tax. Amounts paid to States under secured debts laws in order to render securities tax exempt are deductible. Automobile license fees are ordinarily taxes. (Art. 131.) 
Federal duties and excise taxes.-Import or tariff duties paid to the proper customs officers, and business, license, privilege, excise and stamp taxes paid to internal revenue collectors, are deductible as taxes imposed by the authority of the United States, provided they are not added to and made a part of the expenses of the business or the cost of articles of merchandise with respect to which they are paid, in which case they can not be separately deducted. (Art. 132.)

Taxes for local benefits.-So-called taxes, more properly assessments, paid for local benefits, such as street, sidewalk and other like improvements, imposed because of and measured by some benefit inuring directly to the property against which the assessment is levied, do not constitute an allowable deduction from gross income. A tax is considered assessed against local benefits when the property subject to the tax is limited to property benefited. Special assessments are not deductible, even though an incidental benefit may inure to the public welfare. The taxes deductible are those levied for the general public welfare by the proper taxing authorities at a like rate against all property in the territory over which such authorities have jurisdiction. ${ }^{*}{ }^{*} *$ When assessments are made for the purpose of maintenance or repair of local benefits, the taxpayer may deduct the assessments paid as an expense incurred in business, if the payment of such assessments is necessary to the conduct of his business. Where the assessments are made for the purpose of constructing local benefits, the payments by the taxpayer are in the nature of capital expenditures and are not deductible. Where assessments are made for the purpose of both construction and maintenance or repairs, the burden is on the taxpayer to show the allocation of the amounts assessed to the different purposes. If the allocation can not be made, none of the amounts so paid is deductible. (Art. 133.)

Inheritance taxes.- State inheritance taxes paid by the executor or administrator of an estate of a deceased person, which are provided by law to be deducted from the respective legacies or distributive shares, are not allowable deductions in computing the net income of such estate subject to tax, even though the will contains a direction to pay inheritance taxes out of the residue. An inheritance tax is upon the transfer of the property and not upon the estate of the decedent or upon the executor or administrator, although the latter is required to pay it. In general, taxes paid or accrued within the year imposed by the authority of any State, or otherwise, are limited to those imposed upon the taxpayer and do not include taxes paid by him on behalf of another, even though he is required by law tơ make such payment. See articles 565 and 566. Since, moreover, the tax is imposed upon the transfer before the property reaches the legatee or distributee, and merely diminishes the capital share of the estate received by him, such tax is not imposed upon the legatee or distributee and is not an allowable deduction from his income. Similarly, federal estate taxes are not deductible. (Art. 134.)

Taxable status of amount refunded by government in one year, representing tax paid for which credit has been taken as a deduction 
in a previous year.-Where a taxpayer receives a refund of taxes improperly assessed and collected (as, e. g., Federal excise taxes), he will not be required to include in his return for 1918 the amount received as refund of taxes erroneously paid in the preceding year. He should, how ever, file an amended return for 1917 and claim a deduction therein for the correct amount of taxes due for that year. The further amount of income tax due for 1917 as a result of the reduction in the item of taxes paid during the year and a letter of explanation should accompany the amended return when it is forwarded the Collector of Internal Revenue. (Letter to The Corporation Trust Company, signed by Commissioner Daniel C. Roper, and dated January 8, 1919.)

\section{Deductions allowable: losses in business or trade.}

4. Losses sustained during the taxable year and not compensated for by insurance or otherwise, if incurred in trade or business.

(Source: Fed. Rev. Act 1918-\$214 a-4. See also $\S 353$, supra, Ascertainment of Gain or Loss; and § 356 , supra, Inventories.)

Losses actually sustained during the year incurred in trade are limited by the language of the act itself.

"In trade," is synonymous with business.

"Business" has been defined as:

"That which occupies and engages the time, attention and labor of any one for the purpose of livelihood, profit, or improvement; that which is his personal concern or interest; employment, regular occupation, but it is not necessary that it should be his sole occupation or employment."

The doing of a single act incidentally or of necessity not pertaining to the particular business of the person doing the same will not be considered engaging in or carrying on the business. (T. D. 1989, June 2, 1914.)

The term "in trade," as used in the law and in Treasury Decision 2005 , is held to mean the trade or trades in which the person making the return is engaged; that is, in which he has invested money otherwise than for the purpose of being employed in isolated transactions, and to which he devotes at least a part of his time and attention. A person may engage in more than one trade and may deduct losses incurred in all of them, provided, that in each trade the above requirements are met. As to losses on stocks, grain, cotton, etc., if these are incurred by a person engaged in trade to which the buying or selling of stocks, etc., are incident as a part of the business, as by a member of a stock, grain, or cotton exchange, such losses may be deducted. A person can be engaged in more than one business, but it must be clearly shown in such cases that he is actually a dealer, or trader, or manufacturer, or whatever the occupation may be, and is actually engaged in one or more lines of recognized businesses before losses ean be claimed with respect to either or more than one line of 
business, and his status as such dealer must be clearly established. (T. D. 2090, Dec. 14, 1914.)

Neither the investment by an individual of money in the stock of a company nor the employment by the company of his services in any official capacity can serve to make the business in which the company was engaged a matter of his individual trade. (T. D. 2135, Jan. 23, 1915.)

Shrinkage in book values._. ${ }^{*} *$ The loss considered here has in it no element of "depreciation" or "allowance for wear and tear," or "compensation from insurance or otherwise." It is to be such loss as is absolute and complete and which has been actually sustained.

Depreciation as an allowable deduction in ascertaining annual net income for the income tax is separately provided for, and is not to be confused with loss. The depreciation provided to be taken as a deduction in a return of income is the value assigned to the deterioration of physical improvements or assets, such as are susceptible of having their value lessened through wear and tear, use or obsolescence.

The depreciation referred to in the income tax law does not relate to evidence of a right or interest in property, and hence, any shrinkage in the value of bonds, stocks and like securities, due to fluctuations in their market value, is not deductible in a return of income as depreciation or loss.

Losses may be sustained by individuals or corporations on personal or real property. * * * (T. D. 2005, July 8, 1914.)

Book values which reflect a shrinkage in the value of assets are not a basis for determining taxable income. (T. D. 2090, Dec. 14, 1914.)

Losses on judgment.-Any amount paid pursuant to judgment or otherwise on account of damages is deductible from gross income to the extent of, and when the amount is actually paid, less any amount of such damages as may have been compensated for by insurance. (Art. 158, Reg. 33, Rev., Jan. 2, 1918.)

(2) A loss is none the less actual because an individual can not divest himself of the possession of worthless stock by sale, but that condition alone does not give the loss in question such a character as appears to the department to have been contemplated by the income-tax law. (T. $D$. 2135, Jan. 23, 1915.)

\section{Deductions allowable: losses, not in business or trade.}

5. Losses sustained during the taxable year and not compensated for by insurance or otherwise, if incurred in any transaction entered into for profit, though not connected with the trade or business; but in the case of a taxpayer other than a resident of the state, only as to such transactions within the state.

(Source: Fed. Rev. Act 1918, \& 214, a-5.) 
Loss-Definition.-The difference between "losses * * * incurred in his business or trade" and losses "in transactions entered into for profit but not connected with his business or trade" is illustrated by the difference between the definitions of "avocation": That which takes one from his regular calling; a minor occupation; and "vocation": The oceupation or pursuit to which one devotes his time or life, a calling. It is possible for a man to give sufficient time, attention, and capital to the pursuit of different lines of business to constitute more than one avenue of "business or trade or employment," his business or trade.

\section{Deductions allowable: losses from fire, etc.}

6. Losses sustained during the taxable year of property not connected with the trade or business (but, in the case of a taxpayer other than a resident, only of property within the state) if arising from fires, storms, shipwrecks, or other casualty or from theft, and not compensated for by insurance or otherwise.

(Source: Fed. Rev. Act 1918, \& 214, a-6.)

Losses.-Losses sustained during the taxable year and not compensated for by insurance or otherwise are fully deductible (except by non-resident aliens) if $(a)$ incurred in the taxpayer's trade or business, or $(b)$ incurred in any transaction entered into for profit, or $(c)$ arising from fires, storms, shipwreck or other casualty, or from theft. They must usually be evidenced by closed and completed transactions. In the case of the sale of assets the loss will be the difference between the cost thereof, less depreciation sustained since acquisition, or the fair market value as of March 1, 1913, if acquired before that date, less depreciation since sustained, and the price at which they were disposed of. See section 202 of the statute and articles $39-46$ and 1561. When the loss is claimed through the destruction of property by fire, flood or other casualty, the amount deductible will be the difference between the cost of the property or its fair market value as of March 1, 1913, and the salvage value thereof, after deducting from the cost or value as of Mareh 1, 1913, the amount, if any, which has been or should have been set aside and deducted in the current year and previous years from gross income on account of depreciation and which has not been paid out in making good the depreciation sustained. But the loss should be reduced by the amount of any insurance or other compensation received. See articles 49 and 50. A loss in the sale of an individual's residence is not deductible. Losses in illegal transactions are not deductible. (Art. 141.)

Voluntary removal of buildings.-Loss due to the voluntary removal or demolition of old buildings, the scrapping of old machinery, equipment, etc., incident to renewals and replacements will be deductible from gross income in a sum representing the difference between the cost of such property demolished or scrapped and the amount of a reasonable allowance for the depreciation which the property had undergone prior to its demolition 
or scrapping; that is to say, the deductible loss is only so much of the original cost of the property, less salvage, as would have remained unextinguished had a reasonable allowance been charged off for depreciation during each year prior to its destruction. When a taxpayer buys real estate upon which is located a building which he proceeds to raze with a view to erecting thercon another building, it will be considered that the taxpayer has sustained no deductible loss by reason of the demolition of the old building, and no deductible expense on account of the cost of such removal, the value of the real estate, exclusive of old improvements, being presumably equal to the purchase price of the land and building plus the cost of removing the useless building. (Art. 142.)

Loss of useful value.-When through some change in business conditions the usefulness in the business of some or all of the capital assets is suddenly terminated, so that the taxpayer discontinues the business or discards such assets permanently from use in the business, he may claim as a loss for the year in which he takes such action the difference between the cost or the fair market value as of March 1, 1913, of any asset so discarded (less any depreciation allowances) and its salvage value remaining. This exception to the rule requiring a sale or other disposition of property in order to establish a loss requires proof of some unforeseen cause by reason of which the property must be prematurely discarded, as, for example, where machinery or other property must be replaced by a new invention, or where an increase in the cost of or other change in the manufacture of any product makes it necessary to abandon such manufacture, to which special machinery is exclusively devoted, or where new legislation directly or indirectly makes the continued profitable use of the property impossible. This exception does not extend to a case where the useful life of property terminates solely as a result of those gradual processes for which depreciation allowances are authorized. It does not apply to inventories or to other than capital assets. The exception applies to buildings only when they are permanently abandoned or permanently devoted to a radically different use, and to machinery only when its use as such is permanently abandoned. Any loss to be deductible under this exception must be charged off on the books and fully explained in returns of income. (Art. 143.)

Shrinkage in securities and stocks.-A person possessing securities, such as stocks and bonds, can not deduct from gross income any amount claimed as a loss on account of the shrinkage in value of such securities through fluctuation of the market or otherwise. The loss allowable in such cases is that actually suffered when the securities mature or are disposed of. See, however, article 154. In the case of banks or other corporations which are subject to supervision by State or federal authorities, and which in obedience to the orders of such supervisory officers charge off as losses amounts representing an alleged shrinkage in the value of property, the amounts so charged off do not constitute allowable deductions. The foregoing applies only to owners and investors, and not to dealers in securities, as to whom see article 1585. However, if stock 
of a corporation becomes worthless, its cost or its fair market value as of March 1, 1913, if acquired prior thereto, may be deducted by the owner in the taxable year in which the stock was ascertained to be worthless and charged off, provided a satisfactory showing of its worthlessness be made as in the case of bad debts. (Art. 144.)

Losses of farmers.-Losses incurred in the operation of farms as business enterprises are deductible from gross income. If farm products are held for favorable markets, no deduction on account of shrinkage in weight or physical value or by reason of deterioration in storage shall be allowed. The total loss by frost, storm, flood or fire of a prospective crop, or of a crop which has not been sold, is not a deductible loss in computing net income. A farmer engaged in raising and selling stock, cattle, sheep, horses, etc., is not entitled to claim as a loss the value of animals that perish from among those animals that were raised on the farm. If live stock has been purchased for any purpose, and afterwards dies from disease, exposure or injury, or is killed by order of the authorities of a State or the United States, the actual purchase price of such stock, less any depreciation which may have been previously claimed with respect to such perished live stock, and less also any insurance or indemnity recovered, may be deducted as a loss. The actual cost of other property, less depreciation already allowed, destroyed by order of the authorities of a State or of the United States may in like manner be claimed as a loss; but if reimbursement is made by a State or the United States in whole or in part on account of stock killed or property destroyed, the amount received shall be reported as income for the year in which reimbursement is made. In determining the cost of stock for the purpose of ascertaining the deductible loss there shall be taken into account only the purchase price, and not the cost of any feed, pasturage or care which has been deducted as an expense of operation. If gross income is ascertained by inventories, no deduction can be made for live stock or products lost during the year, whether purchased for resale or produced on the farm, as such losses will be reflected in the inventory by reducing the amount of live stock or products on hand at the close of the year. If an individual owns and operates a farm, in addition to being engaged in another trade, business or calling, and sustains a loss from such operation of the farm, then the amount of loss sustained may be deducted from gross income received from all sources, provided the farm is not operated for recreation or pleasure. (Art. 145.)

\section{Deductions allowable: bad debts.}

7. Debts ascertained to be worthless and charged off within the taxable year.

(Source: Fed. Rev Act 1918, § 214, a-7.)

Bad debts.-An account merely written down or a debt recognized as worthless prior to the beginning of the taxable year is not deductible. Where all the surrounding and attendant circumstances indicate that a 
debt is worthless and uncollectible and that legal action to enforce payment would in all probability not result in the satisfaction of execution on a judgment, a showing of these facts will be sufficient evidence of the worthlessness of the debt for the purpose of deduction. Bankruptcy may or may not be an indication of the worthlessness of a debt, and actual determination of worthlessness in such a case is sometimes possible before and at other times only when a settlement in bankruptcy shall have been had. Where a taxpayer ascertained a debt to be worthless and charged it off in one year, the mere fact that bankruptcy proceedings instituted against the debtor are terminated in a later year confirming the conclusion that the debt is worthless will not authorize shifting the deduction to such later year. In the case of debts existing prior to March 1 , 1913, only their value on that date may be deducted upon subsequently ascertaining them to be worthless. See article 52. If a taxpayer computes his income upon the basis of valuing his notes or accounts receivable at their fair market value when received, which may be less than their face value, the amount deductible for bad debts in any case is limited to such original valuation. (Art. 15l.)

Examples of bad debts.-Worthless debts arising from unpaid wages, salaries, rents and similar items of taxable income will not be allowed as a deduction unless the income such items represent has been included in the return of income for the year in which the deduction as a bad debt is sought to be made or in a previous year. Only the difference between the amount received in distribution of the assets of a bankrupt and the amount of the claim may be deducted as a bad debt. The difference between the amount received by a creditor of a decedent in distribution of the assets of the decedent's estate and the amount of his claim may be considered a worthless debt. A purchaser of accounts receivable which can not be collected and are consequently charged off the books as bad debts is entitled to deduct them, the amount of deduction to be based upon the price he paid for them and not upon their face value. (Art. 152.)

Worthless mortgage debt.-Where under foreclosure a mortgagee buys in the mortgaged property and credits the indebtedness with the purchase price, the difference between the purchase price and the indebtedness will not be allowable as a deduction for a bad debt, for the property which was security for the debt stands in the place of the debt. The determination of loss in such a situation is deferred until the property is disposed of, except where a purchase money mortgage is foreclosed by the rendor of the property. See article 46 . Only where a purchaser for less than the debt is another than the mortgagee may the difference between the debt and the net proceeds from the sale be deducted as a bad debt. (Art. 153.)

Loss must be definite.-In the absence of legal proceedings to determine the collectibility of a debt or account, the question of whether or not it is an asset without value will depend largely upon the judgment of the creditor. 
Compromise.-Where an indebtedness is claimed and contested and a settlement is had by way of compromise whereby an amount, less than the debt claimed, is accepted in full payment and satisfaction of the debt, the difference between the amount paid and that claimed is not allowable as a deduction for bad debts. Where the settlement in compromise consists of a promise to pay an amount less than the debt claimed, the amount promised to be paid forms the basis of a new transaction, and upon failure to make good this promise the question will arise as to the deductibility of the new amount only. (Art. 8, Reg. 33, Rev., Jan. 2, 1918.)

Worthless securities.-Where bonds purchased before March 1, 1913, depreciated in value between the date of purchase and that date, and were in a later year ascertained to be worthless and charged off, the owner is entitled to a deduction in that year equal to the value of the bonds on March 1, 1913. Bonds purchased since February 28, 1913, when ascertained to be worthless, may be treated as bad debts to the amount actually paid for them, but not exceeding their amortized value if purchased at a premium. Bonds of an insolvent corporation secured only by a mortgage from which on foreclosure nothing is realized for the bondholders are regarded as ascertained to be worthless not later than the year of the foreclosure sale, and no deduction for a bad debt is allowable in computing a bondholder's income for a subsequent year. To authorize a deduction for a bad debt on account of notes held prior to March 1, 1913, their value on that date must be estàblished. (Art. 154.)

\section{Deductions allowable: depreciation.}

8. A reasonable allowance for the exhaustion, wear and tear of property used in the trade or business, including a reasonable allowance for obsolescence.

(Source: Fed. Rev. Act 1918, § 214, a-8.)

Depreciation.-A reasonable allowance for the exhaustion, wear and tear and obsolescence of property used in the trade or business may be deducted from gross income. For convenience such an allowance will usually be referred to as covering depreciation, excluding from the term any idea of a mere reduction in market value not resulting from exhaustion, wear and tear or obsolescence. The proper allowance for such depreciation of any property used in the trade or business is that amount which should be set aside for the taxable year in accordance with a consistent plan by which the aggregate of such amounts for the useful life of the property in the business will suffice, with the salvage value, at the end of such useful life to provide in place of the property its cost, or its value as of March 1, 1913, if acquired by the taxpayer before that date. (Art. 161.)

Depreciable property.-The necessity for a depreciation allowance arises from the fact that certain property used in the business gradually 
approaches a point where its usefulness is exhausted. The allowance should be confined to property of this nature. In the case of tangible property, it applies to that which is subject to wear and tear, to decay or decline from natural causes, to exhaustion, and to obsolescence due to the normal progress of the art or to becoming inadequate to the growing needs of the business. It does not apply to inventories or to stock in trade; nor to land apart from the improvements or physical development added to it. It does not apply to bodies of minerals which through the process of removal suffer depletion, other provision for this being made in the statute. See articles 201-233. Property kept in repair may, nevertheless, be the subject of a depreciation allowance. See article 103. The deduction of an allowance for depreciation is limited to property used in the taxpayer's trade or business. No such allowance may be made in respect of automobiles or other vehicles used chiefly for pleasure, a building used by the taxpayer solely as his residence, nor in respect of furniture or furnishings therein, personal effects, or clothing; but properties and costumes used exclusively in a business, such as a theatrical business, may be the subject of a depreciation allowance. (Art. 162.)

Depreciation of intangible property.-Intangibles, the use of which in the trade or business is definitely limited in duration, may be the subject of a depreciation allowance. Examples are patents and copy. rights, licenses and franchises: Intangibles, the use of which in the business or trade is not so limited, will not usually be a proper subject of such an allowance. If, however, an intangible asset acquired through capital outlay is known from experience to be of value in the business for only a limited period, the length of which can be estimated from experience with reasonable certainty, such intangible asset may be the subject of a depreciation allowance, provided the facts are fully shown in the return or prior thereto to the satisfaction of the Commissioner. There can be no such allowance in respect of good will, trade names, trademarks, trade brands, secret formulæ or processes. (Art. 163.)

Capital sum recoverable through depreciation allowances.-The capital sum to be replaced by depreciation allowances is the cost of the property in respect of which the allowance is made, except that in the case of property acquired by the taxpayer prior to March 1, 1913, the capital sum to be replaced is the fair market value of the property as of that date. In the absence of proof to the contrary, it will be assumed that such value as of March 1,1913 , is the cost of the property less depreciation up to that date. To this sum should be added from time to time the cost of improvements, additions and betterments, the cost of which is not deducted as an expense in the taxpayer's return, and from it should be deducted from time to time the amount of any definite loss or damage sustained by the property through casualty, as distinguished from the gradual exhaustion of its utility which is the basis of the depreciation allowance. In the case of the acquisition after March 1, 1913, of a combination of depreciable and nondepreciable property for a lump price, as, for example, land and buildings, the capital sum to be re- 
placed is limited to that part of the lump price which represents the value of the depreciable property at the time of such acquisition. (Art. 164.)

Method of computing depreciation allowance.-The capital sum to be 'replaced should be charged off over the useful life of the property either in equal annual installments or in accordance with any other recognized trade practice, such as an apportionment of the capital sum over units of production. Whatever plan or method of apportionment is adopted must be reasonable and should be described in the return. (Art. 165.)

Modification of method of computing depreciation.-If it develops that the useful life of the property has been underestimated, the plan of computing depreciation should be modified and the balance of the cost of the property, or its fair market value as of March 1, 1913, not already provided for through a depreciation reserve or deducted from book value, should be spread over the estimated remaining life of the property. A taxpayer who in computing depreciation allowances in returns for years prior to 1918 has not taken ordinary obsolescence into consideration may for the year 1918 and subsequent years revise the estimate of the useful life of any property so as to allow for such future obsolescence as may be expected from experience to result from the normal progress of the art. No modification of the method should be made on account of changes in the market value of the property from time to time, such as, on the one hand, loss in rental value of buildings due to deterioration of the neighborhood, or, on the other, appreciation due to increased demand. The conditions affecting such market values should be taken into consideration only so far as they affect the estimate of the useful life of the property. (Art. 166.)

Depreciation of patent or copyright.-In computing a depreciation allowance in the case of a patent or copyright, the capital sum to be replaced is the cost (not already deducted as current expense) of the patent or copyright or its fair market value as of March 1, 1913, if acquired prior thereto. The allowance should be computed by an apportionment of the cost of the patent or copyright or of its fair market value as of March 1, 1913, over the life of the patent or copyright since its grant, or since its acquisition by the taxpayer, or since March 1, 1913, as the case may be. If the patent or copyright was acquired from the Government, its cost consists of the various Government fees, cost of drawings, experimental models, attorney's fees, etc., actually paid. If a corporation purchased a patent and paid for it in stock or securities, its cost is the fair market value of the stock or securities at the time of the purchase. Depreciation of a patent can be taken on the basis of the fair market value as of March 1, 1913, only when affirmative and satisfactory evidence of such value is offered. Such evidence should whenever practicable be submitted with the return. If the patent becomes obsolete prior to its expiration such proportion of the amount on which its depreciation may 
be based as the number of years of its remaining life bears to the whole number of years intervening between the date when it was acquired and the date when it legally expires may be deducted, if permission so to do is specifically secured from the Commissioner. Owing to the difficulty of allocating to a particular year the obsolescence of a patent, such permission will be granted only if affirmative and satisfactory evidence that the obsolescence occurred in the year for which the return is made is submitted to the Commissioner. The fact that depreciation has not been taken in prior years does not entitle the taxpayer to deduct in any taxable year a greater amount for depreciation than would otherwise be allowable. (Art. 167.)

Depreciation of drawings and models.-A taxpayer who has incurred expenses in his business for designs, drawings, patterns, models, or work of an experimental nature calculated to result in improvement of his facilities or his product, may at his option deduct such expenses from gross income for the taxable year in which they are incurred or treat such articles as a capital asset to the extent of the amount so expended. In the latter ease, if the period of usefulness of any such asset may be estimated from experience with reasonable accuracy, it may be the subject of depreciation allowances spread over such estimated period of usefulness. The facts must be fully shown in the return or prior thereto to the satisfaction of the Commissioner. Except for such depreciation allowances no deduction shall be made by the taxpayer against any sum so set up as an asset excēpt on the sale or other disposition of such assets at a loss or on proof of a total loss thereof. (Art. 168.)

Charging off depreciation.-A depreciation allowance, in order to constitute an allowable deduction from gross income, must be charged off. The particular manner in which it shall be charged off is not material, except that the amount measuring a reasonable allowance for depreciation must be either deducted directly from the book value of the assets or preferably credited to a depreciation reserve account, which must be reflected in the annual balance sheet. The allowances should be computed and charged off with express reference to specific items, units or groups of property, each item or unit being considered separately or specifically included in a group with others to which the same factors apply. The taxpayer should keep such records as to each item or unit of depreciable property as will permit the ready verification of the factors used in computing the allowance for each year for each item, unit or group. (Art. 169.)

Closing depreciation account.-If the use of any property in the business is permanently discontinued, although no sale or other disposition of the property has taken place, a determination of any gain or loss may be made; but any deduction in respect of any loss thereon must be disclosed in the taxpayer's return for the year in which the determination is made and a full statement of the facts and the basis upon which the computation is calculated must be attached to the return. Upon a sale or other 
disposition of the property, the consideration received shall be compared with the amount of the estimated salvage value used in computing the gain or loss as above provided, and the amount of the difference shall be treated as a gain or loss, as the case may be, of the year in which the sale or other disposition was made. (Art. 170.)

Depreciation in the case of farmers.-A reasonable allowance for depreciation may be claimed on farm buildings (other than a dwelling occupied by the owner), farm machinery and other physical property, including live stock purchased for draft, dairy or breeding purposes, but no claim for depreciation on live stock raised, or purchased for resale, will be allowed. Live stock purchased for draft, breeding or dairy purposes, or for any purpose other than resale, may be included in the inventory for each year at a figure which will reflect the reduction in value estimated to have occurred during the year through increase of age or other causes. Such a reduction in value should be based on the cost and estimated life of the live stock. If an inventory is not used, a reasonable allowance for depreciation may be claimed based upon the cost of draft and work animals and animals kept solely for breeding purposes and not for resale. (Art. 171.)

Rate for computing.-No definite rate has been fixed by which an allowable deduction on account of depreciation in the value of any class of property subject to wear and tear is to be computed, but it is contemplated that this allowance shall be computed upon the basis of the cost of the property and the probable number of years constituting its life. The deduction to be allowed relates solely to loss due to use, wear and tear, and the matter of obsolescence is not relevant, inasmuch as when the property becomes obsolete a deduction for the loss sustained thereby, representing the difference between the cost and the amount of depreciation previously charged off or which should have been charged off in prior years, will be allowed. (See Arts. 178 and 179.) (Art. 162, Reg. 33, Rev., Jan. 2, 1918.)

Rate based upon life.-In the case of buildings the deduction on account of depreciation shall not include any allowance for an estimated loss due to lessening of rental value, nor shall the computation of the deduction be influenced by the changed environment after a period of years, nor by its lack of adaptability to the use originally intended nor to any other outside influence affecting its value but an allowable depreciation shall be determined solely upon the estimated life of such buildings after making due allowance for ordinary repairs, the cost of which may be deducted as expenses for maintenance and operation. (Art. 162, Reg. 33, Rev., Jan. 2, 1918.).

The appended charge of the court to the jury in the District Court of the United States for the Southern District of New York, in the case of Hyman Cohen v. John Z. Lowe, collector, is published for the information of internal-revenue officers and others concerned. (T. D. 2343, June 14, 1916.) 


\section{Summary of charge.}

1. Depreciation Depends on Life of Building.

The physical loss or deterioration a building suffers during the tax year depends on the life of the building; how many years it would remain so as to be habitable for general purposes for which it was constructed.

2. Yearly Deductions.

The average amount of deduction each year covers the annual percentage.

3. Deductions for Improvements.

When allowance is made for depreciation of a building no deduction shall be allowed for expense of restoring the building or making good the exhaustion thereof.

4. Exhaustion, Wear and Tear.

The words "exhaustion, wear and tear" of a building contemplate only depreciation of the physical property itself, irrespective of its adaptability to the use originally intended or the changing environments.

5. Decrease in Rental Value.

No allowance can be made for depreciation by reason of decrease in rental value nor in value arising from lack of modern improvements.

\section{Opinion of the Court in the Above Case.} [234 Fed. 474.]

The plaintiff was allowed 3 per cent for depreciation on an apartment house owned by him. The burden is on him to show that the depreciation so allowed was too small. This allowance is for the wear and tear suffered by the building during the tax year, which means the physical deterioration that the building suffered during that period. It does not take into account depreciation in value due to a loss in rental value because of the construction of more modern buildings with improved facilities or due to a change in the neighborhood. It is to be based upon the life of the building in the sense of the number of years the building would remain in a condition to be habitable for the use for which it was constructed and used; and which was in the instant case for an apartment house, and not merely the number of years it would stand without being condemned and torn down. The annual depreciation would be an amount represented by a fraction having one (tax year) for the numerator and the number of years, representing the ascertained life of the building, as the denominator. This assumes that there would be an average deterioration suffered each year during the life of the building, and that the plaintiff would keep the building in good repair during the life of it. This the law exacts of him. Upon these assumptions, and giving this meaning to the words of the statute, "a reasonable allowance for the exhaustion, wear and tear of the property, arising out of its use or employment in the business," the amount of the deduction allowed by the Government to the plaintiff on this áccount is deemed to be reasonable. (234 Fed. 474.) 
While each taxpayer must determine the probable lifetime of his property without regard to the following figures, it has been estimated that the average usable lifetime of a frame building is 25 years, a brick building 35 years; a stone building or steel and concrete building, 50 to 100 years. The estimated lifetime of ordinary machinery is ten years, that of automobiles used for business or farm purposes and farm tractors, four to five years.

If a taxpayer wishes to claim the full amount of depreciation estimated to have occurred in the value of a building, or other property, used for business or trade purposes, he may do so, but this precludes his claiming a deduction to cover any amount expended during the same year in making repairs. If he wishes to claim a deduction on account of repairs, their cost must be deducted from the full amount of depreciation, and the balance may then be claimed as a deduction under the heading of Depreciation, that is, if the taxpayer expends $\$ 100$ in making repairs to a building which will depreciate in value $\$ 200$ during the calendar year, he may claim $\$ 100$ as business expense and $\$ 100$ as depreciation, or he may claim $\$ 200$ as depreciation and nothing for repairs. In short, the aggregate deductions claimed on account of repairs and depreciation must not exceed the full amount of depreciation estimated to have occurred.

Use of depreciation reserve.-Depreciation set up on the books and deducted from gross income can not be used for any purposes other than in making good the loss sustained by reason of the wear and tear of the property with respect to which it is claimed.

If, however, an investment is made in extensions, additions, or betterments of the company's own property, representing a part or the whole of the credit balance of the depreciation reserve account, such investment will not be considered a misuse or diversion of the depreciation deduction otherwise allowable. (Art. 164, Reg. 33, Rev., Jan. 2, 1918.)

Depreciation allowance when plant is regularly operated in two. shifts or continuously.-It is obvious that in a case where machinery and equipment are operated more than the usual number of working hours, a greater rate of depreciation would be applicable in determining the actual loss sustained by a corporation due to depreciation than would be the case in the event that the machinery was only operated eight or nine hours as the normal time. *** (Letter to E. G. Shorrock \& Co., Seattle, Wash., signed by Deputy Commissioner L. F. Speer, and dated July 12, 1918.)

Unearned increment.-Unearned increment will not be considered in fixing the value on which depreciation shall be based. (Art. 146, Reg. 33, Jan. 5, 1914.)

\section{Deductions allowable: depletion of mines, wells, timber.}

9. In the case of mines, oil and gas wells, other natural deposits and timber, a reasonable allowance for depletion and for deprecia- 
tion of improvements, according to the peculiar conditions in each case, based upon cost including cost of development not otherwise deducted; provided, that in the case of such properties acquired prior to January first, nineteen hundred and nineteen, the fair market value of the property (or the taxpayer's interest therein) on that date shall be taken in lieu of cost up to that date; provided, further, that in the case of mines, oil and gas wells, discovered by the taxpayer on or after January first, nineteen hundred and nineteen, and not acquired as the result of a purchase of a proven tract or lease, where the fair market value of the property is materially disproportionate to the cost, the depletion allowance shall be based upon the fair market value of the property at the date of the discovery or within thirty days thereafter; such reasonable allowance in all the above cases to be made under rules and regulations to be prescribed by the comptroller. In the case of leases the deductions allowed by this paragraph shall be equitably apportioned between the lessor and lessee.

(Source: Fed. Rev. Act 1918, § 214, a-10.)

Depletion of mines, oil and gas wells.-A reasonable deduction from gross income for the depletion of natural deposits and for the depreciation of improvements is permitted, based $(a)$ upon cost, if acquired after February 28, 1913, or (b) upon the fair market value as of March 1,1913 , if acquired prior thereto, or $(c)$ upon the fair market value within 30 days after the date of discovery in the case of mines, oil and gas wells discovered by the taxpayer after February 28, 1913, where the fair market value is materially disproportionate to the cost. The essence of this provision is that the owner of such property, whether it be a leasehold or freehold, shall secure through an aggregate of annual depletion and depreciation deductions a return of the amount of capital invested by him in the property, or in lieu thereof an amount equal to the fair market value as of March 1, 1913, of the properties owned prior to that date, or an amount equal to the fair market value within 30 days after the date of discovery of mines, oil or gas wells discovered by the taxpayer on or after March 1, 1913, and not acquired as the result of purchase of a proven tract or lease, where the fair market value of the property is materially disproportionate to the cost; plus in any case the subsequent cost of plant and equipment (less salvage value) and underground and overground development, which is not chargeable to current operating expense, but not including land values for purposes other than the extraction of minerals. Operating owners, lessors and lessees are en- 
titled to deduct an allowance for depletion, but a stockholder in a mining or oil or gas corporation is not. (Art. 201.)

Capital recoverable through depletion allowance in the case of owner.-In the case of an operating owner in fee or a lessor the capital remaining in any year recoverable through depletion allowances is the sum of $(a)$ the cost of the property, or its fair market value as of March 1, 1913, or its fair market value within 30 days after discovery, as the case may be, plus $(b)$ the cost of subsequent improvements and development not charged to current operating expenses, but minus $(c)$ deductions for depletion which has or should have been taken to date and (d) the portion of the capital account, if any, as to which depreciation has been and is being deducted instead of depletion. The value of the surface of the land should be taken into consideration. In no case, however, may a lessor include in his capital recoverable through such an allowance any part of development costs not borne by the lessor nor any part of the discovery value. (Art. 202.)

Capital recoverable through depletion allowance in the case of lessee.-In the case of a lessee the capital remaining in any year recoverable through depletion allowances is the sum of $(a)$ the cost of the leasehold, or its fair market value as of March 1, 1913, or its fair market value within 30 days after discovery, as the case may be, plus $(b)$ the cost of subsequent improvements and development not charged to current operating expenses, but minus $(c)$ deductions for depletion which has or should have been taken to date and $(d)$ the portion of the capital account, if any, as to which depreciation has been and is being deducted instead of depletion. Any annual or periodical rents or royalties supplementing the bonus or other amount paid for the lease may be charged to current operating expenses or, until the property reaches the operating stage, to capital account, and in the latter event will form part of the capital returnable through deductions for depletion. (Art. 203.)

Apportionment of deductions between lessor and lessee.-As the value of property comprehends the interests of both lessor and lessee, no computation, for the purpose of depletion allowances, of the value of these interests separately as of any date which combined exceeds the value of the property in fee simple will be permitted. The same principle applies to holders of fractional interests. If the aggregate deduction claimed is deemed excessive, the Commissioner may request the owner or lessee to show that the valuation claimed does not exceed the fair market value of the property at a specified date determined in the manner explained in article 206. The lessor and lessee shall, with the approval of the Commissioner, equitably apportion the allowance in the light of the peculiar conditions in each case and on the basis of their respective interests therein. To the return of every taxpayer claiming an allowance for depletion in respect of $(a)$ property in which he owns a fractional interest only or $(b)$ a leasehold or $(c)$ property subject to a lease, there shall be attached a statement setting forth the name and address and the precise nature of the holdings of each person interested in the property. (Art. 204.) 
Determination of cost of deposits.-In any case in which a depletion or depreciation deduction is computed on the basis of the cost or price at which any mine, mineral deposit, mineral right or leasehold was acquired, the owner or lessee will be required upon request of the Commissioner to show that the cost or price at which the property was bought was fixed for the purpose of a bona fide purchase and sale, by which the property passed to an owner in fact as well as in form different from the vendor. No fictitious or inflated cost or price will be permitted to form the basis of any calculation of a depletion or depreciation deduction, and in determining whether or not the price or cost at which any purchase or sale was made represented the actual market value of the property sold, due weight will be given to the relationship or connection existing between the person selling the property and the buyer thereof. (Art. 205.)

Determination of fair market value of deposits.-Where the fair market value of the property at a specified date in lieu of the cost thereof is the basis for depletion and depreciation deductions, such value must be determined, subject to approval or revision by the Commissioner, by the owner of the property in the light of the conditions and circumstances known at that date, regardless of later discoveries or developments in the property or in methods of mining or extraction. The value sought should be that established assuming a transfer between a willing seller and a willing buyer as of that particular date. No rule or method of determining the fair market value of mineral property is prescribed, but the Commissioner will lend due weight and consideration to any and all factors and evidence having a bearing on the market value, such as cost, actual sales and transfers of similar properties, market.value of stock or shares, royalties and rentals, value fixed by the owner for purposes of the capital stock tax, valuation for local or State taxation, partnersbip accountings, records of litigation in which the value of the property was in question, the amount at which the property may have been inventoried in probate court, disinterested appraisals by approved methods, and other factors. (Art. 206.)

Revaluation of deposits not allowed.-The cost of the property or its fair market value at a specified date, as the case may be, plus subsequent charges to capital account not deductible as current expense, will be the basis for determining the depletion and depreciation deductions for each year during the continuance of the ownership under which the fair market value or cost was fixed, and during such ownership there can be no revaluation for the purpose of this deduction. This rule will not forbid the redistribution of the capital account over the estimated number of units remaining in the property in accordance with either of the next two articles. (Art. 207.)

Determination of quantity of ore in mine.-Every taxpayer claiming a deduction for depletion will be required to estimate with respect to each separate property the total units (tons, pounds, ounces or other units) of ores and minerals reasonably known or on good evidence believed to have existed in the ground on March 1, 1913, or on the date 
of acquisition of the property, or within 30 days after the date of discovery, as the case may be. In estimating the total units of ores and minerals for purposes of depletion the property must be considered in the condition in which it was on March 1,1913, or the date of acquisition, or within 30 days after the date of discovery, but if subsequently during the ownership of the taxpayer making the return additional recoverable mineral deposits have been discovered or developed which were not taken into account in estimating the number of units for purposes of depletion, or if it shall be diacovered by working, development or exploration that ground previously estimated to contain commercially recoverable mineral is barren or contains only commercially unworkable mineral, a new estimate of the recoverable units of ores or minerals (but not of the cost or fair market value at a specified date) shall be made and when made shall thereafter constitute a basis for depletion. In the selection of the unit of estimate the custom or practice applicable to the type of mineral deposit and the character of the operations thereon should be considered. The estimate of the recoverable units of ores or minerals for the purpose of depletion shall include $(a)$ the ores and minerals "in sight," "blocked out," "developed," or "assured," in the usual or conventional meaning of these terms in respect to the type of deposit, and may also include (b) "prospective" or "probable" ores and minerals (in the same sense), that is, ores and minerals that are believed to exist on the basis of good evidence, although not actually known to occur on the basis of existing development; but "probable" or "prospective" ores and minerals may be computed for purposes of depletion only as extensions of known deposits into undeveloped ground. (Art. 208.)

Determination of quantity of oil in ground.-In the case of either an owner or lessee it will be required that an estimate, subject to the approval of the Commissioner, shall be made of the probable recoverable oil contained in the territory with respect to which the investment is made as of the time of purchase, or as of March 1, 1913, if acquired prior to that date, or within 30 days after the date of discovery, as the case may be. The oil reserves must be estimated for all undeveloped proven land as well as producing land. If information subsequently obtained clearly shows the estimate to have been materially erroneous, it may be revised with the approval of the Commissioner. (Art. 209.)

Computation of allowance for depletion of mines and oil wells.When the cost or value as of March 1, 1913, or within 30 days after the date of discovery of the property shall have been determined, and the number of mineral units in the property as of the date of acquisition or valuation shall have been estimated, the division of the former amount by the latter figure will give the unit value for purposes of depletion, and the depletion allowance for the taxable year may be computed by multiplying such unit value by the number of units of mineral extracted during the year. If, however, proper additions are made to the capital account represented by the original cost or value of the property, or unforeseen circumstances necessitate a revised estimate of the number 
of mineral units in the ground, a new unit value for purposes of depletion may be found by dividing the capital account at the end of the year, less deductions for depletion to the beginning of the taxable year which have or should have been taken, by the number of units in the ground at the beginning of the taxable year. This number, unless a revision of the original estimate has been necessary, will equal the number of units in the ground at the date of original acquisition or valuation less the number extracted prior to the taxable year. If, however, a recalculation is needed, the number of units at the beginning of the year will be the sum of the gross production of the year and the estimated mineral reserves in the property at the end of the year. (Art. 210.)

Computation of allowance for depletion of gas wells.-On account of the peculiar conditions surrounding the production of natural gas it will be necessary to compute the depletion allowances for gas properties by methods suitable to the particular cases in question and acceptable to the Commissioner. Usually, the depletion of natural gas properties should be computed on the basis of decline in closed or rock pressure, taking into account the effects of water encroachment and any other modifying factors. The gas producer will be expected to compute the depletion as accurately as possible and submit with his return a description of the method by which the computation was made. The following formula, in which the units of gas are pounds per square inch of closed pressure, may be used and is recommended: the quotient of the capital account recoverable through depletion allowances to the end of the taxable year, divided by the sum of the pressures at the beginning of the year less the sum of the pressures at the time of expected abandonment (which quotient is the unit cost), multiplied by the sum of the pressures at the beginning of the taxable year plus the sum of the pressures of new wells less the sum of the pressures at the end of the tax year, equals the depletion allowance. (Art. 211.)

Gas well pressure records to be kept.-Beginning with 1919 closed pressure readings of representative wells, if not of all wells, must be carefully made and kept. In order to standardize pressure readings the well should remain closed until the pressure does not build up more than 1 per cent of the total pressure in ten minutes. Ordinarily 24 hours will suffice for this purpose, but some wells will need to remain closed for a longer period. If there is any water in the well it should be blown or pumped off before the well is closed. A closed pressure reading of a gas well which has been producing, or is near gas wells that have been producing, is lower than the actual pressure of the gas in the reservoir by an amount depending on the well's location with reference to other producing wells and the length of time it has been closed in. It is necessary to record the length of time the well has been closed and to show how the pressure built up during this period. Successive readings will indicate the point at which the pressure becomes approximately stationary, that is, the point at which the closed pressure approaches as nearly as possible the maximum pressure which would be shown if all wells in 
the pool were closed for several months. The length of time required varies with the character of the sand, position of the packer, the location of the well with reference to other wells, the limits of the pool, and other factors. The depth of the well, diameter of tubing, and line pressure when the well was shut off, should be noted. Since readings at the exact end of the taxable year will ordinarily not be available, the pressure of that date may be obtained by interpolation or extrapolation. In certain cases readings taken regularly in September or some other month may be applicable to the end of the taxable year. As a general rule September closed pressure readings furnish the best indication of depletion and it is recommended that such readings be made with regularity and care. Where interpolated or extrapolated readings are used the data from which they are obtained should be given. Gauges should be of appropriate capacity and should be frequently tested. A record should be kept of the number of gauges, date each was tested, names of men testing, and other significant details. (Art. 212.)

Computation of allowance where quantity of oil or gas uncertain.If by reason of the youth of the field, the restricted production, or for any other cause, it is not possible to determine with any degree of certainty the quantity of oil or gas in a property, it will be necessary to make a tentative estimate which will apply until production figures are available from which an accurate determination may be made. (Art. 213.)

Computation of depletion allowance for combined holdings of oil and gas wells.-(1) The recoverable oil belonging to the taxpayer shall be estimated separately on the smallest unit on which data are available, such as individual wells or tracts, and these added together into a grand total to be applied to the total capital account returnable through depletion. The capital account shall include the cost or value, as the case may be, of all oil or gas leases or rights within the United States and its possessions, plus all incidental costs of development not charged as expense nor returnable through depreciation. The unit value of the total recoverable oil or gas is the quotient obtained by dividing the total capital account recoverable through depletion by the total estimated recoverable oil or gas. This unit multiplied by the total number of units of oil or gas produced by the taxpayer during the taxable year from all of the oil and gas properties will determine the amount which may be allowably deducted from the gross income of that year.

(2) In the case of the gas properties of a taxpayer the depletion allowance for each pool may be computed by using the combined capital account returnable through depletion of all the tracts of gas land owned by the taxpayer in the pool and the average decline in rock pressures of all the taxpayer's wells in such pool in the formula given in article 211 . The total allowance for depletion of the gas properties of the taxpayer will be the sum of the amounts computed for each pool. (Art. 214.)

Depletion of mine based on advanced royalties.-Where the owner has leased a mining property for a term of years with a requirement in the lease that the lessee shall mine and pay for annually a specified 
number of tons or other agreed units of measurement of such mineral, or shall pay annually a specified sum of money which shall be applied in payment of the purchase price or agreed royalty per unit of such mineral whenever the same shall thereafter be mined and removed from the leased premises, the value in the ground to the lessor for purposes of depletion of the number of units so paid for in advance of mining will constitute an allowable deduction from the gross income of the year in which such payment or payments shall be made; but no deduction for depletion by the lessor shall be claimed or allowed in any subsequent year on account of the mining or removal in such year of any ore or mineral so paid fơr in advance and for which deduction has been once made. If for any reason any such mining lease shall be terminated before the ore or mineral therein which has been paid for in advance has been mined and removed, and the lessor repossesses the leased property, an amount equal to the aggregate deductions for depletion allowed in respect of ore or mineral not mined and removed by the lessee, but still in the ground, will be deemed income to the lessor and will be returned as such for the year in which the property is repossessed. (Art. 215.)

Depletion and depreciation accounts on books.-Every taxpayer claiming and making a deduction for depletion and depreciation of mineral property shall keep accurate ledger accounts in which shall be charged the fair market value as of March 1, 1913, or within 30 days after the date of discovery, or the cost, as the case may be, $(a)$ of the property, and $(b)$ of the plant and equipment, together with such amounts expended for development of the property or additions to plant and equipment since that date as have not been deducted as expense in his returns. These accounts shall be credited with the amount of the depreciation and depletion deductions claimed and allowed each year, or the amount of the depreciation and depletion shall be credited to depletion and depreciation reserve accounts, to the end that when the sum of the credits for depletion and depreciation equals the value or cost of the property, plus the amount added thereto for development or additional plant and equipment, less salvage value of the physical property, no further deduction for depletion and depreciation with respect to the property will be allowed. If dividends are paid out of a depletion or depreciation reserve, the stockholders must be expressly notified that the dividend is a return of capital and not an ordinary dividend out of profits. (Art. 216.)

Statement to be attached to return where depletion of mine claimed. -To the return of the taxpayer claiming a deduction for depletion or depreciation or both there should be attached a statement setting out: $(a)$ whether the owner is a fee owner or lessee or both; (b) a description of the property owned in fee, if any, and a description of the leasehold property, if any, including the date of acquisition and the date of expiration of the lease; (c) the fair market value as of March 1, 1913, or within 30 days of the date of discovery, or the cost, as the case may be, of the property owned in fee and the leasehold property, together with a 
statement of the precise method by which the value or the cost of freehold and leasehold property was determined; $(d)$ the estimated number of units of mineral or ore at the date of acquisition or of valuation in the property owned in fee and in the leasehold property separately, together with an explanation of the method used in estimating in each case the number of units of mineral or ore for purposes of depletion; (e) the amount of capital applicable to each unit; $(f)$ the number of units removed and sold during the year for which the return was made; (g) the total amount deducted on account of depletion and on account of depreciation, stated separately, up to the taxable year during the ownership of the taxpayer; and $(h)$ any other data which would be helpful in determining the reasonableness of the depletion and depreciation deductions claimed in the return. (Art. 217.)

Statement to be attached to return where depletion of oil or gas claimed.-To each return made by a person owning or operating oil or gas properties, there should be attached a statement showing for each property the following information, which may be given in the form of a table, if desired, by taxpayers owning more than one property: $(a)$ the fair market value of the property (exclusive of machinery, equipment, etc., and the value of the surface rights) as of March 1, 1913, if acquired prior to that date; or the fair market value of the property within 30 days after the date of discovery; or the actual cost of the property, if acquired subsequently to February 28, 1913, and not covered by the foregoing clause; $(b)$ how the fair market value was ascertained, if the property came under the first or second head under $(a)$; $(c)$ the estimated quantity of oil or gas in the property at the time that the value or cost was determined; $(d)$ the name and address of the person making the estimate and the manner in which this estimate was made, including a summary of the calculations; (e) the amount of capital applicable to each unit (this being found by dividing the value or cost, as the case may be, by the estimated number of units of oil or gas in the property at the time the value or cost was determined); $(f)$ the quantity of oil or gas produced during the year for which the return is made (in the case of new properties it is desirable that this information be furnished by months); $(g)$ the number of acres of producing and proven oil or gas land; $(h)$ the number of wells producing at the beginning and end of the taxable year; $(i)$ the date of completion of wells finished during the taxable year; $(j)$ the date of abandonment of all wells abandoned during the taxable year; $(k)$ a property map showing the location of the property and of the producing and abandoned wells, dry holes, and proven oil and gas land; $(l)$ the average gravity of the oil produced on the tract; $(m)$ the number of pay sands and average thickness of each pay sand or zone on the property; $(n)$ the average depth to the top of each of the different pay sands; $(o)$ any data regarding change in operating conditions, such as flooding, use of compressed air, vacuum, shooting, etc., which have a direct effect on the production of the property; $(p)$ the monthly or annual production of individual wells and the initial daily 
production of new wells (this is highly desirable information and should be furnished wherever possible); $(q)$ (for the first year in which the above information is filed for a property which was producing prior to the taxable year covered by the above statement the following information must be furnished) annual production of the tract or of the individual wells, if the latter information is available, from the beginning of its productivity to the beginning of the taxable year for which the return was filed; the average number of wells producing during each year; and the initial daily production of each well; and $(r)$ any other data which will be helpful in determining the reasonableness of the depletion deduction. When a taxpayer has filed adequate maps with the Commissioner he may be relieved of filing further maps of the same properties, provided all additional information necessary for keeping the maps up to date is filed each year. This includes records of dry holes, as well as producing wells, together with $\operatorname{logs}$, depth and thickness of sands, location of new wells, etc. By "production" is meant the net production of oil or gas belonging to the taxpayer. In those leases where no account is kept of the oil or gas used for fuel, the production will necessarily be that remaining after the fuel used in the property has been taken out. In cases of this kind an estimate of the fuel used from each tract should be given for each year. (Art. 218.)

Discovery of mine.-The discovery of a mine or a natural deposit of mineral, whether it be made by an owner of the land or by a lessee, shall be deemed to mean $(a)$ the bona fide discovery of a commercially valuable deposit of ore or mineral of a value materially in excess of the cost of discovery in natural exposure or by drilling or other exploration conducted above or below ground, or $(b)$ the development and proving of a mineral or ore deposit which has been abandoned or apparently worked out, or sold, leased or otherwise disposed of, by an owner or lessee prior to the development of a body of ore or mineral of sufficient size, quality and character to determine it, in connection with the physical and geological conditions of its occurrence, to be a mineable deposit of ore or mineral having a value materially in excess of the cost of the proving and development. In determining whether a discovery has been made the Commissioner will take into account the peculiar conditions of the case, and every taxpayer claiming the value of a mineral deposit on the date of discovery or within 30 days thereafter for purposes of depletion will be required to attach to his return a statement setting forth the conditions and circumstances of the discovery and the size, character and location of the deposit, together with the cost of discovery, its value and the precise method used in determining the value. (Art. 219.)

Discovery of oil and gas wells.-In order to take advantage of his discovery on or after March 1, 1913, of oil or gas wells, the taxpayer must show $(a)$ that the tract for which such valuation is claimed was not proven oil land as to the particular sand or zone discovery of which is claimed at the time the so-called discovery was made, proven oil land being that which has been shown by finished wells, supplemented by 
geologic data, to be such that other wells drilled thereon are practically certain to be commercial producers; $(b)$ that the discovery was a bona fide discovery of a commercial well of oil or gas or both of these substances on the property in question, a commercial well being one whose production is such as to offer a reasonable expectation of at least returning the capital ifvested in such well through the sale of the oil or gas or both derived therefrom during its economic life; and $(c)$ that the fair market value of the property was materially in excess of the cost. (Art. 220.)

Proof of discovery of oil and gas wells.-In order to meet the requirements of the preceding article to the satisfaction of the Commissioner the taxpayer will be required, among other things, to submit the following with his return: (a) a map of convenient scale, showing the location of the tract and discovery well in question and of the nearest producing well, and the development for a radius of at least three miles from the tract in question, both on the date of discovery and on the date when the fair market value was set; $(b)$ a certified copy of the log of the discovery well, showing the location, the date drilling began, the date of completion and beginning of production, the formations penetrated, the oil, gas and water sands penetrated, the casing record, including the record of perforations, and any other information tending to show the conndition of the well and the location of the sand or zone from which the oil or gas is produced on the date the discovery was claimed; $(c)$ the logs of enough other wells drilled prior to the date of completion of the discovery in the vicinity of the discovery well to convince the Commissioner that the sand or zone discovery of which is claimed was not known prior to the so-called discovery; (d) a sworn record of production, clearly proving the commercial productivity of the discovery well; (e) a sworn copy of the records, showing the cost of the property; and ( $f$ ) a full explanation of the method of determining the value on the date of discovery or within 30 days thereafter, supported by satisfactory evidence of the fairness of this value. (Art. 221.)

Charges to capital and to expense in the case of mine.-In the case of mining operations all expenditures for plant, equipment, development, rent and royalty prior to production, and thereafter all major items of plant and equipment, shall be charged to capital account for purposes of depletion and depreciation. After a mine has been developed and equipped to its normal and regular output capacity, however, the cost of additional minor items of equipment and plant, including mules, motors, mine cars, trackage, cables, trolley wire, fans, small tools, etc., necessary to maintain the normal output because of increased length of haul or depth of working consequent on the extraction of mineral, and the cost of replacements of these and similar minor items of worn-out and discarded plant and equipment, may be charged to current expense of operations, unless the taxpayer elects to write off such expenditures through charges for depreciation. (Art. 222.) 
Charges to capital and to expense in the case of oil and gas wells.Such incidental expenses as are paid for wages, fuel, repairs, hauling, etc., in connection with the exploration of the property, drilling of wells, building of pipe lines, and development of the property may at the option of the taxpayer be deducted as an operating expense or charged to the capital account returnable through depletion. If in exercising this option the taxpayer charges these incidental expenses to capital account, in so far as such expense is represented by physical property it may be taken into account in determining a reasonable allowance for depreciation. The cost of drilling non-productive wells may at the option of the operator be deducted from gross income as an operating expense or charged to capital account returnable through depletion and depreciation as in the case of productive wells. An election once made under this option will control the taxpayer's returns for all subsequent years. Casing-head gas contracts have been construed to be tangible assets and their cost may be added to the capital account returnable through depletion, following the rate set by the oil wells from which the gas is derived, or, if the life of the contract is shorter than the reasonable expectation of the life of the wells furnishing the gas, the capital invested in the contract may be written off through yearly allowances equitably distributed over the life of the contract. All oil produced during the taxable year, whether sold or unsold, must be considered in the computation of the depletion allowance for that year. In computing net income all oil in storage at the beginning and at the end of the taxable year must be inventoried at cost, that is, unit cost plus lifting cost. Where deductions for depreciation or depletion have either on the books of the taxpayer or in his returns of net income been included in the past in expense or other accounts, rather than specifically as depreciation or depletion, or where capital expenditures have been charged to expense in lieu of depreciation or depletion, a statement indicating the extent to which this practice has been carried should accompany the return. (Art. 223.)

Depreciation of improvements in the case of mine.-It shall be optional with the taxpayer, subject to the approval of the Commissioner, $(a)$ whether the cost or value of the mining property, including ores and minerals, plant and equipment, and charges and additions to capital account not charged to expense and deducted as expense on the returns of the taxpayer, shall be recovered at a rate established by current exhaustion of mineral, or $(b)$ whether the cost or value of the mineral and charges to capital account of expenditures other than for physical property shall be recovered by appropriate charges based on depletion and the cost or value of plant and equipment shall be recovered by reasonable charges for depreciation calculated by the usual rules for depreciation or according to the peculiar conditions of the taxpayer's case by a method satisfactory to the Commissioner. Nothing in these regulations shall be interpreted to mean that the value of a mining plant and equipment may be reduced by depreciation or depletion deductions to a sum below the value of the salvage when the property shall have become obsolete or shall have been abandoned 
for the purpose of mining, or that any part of the value of land for purposes other than mining may be recoverable through depletion or depreciation. (Art. 224.)

Depreciation of improvements in the case of oil and gas wells.Both owners and lessees operating oil or gas properties will, in addition to and apart from the deduction allowable for the depletion or return of capital as hereinbefore provided, be permitted to deduct a reasonable allowance for depreciation of physical property, such as machinery, tools, equipment, pipes, etc., so far as not in conflict with the option exercised by the taxpayer under article 223. The amount deductible on this account shall be such an amount based upon its cost or fair market value as of March 1, 1913, equitably distributed over its useful life as will bring such property to its true salvage value when no longer useful for the purpose for which such property was acquired. Accordingly, where it can be shown to the satisfaction of the Commissioner that the reasonable expectation of the economic life of the oil or gas deposit with which the property is connected is shorter than the normal useful life of the physical property, the amount annually deductible for depreciation may for such property be based upon the length of life of the deposit. (Art. 225.)

Depletion and depreciation of oil and gas wells in years before IgI6. -If upon examination it is found that in respect of the entire drilling cost of wells, including physical property and incidental expenses, between March 1, 19 T3, and December 31, 1915, a taxpayer has been allowed a reasonable deduction sufficient to provide for the elements of exhaustion, wear and tear, and depletion, it will not be necessary to reopen the returns for years prior to 1916 in order to show separately in these years the portions of such deduction representing depletion and depreciation, respectively. Such separation will be required to be made of the reserves for depreciation at January 1, 1916, and proper allocation between depreciation and depletion must be maintained after that date. In any case in which it is found that the deductions taken between March 1, 1913, and December 31, 1915, are not reasonable, amended returns may be required for these years. (Art. 226.)

Depletion of timber.-A reasonable deduction from gross income for the depletion of timber and for the depreciation of improvements is permitted, based ( $a$ ) upon cost if acquired after February 28, 1913, or ( $b$ ) upon the fair market value as of March 1, 1913, if acquired prior thereto. The essence of this provision is that the owner of timber property, whether it be a leasehold or a freehold, shall secure through an aggregate of annual depletion and depreciation deductions a return of the amount of capital invested by him in the property, or in lieu thereof an amount equal to its fair market value as of March 1, 1913, plus in any case the subsequent cost of plant, equipment and development which is not chargeable to current operating expenses, but not including eut-over land values. (Art. 227.)

Capital recoverable through depletion allowance in the case of timber.-In general, the capital remaining in any year recoverable through depletion allowances may be determined as indicated in articles 202 and 
203. In the case of leases the apportionment of deductions between the lessor and lessee should be made as specified in article 204 . Where it becomes necessary to determine the cost or fair market value as of March 1,1913 , of the property, the rules laid down in articles 205 and 206 should be followed so far as possible. (Art. 228.)

Computation of allowance for depletion of timber.-An allowance for the depletion of timber in any taxable year shall be based upon the number of feet of stumpage cut during the year and the unit cost of the stumpage at the date of acquisition or the unit market value on March 1, 1913, if acquired prior thereto. The unit market value as of March 1, 1913, shall be the unit price at which the standing timber in its then condition and in view of its then environment could have been sold for cash or its equivalent. The amount of the deduction for depletion in any taxable year shall be the product of the number of feet of stumpage cut during the year multiplied by such unit cost or market value of the stumpage. (Art. 229).

Revaluation of stumpage not allowed.-The fair market value of stumpage when determined as of March 1, 1913, for the purpose of depletion allowances in the case of timber acquired prior thereto, shall be the basis for determining the depletion deduction for each year during the continuanee of the ownership under which the fair market value of the stumpage was fixed, and during such ownership there can be no redetermination of the fair market value of the stumpage for such purpose. However, the unit market value of stumpage adopted by the taxpayer may subsequently be changed if from any cause such value, if continued as a basis of depletion, should upon evidence satisfactory to the Commissioner be found inadequate or excessive for the extinguishment of the fair market value of the timber as of Mareh 1, 1913. (Art. 230.)

Charges to capital and to expense in the case of timber.-In the case of timber operations all expenditures for plant, equipment, development, rent and royalty prior to production, and thereafter all major items of plant and equipment, shall be charged to capital account for purposes of depreciation. After a timber operation and plant has been developed and equipped to its normal and regular output capacity, the cost of additional minor items of equipment and the cost of replacement of minor items of worn-out and discarded plant and equipment may be charged to current expenses of operations. (Art. 231.)

Depreciation of improvements in the case of timber.-The cost or value as of March 1, 1913, as the case may be, of development not represented by physical property having an inventory value, and such cost or value of all physical property which has not been deducted and allowed as expense in the returns of the taxpayer, shall be recoverable through depreciation. It shall be optional with the taxpayer, subject to the approval of the Commissioner, $(a)$ whether the cost or value, as the case may be, of the property subject to depreciation shall be recovered at a rate established by current exhaustion of stumpage, or (b) whether the cost or value shall be recovered by appropriate charges for depreciation 
calculated by the usual rules for depreciation or according to the peculiar conditions of the taxparer's case br a method satisiactory to the Commissioner. In no case may charges for depreciation be based on a rate which will extinguish the cost or value of the property prior to the termination of its useful life. Nothing in these regulations shall be interpreted to mean that the ralue of a timber plant and equipment. so far as it is represented by phrsical property haring an inrentory value, mar be reduced by depreciation deductions to a sum below the ralue of the salvage when the plant and equipment shall have become obsolete or worn out or shall have been abandoned, or that ans part of the ralue of cut-over land may be recorerable through depreciation. (A-t. 232.)

Statement to be attached to return where depletion of timber claimed.-To the return of the taxparer claiming a deduction for depletion or depreciation or both there should be attached a statement setting out (a) whether the owner is an owner in fee or a lessee or both: (b) a description of the property owned in fee, if anr, and a description of the leasehold property, if any, including the date of acquisition and the date of expiration of the lease; (c) the cost of the freehold and the leasehold property; $(d)$ the number of feet of timber remored and sold during the year for which the return was made; $(e)$ the total amount deducted on account of depletion and on account of depreciation, stated separately, up to the taxable year during the ownership of the taxparer; and $(f)$ any other data which would be helpful in determining the reasonableness of the depletion and depreciation deductions claimed in the return. The taxpayer shall keep accurate ledger accounts as outlined in article 216, and in general should comply with the requirements of the foregoing articles relating to the depletion of mines and oil and gals wells so far as applicable. (Art. 233.)

\section{Deductions allowable: charitable contributions.}

10. Contributions or gifts made within the taxable year to corporations incorporated by, or associations organized under, the lau's of this state and operated exclusirely for religious. charitable, scientific or educational purposes, or for the prerention of cruelty to children or animals, no part of the net earnings of which inures to the benefit of any private stockholder or individual, or to the special fund for vocational rehabilitation authorized by section seren of the act of Congress known as the rocational rehabilitation act, to an amount not in excess of fifteen per centum of the taxpayer's net income as computed without the benefit of this subdirision. Such contributions or gifts shall be allowable as deductions only if rerified under rules and regulations prescribed by the comptroller. In the case of a taxpayer other than a resident of the state this deduc- 
tion shall be allowed only as to contributions or gifts made to corporations or associations incorporated by or organized under the laws of this state or to the vocational rehabilitation fund above mentioned.

(Source: Fed. Rev. Act 1918, § 214, a-11. Portions in italics are new.)

Charitable contributions.-Contributions or gifts within the taxable year are deductible to an aggregate amount not in excess of fifteen per cent of the taxpayer's net income including such payments, if made $(a)$ to corporations or associations of the kind exempted from tax by subdivision $(6)$ of section 231 of the statute or $(b)$ to the special fund for vocational rehabilitation under the Vocational Rehabilitation Act of June 27, 1918. For a discussion of what corporations and associations are included within (a) see article 517. A gift to a common agency (as a war chest) for several such corporations or associations is treated like a gift directly to them. In connection with claims for this deduction there shall be stated on returns of income the name and address of each organization to which a gift was made, and the approximate date and the amount of the gift in each case. Where the gift is other than money, the basis for calculation of the amount of the gift shall be the fair market value of the property at the time given. A gift of real estate to a city to be maintained perpetually as a public park is not an allowable deduction. This article does not apply to gifts by partnerships, estates and trusts, or corporations. (Art. 251.)

Religious, charitable, scientific and educational corporations.-The exemption applies only to a corporation or association. It does not include the case of a trust, under which the trustee is authorized to use the trust property for religious purposes. In order to be exempt the corporation or association must meet three tests: $(a)$ it must be organized and operated for one or more of the specified purposes; $(b)$ it must be organized and operated exclusively for such purposes; and $(c)$ no part of its income must inure to the benefit of private stockholders or individuals.

(1) Charitable corporations include an association for the relief of the families of clergymen, even though the latter make a contribution to the fund established for this purpose; or for furnishing the services of trained nurses to persons unable to pay for them; or for aiding the general body of litigants by improving the efficient administration of justice. Educational corporations may include an association whose sole purpose is the instruction of the public. This is true of an association to promote acquaintance with the Spanish language and literature, although it has incidental amusement features; of an association to increase knowledge of the civilization of another country; and of a Chautauqua association whose primary purpose is to give lectures on subjects useful to the individual and beneficial to the community and whose anusement features are incidental to this purpose. But associations formed to disseminate controversial or partisan propaganda are not educational within the meaning of 
the statute. Societies designed to encourage the performance of first class orchestral music are not exempt, the purpose being merely to provide a high grade of entertainment. Scientific corporations include an association for the scientific study of law, to the end of improvement in its administration.

(2) Where a religious corporation owns a large quantity of farm land and works it, and also manufactures and sells clothing and other articles for profit, it is not operated exclusively for religious purposes and is not exempt, even though its property is held in common and its profits do not inure to the benefit of individual members of the society.

(3) It does not prevent exemption that private individuals, for whose benefit a charity is organized, receive the income of the corporation or association. The statute refers to individuals having a personal and private interest in the activities of the corporation, such as stockholders. If, however, a corporation issues "voting shares," which entitle the holders upon the dissolution of the corporation to receive the proceeds of its property, including accumulated income, the right to exemption does not exist, even though the by-laws provide that the shareholders shall not receive any dividend or other return upon their shares. (Art. 517.)

Gifts to foreign organizations of a character specified in the Law are deductible. The American National Red Cross falls within the class of associations enumerated. It is held that every church constitutes a religious corporation or association for the purposes of the deduction. Donations made to missionary funds, to the church building funds and for the benefit of other activities of the church, being for the benefit or furtherance of religious activities, constitute items which may be considered in computing the deductions. (Letter to The Corporation Trust Company, signed by Commissioner Daniel C. Roper, and dated December 24, 1917.) Contributions of gifts made to individuals (as to a needy family) do not constitute allowable deductions. (Questions 86 and 87, 1918 Income Tax Primer.)

With reference to the ninth paragraph of Section 5 of the Act of September 8,1916 , as amended, how am I to determine to what extent contributions or gifts made to corporations or associations, organized exclusively for religious, charitable, scientific or educational purposes, societies for the Prevention of Cruelty to Children or Animals, may be claimed as a deduction?

You should first ascertain what your taxable net income would be were you not entitled to a deduction on account of contributions or gifts made to such corporations, associations or societies, and then if the aggregate of your contributions and gifts made during the year to such organizations does not exceed 15 per cent of your taxable net income so computed, their aggregate amount may be entered in the space provided therefor under General Deductions on a personal return form. If such aggregate amount exceeds 15 per cent of your taxable net income so computed, the excess cannot be claimed.

For example: Your total taxable net income amounts to $\$ 20,000$. Dur- 
ing the year you have contributed to the National Red Cross $\$ 1,000$, to the Young Men's Christian Association $\$ 1,000$, toward the construction of a new church $\$ 1,000$, and to the Associated Charities of your home city $\$ 500$, a total of $\$ 3,500$. Fifteen per cent of your total net income amounts to $\$ 3,000$, therefore, this latter amount may be claimed as a deduction, and the balance of your contributions and gifts may not be claimed. (Question 86, 1918 Income Tax Primer.)

\section{Deductions allowable: taxpayers other than residents.}

11. In the case of a taxpayer other than a resident of the state the deductions allowed in this section shall be allowed only if, and to the extent that, they are connected with income arising from sources within the state; and the proper apportionment and allocation of the deductions with respect to sources of income within and without the state shall be determined under rules and regulations to be prescribed by the comptroller.

(Source: Fed. Rev. Act 1918, § 214b.)

Deductions allowed non-resident alien individuals. - In the case of a non-resident alien individual the deduction for interest paid or accrued is proportionate to his income from sources within the United States (see paragraph (2) of subdivision (a) of section 214 of the statute); for losses incurred in any transaction entered into for profit, or arising from casualty or theft, is confined to transactions and property within the United States $(5), \cdot(6)$; for charitable contributions excludes gifts to foreign corporations (11); and for business expenses, taxes imposed by a foreign country, losses in trade, bad debts, depreciation, amortization, depletion, and loss in inventory (1), (3), (4), (7), (8), (9), (10) and (12), is allowed only if and to the extent that it is connected with income arising from a source within the United States. *** (Art. 271.)

\section{Items not deductible: personal expenses.}

SEc. 361. Items not deductible. In computing net income no deduction shall in any case be allowed in respect of :

1. Personal, living, or family expenses;

(Source: Fed. Rev. Act 1918, \& 215 a.)

Personal and family expenses.-Insurance paid on a dwelling owned and occupied by a taxpayer is a personal expense. Premiums paid for life insurance by the insured are not deductible. In the case of a professional man who rents a property for residential purposes, but incidentally receives there clients, patients or callers in connection with his professional work (his place of business being elsewhere), no part of the rent is deductible as a business expense. If, however, he uses part of the house for his office, such portion of the rent as is properly attributable to 
such office is deductible. The father is legally entitled to the services of his minor children, and allowances which he gives them, whether said to be in consideration of services or otherwise, are not allowable deductions in his return of income. Alimony and an allowance paid under a separation agreement are not deductible from gross income. See article 73 . The cost of the equipment of an army officer to the extent only that it is specially required by his profession and does not merely take the place of articles required in civilian life is deductible. Accordingly, the cost of a sword is an allowable deduction, but the cost of a uniform is not. (Art. 291.)

Traveling expenses.-Traveling expenses, as ordinarily understood, include railroad fares and meals and lodging. If the trip is undertaken for other than business purposes, such railroad fares are personal expenses and such meals and lodging are living expenses. If the trip is on business, the railroad fares become business instead of personal expenses, but the meals and lodging continue to be living expenses and are not deductible in computing net income. (a) If, then, an individual whose business requires him to travel receives a salary as full compensation for his services, without reimbursement of traveling expenses, his expenses for railroad fares, but not for meals and lodging, are deductible from gross income. (b) If such an individual receives a salary and is also repaid his actual traveling expenses, no part of such expenses is deductible from gross income and no part of such repayment is returnable as income. (c) If such an individual receives a salary and also an allowance for meals and lodging, as, for example, a per diem allowance in lieu of subsistence, any excess of the cost of such meals and lodging over the allowance is not deductible, but any excess of the allowance over the actual expenses is taxable income. A payment for the use of a sample room at a hotel for the display of goods is a business expense. (Art. 292.)

Expenses of commuters._"A," who is employed in a city, has his home in a suburb. He pays carfare between his home and place of enployment and takes his noon lunch in the city. Can the amounts expended for carfare and lunch be claimed as a business expense? (Answer.) No, as such amounts are held to be items of personal expense. (Question 52, 1918 Income Tax Primer.)

Items of personal expense or items connected in any way with the support, maintenance and well-being of a family are not allowed; neither are the amounts paid for tools, implements, vehicles, machinery, or surgical instruments which are more or less permanent in character, nor the cost of medical, law or other professional books nor amounts expended in making permanent improvements or betterments of any kind whatsoever, allowable as deductions. These latter items are held to be investments of capital upon which depreciation may be claimed. (Question 46, 1918 Income Tax Primer.) 


\section{Items not deductible: permanent improvements.}

2. Any amount paid out for new buildings or for permanent improvements or betterments made to increase the value of any property or estate;

(Source: Fed. Rev. Act 1918, \& 215 b.)

\section{Items not deductible: restoring property.}

3. Any amount expended in restoring property or in making good the exhaustion thereof for which an allowance is or has been made; or

(Source: Fed. Rev. Act 1918, § 215 c.)

Capital expenditures.-Amounts paid for increasing the capital value or for restoring the depreciated value of property are not deductible from gross income. See section 214 (a) (8) of the statute and article 161. Amounts expended for securing a copyright and plates, which remain the property of the person making the payments, are investments of capital. The cost of defending or perfecting title to property constitutes a part of the cost of the property and is not a deductible expense. The amount expended for architect's services is part of the cost of the building. Commissions paid in purchasing securities are a part of the cost price of such securities. Commissions paid in selling securities are an offset against the selling price. Expenses of the administration of an estate, such as court costs, attorney's fees and executor's commissions, are chargeable against the corpus of the estate and are not allowable deductions. Amounts to be assessed and paid under an agreement between bondholders or stockholders of a corporation, to be used in a reorganization of the corporation, are investments of capital and not deductible for any purpose in returns of income. See article 543. An assessment paid by a stockholder of a national bank on account of his statutory liability is similarly not deductible. (Art. 293.)

\section{Items not deductible: premiums on insurance for employee.}

4. Premiums paid on any life insurance policy, covering the life of any efficer or employee, or of any person financially interested in any trade or business carried on by the taxpayer, when the taxpayer is directly or indirectly a beneficiary under such policy.

(Source: Fed. Rev. Act 1918, \& 215 d.)

Premiums on business insurance.-Where the taxpayer pays premiums on an insurance policy on the life of an officer, employee or individual financially interested in the taxpayer's business, for the purpose of protecting himself from loss in the event of the death of any such person, such premiums are not deductible from his gross income. But if the tax- 
payer is in no sense a beneficiary under such a policy, except as he may derive advantage from the increased efficiency of the employee, and pays the premiums purely as reasonable additional compensation of such employee, they are allowable deductions. See articles 33 and 105-108. In either case whether the proceeds of such policies paid upon the death of the insured may be excluded from gross income or must be included therein depends upon whether the beneficiary is an individual or a corporation. (Art. 294.)

\section{Exemptions : personal.}

SEc. 362. Exemptions. The following exemptions shall be allowed to any resident taxpayer:

1. In the case of a single person, a personal exemption of one thousand dollars, or in the case of the head of a family or a married person living with husband or wife, a personal exemption of two thousand dollars. A husband and wife living together shall receive but one personal exemption of two thousand dollars against their aggregate net income; and in case they make separate returns, the personal exemption of two thousand dollars may be taken by either or divided between them.

(Source: Fed. Rev. Act 1918, § 216 c.)

Credits against net income.-For the purpose of imposing the normal tax the taxpayer's net income as computed pursuant to section 212 of the statute and articles 21-26 is first reduced by the sum of the allowable credits. * * * (Art. 301.)

Personal exemption of head of family.-A head of a family is a person who actually supports and maintains in one household one or more individuals who are closely connected with him by blood relationship, relationship by marriage, or by adoption, and whose right to exercise family control and provide for these dependent individuals is based upon some moral or legal obligation. In the absence of continuous actual residence together, whether or not a person with dependent relatives is a head of a family within the meaning of the statute must depend on the character of the separation. If a father is absent on business or at war, or a child or other dependent is away at school or on a visit, the common home being still maintained, the additional exemption applies. If, moreover, through force of circumstances a parent is obliged to maintain his dependent children with relatives or in a boarding house while he lives elsewhere, the additional exemption may still apply. If, however, without necessity the dependent continuously makes his home elsewhere, his benefactor is not the head of a family, irrespective of the question of support. A resident alien with children abroad is not the head of a family. (Art. 302.) 
Personal exemption of married person.-In the case of a married man or married woman the joint exemption replaces the individual exemption only if the man lives with his wife or the woman lives with her husband. In the absence of continuous actual residence together, whether or not a man or woman has a wife or husband living with him or her within the meaning of the statute must depend on the character of the separation. If merely occasionally and temporarily a wife is away on a visit or a husband is away on business, the joint home being maintained, the additional exemption applies. The unavoidable absence of a wife or husband at a sanatorium or asylum on account of illness does not preclude claiming the exemption. If, however, the husband voluntarily and continuously makes his home at one place and the wife hers at another, they are not living together for the purpose of the statute, irrespective of their personal relations. A resident alien with a wife residing abroad is not entitled to the joint exemption. (Art. 303.)

Date determining exemption.-The status of the taxpayer on the last day of his taxable year determines his right to an additional exemption and to a eredit for dependents. If then he is the head of a family, the personal exemption of $\$ 2,000$ may be taken. If then he is the chief support of a dependent who is under eighteen years of age or incapable of self-support because mentally or physically defective, the credit of $\$ 200$ may be taken. But an unmarried individual or a married individual not living with husband or wife, who during the taxable year has ceased to be the head of a family or to have dependents, is entitled only to the personal exemption of $\$ 1,000$ allowed a single person. A husband and wife living together at the end of the taxable year may receive but one personal exemption of $\$ 2,000$, divisible as they please, against their aggregate net income. If an individual dies during the taxable year, his executor or administrator in making a return for him is entitled to claim his full personal exemption according to his status at the time of his death. See also section 219 (c) of the statute and articles 346 and 421 . If a husband or wife so dies and the joint personal exemption is used by the executor or administrator in making a return for the decedent, an undiminished personal exemption according to the status of the survivor at the end of the taxable year may be claimed in the survivor's return. If a taxpayer makes a return for a period other than a taxable year, the last day of such period shall be treated as the last day of the taxable year for the purpose of this article. (Art. 305.)

\section{Exemptions: for dependents.}

2. Two hundred dollars for each person (other than husband or wife) dependent upon and receiving his chief support from the taxpayer, if such dependent person is under eighteen years of age or is incapable of self-support because mentally or physically defective. 
(Source: Fed. Rev. Act 1918, § 216 d.)

Credit for dependents.-A taxpayer receives a credit of $\$ 200$ for each person (other than husband or wife), whether related to him or not and whether living with him or not, dependent upon and receiving his chief support from the taxpayer, provided the dependent is either (a) under eighteen or $(b)$ incapable of self-support because defective. The credit is based upon actual financial dependency and not mere legal dependency. It may accrue to a taxpayer who is not the head of a family. But a father whose children receive half or more of their support from a trust fund or other separate source is not entitled to the credit. (Art. 304.)

\section{Exemptions: salaries of United States' officials.}

3. A taxpayer receiving salary, wages, or other compensation from the United States as an official thereof, exempt from taxation under this article, shall be entitled to only so much of the personal exemption provided for in this section as is in excess of the aggregate amount of such salaries, wages, or other compensation.

(Source: New.)

\section{Exemptions: credit for taxes in case of taxpayers other than residents.}

SEc. 363. Credit for taxes in case of taxpayers other than residents of the state. Whenever a taxpayer other than a resident of the state has become liable to income tax to the state or country where he resides upon his net income for the taxable year, derived from sources within this state and subject to taxation under this article, the comptroller shall credit the amount of income tax payable by him under this article with such proportion of the tax so payable by him to the state or country where he resides as his income subject to taxation under this article bears to his entire income upon which the tax so payable to such other state or country was imposed; provided that such credit shall be allowed only if the laws of said state or country grant a substantially similar credit to residents of this state subject to income tax under such laws.

(Source: Fed. Rev. Act 1918, § 216 e.)

Credits to non-resident alien individual.-A non-resident alien individual, similarly to a citizen or resident, is entitled for the purpose of the normal tax to credit a personal exemption, and $\$ 200$ for each dependent, except that if he is a citizen or subject of a country which imposes an 
income tax a personal exemption or credit for dependents is allowed him "only if such country allows a similar credit to citizens of the United States not residing in such country." "If such country allows a similar credit" means if such country in imposing its income tax allows a personal exemption or a credit for dependents, as the case may be, and allows it without discrimination to citizens of the United States not residing in such country. For the meaning of "country" see article 382. To satisfy the requirement of a similar credit it is not necessary that the personal exemption or credit for dependents, as the case may be, should be the same as that allowed by the United States statute. The status as to residence of an alien individual on the last day of his taxable year determines his right to be treated as a resident or as a non-resident for such year. (Art. 306.)

(See also § 350-7, Definition of Resident, and Chapter on Residence.)

(Note: The state law does not allow any personal exemption or any exemption for dependents in the case of a taxpayer other than a resident.)

\section{Partnerships: members taxed only in individual capacities.}

Sec. 364. Partnerships. Individuals carrying on business in partnerships shall be liable for income tax only in their individual capacity. There shall be included in computing the net income of each partner his distributive share, whether distributed or not, of the net income of the partnership for the taxable year, or, if his net income for such taxable year is computed upon the basis of a period different from that upon the basis of which the net income of the partnership is computed, then his distributive share of the net income of the partnership for any accounting period of the partnership ending within the fiscal or calendar year upon the basis of which the partner's net income is computed. Taxpayers who are members of partnerships may be required by the comptroller to make a return stating the gross receipts and net gains or profits of the partnership for any taxable year. The net income of the partnership shall be computed in the same manner and on the same basis as provided in computing the net income of individuals except that the deduction provided in subdivision ten of section three hundred and sixty shall not be allowed and the personal exemptions provided for in section three hundred and sixty-two shall be allowed only to the individual partners.

(Source: Fed. Rev. Act, 1918-§ 218-a and d.) 
Note: The federal law taxes the stockholders of a personal service corporation in the same manner as the members of a partnership.)

Partnerships.-Partnerships as such are not subject to taxation under the statute, but are required to make returns of income. See section 224 of the statute and articles 411 and 412. Individuals carrying on business in partnership are, however, taxable upon their distributive shares of the net income of such partnerships, whether distributed or not, and are required to include such distributive shares in their returns. The net income of a partnership shall be computed in the same manner and on the same basis as the net income of an individual, except that the deduction of contributions or gifts is not permitted. * * * (Art. 321.)

Partnerships as such are required to $*^{*} *$ render a correct return of the earnings, profits, and income of the partnership, except income exempt from tax under section 4 of the income-tax law, setting forth the item of gross income and the deductions and credits allowed by law as for an individual, citizen, or resident alien, and the names and addresses of the individuals who would be entitled to the net earnings, profits, and income, if distributed. In computing its profits, for the purpose of the income tax and return as aforesaid, a partnership shall not deduct premiums on life-insurance policies covering the lives of members of the partnership, its employees, or those financially interested in the business or trade conducted by the partnership or otherwise. (Art. 30, Reg. 33, Rev., Jan. 2, 1918.)

Private banks as partnerships.-Private banks which do not have this formal organization but which transact business, not in the name of the bank, but in the name of the individuals who compose the firm, as John Smith \& Co., are held to be co-partnerships $*^{*} *^{*}$. In such cases the individuals who compose the firm, if they have net incomes in excess of $[\$ 1,000$ or $\$ 2,000]$ will be required to make individual returns on Form 1040, accounting for therein their respective incomes arising and accruing from the earnings of the bank. (Mimeograph letter No. 1271 to Collectors, Oct. 19, 1915.)

Distributive shares of partners.-The distributive share of the net income of a partnership which a partner is required to include in his return is his proportionate share of the net income of the partnership, either $(a)$ for the taxable year upon the basis of which the partner's net income is computed, or $(b)$, if the partner's net income is computed upon the basis of a taxable year different from that upon the basis of which the net income of the partnership is computed, for the taxable year of the partnership ending within the taxable year upon the basis of which the partner's net income is computed. Amounts earned and distributed to a partner by a partnership after the end of its taxable year and before the end of his corresponding taxable year should be accounted for both by the partnership and by the partner in their returns for their next succeeding taxable years. (Art. 322.)

Undistributed distributable interests once taxed are not taxed again when distributed.-Undivided annual net profits of partnerships thus 
returned by the individual members thereof, and tax paid thereon, shall not, when said profits are actually distributed and paid to such members, be again included in their annual return as a part of their gross income. (Art. 14, Reg. 33, Jan. 5, 1914.)

Credit to members on account of non-deductible donations made by a partnership.-Any donation allowed as a business expense of the partnership would of course not be deductible by individual members of the partnership in their personal income tax returns. Donations made by the partnership but not allowable as deductions by it may be prorated among the individual members of the partnership for the purpose of their individual income tax returns, as contributions or gifts, subject to the limitations of Section 5 of the Act of September 8, 1916, subdivision a, clause ninth, added by Section 1201 of the Act of October 3, 1917. (Letter to The Corporation Trust Company, signed by Commissioner Daniel C. Roper, and dated May 23, 1918.)

Amount received by an employee of a partnership under a participation of profits agreement is deductible by the partnership as an expense.- "A partnership agrees with an expert to take charge of one of its departments upon a participation of profits basis; that is, the expert serves without salary and his compensation is in the form of $20 \%$ of the net profits of his department at the end of the year. May the amount represented by the $20 \%$ be deducted as an expense to the partnership in determining the amount of taxable income to the actual members of the partnership?" (Answer.) It appears from your statement of facts that the relationship existing between the partnership and the "expert" is merely that of employer and employee and, such being the case, the office holds that the amount of compensation paid to the individual constitutes an item of business expense to the partnership and may be so considered in computing the amount of taxable income accruing to the partnership members. (Letter to The Corporation Trust Company, signed by Acting Commissioner David A. Gates, and dated June 30, 1916.)

\section{Tax on income of estates and trusts.}

SEc. 365. Estates and trusts. 1. The tax imposed by this article shall apply to the income of estates or of any kind of property held in trust, including:

(a) Income received by estates of deceased persons during the period of administration or settlement of the estate;

(b) Income accumulated in trust for the benefit of unborn or unascertained persons or persons with contingent interests;

(c) Income held for future distribution under the terms of the will or trust; and

(d) Income which is to be distributed to the beneficiaries period- 
ically, whether or not at regular intervals, and the income collected by a guardian of an infant to be held or distributed as the court may direct.

(Source: Fed. Rev. Act 1918, \& 219.)

(Note: See Chapter XXVIII on "Estates and Trusts," supra.)

Estates and trusts.-While certain estates and trusts are subject to tax as such and others are not, the fiduciary in every case is required to make a return of income. See section 225 of the statute and articles 421-425. The net income of an estate or trust shall be computed in the same manner and on the same basis as the net income of an individual, except that in place of the deduction allowed individuals of certain gifts or contributions there may be deducted from the gross income any part of it which during the taxable year is pursuant to the will or trust deed paid to or permanently set aside for the United States, a State, a Territory, or any political subdivision thereof, the District of Columbia, or any corporation or association of the kind described in section $231(6)$ of the statute and article 517. See section 212 and articles 21-26. The income of a revocable trust must be included in the gross income of the grantor. (Art. 341.)

\section{Fiduciary responsible for return.}

2. The fiduciary shall be responsible for making the return of income for the estate or trust for which he acts. The net income of the estate or trust shall be computed in the same manner and on the same basis as provided in this article for individual taxpayers, except that there shall also be allowed as a deduction any part of the gross income which pursuant to the terms of the will or deed creating the trust, is during the taxable year paid to or permanently set aside for the United States, any state, territory, or any political subdivision thereof, or the District of Columbia, or any corporation or association organized and operated exclusively for religious, charitable, scientific or educational purposes, or for the prevention of cruelty to children or animals, no part of the net earnings of which inures to the benefit of any private stockholder or individual; and in cases under paragraph (d) of subdivision one of this section, the fiduciary shall include in the return a statement of each beneficiary's distributive share of such net income, whether or not distributed before the close of the taxable year for which the return is made. 


\section{Income credited to beneficiary may be deducted.}

3. In cases under paragraphs (a), (b), and (c) of subdivision one, of this section, the tax shall be imposed upon the net income of the estate or trust and shall be paid by the fiduciary, except that in determining the net income of the estate of any deceased person during the period of administration or settlement there may be deducted the amount of any income properly paid or credited to any legatee, heir or other beneficiary. In such cases, the estate or trust shall be allowed the same exemptions as are allowed to single persons under section three hundred and sixty-two, and in such cases an estate or trust created by a person not a resident and an estate of a person not a resident shall be subject to tax only to the extent to which individuals other than residents are liable under section three hundred and fifty-nine, subdivision three.

(Note: Words in italics are new.)

Where, during the period of administration, an executor converts the estate in his possession as such executor into money for the purpose of settling the estate and closing the administration and in which conversion a profit is realized which with other income exceeds $\$ 1,000$, a return of income should be made by the executor covering the period of administration in which should be included all gains, profits, and income of the estate during such period, and he should pay the tax found by such return to be due. The income of the estate being thus freed of income-tax liability may thereafter be dealt with without further regard to income-tax requirements. (Art. 29, Reg. 33, Rev., Jan. 2, 1918.)

Estates and trusts taxed to fiduciary.-In the case of $(a)$ estates of decedents before final settlement and of (b) trusts, whether created by will or deed, for accumulation of income, whether for unascertained persons or persons with contingent interests or otherwise, the income is taxed to the fiduciary as to any single individual, except that from the income of a decedent's estate there may first be deducted any amount of income properly paid or credited to a beneficiary. See section 200 of the statute and articles 1521 and 1522. Where under the terms of the will or deed the trustee may in his discretion distribute the income or accumulate it, the income is taxed to the trustee, irrespective of the exercise of his discretion. The imposition of the tax is not affected by the fact that an ultimate beneficiary may be a person exempt from tax. A statutory allowance paid a widow out of the corpus of the estate is not deductible from gross income. As an intestate's real estate does not pass to his administrator, upon a sale by the heirs, whether before or after settlement of the estate, each heir is taxed individually on any profit derived. (Art. 342.) 
Decedent's estate during administration.-The "period of administration or settlement of the estate" is the period required by the executor or administrator to perform the ordinary duties pertaining to administration, in particular the collection of assets and the payment of debts and legacies. It is the time actually required for this purpose, whether longer or shorter than the period specified in the local statute for the settlement of estates. Where an executor, who is also named as trustee, fails to obtain his discharge as executor, the period of administration continues up to the time when the duties of administration are complete and he actually assumes his duties as trustee, whether pursuant to an order of the court or not. No taxable income is realized from the passage of property to the executor or administrator on the death of the decedent, even though it may have appreciated in value since the decedent acquired it. In the event of delivery of property in kind to a legatee or distributee, no income is realized. Where, however, the executor sells property of the estate for more than its value at the death of the decedent, the excess is income taxable to the estate. (Art. 343.)

(Note: See also Art. 293 supra, Capital Expenditures-for expenses of administration.)

Incidence of tax on estate or trust.-Liability for payment of the tax attaches to the person of an executor or administrator up to and after his discharge, where prior to distribution and discharge he had notice of his tax obligations or failed to exercise due diligence in determining whether or not such obligations existed. Liability for the tax also follows the estate itself, and when by reason of the distribution of the estate and the discharge of the executor or administrator it appears that collection of the tax can not be made from the executor or administrator, the legatees or distributees must account for their proportionate share of the tax due and unpaid. The same considerations apply to other trusts. Where the tax has been paid on the net income of an estate or trust by the fiduciary, such income is free from tax when distributed to the beneficiaries. (Art. 344.)

Final return on final accounting.-Administrators or executors may, immediately after their discharge, upon final accounting, file with the proper collector of internal revenue a return of income for the income of the estate for the calendar year in which the administration was closed, and should pay the tax found by such return to be due immediately upon receipt of notice and demand for the amount of such tax. There should be attached to this return a copy of the certificate, under seal, setting forth the fact of final accounting and discharge of the executor or administrator. The liability for return is fixed by the law as of December 31, and return will be required in accordance with the provisions of law existing on that date.

An ancillary administrator is held to be merely an agent of the domiciliary administrator and should transmit to him all information as to income of the estate received by the ancillary administrator, to the end 
that the original administrator may make a return covering the entire income of the estate. (Art. 26, Reg. 33, Rev., Jan. 2, 1918.)

\section{When beneficiary makes return of his distributive share.}

4. In cases under paragraph (d) of subdivision one of this section and in the case of any income of an estate during the period of administration or settlement permitted by subdivision three to be deducted from the net income upon which tax is to be paid by the fiduciary, the tax shall not be paid by the fiduciary, but there shall be included in computing the net income of each beneficiary his distributive share whether distributed or not, of the net income of the estate or trust for the taxable year, or, if his net income for such taxable year is computed upon the basis of a period different from that upon the basis of which the net income of the estate or trust is computed, then his distributive share of the net income of the estate or trust for any accounting period of such estate or trust ending within the fiscal or calendar year upon the basis of which such beneficiary's net income is computed. In such cases the income of a beneficiary of such estate or trust not a resident shall be taxable only to the extent provided in section three hundred and fifty-nine, subdivision three, for individuals other than residents.

(Note: Words in italics are new.)

Estates and trusts taxed to beneficiaries.-In the case of $(a)$ a trust the income of which is distributable periodically, $(b)$ an ordinary guardianship of a minor, and $(c)$ an estate of a decedent before final settlement as to any income properly paid or credited as such to a beneficiary, the income is taxable directly to the beneficiary or beneficiaries. Each beneficiary must include in his return his distributive share of the net income, even though not yet paid him, but if the taxable year on the basis of which he makes his returns fails to coincide with the annual accounting period of the estate or trust, then he need only include in his return his distributive share for such accounting period ending within his taxable year. The regulations governing partnerships are generally applicable to such an estate or trust. (Art. 345.)

Credits to trust or beneficiary.-(a) In the case of an estate or trust taxed to the fiduciary it is allowed the same credits against net income as a single person, including a personal exemption of $\$ 1,000$, but no credit for dependents. (b) In the case of an estate or trust taxed to the beneficiaries each beneficiary is allowed for the purpose of the normal tax, in addition to his individual credits, his proportionate share of such dividends from domestic and resident foreign corporations and of such interest 
not entirely exempt from tax upon obligations of the United States and bonds of the War Finance Corporation as are received by the estate or trust. Each beneficiary is entitled to but one personal exemption, no matter from how many trusts he may receive income. (Art. 346.)

Obligation of a receiver for an individual to make return and pay tax.-As to the duty of a receiver under interlocutory orders of the United States District Court to make return for and pay tax on the income received by him on funds which he holds in trust as receiver under an appointment as aforesaid. TUnder the second case, stated in Section 2 (b), Act of September 8, 1916-"The income of $*^{*} *^{*}$ any kind of property held in trust * * * (except when the income is returned for the purpose of the tax by the beneficiary)" is subject to the normal and additional tax, the tax to be assessed to the trustee. Under the provisions of Section 7 (a) of the Act the receiver will be permitted to deduct, as an exemption, $[\$ 1,000]$ in his return. This return is to be made on Income Tax Form 1040. TThe receiver is indemnified by the Act against the claims or demands of every beneficiary for all payments of taxes which he shall be required to make under the provisions of the Act of September 8,1916 , and he shall have credit for the amount of such payments against the beneficiary or principal in any accounting which he makes as such receiver. IThe income being thus freed of tax liability imposed by the statute, it may thereafter be dealt with by the receiver without further regard to the requirements of the tax statute. (Letter to William Beverly Winslow, New York, N. Y., signed by Deputy Commissioner L. F. Speer, and dated February 9, 1917.)

Unless the beneficiary is under some disability which requires the fiduciary to act, the beneficiary will make his own return and account for the tax upon his entire net income. (T. D. 2090, Dec. 14, 1914.)

When fiduciary may make return for beneficiary.-As each such fiduciary acts solely in behalf of the beneficiaries of the trust, the annual return required in such cases has reference only to the income accruing and payable through said fiduciary, and not to the income of the beneficiary derived from other sources. If, however, such fiduciary is legally authorized to act for such beneficiary as agent or attorney in fact, he may in such case also make for the beneficiary the personal annual return required by law. (Art. 72, Reg. 33, Jan. 5, 1914.)

\section{Withholding agent to deduct two per centum from compensa- tion.}

SEc. 366. Information and payment at source. 1. Every withholding agent shall deduct and withhold two per centum from all salaries, wages, commissions, gratuities, emoluments, perquisites and other fixed and determinable annual or periodical compensation of whatever kind and in whatever form paid or received, earned for personal services and taxable under this article, of which he 
shall have control, receipt, custody, disposal or payment, if the amount paid or received or to be paid or received in any taxable year on account of any individual equals or exceeds one thousand dollars, unless there shall be filed with the withholding agent, before the time when he is required to make return and payment thereof, a certificate in such form as shall be prescribed by the comptroller to the effect that the person entitled to such salary, wage, commission, gratuity, emolument, perquisite or other compensation is a resident and setting forth his residence address within the state.

(Source: Fed. Rev. Act 1918, § 221, but the State Law requires withholding only in the case of compensation for personal services. See also $\S 350,10$, supra, for dejinition of "withdrawing agent."

The Regulations of the State Comptroller, Articles 261-269, issued June IIth, I919, will be found under the chapter on Payment and Information at the Source-Withholding, supra.

Fixed or determinable annual or periodical income.-Only $(a)$ fixed or determinable, $(b)$ annual or periodical income is subject to withholding. * * (a) Income is fixed when it is to be paid in amounts definitely predetermined. On the other hand, it is determinable whenever there is a basis of calculation by which the amount to be paid may be ascertained. (b) The income need not be paid annually if it is paid periodically, that is to say, from time to time, whether or not at regular intervals. That the length of time during which the payments are to be made may be increased or diminished in accordance with someone's will or with the happening of an event does not make the payments any the less determinable or periodical. A salesman working by the month for a commission on sales which is paid or credited monthly receives determinable periodical income. (Art. 362.)

No deduction at source on salaries for service rendered abroad or on rent on property located abroad.-It is held that salaries, wages, commissions, and rents paid by domestic corporations, resident individuals, or partnerships to non-resident alien employees for services rendered entirely in a foreign country and for property located in a foreign country are not subject to deduction and withholding of the normal tax and such payments of income will not be subject to the income tax in the hands of the recipient as from a source within the United States. (Art. 32, Reg. 33, Rev., Jan. 2, 1918.)

\section{Withholding agent required to make return of information.}

2. Every withholding agent shall make return to the comptroller of complete information concerning the amount of all interest, rent, 
salaries, wages, premiums, annuities, compensations, remunerations, emoluments or other fixed or determinable gains, profits and income, except interest coupons payable to bearer, of any taxpayer taxable under this article of one thousand dollars or more in any taxable year under such regulations and in such form and manner and to such extent as may be prescribed by the comptroller.

(Source: New. See regulations of State Comptroller, chapter -, supra.)

\section{Date return due: withholding agent indemnified.}

3. Every withholding agent required to deduct and withhold any tax under subdivision one of this section shall make return thereof on or before the fifteenth day of March in each year and shall at the same time pay the tax to the comptroller. Every such individual corporation or partnership is hereby made liable for such tax and is hereby indemnified against the claims and demands of any individual, corporation or partnership for the amount of any payments made in accordance with the provisions of this section.

(Source: Fed. Rev. Act 1918, § 221, c. Portions in italics new.)

Withheld income to be included in return of recipient.

4. Income upon which any tax is required to be withheld at the source under this section shall be included in the return of the recipient of such income, but any amount of tax so withheld shall be credited against the amount of income tax as computed in such return.

(Source: Fed. Rev. Act 1918, § 221, d.)

\section{Tax not to be collected twice.}

5. If any tax required under this section to be deducted and withheld is paid by the recipient of the income, it shall not be recollected from the withholding agent; nor in cases in which the tax is so paid shall any penalty be imposed upon or collected from the recipient of the income or the withholding agent for failure to return or pay the same, unless such failure was fraudulent and for the purpose of evading payment.

(Source: Fed. Rev. Act 1918, § 221, e.) 


\section{Who must make return: individual.}

SEc. 367. Taxpayers' returns. Every taxpayer having a net income for the taxable year of one thousand dollars or over if single or if married and not living with husband or wife, or of two thousand dollars or over if married and living with husband or wife, shall make under oath a return stating specifically the items of his gross income and the deductions and credits allowed by this article. If a husband and wife living together have an aggregate net income of two thousand dollars or over, each shall make such a return unless the income of each is included in a single joint return. If the taxpayer is unable to make his own return the return shall be made by a duly authorized agent or by the guardian or other person charged with the care of the person or property of such taxpayer. A taxpayer other than a resident shall not be entitled to the deductions authorized by section three hundred and sixty unless he shall make under oath a complete return of his gross income both within and without the state.

(Source: Fed. Rev. Act 1918, § 223; portions in italics new.)

Individual returns.-Every individual whose net income, as defined in section 212 of the statute and articles $21-26$, is $\$ 1,000$ or over for the taxable year must make a return of income unless married and living with husband or wife as defined in article 303. The return shall be for his taxable year, whether calendar or fiscal. Whether or not an individual is the head of a family or has dependents is immaterial in determining his liability to render a return. If an individual is a married person living with husband or wife, no return need be made where their aggregate net income is less than $\$ 2,000$; but a separate return must be made by each of them, regardless of the amount of the individual income of each, where their aggregate net income is $\$ 2,000$ or over, unless they join in a single return. The husband shall include in his return the income derived from services rendered by the wife or from the sale of products of her labor if she does not file a separate return or join with him in a return setting forth her income separately. (Art. 401.)

Return of income of minor.-An individual under 21 years of age or under the statutory age of majority where he lives, whatever it may be, is required to render a return of income if he has a net income of his own of $\$ 1,000$ or over for the taxable year. If he is married see article 401 . If the aggregate of the net income of a minor from any property which he possesses, and from any funds held in trust for him by a trustee or guardian, and from any earnings for his own use, is at least $\$ 1,000$, a return as in the case of any other individual must be made by him or by 
his guardian or some other person charged with the care of his person or property for him. See article 422. If, however, a minor is dependent upon his parent, who appropriates or may appropriate his earnings, such earnings are income of the parent and not of the minor for the purpose of the normal tax and surtax. In the absence of proof to the contrary a parent will be assumed not to have emancipated his minor child and must include in his return any earnings of the minor. (Art. 403.)

Return of income of nonresident alien.-A nonresident alien individual shall make or have made a full and accurate return on form 1040 (revised) or form $1040 \mathrm{~A}$ (revised) of his income received from sources within the United States, regardless of amount, unless the tax on such income has been fully paid at the source. See section 217 of the statute and articles 311-316. The responsible representatives of nonresident aliens in connection with any sources of income which such nonresident aliens may have within the United States shall make a return of such income, and shall pay any and all tax, normal and additional, assessed upon the income received by them in behalf of their nonresident alien principals, in all cases where the tax on income so in their receipt, custody or control shall not have been withheld at the source. The agent of a nonresident alien is responsible for a correct return of all income accruing to his principal within the purview of the agency. The agency appointment will determine how completely the agent is substituted for the principal for tax purposes. Where upon filing a return of income it appears that a nonresident alien is not liable for tax, but nevertheless a tax shall have been withheld at the source, in order to obtain a refund on the basis of the showing made by the return there should be attached to it a statement showing accurately the amounts of tax withheld, with the names and post-office addresses of all withholding agents. (Art. 404.)

Return of corporate dividends.-Dividends on stock of domestic corporations or resident foreign corporations are prima facie income of the record owner of the stock, and such record owner will be liable for any additional tax based thereon, unless a disclosure of the actual ownership is made to the Commissioner on form 1087 (revised) which shall show that the record owner is not the actual owner and who the owner is and his address. In all cases where the actual owner is a non-resident alien individual and the record owner is a person in the United States, the record owner will be considered for tax purposes to have the receipt, custody, control and disposal of the dividend income and will be required to make return for the actual owner, regardless of the amount of the income, and to pay any surtax found by such return to be due. (Art. 405.)

Verification of returns.-All income tax returns must be verified under oath or affirmation. Persons in the naval or military service of the United States may verify their returns before any official authorized to administer oaths for the purposes of those services. Income tax returns executed abroad may be attested free of charge before United States consular offcers. Where a foreign notary or other official having no seal shall act as attesting officer, the authority of such attesting officer should be certified 
to by some judicial official or other proper officer having knowledge of the appointment and official character of the attesting officer. (Art. 406.)

\section{Who must make return: partnerships.}

SEc. 368. Partnership returns. Every partnership shall make a return for each taxable year, stating specifically the items of its gross income and the deductions allowed by this article, and shall include in the return the names and addresses of the individuals who would be entitled to share in the net income if distributed and the amount of the distributive share of each individual. The return shall be sworn to by any one of the partners.

(Source: Fed. Rev. Act 1918, § 224.)

Partnership returns.-Every partnership must make a return of income, regardless of the amount of its net income. The return shall be on form 1065 (revised) and shall be sworn to by one of the partners. Such return shall be made for the taxable year of the partnership, that is, for its annual accounting period (fiscal year or calendar year as the case may be), irrespective of the taxable years of the partners. See section 218 of the statute and articles 321-327. If the partnership makes any change in its accounting period, it shall make its return in accordance with the provisions of section 226 and article 431. (Art. 411.)

\section{Who must make return: fiduciary.}

SEc. 369. Fiduciary returns. Every fiduciary (except receivers appointed by authority of law in possession of part only of the property of a taxpayer) shall make under oath a return for the taxpayer for whom he acts, first, if the net income of such taxpayer is one thousand dollars or over if single, or if married and not living with husband or wife, or two thousand dollars or over if married and living with husband or wife, or second, if the net income of such taxpayer, if an estate or trust, is one thousand dollars or over or if any beneficiary is a taxpayer other than a resident of the state, which return shall state specifically the items of the gross income and the deductions, exemptions and credits allowed by this article. Under such regulations as the comptroller may prescribe, a return made by one of two or more joint fiduciaries and filed in the office of the comptroller or collector in the district where such fiduciary resides shall be a sufficient compliance with the above requirement. The fiduciary shall make oath that he has 
sufficient knowledge of the affairs of such individual, estate or trust to enable him to make the return, and that the same is, to the best of his knowledge and belief, true and correct.

Fiduciaries required to make returns under this article shall be subject to all the provisions of this article which apply to taxpayers.

(Source: Fed. Rev. Act 1918, \& 225. Portions in italics new.)

See chapter on Trusts and Estates, supra.

(Note: See Chapters $X X V I$ and $X X V I I I$, supra.)

Fiduciary returns.-Every fiduciary, or at least one of joint fiduciaries, must make a return of income $(a)$ for the individual whose income is in his charge, if the net income of such individual is $\$ 2,000$ or over if married and living with husband or wife or is $\$ 1,000$ or over in other cases, or $(b)$ for the estate or trust for which he acts, if the net income of such estate or trust is $\$ 1,000$ or over or if any beneficiary of such estate or trust is a non-resident alien. * * * In such a case the fiduciary shall include in the return a statement of each beneficiary's distributive share of the net income, whether or not distributed before the close of the taxable year for which the return is made. See section 219 of the statute and articles 341-346. If the net income of a decedent from the beginning of the taxable year to the date of his death was $\$ 1,000$, if unmarried, or $\$ 2,000$, if married, the executor or administrator shall make a return for such decedent. (Art. 421.)

And the said return shall be signed and sworn to by the fiduciary, if an individual, making same, and his full address must be stated. If the fiduciary is an organization, the return shall be signed and sworn to by the president, secretary, or treasurer of said organization. (Art. 73, Reg. 33, Jan. 5, 1914.)

Return by guardian or committee.-A fiduciary acting as the guardian of a minor having a net income of $\$ 1,000$ or $\$ 2,000$, according to the marital status of such person, must make a return for such minor and pay the tax, unless such minor himself makes a return or causes it to be made. A fiduciary acting as the committee of an insane person having an income of $\$ 1,000$ or $\$ 2,000$, according to the marital status of such person, must make a return for such incompetent and pay the tax. (Art. 422.)

Returns where two trusts.-In the case of two or more trusts the income of which is taxable to the beneficiaries, which were created by the same person and are in charge of the same trustee, the trustee shall make a single return for all such trusts, notwithstanding that they may arise from different instruments. When, however, a trustee holds trusts created by different persolis for the benefit of the same beneficiary, he shall make a return for each trust separately. (Art. 423.)

Fiduciaries acting for minors or incompetent persons are permitted to take the personal exemption as to income derived from property of 
which they have charge in favor of each ward or beneficiary. (Art. 14, \151, Reg. 33, Rev., Jan. 2, 1918.)

In all cases where fiduciaries act for minors or other incompetents they are held, for the purpose of the income tax, to be acting as the agents of such minors or other incompetents and must pay all tax (normal and additional) chargeable on such income in their hands as though the persons for whom they act were acting for themselves. (T. D. 2231, July 26, 1915.)

When the required return has not been made by a person acting as guardian, agent of a nonresident alien, or by one acting in any other capacity in which the law makes it a duty for him to represent the individual, notice of failure to make such return will be served upon such guardian or agent.

The person upon whom such notice is served may, however, when the facts warrant, file evidence with the collector showing that the individual for whom he acts did not receive an income subject to tax during the year, or that the said guardian or agent has filed the return with some other collector. (Art. 18, Reg. 33, Jan. 5, 1914.)

Return by receiver.-A receiver who stands in the stead of an individual or corporation must render a return of income and pay the tax for his trust, but a receiver of only part of the property of an individual * * * need not. * * * A receiver in charge of the business of a partnership shall render a return. 'A receiver of the rents and profits appointed to hold and operate a mortgaged parcel of real estate, but not in control of all the property or business of the mortgagor, and a receiver in partition proceedings, are not required to render returns of income. In general, statutory receivers and common law receivers of all the property or business of an individual or corporation must make returns. (Art. 424.)

Return for nonresident alien beneficiary.-Where a citizen or resident fiduciary has the distribution of trust income for which there is a nonresident alien beneficiary, the fiduciary must make a return for such nonresident alien and pay the tax. If there are two or more beneficiaries, the fiduciary shall render a return for each nonresident alien beneficiary. (Art. 425.)

\section{Returns when accounting period changed.}

SEc. 370. Returns when accounting period changed. If a taxpayer, with the approval of the comptroller, changes the basis of computing net income from fiscal year to calendar year, a separate return shall be made for the period between the close of the last fiscal year for which return shall be made for the period between the close of the last fiscal year for which return was made and the following December thirty-first. If the change is made from cal- 
endar year to fiscal year, a separate return shall be made for the period between the close of the last calendar year for which return was made and the date designated as the close of the last fiscal year. If the change is from one fiscal year to another fiscal year, a separate return shall be made for the period between the close of the former fiscal year and the date designated as the close of the new fiscal year. If a taxpayer making his first return for income tax keeps his accounts on the basis of a fiscal year, he shall make a separate return for the period between the beginning of a calendar year in which such fiscal year ends and the end of such fiscal year.

In all of the above cases the net income shall be computed on the basis of such period for which separate return is made, and the tax shall be paid thereon at the rate for the calendar year in which such period is included; and the exemptions allowed in this article shall be reduced respectively to amounts which bear the same ratio to the full exemptions provided for as the number of months in such period bears to twelve months.

(Source: Fed. Rev. Act 1918, § 226; see also under § 358-2, supra.)

\section{Returns: where and when filed.}

SEc. 371. Time and place of filing returns. Returns shall be made to the comptroller on or before the fifteenth day of March in each year of the taxpayer's net income for his last preceding taxable year. The comptroller may grant a reasonable extension of time for filing returns whenever in its judgment good cause exists and shall keep a record of every such extension and the reason therefor. Except in the case of taxpayers who are abroad, no such extension shall be granted for more than six months. Such returns shall, so far as may be, set forth the same or similar items called for in the blank forms of return prescribed by the United States commissioner of internal revenue for the enforcement of the act of congress known as the revenue act of nineteen hundred and eighteen, together with such other facts as the comptroller may deem necessary for the proper enforcement of this article. There shall be annexed to such return the affidavit or affirmation of the person making the return, to the effect that the statements con- 
tained therein are true. Blank forms of return shall be furnished by the comptroller upon application, but failure to secure the form shall not relieve any taxpayer from the obligation of making any return herein required.

(Source: New, but see Fed. Rev. Act 1918, § 227.)

Time for filing return upon death or termination of trust.-As soon as possible after his appointment and qualification, without waiting for the close of the taxable year, an executor or administrator shall file a return of income for the decedent. Upon the completion of the administration of an estate and final accounting an executor or administrator shall file a return of income of the estate for the portion of the taxable year in which the administration was closed, attaching to the return a certified copy of the order for his discharge. An ancillary administrator need make no separate return if the domiciliary administrator includes in his return the entire income of the estate. Similarly, upon the termination of any other trust the trustee shall make a return without waiting for the close of the taxable year. In any such case the requirements with respect to the payment of the tax are the same as if the return were for a full taxable year closing at the end of the month during which the decedent dies or the estate is settled or the trust is terminated, as the case may be. The payment of the tax before the end of the taxable year in such circumstances does not relieve the taxpayer from liability for any additional tax which might subsequently be imposed upon income of the taxable year. (Art. 442.)

Last due date.-The last due date is the last day upon which a return is required to be filed in accordance with the provisions of the statute or the last day of the period covered by an extension of time granted by the collector or Commissioner. When the last due date falls on Sunday or a legal holiday, the last due date for filing returns will be the day following such Sunday or legal holiday. If placed in the mails the return should be posted in ample time to reach the collector's office, under ordinary handling of the mails, on or before the date on which the return is required to be filed. If a return is made and placed in the mails in due course, properly addressed and postage paid, in ample time to reach the office of the collector on or before the last due date, no penalty will attach should the return not be actually received by such officer until subsequently to that date. Where a question may be raised as to whether or not the return was posted in ample time to reach the collector's office on or before the due date, the envelope in which the return was transmitted will be preserved by the collector and forwarded to the Commissioner with the return. (Art. 447.)

Interest runs on amount of installment during period of extension availed of.- "In any case in which the time for the payment of any installment is at the request of the taxpayer thus postponed, there shall be added as part of such installment interest thereon at the rate of $1 / 2$ of 1 
per centum per month from the time it would have been due if no extension had been granted, until paid."

For discussion of administrative features see Part III of this volume.

\section{Tax districts.}

SEc. 372. Administration of income tax law. The comptroller shall administer and enforce the tax herein imposed for which purpose he may divide the state into districts in each of which a branch office of the comptroller may be maintained; provided that in no cases shall a county be divided in forming a district.

(Source: New.)

\section{Powers of comptroller.}

SEc. 373. Powers of comptroller. If in the opinion of the comptroller any return of a taxpayer is in any essential respect incorrect he shall have power to revise such return, or if any taxpayer fails to make return as herein required, the comptroller is authorized to make an estimate of the taxable income of such taxpayer from any information in his possession, and to audit and state an account according to such revised return or the estimate so made by him for the taxes, penalties and interest due the state from such taxpayer. The comptroller shall also have power to examine or cause to have examined, in case of failure to report the books and records of any such taxpayer, and may take testimony and require proof material for his information.

(Source: New. See Part III, supra.)

\section{Revision.}

SEC. 374. Revision and readjustment of accounts by comptroller. If an application for revision be filed with the comptroller by a taxpayer within one year from the time of the filing of the return, or if the tax of such taxpayer shall have been recomputed, then from the time of such recomputation, the comptroller shall grant a hearing thereon and if it shall be made to appear, upon any such hearing by evidence submitted to him or otherwise, that any such computation includes taxes or other charges which could not have 
been lawfully demanded, or that payment has been illegally made or exacted of any such amount so computed, the comptroller shall resettle the same according to law and the facts, and adjust the computation of taxes accordingly, and shall send notice of his determination thereon to the taxpayer.

(Source: New, but see Part III, supra.)

\section{Writ of Certiorari.}

SEc. 375. Review of determination of comptroller by certiorari and regulations as to writ. The determination of the comptroller upon any application made to him by any taxpayer for revision and resettlement of any computation of tax, as prescribed by this article, may be reviewed in the manner prescribed by and subject to the provisions of section one hundred and ninety-nine of this chapter. No certiorari to review any statement of a computation or any determination by the comptroller under this article shall be granted unless notice of application therefor is made within thirty days after the service of the notice of such determination. Eight days' notice shall be given to the comptroller of the application for such writ. Before making the application an undertaking must be filed with him, in such amount and with such sureties as a justice of the supreme court shall approve, to the effect that if such writ is dismissed or the determination of the comptroller affirmed, the applicant for the writ will pay all costs and charges which may accrue against him in the prosecution of the writ, including costs of all appeals.

(Source: New. See Part III, supra.)

\section{False returns-Failure to make returns-Penalties.}

Sec. 376. Penalties. 1. Any person required by this article to make, render, sign or verify any return, who fails to make, render, sign or verify such return within the time required by or under a provision of law, or who makes any false or fraudulent return or statement, with intent to evade any tax imposed by this article, shall be guilty of a misdemeanor and shall, upon conviction, be fined not to exceed one thousand dollars, or be imprisoned not to exceed one year, or both, at the discretion of the court. 
2. If any such person shall fail or refuse to make a return of income at the time or times hereinbefore specified, but shall voluntarily make a correct return of income within sixty days thereafter, there shall be added to his tax five per centum of the amount otherwise due, but such additional amount shall in no case be less than two dollars.

3. If any person liable to taxation under this article fails to make a return as herein required, the amount of income of such person discovered to be taxable shall be subject to twice the ordinary rate of taxation. If any person liable to taxation under this article makes any false or fraudulent return or statement, with intent to evade any tax imposed by this article, and an additional amount is discovered to be taxable, such additional amount shall be subject to twice the ordinary rate of taxation. Such tax shall be collected at such time and in such manner as may be designated by the comptroller. This penalty shall be additional to all other penalties in this or any other section provided.

(Source: New, but compare Fed. Rev. Act 1918, § 253.)

The specific penalty will not be asserted under certain circumstances.-Liability to specific penalty attaches upon all delinquent returns and is recoverable by suit. By Section 3214 R. S. the Commissioner of Internal Revenue may or may not institute suit. It has been decided not to institute suit nor to assert specific penalty in certain cases. The assertion of specific penalty does not depend upon the fact of whether or not the $[25] \%$ addition to tax has been assessed. In some cases where the the [25] $\%$ addition to tax must be assessed because the return was filed after notice from the collector, the specific penalty will not be asserted. It will not be asserted, regardless of whether the [25]\% addition to tax has been assessed, in cases falling under any of the following designations:

1. Extension granted. Where a return is filed within the thirty-day period of extension granted by the collector or within a further period of extension granted by the Commissioner of Internal Revenue, as provided by Section 14 (c) of the Act of September 8, 1916.

2. Return on time. Specific penalty will not be asserted upon an amended return provided the original return was filed within the prescribed time.

3. Mailed in time. Where an affidavit is filed satisfactorily establishing that the return was placed in the mails in ample time to reach the Collector's office in ordinary course of mails before the close of business on the final day for filing.

4. Tentative return. Where an informal return was filed within the 
time prescribed. The return of a parent company including therein the income of a subsidiary company will be accepted as a tentative return of the subsidiary company, if the fact is stated that the tentative return includes the income of the subsidiary.

5. Filed in wrong district. Where the return was filed in some other collection district within the prescribed time.

6. Net income under $\$ 3,000$. Where it develops that the net income of an individual for $1913,1914,1915$ or 1916 was less than $\$ 3,000$, or under the Act of October 3, 1917, for 1917, etc., less than $\$ 1,000$ or $\$ 2,000$.

7. Erroneous information. Where the delinquency is alleged to be due to erroneous or misleading information given by officials or employees of the Internal Revenue Service and there is no evidence in conflict therewith.

8. Organization incomplete. Where it is established that the organization of a corporation, joint-stock company or association, or insurance company was not completed until after the expiration of the period for which the return should have been filed.

9. Death. Where by reason of the death of an individual his return for the year or portion of the year prior to his death is not filed within the time preseribed. The death of a delinquent abates liability to specific penalty. An administrator or executor is charged with the duty of rendering a return for the decedent, and if he is appointed in ample time to make the return prior to March lst and fails to do so, he should be charged as delinquent and the specific penalty should be asserted against him. The administrator or executor will not be relieved from specific penalty unless the return is made within a reasonable time after his appointment.

10. Severe illness or unavoidable absence. Where it is clearly established that the delinquency in the filing of a return of an individual or of a corporation within the time prescribed was due to severe illness of the individual or of an officer of a corporation whose duty it was to prepare or sign the return, or to unavoidable absence from place of business or place of abode.

11. Absence from the United States. Where it appears that the filing of a return within the time prescribed was rendered impossible by reason of absence from the United States. Delinquency beyond the period of extension which may be granted by the Commissioner of Internal Revenue will not be excused under this heading.

12. Military or naval service of United States. Where delinquency of an individual was occasioned by service in the military or naval forces of the United States.

13. Not organized for profit. Comprehends numerous small corporations not organized primarily for profit, such as local telephone companies, co-operative purchasing societies, etc., concerning whose liability under the law to make a return there may have been a reasonable doubt.

14. Inactive corporations. Those which transacted no business and had no income during the return year. 
15. Fiscal year. Corporations which have established a fiscal year in the manner prescribed by law which file a return on or before the first day of the third month following the close of the fiscal year.

16. Assigned. Where corporations have made an assignment on account of insolvency and do not intend again to engage in business.

17. Insolvent. Where the assets of a corporation are insufficient for the payment of its debts and the corporation has ceased to do business.

18. Charter forfeited. Where, prior to the date when the return was due, the charter of a corporation is forfeited on account of noncompliance with state laws. It must be clear, however, that business in the name of the corporation was suspended at the time of such forfeiture. If business was continued under the same name, the concern will be held to be an association and the same liabilities will attach as if the charter had not been forfeited.

19. Defunct. Where corporations are out of business, have no assets, maintain no organization, and the purpose for which organized has been abandoned.

20. Dissolved. Where all the assets of a corporation have been distributed.

21. Sale. Where corporations have disposed of all their assets and property by sale to other corporations, firms, or individuals and business is not longer carried on under their charters.

22. Consolidated, merged or succeeded. Where corporations have terminated their existence as represented by these terms and it appears that no assets or property remain in the name of the retiring corporation.

23. No assets. Includes all corporations having no assets from which to submit an offer in compromise. (L. Mimeograph Letter No. 1675 to Collectors, November 3, 1917.

\section{Tax payable at time of filing return.}

SEc. 37\%. When payable. 1. Each taxpayer shall, at the time of filing his return, pay to the comptroller the amount of tax payable hereunder as the same shall appear from the face of the return. If the time for filing the return shall be extended, he shall pay in addition interest thereon at the rate of six per centum per annum from the time when the return was originally required to be filed to the time of payment.

2. As soon as practicable after the return is filed, the comptroller shall examine it and compute the tax.

3 . If the amount of tax as computed shall be greater than the amount theretofore paid, the excess shall be paid by the taxpayer to the comptroller within thirty days after the amount of the tax as computed shall be mailed by the comptroller. 
4. If the amount of tax as computed shall be less than the amount theretofore paid, the excess shall be refunded by the comptroller out of the proceeds of the tax retained by him as provided in this article.

(Source: New.)

\section{Notice of assessment.}

Sec. 378. Notice of assessment. Notice of tax assessment shall be sent by mail to the post office address given in the report, and the record that such notice has been sent shall be presumptive evidence of the giving of the notice and such record shall be preserved by the comptroller.

(Source: New.)

Collection of taxes; penalties and interest.

SEc. 3\%9. Collection of taxes; penalties and interest. 1. The comptroller is authorized at his discretion to designate agents for the purpose of collecting income taxes and shall require from them reasonable bond.

2. If the tax imposed by this article or any part of such tax be not paid at the time when required to be paid under the provisions of this article or in the case of additional taxes, at the time designated by the comptroller, the taxpayer liable to pay such tax shall pay to the comptroller, in addition to the amount of such tax, or part thereof, five per centum of said amount, plus one per centum for each month, or fraction of a month, the tax, or part thereof, remains unpaid.

(Sourse: New. See Part III, supra.)

\section{Warrant for collection of taxes.}

Sec. 380. Warrant for the collection of taxes. If any tax imposed by this article or any portion of such tax be not paid within sixty days after the same becomes due, the comptroller shall issue a warrant under his hand and official seal directed to the sheriff of any county of the state commanding him to levy upon and sell the real and personal property of the person owning ${ }^{1}$ the same, found

${ }^{1}$ So in the original; probably intended for "owing." 
within his county, for the payment of the amount thereof, with the added penalties, interest and the cost of executing the warrant, and to return such warrant to the comptroller and pay to him the money collected by virtue thereof by a time to be therein specified, not less than sixty days from the date of the warrant. The sheriff shall within five days after the receipt of the warrant, file with the clerk of his county a copy thereof, and thereupon the clerk shall enter in the judgment docket, in the column for judgment debtors, the name of the taxpayer mentioned in the warrant, and in appropriate columns the amount of the tax or portion thereof and penalties for which the warrant is issued and the date when such copy is filed, and thereupon the amount of such warrant so docketed shall become a lien upon the title to and interest in real property or chattels real of the person against whom it is issued in the same manner as a judgment duly docketed in the office of such clerk. The said sheriff shall thereupon proceed upon the same in all respects, with like effect, and in the same manner prescribed by law in respect to executions issued against property upon judgments of a court of record, and shall be entitled to the same fees for his services in executing the warrant, to be collected in the same manner. In the discretion of the comptroller a warrant of like terms, force and effect may be issued and directed to any agent authorized to collect income taxes, and in the execution thereof such agent shall have all the powers conferred by law upon sheriffs, but shall be entitled to no fee or compensation in excess of actual expenses paid in the performance of such duty. If a warrant be returned not satisfied in full, the comptroller shall have the same remedies to enforce the claim for taxes against the taxpayer as if the people of the state had recovered judgment against the taxpayer for the amount of the tax.

(Source: New. See Part III, supra.)

\section{Attorney-General may sure.}

SEc. 381. Action for recovery of taxes. Action may be brought at any time by the attorney-general of the state at the instance of 
the comptroller, in the name of the state to recover the amount of any taxes, penalties and interest due under this article.

(Source: New. See Part III, supra.)

\section{How proceeds of tax to be distributed.}

SEC. 382. Distribution of the income tax. Of the revenue collected under this article the comptroller shall retain in his hands sufficient to provide at all times a fund in his hands in the sum of two hundred and fifty thousand dollars out of which he shall pay any refunds to which taxpayers shall be entitled under the provisions of this article. Of the remainder, fifty per centum shall be paid into the state treasury to the credit of the general fund. The remaining fifty per centum thereof shall, not later than the first day of July, and in case of moneys subsequently collected at least quarterly thereafter, be distributed and paid to the treasurers of the several counties of the state, in the proportion that the assessed valuation of the real property of each county bears to the aggregate assessed valuation of the real property of the state. As to any county included in the city of New York such payment shall be made to the receiver of taxes in such city and be paid into the general fund for the reduction of taxation of the city of New York. The county treasurer shall apportion the amount so received among the several towns and cities within the county in proportion that the assessed valuation of the real property of each town or city bears to the aggregate assessed valuation of the real property of the county, and shall credit the amount apportioned to each town against the county tax payable by it, and shall pay the amount apportioned to each city to the chief fiscal officer of the city to be paid into the general fund for city purposes. If the amount of the credit to a town exceeds the county tax from such town, the excess shall be paid to the supervisor of the town and be by him credited to general town purposes.

(Source: New.)

\section{Comptroller to make regulations.}

SEc. 383. Comptroller to make regulations and to collect facts. The comptroller is hereby authorized to make such rules and reg- 
ulations, and to require such facts and information to be reported, as it may deem necessary to enforce the provisions of this article.

(Source: New.)

\section{Secrecy.}

SEc. 384. Secrecy required of official; penalty for violation. 1. Except in accordance with proper judicial order or as otherwise provided by law, it shall be unlawful for the comptroller, any agent, clerk, or other officer or employee to divulge or make known in any manner the amount of income or any particulars set forth or disclosed in any report or return required under this article. Nothing herein shall be construed to prohibit the publication of statistics so classified as to prevent the identification of particular reports or returns and the items thereof, or the inspection by the attorneygeneral or other legal representatives of the state of the report or return of any taxpayer who shall bring action to set aside or review the tax based thereon, or against whom an action or proceeding has been instituted in accordance with the provisions of sections three hundred and eighty and three hundred and eighty-one of this chapter. Reports and returns shall be preserved for three years and thereafter until the comptroller orders them to be destroyed.

2. Any offense against subdivision one of this section shall be punished by a fine not exceeding one thousand dollars or by imprisonment not exceeding one year, or both, at the discretion of the court, and if the offender be an officer or employee of the state he shall be dismissed from office and be incapable of holding any public office in this state for a period of five years thereafter.

(Source: New. See Fed. Rev. Act 1918, § 1317 amending \& 3167 Rev. Stats.)

\section{Contract to assume tax illegal.-Act separable, etc.}

SEC. 385. Contract to assume income tax illegal. It shall be unlawful for any person to agree or contract directly or indirectly to pay or assume or bear the burden of any tax payable by any taxpayer under the provisions of this article. Any such contract or agreement shall be null and void and shall not be enforced or given effect by any court.

2. If any clause, sentence, paragraph, or part of this act shall for any reason be adjudged by any court of competent jurisdiction 
to be invalid, such judgment shall not affect, impair, or invalidate the remainder of this act, but shall be confined in its operation to the clause, sentence, paragraph, or part thereof directly involved in the controversy in which such judgment shall have been rendered.

3. An assessment on account of personal property made prior to August first, nineteen hundred and nineteen, shall be as valid and effectual as if this act had not been passed, and nothing in this act shall be construed to impair the obligation to pay taxes assessed on account of personal property in the year nineteen hundred and eighteen or the year nineteen hundred and nineteen prior to August first whether payable in that year or not.

4. If in any city entitled to receive a portion of the taxes collected under article sixteen of the tax law as added by this act the budget for the fiscal year current on July first, nineteen hundred and twenty, shall be completed prior to that date, the board of estimate and apportionment or other board or body having the duty of preparing the budget in such city shall have the power subsequent to such date and before the levy of the taxes on account of the appropriations made by such budget to revise the estimates of city revenue so as to include in such calculations the income to the city from taxes collected under article sixteen of the tax law as added by this act.

5. The sum of three hundred thousand dollars $(\$ 300,000)$, or so much thereof as may be needed, is hereby appropriated out of any money in the treasury, not otherwise appropriated, for the administration of article sixteen of the tax law as added by this act, but any position established or salary fixed for such purpose shall be deemed temporary only and subject to the future action of the legislature, but no new position shall be created nor salary fixed except on the unanimous approval of the Governor, the Chairman of the Senate Finance Committee and the Chairman of the Assembly Ways and Means Committee.

6. Except as otherwise provided herein this act shall take effect immediately.

Approved by Governor, May 14, 1919.

(Source: New.) 


\section{EXCESS PROFITS TAX DECISION.}

The People of the State of New York ex rel. Barcalo Manufacturing Company, Relator, Appellant, Against Walter H. Knapp, Ralph W. Thomas and John J. Merrill, as and Constituting the State Tax Commission of the State of New York, Respondents.

The People of the State of New York ex rel. American Broom and Brush Company, Relator, Appellant, Against Walter H. Knapp, Michael J. Walsh and John J. Merrill, as and Constituting the State Tax Commission of the State of New York, Respondents.

Argued March term, 1919.

Decided April 8, 1919.

Certiorari to review the action of the State Tax Commission in the assessment of taxes against the above-named corporations under the provisions of the State Franchise Tax Law of 1917.

Elon R. Brown and Edward H. Letchworth, of Watertown, for the relators, appellants; Charles D. Newton, Attorney-General (C. T. Dawes, Deputy Attorney-General, of counsel), for the State Tax Commission.

Woodward, J.-The questions involved in this review relate to the construction of chapter 726 of the Laws of 1917, in effect June 4th of that year, and especially section 209 of that act. By the provisions of chapter 276 of the Laws of 1918, sections 209, 211, 214 and 219-d of the original act were amended, and it was provided in section 5 of the amending act that the "sections of such chapter amended by this act shall be construed as having been in effect, as so amended, as of the date of the original enactment of article nine-a of the tax law, as added by chapter seven hundred and twenty-six of the laws of nineteen hundred and seventeen," so that, except as it may bear upon the proper construction of the law, there is no occasion for considering the provisions of the original sections for which substitutions have been made.

The act of 1917 inaugurated a new policy in the taxation of corporations engaged in merchandizing and manufacturing, or, more accurately speaking, it put these corporations under the provisions of a franchise tax in lieu of taxes on personal property, etc., and in this regard took them out of the jurisdiction of local assessors. It was a move looking to the simplification of the tax system; of plucking the maximum of feathers with the minimum of noise from the goose, to borrow the expression of an ancient political philosopher, and it is to be construed from the standpoint of its policy and purpose. Section 209 of the act, as it now stands, and as it stood at the time the assessments here under consideration were made, provides: "For the privilege of exercising its franchise in this state in a corporate or organized capacity every domestic manufacturing and every domestic mercantile corporation $*^{*}{ }^{*}$ shall annually pay in advance for the year beginning November first next preceding an annual franchise tax, to be computed by the tax commission upon the basis of its net income for its fiscal or the calendar year next preceding, as hereinafter provided, which income is presumably the same as the 
income upon which such corporation is required to pay a tax to the United States."

Section 211 of the act provided that every "corporation, taxable under this article," should make an annual report on or before the first day of July in each year to the tax commission, giving the name and location of the principal place of business of such corporation, the State under the laws of which organized, and the date thereof; the kind of business transacted, and (2) the "amount of its net income for its preceding fiscal or the preceding calendar year as shown in the last return of annual net income made by it to the United States treasury department, and if the corporation shall claim that such return is inaccurate, the amount claimed by it to be the net income for such period."

Having thus provided for ascertaining the amount of net income upon which the corporation was called upon to pay taxes to the United States, section 214 provides that if "the entire business of the corporation be transacted within the state, the tax imposed by this article shall be based upon the entire net income of such corporation for such fiscal or calendar year as returned to the United States treasury department, subject to any correction thereof for fraud, evasion or errors, ascertained by the State Tax Commission."

The corporations involved in this discussion are domestic organizations, and so far as appears all their business is transacted in the State of New York. They are subject to a tax of 3 per cent. upon "the entire net income" for the fiscal or calendar year involved in the assessment, "as returned to the United States treasury department, subject to any correction thereof for fraud, evasion or errors ascertained by the state tax commission." The rule seems entirely simple. The presumption is that the "entire net income" returned by the corporation to the United States treasury department is the real net income of the corporation. If the corporation, in its return to the State, finds that it has erroneously stated any fact in its report to the United States it is privileged to state the amount claimed by it to be the net income, and the State Tax Commission is authorized to make corrections for "fraud, evasion or errors," so that the actual "entire net income" for the year involved shall be made to appear, and upon this basis the tax of 3 per cent. is imposed for the privilege of exercising corporate franchises in this State.

In the cases now before us, the State Tax Commissioners have followed the statute literally; they have taken the "entire net income" of the corporations involved, as returned to the United States treasury department, and upon such "entire net income" they have levied a tax of 3 per cent. There is no claim that there were any errors in the returns made to the United States treasury department, and no question of fraud or evasion are involved. The relators contend, not that there is anything wrong with their returns to the United States, but that in some manner the United States statutes operate to change the law as it appears from a literal reading, and that the so-called excess profits taxes assessed for and as of the year 1917 should be deducted from the incomes of these corporations before the computation of the State franchise tax is made, 
and that the income taxes paid to the Federal government during the year 1917 by the American Broom and Brush Company should be deducted from its income before such computation by the State Tax Commission is made.

But, why? This is not an income tax; it is a franchise tax. It is a tax for the privilege of doing business in a corporate form in the State of New York, and the only relation of the Federal act to the statute of New York is the basis for the computation of the State tax. It provides for a 3 per cent. tax upon the basis of the "entire net income" of the corporation as shown by its report to the United States government, unless such income is erroneously stated, when the actual "entire net income" as determined by the Tax Commission becomes the foundation of the assessment. This act was passed in its present form subsequent to the United States statute under which the "entire net income" was determined in the cases before us, and if there had been any intention of allowing the credits which are allowed under the Federal act for the purpose of determining the amount to be paid it would have been very easy to have made this fact manifest in the language used, and not left it to inferences not suggested by anything in the policy of the law. Under the Federal act the income taxes are levied after making a deduction for the excess profits taxes assessed for the current year and to be paid in the following year; but the State statute is not concerned with the excess profits taxes; it bases its franchise tax upon the amount of the "entire net income" for the previous year, as returned to the United States treasury department, or as corrected in manner provided for in the act, and this is not affected by the excess profits tax assessed for the year upon such profits. Excess profits are the income of the year on which the State taxes are based, and such income constitutes a part of the basis on which the "entire net income" is founded, and the fact that the United States permits a credit for such excess profits does not serve to change the actual income which is disclosed in the returns of the taxpayer. What is income for the year prior to the levying of the tax is the matter to be determined by the Tax Commission, and this is clearly not affected by what the Federal government allows in the way of deductions or credits in fixing the amount of the tax which the corporation is to pay to the treasury of the United States.

The changes in the State statute, following the adoption of the Federal act, indicate no change in the policy of the State; no intention of modifying the provision that there shall be a tax of 3 per cent. upon the "entire net income," as shown by the taxpayer's return to the Federal government, with such corrections as shall be shown to be justified by reason of fraud, evasion or errors. To say that the errors here mentioned refer to errors of law, through a failure of the State Legislature to adjust itself to the credits and exemptions of the Federal act, is to give a strained construction to language, and one which is entirely out of harmony with the general structure of the act. The errors are those referred to in subdivision 2 of section 211 as amended, where "if the corporation shall claim that such return to the Federal government is inaccurate, the 
amount claimed by it to be the net income for such period" shall be given, and then it is made the duty of the Tax Commission to determine the true net income.

There is here no question of unequal or double taxation. The United States imposes an income tax upon a basis which seeks to arrive at the actual income, through reports submitted under oath by the taxpayer. The State of New York makes use of the net income thus established as the foundation for a franchise tax, and establishes machinery for determining what the actual "entire net income" is where for any reason the Federal report does not disclose the true amount. The only relation of the Federal act is in so far as it presumptively shows the "entire net income" of the corporation for the year involved, and the deductions or credits or exemptions which the Federal government provides in connection with the fixing of its income and excess profits taxes finds no place in our statute law, because it has no bearing upon the fact of "entire net income," which is the only fact which is important. Suppose, for instance, that the Legislature had merely provided for a 3 per cent. franchise tax upon the "entire net income" or corporations, and had provided exactly the same system of ascertaining the fact of net income which is in use by the United States. Can any one suggest that it would not have arrived at the same net income which is shown in the Federal reports for the same periods, or that the exemptions, deductions and credits allowed in the Federal act would have had any part in determining such "entire net income?" The net income of a corporation is, of course, the amount of its income after paying its expenses; its overhead, its interest on borrowed money, its labor and material costs, etc., and these, in the absence of statutory provisions, include moneys actually paid out for taxes. They do not, of course, include credits such as these allowed for excess profits, subsequently to be paid, nor have they anything to do with exemptions. The Federal statute has prescribed what shall constitute net income, and the State of New York has adopted that standard, giving to the Tax Commission merely the power to correct any errors which may have occurred in the making of such reports to the Federal government, and in the assessments here under consideration the State Tax Commission has followed the law and has levied the tax upon the returns of the "entire net income" made by the relators. The State franchise tax thus assessed bears equally upon every like corporation within the State of New York. It does not constitute a double franchise tax, though the National government makes use of the same foundation in levying an income tax. The two governments act independently, and levy different taxes, and we are unable to discover any of the evils which are charged against the assessments here under consideration.

It is difficult in advance to determine what the right to do business in an organized capacity for the coming year is worth. The fixing of a measure upon which the value of the right can be determined to quite an extent must be arbitrary-perhaps artificial. In no case under our law is the actual net income the basis of a franchise tax. Either capital employed, or the gross earnings, or the capital and dividends, the pre- 
miums received, the capital stock, surplus and undivided profits, or the surplus and undivided profits, is made the measure of the tax. In this case the Legislature measures the tax by the net income as defined by, and as reported under, the Federal act. The sole question is, what is the measure adopted, and the act itself leaves no doubt upon that questionthe return of net income made.

The presumption found in section 209 of the act is not in our way. It is stated as a presumption, and if a particular case does not come within the presumption that would not destroy the plain intent and purpose of the act as otherwise declared. But the presumption comes true. Every taxable corporation is required to pay a tax upon its net income. In the case of a corporation not paying an excess profits tax the normal income $\operatorname{tax}$ is based solely upon net income returned. In the case of a corporation paying an excess profits tax that tax is based solely upon the net income returned. If we adopt the appellant's theory that the excess profits tax changes the net income, so far as the normal tax is concerned, it cannot change the result here because the appellants' excess profits tax was computed upon the return. The statute does not require that all the taxes paid must be based upon the net income, but it suggests a probability that the return is the basis of some tax required from the corporation.

The determination of the State Tax Commission should be confirmed, with costs.

\section{Removable Machinery is Personal Property and Exempt from Taxa- tion Under Art. 9-a.}

By Mr. Justice Delehanty.

People ex rel. Gen. Chemical Co. v. Cantor et al.-This proceeding is instituted to review the assessments made by defendants for the purpose of taxation for the year 1918 of real property owned by relator, located in the Borough of Queens in the City of New York. The properties were assessed as follows: Lot 5, land improved $\$ 25,000$, land with improvements thereon $\$ 105,000$; lot 50 , land improved $\$ 169,000$, land with improvements thereon $\$ 306,000$; lot 60 , land improved $\$ 23,500$, land with improvements thereon $\$ 88,000$. The amounts included for improvements on the land, viz., $\$ 80,000$ on lot $5, \$ 137,000$ on lot 50 , and $\$ 64,500$ on lot 60 , were fixed as follows: Lot 5 , buildings $\$ 40,000$, machinery and equipment $\$ 40,000$; lot 50 , buildings $\$ 77,000$, machinery and equipment $\$ 66,000$; lot 60 , buildings $\$ 26,200$, machinery and equipment $\$ 38,300$. Included in the item for machinery and equipment is an assessment conceded by relator as correctly made for "boilers, ventilating apparatus, elevators, gas, electric and water power, generating apparatus and shafting" on the following valuations. Lot 5, $\$ 12,230$; lot $50, \$ 16,840$, and lot $60, \$ 7,000$. During the time the books of annual record were open for inspection, relator filed with defendants application for correction of said assessments on the ground that same were erroneous because there was included therein the value of machinery and equipment which relator claimed were exempt from assessment by virtue of section $219 \mathrm{~J}$ of chapter 726 , 
Laws of 1917. After hearing duly had thereon the respondents decided that said machinery and equipment were properly and legally assessable as real estate as defined by subdivision 6 of section 2, article 1 of the Tax Law, and that such machinery and equipment were not exempt from assessment for taxation for local purposes under the provisions of said section $219 \mathrm{~J}$ of the Tax Law. The amount of the assessment in dispute is the difference between the total amount added for machinery and equipment and the amount at which the boilers, \&c., were included, which is as follows: Lot $5, \$ 27,770$; lot $50, \$ 43,150$; lot $60, \$ 31,300$. In other words, it is the contention of the relator that under article $9 \mathrm{~A}$ of the Tax Law (added by chap. 726, Laws of 1917, in effect June 4, 1917, amended by chaps. $271,276,292$ and 417 , Laws of 1918), the machinery and equipment other than the boilers, \&c., were exempt from taxation and therefore improperly included in the assessments. The question submitted for determination, therefore, is as to the change chapter 726 of the Laws of 1917 has made in the taxable status of machinery and equipment of manufacturing and mercantile corporations. Article 9A of the Tax Law, above mentioned, is commonly known as the Emerson Act or the "New York State Income Tax Law." It substitutes a new system of taxing manufacturing and mercantile corporations, to wit, 3 per cent. on their net income, and provides that thereafter such corporations shall not be subject to assessment or taxation on their personal property which the act defines. Section 219J of the Tax Law, so far as material, reads as follows: "Manufacturing and mercantile corporations exempt from personal property tax and from the provisions of sections twelve, twentyseven, one hundred and eighty-two and one hundred and ninety-two of the Tax Law. After this article takes effect manufacturing and mercantile corporations shall not be assessed on any personal property which for the purpose of this exemption shall include such machinery and equipment affixed to the building as would not pass between grantor and grantee as a part of the premises if not specifically mentioned or referred to in the deed, or as would, if the building were vacated or sold, or the nature of the work carried on therein changed, be moved, except boilers, ventilating apparatus, elevators, gas, electric and water power generating apparatus and shafting." Prior to the passage of the Emerson Act, "real estate" for the purpose of taxation was defined by subdivision 6, section 2 , of the Tax Law as "the land itself above and under water, all buildings and other articles and structures, substructures and superstructures, erected upon, under or above, or affixed to the same," \&c., and under the decisions of this state it has been held that pursuant to said section quoted machinery installed in a building and affixed to the realty is taxable as real estate. (N. Y. Edison Co. v. Wells, 135 App. Div., 644, and cases there cited). But the situation in this respect is now changed. The Legislature by the Emerson Act has defined what shall constitute "personal property" for the purpose of taxation of mercantile and manufacturing corporations and has made such exempt from local taxation. The language used in the statute is in nowise uncertain or doubtful of meaning, and in my opinion the plain intent thereof was to exempt from personal 
property tax such machinery and equipment affixed to the building as could be removed therefrom without material injury thereto, except, of course, boilers, \&c., expressly precluded. This is obvious from the context of the statute quoted; otherwise why an enumeration of machinery and equipment not exempt from taxation? It is well settled that the only machinery and equipment affixed to a building that would not pass by deed unless specifically mentioned therein would be such as are detachable and removable without material injury to the building, and the same rule of construction applies to the other clause of the statute, for if the machinery and equipment were permanently affixed to the building it would be properly taxable as real estate, whether or not the building were vacated or sold, or the nature of the work carried on therein changed. Viewing this legislation from all angles contended for, I am unable to reach any other conclusion than that claimed by the relator and intervenor, and as defendants conceded by stipulation that all said machinery and equipment of relator could be detached and removed without material injury to the building in question, I conclude that the motion for reduction of assessment should be granted as prayed for. Settle order accordingly on notice.

\section{FORMS.}

FORM 101.

\section{NEW YORK STATE INCOME TAX}

Eugene M. Travis, State Comptroller

(This certificate has no effect on citizenship or voting residence.)

Certificate of Taxpayer Claiming Residence in the State of New YoRK

(To be filed with withholding agent by resident of New York State, pursuant to section 366 of the tax law, for the purpose of claiming the benefit of such residence for income tax purposes.)

To

(Withholding agent)

(Address)

I hereby declare that I am a resident of the state of New York; that I reside at.........................................

(Street and number)

(City, town or village)

that I have no definite intention as to when (if at all) I will establish my home without the state; and that if I decide to establish my home without the state, or at another place within the state, I will promptly give you notice of that fact and of my new residence address.

(Signed) 
Affidavit by Corporation that has Discontinued Business. STATE OF NEW YORK, County of....................

.................. being duly sworn, deposes and says:

That up to the ..... day of $. . \ldots \ldots \ldots, 191 \ldots$, he was an officer of the $\ldots \ldots \ldots \ldots \ldots$ corporation, to wit, its $\ldots \ldots \ldots \ldots$ That on said date, the said company discontinued its business in the State of New York.

That since said .... day of $\ldots . \ldots \ldots, 191 \ldots$, the said corporation has not transacted business of any kind whatsoever in New York State and has entirely ceased to exercise its corporate franchise in New York State; it has given up its place of business and cancelled the lease which it held on its New York office, and has now no place of business and no property of any kind in this state, nor has it since ...... day of ........ 191... (Here state any additional facts to show that on or before the 1 st day of November, 191.., or for the taxable year in question, the corporation had ceased doing business or had ceased exercising its corporate franchises.)

That said company has no outstanding accounts of any kind, and no bank account in New York State.

Sworn to before me, this

day of $191 \ldots$

The form of application for a revision of a tax, preliminary to certiorari proceedings is given in the body of the book.

The following forms in certiorari are under Article 9-a, but the forms may be varied to suit the facts and law under Articles 9 and 16.

Notice of Application for Writ of Certiorari.

SUPREME COURT-.............. County.

The People of the State of New York

ex rel. ................ Company, against

and

Constituting the State Tax Commission of the State of New York.

Sirs :

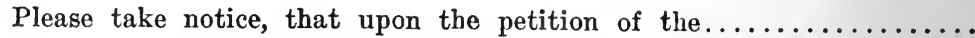

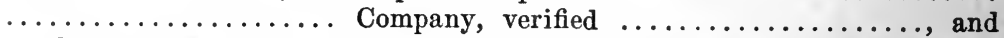
on the undertaking for costs herein filed with the State Tax Commission 
of the State of New York, copies of which are hereto annexed, the undersigned will move this court, at Special Term thereof, to be held at the County Court House, eity of Albany, on the ............ day of .............................. or as soon thereafter as counsel can be heard, for an order for a writ of certiorari and also for a writ of certiorari to be directed to you to review the determination of the State Tax Commission of the State of New York, dated .................. a copy of which is hereto annexed, and to be returnable according to law, and for such other and further relief as may be just.

Dated

Yours, etc.,

To

Attys. for Petitioner.

Chairman of the State Tax Commission of the State of New York.

\section{Petition for Writ of Certiorari.}

(Same title as in previous form.)

To the Supreme Court of the State of New York:

The petition of $\ldots \ldots \ldots \ldots \ldots \ldots$ Company respectfully shows:

I. The defendant is a $\ldots \ldots \ldots \ldots$ corporation, organized under the laws of the State of $\ldots \ldots \ldots \ldots \ldots$ having its principal office at ................... (if the petitioner is a foreign corporation add "and also having an office at ................, within the State of New York") for the purpose of ..............., and actually engaged in the business of

II. The defendants, $\ldots \ldots \ldots \ldots, \ldots \ldots \ldots$ and $\ldots \ldots \ldots$, are and have been since ................ all of the members of the State Tax Commission of the State of New York.

III. That on or about the $\ldots \ldots \ldots \ldots$ day of $\ldots \ldots \ldots \ldots, 191 \ldots$, this petitioner duly made a written report to the State Tax Commission of the State of New York, as required by section 211, article IX-a of the Tax Law, being Chapter 60 of the Consolidated Laws. A copy of said report is hereto annexed, marked "A," and made part hereof.

IV. That said report shows the condition of the petitioner for the calendar year ending December 31, 191.. [or the fiscal year as reported to the United States treasury department], which was as follows:

(Here state the material facts embodied in such report.)

V. That on or about .............. [state date when account was audited], the State Tax Commission audited and stated an account of taxes to be paid by this petitioner, under section 209 of the Tax 
Law, and sent a nottce thereof to your petitioner, a copy of which is hereto annexed, marked " $B$," and made part hereof.

VI. That on or about the $\ldots \ldots \ldots \ldots$ day of $\ldots \ldots \ldots \ldots, 191 \ldots$, and within one year from the time that said account of the Commission had been audited and stated and notice thereof sent to your petitioner, it applied to the said State Tax Commission to revise and readjust said account and to have said account resettled. That said application was made by written petition duly verified on or about the $\ldots . \ldots \ldots \ldots \ldots$. day of..$\ldots \ldots \ldots \ldots$. a copy of which is hereto annexed, marked "C," and made part hereof.

VII. That on such petition a rehearing was granted to your petitioner by said Commission on the $\ldots \ldots \ldots \ldots \ldots$ day of $\ldots \ldots \ldots \ldots$, at the office of the Commission, in the city of Albany. On such rehearing your petitioner appeared by one of its officers (or other witness) and by its counsel $\ldots \ldots \ldots \ldots \ldots \ldots \ldots$, before the Hon. ..............., a member of said Commission, and answered such questions as were put to him [or them] by said Commissioner, and gave testimony in support of said application.

That your petitioner is advised and believes from the evidence and proofs then and there given that it is not taxable in this state upon its annual net income for more than $\$ \ldots \ldots \ldots \ldots \ldots$ [or for any sum whatever], for the reason that [state reasons in full].

VIII. That thereafter and on the $\ldots \ldots \ldots \ldots \ldots$ day of $\ldots \ldots \ldots \ldots$, $191 .$. , the said Commission made its determination and sent written notice thereof to the applicant, a copy of which determination is hereto annexed, marked "D," and made part hereof. That in and by said determination said Commission refused to revise or readjust said tax (except to the amount of $\$ \ldots \ldots \ldots \ldots \ldots$. . .

IX. Your petitioner further shows that the said appraisal of its annual net income subject to state taxation is illegal and erroneous (to the amount of $\$$...............

$\mathrm{X}$. Your petitioner is advised and believes that the said determination of the Commission may be reviewed by this court by writ of certiorari and relief granted to your petitioner as provided by sections 199 and 218 of the Tax Law.

XI. Your petitioner, pursuant to the statute in such case made and provided, duly deposited with the State Comptroller of the State of New York $\$ . . . \ldots \ldots \ldots \ldots$, being the full amount of the taxes, percentages, interest and other charges stated in said account, and duly filed an undertaking with the State Tax Commission in an amount and with sureties approved by a justice of the Supreme Court of the State of New York to the effect that if the said writ of certiorari is dismissed and said determination is confirmed this petitioner will pay any and all charges and costs which may accrue against it in the prosecution of the 
writ, including the cost of all appeals; a copy of this undertaking is hereto annexed, marked "E," and made part hereof.

XII. That thirty days have not elapsed since the Commission served notice on your petitioner of its said determination, upon the application of your petitioner for revision and readjustment of the said account stated against it.

XIII. That your petitioner is aggrieved by the said determination of the Commission. That no previous application has been made for the writ to any court or judge.

WHEREFore, your petitioner, desiring to review both on law and the facts, said determination of said Commission upon such application made to it by your petitioner for a revision and resettlement of the said account, as hereinbefore set forth, prays that a writ of certiorari may issue out of this court, directed to the members of the State Tax Commission, commanding them to certify and return to this court at the office of the clerk of Albany County, all and singular the evidences before the said Commission on such appiication and all the papers and proofs upon the original statement of such account, and all proceedings thereon, and all its decisions and actions in the premises, with all the evidence, documents, reports, records and papers relating thereto in its possession or under its control, submitted to or considered by it, concerning said account and the grounds of its refusal to revise and readjust the same, to the end that its said determination and decision may be reviewed and the said original and resettled account corrected and restated, and that this petitioner have such other and further relief as may be proper.

Dated

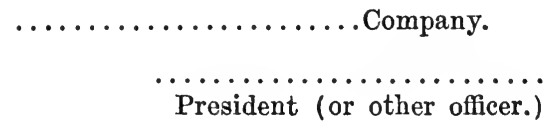

Attorneys for Petitioner.

\section{Order for Writ of Certiorari.}

At a Special Term of the Supreme Court, held in and for the county of ............, at the County Court House, in the city of $\ldots \ldots \ldots \ldots$ on the $\ldots \ldots \ldots$. day of $\ldots \ldots \ldots$, 191. .

Present-Hon. Justice.

(Same title as in previous form.)

Upon reading and filing the petition of $\ldots \ldots \ldots \ldots \ldots$. Company, verified ................., and the exhibits thereto attached, and 
upon the undertaking heretofore filed as required by law, and upon the notice of this application duly served on the State Tax Commission of the State of New York, and with proof of due service thereof with copy of the petition and exhibits annexed.

Now, after hearing ................. counsel for the petitioner, in favor of the motion, and $(\ldots \ldots \ldots \ldots \ldots \ldots$ deputy attorney-general, for the State Tax Commission) (or no one appearing) in opposition thereto, and on motion of.$\ldots \ldots \ldots \ldots \ldots \ldots$ attorney for the petitioner, it is

ORDERED, that a writ of certiorari, as prayed for in said petition, be issued, directed to the above-named members of the State Tax Commission of the State of New York, to review the decision and determination of the said Commission mentioned and described in the petition, and the questions involving the merits therein mentioned, both upon the law and the facts, which writ shall be returnable within twenty days after the service thereof upon the chairman of said Commission, at the office of the clerk of Albany County.

$$
\text { Enter, }
$$

Justice.

(Endorsed): Sir: You will please take notice that an order of which the within is a copy, was this day duly entered in the office of the clerk

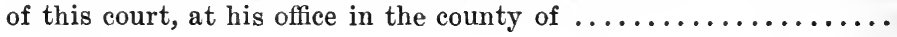

Dated, Yours, etc.,

Attorney for Relator.

To Hon.

Constituting the State Tax Commission of the State of New York. Albany, N. Y.

\section{Writ of Certiorari.}

(Same title as in previous form.)

WhEREAS, we have been informed by the verified petition of........... ........... Company, dated and verified the $\ldots \ldots \ldots \ldots \ldots$ day of $. . \ldots \ldots \ldots \ldots, 191 \ldots$, that certain proceedings have been had before the State Tax Commission of the State of New York, upon the application of the said .................. Company to revise and readjust an account theretofore audited and stated by the said Commission for taxes to be paid by the said .................... Company, 
under section 209 of the Tax Law, the petition upon which the said application was made being verified ................, 191.., and a hearing upon such application having been had on the $\ldots . \ldots \ldots \ldots \ldots$ day of $\ldots \ldots \ldots \ldots \ldots \ldots, 191 . .$, and the said Commission having thereafter made its determination and sent written notice of its determination upon such application to the applicant, the petitioner herein, denying the application and declining to make any revision or readjustment of the said

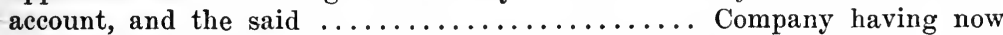
made application to this court for a writ of certiorari to review the said decision and determination of the said Commission;

And we being willing for certain purposes to be certified of such proceedings, if any such were had, do hereby command and strictly enjoin $\ldots \ldots \ldots \ldots \ldots \ldots \ldots \ldots \ldots$ and $\ldots \ldots \ldots \ldots$ constituting the members of the State Tax Commission of the State of New York, that the said Commission certify and return all and singular the evidence before it on such application, and all the papers and proofs upon the original statement of such account and all proceedings thereon, and all its decisions and actions in the premises, with all the evidence, documents, reports, records and papers relating thereto in its possession or under its control, submitted to or considered by it, concerning the said account and the grounds of its refusal to revise and readjust the same, as prayed for in the petition, within twenty days after the service upon the chairman of said Commission of this writ, at the office of the clerk of Albany County, under his proper hand, pursuant to the provisions of the Tax Law and the provisions of Title II of Chapter 16 of the Code of Civil Procedure, so that our Supreme Court may further cause to be done thereon what of right and according to law ought to be done, and let the defendants have then and there this writ.

Witness, the Hon. .................. Justice of our Honorable

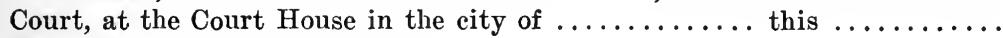
day of $\ldots \ldots \ldots \ldots \ldots, 191 \ldots$

(Seal.)

Clerk.

.....................

\section{Attorney for Relator.}

The above writ is hereby allowed this $\ldots \ldots \ldots \ldots \ldots$ day of ............., $191 \ldots$

\section{Justice Supreme Court.}

\section{Undertaking for Costs.}

(Same title as in previous form.)

Whereas, the above-named $\ldots \ldots \ldots \ldots \ldots \ldots$ Company, heretofore applied to the State Tax Commission of the State of New York to revise and readjust the account heretofore audited and stated by the 
said Commission, imposing a tax against thè said $\ldots \ldots \ldots \ldots \ldots \ldots$ Company for the year ............., under (sec. 209) of the Tax Law, and the said Commission having denied said application; and

Whereas, said ................ Company, feeling aggrieved thereby, is about to apply to the Supreme Court of the State of New York for a writ of certiorari, under the Tax Law, Chapter 60, of the Consolidated Laws, to review the action of the said Commission.

Now, therefore, the ............. Surety Company, a corpora-

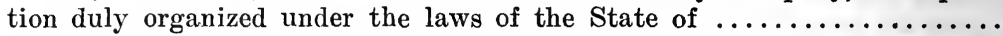
to execute surety bonds, having an office at .............. city of ..............., does hereby undertake that if the said writ of certiorari, which may be granted upon the application of the said ................ Company to review the said determination, be dismissed, or the determination of the said Commission be confirmed, the said $\ldots \ldots \ldots \ldots \ldots \ldots \ldots$. Company will pay all costs and charges which may accrue against it in the prosecution of the said writ, including the costs of all appeals, not exceeding the sum of five hundred dollars.

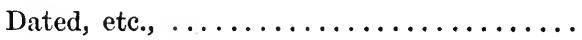

Surety Company, By $\ldots \ldots \ldots \ldots \ldots \ldots \ldots$ President.

Form of acknowledgment by officer of surety company in usual form for taking corporate acknowledgments.

(The above bond may also be given by two individuals, each qualifying for twice the amount of the bond, with affidavit and acknowledgment annexed in each case.)

\section{Commission's Return to the Writ of Certiorari.}

SUPREME COURT-Albany County.

The People of the State of New York ex rel................. Company, against

Constituting the State Tax Commission of the State of New York.

To the Supreme Court of the State of New York:

The return of $\ldots \ldots \ldots \ldots, \ldots \ldots \ldots \ldots$ and $\ldots \ldots \ldots \ldots$, constituting the members of the State Tax Commission of the State of New York, to the writ of certiorari directed to the said Commission, issued out of 
this court $\ldots \ldots \ldots \ldots \ldots \ldots, 191 .$. , directed, a copy of which is hereto annexed, respectfully shows to this court:

By virtue of and in obedience to the said writ of certiorari, we do hereby certify and return to the Supreme Court all and singular the evidence before said Commission on such application, all the papers and proofs upon the original statement of such account and all the proceedings therein, documents, reports, records and papers relating thereto in its possession or under its control, submitted to or considered by said Commission concerning the said account as prayed for in the petition herein, to wit:

The corporate franchise tax report based on net income of the ................... Company for the calendar year ending December $31,191$. . [or the fiscal year reported to the United States Treasury Department].

The bill of the Commission to the relator for its franchise tax for the said year;

The petition of relator for a revision, dated ........., 191..;

Notice to the Commission of the payment of the tax as fixed under protest and duress by the present of said company, dated............, 191..;

The determination of the Commission, dated ........, 191..;

Petition and notice of motion for an order for writ of certiorari, dated .............., 191.., and writ;

Order allowing the writ of certiorari, dated ............, 191.., and writ also dated $\ldots \ldots \ldots \ldots \ldots \ldots, 191 .$. , together with notice of entry in the office of the clerk of Albany County on the .......... day of $\ldots \ldots \ldots \ldots, 191 \ldots$, all other papers used on the hearing or considered by the Commission in this proceeding and undertaking on appeal heretofore filed.

In witness whereof, I have hereunto set my hand and seal this ............ day of $\ldots \ldots \ldots \ldots, 191 \ldots$

Chairman of the State Tax Commission of the State of New York. 


\title{
FORM 3 IT \\ CORPORATION INCOME TAX (9-a)
}

FILE WITH

STATE TAX DEPARTMENT,

\begin{abstract}
Albany, N. Y.
TAXATION OF CORPORATE FRANCHISES UNDER ARTICLE 9-a OF THE TAX LAW FOR THE TAX YEAR BEGINNING NOVEMBER 1,1919
\end{abstract}

THIS REPORT IS DUE JULY 1,1919 , or within thirty days after filing report with the United States Treasury Department

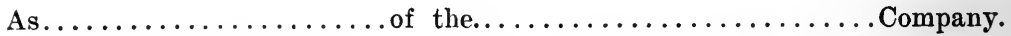

I make the following report of such company for the year ending...... ................., pursuant to Article 9-a of the Tax Law.

(Date inserted above must be the same as given in answer to (7) below.)

(1) Organized........., 19..., under the Laws of..... (2) Began business in New York....................., 19....

(3) If not incorporated under laws of New York, has it been authorized

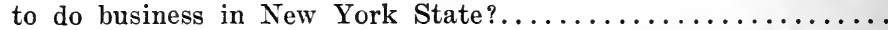

(4) Authorized capital stock, $\$ \ldots \ldots \ldots \ldots \ldots$ (5) Issued capital stock,

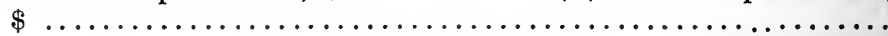

(If organized with shares without par value, insert the amount of paid-in capital.)

(6) Amount of average indebtedness for year, $\$ \ldots \ldots \ldots \ldots \ldots \ldots \ldots \ldots$

(7) ENTIRE NET INCOME FOR THE YEAR ENDING............ $191 .$. , as shown by its report to UNITED STATES TREASURY DEPARTMENT, before any deduction for excess profit or normal income tax has been made, .....................

Note: The date used must be that of the last period ending on or before June 30,1919 , for which a report was made to the Federal government.

(8) If a corporation is not organized under the laws of any state within the United States it should return its entire net income, wherever

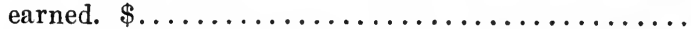

(9) If the amount reported above is inaccurate, state the amount claimed to be correct, $\$$.

(10) Nature of business and how transacted

(11) Place, street and number where such business is conducted 


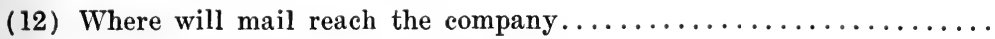

(13) State the city or town, street number and state where this company maintained any store, warehouse, factory or other place of business

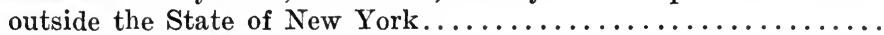

(14) Any corporation taxable hereunder may omit from this report the segregation of assets on this page only by signing the following consent

I AM AUTHORIZED by the Board of Directors of this corporation to consent and I do hereby consent that said corporation be taxed upon its entire net income at $4 \frac{1}{2}$ per cent or upon its entire issued capital stock at one mill on the dollar, as provided by law.

Do not sign consent unless taxable by the State of New York on entire income or entire issued capital stock.

(Official title)

\section{TOTAL SEGREGATED ASSETS WHEREVER LOCATED}

(a) Average monthly value of bills and accounts receivable for personal property manufactured by it...\$. $\ldots \ldots \ldots \ldots \ldots \ldots$

(b) Average monthly value of bills and accounts receivable for personal property sold by the corporation from merchandise owned by it at the time of acceptance of order but not manufactured by it..... $\$ \ldots \ldots \ldots \ldots \ldots$

(c) Average monthly value of bills and accounts receivable for services performed, based on orders received at offices maintained by the corporation, excluding bills and accounts receivable on orders filled from a stock of merchandise or other property maintained by the corporation...... $\$ \ldots \ldots \ldots \ldots \ldots$ $\$$ Average monthly value of all its real property wherever located (actual value) $\ldots \ldots \ldots \ldots \ldots \ldots \ldots \ldots . \ldots \ldots \ldots \ldots \ldots \ldots$ $\$$ Average monthly value of all its tangible personal property wherever located (actual value $) \ldots \ldots \ldots \ldots \ldots . \ldots \ldots \ldots \ldots$ Total....................... Not To BE FILLED 
\$Average total actual value of shares of stocks of other corporations owned by this corporation....................

\section{ASSETS SEGREGATED TO NEW YORK STATE ONLY}

(a) Average monthly value of bills and accounts receivable for personal property manufactured by it within this state...................

(b) Average monthly value of bills and accounts receivable for personal property sold by it from merchandise owned by it and located in this state at the time of acceptance of the order, but not manufactured by it within this state $\ldots \ldots \ldots \ldots \ldots \ldots \ldots \ldots . \ldots \ldots \ldots$

(c) Average monthly value of bills and accounts receivable for services performed, based on orders received at offices maintained by the corporation within this state, excluding bills and accounts receivable arising from sales made from a stock of merchandise or other property at a place of business maintained by the corporations within this state................

\$Average monthly value of its real property within this State as detailed in this report (actual value) ...\$........

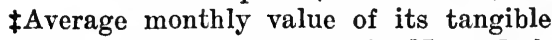
personal property in New York State as detailed in this report (actual value) \$........ NOT TO BE FILLED

Total.......................... $\$ \ldots \ldots \ldots \ldots$ 8 Average total actual value of shares of stocks of other corporations owned by it and allocated to this State by rule below $\ldots \ldots \ldots \ldots \ldots \ldots \ldots . . \ldots \ldots \ldots \ldots$

$¥$ Real property and tangible personal property shall be taken as its actual value where located.

$\S$ The value of share of stock of another corporation owned by a corporation liable hereunder shall for purposes of allocation of assets be appor- 
tioned in and out of the State in accordance with the value of the physical property in and out of the State representing such share stock.

Note.-If the amount of the annual net income of any corporation taxable under this article as returned to the United States treasury department is changed or corrected by a commissioner of internal revenue or other officer of the United States, such corporation, within ten days after receipt of such notification of change or correction, shall make return under oath or affirmation to the Tax Commission of such changed or corrected net income upon which the tax is required to be paid to the United States.

\section{INSTRUCTION}

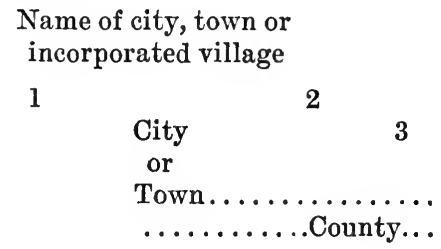

If the company has no real or tangible personal property in this State it should give the name of the city, town, or incorporated village where its principal financial concërns are transacted within the State in panel 1 at the right and the word "none" should be entered in panel 2.

If the company's entire real and tangible personal property in this State is in one city, or in one town outside a city or incorporated village, the schedules below need not be made, but the name of the city or town, and of the county where located must be entered in panel 3 .

If the company has real or tangible personal property in an incorporated village (or villages) in this State the name of such village and the town and county where such village is located must be entered below, together with the value of such property.

Incorporated village of In the town of County of $\underset{\$^{\circ}}{\text { Personal }} \$^{\text {Real }}$

(If more space is needed add a paster)

The values of real and tangible personal property in villages must be distributed to the proper TOWNS in the table below. Do not confuse the political subdivisions "incorporated village" and "town." Names of hamlets or postoffices other than incorporated villages are not wanted. 
Schedule of Real and Tangible Personal

Property in New York State by

Citries ANd Towns

City of.........................

Street address................. \$... $\$ \ldots \ldots \ldots \ldots \ldots$

City of............. County of..........

Street address................. \$... $\$ \ldots \ldots \ldots \ldots \ldots$

City of..........................

Street address................. \$ ... $\$ \ldots \ldots \ldots \ldots \ldots$

City of.............. County of..........

Street address................. \$ ... $\$ \ldots \ldots \ldots \ldots \ldots$

City of.............. County of..........

Street address................. \$.... \$... . \$....

City of.............. County of..........

Street address................ \$.... \$.... \$....

Town of .......... County of ........ \$ ... \$... $\$ \ldots \ldots \ldots$

Town of ........... County of....................

Town of ........... County of....................

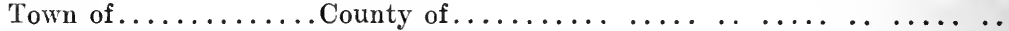

Town of............ County of .....................

Town of ............ County of...

(If more space is needed add a paster)

AFFIDAVIT OF PRESIDENT, VICE-PRESIDENT, SECRETARY OR TREASURER

\section{STATE OF NEW YORK,} COUNTY OF. ss.:

On this........ day of.............. D. 191..., personally appeared before me, a Notary Public in and for the County of............ ............... of the above named company, who, being duly sworn according to law, did depose and say that the foregoing report is just, true and correct and that it includes a true statement of the annual net income of said company for the year.

(Official title)

Sworn to before me the day and year aforesaid. 


\section{FORM 3 IT \\ PENALTY NOTICE}

Any corporation which fails to make any report required by this article shall be liable to a penalty of not more than five thousand dollars to be paid to the State to be collected in a civil action, at the instance of the Commission; and any officer of any such corporation who makes a fraudulent return or statement with intent to defeat or evade the payment of the taxes prescribed by this article shall be liable to a penalty of not more than one thousand dollars, to be recovered by the State. (Tax Law, § 216.)

STATE TAX COMMISSION,

Receiving stamp

\section{Form 42.}

CAPITAL STOCK REPORT

For Year Ending October 3I, I9I8, of

No.<smiles>[GeH3]</smiles>

\section{Duplicate copy should be kept \\ for your files. All annexed \\ statements must be sworn to \\ thereon.}

Report Due on or before December I5th

\section{Corporations Liable to Taxation Under Article IX-A of the Tax Law Should Not Make This Report.}

This report is not to be made before October 31, 1918. When completed mail to State Tax Department, Albany, N. Y., to arrive not later than December 15, 1918. (See penalty notice.)

As $\ldots \ldots \ldots \ldots \ldots \ldots \ldots \ldots \ldots$ of the

I make the following report of such Company for the year ending October 31, 1918, pursuant to the provisions of Section 192, Chapter 60 of Consolidated Laws:

(1) The last preceding report made by this Company to the State of New York under the provisions of the above acts was for the year ending October $31,191 \ldots$

(2) Organized $\ldots \ldots \ldots \ldots \ldots, 19 . \ldots$, under the laws of...$\ldots \ldots \ldots$

(3) This Company began business in the State of New York on $19 \ldots$ 
(4) Authorized capital stock of Company....................

(5) Number of shares of stock authorized: Common..... Preferred....

(6) Number of shares of stock issued: Common........Preferred......

(7) Par value of each share: Common $\$ \ldots . . \ldots$. Preferred, $\$ \ldots . . .$.

(8) Amount paid into Treasury of Company on each share: Common, $\$$ ......... Preferred, $\$ \ldots \ldots \ldots$.

(9) Amount of Capital stock issued for cash or property except as in (10) $\$ \ldots \ldots \ldots . . . .$.

(10) Amount of Capital stock issued for good will, copyrights, brands, patents, trade-marks, formulæ, services, etc., other than cash or property as in $(9) \ldots \ldots \ldots \ldots \ldots \ldots \ldots \ldots$.

(17) Net corporate income for the last fiscal or calendar year.......... $\rightarrow$ Amount of common stock on which dividends were deنே clared Amount and date of each dividend on common stock.......

Rate per cent per annum of dividends on common stock.... Amount of preferred stock on which dividends were declared $\$ \ldots . .$.

Amount and date of each dividend on preferred stock

(18) Nature of business in State of New York and how transacted.....

(19) (a) Place, street and number where such business is conducted

\section{(b) Where will mail reach the Company?.}

(Place, street and number)

Give the exact location where this corporation maintained any store, warehouse, factory or place of business outside the State of New York

(21) Highest bona fide price at which stock sold during the year ending October $31,1918 \ldots . \ldots \ldots$. Preferred, $\$ \ldots .$. Common, $\$ \ldots .$. .

(22) Lowest bona fide price at which stock sold during year ending October $31,1918 \ldots \ldots \ldots$.... Preferred, $\$ \ldots . .$. Common, $\$ \ldots . .$. All amounts inserted below should be for the year ending October 31, 1918

FOREIGN and DOMESTIC corporations must answer all paragraphs 24-37 inclusive. Property classified under paragraph IO, page I, should not appear below.

\section{IN NEW YORK STATE.}

(23) Average value of stock in trade carried during the

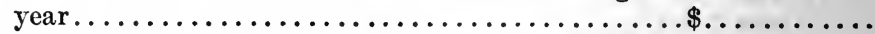

(24) Average monthly bank and cash balance employed

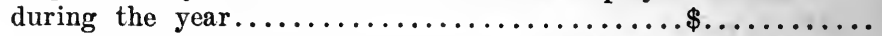

$(25) \dagger$ Average value of bills and accounts receivable during the year.......................... 
(26)* Average cash value of shares of stocks of other corporations doing business in the State of New York and owned by this Company during the year...............

(27) $\$$ Average value of bonds, loans on call and other financial securities held, used or employed in New York

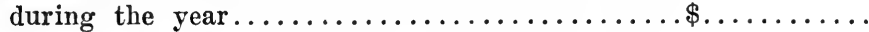

(28) Average value of all personal property other than heretofore mentioned during the year.................

(29) Average gross actual value of real estate located in the State of New York and owned by this Company

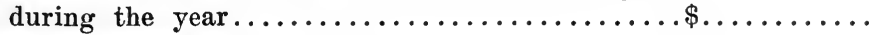

(29a) Average assessed value of above real estate....... $\$ \ldots \ldots \ldots \ldots$ Location. Location. . Location

\section{OUTSIDE NEW YORK STATE}

(30) Average value of stock in trade carried during the

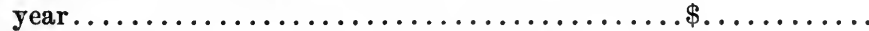

(31) Average monthly bank and cash balance employed

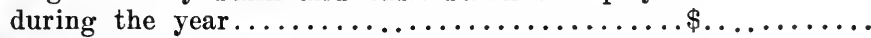

$(32) \uparrow$ Average value of bills and accounts receivable

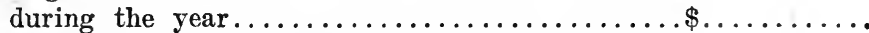

(33)* Average cash value of shares of stocks of other corporations owned by this corporation where such corporations are doing business wholly without the State of New York

$(34) \ddagger$ Average value of bonds, loans on call and other financial securities held, used or employed outside the State of New York during the year.................. Average value of personal property, other than heretofore mentioned during the year.................

(36) Average gross actual value of real estate located outside the State of New York and owned by this Company during the year, and where situated....\$........

(36a) Average assessed value of above real estate................. Location.

Location

Location

(In stating location, city or village or town must be given, with street and number)

Total of assets above enumerated located in the State of New York during the year ending October $31,1918 \ldots \ldots \ldots \ldots \ldots \ldots \ldots$

Total of assets above enumerated located outside the State of New York during the year ending October $31,1918 \ldots \ldots \$ \ldots \ldots \ldots$

The word "average" wherever it appears in this report has its plain, ordinary significance; neither the highest amount nor the lowest, but the 
mean. The same method employed in determining average assets should be used in determining average liabilities.

$\dagger$ Bills and accounts receivable are generally located at the place from which the goods are shipped, provided the corporation there maintains at its own expense a place of business, including a store or warehouse. The residence of the debtor is of no importance.

* In answering Nos. 25 and 32 , if the assets of the company whose stock is owned by your corporation are employed both "In" and "Outside" New York, an apportionment of your holdings may be made on the basis of employment.

$¥$ Assets in Nos. 26 and 33 should be considered as located wherever the same are held.

(37) AVERAGE LIABILITIES:

Bonds not secured by mortgage, average............... Mortgages, average.....................

Bills payable, average...................

Accounts payable, average..............\$

Other liabilities, not including capital stock, average as explained below...........\$.

Total average liabilities..........

(38) Percentage of total assets of the Company employed in manufacturing by the Company in the State of New York during the year ending October 31, 1918, and in the sale of the products so manufactured

(39) Are goods handled by you manufactured for you by others or bought for sale?

(40) Do you operate a factory?.......... If so, where?.

\section{REMARKS.}




\section{Officers Names:}

$$
\text { ................President, }
$$

Company, estimates and appraises the Capital Stock of said Company as follows:

.............shares at.......................... dollars $\ldots \ldots \ldots \ldots$. cents per share, amounting in the whole to......... 100 dollar

In Witness Whereof, I have set my hand this day of.

\section{(Official title)}

[Over]

Note.-Corporations paying six or more than six per centum on their ENTIRE issued capital stock need not appraise their capital stock; all others must appraise.

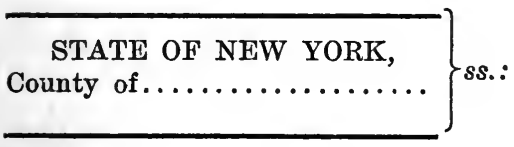

26.5.

On this.......... day of ............... D. 191.., personally appeared before me, a Notary Public in and for the County of........... ..................... of the above named Company, who, being duly sworn according to law, did depose and say that the foregoing report is just, true and correct and that it includes all dividends of any description declared by said Company during the year ending October 31, 1917, and that he has, according to his best knowledge and belief, appraised the Capital Stock of the Company as provided by statute, at not less than the average price at which it sold and not less than the difference between its assets and liabilities, exclusive of capital stock.

Sworn to before me the day and year aforesaid. 


\section{PENALTY NOTICE.}

Every corporation, association, joint-stock company, person or partnership failing to make the annual report required by this article, or failing to make any special report required by the commission, within any reasonable time to be specified by the commission shall forfeit to the people of the state the sum of one hundred dollars for every such failure, and the additional sum of ten dollars for each day that such failure continues. (Tax Law, section 197.) 


\section{TABLE OF CASES}

PAGE

American Printing Com. v. Commonwealth of Mass, 120 N. E. $686 \ldots \ldots 87$

Bartlett v. City of N. Y., 5 Sanford $44 \ldots \ldots \ldots \ldots \ldots \ldots \ldots \ldots \ldots$

Bells Gap Co. v. Pennsylvania, 134 U. S. $32 \ldots \ldots \ldots \ldots \ldots \ldots \ldots \ldots$

Binghamton Trust Co. v. Binghamton, 72 A. D. $341 \ldots \ldots \ldots \ldots \ldots 61$

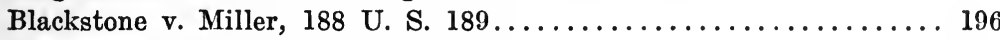

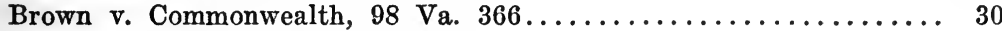

Burr v. Palmer, 53 A. D. $358 \ldots \ldots \ldots \ldots \ldots \ldots \ldots \ldots \ldots \ldots \ldots \ldots$

Carson v. Maryland, 120 U. S. $502 \ldots \ldots \ldots \ldots \ldots \ldots \ldots \ldots \ldots \ldots$

Central Trust Co. v. N. Y. C. \& H. R. R. Co., 110 N. Y. 250 . . . . .71-111

Central Trust Co. v. Third Ave. R. Co., 186 Fed. 291.......... 72

Chae Chang Ping v. U. S., 130 U. S. $581 \ldots \ldots \ldots \ldots \ldots \ldots \ldots \ldots \ldots \ldots$

Champion Copper Co. v. Massachusetts, 246 U. S. $147 \ldots \ldots \ldots \ldots \ldots . . \ldots 3$

Cheney Bros. v. Massachusetts, 246 U. S. $147 \ldots \ldots \ldots \ldots \ldots \ldots \ldots \ldots . \ldots 2$

City of N. Y. v. McLean, 170 N. Y. $374 \ldots \ldots \ldots \ldots \ldots \ldots \ldots \ldots \ldots$

Commonwealth v. Pa. R. R. Co., 94 Pa. $474 \ldots \ldots \ldots \ldots \ldots \ldots \ldots \ldots 117$

Cohen, Hyman, v. John Z. Lowe, June 14, '16............ 287

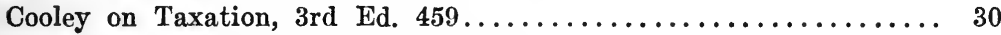

Crenshaw v. Arkansas, 227 U. S. $389 \ldots \ldots \ldots \ldots \ldots \ldots \ldots \ldots \ldots \ldots$

Crew Levick Co. v. Pennsylvania, 245 U. S. $292 \ldots \ldots \ldots \ldots \ldots \ldots \ldots 9$

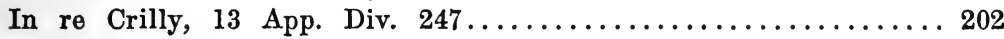

Cudahy Packing Co. v. Minnesota, 246 U. S. $450 \ldots \ldots \ldots \ldots \ldots \ldots . \ldots 3$

Dalton Adding Machine Co. v. Virginia, 246 U. S. $498 \ldots \ldots \ldots \ldots \ldots .92$

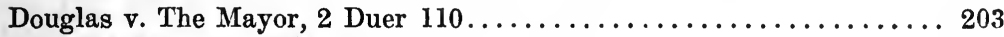

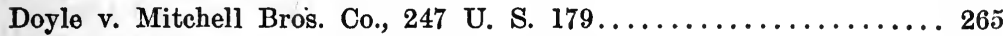

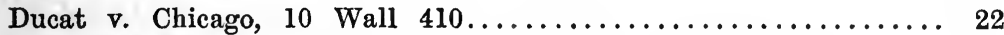

Dunbarton Flax Spinning Co. v. G. \& J. R. Co., 87 A. D. 21..... 21

Emmerich v. Sloan, 108 A. D. $330 \ldots \ldots \ldots \ldots \ldots \ldots \ldots \ldots \ldots \ldots$

Flint v. Stone Tracy Co., 220 U. S. $107 \ldots \ldots \ldots \ldots \ldots \ldots \ldots \ldots$. . . . . . . .

Fong Yue Ting v. U. S., 149 U. S. $968 \ldots \ldots \ldots \ldots \ldots \ldots \ldots \ldots \ldots$

Fóster Pump Works v. The Mayor, 100 A. D. $515 \ldots \ldots \ldots \ldots \ldots \ldots \ldots 169$

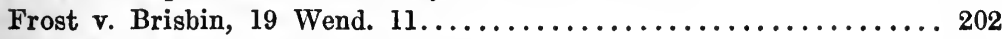

General Railway Signal Co. v. Va., 246 U. S. 500.......... 93

Green v. Railway Co., 205 U. S. $530 \ldots \ldots \ldots \ldots \ldots \ldots \ldots \ldots \ldots \ldots$ 
Halsey v. Jewett Dramatic Co., 114 A. D. $420 \ldots \ldots \ldots \ldots \ldots \ldots 19$

Hamilton Wheel Co. v. Commissioners, 12 W. N. C. $328 \ldots \ldots \ldots \ldots 157$

Hardenbergh's Decisions under Acts of Pennsylvania, $131 \ldots \ldots \ldots \ldots 157$

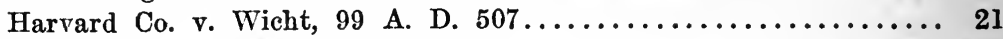

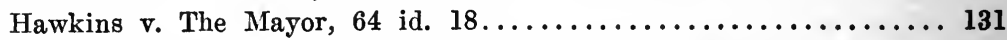

Herkimer Co. Light \& Power Co. v. Johnson, 37 A. D. $257 \ldots \ldots \ldots \ldots 123$

Home Ins. Co. v. N. Y., 134 U. S. $594 \ldots \ldots \ldots \ldots \ldots \ldots \ldots \ldots, 40$

Horn Silver Mining Co. v. N. Y., 143 U. S. $305 \ldots \ldots \ldots \ldots \ldots \ldots, 11$

Internätional Harvester Co. v. Kentucky, 234 U. S. 579......... 91

International Paper Co. v. Mass., 246 U. S. $135 \ldots \ldots \ldots \ldots \ldots \ldots . . \ldots 3$

International Text Book Co. v. Begg, 217 U. S. $92 \ldots \ldots \ldots \ldots \ldots \ldots 2$

Kinney v. Reid Ice Cream Co., 57 A. D. 208.............. 19

Lanston Monotype Case, 246 U. S. 147................. 93

Lathers v. Keogh, 109 N. Y. $583 \ldots \ldots \ldots \ldots \ldots \ldots \ldots \ldots \ldots \ldots \ldots$ 71

Locomobile Co. v. Massachusetts, 246 U. S. 146.............. 93

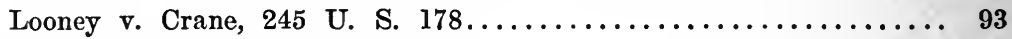

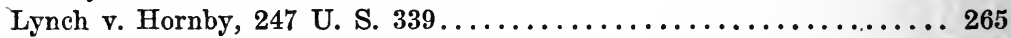

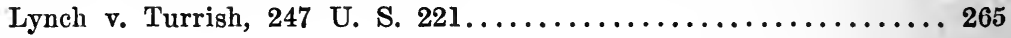

McCall v. California, 136 U. S. $104 \ldots \ldots \ldots \ldots \ldots \ldots \ldots \ldots . \ldots 2$

McLean, Receievr of Taxes, v. Julian Elec. Co., 28 Abb. N. C. 349.... 99

Macomber v. Eisner, U. S. Dist. Ct. (So. Dist. N. Y.), Jan. 23, 1919.. 232

Maine v. Grand Trunk Railway, 142 U. S. $217 \ldots \ldots \ldots \ldots \ldots \ldots \ldots . \ldots$

Matter of Carnegie Trust Co., 206 N. Y. 398.............. 72

Matter of Consolidated Kansas City Smelting Co., 13 A. D. 50..... 13

Matter of Crilly, 13 A. D. 247....................... 202

Matter of Estate of Hetty Green, 99 Mis. 582............. 200

Matter of Maltbie v. Lobsitz Mills Co., 223 N. Y. $230 \ldots \ldots \ldots \ldots .169$

Matter of Maltbie v. N. Y. \& Philadelphia Coal \& Coke Co., 223

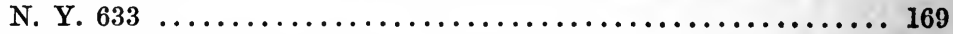

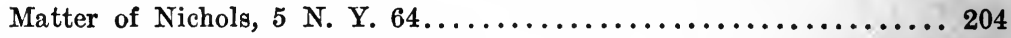

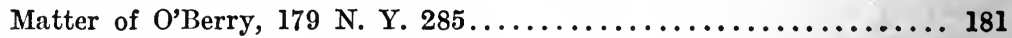

Matter of Tiffany \& Co., 80 Hun $486 \ldots \ldots \ldots \ldots \ldots \ldots \ldots \ldots \ldots . \ldots 7$

Matter of Waterman Co. v. Gilman, 33 Misc. 569........... 181

Myer v. Wells Fargo \& Co., 223 U. S. 298.................. 93

N. Y. Edison Co. v. Wells, 135 A. D. $644 \ldots \ldots \ldots \ldots \ldots \ldots \ldots \ldots . \ldots 124$

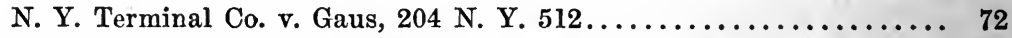

N. Y. Terra Cotta Co. v. Williams, 102 A. D.............. 100

Northwestern Consolidated Milling case, 245 U. S. 644.......... 93

Novelty Mfg. Co. v. Connell, 88 Hun 254................. 21 


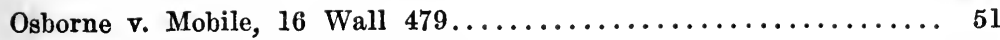

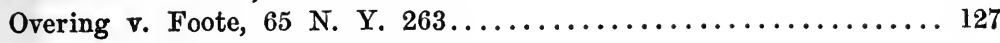

Pacific Express Co. v. Seibert, 142 U. S. $339 \ldots \ldots \ldots \ldots \ldots \ldots \ldots \ldots 1$

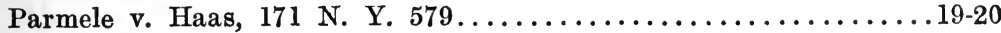

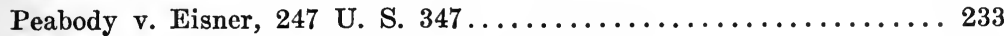

Peck \& Co. v. Lowe, 247 U. S. 165 (May, 1918) ............. 98

People v. Albany Ins. Co., 92 N. Y. $460 \ldots \ldots \ldots \ldots \ldots \ldots \ldots \ldots 68$

People v. Amer. Bell Telephone Co., 117 N. Y. 241........... 48

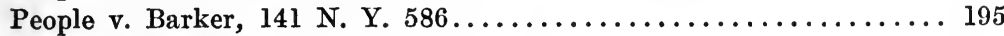

People v. Campbell \& Roberts, 88 Hun $545 \ldots \ldots \ldots \ldots \ldots \ldots \ldots 43$

People v. Gold \& Stock Tel. Co., 98 N. Y. $67 \ldots \ldots \ldots \ldots \ldots \ldots \ldots 167$

People v. Spring Valley Hydraulic Gold Co., 92 N. Y. $383 \ldots \ldots \ldots 667$

People v. Sohmer, 207 N. Y. 272.................... 53

People v. Thames \& Mersey Marine Ins. Co., 176 N. Y. $531 \ldots \ldots \ldots .58$

People ex rel. A. C. \& D. Co. v. Wemple, 129 N. Y. $558 \ldots . \ldots \ldots \ldots 179$

People ex rel. American Axe \& Tool Co. v. Roberts, 82 Hun 313... 69

People ex rel. American Bank Note Co. v. Sohmer, 157 A. D. 1...30-37

People ex rel. Amer. Broom \& Brush Co. v. Knapp, A. D. Apr., 1919. 22

People ex rel. American Contracting Co. v. Wemple, 60 Hun 225 ...46-47

People ex rel. American Surety Co. v. Campbell, 74 Hun $101 . . . \ldots .43$

People ex rel. Armstrong Cork Co. v. Commissioners, 157 N. Y. 159. 18

People ex rel. Astor v. Tax Commsrs., 33 Misc. 358.......... 204

People ex rel. Automatic Vending Co. v. Kelsey, 101 A. D. 325.... 40

People ex rel. Badische Anilin \& Soda Fabrik Co. v. Roberts, 152

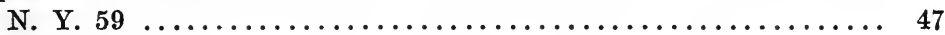

People ex rel. Bank for Savings v. Miller, 177 N. Y. $461 \ldots \ldots \ldots 663$

People ex rel. Barcalo Mfg. Co. v. Knapp, A. D. Apr., 1919 ...... 89

People ex rel. Brooklyn City R. R. Co. v. Assessors of Brooklyn,

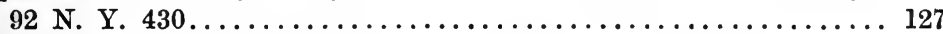

People ex rel. Brooklyn El. R. R. Co. v. Roberts, 90 Hun $537 \ldots \ldots . .37$

People ex rel. B. R. T. Co. v. Morgan, 57 A. D. $335 \ldots \ldots \ldots$ 37-61-114

People ex rel. Brooklyn Union Gas Co. v. Morgan, 114 A. D. 266... 54

People ex rel. Brush El. Mfg. Co. v. Wemple, 129 N. Y. 543 ...... 46

People ex rel. Central Park, etc., R. R. v. Tax Commrs., 21 N. Y. St.

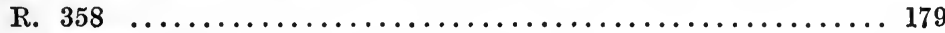

People ex rel. Chicago Junction Railway Co. v. Roberts, 154 N. Y. 1.45-48

People ex rel. Cohen \& Co. v. Miller, 94 A. D. 564............37-114

People ex rel. Colonial Trust Co. v. Morgan, 47 A. D. $126 \ldots \ldots \ldots .38$

People ex rel. Commercial Cable Co. v. Morgan, 178 N. Y. $433 \ldots \ldots 8-42$

People ex rel. Coney Island Jockey Club v. Sohmer, 140 N. Y. Supp.

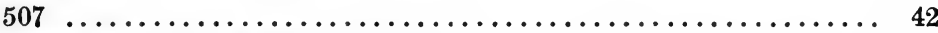

People ex rel. Conn. Mutual Life Ins. Co. v. Kelsey, 116 A. D. 97..56-59 
People ex rel. Consol. Ginseng Co. v. Kelsey, 182 N. Y. 526........ 16

People ex rel. Continental Ins. Co. v. Miller, 177 N. Y. 515........ 59

People ex rel. Cornell Steamboat Co. v. Sohmer, 206 N. Y. 651... 51

People ex rel. C. T. R. Co. v. Miller, 178 N. Y. $194 \ldots \ldots \ldots \ldots \ldots \ldots$.......

People ex rel. Dann v. Williams, 36 N. Y. $441 \ldots \ldots \ldots \ldots \ldots \ldots 179$

People ex rel. Dunkirk, etc., Ry. Co. v. Campbell, 74 Hun $210 \ldots . .50$

People ex rel. Dutilh Smith Co. v. Miller, 90 A. D. 545..........16-21

People ex rel. Edison Co. v. Kelsey, 101 A. D. $205 \ldots \ldots \ldots \ldots \ldots \ldots 48$

People ex rel. Edison Elec. Ill. Co. v. Wemple, 61 Hun $53 . . . \ldots .440-46$

People ex rel. Edison Elec. Light Co. v. Campbell, 138 N. Y. 543.... 49

People ex rel. Elliott-Fisher Co .v. Sohmer, 148 A. D. $514 \ldots \ldots \ldots 16$

People ex rel. Eppens Co. v. Roberts, 51 A. D. 152............. 161

People ex rel. Fed. Tel. \& Telegr. Co. v. Longwell, 131 N. Y. Supp.

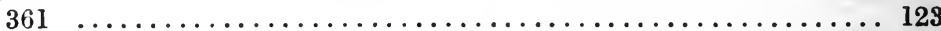

People ex rel. Fifth Ave. Bldg. Co. v. Williams, 198 N. Y. 242 ...41-42

People ex rel. Fort George Co. v. Miller, 179 N. Y. $49 \ldots \ldots \ldots \ldots .41$

People ex rel. Fourteenth Str. Realty Co. v. Kelsey, 110 A. D. 797.. 42

People ex rel. Gen. Chemical Co. v. Cantor, 105 Misc. 62......... 124

People ex rel. Genesee Light \& Power Co. v. Sohmer, 162 A. D. 207.. 54

People ex rel. Genesee Light \& Power Co. v. Saxe, 179 A. D. 417.... 54

People ex rel. Gould v. Barker, 14 Misc. 586............... 204

People ex rel. Gramercy Co. v. Roberts, 91 Hun, $146 \ldots \ldots \ldots \ldots . . .179$

People ex rel. Harlin \& H. Co. v. Campbell, 139 N. Y. 68........45-48

People ex rel. Hoyt v. Tax Commissioners, 28 N. Y. 244......... 91

People ex rel. Hyde \& Sons v. Miller, 90 A. D. 599............38-39

Péople ex rel. A. G. Hyde \& Sons v. O'Donnell, 116 A. D. $161 \ldots . .116$

People ex rel. Hubert Apt. Assn. v. Kelsey, 110 A. D. 618....... 41

People ex rel. Interboro R. T. Co. v. Williams, 200 N. Y. 93...... 53

People ex rel. International Elevator Co. v. Roberts, 116 A. D. 30.. 46

People ex rel. International Text Dook Co. v. Begg, 217 U. S. 92 ... 92

People ex rel. International Text Book Co. v. Tone, 220 N. Y. 313.21-22-91

People ex rel. Iroquois Door Co. v. Knapp, 173 N. Y. Supp. 641... 129

People ex rel. J. B. Co. v. Roberts, 37 A. D. $1 \ldots \ldots \ldots \ldots \ldots \ldots 37-38$

People ex rel. Jerome Pk. Villa Site Impr. Co. v. Roberts, 41 A. D. 2138

People ex rel. Johnson Co. v. Roberts, 159 N. Y. 70...........38-46

People ex rel. John Turl's Sons v. O’Donnell, N. Y. Law Jn'l, June

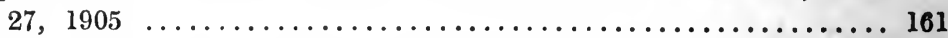

People ex rel. Joline v. Willcox, 129 App. Div. $267 \ldots \ldots \ldots \ldots \ldots \ldots .46$

People ex rel. Joline v. Willcox, 134 App. Div. 563........... 47

People ex rel. Journeay \& Burnham Co. v. Roberts, 37 A. D. 1... 116

People ex rel. A. M. Kellogg Newspaper Co. v. Roberts, 30 A. D. 150.47

People ex rel. Keochl \& Co. v. Morgan, 96 A. D. $110 \ldots \ldots \ldots \ldots .40$

Peöple ex rel. Kingsland v. Palmer, 52 N. Y. $83 \ldots \ldots \ldots \ldots \ldots \ldots 131$ 
People ex rel. Knickerbocker Trust Co. v. Kelsey, 114 A. D. $319 \ldots 181$

People ex rel. Lehigh \& N. Y. R. R. Co. v. Sohmer, 217 N. Y. 443 . 27-100

People ex rel. Lester v. Eno, 176 N. Y. 513............... 178

Pèople ex rel. Lincoln Trust Co. v. Glynn, 132 A. D. $546 \ldots \ldots \ldots \ldots 61$

People ex rel. Lorena Co. v. Morgan, 55 A. D. $265 \ldots \ldots \ldots \ldots \ldots 37$

People ex rel. Lord v. Feitner, 78 A. D. $287 \ldots \ldots \ldots \ldots \ldots \ldots \ldots 203$

People ex rel. Lorillard v. Barker, 70 Hun $397 \ldots \ldots \ldots \ldots \ldots . \ldots 204$

People ex rel. MeCord v. Cantor, Sup. Ct. N. Y. Co........... 81

People ex rel. McNeary v. McLean, 64 Hun $205 \ldots \ldots \ldots \ldots \ldots \ldots 46$

People ex rel. Manhattan R. R. Co. v. Commissioners, 146 N. Y. 304.115

People ex rel. Martin v. Feitner, 33 Misc. $358 \ldots \ldots \ldots \ldots \ldots \ldots \ldots 204$

People ex rel. Mercantile S. D. Co. v. Sohmer, 158 A. D. $110 \ldots \ldots \ldots 36-39$

People ex rel. Metropolitan S. Co. v. Kelsey, 101 A. D. 248...... 69

People ex rel. Metropolitan Street Ry. Co. v. Tax Commrs., 174

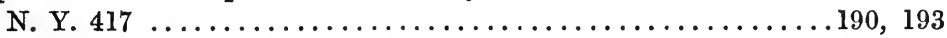

People ex rel. Miller v. Peck, 73 App. Div. $89 \ldots \ldots \ldots \ldots \ldots \ldots .47$

People ex rel. Mutual Trust Co. v. Miller, 177 N. Y. 51.......37-61-114

People ex rel. Nat'l Enameling Co. v. Miller, 112 A. D. $880 \ldots \ldots \ldots 16-38$

People ex rel. Nat'l Starch Co. v. Waldron, 26 A. D. $527 \ldots \ldots \ldots \ldots 123$

People ex rel. N. Eng. Dressed Meat \& Wool Co. v. Roberts, 155 N. Y.

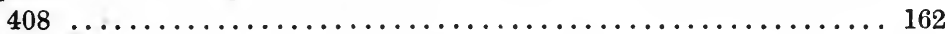

People ex rel. N. E. Loan \& Investing Co. v. Roberts, 25 A. D. 16.. 46

People ex rel. N. Y. Realty Co. v. Miller, 92 App. Div. 116......177, 178

People ex rel. N. Y. \& E. R. Ferry Co. v. Roberts, 168 N. Y. 14... 28

People ex rel. N. Y. C. \& H. R. R. Co. v. Gaus, 200 N. Y. $328 \ldots \ldots \ldots 36$

People ex rel. N. Y. C. \& H. R. R. Co. v. Knight, 173 N. Y. $255 \ldots \ldots 39$

People ex rel. N. Y. C. \& H. Riv. R. R. v. Morgan, 168 N. Y. $1 \ldots \ldots 52$

People ex rel N. Y. C. \& H. Riv. R. R. v. Roberts, 32 A. D. 113... 52

People ex rel. N. Y. Edison v. Feitner, 99 A. D. $274 \ldots \ldots \ldots \ldots \ldots 123$

People ex rel. N. Y. Mail \& Transp. Co. v. Gaus, 198 N. Y. 250...29-31

People ex rel. Niagara Falls Co. v. Russell, 57 Hun $53 \ldots \ldots \ldots \ldots 181$

People ex rel. Niagara R. Hydraulic Co. v. Roberts, 30 A. D. $180 \ldots 40$

People ex rel. N. Am. Trust Co. v. Knight, 96 A. D. $120 \ldots \ldots \ldots \ldots 39$

People ex rel. Osgood v. Tax Commsrs., 99 N. Y. $154 \ldots \ldots \ldots \ldots \ldots 179$

People ex rel. Parke, Davis \& Co. v. Roberts, 91 Hun $158 \ldots \ldots \ldots \ldots 17$

People ex rel. Pa. R. R. Co. v. Tax Commsrs., 104 N. Y. $240 \ldots . . .179$

People ex rel. Pa. R. R. v. Wemple. 65 Hun $252 \ldots \ldots \ldots \ldots \ldots \ldots 45$

People ex rel. Pa. R. R. v. Knight, 67 A. D. $398 \ldots \ldots \ldots \ldots \ldots \ldots 46$

People ex rel. Platt v. Wemple, 117 N. Y. $136 \ldots \ldots \ldots \ldots \ldots \ldots 43$

People ex rel. Port Morris Land \& Improve. Co. v. Glynn, 205

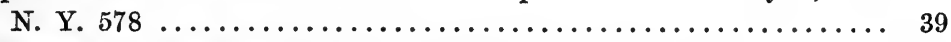

People ex rel. Postal Tel. Co. v. Campbell, 70 Hun, $507 \ldots \ldots \ldots .43$

People ex rel. Pres., etc., D. \& H. Canal Co., 54 Hun $598 \ldots . \ldots \ldots \ldots 38$ 
People ex rel. Provident S. L. A. Soc. v. Miller, 179 N. Y. 227 ..... 59

People ex rel. Pullman Co. v. Glynn, 130 A. D. $332 \ldots \ldots \ldots \ldots \ldots . . . .39$

People ex rel. Rees' Sons v. Miller, 90 A. D. 592. . . . . . . . . 37-43-114

People ex rel. Rockefeller v. O'Brien, 224 Fed. 541............. 202

People ex rel. Roebling's Sons Co. v. Wemple, 138 N. Y. 582....... 179

People ex rel. Schurz v. Cook, 110 N. Y. 443............... 13

People ex rel. Schurz v. Mertens, 110 N. Y. 443............. 13

People ex rel. Second Ave. R. R. Co. v. Barker, 72 Hun 126...... 121

People ex rel. Seth Thomas Clock Co. v. Wemple, 133 N. Y. 323.... 179

People ex rel. Singer Mfg. Co. v. Wemple, 150 N. Y. $46 \ldots \ldots \ldots \ldots \ldots$. . 40

People ex rel. Smith v. Roberts, 27 A. D. $455 \ldots \ldots \ldots \ldots \ldots \ldots \ldots \ldots 47$

People ex rel. Southern Cotton Oil Co. v. Roberts, 25 A. D. 13... 47-92

People ex rel. Southern Cotton Oil Co. v. Wemple, 61 Hun 83..... 17

People ex rel. Spencerian Pen Co. v. Kelsey, 105 A. D. 133....... 40

People ex rel. Staten I. R. R. v. Roberts, 4 App. Div. 334 . . . . . . . 178

People ex rel. F. A. Stokes Co. v. Roberts, 90 Hun 533.......... 71

People ex rel. Strong v. O'Donnell, 47 Misc. 226............. 203

People ex rel. Studebaker Co. v. Knight, 66 A. D. $150 \ldots \ldots \ldots \ldots \ldots \ldots 1$

People ex rel. Town of Pelham v. Pelham, 215 N. Y. 374........ 193

People ex rel. Union Pacific Tea Co. v. Roberts, 145 N. Y. 375 ... 178

People ex rel. Union Trust Co. v. Coleman, 126 N. Y. 433....... 121

People ex rel. U. S. Aluminum Plate Co. v. Knight, 174 N. Y. $475 \ldots 40-46$

People ex rel. Vandervoort v. Glynn, 194 N. Y. $387 \ldots \ldots \ldots \ldots \ldots \ldots 42$

People ex rel. Waclark R. Co. v. Williams, 198 N. Y. 54.......... 42

People ex rel. Wall \& H. St. Realty Co. v. Miller, 181 N. Y. 328... 41

People ex rel. Washington Mills v. Roberts, 8 A. D. 201....... 47

People ex rel. Westchester L. Co. v. Gaus, 199 N. Y. $147 \ldots . . \ldots \ldots .54$

People ex rel. West F. I. Co. v. Davenport, 91 N. Y. 574........ 179

People ex rel. Western Co. v. Campbell, 145 N. Y. $587 \ldots \ldots \ldots \ldots \ldots 179$

People ex rel. Western El. Co. v. Campbell, 80 Hun $466 \ldots . . . \ldots 179$

People ex rel. Wiebusch \& Hilger Co. v. Roberts, 19 A. D. 574.... 37-42

People ex rel. Williams v. Sohmer, 151 A. D. 764............ 43

People ex rel. Wright v. O'Rourke, 32 A. D. $66 \ldots \ldots \ldots \ldots \ldots \ldots \ldots . \ldots 203$

Philadelphia Fire Ins. Co. v. N. Y., 119 U. S. $110 \ldots \ldots \ldots \ldots \ldots \ldots \ldots 2$

Phila. Read. R. R. Co. v. Commissnrs., 104 Pa. 86............. 157

Philadelphia \& S. S. Co. v. Pennsylvania, 122 U. S. $326 \ldots \ldots \ldots \ldots \ldots-95$

Postal Tel. Cable Co. v. Adams, 155 U. S. 688............... 96

Postal Tel. Co. v. Charleston, 153 U. S. 692................ 61

Reading R. R. v. Pennsylvania, 15 Wall 284.............. 61 Reedy Elevator Co. v. Amer. Grocery Co., 24 Misc. 678........... 19-21 Robbins v. Shelby County Taxing District, 120 U. S. 489.......... 17 
San Francisco F. L. Co. v. Banbury, 106 Cal. 129............ 30

Savage v. Atlanta Home Ins. Co., 55 A. D. $20 \ldots \ldots \ldots \ldots \ldots \ldots . \ldots 2$

Shaffer v. Howard, 250 Fed. Rep. $874 \ldots \ldots \ldots \ldots \ldots \ldots \ldots \ldots \ldots 7$

Southern Pacific Co. v. Lowe, 247 U. S.................. 67

State v. Wisconsin Tax Comm., 161 Wisc. $111 \ldots \ldots \ldots \ldots \ldots \ldots . \ldots 195$

State ex rel. Ashbrook, 154 Mo. $375 \ldots \ldots \ldots \ldots \ldots \ldots \ldots \ldots \ldots . \ldots \ldots$

State ex rel. Bolens v. Frear, $148 \mathrm{Wis} .456 \ldots \ldots \ldots \ldots \ldots \ldots \ldots 19 . \ldots \ldots$

State ex rel. Daniels v. Hussy, 143 Wisc., $649 \ldots \ldots \ldots \ldots \ldots \ldots \ldots 19$

State Tax on Foreign Held Bonds, 15 Wall $300 \ldots \ldots \ldots \ldots \ldots \ldots .9$

Sweet v. The All-Package Grocery Stores Co., N. Y. Law Jnl., Apr.

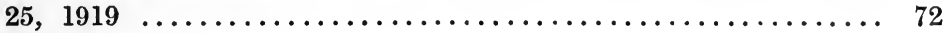

Tanza v. Susquehanna Coal Co., 220 N. Y. $259 \ldots \ldots \ldots \ldots \ldots \ldots \ldots 91$

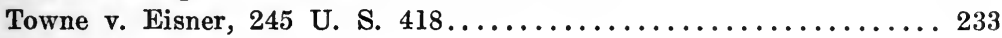

Underwood Typewriter Co. v. Chamberlain, 102 Atlantic $600 \ldots \ldots .98$

U. S. Glue Co. v. Town of Oak Creek, 161 Wis. $211 \ldots \ldots \ldots \ldots . . . .94-110$

U. S. ex rel. Turner v. Williams, 194 U. S. $279 \ldots \ldots \ldots \ldots \ldots . \ldots 195$

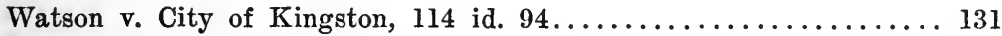

Welsbach v. Norwich Gas Co., 96 A. D. 52............... 18-19

Western Union Tel. Co. v. Kansas, 216 U. S. $27 \ldots \ldots \ldots \ldots \ldots \ldots 22$

White Co. v. Massachusetts, ..................... 93

Wilson, McNeil Co. v. Standard Oil Co., 110 A. D. $888 \ldots \ldots \ldots \ldots 19$

Wise v. Wise Co., 153 N. Y. $507 \ldots \ldots \ldots \ldots \ldots \ldots \ldots \ldots \ldots \ldots . \ldots \ldots$

Wood \& Sellick Co. v. Ball, 114 A. D. $744 \ldots \ldots \ldots \ldots \ldots \ldots \ldots \ldots$ 


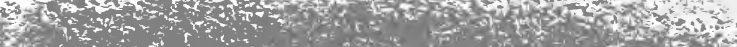

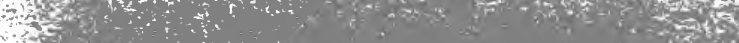
$\frac{1}{4}$ 


\section{INDEX TO CORPORATION TAXES (PARTS I, II, III)}

Accounting (See "bookkeeping")

PAGE

Action for recovery of taxes $(9-a) \ldots \ldots \ldots \ldots \ldots \ldots \ldots \ldots 146,166$

Agricultural and horticultural companies exempt from Section 182... 24

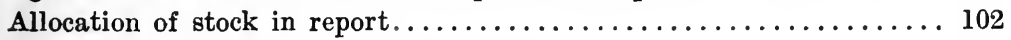

Amendments of 1919 to business corporations tax (Art. 9-a) ..... 77

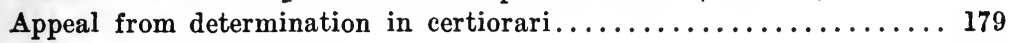

Application for revision............................. 158

Apportionment of tax under Article 9 -a.................. 116

between states, cities, towns and villages under $9-a \ldots \ldots \ldots \ldots 132,139$

revenue collected under $9-\mathrm{a} \ldots \ldots \ldots \ldots \ldots \ldots \ldots \ldots \ldots \ldots \ldots$

Assignees to file report............................ 111

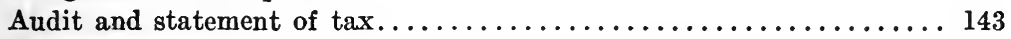

Average capital and price how ascertained (Art. 9) .......... 37

monthly values how ascertained (Art. 9-a) ................ 114

Bankers (See foreign bankers)

Banks, savings banks, etc., exempt from Section $182 \ldots \ldots \ldots \ldots \ldots 24$

Bells Gap Company case......................... 108

Bookkeeping methods for arriving at net income............. 112

Book value (See value)

Burden of proof is on the relator in certiorari.............. 179

Business corporations tax (Art. 9-a), amendments to.......... 77

are subject to tax under 9 -a....................... 81

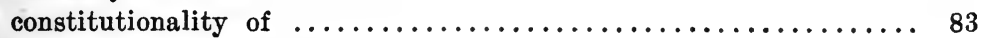

Business (See Doing business) ..................... 81

Canal companies taxable under Section $182 \ldots \ldots \ldots \ldots \ldots \ldots \ldots 23$

Certiorari, general purpose of law as to writ of............. 171

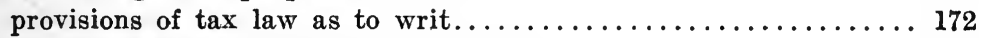

deposit of taxes with state comptroller................... 173

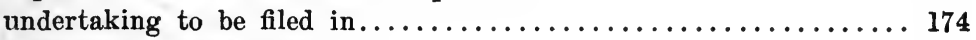

code provisions applicable to....................... 174

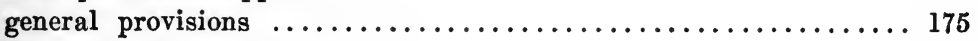

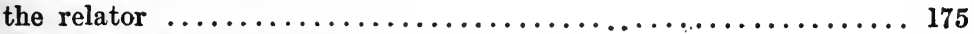

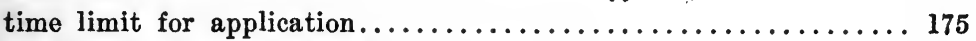

application for rehearing a prerequisite of $\ldots \ldots \ldots \ldots \ldots \ldots \ldots 176$ 


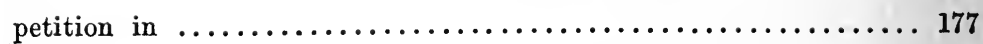

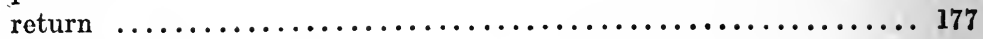

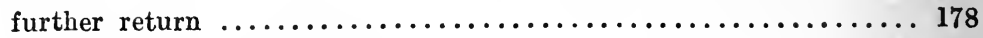

appeal from determination in....................... 179

burden of proof is on the relator in..................... 179

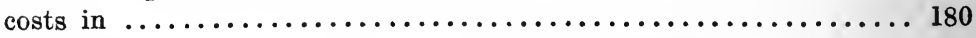

reassessment commission if held erroneous on appeal in......... 180

corporations estopped by ......................... 181

Changes in Federal report, corporation to notify commission of..... 144

Charter forfeiture by delinquent corporation $(9-a) \ldots \ldots \ldots \ldots \ldots 146$

of delinquent corporation forfeited...................... 166

Coal company, segregation of assets................... 105

Code of Civil Procedure does not apply to limitation of time (9-a) .. 151

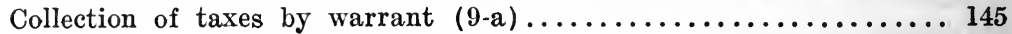

Commission corporation, segregation of assets............... 106

Comptroller may refund under 1919 Act.................79, 128

shall deposit revenue collected under 9 -a................. 146

Computation of tax under Art. 9 -a................... 117

Connecticut Act permits deduction of Excess Profits Tax......... 87

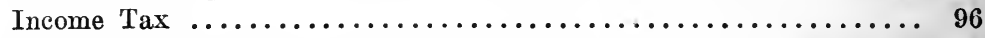

Consolidated corporations taxed under 9 -a................ 141

Constitutionality of tax on gross earnings on transportation com-

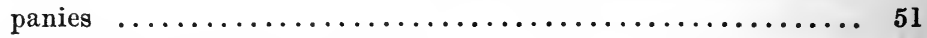

business corporations tax (Art. 9 -a) $\ldots \ldots \ldots \ldots \ldots \ldots \ldots \ldots \ldots, 83$

Contracting corporation, segregation of assets.............. 106

Copyrights, valuation of under $\S 182$, Art. $9 \ldots \ldots \ldots \ldots \ldots \ldots \ldots, 40$

Corporations exempt from taxation under Art. 9-a............ 136

Corporation includes a joint stock company or association........ 136

Correspondence School is not "Doing Business".............. 92

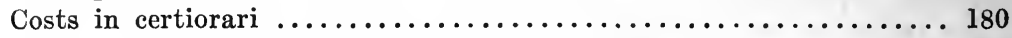

Cotton converting corporation, segregation of assets........... 104

Credit to be given to corporation for state bonds..............62

to corporations for personal taxes paid in $1917-18 \ldots \ldots \ldots \ldots \ldots 125$

by corporations paying taxes 1917-18 under Art. 9-a.......... 150

for excess taxes................................. 160

Debts to be deducted in assessing franchise tax.............. 37

Decision in People ex rel. Barcola Mfg. Co. v. Knapp............ 89

Deduction of excess profits tax.........................85-86

Definition of fixtures.............................. 79

of holding corporation........................... 82

of personal property $\ldots \ldots \ldots \ldots \ldots \ldots \ldots \ldots \ldots \ldots \ldots \ldots \ldots, 151$

of entire net income.............................. 136 
Disposition or apportionment of revenue collected under 9 -a...... 147

"Doing Business" defined under Article 9-a................. 91

selling through a commission house is not............... 92

keeping a sales manager, with resident manager............. 92

various kinds of activities held to be................... 93

Domestic Corporations must report under Art. 9-a unless dissolved.. 99

to what extent taxable under Article 9 -a................ 99

Electric companies taxable under Sec. $186 \ldots \ldots \ldots \ldots \ldots \ldots \ldots . \ldots 3$

Elevated railroad and surface railroad companies exempt from Sec. 18224

Entire net income defined........................ 136

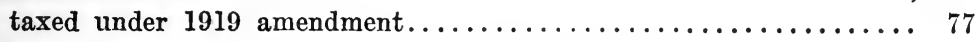

under 1918 Federal Act includes $\$ 2,000$ exemption........... 89

Excess profits deduction........................... 85

passed on in New York Court...................... 89

deducted under Connecticut Act................... 87

deducted under Massachusetts Act................... 87

Excess taxes to be refunded......................... 160

Exemption from personal property tax under Art. 9-a..........121, 149

from Section 182 (Art. 9) of business corporations, banks, savings banks, institutions for savings, title guaranty, insurance, surety companies, trust companies, elevated and surface railroad, water, lighting and power companies, agricultural and horticultural associations $\ldots \ldots \ldots \ldots \ldots \ldots \ldots \ldots \ldots \ldots \ldots, 24$

from tax under Article $9-a \ldots \ldots \ldots \ldots \ldots \ldots \ldots \ldots \ldots . \ldots 2$

(under Art. 9-a) of steam surface railroad, canal, steamboat, ferry, express, navigation, pipe-line, transfer, baggage express, telegraph, telephone, palace or sleeping car corporations......... elevated surface railroads, water works, gas, heat, light and power, electric and steam companies.................... 83

insurance corporations, trust companies, savings banks........ 83

of fixtures passed on General Chemical case............... 124

of school taxes under 9 -a not granted................... 130

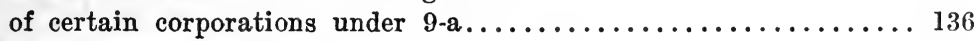

Express companies taxable under Section $182 \ldots \ldots \ldots \ldots \ldots \ldots \ldots 23$

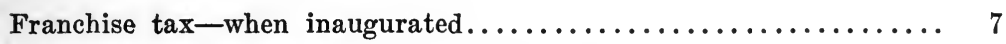

corporations subject to, under Section 182, viz............ 23

realty, holding, steam-surface, railroad, canal, steamboat, ferry, express, navigation, pipe-line, transfer and baggage, telephone, telegraph, palace-car companies......................

exempt from, under Section 182, viz., business corporations (manufäcturing and mercantile), banks, savings banks, and institu- 
tions for savings, title guaranty, insurance, surety companies and trust companies, elevated and surface railroad, water, lighting and power companies, agricultural and horticultural asso-

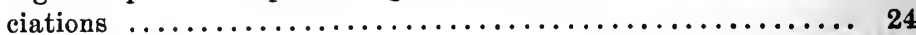

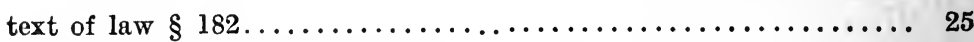

appraisement of capital stock for .................... 27

business corporations no longer taxed under, $\S 182 \ldots \ldots \ldots \ldots \ldots 27$

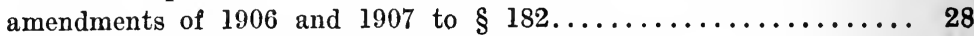

ambiguity as to rate decided in taxpayer's favor............ 28

when dividends are $6 \%$ or more..................... 32

when no dividends are declared..................... 32

when dividends are less than $6 \% \ldots \ldots \ldots \ldots \ldots \ldots \ldots \ldots \ldots, 34$

under drag-net clause............................ 35

when there is more than one kind of stock............... 36

payable in advance........................... 37

based on average capital and average price............... 37

actual or intrinsic value to be ascertained............... 37

debts to be deducted........................... 37

when not to be deducted.......................... 38

book value does not govern assessment for............... 38

good will to be considered in assessment................ 38

when stock dividend to be considered in assessing............. 39

when distribution and condemnation proceedings considered for... 39

payable on U. S. securities if part of capital stock.......... 40

payable on eapital invested in trade marks or patent rights..... 40

payable on realfy corporations $\ldots \ldots \ldots \ldots \ldots \ldots \ldots \ldots \ldots \ldots .41-42$

realty corporations .............................43

payable by joint stock associations.................. 43

on corporations having stock without par value............ 44

based on net income under $9-a \ldots \ldots \ldots \ldots \ldots \ldots \ldots \ldots \ldots . . .63,136$

Fixtures defined $\ldots \ldots \ldots \ldots \ldots \ldots \ldots \ldots \ldots \ldots \ldots \ldots \ldots \ldots \ldots, 123$

Fixtures when exempted from local tax................. 122

Foreign bankers, tax upon.........................63

Foreign corporations

to pay license $\operatorname{tax} \ldots \ldots \ldots \ldots \ldots \ldots \ldots \ldots \ldots \ldots \ldots \ldots \ldots \ldots \ldots$

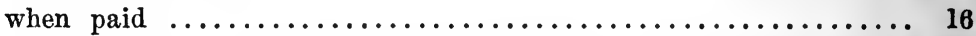

method of computing license tax changed................ 17

not citizens for license tax purposes................... 17

when liable for it................................ 17

when barred from business on failure to pay............... 18

correspondence school when not liable for tax.............. 21

not in business thirteen months need not pay tax........... 21

not within jurisdiction until certiftcate filed............... 21 
soliciting business here when taxable.................. 46

return under 1919 amendment (Art. 9-a) ............... 77

when taxable under Article 9 -a..................... 81

when obliged to make a report under Art. 9-a............ 100

Foreign insurance companies subject to taxation.............. 58

Forfeiture of charter by delinquent corporation $(9-a) \ldots \ldots \ldots \ldots 146,166$

Gas companies taxable under $\S 186 \ldots \ldots \ldots \ldots \ldots \ldots \ldots \ldots \ldots . \ldots 53$

Good will to be considered in assessment of franchise tax $(\S 182) \ldots 38$

Gross earnings (additional) taxed, when introduced............ 8

on insurance companies, trust companies, banks, etc........... 8

on transportation, transmission, heat, light and power companies.. 50

additional tax on, in the nature of a license fee............. 51

constitutionality of $\operatorname{tax}$ on ........................... 51

United States carriers not taxable, if they carry mails......... 52

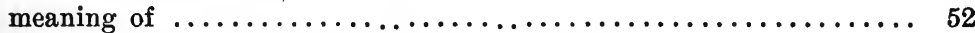

Gross premiums of insurance companies taxable............ 56

Heat, light and power companies taxable on gross earnings....... 50

Holding corporations taxable under Section $182 \ldots \ldots \ldots \ldots \ldots \ldots . \ldots 23$

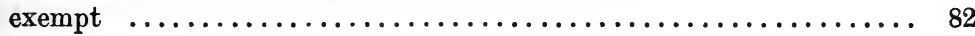

defined $\ldots \ldots \ldots \ldots \ldots \ldots \ldots \ldots \ldots \ldots \ldots \ldots \ldots \ldots \ldots \ldots \ldots, 82$

Illustration of report segregating assets................. 108

Import company, segregation of assets.................. 105

Instructions for preparing report....................... 111

Insurance companies exempt from Section $182 \ldots \ldots \ldots \ldots \ldots \ldots .24$

Insurance companies taxed on gross premiums.............. 56

Interstate commerce in connection with local business.......... 92

Interest uncollectible as part of penalty................... 167

Interstate commerce, maximum limit clause in connection with..... 93

Investment companies taxable under $\S 188 \ldots \ldots \ldots \ldots \ldots \ldots \ldots, 61$

Joint stock associations taxable for franchise tax............ 43

Joint stock company or association is included in corporation....... 136

License $\operatorname{tax}(\S 181)$, when introduced................... 8

defined $\ldots \ldots \ldots \ldots \ldots \ldots \ldots \ldots \ldots \ldots \ldots \ldots \ldots \ldots \ldots \ldots \ldots \ldots \ldots \ldots \ldots, 14$

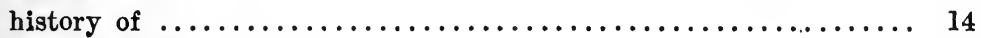

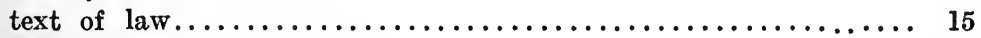

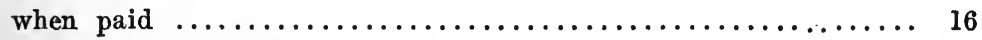

method of computing, changed...................... 17

failure to pay bars corporation from State business........... 18

not payable until company here thirteen months.............. 21 
fee, the additional tax on transportation, transmission, heat, light and power companies in the nature of $\ldots \ldots \ldots \ldots \ldots \ldots \ldots, 51$

Lien of tax on real and personal property.................. 71

Light and power companies taxable on gross earnings.......... 50

Lighting and power companies taxable under $\S 186 \ldots \ldots \ldots \ldots \ldots .53$

Limitation of time to assess or collection under $9-a \ldots \ldots \ldots \ldots \ldots .151$

Limitation of time............................... 169

Local business in connection with interstate commerce.......... 92

Mail carrier companies not taxable on gross earnings.......... 52 Massachusetts Act permits deduction of Excess Profits Tax........ 87

Maximum limit clause in connection with interstate commerce..... 93 Merged or consolidated corporations....................78, 141 Minimum tax provision............................ 100 Morris Plan companies taxable under $\S 188$-a.............. 62

Navigation companies taxable under Section 182

Net income (See entire net income)

franchise $\operatorname{tax}$ on corporations based on.................. 83

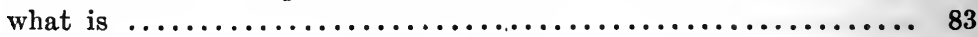

Non-resident, is personally liable for tax................. 168

Notice of statement of tax to be sent corporations............. 69

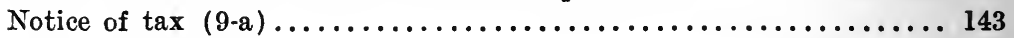

Palace-car and sleeping-car companies taxable under Section 182

Patent rights considered in assessing franchise tax........... 40 Payment of personal taxes 1917-18 is not a contract with the State.. 128 of tax and penalty for failure $\ldots \ldots \ldots \ldots \ldots \ldots \ldots \ldots \ldots \ldots, 70$

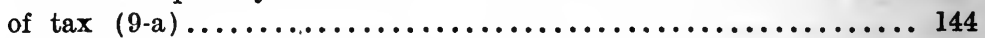

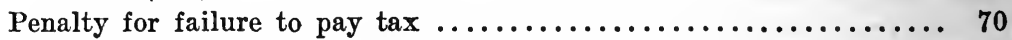
for failure to report under Art. 9-a..................141, 165 for violation of secrecy....................... 148, 170

Personal liability of non-resident for tax.................. 168 property defined $\ldots \ldots \ldots \ldots \ldots \ldots \ldots \ldots \ldots \ldots \ldots \ldots \ldots \ldots, 151$ lien of $\operatorname{tax}$ under Art. 9 on......................... 71 exemption from $\operatorname{tax}$ on under 9 -a...................... 149

Personal service corporations are now taxed under 9-a......... 81 taxes paid by corporations in $1917-18 \ldots \ldots \ldots \ldots \ldots \ldots \ldots \ldots . \ldots \ldots$

Petition for revision................................ 158

Place of business of corporation outside the state to be reported... 113

Powers and duties of tax commission (See tax commission) ...... 163 of $\operatorname{tax}$ commission..........................68, 69, 141, 163 of comptroller ................................. 163

Priority in payment of State tax from insolvent estate......... 71 
Räte of tax under Art. 9-a increased to $41 \frac{1}{2} \% \ldots \ldots \ldots \ldots \ldots \ldots . \ldots 79$

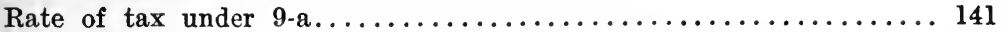

Realty corporations taxable on franchise under Sec. $182 \ldots \ldots \ldots 23,40$ whether capital be productive or not................... 41

without the state taxable.......................... 43

Real property, lien of tax on, under Art. $9 \ldots \ldots \ldots \ldots \ldots \ldots \ldots 71$

assessment of fixtures modified by Art. 9-a............... 125

Realty corporations exempt under Art. 9-a............... 82

Reassessment by commission if same be deemed erroneous on appeal

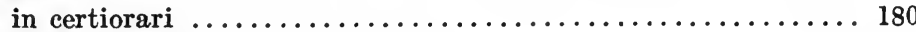

Refund, by comptroller under 1919 act.................. 128

for payment of excess taxes........................ 160

Rehearing, see revision and resettlement and rules applying to.... 160

Reports of corporations under $\S 182 \ldots \ldots \ldots \ldots \ldots \ldots \ldots \ldots \ldots . \ldots 6$

transportation and transmission companies...............65

elevated and surface companies....................... 65

water-work, gas, electric, steam heating, lighting and power cor-

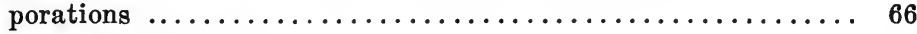

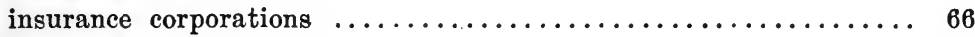

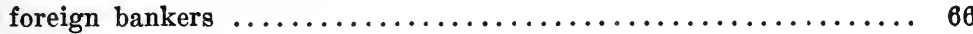

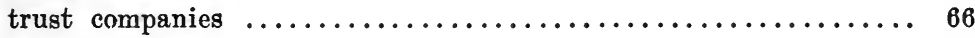

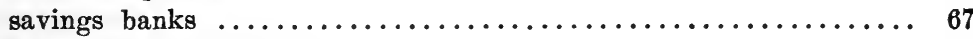

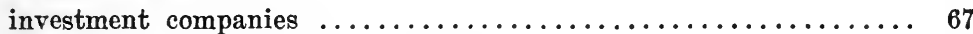

verification of by officer of company................... 68

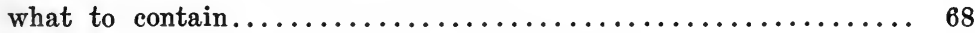

due from domestic corporations under Art. 9-a............ 99

Report by foreign corporations under Art. 9-a............. 100

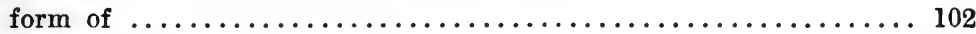

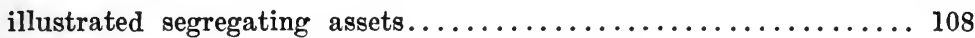

Receivers, assignees, trustee to file under Art. 9 -a.......... 111

by corporation on basis of fiscal year................. 138

accounts receivable and bills receivable duplicated in 1917 form... 102

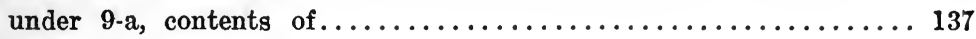

Return (See Report)

Revision and readjustment under 9 -a................... 142

Review of tax commission's decision by certiorari $(9-a) \ldots \ldots \ldots 142$

Report comptroller not bound by corporations............. 69

failure to, subjects corporation to penalty.............. 165

Revenue deposited under 9 -a......................146

Revision of corporation taxes, similar provision under Article 16... 155

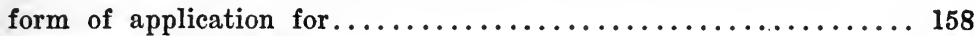

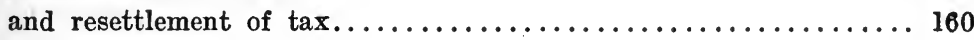


Savings banks taxable under $\S 189 \ldots \ldots \ldots \ldots \ldots \ldots \ldots \ldots \ldots \ldots, 62$

School taxes, corporations taxed under 9 -a not relieved from...... 130

Secrecy required of officials........................148, 170

Segregation required for corporations having no net income...... 78

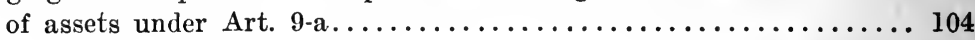

Cotton converting company....................... 104

Cotton converting company selling in N. Y............. 104

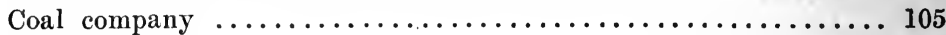

Import company .............................. 105

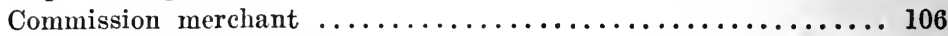

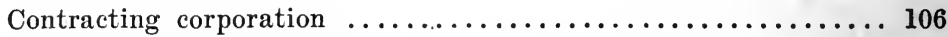

Selling goods through a commission house is not "doing business" ... 92

Settlement of tax after January 15 th.................... 71

State bonds, credit to be given corporation in purchase of........ 62

Steam heating companies taxable under $\S 186 \ldots \ldots \ldots \ldots \ldots \ldots \ldots .53$

Steam-surface railroad, steamboat and ferry companies taxable under

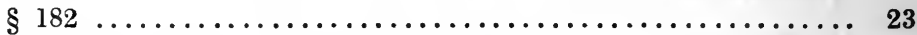

Stock dividends, when to be considered in assessing franchise tax... 39

Stock in other corporations to be allocated or segregated......... 78

Stocks in other corporations allocated under report, Art. 9-a...... 102

Subjects of taxation under 9-a are business corporations........ 81

Subway railroad not taxable under $\S 185 \ldots \ldots \ldots \ldots \ldots \ldots \ldots \ldots, 53$

Surety cỏmpanies exempt from $\S 182 \ldots \ldots \ldots \ldots \ldots \ldots \ldots \ldots \ldots .24$

Surplus and undivided earnings of savings banks taxable under $\S 189 \quad 62$

Tax commission, powers and duties of $\ldots \ldots \ldots \ldots \ldots \ldots \ldots \ldots . \ldots \ldots$

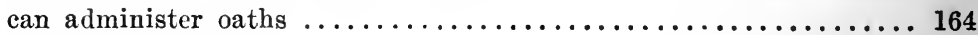

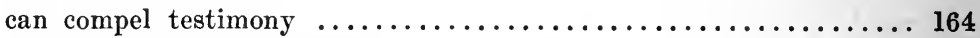

cannot punish for contempt......................... 165

provisions for furnishing necessary data to.............. 164

Tax under 9-a to be apportioned between states, cities, towns and

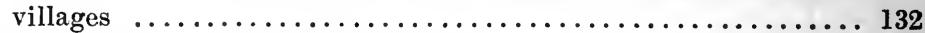

"Tangible personal property" defined.................... 136

Telephone, telegraph, transfer and baggage companies taxable under

Section 182

Title guaranty companies exempt from Section $182 \ldots \ldots \ldots \ldots \ldots \ldots 24$

Trade marks to be considered in assessment under $\S 182 \ldots \ldots \ldots \ldots 40$

Transportation, transmission companies taxable on gross earnings... 50

Trust companies exempt from $\S 182 \ldots \ldots \ldots \ldots \ldots \ldots \ldots \ldots \ldots . . \ldots 24$

Trust companies, savings banks and investment companies taxable under $\S 188 \ldots \ldots \ldots \ldots \ldots \ldots \ldots \ldots \ldots \ldots \ldots \ldots \ldots \ldots, 61$

Trustees to file report under Art. 9 -a..................... 111

United States securities considered for franchise tax purposes...... 40 
Verification reports $\ldots \ldots \ldots \ldots \ldots \ldots \ldots \ldots \ldots \ldots \ldots \ldots \ldots \ldots \ldots \ldots$

Verification of petition............................. 159

Warrant for the collection of taxes $(9-a) \ldots \ldots \ldots \ldots \ldots \ldots \ldots \ldots \ldots$

Warrant for collection of taxes.......................... 167

Warrant for unpaid personal income tax................. 168

Water works, gas, electric, steam heating, lighting and power com-

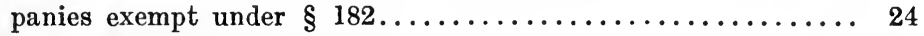

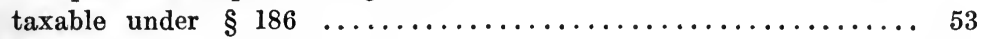

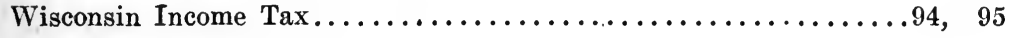




\section{INDEX TO INCOME TAX (PART IV) \\ (Index to Corporation Taxes supra)}

Accounting method of, what, $\S 358$, subd. $1 \ldots \ldots \ldots \ldots \ldots \ldots \ldots 246$

period, separate, return when changed, $\S 370 \ldots \ldots \ldots \ldots \ldots \ldots 326$

Accounts, revision and readjustment of, by comptroller, $\S 374 \ldots \ldots 329$

Action for recovery of, may be brought by attorney general, $\S 381 \ldots 335$

Act not invalidated if part thereof adjudged to be invalid, $\S 385$,

subd. 2 ................................ 335

Administration of Income Tax appropriation of $\$ 300,000$, $\S 385$, subd.

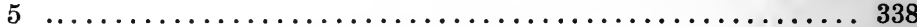

Affidavit, return, to be annexed to, $\S 371 \ldots \ldots \ldots \ldots \ldots \ldots \ldots \ldots 327$

Agent, fiduciary distinct from return, when to make, $\S 367 \ldots \ldots \ldots 322$

warrant to, for collection of unpaid tax, $\S 380 \ldots \ldots \ldots \ldots \ldots . \ldots 334$

Agents, withholding (see withholding agent)

Amounts received through accident or health insurance, $\S 359$, subd.

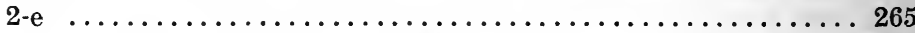

soldiers or sailors benefit law, $\S 359$, subd. 2-e............ 265

war risk insurance act, through, $\S 359$, subd. 2 -e........... 265

under workmen's compensation acts as compensation or damages,

$\S 359$, subd. 2-e........................... 265

Amount withheld to be credited against income tax as computed in

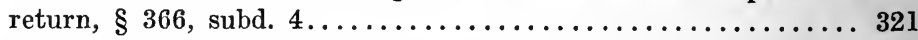

Analysis of Personal Income Tax...................... 185

Annuities, to non-residents, gross income from, when included in, § 359 ,

subd. 3 .............................. 267

Appropriation of $\$ 300,000$ for administration of act, $\S 385$, subd. 5. .

Assembly ways and means committee chairman to approve new posi-

tions and fixed salaries, $\S 385$, subd. $5 \ldots \ldots \ldots \ldots \ldots \ldots \ldots$

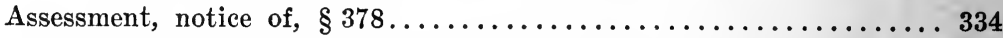

record to be preserved by comptroller, $\S 378 \ldots \ldots \ldots \ldots \ldots \ldots . \ldots 334$

Assessment of personal property made prior to Aug. 1, 1919

taxes thereon, obligation to pay, $\S 385$, subd. 5............ 338

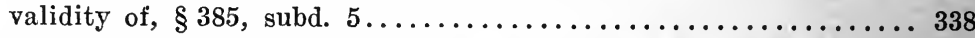

Attorney-general, action by, for recovery of unpaid taxes, $\S 381 \ldots \ldots 335$

opinions of, construing N. Y. law..................... 213

taxes, unpaid, action by for recovery, $\S 381 \ldots \ldots \ldots \ldots \ldots \ldots . \ldots 335$ 
Beneficiaries of estate or trust

distributive share of estate or trust to be included in return by fidu-

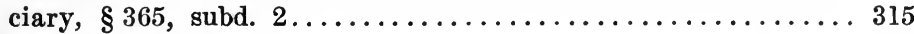

fiduciary to include in return distributive share of, $\S 365$, subd. 2 . 315

income distributed to periodically, $\S 365$, subd. 1-d........... 314

when tax paid by fiduciary, $\S 365$, subd. $3 \ldots \ldots \ldots \ldots \ldots \ldots 316$

net income to include distributive share, $\S 365$, subd. $4 \ldots \ldots \ldots \ldots 318$

Betterments, not deductible from net income, $\S 361$, subd. $2 \ldots \ldots \ldots 308$

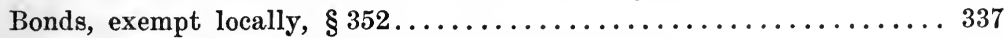

Books and records, when comptroller to examine, $\S 373 \ldots \ldots \ldots \ldots 329$

Branch offices to be established for administration of, $\S 372 \ldots \ldots . \ldots 329$

Budget, cities, inclusion of tax therein; when, $\S 385$, subd. $4 \ldots \ldots \ldots$

revenue from Act to be included in; when, $\S 385$, subd. $4 \ldots \ldots \ldots$

Business of non-resident individuals in state subject to, $\S 351 \ldots \ldots 236$

Capital expenditures, not deductible $\ldots \ldots \ldots \ldots \ldots \ldots \ldots \ldots . \ldots 308$

Certiorari (See Chapters XX to XXII, Part III)

eight days' notice to be given comptroller of application for writ,

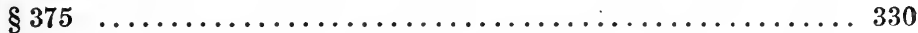

notice of application therefor must be made within thirty days after

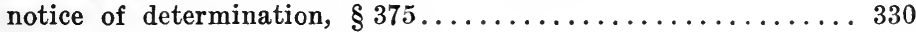

review of determination of comptroller, $\S 375 \ldots \ldots \ldots \ldots \ldots \ldots 330$

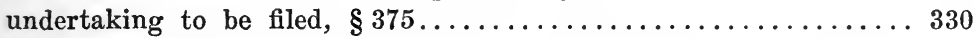

writ; regulations as to comptroller; determination of, reviewable

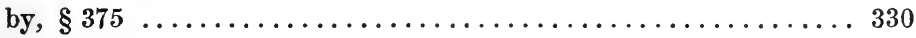

Charitable contributions or gifts deductible from net income, $\S 360$, subd. 10 .............................. 303

Choses in action, exempt locally (See Chapter XXVII, Part IV), § 352237

Cities, budget, when, to include revenue from act; when Ch. 627, L.

$1919, \S 385$, subd. $4 \ldots \ldots \ldots \ldots \ldots \ldots \ldots \ldots \ldots \ldots \ldots \ldots \ldots \ldots$

revenue collected, apportioned among, $\S 382 \ldots \ldots \ldots \ldots \ldots \ldots 336$

revenue to; when to be included in budget, Ch. $627, \mathrm{~L} .1919, \S 385$,

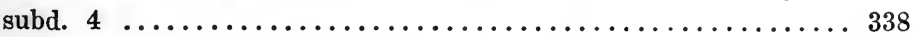

Collection of warrant for (See Chapter XXI, Part III), § 380, subd. 1334

Comptroller, account for taxes, penalties, etc., to audit and state, $\S 373329$

accounting period, new, basis of computing net income, when, $\S 358$,

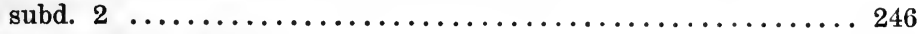

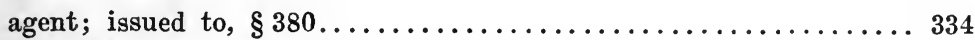

assessment; notice of, to be preserved by, $\S 378 \ldots \ldots \ldots \ldots \ldots 334$

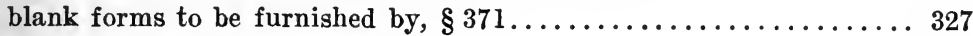

books and records, to examine, $\S 373 \ldots \ldots \ldots \ldots \ldots \ldots \ldots . \ldots . \ldots 329$

branch offices of for administration to be maintained, $\S 372 \ldots \ldots . \ldots 329$ 
certiorari (See Chapters XX to XXII, Part III)

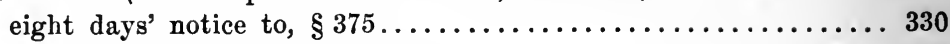

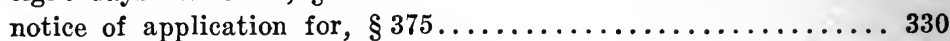

undertaking to be filed with, $\S 375 \ldots \ldots \ldots \ldots \ldots \ldots \ldots \ldots \ldots \ldots \ldots \ldots \ldots \ldots$

collection of, by (See Chapter XXI, Part III), §379, subd. 1.... 334

computation of, by, $\S 377$, subd. $2 \ldots \ldots \ldots \ldots \ldots \ldots \ldots \ldots \ldots \ldots \ldots \ldots \ldots \ldots \ldots \ldots \ldots$

credit allowed by, to non-residents, when, $\S 363 \ldots \ldots \ldots \ldots \ldots . \ldots 311$

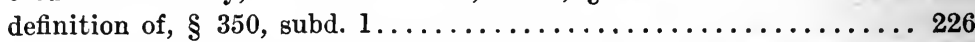

depletion allowance, to be determined by, $\S 360$, subd. 9...... 266

determination of, reviewable by certiorari, $\S 375 \ldots \ldots \ldots \ldots \ldots . \ldots 330$

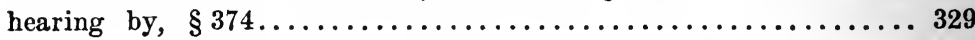

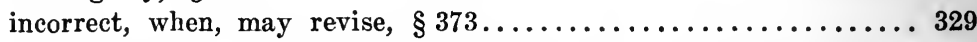

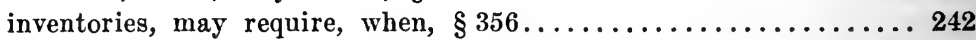

may estimate taxable income when no return made, $\S 373 \ldots \ldots . .329$

net income, manner of computing, to be determined by, when, $\S 358$,

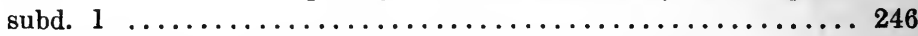

notice of assessment; record of to be preserved by, $\S 378 \ldots \ldots \ldots 334$

partnership, may require return for, when, $\$ 364 \ldots \ldots \ldots \ldots \ldots 312$

payment of tax to, by withholding agent, $\S 366$, subd. $3 \ldots \ldots \ldots 321$

penalty for violation of, $\S 384$, subd. $2 \ldots \ldots \ldots \ldots \ldots \ldots \ldots \ldots 337$

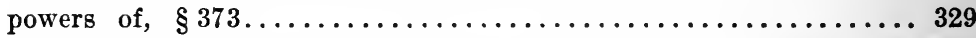

resettlement and readjustment of, by, $\S 374 \ldots \ldots \ldots \ldots \ldots \ldots . \ldots 329$

return and payment of tax to, by withholding agents, $\S 366$, subd. 3321

may estimate taxable income when no return made, $\$ 373 \ldots \ldots 329$

may revise when incorrect, $\S 373 \ldots \ldots \ldots \ldots \ldots \ldots \ldots \ldots \ldots . \ldots \ldots \ldots$

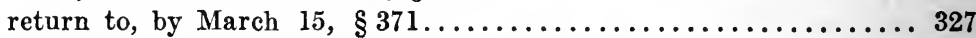

return to, by withholding agents, $\S 366$, subd. $2 \ldots \ldots \ldots \ldots \ldots 320$

revision and readjustment of accounts by, $\S 374 \ldots \ldots \ldots \ldots \ldots 329$

rules and regulations for deduction and withholding at source.... 208

re depletion allowance, to be prescribed by, $\S 360$, subd. $9 \ldots \ldots 289$

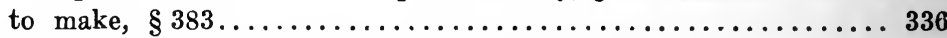

secrecy required of, re income returns, $\S 384$, subd. $1 \ldots \ldots \ldots \ldots 337$

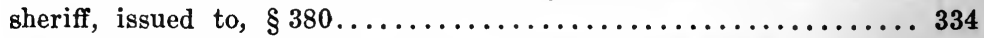

taxable income, to estimate, when no return made, $\$ 373 \ldots \ldots \ldots 329$

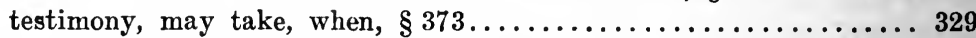

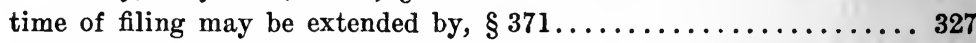

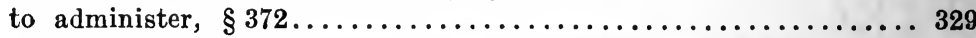

to audit and state account for taxes, penalties, etc., $\S 373 \ldots \ldots \ldots 329$

to be given eight days' notice of application for writ of certiorari,

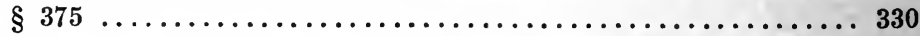

to estimate taxable income when no return made, $\S 373 \ldots \ldots \ldots 329$

to examine books and records, when, $\$ 373 \ldots \ldots \ldots \ldots \ldots \ldots . \ldots 329$

to provide a fund for payment of refunds, $\$ 382 \ldots \ldots \ldots \ldots \ldots . \ldots 336$ 
to receive excess when computation of tax greater than amount theretofore paid, $\S 377$, subd. $3 \ldots \ldots \ldots \ldots \ldots \ldots \ldots \ldots \ldots \ldots \ldots \ldots$

to refund excess when computation of tax less than amount there-

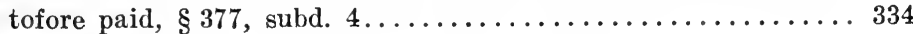
to retain amount of tax to provide a fund of $\$ 250,000$ for payment

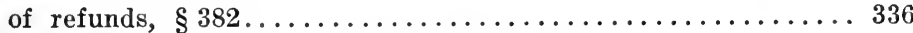
undertaking re certiorari to be filed with, $\S 375 \ldots \ldots \ldots \ldots \ldots \ldots . \ldots 330$

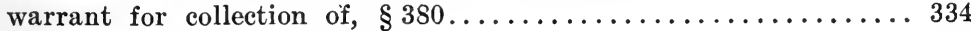

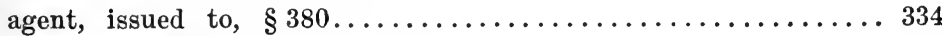

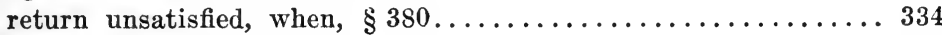

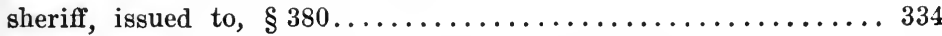

when greater than amount theretofore paid, $\S 377$, subd. $3 \ldots \ldots . .333$

when less thán amount theretofore paid, $\S 377$, subd. $4 \ldots \ldots \ldots . \ldots 334$

Computation of tax, $\S 377$, subd. $2 \ldots \ldots \ldots \ldots \ldots \ldots \ldots \ldots \ldots \ldots \ldots \ldots \ldots$

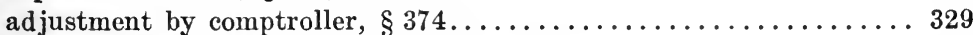

estates and trusts, net income of, $\S 365$, subd. $2 \ldots \ldots \ldots \ldots \ldots 315$

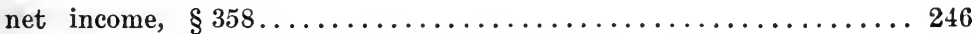

when greater than amount theretofore paid, $\S 377$, subd. $3 \ldots \ldots 333$

Constitutionality of $\operatorname{tax}$ on Personal Incomes............... 190

Contract to assume tax illegal, $\S 385 \ldots \ldots \ldots \ldots \ldots \ldots \ldots \ldots \ldots \ldots \ldots \ldots$

Home Rule Principle involved in.................... 191

Contributions, gifts deductible from net income, $\S 360$, subd. $9 \ldots \ldots 289$

Corporation, gain through issuance or exchange of stock, $\S 355 \ldots \ldots 241$ gifts or contributions to certain deductible from net income, $\S 360$,

subd. 10 ............................... 303

Corporations,individuals, partnerships, claims and demands, indemni-

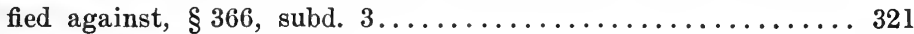

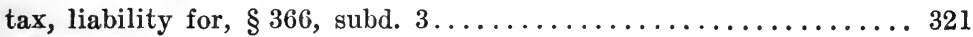

County not to be divided in forming district, $\S 372 \ldots \ldots \ldots \ldots \ldots 329$

County treasurer, revenue collected, portion of, to, $\S 382 \ldots \ldots \ldots 336$

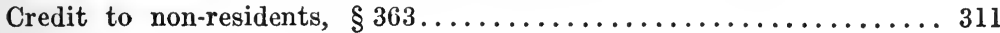

Debts, worthless, when deducted from net income, $\S 360$, subd. $7 \ldots 281$ Deceased persons, taxed on estates of, imposed upon net income of,

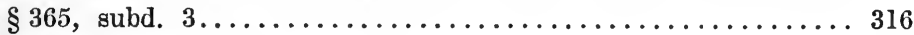

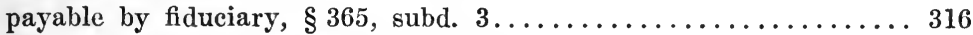

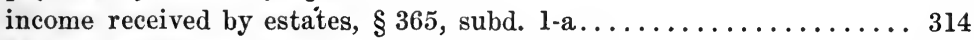
income to legatee, heir, etc., deductible, $\S 365$, subd. $3 \ldots \ldots \ldots \ldots 316$

Decisions under the Corporation Income Tax................ 339

Deduction at source, no penalty for failure to return or pay same, except for fraud, $\S 366$, subd. $5 \ldots \ldots \ldots \ldots \ldots \ldots \ldots \ldots . \ldots . \ldots 1$

not re-collectible from withholding agent, $\S 366$, subd. $5 \ldots \ldots \ldots 321$

Deductions, apportionment and allocation of, $\S 360$, subd. $11 . \ldots .306$ 
at source, from income, $\S 366$, subd. $1 \ldots \ldots \ldots \ldots \ldots \ldots \ldots \ldots . \ldots 319$ comptroller's rules and regulations for, $\S 549 \ldots \ldots \ldots \ldots \ldots \ldots 208$ deceased person, estate of, when income paid to legatee, heir, etc.,

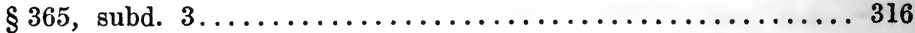
gross income, when part of, payable to U. S., state, etc., or to charitable corporation, $\S 365$, subd. $2 \ldots \ldots \ldots \ldots \ldots \ldots \ldots \ldots \ldots \ldots \ldots \ldots$ net income, allowed; business, necessary expenses of, $\S 360$, subd. 1268 contributions or gifts, $\S 360$, subd. $10 \ldots \ldots \ldots \ldots \ldots \ldots \ldots . \ldots . \ldots 6$ debts, worthless, charged off, $\S 360$, subd. $7 \ldots \ldots \ldots \ldots \ldots \ldots 281$ exhaustion, wear and tear, depreciation, obsolescence, $\S 360$, subd. 8 283

interest on indebtedness, proportion of, $\S 360$, subd. $2 \ldots \ldots \ldots \ldots 274$ losses in business, not compensated for, $\S 360$, subd. $4 \ldots \ldots \ldots \ldots 277$ fires, storms, shipwrecks, theft, $\S 360$, subd. 6........ 279 transactions for profit, when, $\S 360$, subd. $5 \ldots \ldots \ldots \ldots \ldots \ldots 278$ mines, oil, gas wells, timber, natural deposits, $\S 360$, subd. 9... 289 non-resident, apportioñment and allocation of, $\S 360$, subd. $11 \ldots 306$ arising within state, $\S 360$, subd. $11 \ldots \ldots \ldots \ldots \ldots \ldots \ldots$

contributions or gifts, $\S 360$, subd. $10 \ldots \ldots \ldots \ldots \ldots \ldots \ldots . \ldots 306$

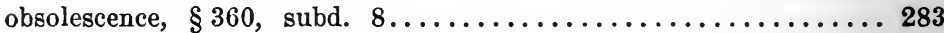
taxes paid or accrued, what, $\S 360$, subd. $3 \ldots \ldots \ldots \ldots \ldots \ldots 275$ net income, not allowed

non-resident, when, $\S 367 \ldots \ldots \ldots \ldots \ldots \ldots \ldots \ldots \ldots \ldots 22$ permanent improvements, betterments, new buildings, $\S 361$, subd. personal expenses, living or family, $\S 361$, subd. $1 \ldots \ldots \ldots \ldots \ldots$. premiums on life insurance policies, what, $\S 361$, subd. 4..... 308 restoring property, when, $\S 361$, subd. $3 \ldots \ldots \ldots \ldots \ldots \ldots \ldots . \ldots 308$ non-resident, when not entitled to, $\S 367 \ldots \ldots \ldots \ldots \ldots \ldots \ldots \ldots 22$ partnerships, what allowed in computing net income of, $\S 364 \ldots 312$ Definitions of

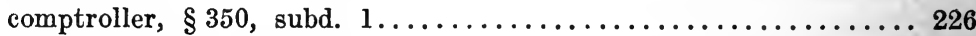

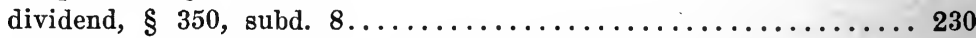

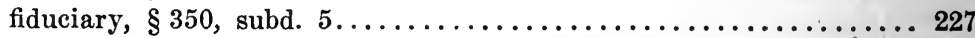

foreign country or foreign government, $\S 350$, subd. $9 \ldots \ldots \ldots \ldots 235$ gross income, $\S 359$, subd. $1 \ldots \ldots \ldots \ldots \ldots \ldots \ldots \ldots \ldots \ldots \ldots \ldots . \ldots \ldots$ military or naval forces of the United States, $\S 350$, subd. 3....227

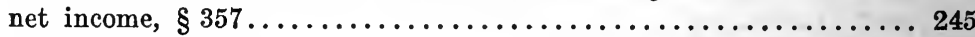

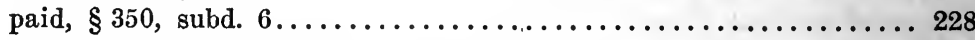

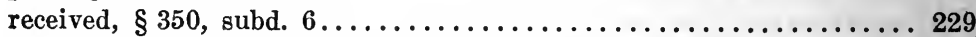

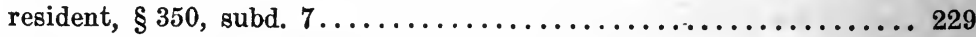

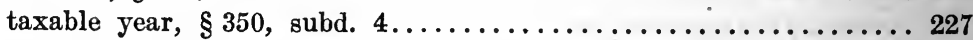

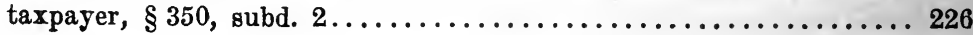




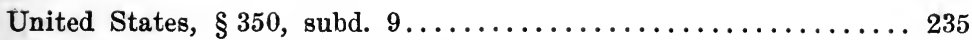

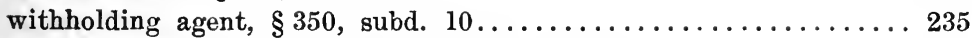

Dependents, exemptions allowed, $\S 362$, subd. $2 \ldots \ldots \ldots \ldots \ldots \ldots 310$

Depreciation of improvements deductible from net income, when, $\S 360$,

subd. 9 ............................... 289

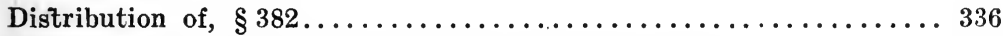

Districts, county not to be divided in forming, $\$ 372 \ldots \ldots \ldots \ldots 329$ state to be divided into, for administration purposes, $\S 372 \ldots \ldots 329$

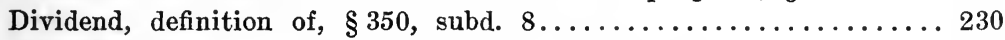

paid in Liberty Bonds, property, etc., $\S 350$, subd. $8 \ldots \ldots \ldots \ldots 230$

Domicile defined and distinguished from residence............ 199

Educational corporations, gifts or contributions to, deductible from

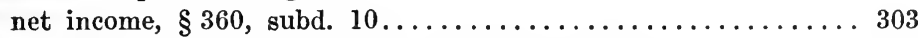

Employees and officers, penalty for violation of, $\S 384$, subd. $2 \ldots \ldots 337$ secrecy required of, re income returns, $\S 384$, subd. $1 \ldots \ldots \ldots \ldots 337$

Estate, certain personal property belonging to, exempt locally, §352.. 237

Estates and trusts (sce Chapter XXVIII on Estates and Trusts) beneficiary's net income to include distributive share, $\S 365$, subd. 4318

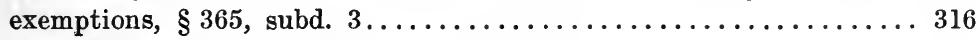
fiduciary, not to pay tax; when, $\S 365$, subd. $4 \ldots \ldots \ldots \ldots \ldots 318$

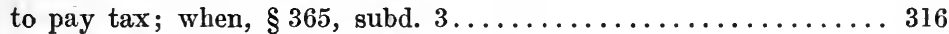

imposed upon net income of, $\S 365$, subd. $3 \ldots \ldots \ldots \ldots \ldots \ldots 316$

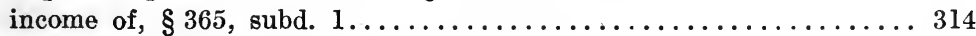

net income, computation of, $\S 365$, subd. $2 \ldots \ldots \ldots \ldots \ldots \ldots \ldots \ldots \ldots$

non-resident, created by, taxation of, $\S 365$, subd. $3 \ldots \ldots \ldots \ldots 316$

return, fiduciary responsible for making, $\S 365$, subd. $2 \ldots \ldots \ldots 315$

Excess to be refunded when tax less than amount theretofore paid,

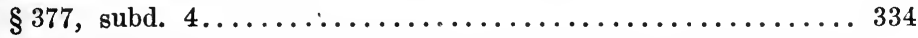

to be paid comptroller when greater amount theretofore paid, $\S 377$,

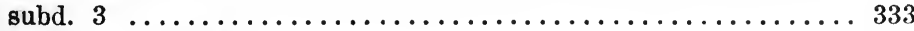

Exchange of property, gain or loss with respect to, $\S 354 \ldots \ldots \ldots 238$ stock, new, issued in place of old, upon reorganization of corpora-

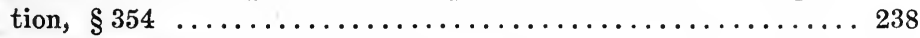

Exemptions, amounts received through accident or health insurance,

$\S 359$, subd. 2-e............................. 265

for benefit of disabled soldiers or sailors, $\S 359$, subd. 2 -e..... 265

war risk insurance act, $\S 359$, subd. 2 -e................ 265

workmen's compensation acts, $\S 359$, subd. $2-\Theta \ldots \ldots \ldots \ldots \ldots 265$

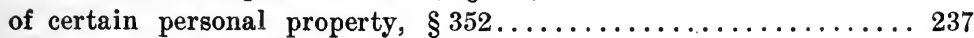

estates and trusts, income of, $\S 365$, subd. $3 \ldots \ldots \ldots \ldots \ldots \ldots \ldots \ldots$

gross income, from premiums returned to insured upon life insur-

ance policies, $\S 359$, subd. 2 -b...................... 261 
proceeds from life insurance policies paid upon death of insured,

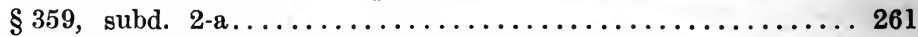
value of property acquired by gift, bequest, devise or descent, $\S 359$, subd. 2-c........................... 262 interest upon bonds issued by war finance corporation, $\S 359$, subd. $2-d$.................................... 263

obligations of the U. S. or its possessions, § 359, subd. 2-d.... 263 securities under federal farm loan act of July 17, 1916, §359,

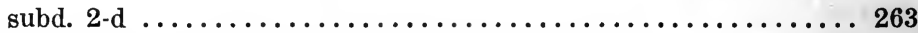
partnerships, net income of, what allowed, $\S 364 \ldots \ldots \ldots \ldots \ldots 312$ reduction of, when accounting period changed, $\S 370 \ldots \ldots \ldots \ldots 326$ resident taxpayer

dependents, amount of, $\S 362$, subd. $2 \ldots \ldots \ldots \ldots \ldots \ldots \ldots \ldots . \ldots \ldots$

head of family, amount of, $\S 362$, subd. $1 \ldots \ldots \ldots \ldots \ldots \ldots . \ldots 309$

husband and wife, amount of, $\S 362$, subd. $1 \ldots \ldots \ldots \ldots \ldots . \ldots 309$ single person, amount of, $\S 362$, subd. $1 \ldots \ldots \ldots \ldots \ldots \ldots \ldots . \ldots 309$ taxpayer, receiving compensation from United States, amount of,

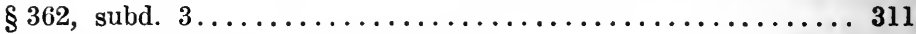

United States official, to, $\S 362$, subd. $3 \ldots \ldots \ldots \ldots \ldots \ldots \ldots \ldots \ldots$

Exhaustion, wear and tear, deduction allowance from net income, $\S 360$,

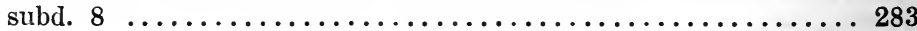

Expenses, ordinary and necessary, of business, deducted from net in-

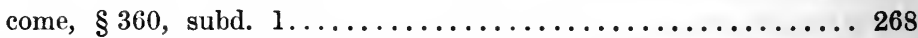
personal, living, family, not deductible from net income, $\S 361$, subd. I

Failure to return or pay same, when penalty does not attach, $\S 366$, subd. 5

Fiduciary, beneficiary's distributive share to be included in return by,

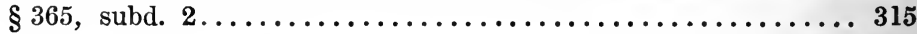

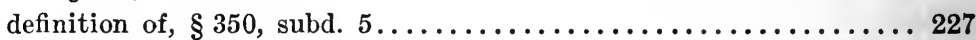
distinct from agent, $\S 350$, subd. $5 \ldots \ldots \ldots \ldots \ldots \ldots \ldots \ldots \ldots . \ldots \ldots$

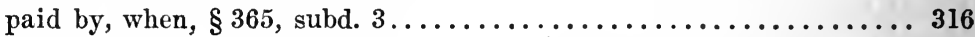

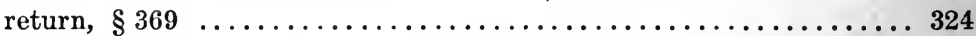
responsible for making re income for estate or trust, $\S 365$, subd. 2315 subject to provisions of this article which apply to taxpayers, $\S 369324$ when not paid by, $\S 365$, subd. $4 \ldots \ldots \ldots \ldots \ldots \ldots \ldots \ldots \ldots \ldots \ldots \ldots \ldots \ldots \ldots \ldots \ldots$

Fixed or determinable income to be deducted and withheld, $\S 365$, subd.

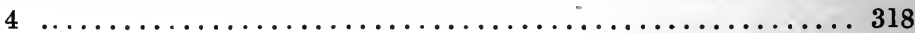

First levied, collected and paid, when, $\S 351 \ldots \ldots \ldots \ldots \ldots \ldots 236$

Foreign country or foreign government, definition of, $\S 350$, subd. $9 . .235$ 
Forms for return

failure to secure does not relieve taxpayer from making return, $\S 371$

to be furnished by comptroller, $\S 371 \ldots \ldots \ldots \ldots \ldots \ldots \ldots \ldots \ldots$

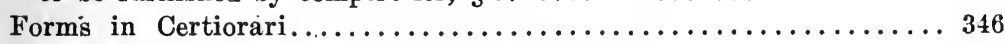

of Reports or Returns under Arts. 9 and 9 -a............. 353

From fires, storms, shipwrecks, theft, when deductible from net income, $\S 360$, subd. $6 \ldots \ldots \ldots \ldots \ldots \ldots \ldots \ldots \ldots \ldots \ldots$

Gain and loss

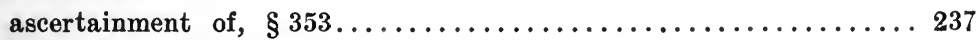

ascertainment, in case of stocks of "fair market value",....... 237

basis of, on

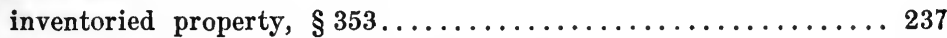

property acquired before, on or after Jan. 1, 1919, §353..... 237

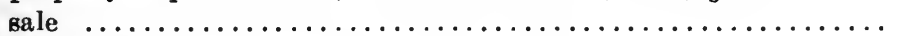

exchange of property in determining, $\S 354 \ldots \ldots \ldots \ldots \ldots \ldots 238$

none deemed to occur re-exchange of stock or securities; when, $§ 354238$

Gain through exchange

stock or securities, $\S 355 \ldots \ldots \ldots \ldots \ldots \ldots \ldots \ldots \ldots \ldots \ldots \ldots \ldots$

amount in excess of par treated as gain, $\S 355$.

when treated as taking place of those exchanged, $\S 355 \ldots . . .$.

Gifts, contributions

deductible from net income, $\S 360$, subd. $10 \ldots \ldots \ldots \ldots \ldots \ldots \ldots$

Governor to approve new positions and fixed salaries, $\S 5 \ldots \ldots \ldots 338$

Gross income

amount of, includes what, $\S 359$, subd. $1 \ldots \ldots \ldots \ldots \ldots \ldots \ldots \ldots$

compensation for personal services, $\S 359$, subd. $1 \ldots \ldots \ldots \ldots \ldots 249$

deduction contracts, from, $\S 359$, subd. $1 \ldots \ldots \ldots \ldots \ldots \ldots \ldots \ldots 249$

when part payable to U. S., state, etc., or to charitable corpora-

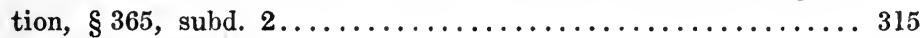

defined, $\S 359$, subd. $1 \ldots \ldots \ldots \ldots \ldots \ldots \ldots \ldots \ldots \ldots \ldots \ldots \ldots . \ldots \ldots$

derived from what, $\S 359$, subd. $1 \ldots \ldots \ldots \ldots \ldots \ldots \ldots \ldots \ldots \ldots$

does not include, $\S 359$, subd. $2 \ldots \ldots \ldots \ldots \ldots \ldots \ldots \ldots \ldots$

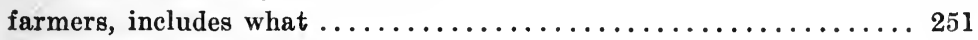

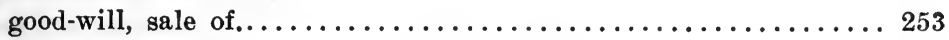

non-residents, includes what, $\S 359$, subd. $3 \ldots \ldots \ldots \ldots \ldots \ldots 7$

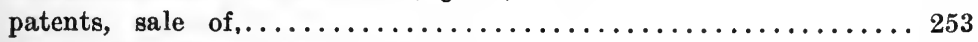

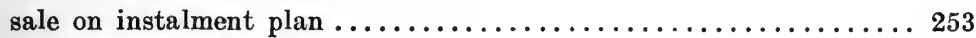

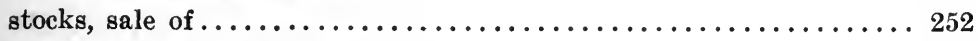

Gross receipts

partnerships, returns showing, may be required, $\S 364 \ldots \ldots \ldots \ldots 312$ 
Guardian

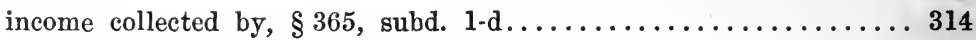

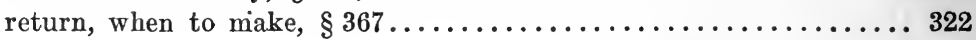

Head of family, exemption allowed, $\S 362$, subd. $1 \ldots \ldots \ldots \ldots \ldots . \ldots 309$

Hearing by comptroller

revision and readjustment of accounts; re, $\S 374 \ldots \ldots \ldots \ldots \ldots 329$

"Home rule" principle of state constitution................. 192

Husband and wife, exemptions to, $\S 362 \ldots \ldots \ldots \ldots \ldots \ldots \ldots \ldots \ldots$

return when net income $\$ 2,000$ or more, $\S 367 \ldots \ldots \ldots \ldots \ldots . \ldots 322$

Income accounting period; change in; computation of, $\S 370 \ldots \ldots 326$ accumulated in trust for benefit of unborn or unascertained persons

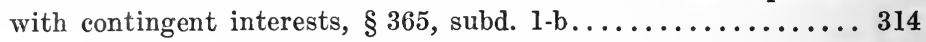
amount of not to be divulged, $\S 384$, subd. $1 \ldots \ldots \ldots \ldots \ldots \ldots . \ldots 337$

penalty for violation of, $\S 384$, subd. $2 \ldots \ldots \ldots \ldots \ldots \ldots \ldots \ldots \ldots$ beneficiaries of estate or trust

distributed to, $\S 365$, subd. $1-d \ldots \ldots \ldots \ldots \ldots \ldots \ldots \ldots \ldots \ldots \ldots \ldots \ldots \ldots \ldots$

fiduciary to include in return statement of, $\S 365$, subd. $2 \ldots \ldots 315$

non-resident, extent of tax, $\S 365$, subd. $4 \ldots \ldots \ldots \ldots \ldots \ldots . \ldots \ldots$

when tax not paid by fiduciary, $\S 365$, subd. $4 \ldots \ldots \ldots \ldots \ldots . \ldots 318$

business, trade, profession, etc., from, $\S 351 \ldots \ldots \ldots \ldots \ldots \ldots 236$

comptroller, return to, by March $15, \S 371 \ldots \ldots \ldots \ldots \ldots \ldots . \ldots 327$

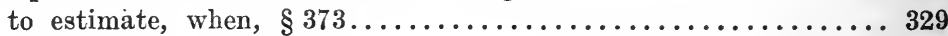

computation of when accounting period changed, $\S 370 \ldots \ldots \ldots . \ldots 326$

deceased persons, estates of, $\S 365$, subd. $1-a \ldots \ldots \ldots \ldots \ldots \ldots 314$

imposed upon net income of and payable by fiduciary, $\S 365$, subd.

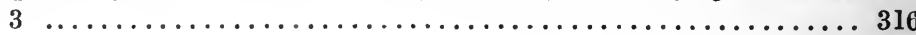

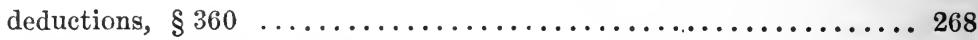

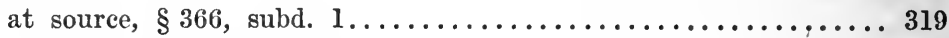

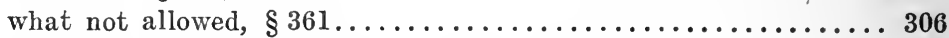

dependents, exemptions allowed, $\S 362$, subd. $2 \ldots \ldots \ldots \ldots \ldots \ldots 310$

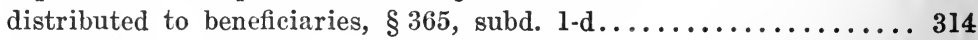

distributive share from partnership, $\S 364 \ldots \ldots \ldots \ldots \ldots \ldots \ldots . \ldots \ldots 12$

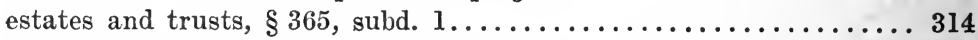

estimate of, by comptroller, when, $\S 373 \ldots \ldots \ldots \ldots \ldots \ldots \ldots \ldots . \ldots \ldots$

exemptions from, gross, $\S 359$, subd. $2 \ldots \ldots \ldots \ldots \ldots \ldots \ldots \ldots \ldots \ldots$

failure to report

comptroller to examine books and records and take testimony, $\S 373$

fiduciary, when tax not paid by, $\S 365$, subd. $4 \ldots \ldots \ldots \ldots \ldots \ldots . \ldots 318$

gain and loss, ascertainment of, in determining, $\S 353 \ldots \ldots \ldots \ldots 237$

guardian of infant, collected by, $\S 365$, subd. 1-d............ 314 
imposed upon net income of, $\S 365$, subd. $3 \ldots \ldots \ldots \ldots \ldots \ldots \ldots 316$ payable by fiduciary, $\S 365$, subd. $3 \ldots \ldots \ldots \ldots \ldots \ldots \ldots \ldots \ldots \ldots$ information concerning non-residents given to comptroller by with-

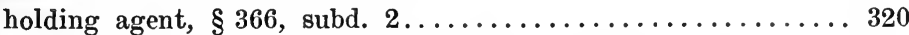

in addition to all other taxes with certain exceptions, $\S 352 \ldots \ldots 237$

inventories may be required to show, when, $\S 356 \ldots \ldots \ldots \ldots \ldots 242$

legatee, heir, etc., deductible when paid to, $\S 365$, subd. $3 \ldots \ldots \ldots 316$

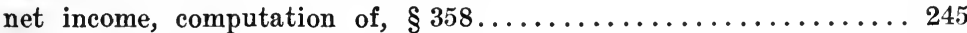

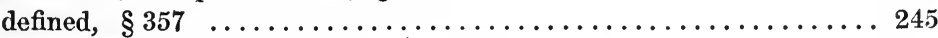

non-residents, gross, includes what, $\S 359$, subd. $3 \ldots \ldots \ldots \ldots \ldots 267$

two per cent, deductible therefrom at source, $\S 366$, subd. $1 \ldots . .319$

officer religious denomination, institution or trust, what exempt,

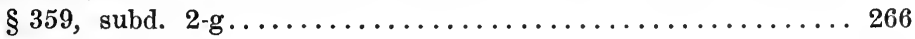

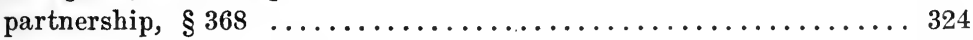

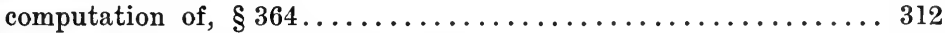

partners, taxable individually, $\S 364 \ldots \ldots \ldots \ldots \ldots \ldots \ldots \ldots \ldots$

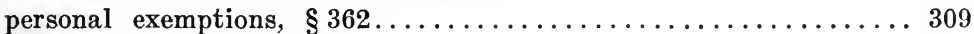

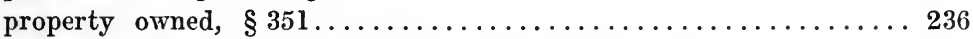

property, sale of, gain or loss, in determining, $\S 353 \ldots \ldots \ldots \ldots 237$

recipient, to be included in return of, $\S 366$, subd. $4 \ldots \ldots \ldots \ldots . \ldots 321$

return to comptroller by March $15, \S 371 \ldots \ldots \ldots \ldots \ldots \ldots \ldots \ldots 327$

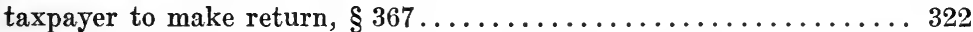

to be computed on basis of period for which separate return made

when accounting period changed, $\S 370 \ldots \ldots \ldots \ldots \ldots \ldots \ldots$

to be included in return of recipient, $\S 366$, subd. $4 \ldots \ldots \ldots \ldots \ldots 327$

two per cent thereof withheld by withholding agent, when $\$ 1,000$ or

more, when, $\S 366$, subd. $1 \ldots \ldots \ldots \ldots \ldots \ldots \ldots \ldots \ldots \ldots$

will or trust, $\S 365$, subd. $1-c \ldots \ldots \ldots \ldots \ldots \ldots \ldots \ldots \ldots \ldots \ldots$

imposed upon net income of and payable by fiduciary, $\S 356$, subd.

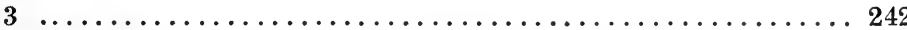

withholding agent, two per cent withheld by, when $\$ 1,000$ or more,

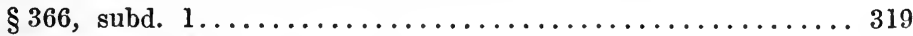

Individual partners liable for, $\S 364 \ldots \ldots \ldots \ldots \ldots \ldots \ldots \ldots \ldots \ldots \ldots$

Individuals, corporations, partnerships, claims and demands; indemni-

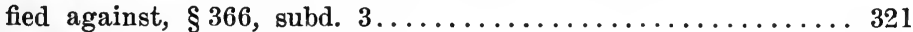

tax, liability for, $\S 366$, subd. $3 \ldots \ldots \ldots \ldots \ldots \ldots \ldots \ldots \ldots \ldots$

Information and payment at source, $\S 366 \ldots \ldots \ldots \ldots \ldots \ldots \ldots \ldots$

Improvements, permanent

not deductible from net income, $\S 361$, subd. $2 \ldots \ldots \ldots \ldots \ldots 308$

Interstate commerce clause of Federal constitution ...........196

Interest

on indebtedness, when deductible from net income, $\S 360$, subd. 2. . 274 payable thereon when time for filing return extended, $\S 377$, subd. 1. 333 
when exempt from, $\S 359$, subd. 2 -d.................... 263

Interest, penalties, taxes

comptroller to audit and state account for, $\S 373 \ldots \ldots \ldots \ldots \ldots . \ldots 329$

Invalid, when parts of act adjudged to be, remainder not affected,

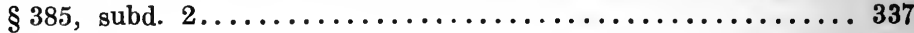

Inventory

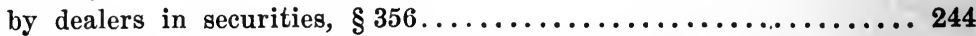

comptroller may require and prescribe basis of, when, $\S 356 \ldots \ldots 242$ to conform to accounting methods and forms of internal revenue

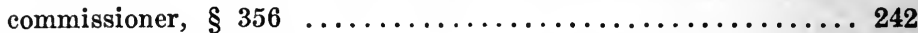

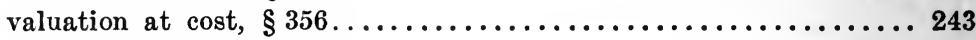

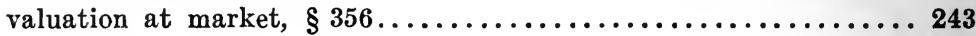

Law, valid, except as to illegal parts, §385, subd. 2.......... 337

Leases, net income, depletion allowance, apportionment of, $\S 360$, subd.

9

Legatee, heir, etc.

income to, when deductible, $\S 365$, subd. $3 \ldots \ldots \ldots \ldots \ldots \ldots . \ldots 316$

Levied, collected and paid in 1920 and annually thereafter, $\S 351 \ldots \ldots 236$

Levy and sale of property for non-payment of, $\S 380 \ldots \ldots \ldots \ldots 334$

Liability for, of individuals, corporations and partnerships, §366, subd. 3

Lien on property

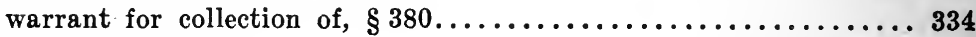

Local assessments

not deductible from net income, $\S 360$, subd. $3 \ldots \ldots \ldots \ldots \ldots \ldots 276$

Loss and gain

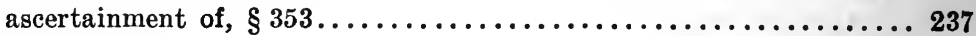
basis of, on

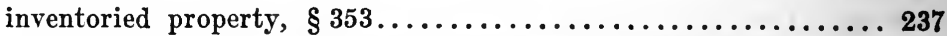

property acquired before, on or after Jan. 1, 1919, §353...... 237

Losses

trade or business, deductible from net income, $\S 360$, subd. $4 \ldots \ldots 277$

Market value

depletion allowance, when based on, $\S 360$, subd. $9 \ldots \ldots \ldots \ldots \ldots 290$

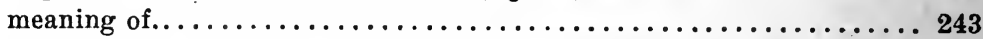

stock, upon exchange, in determining gain, $\S 355 \ldots \ldots \ldots \ldots \ldots .241$

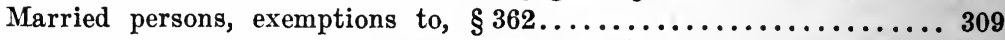

Method of accounting, in determining, $\S 358 \ldots \ldots \ldots \ldots \ldots \ldots \ldots 245$

Military or naval forces of the United States

definition of, $\S 350$, subd. 3

227

Mines, depletion allowance

deductible from net income, $\S 360$, subd. 8 


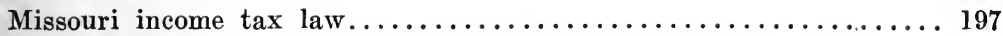

Money on hand, on deposit or at interest, exempt locally, $\S 352 \ldots \ldots 237$

Net income

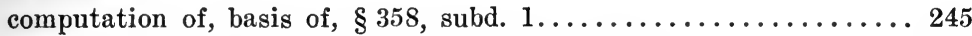

when accounting period changed, $\S 358$, subd. $2 \ldots \ldots \ldots \ldots \ldots 246$

deceased person, estate of

when payable to legatee, heir, etc., deductible, $\S 365$, subd. $3 \ldots 316$ deductions

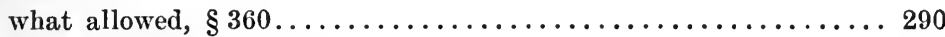

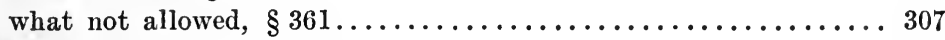

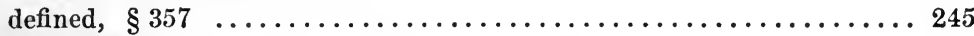

dependents, exemptions allowed, $\S 362$, subd. $2 \ldots \ldots \ldots \ldots \ldots \ldots 310$

distributive share of partner, what included, $\S 364 \ldots \ldots \ldots \ldots . \ldots 312$ estate or trust

beneficiary's distributive share included in, $\S 365$, subd. $4 \ldots \ldots 318$

fiduciary to include in return, $\S 365$, subd. $2 \ldots \ldots \ldots \ldots \ldots 315$

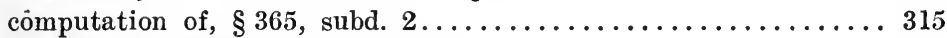

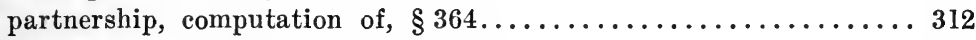

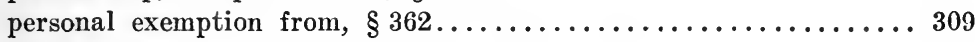

tax, credit to non-residents, when, $\S 363 \ldots \ldots \ldots \ldots \ldots \ldots \ldots \ldots \ldots \ldots \ldots$

New York City

revenue collected, portion of, to receiver of taxes, $\S 382 \ldots \ldots \ldots 336$

Non-payment, penalty for, $\S 379$, subd. $2 \ldots \ldots \ldots \ldots \ldots \ldots \ldots \ldots . \ldots \ldots$

Non-resident

non-resident alien under Fed. L...................... 230

credit on income tax payable in this state, when, $\S 363 \ldots \ldots \ldots . \ldots 311$

deductions under Sec. 360 , when not entitled to, $\S 367 \ldots \ldots \ldots . \ldots 322$

estates and trusts

income from, extent of tax, $\S 365$, subd. $4 \ldots \ldots \ldots \ldots \ldots \ldots . \ldots 318$

taxation of, when created by, $\S 365$, subd. $3 \ldots \ldots \ldots \ldots \ldots \ldots . \ldots 316$

gifts or contributions deductible from net income, $\S 360$, subd. 10.. 303 gross income, includes what, $\S 359$, subd. $3 \ldots \ldots \ldots \ldots \ldots \ldots 267$ income of, within state:

two per cent deductible therefrom at source, $\S 366$, subd. $1 . \ldots . .319$

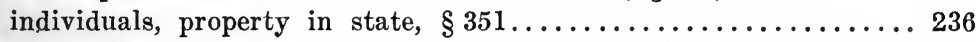

information of, to comptroller by withholding agent, $\S 366$, subd. 2320 interest on indebtedness

what deducted from net income, $\S 360$, subd. $2 \ldots \ldots \ldots \ldots \ldots 274$

return of withholding agent, concerning, $\S 366$, subd. $2 \ldots \ldots \ldots \ldots 320$

to be included in return of recipient of income, $\S 366$, subd. 4... 321

when not entitled to deductions authorized by Sec. $360, \S 367 \ldots \ldots 322$

withholding agent, return concerning, $\S 366$, subd. $2 \ldots \ldots \ldots \ldots 320$ 


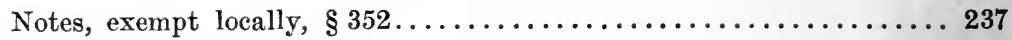

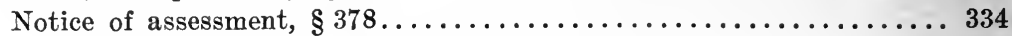

record of to be preserved by comptroller, $\S 378 \ldots \ldots \ldots \ldots \ldots \ldots 334$

Obsolescence

deductible from net income, $\S 360$, subd. $8 \ldots \ldots \ldots \ldots \ldots \ldots \ldots 283$

Occupations of non-resident individuals in state

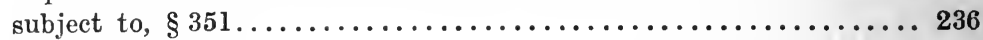

Officers and employees

secrecy required of, re income returns, $\S 384$, subd. $1 \ldots \ldots \ldots \ldots 337$

penalty for violation of, $\S 384$, subd. $2 \ldots \ldots \ldots \ldots \ldots \ldots \ldots \ldots . \ldots \ldots$

Oil and gas wells

depletion allowance, deductible from net income, $\S 360$, subd. 9... 290

Oklahoma income tax law......................... 197

Opinions of Attorney-General construing N. Y. Law.......... 213

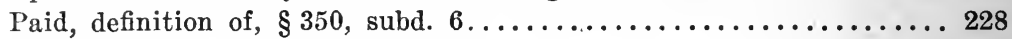

what may be deducted as, $\S 350$, subd. $6 \ldots \ldots \ldots \ldots \ldots \ldots \ldots 228$

Partners

comptroller may require return for partnership, $\S 364 \ldots \ldots \ldots \ldots 312$

net income, distributive share of partnership income, $\S 364 \ldots \ldots \ldots$

Partnership

indemnified against claims and demands, $\S 366$, subd. $3 \ldots \ldots \ldots . . .321$

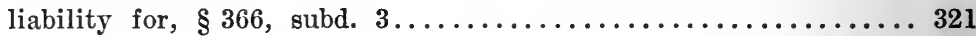

members of, liable individually for income tax, $\S 364 \ldots \ldots \ldots \ldots . \ldots 312$

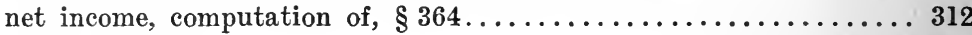

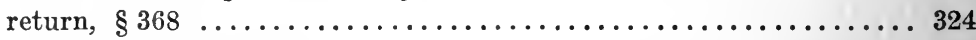

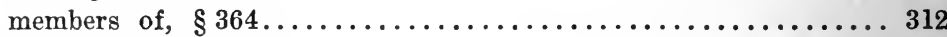

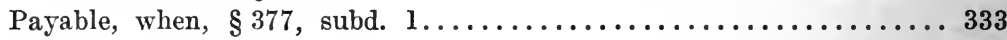

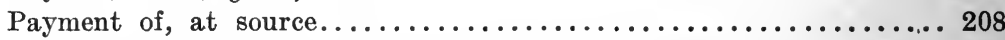

Rules and regulations by comptroller as to, $\S 366 \ldots \ldots \ldots \ldots \ldots 319$

by withholding agent to comptroller by March 15, § 366, subd. 3.. 321

in cases where accounting period changed by taxpayer, $\S 370 \ldots \ldots 326$

Penalties, taxes, interest

comptroller to audit and state account for, $\S 373 \ldots \ldots \ldots \ldots \ldots . \ldots 329$

Penalty

for failure to return or pay tax required to be withheld when paid

by recipient of income, when, $\S 366$, subd. $5 \ldots \ldots \ldots \ldots \ldots . \ldots 321$

for non-payment, at proper time, $\S 379$, subd. $2 \ldots \ldots \ldots \ldots \ldots \ldots 334$

for violating secrecy of returns, $\S 384$, subd. $1 \ldots \ldots \ldots \ldots \ldots \ldots 337$

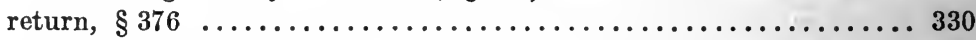

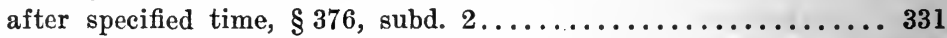

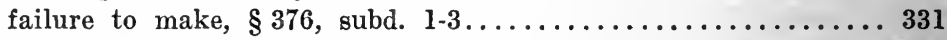

false or fraudulent, $\S 376$, subd. $1-3 \ldots \ldots \ldots \ldots \ldots \ldots \ldots \ldots . \ldots \ldots \ldots$ 
tax, non-payment of, $\S 379$, subd. $2 \ldots \ldots \ldots \ldots \ldots \ldots \ldots \ldots \ldots . \ldots 334$

violation re divulging income returns, $\S 384$, subd. $2 \ldots \ldots \ldots \ldots \ldots 337$

Personal property

assessment of, prior to Aug. 1, 1919, deemed to be valid, § 385 , subd. 3 ............................... 338

eertain, after July 31,1919 , exempt locally, $\S 352 \ldots \ldots \ldots \ldots \ldots 237$

intangible, exempt from local taxation, $\S 352 \ldots \ldots \ldots \ldots \ldots \ldots .237$

Positions

deemed temporary, $\S 385$, subd. $3 \ldots \ldots \ldots \ldots \ldots \ldots \ldots \ldots \ldots . \ldots 338$

no new, except on unanimous approval of governor and chairmen senate finance and assembly ways and means committees, $\S 385$, subd. 5 ................................ 338

\section{Premiums}

what not deductible from net income, $\S 361$, subd. $4 \ldots \ldots \ldots \ldots . \ldots 308$

Professions of non-resident individuals in state subject to, $\S 351 \ldots 236$

Property

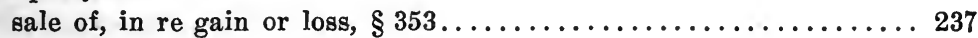

Property exchanged

gain or loss

equivalent of cash for purposes of determining, when, $\S 354 \ldots \ldots 238$ market value of, re-determining gain or loss, $\S 354 \ldots \ldots \ldots \ldots 238$ taxpayer, stock exchanged, gain or loss, when, $\$ 354 \ldots \ldots \ldots \ldots 238$

Property, restored, certain

expense of, not deductible from net income, $\S 361$, subd. $3 \ldots \ldots \ldots 308$

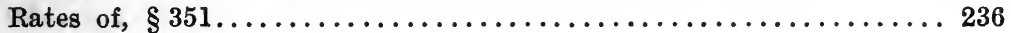

Received

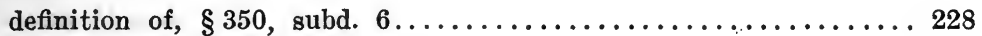

Receiver of taxes (N. Y. City) revenue collected, portion of, to, $\S 382 \ldots \ldots \ldots \ldots \ldots \ldots \ldots \ldots \ldots \ldots$

Reciprocal laws

credit to non-residents dependent upon, $\S 363 \ldots \ldots \ldots \ldots \ldots \ldots . \ldots 311$

Records and books

comptroller to examine, when, $\S 373 \ldots \ldots \ldots \ldots \ldots \ldots \ldots \ldots . \ldots . \ldots . \ldots$

Refunds

fund for, comptroller to retain $\$ 250,000$ of revenue collected, $\S 382$. 336 taxpayer, to, when, $\S 377$, subd. $4 \ldots \ldots \ldots \ldots \ldots \ldots \ldots \ldots \ldots \ldots \ldots \ldots \ldots$

Regulations and rules, comptroller to make, $\S 383 \ldots \ldots \ldots \ldots \ldots 336$

for deduction and withholding at source................ 208

Religious contributions or gifts deductible from net income, $\S 360$,

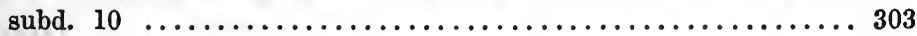

Rentals

proper deduction from net income, when, $\S 360$, subd. $1 . \ldots \ldots \ldots 268$ 
Residence under N. Y. Transfer Tax Act. . . . . . . . . . . . . 200

Ohio Personal Tax Law........................ 201

N. Y. Personal Tax Law.......................... 202

Resident, definition of, $\S 350$, subd. $7 \ldots \ldots \ldots \ldots \ldots \ldots \ldots \ldots \ldots \ldots$

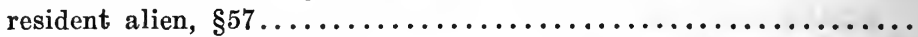

Residents and non-residents

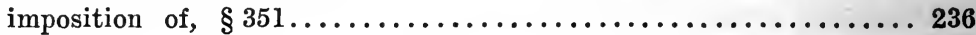

Return

accounting period, change in, $\S 370 \ldots \ldots \ldots \ldots \ldots \ldots \ldots \ldots \ldots . \ldots \ldots$

affidavit to be annexed thereto, $\S 371 \ldots \ldots \ldots \ldots \ldots \ldots \ldots \ldots \ldots . \ldots \ldots$

agent or guardian, $\S 367 \ldots \ldots \ldots \ldots \ldots \ldots \ldots \ldots \ldots \ldots \ldots \ldots \ldots 2$

attorney-general, inspection by, of, $\S 384$, subd. $1 \ldots \ldots \ldots \ldots \ldots . \ldots 37$

beneficiary's distributive share, to be included in, by fiduciary,

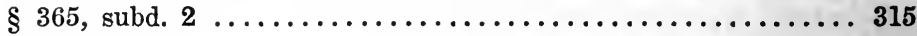

blank forms

failure to secure, taxpayer not relieved from making, § 371... 327

to be furnished by comptroller, $\S 371 \ldots \ldots \ldots \ldots \ldots \ldots \ldots \ldots . \ldots 327$ comptroller

blank forms to be furnished by, $\S 371 \ldots \ldots \ldots \ldots \ldots \ldots \ldots \ldots 327$

may extend time of filing, $\S 371 \ldots \ldots \ldots \ldots \ldots \ldots \ldots \ldots \ldots \ldots$

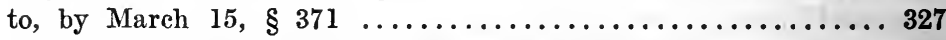

to, by withholding agent, $\S 366$, subd. $2,3 \ldots \ldots \ldots \ldots \ldots \ldots \ldots 320$

to revise, when, $\S 373 \ldots \ldots \ldots \ldots \ldots \ldots \ldots \ldots \ldots \ldots \ldots$

estate or trust

fiduciary responsible for making, $\S 365$, subd. $2 \ldots \ldots \ldots \ldots \ldots . .315$

estimate of income by comptroller, when none, $\S 373 \ldots \ldots \ldots \ldots \ldots . . .329$

failure to make, comptroller to examine books and records and

take testimony, $\S 373 \ldots \ldots \ldots \ldots \ldots \ldots \ldots \ldots \ldots \ldots . \ldots \ldots$

fiduciary, $\S 369 \ldots \ldots \ldots \ldots \ldots \ldots \ldots \ldots \ldots \ldots \ldots \ldots \ldots \ldots \ldots \ldots$

to include beneficiary's distributive share, $\S 365$, subd. $2 \ldots \ldots . .315$ filing

extension of, none for more than six months, when, $\S 371 \ldots \ldots .327$

time of may be extended by comptroller, $\S 371 \ldots \ldots \ldots \ldots \ldots 327$

husband and wife, when net income $\$ 2,000$ or more, $\S 367 \ldots \ldots \ldots 322$

income upon which tax withheld at source, to be included in, $\S 366$,

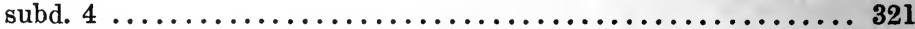

incorrect, comptroller may revise, $\S 373 \ldots \ldots \ldots \ldots \ldots \ldots \ldots \ldots \ldots . \ldots 329$

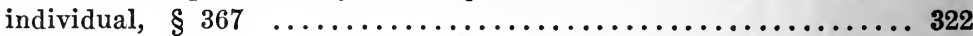

net income, re, to comptroller by March 15, $\S 371 \ldots \ldots \ldots \ldots \ldots \ldots . . .327$

none, comptroller to estimate income, when, $\S 373 \ldots \ldots \ldots \ldots \ldots \ldots . . .329$

particulars as to, not to be divulged, $\S 384$, subd. 1.......... 337

penalty for violation of, $\S 384$, subd. $2 \ldots \ldots \ldots \ldots \ldots \ldots \ldots \ldots \ldots . \ldots 337$

partnership, $\S 368 \ldots \ldots \ldots \ldots \ldots \ldots \ldots \ldots \ldots \ldots \ldots \ldots \ldots \ldots \ldots \ldots \ldots . \ldots \ldots$ 


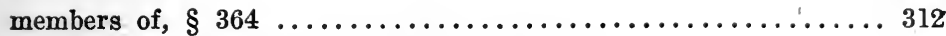

penalty after specified time, $\S 376$, subd. $2 \ldots \ldots \ldots \ldots \ldots \ldots \ldots . \ldots \ldots 1$

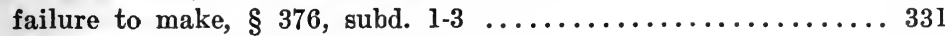

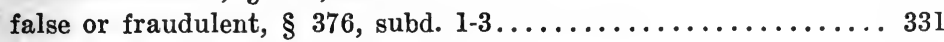

revision of by comptroller, when, $\S 373 \ldots \ldots \ldots \ldots \ldots \ldots \ldots . \ldots . \ldots 329$

separate

exemptions to husband and wife, $\S 362$, subd. $1 \ldots \ldots \ldots \ldots \ldots 309$

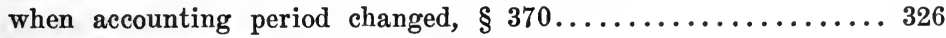

statistics re, publication of, $\S 384$, subd. $1 \ldots \ldots \ldots \ldots \ldots \ldots \ldots . \ldots \ldots$

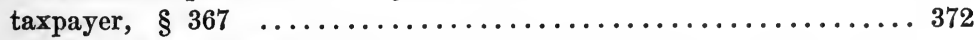

not relieved from making, because of failure to secure blank

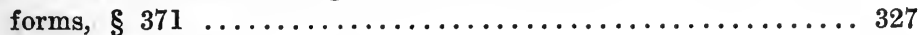

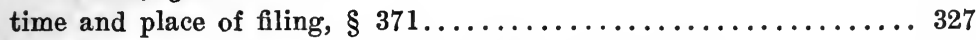

to be preserved for at least three years, $\S 384$, subd. $1 \ldots \ldots \ldots . \ldots 337$

to set forth same items in forms prescribed by U. S. revenue act,

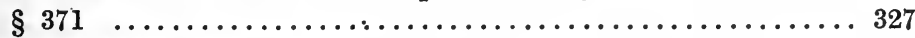

to set forth such facts as comptroller deems necessary, $\S 371 \ldots \ldots 327$

withholding agent, by, $\S 366$, subd. $2,3 \ldots \ldots \ldots \ldots \ldots \ldots \ldots \ldots 320$

Review of determination of comptroller by certiorari, $\S 375 \ldots \ldots \ldots 330$

Revision and readjustment of accounts by comptroller, $\S 374 \ldots \ldots .329$

Revision and resettlement of tax

Rules (see regulations), certiorari, reviewable by, $\S 375 \ldots \ldots \ldots 330$

Salaries deemed temporary, $\S 385$, subd. $5 \ldots \ldots \ldots \ldots \ldots \ldots \ldots . \ldots 338$

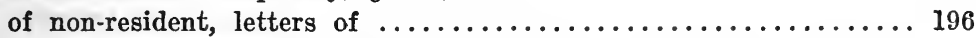

none fixed, except on unanimous approval of governor, chairman

senate finance and assembly ways and means committees, $\S 385$,

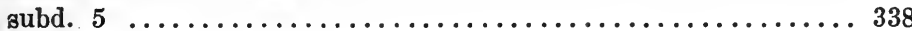

Salaries, wages and compensation

officers and employees of federal government, exempt from, $\S 359$,

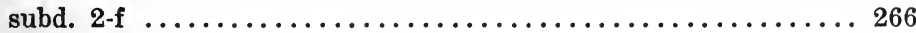

Sale of property re gain or loss, $\S 353 \ldots \ldots \ldots \ldots \ldots \ldots \ldots \ldots \ldots \ldots \ldots$

Scientific corporations

gifts or contributions to, deductible from net income, $\S 360$, subd. 10303

Secrecy re income returns

penalty for violation of, $\S 384$, subd. $1 \ldots \ldots \ldots \ldots \ldots \ldots \ldots 37$

Senate finance committee

chairman to approve new positions and fixed salaries, $\S 385$, subd. 5338

Sheriff

to levy upon and sell property for non-payment of tax, $\S 380 \ldots \ldots 334$ warrant

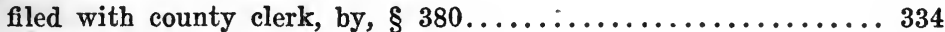

for collection of unpaid, $\S 380 \ldots \ldots \ldots \ldots \ldots \ldots \ldots \ldots \ldots . \ldots \ldots 34$ 
Situs of income from salary of non-resident discussed......... 196

Source, payment at, $\S 366$, subd. $1 \ldots \ldots \ldots \ldots \ldots \ldots \ldots \ldots \ldots \ldots \ldots$

State constitution, is the "home rule" section of, violated......... 190

State treasury, revenue collected, portion of, to, $\S 382 \ldots \ldots \ldots \ldots . \ldots 336$

Statistics

publication of, re income returns, $\S 384$, subd. $1 \ldots \ldots \ldots \ldots \ldots \ldots 37$

Stock

gain through exchange, $\$ 355 \ldots \ldots \ldots \ldots \ldots \ldots \ldots \ldots \ldots \ldots \ldots \ldots$

shares of, exempt locally, when, $\S 352 \ldots \ldots \ldots \ldots \ldots \ldots \ldots \ldots \ldots$

Stock or securities

exchange of, when no gain or loss, $\S 354 \ldots \ldots \ldots \ldots \ldots \ldots \ldots \ldots 238$

takes place of those exchanges, when, $\S 354 \ldots \ldots \ldots \ldots \ldots \ldots \ldots$

Supervisor of town

revenue collected, excess of, to, $\S 382 \ldots \ldots \ldots \ldots \ldots \ldots \ldots \ldots$

Taxable year

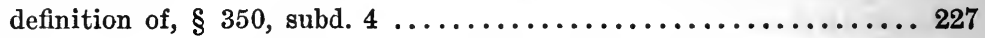

Taxes

on personal property, obligation to pay, what, $\S 385$, subd. 3..... 338

what deductible from net income, $\S 360$, subd. $3 \ldots \ldots \ldots \ldots \ldots \ldots$

Taxes, penalties, interest

comptroller to audit and state account for, $\S 373 \ldots \ldots \ldots \ldots \ldots \ldots 329$

Taxpayer

accounting period, change in, separate return, $\S 370 \ldots \ldots \ldots \ldots \ldots$

blank forms, failure to secure, not relieved from making return,

\& 371

definition of, $\S 350$, subd. 2

exemption of (see exemptions)

failure to report income

comptroller to examine books and records and take testimony,

$\S 373 \ldots \ldots \ldots \ldots \ldots \ldots \ldots \ldots \ldots \ldots \ldots \ldots \ldots \ldots . \ldots \ldots 2 . \ldots \ldots$

income, return re to comptroller by March $15, \S 371 \ldots \ldots \ldots \ldots \ldots 327$

inventory by, when required, $\S 356 \ldots \ldots \ldots \ldots \ldots \ldots \ldots \ldots \ldots \ldots . \ldots 242$

may file application for revision with comptroller within one year

from filing of return, $\S 374 \ldots \ldots \ldots \ldots \ldots \ldots \ldots \ldots \ldots \ldots \ldots . \ldots . \ldots$

net income (see net income)

non-resident (see non-resident)

partner, liable individually for income $\operatorname{tax}, \S 364 \ldots \ldots \ldots \ldots \ldots \ldots . \ldots 12$

return (see return), $\S 367 \ldots \ldots \ldots \ldots \ldots \ldots \ldots \ldots \ldots \ldots \ldots \ldots . \ldots . \ldots 22$

Testimony, comptroller may take, $\S 373 \ldots \ldots \ldots \ldots \ldots \ldots \ldots \ldots \ldots \ldots . \ldots 329$

Towns

revenue collected

apportioned among, § 382 
excess of, to supervisor, when, $\S 382 \ldots \ldots \ldots \ldots \ldots \ldots \ldots \ldots \ldots$

Trades of non-resident individuals in state, subject to, $\S 351 \ldots \ldots 236$ Transactions for profit deductible from net income, $\S 360$, subd. 5... 278 Trust, certain personal property of, exempt locally, $\S 352 \ldots \ldots \ldots 237$ Trusts and estates (see estates and trusts)

Treasurer county revenue collected

apportioned among towns and cities, $\S 382 \ldots \ldots \ldots \ldots \ldots \ldots 36$

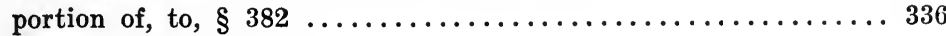

Unborn or unascertained persons

imposed upon net income of, $\S 365$, subd. $3 \ldots \ldots \ldots \ldots \ldots \ldots \ldots$

payable by fiduciary, $\S 365$, subd. $3 \ldots \ldots \ldots \ldots \ldots \ldots \ldots \ldots \ldots$ income accumulated in trust for, $\S 365$, subd. $1-b \ldots \ldots \ldots \ldots \ldots \ldots 314$

United States compensation from, of officials or employees thereof, exempt from,

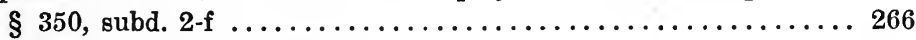
constitution (see Constitution)

definition of, $\S 350$, subd. 9

Unpaid

attorney-general, action by, for recovery of, $\S 381 \ldots \ldots \ldots \ldots \ldots 335$

warrant to issue after 60 days, $\S 380 \ldots \ldots \ldots \ldots \ldots \ldots \ldots \ldots \ldots \ldots$

Validity of, not impaired by illegal provision, $\S 385$, subd. 2..... 338

Vocational rehabilitation

gifts or contributions for, deductible from net income, $\S 360$, subd. 10

Warrant for collection of

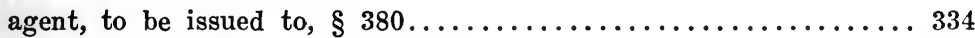

amount of, lien on property, $\S 380 \ldots \ldots \ldots \ldots \ldots \ldots \ldots \ldots \ldots$

copy to be filed by sheriff with county clerk, $\S 380 \ldots \ldots \ldots \ldots \ldots 334$

returned unsatisfied, when, $\S 380 \ldots \ldots \ldots \ldots \ldots \ldots \ldots \ldots \ldots$

sheriff, to be issued to, $\S 380 \ldots \ldots \ldots \ldots \ldots \ldots \ldots \ldots \ldots \ldots$

Will or deed

gross income, part of, payable to U. S., state, etc., or to charitable corporation, deductible, $\S 365$, subd. $2 \ldots \ldots \ldots \ldots \ldots \ldots \ldots$

Will or trust

imposed upon net income of, $\S 365$, subd. $3 \ldots \ldots \ldots \ldots \ldots \ldots \ldots 316$

payable by fiduciary, $\S 365$, subd. $3 \ldots \ldots \ldots \ldots \ldots \ldots \ldots \ldots \ldots$

income held for future distribution under, $\S 365$, subd. 1-c...... 314 Withheld, paid to comptroller by March 15, $\S 366$, subd. 3....... 321 
Withholding agent, $\S 366$, subd. $2 \ldots \ldots \ldots \ldots \ldots \ldots \ldots \ldots \ldots \ldots \ldots \ldots$

deductions by, of 2 per cent from income of non-residents, $\S 366$,

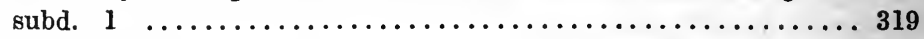

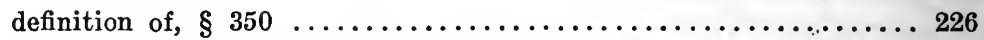

income, non-residents, deductions from, of 2 per cent, § 366, subd. 1. 319

paid by, to comptroller by March 15, § 366, subd. 3.......... 321 return of tax withheld by, to be made to comptroller by March 15,

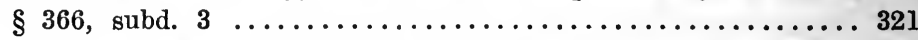

return to be made of information concerning income......... 205

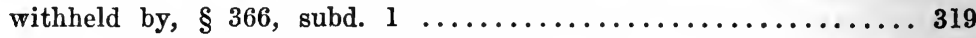

when not re-collected from, $\S 366$, subd. $5 \ldots \ldots \ldots \ldots \ldots \ldots 321$

[See Chapter XXVI for Rules and Regulations of Comptroller and Withholding at Source.] 


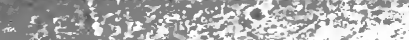



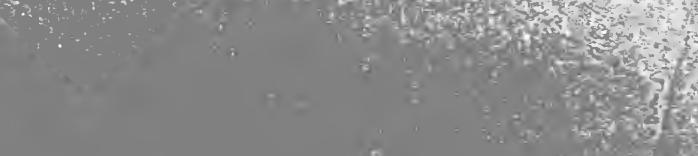


\section{SUPPLEMENT TO}

\section{TAXATION OF CORPORATIONS}

AND

\section{PERSONAL INCOME}

\section{IN NEW YORK}

Containing a Commentary on all important matters affecting the Taxation of Persons and of Corporations since July 1, 1919

$$
\text { including the }
$$

New Rules and Regulations of the State Comptroller governing the administration of the new

Personal Income Tax Law with a full explanation thereof.

\section{BY \\ HENRY M. POWELL}

OF THE NEW YORK BAR

NEW YORK

CLARK BOARDMAN CO., LTD.

Law Book Dealers and Publishers

1920 
Copyright 1920

by Henry M. Powell. 


\section{PREFACE TO SUPPLEMENT}

The perplexities attendant to carrying into effect the new system of taxing personal incomes in the State of New York, involving the preparation of returns by more than half a million taxpayers and the promulgation of the State Comptroller's rules and regulations, have made it incumbent upon the author to add a supplement to his book on the "Taxation of Corporations and Personal Income in New York" published last July. Most of these regulations like the New York Income Tax Act itself are taken from the federal procedure, and excellent as they are, there will no doubt be a difference of opinion as to their validity in many cases as well as to their application to a State system of income taxation. In the short time between the promulgation of the regulations and the publication of this supplement, an effort has been made to include a brief commentary on the more important of the regulations. In this I have received the efficient aid of Mr. Glenn Harrison Speece of my office, who wrote Chapter $\mathrm{XXXV}$, and who, otherwise, assisted me in the preparation of the manuscript.

Sections in the Personal Income Tax Law affecting the taxation of personal property for local purposes, rulings and decisions since July 1, 1919, governing the assessment of business corporations under Article 9-a of the Tax Law, and those relating to the assessment of personal property and personal income, have been commented on by the author as fully as circumstances permitted.

HENRY M. POWELL.

Dated, January 26, 1920. 


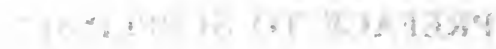

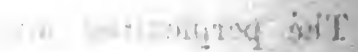

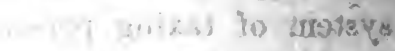

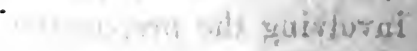

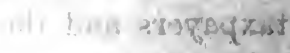

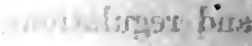

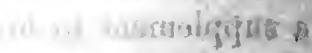

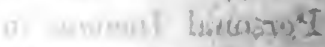

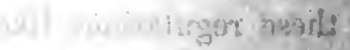

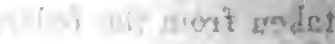

1) wh wo no Ilive

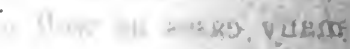

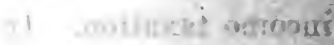

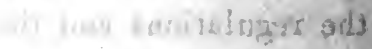

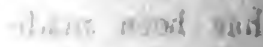

whis ing wathogers:

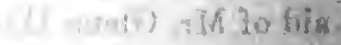

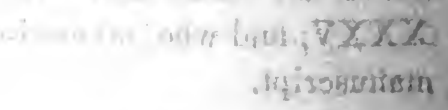

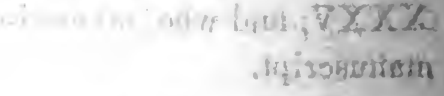

wit ni sostifnes?

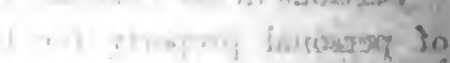

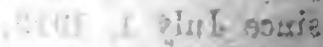

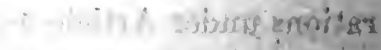

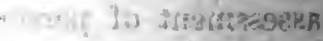

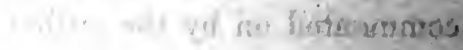

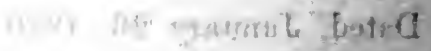




\section{CONTENTS TO SUPPLEMENT}

$\begin{array}{ll}\text { CHAPTER } & \text { PAGE }\end{array}$

XXXI. Exemption of Intangibles from Personal Tax...........401

XXXII. Exemption of Business Corporations from Personal Tax..... 408

XXXIII. Decisions Affecting Business Corporation Taxed Under Article

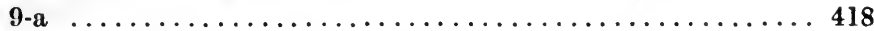

XXXIV. Constitutionality of the New York Personal Income Tax Law. 426

XXXV. The State Comptroller's Regulations.............437

XXXVI. The State Comptroller's Regulations Continued - Withholding and Information at the Source..............462

XXXVII. The State Comptroller's Regulations Continued - Non-resident

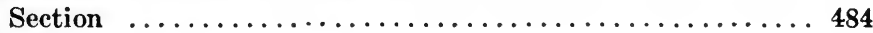

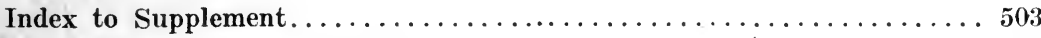

The Text of Comptroller's Regulations................. 515

Appendix I. Cross References to United States Regulations and State Comptroller's Regulations ..............6621

II. The Text of the New York Personal Income Tax Act... 6 $\geq 4$ Index to Comptroller's Regulations and to Personal Income Tax Act...647 


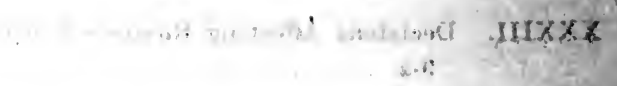

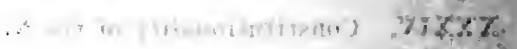

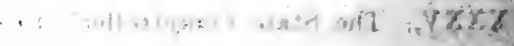

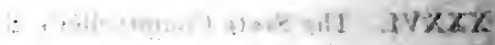

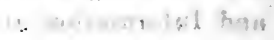

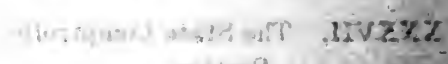$$
\text { numitent? }
$$

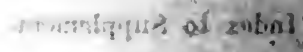

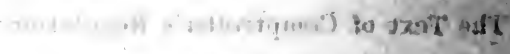

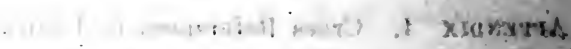

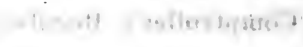

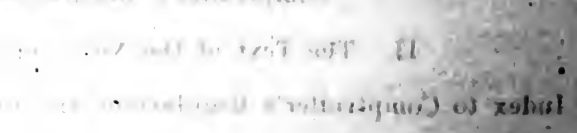




\section{CHAPTER XXXI.}

Exemption of Intangibles from Personal Tax.

Principal Tax Events in Second Half of 1919. - The principal events that mark corporate taxation and the administration of the new Personal Income Tax Law in the State of New York during the last half of the year 1919 may be classified as follows:

I. Changes in the local taxation of persons and of corporations.

II. Statutory changes and court decisions that affect the taxation of corporations for State purposes.

III. The promulgation of rules and regulations affecting the administration of the new Personal Income Tax Law.

I. The Local Taxation of Persons and of Corporations.

Exemption of Intangibles.-First: As to the local taxation of persons:

Section 352 of the Personal Income Tax Law (article 16 of the Tax Law), chapter 626 of the Laws of 1919 provides:

Exemption of certain personal property from taxation.- "Money on hand, on deposit or at interest, bonds, notes and choses in action and shares of stock in corporations other than banks and banking associations, owned by any individual or constituting a part of a trust or estate subject to the income tax imposed by this Article, and from which any income is derived, shall not after July thirty-first, nineteen hundred and nineteen, be included in the assessment rolls of the several tax districts, villages, school districts and special tax districts of the state."

It was the intention of the framers of the new Income Tax Law to exclude intangible personal property from local taxation. In the closing hours of the legislative session, the words "and from which any income is derived" were inserted after the 
enumeration of the classes of intangible property to be exempted, and the result has been to make the entire section ambiguous. Three constructions may be placed upon this section:

1. It may be interpreted as meaning that "money on hand (whether), on deposit or at interest" is exempt and that the words "and from which any income is derived" shall modify or limit only those classes of intangible property beginning with the word "bonds;" in other words, this construction would exempt all money on hand, on deposit, or at interest, from taxation, whether the money on hand or on deposit bore interest or not. The other classes of property beginning with the word "bonds" must bear interest to be free from personal taxation.

2. A second construction to be placed upon this section, and that most generally adopted, would be to have the words "and from which any income is derived" modify each one of the classes of intangible property referred to in section 352 . This would mean that if a bank deposit bore interest, it would be exempt from personal property taxation, but, if not, it would be subject to tax; and that an account receivable or a note which bore interest would be exempt from tax, and if these items of personal property bore no interest they would, on the other hand, be subject to the tax.

3. A third construction which has heretofore been referred to (chapter 27 , supra), is that where intangible property, such as money on hand, or choses in action represented by outstanding accounts, is used in a going business, such property should be exempt from taxation on the ground that it is used productively and is income producing. This would be on the general theory that capital employed in business will yield an income. (McLean v. Julian Electric Co., 29 Abb. N. C. 349.) 
Directions to Local Assessors. - Keeping in mind the various constructions that can be placed upon the statute, it can easily be understood why local assessors were in doubt, when the time arrived to assess or complete the assessments of personal property. Pursuant to the injunction contained in section 352 of the Tax Law, to exempt eertain personal property from local taxation, the assessors in the various tax districts of the State proceded to prepare their assessment-rolls after July 31,1919 , or to complete the assessment-rolls that had already been commenced at that time. In accordance with supervisory powers exercised under sections 171 and 171-a of the Tax Law, the State Tax Commission, under date of May, 1919, issued a bulletin to local assessors containing the following instructions:

\section{" PERSONAL INCOME TAX LAW \\ (Chapter 627, Laws of 1919)}

'This is the most important piece of legislation affecting taxation recently enacted. It became a law on the 14th day of May, 1919.

While the administration of the law is under the jurisdiction of the State Comptroller, in some respects it affects the duties of local assessors.

First: As to the assessment of personal property. You are advised that this law does not modify your duties as to the assessment of personal property in the year 1919, provided the assessment is completed prior to July 3lst. Taxable personal property should, therefore, be assessed this year by all town assessors at the full value thereof and as required by section 6 of the tax law. Village and city assessors, whose rolls are not completed before July 31st, must not include ' money on hand, on deposit or at interest, bonds, notes and choses in action and shares of stock in corporation other than banks and banking associations, owned by any individual or constituting a part of a trust or estate subject to the income tax * * and from which any income is derived.' 'I'his, however, does not apply to public service corporations which are taxable as heretofore for personal property.

After this year assessors must omit all such intangible personal property except bank stock, but must include taxable tangible personal property except when owned by corporations other than public service or public utility corporations 
Assessment of Personal Property in the City of New York. - The New York city deputy tax commissioners charged by law with the duty of making personal tax assessments, had already proceeded with that work under section 889 of the New York charter when the Income Tax Law went into effect. On October 1st the assessments had already been completed in the city of New York and the books were open for examination and correction. All taxpayers finding themselves aggrieved, under the provisions of the New York charter (section 895), were required to make application in writing, between October 1st and December 1st, for the correction of assessments, on a blank form provided by the department. This blank form provided for a listing of " cash on hand or on deposit in banks or trust companies from which no income is derived (exclusive of savings bank accounts)." It also provided for a listing of bills receivable and open accounts and for "all other notes, loans, bonds, mortgages and debts due or to become due, from which no income is derived."

In the items of "Deductions Claimed," the city tax department took the position that "indebtedness evidenced by notes from which no income is derived" might be offset, but that per contra, indebtedness evidenced by notes bearing interest or from which income is derived could not be offset. This position was evidently based on an incorrect conception of section 6 of the Tax Law, which provides, among other things, that "no such deduction shall be allowed by reason of the indebtedness of the owner, contracted or incurred in the purchase of non-taxable property." There is no warrant for the refusal of the tax department to permit deduction of such indebtedness merely because the property, viz., the debt represented by the note in the hands of the creditor may be subject to an income tax and thus free from the personal tax in the hands of the creditor. Such debt cannot be said to arise out of the purchase of nontaxable property, nor is it the property of the debtor. It will remain for the courts to decide this question whenever it is raised by the taxpayer. 
Should Intangible Property Bear Interest on Tax Day, to be Exempt from Personal Tax? - In the assessment of intangible personal property, the New York City Tax Department has up to the present time maintained that such property must bear interest on tax day in order that it may be said to be property "from which any income is derived." The difficulty of this construction is that while exemption from personal property taxation is thus based on its condition on tax day, the income-deriving power of the property may only become effective during the year, thus money in the eash drawer, or in pocket, on tax day, under a narrow construction of the statute is not income producing, but if placed in bank and drawing interest on the same day, it is exempt, even if withdrawn the week after and kept idle for the remainder of the year. Bonds, on which there had been a default in interest on tax day, would be taxable, even though the interest were paid later in the year. Such a construction leads to absurdity. What meaning can be placed on the words "money on hand," "from which any income is derived," if by "money on hand," under the ordinary meaning given to those words, we mean money in the pocket, or in the cash drawer, which can yield no interest? The only construction that does not result in nonsense and in a double tax, such as is prohibited by section 352 , is, that property that is, or has been, income-producing during the year, or is potentially capable of producing income, when used in connection with a going business in the State, should be exempt from personal property taxation.

It is believed that amendatory legislation early in 1920 will lead to the elimination of the words in dispute and to the exemption of all intangibles, as was first proposed by the Tax Revision Committee.

Relief from Erroneous Assessments on Intangible Property.- Taxpayers who have not filed an application with the assessors for the 
correction of an erroneous assessment within the time required by law, may be denied relief in certiorari under section 250 of the Tax Law, since that section requires that due application to the assessors for the correction of the assessment must be alleged in the petition for certiorari before a writ can be obtained. When there was no jurisdiction to assess, no application need be mado for cancellation on review day. People ex rel. Powder Co. v. Feitner, 41 App. Div. 544; People ex rel. Edison Co. v. Feitner, 99 App. Div. 274.

Proceedings Under the New York Charter for Relief.-Under section 934 of the New York charter, a delinquent taxpayer may be relieved from an erroneous assessment where inability to pay the tax in whole or in part is shown, or where the defense is such that a court of equity would recognize it. City v. Halsey, 132 App. Div. 192. Want of notice is not sufficient, but relief under this section could be granted to a defendant upon whom a tax is imposed by mistake resulting in illegal discrimination. City v. Holzderber, 44 Mise. 509 ; affd., 102 App. Div. 615.

In connection with the above, the following letter from the counsel to the State Tax Department will be of interest:

Letter from Counsel to the State Tax Department on the question as to whether intangible property can be taxed for local purposes:

"STATE OF NEW YORK-TAX DEParTMENT, Albany, May 28, 1918.

Hon. Henry M. Powfil, 51 Chambers Street, New York City. Dear Mr. Poweill:

Referring to your letter of the twenty-fourth instant, my reply his been delayed owing to the fact that we have been unable until to-day to ascertain the reason for the insertion of the words ' and from which any income is derived' in section 352 of the personal income tax law and to base our opinion upon the apparent intention of the legislature.

It appears, however, that these words were deliberately inserted in one of the later drafts of the bill at the request of the officials of New York 
City, the intent being to tax intangible personal property locally from which no income is derived. This apparently would apply to money on hand or on depasit, bonds or other securities which yield no income. The result of this amendment, as you see, will be to subject to the looal personal property tax a class of intangible personal property of less value and less able to pay a tax than other intangibles paying interest and exempt from taxation from the personal income tax. The tax on such property at the local rate in many instances would be almost confiscatory, working a considerable injustice to the holders thereof.

Very truly yours,

(Signed) WILLIAM E. SILL, Counsel." 


\section{CHAPTER XXXII.}

Exemption of Business Corporations from Local Personal TAX.

Taxation of Foreign Business Corporations on Their Personal Property.-Are foreign corporations taxable unler article 9-a, liable to a local tax on personal property?

Chapter 726 of the Laws of 1917 imposed a franchise tax on manufacturing and mercantile corporations based on net income returned to the United States Treasury Department, and under section $219-\mathrm{j}$ of the law, such corporations, domestic and foreign, were exempt from the personal property tax. Section $219-j$ in the law, as originally enacted in 1917 , so far as it related to the above question, read as follows:

"Manufacturing and mercantile corporations exempt from personal property $\operatorname{tax}$ and from the provisions of sections twelve, twenty-seven, one hundred and eighty-two and one hundred and ninety-two of the Tax Law. After this article takes effect, manufacturing and mercantile corporations shall not be assessed on any personal property which, for the purpose of this exemption, shall include such machinery and equipment affixed to the building ***. After this article takes effect, manufacturing and mercantile corporations shall not be assessed or taxed upon their capital stock, as provided for in section twelve of this Chapter * * *."

It may be added, in explanation of the above extract from the original law, that foreign corporations are assessed on their personal property under section 7 of the Tax Law, and domestic corporations are taxed on their capital stock under section 12 . Section $T$ of the Tax Law is not referred to specifically either in the 1917 law or in the 1918 or 1919 amendments to the law, but no one questioned the right of foreign manufacturing and mercan- 
tile corporations to exemption from the personal property tax under the 1917 law and there were no assessments for local taxation in 1917 or 1918 of either foreign or domestic corporations taxed under article 9-a.

-The assessment of capital stock of domestic corporations under section 12, not only included personal property, but it also included in the valuation thereof the difference between the assessed value of the real estate and the actual value thereof. Prior to the passage of the Special Franchise Tax Law (chap. 712, L. .1899) local assessors had attempted to tax corporate franchises as personalty under section 12. (People ex rel. Manhattan Ry. Co. v. Barker, 146 N. Y. 304.) The value of the capitil stock also included so much of the surplus profits as exceeded 10 per cent of the capital. (People ex rel. Citizens Electric Illuminating Co. v. Neff, 26 App. Div. 542.)

Bearing in mind the statements contained in the last two paragraphs, it seems clear that the words "personal property" in the first sentence of the section quoted were used in a different sense than the words "capital stock" in the second sentence. Until 1918 no one doubted that foreign corporations should be exempted from local taxation, but in that year there was a consolidation of the two sentences as above quoted in section 219-i; the words "manufacturing and mercantile" were omitted (the law now applying to business corporations generally) and the provision as to certain fixtures being exempt from real estate assessment was thrown into a separate section, known as 219-1, and headed "Personal Property Defined." After these changes, section 219-j, so far as it concerns the exemption from taxation of corporations, reads as follows:

"Section 219-j. Exemption from Certain Other Taxation.-After this article takes effect, corporations taxable thereunder shall not be assessed on any personal property or capital stock, as provided for in section twelve of this chapter 
The words "taxable thereunder" had reference to section 209, which provided that "every domestic corporation, * * * and every foreign corporation, except corporations mentioned in the next section" (which provided for the taxation of realty, casualty, insurance, public utility corporations, etc.).

The above statement of how the changes in the original statute arose, does not show an intent to exclude foreign corporations from the exemption, and the courts, in recent decisions have accepted a construction of this section exempting all corporations taxable thereunder from local personal taxation. In People ex rel. Barcalo Mfg. Co., 187 A. D. 89, Judge Woodward said:

"The Act of 1917 inaugurated a new policy in the taxation of corporations * * * It put these corporations under the provisions of a franchise tax in lieu of taxes on personal property and in this regard, took them out of the jurisdiction of local assessors

In a more recent case, People ex rel. Franklin Mill v. Collins, 109 Misc. 1, the court calls attention to the exemption of business corporations from local taxation, saying:

"The language of the section quoted is broad and explicit exempting manufacturing corporations from all assessments on any of its personal property."

In the Franklin Mill case, the point was raised that in order to exempt corporations from assessment under the Educational Law, it was necessary to refer to the Educational Law by name or by section, but the court held the language of article 9 -a was sufficiently broad to cover the exemption of all corporations taxed thereunder from all local taxation.

In a special bulletin for the information of assessors, issued by the New York State Tax Commission May, 1919, directed to all assessors, attention was called to the fact that 
“The so-called Corporation Income Tax Law has been amended to include all corporations, except those mentioned in section two hundred and ten of the tax law * * *. They are exempt from any tax on personal property * * *."

It appears in the city of New York that this direction was not obeyed or carried out and that there were placed on the rolls about four thousand foreign corporations, whose names should have been omitted. There is some reason to believe that before the tax rate is finally fixed on March 1st, the New York city assessor:s will see the obvious error that has been committed and purge the rolls accordingly. If these corrections are not made, the courts will undoubtedly in proper cases where relief is applied for in accordance with the statute, cancel the assessments. Should these assessments remain against the names of foreign corporations who have failed to make application for relief, they would still be able to plead a jurisdictional defense at any stage of the assessment or tax collection procedure. The question as to whether property or persons are assessable under the law is jurisdictional and is always open to inquiry when the authority to make an assessment is assailed. Under the act taxing nonresidents doing business in this State, the jurisdiction of the assessors depends on the existence of the facts stated in the statute and they cannot acquire jurisdiction by determining that they have it. (McLean v. Jephson, 123 N. Y. 142.)

Aside from the jurisdictional defense, it has been held in a number of cases that the city of New York is without any personal remedy to collect a tax from a nonresident. A demurrer may be interposed to an action thus brought (City of New York: v. McLean, 174 N. Y. 374). Neither can supplementary proceedings be brought to collect such a tax, and the attempt to give a tax the force of a judgment against the general property of a nonresident was overruled in Matter of Maltbie, $223 \mathrm{~N}$. Y. 230 . 


\section{Letter from counsel to State Tax Department on the exemption of foreign corporations from the personal property tax:}

\section{"STATE OF NEW YORK - TAX DEPaRTMENT,}

Albany, November 7, 1919.

Hon. Henry M. Powell, 51 Chambers Street, New York City.

Dear Mr. Poweil:

I am in receipt of your letter under date of the 5th inst., in connection with the question of the exemption of foreign corporations from the personal property tax.

It seems to me there can be no question but that the clear intent of the legislature was to exempt all corporations taxable under Article 9-A of the tax law from the personal property tax. As you have indicated the original draft of the law by the Mills Committee exempted not only the 'personal property as defined in Article 1' but also in a subsequent provision 'corporations liable to the income tax shall not be assessed or taxed upon their capital stock as provided in section 12.' The section containing this language appears to have been condensed in $\$ 219-\mathrm{j}$ to 'corporations taxable thereunder shall not be assessed on any personal property or capital stock.' In order that no question might arise as to whether or not 'capital stock' included personal property the words ' personal property' were inserted in the statute. The words 'as provided for in \& 12 of this chapter' were intended to relate only to 'capital stock' but as you state by improper punctuation a doubt has been cast upon the construction.

Undoubtedly this construction is strengthened by the recent decision in the Franklin Mill Co. case and also the expression of the court in the Barcalo Manufacturing Company case. Our statement in relation to the applicability of $\S \S 12$ and 27 of the tax law to foreign corporations was not strictly correct. Although the courts do not seem to have passed upon the question it is altogether probable a foreign corporation not liable in personam for a tax upon its personal property in this state would not be 'liable to taxation' within the provisions of $\& 12$.

It appears from the many communications to this office from foreign corporations that this class of corporations has been assessed generally in your city for the personal property tax.

Very truly yours,

(Signed). WM. E. SILL, Counsel, State Tax Commission." 
Exemption of Corporations from Local Taxes on Personal Property Assessed for School Purposes. - In Chapter XVII of this book (p. 130), reference was made to the opinion of the AttorneyGeneral (State Department Reports, No. 81), holding that corporations should not be relieved from local taxes on personal property assessed for school purposes. The Attorney-General assumed then, as the New York City Tax Department did later in connection with the assessments of foreign corporations, that because the Educational Law was not specifically mentioned in section 219-j providing for the exemption from local taxation of corporations taxed under article 9-a, the property of such corporations might still be assessed in school districts for personal taxes. The inequity of this construction and the discrimination that would result therefrom in tax districts where there was no city budget, was pointed out in page 131, chapter 17, supra.

In People ex rel. Franklin Mill v. Collins, 109 Misc. 1, the issue as to the assessment of corporations on personal property for school purposes, was raised, and the court at Special Term, Supreme Court, Genesee county, held that the relators were entitled to the relief prayed for in the writ, viz.: exemption from local taxation on personal property for school purposes.

Since many school districts are dependent for their maintenance largely on personal taxes so assessed it may be expected that amendatory legislation will be enacted to supply this lost revenue. In the meantime, an appeal in this case has been taken to the Appellate Division, the Attorney-General intervening.

The opinion of Judge Wheeler in the Franklin Mill case is given below in full: 
SUPREME COURT - Genesee County.

The People of the State of New York on the relation of Frankin Mill Company, against

LEwIS D. ColuIss and others, as members of and comprising the Board of Education of Union Free School District No. 2, of Batavia, Genesee County, N. Y.

The People of the State of New York on the relation of Wiard Plow Company, against

LEWIS D. Collixs and others, as members of and comprising the Board of Education of Union Free School District No. 2, of Batavia, Genesee County, N. Y.

The People of the State of New York on the relation of BAtavia RUBBer CoMpany, against

LEWIS D. Colisiss and others, as members of and comprising the Board of Education of Union Free School District No. 2, of Batavia, Genesee County, N. Y.

The People of the State of New York on the relation of Johnston HARvester CoMPANY,

against

LEwIS D. Coliriss and others, as members of and comprising the Board of Education of Union Free School District No. 2, of Batavia, Genesee County, N. Y.

EDWARD A. WASHBURN for the relators.

BAYARD J. STEDMAN for the respondents.

WheErer, J.-The above entitled proceedings come before this court by virtue of writs of certiorari to review the action of the Board of Education of Union Free School District No. 2 of Batavia in assessing the relators upon personal property for school tax purposes. 
It is conceded the relator in each case is a manufacturing corporation within the definition of the so-called "Emerson Act" section 208 subdivision 3 of chapter 726 of the Laws of 1917. The relators contend that by virtue of section 219-j of that act they are exempted from any assessment on any personal property after the act in question took effect.

On the other hand the respondents contend that the section referred to does not operate to withdraw the personal property of manufacturing corporations from the operation of the General Education Law, which provides a method of assessing property and collecting taxes for educational purposes. The cases presented for decision raise purcly questions of law, to wit-a judicial interpretation of the force and effect of the "Emerson Act" as regards the Education Law and the power to tax manufacturing corporations on personal property for school purposes.

'The "Emerson Act" materially changed the system of taxation in the State. This legislation was enacted in furtherance of a report of a committee appointed to examine and report on the general tax situation in the state. This report recommended "(1) The abolition of the present tax on personal property, (2) the withdrawal of general business corporations from the provisions of Section 182 of the tax law; and (3) the imposition of an income tax on individuals and general business corporations, including manufacturing corporations." Pursuant to this report a bill was drafted and passed by the Legislature which became chapter 726 of the Laws of 1917.

'I'his act imposes a tax of 3 per cent. on the net income of the corporation (section 215) and provides that from the revenue so received the State Comptroller shall pay into the State Treasury two-thirds of the amount, and distribute and pay the balance to the treasurers of the several counties where the corporations are located (219-h).

Section 219-j then provided "After this artiele takes effect manufacturing and mercantile corporations shall not be assessed on any personal property" * * * "After this article takes effect manufacturing and mercantile corporations shall not be assessed or taxed on their capital stock as provided for in section twelve of this chapter, nor shall they be required to pay the franchise tax imposed by section one hundred and eighty-two of this chapter."

The language of the section quoted is broad and explicit, exempting manufacturing corporations from all assessments on any of its personal property. The respondents, however, contend that inasmuch as the Act of 1917 does not in express terms refer to or repeal any of the provisions of the Education Law, and as the Education Law constitutes a separate and distinct chapter of the Statutes of the State it could not have been 
the intention of the Legislature by chapter 726 of the Laws of 1917 to in any manner modify or alter the provisions of the Education Law, and that the personal property of manufacturing and mercantile corporations is still taxable for the purpose of raising revenue for educational purposes. 'To a certain extent the Education Law does constitute a separate and distinct chapter, but we shall presently see that certain sections of that law must necessarily be read and construed in connection with the Tax Law of the State of which chapter 726 of the Laws of 1917 forms a part.

Section 410 of the Education Law provides that " after a tax shall have been voted by a district meeting for a purpose arising during the current school year the trustees shall assess it, and make out the tax list therefor and annex thereto their warrant for its collection."

Section 411 of the Law provides that "school district taxes shall be apportioned by the trustees upon real estate within the boundaries of the district which shall not be by law exempt from taxation." The second subdivision of the section provides that "The trustees shall also apportion the district taxes upon all persons residing in the district, and upon all corporations liable to taxation therein, for the personal estate owned by them and liable for taxation."

Section 412 provides for the purpose of ascertaining the valuation of taxable property, the trustees shall ascertain it "so far as possible from the last assessment roll of the town," etc.

It is to be noted by the Education Law that the assessment against corporations is to be only on "the personal estate owned by them and liable for taxation."

The Education Law nowhere undertakes to define what personal property of a corporation is "liable for taxation." It nowhere lists the personal property to be exempt. Consequently in order to ascertain for what personal property a corporation may be assessed or taxed we necessarily must consult and read the other Statutes of the State, and particularly the General Tax Law of the State declaring the exemptions from taxation. It follows that the Education Law is not an entirely separate and independent statute, but one to be interpreted and construed in connection with the General Tax Law, and if by the General Tax Law certain property is legally exempted from all taxes in lieu of a percentage of income to be paid, then it remains no longer taxable even for school purposes. 'lo illustrate, real estate mortgages are required to pay a recording tax, and when paid the holder of the mortgage is entitled to exemption from personal tax on that security for the amount represented. We think no one would contend that the trustees of a school district could claim the 
right to consider such mortgages property "liable for taxation" because the Act exempting them from further taxation contained no reference to the Education Law. What we say in reference to mortgages is equally true of real estate purchased by pension money.

We, therefore, are of the opinion that in order to limit the jurisdiction of school trustees to assess personal property of manufacturing corporations, it was not necessary for the Legislature to make specific reference to the Education Law - but it was sufficient by appropriate language to enlarge the exemption and place the personal property of corporations in the list of property exempted.

The Act of 1917 simply limited the class of property against which school boards could assess taxes for school purposes. This the Legislature has power and authority to do. And the Act is just as effective as though it had undertaken to amend the Education Law by an added section to that Act itself. Indeed it is manifest that the method pursued in the "Emerson Act" was the appropriate method of exempting corporate personal property not only from general taxation but from taxation for school purposes as well.

We find nothing ambiguous in the Act of 1917 so far as the question now under consideration is concerned. It may be that the statute works a hardship on certain school districts. As to the wisdom of the law the courts have nothing to do. The Legislature is the sole judge of those questions.

"All statutes must have a construction according to the language employed, and where no ambiguity exists courts cannot correct supposed defects." Denton v. Wickwire, 54 N. Y. 226.

Where language is apt and the construction plain, it cannot be departed from in deference to any supposed intent.

Matter of Village of Middletown, 82 N. Y. 196.

Matter of Simmons, 151 App. Div. 444.

People v. Long Island R. R. Co., 194 N. Y. 130.

We are of the opinion the relators are entitled to the relief asked.

So ordered. 


\section{CHAPTER XXXIII}

Decisions Affeuring Business Corporations Taxed for State Plrposes Under Article 9-A

Decision in Connecticut's Corporation Income Tax Case-- Reference has heretofore been made in Chapter XIV, supra, page 98, to the case of the Underwood Typewriter Co. v. Chamberlain, 102 Atlantic 600 , in which the question of the constitutionality of Connecticut's franchise tax law based on net income, was involved. The highest court in Connecticut has now affirmed the constitutionality of the act. An important question involved in the case, and one which must be of interest to New York corporations, is the apportionment of net income under the Connecticut act, which is substantially like the New York statute. A tax of two per cent. is imposed on the net income of manufacturing and mercantile corporations based on their return to the United States Treasury Department, and corporations doing business within and without the State may apportion the net income on the basis of tangible property in and out of the State.

The plaintiff, the Underwood Typewriter Co., a corporation organized under the laws of Delaware, was entirely engaged in the manufacture of typewriters in Hartford, in the State of Connecticut, although its sales office and business headquarters were outside the State, in the city of New York. Its income was principally derived from the sale of typewriters so manufactured, but it also received some income from repair work, investments, and the sale of goods manufactured by others. A large percentage of tangible property being located in the State of Connecticut, a tax, paid under protest and duress, was imposed 
on that proportion of the corporation's net income, the corporation contending that the proportion of tangible property in the State was an improper measure of the company's intrastate income, and that the act was unconstitutional.

The questions coming before the court and raised on appeal were as to the constitutionality of the statute.

1. That the provisions of the statute providing for a disclosure of its report made to the Federal govermment for income tax purposes was an unreasonable search and seizure in violation of section 2, article 4 of the United States Constitution and contrary to the Fourth, Fifth and Fourteenth Amendments thereof.

2. That the tax imposed a burden on interstate commerce contrary to section 8, article 1 of the United States Constitution.

3. That the statute violated the Fourteenth Amendment by taking property beyond the jurisdiction of the State of Connecticut, thus depriving the company of its property without due process of law.

The court first passed on the question as to whether the tax was an excise tax, as claimed by the Statc, or a property tax, as claimed by the Underwood Typewriter Co., or an income tax, as contended by the amicus curiae, and upheld the State's contention that it was an excise tax paid for the corporation's privilege of doing business in the State; that it was not a property tax because it was not payable unless there was net income. It was not an income tax because it was not imposed on the corporation unless it was engaged in business in the State on the basis of such income arising from business so transacted.

The issue raised as to the disclosure of information contained in the Federal return was dismissed on the ground that it was a convenience to taxpayers and a matter of economy in the administration of the state law and was no violation of the constitutional privilege of the corporation. The objection that the tax 
was a burden on interstate commerce was overcome by the decision in United State Glue Co. v. Town of Oak Creek, 247 U. S. 321 , recently decided by the United States Supreme Court and referred to in Chapter XIV, page 98, supra, in which the Federal court held that the tax on net income does not discriminate or interfere with interstate commerce. The objection that the statute violated the Fourteenth Amendment by taking property beyond the jurisdiction of the State of Connecticut and depriving the plaintiff of property without due process of law, was met by the statement that this argument was based on the erroneous theory that the tax was an income tax and not a privilege tax measured by net income, in the instant case to only a part of the net income. The real issue was, whether a privilege tax of two per cent. on forty-seven per cent. of the corporation's income was a tax on business outside the State, and the facts in the case showed that the tax imposed by the State of Connecticut was entirely reasonable and a proper apportionment made on the basis of the figures presented.

There is a dissenting opinion by Judge Wheeler in which he holds that the apportionment of the tax on the basis of tangible property in and out of the State brings into question a measure of income which' was not earned there; that the apportionment was not, in fact, based upon property but on income earned in the State and if the basis of apportionment in the law was not reasonable, the act itself was unconstitutional.

This case will probably be carried to the United States Supreme Court and since the measure of apportioning the Connecticut tax is substantially like ours, the final result will be worth noting by corporate taxpayers in New York.

The Excess Profits Tax not Deductible.- The Court of Appeals, on July 15, 1919, affirmed the order of the Appellate Division (Justices Hiscock and Andrews dissenting) in People ex rel. Bar- 
calo Mfg. Co. v. Knapp, 187 App. Div. 89. The decision upholds the State Tax Commission's ruling that the total net income upon which corporations are obliged to pay a franchise tax under article 9-a of the Tax Law, was the entire net income returned to the United States Treasury Department from which the excess profits tax could not be deducted. There is little in the Court of Appeals opinion that will add to the strength of the unanimous opinion of the Appellate Division, but it treats the question of what is "net income" from a broader viewpoint. The argument in the opinion is divided into two parts, the first of which points out that the intent of the New York law was to tax corporations on their entire net income without any deduction or credit for the excess profits tax, and the second shows that under the Federal income tax statute the net income upon which the tax was to be paid to the United States was the net income without deduction of excess profits tax. The salient features of the Court of Appeals opinion are stated below:

-The-languge of the statute expresses clearly the legislative intentions and enactments. The tax imposed was upon the entire net income of each year. This conclusion is repetitiously expressed and is indubitable. A definition of the words "net income" was not incorporated in the statute. The meaning given and characterizing them through and as used in the Federal statutes was their meaning as used in the state statute. The conditions and limitations, expressed in the Federal statutes, ereating their office and effect under those statutes are adopted hy the state statute. It used the term net income as rstablished by the Federal statutes. While the net income is declared by the statute to be presumably the same as the income upon which the corporation is required to pay a tax to the United States, it is clear and certain that within the legislative intention the net income of the statute is that returned or reported to the United States in accordance with the Federal statutes. While the basis for the computation of the commission is the returned net income under the Federal statutes, the commission is free to fix, from the return and any other information, the true and correct amount of the net income, but not to change the nature or definition of it. 
The language of section 5 of chapter 276 of the Laws of 1918, which I have already stated makes certain and mandatory the conclusion that the relator is governed and obligated by the provisions of article 9-A of the tax law existing and in force on November first, 1918. It is equally certain that those provisions were to be read and enforced, in so far as Federal statutes were involved, with the Federal statutes existing and in force on that date. In case section 209 of article 9 -A had originally read as chapter 276 of the Laws of 1918 framed it, the net income returned to the United States in any year, if true and correct, would, in virtue of the statute, be the net income for that year under the state statute, the tax commission was given no power to change or correct it other than to make it as established by the then existing Federal statute, true and correct in amount. To hold otherwise would be to pervert legislative intention.

"It remains for us to determine whether or not the term net income, within the meaning and effect of the Federal statutes, excludes the amount of any excess profits tax imposed by act of Congress and assessed for the year upon the taxpayer. Under the language of those statutes the problem is not difficult; the solution is not uncertain. It should be borne in mind that we are to reach the correct comprehension of the net income which those statutes require to be returned or reported to the United States treasury department, and not of the amount those statutes require the tax to be paid upon. The Federal statutes define the taxable net income as including gains, profits and incomes from manifold sources, subject only to such exemptions and deductions as they allow. (Laws of 1916, chapter 463, sections 1 (a) , 2; Laws of 1917, chapter 63, title 12, section 1200.) They state the exemptions they allow (Laws of 1916 , chapter 463 , sections $4,7,11$; Laws of 1917 , chapter 63 , title 12 , section 1200) and the deductions. (Laws of 1916, chapter 463, sections 5,12 ; Laws of 1917 , chapter 63 , sections $1201,1203,1208$.) Neither the exemptions nor the deductions include the income taxes or the excess profits tax. 'The tax sliall be computed upon the net income, as thus ascertained.' (Chapter 463, sections 8, 13; Laws of 1917, chapter 63, sections 1204,1208 .) The sections I have referred to have no relation to the excess profits tax. They relate to the income tax or the war income tax. Within them or within the other sections relating to those taxes it is not enacted that the net income to be returned is affected by or dependent in any way upon those taxes or the excess profits tax. Title 11 of chapter 63 of the Laws of 1917 provides for the excess profits tax. The discussion does not require consideration of it. The act of 1917 amended title 1 of the act of 1916 by adding to part 3, relating to general administrative provisions, six new sections (Laws of 1917, chap- 
ter 63, section 1211), of which section 29 is: 'That in assessing income tax the net income embraced in the return shall also be credited with the amount of any excess profits tax imposed by the act of Congress and assessed for the same calendar or fiscal year upon the taxpayer, and, in the case of a member of a partnership, with his proportionate share of such excess profits tax imposed upon the partnership.' This provision does not affect the definition of the words ' net income' as established by the statute. It provides that in the case of the corporation, partnership or individual liable for the excess profits tax, the net income returned to the United States shall, in assessing the income tax upon that net income, be eredited with the amount of the excess profits tax. The net income is not changed. A part of it equal to the sum of the excess profits tax is not, in such case, taxed. The corporations, partnerships or individuals who are not assessed the excess profits tax are assessed upon the net income for the income taxes. The net incomes of those who were and who were not assessed were ascertained under the same enactments and based upon identical specifications.

"The return by the relator of its" annual net income to the United States treasury department showed the annual total net income to be $\$ 256,201.75$. It was not inaccurate. The statute did not authorize the state tax commission to credit that net income with the sum of the excess profits tax assessed upon the relator or to assess the franchise tax upon the sum of it exceeding that tax.

"The order should be affirmed, with costs.

"Cuddeback, Cardozo, Pound and MeLaughlin, JJ., coneur; Hiscock, Ch. J., and Andrews, J., dissent.

"Order affirmed."

\section{What is a Holding Corporation? - Section 209 of the Tax} Law exempts "holding corporations" from the provisions of article 9-a under which business corporations are taxed upon their net income, and taxes "holding corporations" on their capital stock under section 182 (article 9) of the Tax Law. Attention has been called in chapter 12 supra, to the Tax Department's ruling as to what is a holding corporation. Its definition has been somewhat amplified by another ruling under date of June 27, 1919, in which the Tax Department says:

"It should be noted that there are two concurrent purposes. First, the "owning" and second, the "holding of 
stocks." The word and is used conjunctively and the three words here used together indicate a permanency of ownership for a specific purpose. The purpose of a holding company as indicated in all the cases examined, is to control the manage ment and dictate the conduct of the affairs of another or other corpcrations. * * *

"It does not apply merely to owning corporations but to purely holding corporations. If the word "holding" before the word "corporations" be eliminated from the sentence then all companies deriving their principal income from stocks and bonds would be entitled to exemption from the provisions of Article 9-a of the tax law and the contention of certain securities holding companies could not be gainsaid. But the word "holding," as used in the statute before the word "corporations," must have some definite meaning as affecting the word corporations and it is difficult to ascribe any such meaning except that of the ordinary significance in business, that is to say, that of a company holding stocks for purposes of control."

The statute evidently meant something more than a corporation that was exclusively a so-called holding corporation because it used the words "whose principal income is derived from holding the stocks and bonds of other corporations." Apparently, it referred to corporations that are engaged in other business besides holding the stocks and bonds of other corporations, otherwise, there would be no significance in the words " whose principal income is derived from holding the stocks and bonds of other corporations." The 1917 Law had reference to manufacturing and mercantile corporations dealing in tangible property, so that the definition of what is a holding corporation only became important with the amendment of 1918. Holding corporations were not taxed under article 9-a in 1917 as manufacturing or mercantile corporations on net income. The word "control" to which reference is made 
in the ruling of the State Tax Department does not appear in the statute, and if it is intended to restrict the exemption to corporations controlling as well as holding the stocks and bonds of other corporations, amendatory legislation seems to be necessary. A corporation might have been organized to hold and control the stocks of other corporations and by selling a portion of its majority interest, might lose control of the subsidiary corporations. If it did not change the nature of its business, would it not still be a holding corporation?

Movable Machinery of Business Corporations Exempt.-A decision of the Court of Appeals on January 20, 1920, has now finally affirmed the order of the Appellate Division, which, in turn, affirmed the order of the Special Term of the Supreme Court, New York county, in People ex rel. General Chemical Co. v. Cantor, 105 Misc. 62 . The decision of Judge Delehanty in the lower court referred to in chapter XVI supra, p. 123 (See opinion p. 353 supra) held that movable machinery and equipment of manufacturing and mercantile corporations taxed under article 9-a could not be assessed for local purposes either as real or personal estate. Permission had been granted to the City of New York to appeal to the Court of Appeals from the unanimous affirmance of the Appellate Division, and the final affirmance of the Court of Appeals seems to settle this question.

It should be noted, however, that under the 1919 amendment to section 219-1, in addition to boilers, ventilating apparatus, elevators, power generating apparatus, the following machinery and equipment will still continue to be taxed as real estate where used in connection with a building:- " plumbing, heating, lighting and" * * * "equipment for the distribution of heat, light, power, gases and liquids, nor (and) any equipment consisting of structures or erections to the operation of which machinery is not essential." 


\section{CHAPTER XXXIV}

Constitutionality of the New York Personal Income Tax Law

(See Chapter 24, supra.)

In the case of Travis, as Comptroller, v. Yale \& Towne Mfg. Co., decided August 6, 1919, in the United States District Court of New York, the constitutionality of the personal income tax law was raised insofar as it affects the taxation of nonresidents, by imposing a tax upon the entire net income from all property owned and from every business, trade, profession or occupation carried on in this State.

The facts in the case are stated in the opinion of Judge Knox, which is given at length below. The complainant, a Connecticut corporation, sued to enjoin the collection of the tax on the ground that the New York statute was unconstitutional, and in particular, was contrary to and in violation of article 1 , section 8 of the federal constitution, in that it interfered with and directly burdened interstate commerce; that it was contrary to and in violation of article 1, section 10 of the constitution, in that it impaired the obligation of contracts between the complainant and its employees; that it was in violation of section 2 , article 4 of the constitution, in that it deprived citizens of the states of Connecticut and New Jersey of the privileges and immunites enjoyed by the citizens of New York, and further, that it was in violation of the Fourteenth Amendment of the said constitution, in that it abridged the privileges and immunities of the citizens of the United States, residing in, and citizens of, Connecticut and New Jersey, and that it deprived the complainant's employees of their 
property without due process of law and denied to them equal protection of the laws.

The court denied the motion of the State Comptroller to dismiss the bill of complaint, on the ground that the personal income tax law, insofar as it attempted to assess and collect a tax from citizens of the United States who were not citizens of the State of New York but who were citizens of other states, without according them the privileges and immunities afforded to citizens of the State of New York, was unconstitutional and void. Judge Knox did not consider it necessary to pass on the question as to the power of the State of New York to lay a tax upon nonresidents, citizens of another state, based on their earnings in New York State for personal service rendered. From the decision rendered by Judge Knox, the State Comptroller appealed to the United States Supreme Court, and the case has now been argued and is pending in that court. A decision may be looked for some time early in 1920.

Upon the argument, a brief was presented on behalf of the State of New Jersey, by Hon. John W. Griggs, as amicus curiae, and there also appeared, as amicus curiae, Mr. Laurence Arnold Tanzer, on behalf of the corporation counsels of the cities of New York, Buffalo and Yonkers. The chief points presented by the Attorney-General, on behalf of the State Comptroller, and by Mr. Tanzer, as amicus curiae, before the United States Supreme Court, in support of the personal income tax, were briefly: That the income tax was a proper subject of State revenue and that whether it was a direct or indirect tax, whether it was a tax on persons, or on property, or on privileges, was a matter of no importance. Whether or not the State had sovereign power to enforce the tax depended solely on its ability to collect it without extending its jurisdiction beyond its territorial boundaries. This inherent power in the sovereign extended equally to residents and 
to nonresidents. The New York income tax did not deny to citizens of any state any of the privileges or immunities of citizens of the sereral states, and the classification of residents and nonresidents in the New York income tax act was reasonable; that the difference made in the act between residents and nonresidents was necessarily due to the limited jurisdiction of the State over nonresidents; that the base of the tax being different and narrower in the case of a nonresident since he is taxed only upon income from sources within the State, the exemption was different; that the statute did not, in fact, discriminate against nonresidents as. a class.

The appellee contended that the attempt by the State of New York to tax nonresidents on their salaries and earnings, was an attempt to tax persons and things outside of the jurisdiction of the State and within the jurisdiction of other states; that individual "net income" was personal to the nonresident and was not within the jurisdiction of the State other than that of which he was a resident and citizen; that such tax had been imposed as an income tax and not as a privilege or license tax, and the State of New York had neither the jurisdiction nor power to collect the tax.

The Taxation of Nonresidents Under Oklahoma's Income Tax Act. - Practically the same issue raised in the Yale and Towne case was presented to the same court at the same term in Shaffer v. Carter, in which the question of the right of the State of Oklahoma to tax a nonresident upon income from oil wells located in the State, under its State Income Tax Law, was an issue.

The Carter case was a corollary to Shaffer v. Howard, 250 Fed. Rep. 874, referred to in chapter 24, supra, page 197, the latter case having been dismissed by the United States Supreme Court by reason of change of parties since the commencement of the suit. Oklahoma's law, so far as it imposed a tax on nonresidents, is substantially like New York's, the chief difference 
lying in the facts, the income in the New York case arising from salaries for personal or professional service, and the income in the Oklahoma case being derived from profits in oil wells located in that State. A decision by the Supreme Court of the United States in the New York and Oklahoma cases will probably clear up many difficulties affecting the taxation of nonresidents.

The opinion of Judge Knox in the Yale and Towne case is given below in full:

Decision of District Court of the United States, Southern District of New York.

'The Yale and Towne Manufacturing Company, Complainant, vs. Eugene M. 'Travis, Comptroller of the State of New York, Defendant. In Equity. Upon motion to dismiss the bill upon the ground that it does not state a cause entitling the complainant to the relief sought. Motion denied. Louis H. Porter and Archibald Cox (F. Carroll Taylor with them on the brief), for Complainant; James Y. Ivins, Deputy AttorneyGeneral of the State of New York, for Defendant. (No brief was submitted' upon behalf of the defendant).

The complainant, a Connecticut corporation, has its plant and principal business place at Stamford, Connecticut. It is authorized to do business in this State, where it maintains an office, owns property and employs numerous residents of other States, to wit, of New Jersey and Connecticut who are occupied in whole or in part in the complainant's business within this State. A number of complainant's employees, who are non-residents of New York, perform substantially all of their services at the New York office, and their salaries are paid at stipulated times in the City of New York from funds of the complainant within the State. Still other employees similarly situated have their salaries paid to them by checks sent by mail from the home office to such employees in New York. Still other non-resident employees are occupied in services which are rendered partly in Connecticut and partly in New York, some spending relatively little time in Connecticut and vice versa, the amount of time spent in each place depending upon circumstances. The complainant also employs certain non-residents as traveling salesmen, who spend their time in New York and in traveling through other states.

The number of employees occupied as above set forth, whose salaries are in excess of $\$ 1,000$ per annum, exceed fifty in number and their total salaries are in excess of $\$ 200,000$. 
Upon May 14, 1919, what is known as "Chapter 627 of the Laws of 1919 " and entitled "An Act to amend the tax law, in relation to imposing taxes upon and with respect to incomés" became a law of this State.

Section 351 of the Act provides:-

"A tax is hereby imposed upon every resident of the state, which tax shall be levied, collected and paid annually upon and with respect to his entire net income as herein defined at rates as follows:" $1 \%$ on amounts not exceeding $\$ 10,000,2 \%$ upon amounts in excess of $\$ 10,000$ and not in excess of $\$ 50,000$, and $3 \%$ on amounts in excess of $\$ 50,000$.

The section continues, "A like tax is hereby imposed and shall be levied, collected and paid annually, at the rates specified in this section, upon and with respect to the entire net income as herein defined, except as hereinafter provided, from all property owned and from every business, trade, profession or occupation carried on in this state by natural persons not residents of the state." The tax shall first be levied and paid with respect to the calendar year 1919.

From here on the Act proceeds to specify its provisions in much detail. " In general," says Mr. Powell in his very recent work, Taxation of Corporations and Personal Income, "it may be said that the New York law has copied the Federal Income Tax Act, substituting 'taxpayer other that a resident' for 'non-resident alien' and 'January 1, 1919' for 'March 1, 1913.' The remedial procedure and method of collection in the New York Corporation Tax Law, Arts. 9 and 9a, are substituted for the Federal procedure." * * *

Non-residents are not entitled to the personal exemption provided for residents, to wit, $\$ 1,000$ for unmarried persons, and $\$ 2,000$ for married persons and $\$ 200$ for each dependent.

Residents are likewise entitled to certain deductions in computing net income, but non-residents are allowed such proportion of deduction as the income arising from sources within the State bears to the total income. The method of apportionment and allocation of claimed deductions is to be determined by the State Comptroller.

The Act creates "withholding agents," and the complainant woukd be one under the definition of the term, and such agents are required "to deduct and withhold $2 \%$ from all salaries, wages, commissions, annuities, emoluments, and other fixed and determinable annual or periodical gains, profits and incomes of which he shall have control, receipt, custody, dis posal or payment, if the amount paid or received in any year equals or exceeds $\$ 1,000$, unless there shall be filed with the withholding agent before the time to return any payment a certificate . . : to the effect 
that the person entitled to such salary," etc., is a resident, and setting forth his residence in the State.

The complainant alleges the existence between it and its employees of term contracts and is so positioned generally as to come within the terms of this Act, and would, it says, be put to considerable expense in withholding a percentage of the salaries of its employees. The defendant as Comptroller is alleged to threaten to enforce the penalties of the statute against the complainant unless it complies with the terms of the statute. The jurisdictional allegations of the bill being sufficient, the complainant asks for equitable relief against the threatened action of the Comptroller upon the grounds:

(1) That the statute is illegal and unconstitutional, in that it is contrary to and in violation of article I, section 8 , of the Constitution by interfering with and directly hindering commerce;

(2) That it impairs the obligation of contracts between the complainant and its employees;

(3) That it is contrary to section 2 of article IV of the Constitution, in that it deprives the citizens of the State of Connecticut and of New Jersey of the privileges and immunities enjoyed by citizens of the State of New York;

(4) That it contravenes the Fourteenth Amendment of the Federal Constitution, in that it abridges the privileges and immunities of citizens of the United States residing in, and citizens of Connecticut and New Jersey and States other than New York, and that the complainant and its employees are deprived of their property without due process of law, and that they are denied the equal protection of the laws.

Knox, D. J.

By reason of the decision which I have determined should be made in this case, it will be unnecessary to enter upon a discussion of the enactment in its entirety. That a State possesses practically unlimited powers of taxation within the realm of its jurisdiction save as circumscribed by constitutional limitations, is elementary, and income taxes are no exception.

The outstanding question, it seens to me, in this litigation is whether the Act as drawn transgresses upon the equal privilege and immunity provisions of the Federal Constitution. If it does, I need proceed no further.

So far as decided cases upon this precise question go, there appear to be none.

It is true the question was raised in the Income Tax Cases of Wisconsin, 148 Wisconsin, 456, wherein Chief Justice Winslow said: 
"It is argued that the provisions which deny to non-residents the exemptions which are allowed to residents . . . violates Section 2 of Article IV of the Federal Constitution, which provides that 'the citizens of each state shall be entitled to all privileges and immunities of citizens in the several states.' . . . We regard it as a question involved in considerable doubt, and one not necessary to be passed upon now."

The case of Shaffer v. Howard, 250 Federal, 873, by reason of its facts, is but of little help in this instance, and it is necessary to consider more or less original sources, and resort is had to the case of Corfield v. Coryell, 4 Washington Circuit Court Reports, 381.

The accuracy of the language, and the authority of this case, so far as I know, have not been questioned, and Justice Washington there said that he had no hesitation in confining the expression, that "the citizens of each state shall be entitled to all privileges and immunities of citizens in the several States" to those privileges and immunities which were in their nature fundamental, which belong of right to citizens of all free governments and which have at all times been enjoyed by the citizens of the several States which compose the Union from the time of their becoming free, independent and sovereign. Among these fundamental rights, said Justice Washington, were "the right of a citizen to pass through or to reside in any other state for the purposes of trade, agriculture, professional pursuits, or otherwise; to claim the benefit of the writ of habeas corpus; to take, hold and dispose of property, either real or personal, and an exemption from higher taxes or impositions than are paid by the other citizens of the state."

Thereafter, in Paul v. Virginia, 8 Wall. 168, at page 180, the Supreme Court said:

"It was undoubtedly the object of the" (Constitutional) "clause in question to place the citizens of each state upon the same footing with citizens of other states, so far as the advantages resulting from citizenship in those states are concerned. It relieves them from the disabilities of alienage in other states; it inhibits discriminating legislation against them by other states; it gives them the right of free ingress into other states, and egress from them; it insures them in other states the same freedom possessed by the citizens of those states in the acquisition and enjoyment of property and in the pursuit of happiness; and it secures to them in other states the equal protection of their laws. It has been justly said that no provision in the Constitution has tended so strongly to constitute the citizens of the United States one people as this." 
Again, in Ward v. Maryland, 12 Wall. 418, the court, in specifying some of the rights included within the words "privileges and immunities," said one of them was that a citizen of one State should be ". . . exempt from any higher taxes or excises than are imposed by the state upon its own citizens." See also, Cooley, Const. Limitations, 16. Subsequently in the Slaughter House Cases, 16 Wall. 36, it was said that the purpose of the Fourteenth Amendment ". . . was to declare to the several states, that whatever those rights, as you grant or establish them to your own citizens or as you limit or qualify, or impose restrictions on their exercise, the same, neither more nor less, shall be the measure of the rights of citizens of other states within your jurisdiction." Certainly, the force of this pronouncement was not qualified by the vigor of the dissents in these cases; and also in Barbier v. Connolly, $113 \mathrm{U}$. S. 27, in a discussion of the Fourteenth Amendment somewhat similar language was used.

Then there may be found the cases of Blake v. McClung, 176 U. S. 59, followed by Sully v. American National Bank, 178 U. S. 289, wherein it was held that non-resident unsecured ereditors stood upon the same footing with resident unsecured creditors, a statute of Tennessee to the contrary notwithstanding.

It need not be argued that the rights of a corporation created by one State within the borders of another State are not altogether similar to the rights of a natural person so circumstanced. Paul v. Virginia, supra; but even so, it was decided in Southern Railway v. Greene, 216 U. S. 400 , that to tax a foreign corporation under the circumstances there present by a different and more onerous rule than was used in taxing domestic corporations for the same privilege, constituted a denial of the equal protection of the law.

In Wiley v. Parmer, 14 Ala. 627, it was held that the statute of that State, taxing the slaves of a non-resident at double the amount at which those of a resident were taxed, was unconstitutional.

In Bliss's Petition, $63 \mathrm{~N}$. H. 135, it was held that a State cannot refuse a pedler's license to a citizen of another State, asked for upon the same terms that it grants licenses to its own citizens. Among other things the court said:

"The equality of privileges and immunities guaranteed by the federal constitution to the citizens of each state exempts them from any higher taxes than the state imposes upon her own citizens."

Other cases to the same general effect are, State v. Lancaster, $63 \mathrm{~N}$. H. 267; McGuire v. Parker, 32 La. Ann. 832; Oliver v. Washington Mills, 11 Allen, 280; Town of Farmington v. Downing, 30 Atl. Rep. 345. 
In Sprague v. Fletcher, $69 \mathrm{Vt} .69$, it was declared that an act of Vermont which denies to non-residents of the State rights which are allowed to residents under the same circumstances, in respect to deduetions from taxable personal property by reason of debts owed by the taxpayers, conflicts with article IV, section 2, of the Federal Constitution, which secures to citizens of each State "all the privileges and immunities in the several states."

Tested by the standard of the principles set forth in the foregoing eases, does the failure to accord to non-residents of the State the exemptions and immunities provided for to residents make this law, or part of it, invalid?

It becomes necessary to determine what persons are meant by the term "non-residents." The Comptroller of the State has used this language in referring to the term: "A person is a non-resident within the meaning of the act, if he receives taxable income from property owned or from a business, trade, profession or occupation carried on in the state, but is not a resident thereof." What I have to say will be confined to such nonresidents who are eitizens of States other than New York.

The question is of importance to the State of New York and is likewise of importance to the thousands of persons, residents and eitizens of adjoining States, who daily come into this State and here contribute to its welfare and prosperity.

It may be well to inquire what is the nature of the discrimination which it is alleged non-residents will be subjected to under the operation of the law. The following illustration will serve to answer the inquiry:

Two persons are employed in this State by the plaintiff. Their work is in all respects similar, and each receives a salary of $\$ 2,000$ per annum. Assume that each employee is married, one living with his wife in New York, and the other living with his wife in Connecticut. Under the law as it is written the resident of New York would be exempt from taxation, but the resident of Conneeticut would be subject to a tax of $\$ 20$.

Section 366 provides that " every withholding agent shall deduct and withhold two per centum from all salaries," etc., of non-residents. The tax imposed by section 351 is at the rate of one per cent on net incomes up to $\$ 10,000$; this is obviously an error in the Aet, and under the regulations withholding agents are required to withhold but one per cent. Without commenting upon the authority of the regulation so imposed, this discrepancy may be passed. The withholding of any sum from the salaries of non-residents is objected to, inasmuch as there is no withholding from residents. Assuming the power to lay a tax upon nonresidents based upon personal service, this feature of the Act I am inclined to think is not necessarily fatal to its validity. It is the law, 
I think, that not only must the final purpose of the law be considered, but the means of its administration - the ways it may be defeated. St. John v. New York, 201 U. S. 633. As to this feature of administration - I believe that some classification between residents and non-residents may with propriety be made. District of Columbia v. Brooks, 214 U. S. 138; Field v. Barber Asphalt Co., 194 U. S. 618. Reference may also be had to Bell's Gap Railroad Co. v. Pennsylvania, 134 U. S. 232, wherein the court held that the deduction of a tax by a withholding agent is merely a matter of convenience adopted as a secure method of collecting the tax, and as such is not objectionable.

As to the inconvenience resulting to the non-resident by reason of the payment by the withholding agent of the gross amount so withheld, and the trouble and expense of the taxpayer in recovering any excess over the tax finally determined upon, I need not now comment.

Paragraph 5 of section 360 provides that a resident may deduct losses incurred in any transaction entered into for profit, though not connected with the trade or business, "but in the case of a taxpayer other than a resident of the state only as to such transaction within the state." The result of this is that two employees of complainant, each receiving a salary of $\$ 5,000$ a year, may together enter into a business venture in another State; if the venture within a year results in a loss of say $\$ 5,000$ to each, the resident of New York may deduct his loss and pay no tax, but the non-resident of New York is subject to the tax. Also under paragraph 6 a resident may deduct his losses from fires, but unless the property of a non-resident injured by fire is within this State he can make no deduction.

Theoretically, the first of the two last-mentioned discriminations may be justifiable upon the ground that as to a resident of New York the State is entitled to tax upon his gains and profits from sources without the State, whereas as to a non-resident the tax may be recovered only as to net income from property, businesses and occupations within the State of New York. The fact, however, remains that it is the personal knowledge of us all that the only appreciable source of income of thousands of non-residents subject to this tax lies within the confines of this State, and that as a matter of practical operation of the statute the effect will be simply to deny to a non-resident, no matter what his misfortune, any exemptions. That there are in these provisions of the law a number of problems as to the character and place of income sought to be taxed well worthy of serious consideration, is undeniable; but in the aggregate, I am of opinion that as now framed the statute cannot operate without depriving citizens of other States of privileges and immunities which are open to citizens and residents of New York. 
The difficulty here has arisen, it would appear, by the Legislature having assumed that a citizen of the United States residing in a State other than New York sustains to the taxing power of that State the same relationship that a non-resident alien sustains to the Federal taxing power. There is, however, a distinction. Generally speaking, the United States government, as suggested by Mr. Powell in his book "Taxation of Corporations and Personal Incomes," may prescribe terms under which aliens may do business here or prevent them from doing business here altogether. By the Fourteenth Amendment it is declared that "All persons born or naturalized in the United States, and subject to the jurisdiction thereof, are citizens of the United States and of the state wherein they reside" and "No state shall make or enforce any law which shall abridge the privileges or immunities of citizens of the United States."

It is this provision of the Constitution along with the second section of Article IV and the Interstate Commerce section of our fundamental law that have been largely responsible for the community of interest, the unanimity of purpose, the united effort, and the magnificent accomplishments of our people. If now, under one pretence or another, the States are to erect economic and taxation barriers along their boundaries, it is but a question of time when the citizens of the various States will for all practical purposes be burdened with the disabilities of alienage, and this would be intolerable.

For these reasons, I am constrained to hold that the provisions of chapter 627 of the Laws of the State of New York for the year 1919 are, in so far as they attempt to assess, lay and collect a tax upon citizens of the United States who are not residents of the State of New York, and who are citizens of other States, without according them the privileges and immunities afforded by said Act to citizens of the United States who are citizens of the State of New York and resident therein, are unconstitutional and void. Nothing herein, however, is meant to be decided as to the validity of the statute so far as it relates to residents of the State of New York.

Neither that question nor the question as to the power of the State to lay a tax upon non-resident citizens of another State based upon their earnings in this State for personal service rendered, need, in view of the basis of my decision, now be considered.

The motion will be denied.

JNO. C. KNOX, U. S. District Judge.

August 6, 1919.

Filed August 6, 1919. 


\section{CHAPTER XXXV.}

'The State Comptroller's Regulations.

The following comments on the State Comptroller's regulations only treat the salient points. In the main, these regulations closely follow the Federal rulings, and it is only where they are entirely novel or diverge in important particulars from the Treasury Department regulations that they are discussed in detail.

Bad Debts Charged Off and Not Deducted.- (Art. 44.) "Bad debts or accounts charged off because of the fact that they were determined to be worthless, which are subsequently recovered, whether or not by suit, constitute income for the year in which recovered, regardless of the date when the amounts were charged off."

This ruling does not refer to debts which have been charged off but not deducted in returns of income. What the article means is, that if a bad debt has been charged off and deducted in a State income tax return, as a loss, any part thereof subsequently recovered must be returned as income for the year of recovery. Debts due to the taxpayer, therefore, whether of principal or of income, if written off subsequent to January 1, 1919, and deducted as losses in State income tax returns, must, if subsequently recovered, be returned as income for the year of recovery; but if written off prior to January 1, 1919, the retroactive date of the State Personal Income Tax Law, such debts could not be deducted in any return, and herpe no part thereof subsequently recovered should be returned as income.

As to when debts of income are deductible, because uncollectible, see $\Lambda$ rt. 162, and comments. 
Interest Accrued Prior to January 1, 1919.-(Art. 46.) "Where interest coupons have matured, but have not been cashed, such interest, though not collected when due and payable, is nevertheless arailable to the taxpayer and should therefore be included in his gross income for the year during which the coupons matured unless the debtor be in default ***. Interest accrued on savings bank deposits $* * *$ is income to the depositor when credited."

The foregoing provisions do not refer to interest which accrued prior to January 1, 1919, whether due and payable on that date or not. Such interest is exempt from tax. (See Art. 79 ; also Art. 61.)

\section{Difference in Taxing Dividends Between State and Federal Law.}

(Art. 61.) Under the State law, income accruing to the taxpayer prior to January 1, 1919, and under the Federal law, income accruing prior to March 1, 1913, is exempt from incomo taxation. There is an important difference, however, between the taxation of dividends under the Federal law, with reference to March 1, 1913, and the taxation of dividends under the State law, with reference to January 1, 1919.

The Federal law, decisions and regulations make the exemption of dividends dependent upon the year in which the profits distributed were earned, earnings accumulated prior to March 1, 1913, being tax-free, while earnings accumulated subsequent to that date are taxable as dividends. Accordingly, the Federal law provides that distributions of corporate dividends are deemed to be made from earnings accumulated subsequent to March 1, 1913 ; and the Commissioner of Internal Revenue has ruled (with doubtful propriety) that losses by casualty must be charged first against earnings accumulated prior to March 1, 1913.

Under the State law and regulations, the exemption of divi- 
dends is dependent upon the date of declaration of the dividend, with reference to January 1, 1919, regardless of when the dividend was earned by the distributing company and regardless of the date of actual payment thereof. If the dividend was declared prior to January 1, 1919, it is exempt; otherwise it is taxable. There is therefore no provision of the State law, nor any regulation of the Comptroller, which raises any presumption as to the earnings from which distributions of dividends shall be deemed to be made, with reference to January 1, 1919. As regards the presumption that all distributions are made from earned surplus and undivided profits, however, see article 66.

\section{Constitutionality of Tax on Income from Mortgages.-(Art. 74.)} "However, the income from securities (1) upon which the investment tax was paid after May 14, 1919, or (2) upon which the secured debt or the mortgage tax was paid, is not exempt."

Section 251, article 11, of the Tax Law, exempts from all other taxation by the State, counties, cities, towns, villages, school districts and other local subdivisions of the State, all mortgages of real property situated within the State upon which the mortgage tax imposed by that article has been paid.

$\Lambda$ s indicated by the above quotation from article 74 , the Personal Income Tax Law does not exempt the interest on such mortgages from income taxation. This is not, however, an impairment of any contract between the State and the taxpayer (People v. Diamond. 121 A. D. 559), nor is a tax upon the income from a mortgage a tax upon the mortgage. Section 359 , subdivision (d), expressly excludes the income from investments upon which the tax has been paid since June 1, 1917, as provided in section 331, article XV of the Tax Law, known as the Investment Tax, but only during the period for which such tax has been paid. 
Inventory Valuations.- (Art. 91.) For the purpose of computing gain or loss from the sale of inventory property acquired prior to January 1, 1919, the law and regulations provide that the taxpayer may use any one of the three following bases: (1) The fair market value of the property as of January 1, 1919; or (2) the cost; or (3) the cost or market value of each item, whichever is lower.

Provisions of the Statute. - Section 353 of the law reads as follows: "For the purpose of ascertaining the gain derived or loss sustained from the sale or other disposition of property, real, personal or mixed, the basis shall be first, in the case of property acquired before January first, nineteen hundred and nineteen, the fair market price or value of such property, as of January first, nimeteen hundred and nineteen, and second, in case of property acquired on or after that date, the cost thereof; or the inventory value, if the inventory is made in accordance with this article (the Personal Income Tax Law)."

The provision of the article which relates to inventories is embodied in section 356 . It reads in part as follows: "Whenever in the opinion of the comptroller the use of inventories is necessary in order clearly to determine the income of any taxpayer, inventories shall be taken by such taxpayer upon such hasis as the comptroller may prescribe, conforming as nearly as mav he *** to the forms and methods prescribed by the United States commissioner of internal revenue under the act of congress known as the revenue act of nineteen hundred and eighteen."

Regulations of Comptroller. - In pursuance of the authority conferred by section 356, the valuation of inventories is prescriber by articles 91 and 217 of the Comptroller's regulations. 
Taxpayer's Option as to Inventory Valuations.-- Article $217 \mathrm{pr}$ vides: "Inventories should be valued at (a) cost, or (b) cosit or market whichever is lower."

Article 91 states: "For the purpose of ascertaining the gain or loss from the sale, gift, exchange or other disprosition of property, the basis is (a) its fair market price or value as of January 1, 1919, if acquired prior thereto, or $(b)$ if acquired on or. after that date, its cost or its approved inventory value." This language clearly indicates that the inventory valuations prescribed in article 217 are required to be used only in the case of property acquired subsequent to January 1, 1919. Moreover, the last clause of section 353 - "or the inventory value if the inventory is'made in accordance with this article" - applies to all property of the taxpayer which may be properly included in his inventory, whether acquired prior or subsequent to January 1 , 1919. The use of the word "or" in this clause indicates that an option is given the taxpayer to use the "inventory values," as defined in article 217, or to disregard such inventory values altogether, in the case of property acquired prior to January 1. 1919 , substituting therefor the fair market value of the property as of that date.

Mlustration.- Basis for determining gain or loss from the sale of property, real, personal or mixed.

\begin{tabular}{|c|c|c|c|}
\hline \multicolumn{2}{|c|}{$\begin{array}{l}\text { Property ACQUIRED PrIOR to } \\
\text { JANUARY } 1,1919\end{array}$} & \multicolumn{2}{|c|}{$\begin{array}{l}\text { Property AcQuired Subsequent to } \\
\text { JANUARY 1, } 1919\end{array}$} \\
\hline $\begin{array}{c}\text { Included in } \\
\text { Inventory }\end{array}$ & $\begin{array}{l}\text { Not Included } \\
\text { in Inventory }\end{array}$ & $\begin{array}{l}\text { Included in } \\
\text { Inventory }\end{array}$ & $\begin{array}{l}\text { Not Included } \\
\text { in Inventory }\end{array}$ \\
\hline $\begin{array}{l}\text { (1) Fair value as of Jan- } \\
\text { uary 1, 1919, or } \\
\text { (2) Inventory value. } \\
\text { which must be- } \\
\text { (a) cost; or } \\
\text { (b) cost or market, } \\
\text { whichever is } \\
\text { lower }\end{array}$ & $\begin{array}{l}\text { Fair market value as of } \\
\text { January 1, 1919 (less } \\
\text { depreciation. deple- } \\
\text { tion, or obsolescence } \\
\text { subsequent to that } \\
\text { date)! } \\
\text { : }\end{array}$ & $\begin{array}{l}\text { (a) Cost; or } \\
\text { (b) Cost or market, } \\
\text { whichever is } \\
\text { lower }\end{array}$ & $\begin{array}{l}\text { Cost (less deprecia- } \\
\text { tion. depletion, or } \\
\text { obsolescence sub- } \\
\text { sequent to acquisi- } \\
\text { tion) }\end{array}$ \\
\hline
\end{tabular}


Inasmuch as the Federal law prescribing inventory valuations was retroactive only to January 1, 1918, practically all merchandise which was included in the taxpayer's inventory for the first year of its operation had been acquired subsequent to March 1, 1913 , so that it was impossible for taxpayers to use the fair value thereof as of March 1, 1913. Under the State law, however, the situation is different, since all merchandise on hand as of January 1, 1919, must have been acquired prior to that date. Such property may be valued, for the purpose of computing gain or loss from the sale thereof, according to either of the methods specified in the first column of the above table, that is, (1) fair market value as of January 1, 1919, or (2) the inventory value, which must be (a) cost, or (b) cost or market, whichever is lower.

\section{Gift, as Closed Transaction Resulting in Taxable Profit.- The} Comptroller has ruled in article 91 that gifts constitute a disposition of property which may result in a profit or loss to the donor, measured by the difference between the cost of the property (or its value as of January 1, 1919, if acquired prior thereto) and its value at the date of the gift. It is believed that this ruling is intended to check the practice which has no doubt been heretofore indulged in, of donating property for the purpose of avoiding a Federal income tax upon the profits which would be realized by the donor if he personally sold the property at the market price. Under this practice, if the owner makes a gift of the property, and it is immediately sold by the donee, the taxable profit is measured by the difference between the value of the property at the date of the gift and its value at the date of sale, which would be practically zero. Whatever may be the reason for the Comptroller's ruling, it will be difficult to spell out of the law any authority upon which to support it. 
Fair Market Value January 1, 1919.-(Art. 92.) The phrase "bona fide sales nearest January 1, 1919," would no doubt include sales immediately following, as well as immediately preceding, January 1, 1919, at least in cases where there were no sales immediately preceding that date.

Exchange of Property for Stock, Treasury Ruling.- (Art. 97.) The original corresponding article of the Federal regulation. (Art. 1566) read in part as follows: "(a) Where property is transferred to a corporation in exchange for its stock, if the previous owner of the property receives 50 per cent or more of the stock of the corporation, so that an interest of 50 per cent or more in such property remains in him, then no gain or loss is realized by such owner from the transaction." This article was amended by T. D. 2924 , dated September 26, 1919, by striking out the provision quoted above, so that the language of article 1566 is now identical with that of article 97 of the Comptroller's regulations.

Exchange of Stock for Stock of Greater Aggregate Par Value.(Art. 100.)

Stock Dividends and Reorganization "Profits." - Ender both the State and Federal law, a tax is imposed in specific language upon stock dividends and reorganization profits. The practical result in both cases is a tax upon shareholders measured by undistributed corporate earnings or appreciation values. In both cases the shareholder finds himself possessed of stock of "greater aggregate par value;" the only difference between the two cases is, that the recipient of a stock dividend receives new stock from the same company which issued his old stock, whereas the recipient of reorganization "profits" receives new stock from a new company which has no assets of its own, other than the stock of the old company which the shareholder gives in exchange. In both cases alike, as a general rule, the corporate assets are not increased, nor are the proportions of stock holdings changed; no gain has 
been derived, nor any loss sustained, by either the stockholders or the old corporation. In neither case does it make any difference that the good will of the old company may have been capitalized by the issuance of new stock; the mere issuance of such stock does not create any good will which did not exist prior thereto, or which was not represented by the old stock previously outstanding.

If Stock Dividends not Taxable, Tax on Reorganization "Profits" Must Fail._ The Supreme Court of the United States has already decided that stock dividends are not income in the sense of "gains" or "profits." (Towne v. Eisner, 245 U. S. 418.) It now remains for that court to determine whether such dividends are income within the Sixteenth Amendment to the Constitution pernitting Congress to lay "income taxes" without apportionment according to population. Unless the court is prepared to reverse its former decision, the answer will no doubt be that such dividends are not within the terms of the amendment. In the event of the failure of the provision of the Federal law taxing stock dividends, the tax on reorganization "profits" must also fail, not only ipon principle, but also because of the facility with which corporations may increase the par value of their share holders' stock by the payment of stock dividends, capitalizing profits and good will, prior to a reorganization.

As regards the State law, in the absence of any constitutional restriction, the intent of the Legislature concerning the nature of the tax, must govern. The tax was clearly intended to be an income tax, not a property tax. Returns are to be made only of "gains, profits and income." If stock dividends are not income, in the sense of "gains" or "profits," then there is no provision of law requiring a return thereof. And it is the function of the courts to determine whether such dividends are or are not income in that sense. 
If the State courts should decide that stock dividends are not income in the sense of gains or profits, then the provision of the State law taxing reorganization profits must also fail, for the reasons mentioned above in reference to the corresponding provisions of the Federal law.

Deduction of Federal Taxes.-(Art. 142.) Income taxes imposed by any authority whatever cannot be deducted from gross income; nor can Federal business, license, privilege, excise or stamp taxes, which are deducted as part of the cost of merchandise, be also deducted as taxes paid or accrued. But the mere inclusion of such taxes in the price for which the merchandise is sold will not render payments or accruals thereof nondeductible as taxes, so long as they are not actually deducted as a part of the cost of goods sold.

When Bad Debts Deductible-_(Art. 162.) This article does not apply to debts of the character specified which accrued prior to January 1, 1919, whether due and pavable on that date or not. Such debts are deductible for the year in which charged off, notwithstanding they were not required to be returned as income for the year of accrual. (See Art. 79.)

Personal Exemption of Residents- (Art. 209.) Under the Federal regulations the status of individuals for purposes of the personal exemption of $\$ 1,000$ or $\$ 2,000$, is determined as of the last day of the taxable year. Under the regulations of the Comptroller, however, the taxpayer is entitled to an exemption of $\$ 2.000$ as the head of a family, or as a married person, if at any time during the taxable year he or she was the head of a family or a married person living with husband or wife, with an exception in case of the death of husband or wife. If either spouse dies during the taxable year, the decedent's personal representative is entitled to claim for him or her the undiminished married per- 
son's exemption, and the survivor, if he or she remarries prior to the end of the taxable year, is likewise entitled to an undiminished exemption of $\$ 2,000$; but if the survivor does not remarry prior to the end of the taxable year, he or she is entitled to an undiminished single person's exemption of $\$ 1,000$. In fact, in all cases the personal exemption may be taken in full, if at all, except in the case of employees of the United States (Art. 210), and except that husband. and wife are entitled to only one exemption of $\$ 2,000$ between them. $\Lambda_{\mathrm{s}}$ to whether any apportionment is required in the case of a taxpayer becoming a nonresident during the taxable year, see page 455 , article 501 , and comments.

Apportionment of Personal Exemption between Husband and Wife. Where neither husband nor wife has an income in excess of $\$ 10,000$, the personal exemption may be apportioned between them in any way they see fit; but if one has an income in excess of $\$ 10,000$ and the other has not, it will be advantageous to apportion the entire exemption to the one having the larger income, since the rate of tax on income in excess of $\$ 10,000$ and not in excess of $\$ 50,000$ is 2 per cent, as compared with 1 per cent where the income does not exceed $\$ 10,000$.

Withdrawals of Partnership Earnings.-(Art. 232.) Amounts "withdrawn" by partners during the taxable year, are not taxable apart from and in addition to their shares in the partnership earnings for the taxable year whether distributed or not. The reason for this is, of course, that the earnings of all years prior to the taxable year are presumably tax-paid, or constitute income accruing to the partnership prior to January 1, 1919, which is exempt from tax. (See Art. 79.)

\section{Income from Estates and Trusts.-(Art. 242.)}

Only One Tax Payable.- The law imposes only one tax upon the income of an estate or trust; and although such income may be taxable either to the fiduciary or to the beneficiary, depending 
upon the conditions referred to in article 242 , in no case is it taxable to both. If such income is tax-paid by the fiduciary, it becomes, in effect, capital, and is not again subject to tax when distributed to beneficiaries; and if, in accordance with the provisions of this article the tax is paid by the beneficiaries upon undistributed income of the estate or trust, no additional tax is payable by them upon actual distribution thereof.

When Tax Payable by Fiduciary and When by Beneficiary.-If income is received by the executor or administrator during the period of administration, and is not during such period properly paid or credited to a beneficiary, or if it is received by a trustee in trust for future distribution, the tax must be paid by the fiduciary for the trust or estate, the personal exemption in case of a resident estate or trust being $\$ 1,000$, the same as for an unmarried resident individual. (Art. 242-c.)

But if the income is, by the terms of the will or deed of trust, properly paid or credited to beneficiaries or is distributable to them periodically, whether or not at stated intervals, such income is regarded as income of the beneficiaries, and the tax must be paid by them upon their distributive shares, whether actually distributed or not, in the same manner as members of partnerships are required to pay a tax on their shares of the net earnings of the partnership. (Art. 242-d.) As stated above, no additional tax is payable by the beneficiaries upon an actual distribution of earnings upon which a tax has already been paid.

Where, however, under the terms of the will or deed, the trustee may in his discretion distribute income periodically, or accumulate it, the amount actually distributed is taxable to the beneficiaries, and the amount accumulated is taxable to the trust; excepting that such part of the amounts distributed as represents earnings the tax upon which has already been paid by the trustee, need not be reported by the beneficiaries. 


\section{Presumption That Distributions Made Ratably from Taxable and} Non-taxable Income.-As to whether any particular payment to a resident beneficiary represents income of a nonresident estate or trust the tax upon which has been paid by the fiduciary, or as to whether payments made to beneficiaries, whether resident or nonresident, represent income which is exempt by law from tax, the regulations state (Art. 242), "In the absence of any specific allocation of income, under the will or deed of trust, every distribution shall be deemed to apply ratably to taxable and nontaxable income of the estate or trust and the beneficiary must be guided by the same allocation." This ruling no doubt is intended to include all income which is non-taxable, whether by reason of the exempt character of the income of the trust or estate, or by reason of the nonresidence of the trust or estate. Of course, any income which would, under the foregoing rules, be taxable to a resident estate or trust, but which is not so taxable because the estate or trust is a nonresident, would be taxable, nevertheless, when received by resident beneficiaries. "A resident beneficiary is taxable on the income of an estate or trust regardless of whether such income is derived from sources within or without the State and without consideration as to whether the estate or trust is a resident or a nonresident estate or trust." (Art. 245.)

In computing income of an estate or trust from sources within the State of New York, expenses and losses incurred in earning income from sources other than New York must be excluded (section 360 , subdivision 11), as well as expenses which by the terms of the will or deed or by rule of law are chargeable against the corpus of the estate. (Art. 254.)

Illustrations of Taxation of Income of Resident and Nonresident Trusts. - Let us suppose that a trust has a net income (exclusive of exempt income) of $\$ 40,000$, of which three-fifths $(\$ 24,000)$ is to be accumulated for the benefit of unborn or unascertained persons, one-fifth $(\$ 8,000)$ is to be distributed periodically and 
equally to two known beneficiaries, one of whom is a resident and the other a nonresident, and one-fifth $(\$ 8,000)$ or any part thereof may be distributed to these same known beneficiaries in the fiduciary's discretion, of which amount the fiduciary actually distributes one-half and retains the other one-half for the trust; also, that one-half the net income of the trust (exclusive of exempt income) is derived from New York and one-half from other sonices.

The first of the following tables will illustrate the taxability of the income of this trust in case it is a resident of New York; and the second table will illustrate the taxability of the income of such trust in case it is a nonresident of New York.

Taxation of Income of Resident Trust.

\begin{tabular}{|c|c|c|c|c|c|c|c|}
\hline \multirow{2}{*}{$\overline{x+2+10}$} & \multicolumn{3}{|c|}{ APPORTIONMENT OF INCOME } & \multicolumn{3}{|c|}{ SOURCE OF INCOME } & \multirow[b]{2}{*}{$\begin{array}{c}\text { By Whom } \\
\text { Tax Payable }\end{array}$} \\
\hline & $\begin{array}{l}\text { Manda- } \\
\text { tory } \\
\text { Appor- } \\
\text { tionment } \\
\text { of Will } \\
\text { or Deed }\end{array}$ & $\begin{array}{c}\text { Appor- } \\
\text { tionment } \\
\text { in Fidu- } \\
\text { ciary's } \\
\text { Discre- } \\
\text { tion }\end{array}$ & Total & $\begin{array}{l}\text { New } \\
\text { York }\end{array}$ & $\begin{array}{l}\text { Other } \\
\text { Sources }\end{array}$ & $\begin{array}{c}\text { Total } \\
\text { Taxable } \\
\text { Income }\end{array}$ & \\
\hline \multirow{4}{*}{$\begin{array}{l}\text { Resident benefi- } \\
\text { ciary ......... } \\
\text { Nonresident bene- } \\
\text { ficiary.......... } \\
\text { Trust for fac- } \\
\text { cumulation. . }\end{array}$} & $\$ 4,000$ & $\$ 2,000$ & $\$ 6,000$ & $\$ 3,000$ & $\$ 3,000$ & $\$ 6,000$ & \multirow{4}{*}{$\begin{array}{l}\text { Beneficiary } \\
\text { Beneficiary } \\
\text { Fid ry }\end{array}$} \\
\hline & 4,000 & 2,000 & 6,000 & 3,000 & 3,000 & 3,000 & \\
\hline & 24,000 & 4,000 & 28,000 & 14,000 & 14,000 & 28,000 & \\
\hline & $\$ 32,000$ & $\$ 8,000$ & $\$ 40,000$ & $\$ 20,000$ & $\$ 20,000$ & $\$ 37,000$ & \\
\hline
\end{tabular}

Taxation of Income of Nonresident Trust.

\begin{tabular}{|c|c|c|c|c|c|c|c|}
\hline \multirow{2}{*}{ 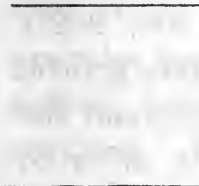 } & \multicolumn{3}{|c|}{ APPORTIONMENT OF INCOME } & \multicolumn{3}{|c|}{ SOURCE OF INCOME } & \multirow[b]{2}{*}{$\begin{array}{c}\text { By Whom } \\
\text { Tax Payable }\end{array}$} \\
\hline & $\begin{array}{l}\text { Manda- } \\
\text { tory } \\
\text { Appor- } \\
\text { tionment } \\
\text { of Will } \\
\text { or Deed }\end{array}$ & $\begin{array}{c}\text { Appor- } \\
\text { tionment } \\
\text { in Fidu- } \\
\text { ciary's } \\
\text { Discre- } \\
\text { tion }\end{array}$ & Total & $\begin{array}{l}\text { New } \\
\text { York }\end{array}$ & $\begin{array}{l}\text { Other } \\
\text { Sources }\end{array}$ & $\begin{array}{c}\text { Total } \\
\text { Taxable } \\
\text { Income }\end{array}$ & \\
\hline \multirow{2}{*}{$\begin{array}{l}\text { Resident benefi- } \\
\text { ciary........ } \\
\text { Nonresident bene- } \\
\text { ficiary......... } \\
\begin{array}{l}\text { Trust for } \\
\text { cumulation .... }\end{array}\end{array}$} & $\begin{array}{r}\$ 4,000 \\
4,000 \\
24,000\end{array}$ & $\begin{array}{r}\$ 2,000 \\
2,000 \\
4,000\end{array}$ & $\begin{array}{r}\$ 6,000 \\
6,000 \\
28,000\end{array}$ & $\begin{array}{r}\$ 3,000 \\
3,000 \\
14,000\end{array}$ & $\begin{array}{r}\$ 3,000 \\
3,000 \\
14,000\end{array}$ & $\begin{array}{r}\$ 6,000 \\
3,000 \\
14,000\end{array}$ & \multirow[t]{2}{*}{$\begin{array}{l}\text { Beneficiary } \\
\text { Beneficiary } \\
\text { Fiduciary }\end{array}$} \\
\hline & $\$ 32,000$ & $\$ 8,000$ & $\$ 40,000$ & $\$ 20,000$ & $\$ 20,000$ & $\$ 23,000$ & \\
\hline
\end{tabular}


In the case of the resident trust, if the item of $\$ 28,000$, or any part thereof, is distributed in a subsequent year, no tax is payable by the beneficiaries, since the tax has already been paid in a prior year by the fiduciary.

In the case of the nonresident trust, if the item of $\$ 28,000$, which represents partly non-taxable and partly taxable income of the trust, or any part thereof, is distributed to beneficiaries in a subsequent year, after the distribution of any undistributed distributive shares upon which the tax may previously have been paid by the beneficiaries, resident beneficiaries participating will be required to pay a tax on an amount of their distribution equal to the proportion thereof which the net income remaining in the trust at the time of distribution, upon which the tax has not been paid by the fiduciary (excluding exempt income), bears to the total net income remaining in the trust at the time of such distribution (including exempt income). If $\$ 2,000$ were distributed to each of the beneficiaries the resident beneficiary would pay a tax on $14 / 28$ of $\$ 2,000$, or $\$ 1,000$ assuming the trust had no exempt income. In the case of the nonresident beneficiary, however, the result would be different; for since all income of the trust from sources in New York has previously been tax-paid, he would not be required to pay any tax at all upon his distributive share.

\section{Sale of Property Acquired by Gift or Bequest.- (Art. 252.)} Under the law (section 353) and the provisions of this article, if property is given in trust prior to January 1, 1919, and the trustee sells such property subsequent to that date, in order to make distribution of the fund, the trustee will be required to pay a tax upon the income represented by the difference between the fair market value of such property as of January 1, 1919, and the price for which the property was sold; but if the trustee were to make a distribution of the property in specie, to the beneficiaries, and the beneficiaries should immediately convert 
the property into money, no taxable profits would be realizer, since the basis for determining the gain or loss in such case is the value of the property as of the date of receipt by the beneficiaries and not as of January 1, 1919.

\section{Depreciation and Depletion in. Case of Trust or Estate--(Art. 254.)} Under the Comptroller's ruling, a reasonable amount is deductible by the fiduciary for depreciation or depletion of wasting assets of an estate or trust, regardless of whether the will, deed, or statute requires that the corpus be maintained intact; and the fiduciary or beneficiaries, as the case may be, are required to pay a tax only upon the income of the estate or trust after the deduction by the fiduciary of proper amounts for depletion or depreciation, such amounts being regarded as capital, exempt from tax.

The Federal regulations upon this subject, since the passage of the Revenue Act of 1918, are identical with those of the Comptroller. Formerly, however, the Federal authorities rofused to allow such deductions in case of a trust or estate, unless provided for in the will or deed creating it, or by a statute.

When Tax Withheld, Information Returns Not Required.(Art. 281.) In the case of payments to a nomresident for services rendered within the State, by a person, firm, association or corporation which is one of a type listed in this article, the law provides that the tax shall be withheld at the source by the person making payment. In such cases no returns of information are required. Moreover, if the person making payment is not of a type listed in this article, or if the payments are for services rendered without the State, no tax is required to be withheld at the source, nor is any return of information required.

The payments with which this article is concerned are those of $\$ 1,000$ or more which are made during the calendar year to a resident. In this class of cases no tax is to be withheld at the 
source, and returns of information are or are not required, according to the status of the person making the payment. Such returns are required to be made when the person, firm, association or corporation making payment is one of a type listed in th:s article (as to interest on registered bonds, see article 287); in all other cases such returns of information are not required.

Calendar Year versus Taxable Year.- While this article requires returns of information to be made concerning all payments to a taxpayer of fixed or determinable taxable income of $\$ 1,000$ or more in a "calendar year," it is to be noted that the law. (section 366, subdivision 2) provides that such returns. shall be required concerning all such payments "in any taxable year." The substitution of calendar year for taxable year avoids confusion, however, since the person making payment could not be expected to know what period was included in the recipient's taxable year in case it did not coincide with the calendar year.

Credit for Taxes.- (Art. 482.) The taxes here referred to are not deductions from gross income (section 360 , subdivision 3 ), but are, as this article states, deductions from (or credits to) the total New York State Income Tax otherwise payable (section 363 ).

Penalties for Fraudulent Returns.-(Art. 481.) A nonresident must exercise care in disclosing his gross income from all sources, both within and without the State, since, in case of fraud, the tax may be assessed upon his gross income in lieu of his net income from sources within New York (section 367). More over, section 376, subdivision 1, provides: "Any person * * * who makes any false or fraudulent return or statement, with intent to evade any tax imposed by this article, shall be guilty of a misdemeanor and shall, upon conviction, be fined not to exceed one 
thousand dollars, or be imprisoned not to exceed one year, or both, at the discretion of the court." And the same section, subdivision 3, provides: "If any person liable to taxation under this article makes any false or fraudulent return or statement, with intent to evade any tax imposed by this article, and an additional amount is discovered to be taxable, such additional amount shall be subject to twice the ordinary rate of taxation $* * *$ This penalty shall be additional to all other penalties in this or any other section provided."

It seems, therefore, that a nonresident who makes a fraudulent report will be subject to the following penalties: (1) A tax at the ordinary rates upon his gross income from sources in New 'York, in lieu of a like tax upon his net income from such sources; (2) a specific penalty of not more than $\$ 1,000$; and (3) a tax at double the ordinary rates upon the portion of his net income from sources within New York which was fraudulently omitted from his report. The voluntary filing of a correct return within sixty days after March 15 th, in accordance with the provisions of section 376 , subdivision 2, does not cure a fraudulent return so as to avoid the specific penalty of not more than $\$ 1,000$ in such case provided. Such voluntary filing of a correct return is intended to relieve from that penalty only those who in good faith omitted or refused to file any return whatever at the time fixed by law.

Who Are Residents.- (Art. 501.) The law does not define the term "resident," although it is stated in section 350, subdivision 7, that the term as used in the act includes "any person who shall, at any time on or after January first and not later than March fifteenth" of the calendar year following the taxable year "be or become a resident of the State." It will be observed that the dates mentioned are respectively the first and last days on which a return of income for the preceding taxable year may be filed without penalty. 
Residence in Certain Cases Largely a Question of Intent.-The gist of articles 501-504 seems to be that the question of residence is largely determined by the intent with which the person concerning whom the question arises entered the State. If he had at that time the intention of making his permanent home in the State, or if he then had no definite intention of residing in some other jurisdiction (Liscomb v. Railroad \& Transp. Co., 6 Lans. $75)$, or if at that time he had such definite intention of residing in another jurisdiction, but finds it expedient to remain within the State for such length of time as will enable him to accumulate sufficient funds for his journey, he is a resident from the time he enters the State, and continues to be a resident until, by similar conduct and intent, he establishes a residence elsewhere.

Facts Establishing Intent.- The person's statement that he is not a resident must be supported by facts. His purpose in entering the State, as evidenced by his declarations or subsequent conduct (Peterson v. Chemical Bank, 32 N. Y. 21); the domicile of his family, if any (Burke v. Lawrence, 17 How. Pr. 544; Lee v. Stanley, 9 id. 272 ; Campbell v. Campbell, 90 Hun. 233), and his residence for election purposes James v. Surrogate, 36 Hun, 218 ; the location of his place of business or employment, if any; the length of time he has remained with the State (Elbers v. Insurance Co., 16 Johnson, 128); whether he owns real property with the State Houghton v. Ault, 16 How. Pr. 77 ; ; and various other matters would be proper for consideration in determining the question of intent. (See Cases in Chap. XXV Supra).

Definition Given in Regulations Misleading.-The definition given in the first sentence of article 501 is an unhappy one which does not harmonize with the illustrations given in the two next succeeding articles. It would have been better to omit altogether 
the phrase "and from which he has no present intention of removing." The expression is vague, indefinite and misleading. It is no doubt intended to exclude the "typical transient" referred to in article 502 (Crawford v. Wilson, 4 Barb. 504); it certainly does not refer to those who have been admittedly and continuously residents of the State for many years. (Chaine v. Wilson, $8 \mathrm{Abb}$. Pr. 78, and note; Bassett v. Wheeler, 84 N. Y. 466.) The status of such persons for purposes of the tax is determined as of the last day of their taxable year. Such persons, if residents on the last day of their taxable year, are residents for the purpose of making returns, even though they may at that time have a definite intention of removing from the State, and even though in pursuance of such intention they actually become nonresidents prior to the succeeding 15th day of March.

Recent Ruling of Comptroller Conflicts with Article 501.- Under a later ruling of the Comptroller published in the New Yor's Law Journal Jan. 16, 1920, if a person is a resident of New York at any time during his taxable year (fiscal or calendar, as the case may be), he is taxable as a resident upon his entire net income from all sources during such taxable year. According to this ruling, not only intent to remove, but actual removal and establishment of residence elsewhere, is insufficient to relieve sucis a person from tax, as a resident, upon the entire net income of his taxable year.

The truth must lie somewhere between these two extremes. Certainly, the ruling published in the New York paper, referred to above, cannot be supported upon principle, or ly any provision of the law.

Apportionment Theory.- Another theory which would naturally suggest itself is, that the income and exemption, for the taxable year, of a person establishing a residence outside of the State 
during such taxable year, should be apportioned for purposes of the tax, in the proportion which the part of the taxable year during which such person was a resident bears to the whole of such taxable year. But even this theory is unsound and impractical. The law taxes residents and nonresidents, and no reference is made therein to persons who are both residents and nonresident.s. The law declares that the net income of a person, whether a resident or a nonresident, is to be determined as of the close of his "taxable year" (fiscal or calendar, as the case may be). (Section 358.) Assuming, then, that such person has, at the close of his taxable year, a net income of $\$ 1,000$ if single, of $\$ 2,000$ if married, the question is: Is such person a resident or a nonresident? If the person is a resident, he is entitled to a personal exemption; if he is a nonresident, he is entitled to no personal exemption. If he is a resident, he may deduct all expenses and losses incurred in earning taxable income; if he is a nonresident, he may deduct only a proportionate part thereof. (Section 360, subdivision 11.) Moreover, if he is a nonresident, the tax must be withheld at the source. (Section 366.) Are withholding agents to refuse to deduct the tax on fixed or determinable income paid by them to a person in their employ, whom they know to be a nonresident at the close of his taxable year, merely because they also know that at some time during such year he was a resident of the State? And is it not incumbent upon them to verify, as of the close of such taxable year, the residential status of employees who previous to that time shall have filed with them certificates of residence? If the ruling of the Comptroller relieves withholding agents from this duty, it is likely to be a boomerang.

Determination of Residential Status. - The only rule for determining residential status which will not conflict with the law as enacted is, that if at the close of the taxpayer's taxable year he is 
a resident of the State, he must be taxed as a resident; and if at the close of his taxable year he is a nonresident, he must be taxed as such, unless subsequent to that time, and on or before the succeeding 15th day of March, he becomes a resident of the State, in which case he is to be taxed as a resident. (Section 350, subdivision 7.)

Residence of Married Woman.-A married woman may establish a residence apart from that of her husband, if separated or divorced, or if the husband deserts her unjustly or his conduct justifies her in leaving him. (Harry v. Dodge, 66 Misc. 302; Post v. Post, 149 App. Div. 452; Atherton v. Atherton, 82 Hun, 179 ; affd., 155 N. Y. 129.)

Residence of Incompetent.-Under section 8 of the Tax Law the residence of an incompetent for tax purposes is his place of residence prior to commitment. (City v. Brinckerhoff, 63 Misc. 445.)

Emancipated Minor-An emancipated minor may establish a residence apart from that of his or her father. (Matter of MiDowle, 8 Johns. 328 ; Matter of Waldron, 13 Johns. 418; People v. Pillow, 3 Super. Ct. 672; Wehle v. Weissenbach, 60 N. Y. 385.)

Separate Returns of Husband and Wife-(Art. 521.) Under this article a separate return by the wife, or a joint return of husband and wife, is not required, provided the husband includes his wife's income in his own return. If, however, the combined income of husband and wife exceeds $\$ 10,000$, separate returms should be made, in order that each may receive the full benefit of the low rate of tax on the first bracket of taxable income. As to apportionment of personal exemption between husband and wife, see page 446 , supra. 
Fiduciary May Make Returns by Agent.-(Art. 522.) This article permits a fiduciary, under certain circumstances, to make returns by an agent. This is not permitted under the Federa? regulations.

No Personal Exemption for Nonresidents.- (Art. 523.) While the law does not provide any personal exemption for nonresidents of $\$ 1,000$ or $\$ 2,000$, as in the case of residents, the tax does not apply to the income of a nonresident from sources within the State unless such income amounts to $\$ 1,000$ or more, if the nonresident is unmarried and is not the head of the family, or to $\$ 2,000$ or more, if the nonresident is the head of a family or a married person living with husband or wife (section 367), in which case the tax applies to the entire amount so received from sources within the State. However, an unmarried person, whether the head of a family or not, is required to make a return and disclose his status, if his income is $\$ 1,000$ or more for the taxable vear.

\section{Returns Where Excessive Tax Withheld-- Notwithstanding the} rate of tax imposed by law (section 351) upon the first $\$ 10,000$ of taxable income is 1 per cent., section 366 requires every employer ("withholding agent") to deduct and pay to the Comptroller on or before March 15th, 2 per cent from all salaries, wages etc., for personal services, amounting to $\$ 1,000$ or over, and paid to a nonresident during the preceding taxable year. The incongruity of these provisions of law was so apparent that the Comptroller, acting upon advice from the Attomey-General, has ruled (article 261) that only 1 per cent. need be withheld from the first $\$ 10,000$ of such income, including all payments of $\$ 1,000$ or over. The law, as so administered, still applies, however, to all payments of the kind specified, whether made to nonresidents who are married or are heads of families, or to those who are 
unmarried and who are not heads of families. 'It is apparent, therefore, that the tax must be withheld and paid to the Comptroller, in many cases, where no tax is due because the payee is married, or is the head of family, and that, in other cases, the tax due will be less than the amount so required to be withheld, because the payee has business expenses or losses to offset against the income received. In all such cases a return must be filed showing the true amount of net income from sources within the State, and requesting that refund be made of any excess tax so withheld and paid to the Comptroller. Section 377, subdivision 4 , provides that any such excess shall, as soon as practicable, be refunded by the Comptroller out of the proceeds of the tax retained by him as provided by law.

\section{Returns Where Tax Withheld Because No Certificate of Residence} Filed.-Where the employee or person receiving income fails or refuses to file a certificate of residence with the person making payment of such income, the tax will be withheld and paid to the Comptroller, and a return must be filed by the recipient, with the Comptroller, on or before March 15th, together with an affidavit claiming refund of any excess tax withheld because of failure or refusal to file such certificate.

Returns by Executors and Administrators upon Final Accounting; Comptroller's Ruling.- (Art. 542.) Attention is called to the following language of this article:

"Upon the completion of the administration of an estate and final accounting, an executor or administrator shall file a return of income of the estate for the portion of the taxable year in which the administration was closed. * * * In any such case the tax must be paid at the time the return is filed." 
The foregoing rulings are misleading and must be read in connection with section 369 of the law, which provides that "Fiduciaries required to make returns under this article shall be subject to all the provisions of this article which apply to taxpayers," and also section 371, which provides that "Returns shall be made to the Comptroller on or before the fifteenth day of March in each year of the taxpayer's net income for his last preceding taxable year."

Burden of Proof ; Presumption That Comptroller's Assessment Correct.-(Art. 573.) The "burden of proof" referred to in this article relates only to applications made to the Comptroller for abatement or refund of taxes alleged to have been erroneously or illegally assessed or collected. The same rule applies to certiorari proceedings in the supreme court to review the determination of the Comptroller, and has been so decided by the courts (see Chapts. $X V, X X I$ and XXII supra.) Under the Federal practice, section 3176 of the Revised Statutes, as amended, expressly provides that the determination of the Commissioner of Internal Revenue, in case of an additional assessment, "shall be prima facie, good and sufficient for all legal purposes," and hence under this section, in case of suit for recovery of taxes paid, the burden is clearly imposed upon the taxpayer to prove that the assessment was erroneous or illegal.

No Statute of Limitations Affects Right of State to Sue.-There is no statute of limitations affecting the right of the State to sue for the recovery of taxes claimed by it to be due.

Penalties; Comptroller's Ruling-_- (Art. 566.) As the law (sections 376 and 379 ) is interpreted in paragraph 4 of this 
article, any taxpayer who in good faith fails or refuses to make a return within the prescribed time, but who makes a correct return of income within sixty days thereafter, is relieved from the penalty prescribed in subdivision 3 of section 376 , and is subject only to the penalties provided in section 376 , subdivision 2 , and section 379 , subdivision 2 , the penalties of these two subdivisions, for this purpose, being consolidated. 


\section{CHAPTER XXXVI.}

\section{The State Comptrollers's Regulations (continued).}

\section{Withholding and Information at the Source.}

Income from Personal Service Only Deducted.- In Chapter XXVI, supra, the statutory provisions as to withholding and information at the source were discussed and analyzed. In commenting on the State Comptroller's regulations for deducting and withholding the tax at the source, it should again be borne in mind that while the statue (section 350, subdivision 10) defines a withholding agent, not all "withholding agents" as so defined a withhold. Thus a withholding agent (section 350) is defined as one having the "control, receipt, custody, disposal or payment of interest, rents, salaries, wages, premiums, annuities, compensations, ro munerations, emoluments or other fixed or determinable annual or periodical gains, profits and income taxable under this article;" but rent, interest, annuities and premiums of nonresidents are not deducted, and although such payments may be classed under the head of "fixed or determinable annual or periodical gains, profits and income" they are not income from personal services and it is only such income as is comprehended under the term "personal service" that is deductible and withheld. Article 2:61 of the Comptroller's regulations emphasizes that fact by pointing out that only the " income from all salaries, wages, commissions, gratuities, emoluments, perquisities and other fixed and determinable annual or periodical compensation earned for personal services in a business, trade, profession or occupation carried on within the State is to be deducted." 
THE STATE COMPTROLILE'S REgULATIONS - (CONT'D) 463

No More Than 2 Per Cent Withheld.-While the statute required 2 per cent to be deducted from all such personal service incomes, where it equalled or exceeded $\$ 1,000$ in the case of a nonresident, the Comptroller's regulations (article 261) only provide for the deduction of 1 per cent on $\$ 10,000$ and 2 per cent on sums in excess of $\$ 10,000$. In other words, a smaller amount is deducted under the regulations, under the advice of the Attorney-General (see Income Tax letter No. 1, May 29, 1919) than under the statute, which called for a withholding of 2 per cent. The reason for this discrepancy between the regulation and the statute was because the original bill introduced in the Legislature called for a flat rate of 2 per cent on all income, and hence for deduction of the same amount, but in the closing days of the session, the tax was fixed at a progressive rate of 1,2 and 3 per cent, and the deduction should have been at the same rates in the appropriate cases.

Through an oversight, the withholding provision of 2 per cent in the original bill was retained, and hence, the regulation for withholding has been made to conform to the rate of tax as imposed at 1 and 2 per cent, but not at 3 per cent. This undoubtedly was done to conform the regulation to the spirit of the law. The regulation calls for withholding something less than the rate of tax imposed, where the income was $\$ 50,000$ or more, but it would be taking away property without due process of law if it withheld something more in such cases.

No Tax Withheld, Unless Income is $\$ 1,000$ or More.- No tax is withheld or deducted in the case of a nonresident, unless the income is at least $\$ 1,000$ whether the recipient is married or unmarried. When the income equals this figure, the deduction is made on the total income received, because in the case of a nonresident no exemption is allowed. An erroneous impression 
is conveyed that by this means there is an exemption to the nonresident of $\$ 1,000$.

The opinion of the Attorney-General, which follows, explains this apparent inconsistency. The real basis for computing the tax is the return and no return is required in any case whether resident or nonresident, when the net income is less than $\$ 1,000$ (if single) or $\$ 2,000$ (if married).

(Attorney-General's Income Tax Letter No. 11.)

No Return or Tax Liability on Net Taxable Incomes of Less Than $\$ 1,000$ in Any Event (\$2,000, if Married).

Office of the Attorney-General.

AlbaNY, N. Y., November 10, 1919.

Hon. Eugene M. Travis, Comptroller,

Albany, N. Y.,

Attention of Mr. Graves.

DeAR SIR:

I have considered the questions contained in your letter dated September 18, 1919. You cite the controlling sections of the Tax Law, and inquire: (1) Assuming an officer of the United States Army, residing in this state, receives from the feleral government a salary of $\$ 4,000$ and has other income of $\$ 900$ not exempt nor excluded from gross income; is such officer liable to the income tax on the $\$ 900$ ? (2) Is the comptroller authorized to require residents or non-residents to render a return or to pay a tax on an amount of net income of less than $\$ 1,000$; or was it the intention of the legislature that no tax should be imposed in any case where the net income of a resident or non-resident is less than $\$ 1,000$.

The second question really includes the first, and the answer to the first is corollary to the answer to the second, so I shall consider them in reverse order.

(2) While it is true that section 351 in laying down the general basis for income taxation, provides for a tax, at specified rates, on the "entire net income as herein defined" of residents, and on the "entire net income as herein defined" derived from specified sources within the state, by non-residents, that section must be read in conjunction with the other sections of the article, and where other sections make specific exceptions to the general rule, they must control. It is obvious that, in spite of the general rules, taxes do not become payable by residents on the " entire 
net income as herein defined." Gross income, excluding certain items which because of their nature do not fall within what the legislature regarded as "income," and excluding certain other items which are in the nature of income but which are derived from exempt sources, is carefully defined in section 359. And in section 360 it is provided that " in computing net income there shall be allowed as deductions" certain specified items. Net income is defined in section 357 as gross income less the "deductions"" allowed by this article. But before the tax is computed, a further amount is "exempted" from the tax by section 362, in the case of residents. This amount exempted cannot be regarded as a "deduction" to be taken out in computing " net income," for it is subtracted from "net income" after the latter has been computed. This is demonstrated by the fact that section 362 , subdivision 2 , specifically provides that a husband and wife living together shall receive but one personal exemption of two thousand dollars "against their aggregate net income." (The adjective "aggregate" is not inserted for the purpose of distinction between "net income" as computed under section 360 and something else, but to show that the "net income" of the husband and the "net income" of the wife are to be considered together.)

If the provision of section 351 that the tax is payable on the "entire net income" can be modified by the subtraction of amounts exempted under section 362 , it can be modified in other ways by the other sections of the article.

The only basis for computation of taxes, contemplated by the article, is a return. And the only basis for collection of the tax is the computation so made upon the return. It follows that the collection of a tax is contemplated only where a return is required.

An individual is required to make a return (Sec. 367) only when his net income is $\$ 1,000$ (if single) or $\$ 2,000$ (if married) or over. A withholding agent (Sec. 366) is required to make returns only with respect to individuals receiving $\$ 1,000$ or over. And a fiduciary (Sec. 369) is required to make returns only with respect to individuals receiving $\$ 1,000$ (if single) or $\$ 2,000$ (if married) or over. No return is contemplated where the net income is less than the stated amount. And it follows that no collection is contemplated in such cases.

Payment is required at the time of filing the return (Sec. 366, subd. 2; 377 , subd. 1) - no time for payment is fixed where no return is filed. This further indicates the intent that no tax shall be collected where no return is required.

Even if we assumed that the legislature intended a tax to be collected where no return is filed, we have no method provided for its computation, nor any time fixed for its payment-and the intent would fail of execution. 
Section 383 authorizes the Comptroller to make rules and regulations to enforce the provisions of the article, but such regulations must be consistent with the specific provisions of the article. Where the article specifically provides that returns shall be made whenever a net income exceeds $\$ 1,000$ or $\$ 2,000$, the rule inclusio unius est exclusio alterius should be applied to its construction, and it should be construed to imply that where net incomes are less than the specified amounts, no return is required. A regulation by the Comptroller, requiring returns on net incomes of less than $\$ 1,000$ or $\$ 2,000$, would not be in furtherance of the provisions of the article, but in violation of them.

Hence the answer to the second question is that the Comptroller has no power to make a regulation requiring an individual whether resident or non-resident, or a fiduciary, to make returns with respect to incomes under $\$ 1,000$ (for a single man, etc.) or $\$ 2,000$ (for a married man, etc.), nor requiring a withholding agent to make a return with respect to an income of less than $\$ 1,000$. If it be argued that the purpose of the statute is thus in part defeated, the answer to that argument is that such defeat is necessitated by the unambiguous language of the statute itself.

(1) The answer to the first question follows logically. If an officer of the United States has a "net income" of less than $\$ 1,000$ (if single) or $\$ 2,000$ (if married), he need make no return, even though he be entitled to no "exemption" (of Sec. 362, subd. 3) on that part of his income. And if he makes no return, there is no time fixed at which he must pay a $\operatorname{tax}$ and no basis for the computation of a tax.

Yours very truly,

CHARLES D. NEWTON, Attorney-General.

By JAMES S. Y. Ivins,

\section{Deputy.}

Payment for Professional Services on an Annual Basis.-Payment for professional services on an annual retainer basis would seem to refer to a lawyer, doctor, architect or engineer who is paid a regular salary. It evidently does not refer to a professional man having an established office or place of business in New York and employing others to assist him in his work. This would seem to be true from the special ruling of the State Comptroller in the case of an insurance agent having a general office in the State which is given here in full. 
THE STATE COMPTROLLER'S REGULATIONS - (CONT'D) 467

Withholding in the case of commissions paid to general insurance agents and, by them, to their soliciting agents. "In reply to your letter of October 10 you are advised that the deducting and withholding regulations do not apply with respect to commissions paid to general agents who maintain offices and employ soliciting agents, paying the expenses of the office and the commissions of the soliciting agents out of their receipts of commissions."

The general agent, however, must deduct and withhold with respect to commissions paid by him to soliciting agents, working within the State of New York, who do not file a certificate of residence on Form 101.

\section{Art. 265. Income Not Subject to Withholding.}

(a) Income of residents, provided certificate 101 is filed.

(b) If the service was other than personal and not for a fixed or determinable period, viz.: work done in the State by a nonresident printer, architect, engineer, not employed at a yearly, monthly, weekly or daily basis and having an office or place of business of his own.

(c) "Where the personal services are rendered entirely without the state by a nonresident, whether payment be made from within or without the state, irrespective of the status of the withholding agent. The occasional entry into the state of a nonresident employee who performs the duties for which he is employed entirely without the state, but enters the state for the purpose of reporting, receiving instructions, accounting, etc., incidental to his duties without the state, shall not be deemed to take such employee out of the class of those rendering their services entirely without the state."

These two sentences in subdivision c, article 265 , must be taken together for a full understanding of the intent of the statute. Thus the tax on the income of a nonresident collector for a New 
York furniture house making collections in Connecticut and receiving instructions from the home office in New York, is not deductible, nor should there be a deduction of a tax in the case of a nouresident reporter for a New York daily newspaper, the reporting work being done in New Jersey. The same rule may be applied to a nonresident architect designing his plans at home, even though the sketches were completed at a New York office. Attention has already been called in chapter XXIV, pages 194 198 , to the constitutional questions involved in this form of taxation, and the State Comptroller in his regulation has sought as far as possible, to minimize the danger of taxing income beyond the State's jurisdiction. (See article 266.) The important point to be considered is whether the work in New York, of the character above referred to, is merely incidental to the services rendered outside the State. If so, the income has been earned without the State.

Subdivision d, article 265, covers a case like that of a salaried buyer or sales agent located in New York and employed by a nonresident firm, or foreign corporation not registered in New York, the income of the employee being paid from outside the State. The State Comptroller holds such persons liable for the tax but he is unable to withhold the tax for there is no withholding agent in the State's jurisdiction. Unless the employee has property within the State, it is doubtful whether the tax can be collected in such cases.

Art. 266. Deduction in the Case of Apportionable Income.-The basis of taxing apportionable income is treated more at length in the next chapter dealing with the nonresident section. The same principles of apportionment applicable to a nonresident doing business on his own account, apply to a nonresident employee. Since the rule of apportionment in such cases is entirely an artificial one fixed by the State for convenience of 
THE STATE COMPTROLLER'S REGULATIONS - (CONT'D) 469

administration, it will probably be attacked in the courts in cases where the State's method of apportionment, when applied to the particular facts of the case at issue, make the taxable proportion unreasonable. For instance, under subdivision a, article 266 revised, a salesman receiving a salary for services rendered in and out of the State, may receive a sum of $\$ 50,000$ a year for selling $\$ 1,000,000$ of goods in and out of the State. The rule of apportionment under subdivision a, article 266 in this case is according to "the volume of business transacted within and without the state by such employee." In the present case the volume of business means the amount of sales, yet the income earned by the employer may be greater on half the sales made in the State than on the remaining half sold without the state so that the volume of sales may not be a fair proportion of income earned. It may also be questioned whether the rule of apportionment by time referred to is a reasonable one in fixing the value of services in the case of certain employees, such as clerks, bookkeepers, laborers, etc., as referred to in article $266, \mathrm{~b}$. Subdivision c offers an alternative for the difficulties that may be encountered in subdivisions $a$ and $b$ and leaves room for a rulc which may afford a more reasonable basis of apportionment in doubtful cases.

Retention of Residence Certificate for Inspection. Article 267 provides that withholding agents shall "retain, preserve and keep available for examination and inspection by the Comptroller, or his authorized representative, all residence certificates for a period of one year next following the close of the calendar year for which such certificates shall have been given." This evidently implies an examination by the Comptroller, through his inspectors, of the payrolls, books and records of the taxpayer and by "taxpayer" may be included the withholding agent, such agent to be deemed the representative of the taxpayer. (See section 373, Tax Law, under the head of "Powers of Comptroller)." The form of residence certificate, as required by law, is here given in full: 

${ }_{101}^{\text {Form }}$ THIS CERTIFICATE HAS NO EFFECT ON CITIZENSHIP OR VOTING RESIDENCE

\section{CERTIFICATE OF TAXPAYER CLAIMING RESIDENCE IN THE}

STATE OF NEW YORK
(To be filed with withholding agent by resident of New York State, pur- suant to section 366 of the Tax Law, for the purpose of claiming the benefit of such residence for income tax purposes.)

To

(Withholding agent)

(Address)

I hereby declare that I am a resident of the State of New York; that $\mathrm{I}$ reside at.

N. Y., that I have no definite intention as to when (if at all) I will establish my home without the State; and that if I decide to establish my home without the State, or at another place within the State, I will promptly give you notice of that fact and of my new residence address.
\end{abstract}

(Signed)

Revocation and Renewal of Residence Certificates; Repayment of Tax; Return of Tax Withheld.- (Arts. 268, 269 and 270.) The residence certificates under article 267 are effective "for the period of one year next following the close of the calendar year for which such certificate shall have been given." This evidently means that the certificate is given for one year from December 31, 1919 , or for such other calendar year for which the withholding applies. The status of residents should be fixed at the end of the calendar year, viz.: December 31st, for purposes of withholding and otherwise, at the end of the taxable period. This is true of taxable liability for local purposes in New York city in the assessment of real and personal property. Matter of $\mathrm{Bab}$ cock, $115 \mathrm{~N}$. Y. 450, and under the Federal Income Tax Law it is true in fixing the status of a resident for the purpose of determining the right to the personal exemption. (See letter of Roper, Commissioner of Internal Revenue, dated June 12, 
The STATE COMPtroller's REgulations - (CONT'D) 471

1919.) Under the New York Law, a residence once established is presumed to continue until a taxpayer changes his residence or removes from the State. (Section 8, Tax Law.) Residence, once proved, the burden of proof shifts to the person desiring to establish nonresidence. Under article 268, the employer should be notified of change of residence, and an employer having reasonable grounds for believing that the residence has been changed may revoke the certificate after notice to the employee, and withhold the income. This "change of residence" evidently refers to change of residence without the State, as this is the only status that could affect withholding of the tax. A residence certificate once having been obtained, there does not seem to be any legal liability of the employer to withold the tax, unless the change of residence can be shown to have been brought to his notice. Indeed, in the case of employees of municipal corporations and of the State of New York, since residence is generally a prerequisite to public employment, the Comptroller has ruled that it will bo assumed that such employees are residents of the State unless the head of the department in which he is employed has reasonable grounds for believing him to be a nonresident. No certificate of residence need therefore be secured in such cases unless there is ground for a belief in the taxpayer's nonresidence.

If a nonresident becomes a resident at any time before March 15th of the year following the tax year and shall file a residence certificate, the entire amount of income withheld shall be paid to him.

Verified reports of withholding on or before March 15th next following the calendar year for which the deduction of tax is to be made.

A verified report of all sums withheld will be made on Form 103, accompanied by separate reports; one for each individual on Form 102. Forms 102, 102-a and 103 follow: 
NEW YORK STATE INCOME TAX

\section{REPORT OF TAX WITHHELD AT SOURCE}

Personal Service Income of $\$ 1000$ or More Paid to a Nonresident During the Calendar Year 19.

See Instructions on Form 102=A

Do Not Fold or Mar This Card

Name in full To Whom Paid

Address

Name in full By Whom Paid

Address

Is Payee

Married?

If Not, Is $\mathrm{He}$ the

Head of a Family?
1. Class of Compensation

(Salaries, wages, commissions, etc.)

2. Total Paid to This

Employee During

the Calendar Year.

3. Paid for Services

Within the State*.. \$

4. Amount Withheld....

$\{1 \%$ from First $\$ 10,000$

$2 \%$ from All Over $\$ 10,000$

* See Article 266, Income Tax Regulations for Rule of Apportioning Compensation for Services Performed Partly Within and Partly Without the State.

Form 102-A

\section{NEW YORK STATE INCOME TAX RETURN OF TAX WITHHELD AT SOURCE}

\section{INSTRUCTIONS FOR USE OF REPORT OF TAX WITHHELD - FORM 102}

1. For the purposes of the withholding at the source provisions of the law the status of nonresident attaches to every person receiving personal service compensation, who has not filed with the withholding agent a certificate of residence on Form 101.

2 . The tax must be $\mathrm{rithheld}$ at source only on payments of salaries, wages, commissions and other fixed and determinable annual or periodical compensation for personal services rendered by a nonresident of $\$ 1000$ or more during the calendar year.

3. A separate report on Form 102 must be made for each person who did not file a certificate of residence, Form 101, and received compensation for services rendered within the State of $\$ 1000$ or more during the calendar year.

4. No report or withholding is required if the amount paid for services within the State is less than $\$ 1000$.

5. Do not report on this form any income other than compensation for personal services.

6 . Where services are rendered by a nonresident partly within and partly without the State. withholding is based upon the amount paid for services rendered within the State as determined by article 266 of the income tax regulations.

7. All reports on Form 102, accompanied by return on Form 103, must be filed with the New York State Income Tax Bureau on or before March 15 following the calendar year for which the report is made. The tax must be paid at the time of filing the return. 


\section{Form 103.- NEW YORK STATE INCOME TAX \\ RETURN OF TAX WITHHELD AT SOURCE}

FOR THE CALENDAR YEAR 19...

on payments of Carefully

This return accompanied by individual reports on Form 102 must be filed with the New York State Income Tax Bureau at any district office thereof, on or before March 15 following the calendar year for which this return is made. The tax must be paid at the time of filing the return.
Read Instructions

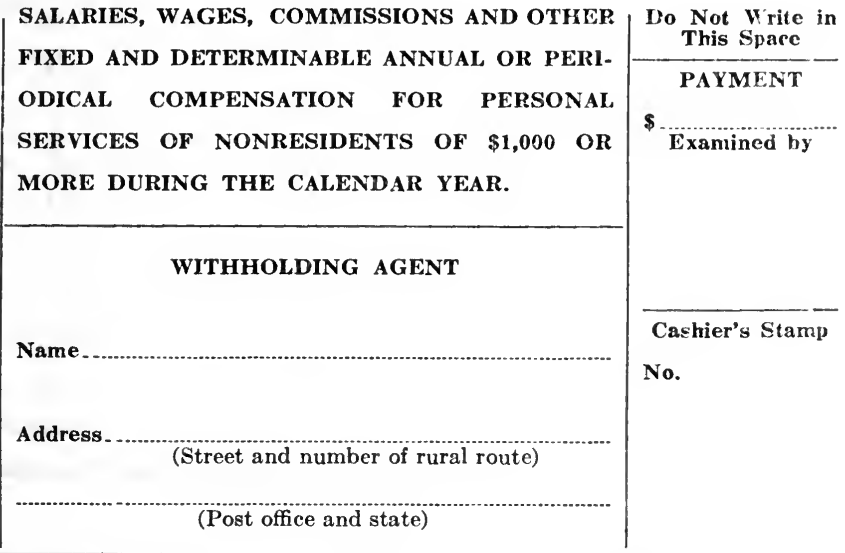

\section{SEE INSTRUCTIONS ON REVERSE SIDE OF THIS SHEET}

State

County of. , ss:

I swear (or affirm) that the following is a true and complete return of all payments of salaries. wages, commissions, and other fixed or determinable annual or periodical compensation for nersonal services of $\$ 1,000$ or more paid during the calendar year $19 \ldots \ldots$. by the above withholding agent for which a certificate of residence on Form 101 has not been filed. Each iten on this return is evidenced on Form 102 which is transmitted herewith, showing the name and address of the person to whom payment was made, and stating the amount of such payment and the amount of the tax withheld.

I further declare that the aggregate amount of taxes withheld is $\$$

Sworn to and subscribed before me this. day of 19

(Signature)

(Signature)

Seal not required

(Title)

(Capacity in which acting) 


\section{THE STATE COMPTROLLER'S REGULATIONS - (CONT'D)}

1. Name of person to whom compensation
was paid $\left|\begin{array}{c}\text { 2. Amount on which } \\ \text { tax was withheld }\end{array}\right|$ 3. Amount withheld

If all names cannot be placed on this sheet, use extra sheets of same size, numbering each sheet.

Form 103

INSTRUCTIONS

1. For the purposes of the withholding at the source provisions of the law, nonresident status attaches to every person receiving personal service compensation who has not filed with the withholding agent a certificate of residence. (Form 101.)

2. Every individual, partnership, corporation or other organization, in whatever capacity acting, is required to deduct and withhold a tax of one per cent from the first $\$ 10,000$ and two per cent from all over $\$ 10.000$ of payments for salaries, wages, commissions, gratuities, emoluments, perquisites, and other fixed or determinable compensation for personal services, if the amount paid or credited to any individual is $\$ 1,000$ or more during the calendar year, unless the person to whom the compensation is paid files a certificate of residence on Form 101 .

3 . This return must be accompanied by a report on Form 102 for each individual to whom was paid compensation on which tax was withheld. (See Form 102 and instruction card Form 102-A.)

4. No report or withholding is required with respect to payments to any individual of less than $\$ 1,000$ for services rendered within the State.

5 . The payments included in this return should not be included in the return of information on Form 105.

6. This return must be filed with the New York State Income Tax Bureau on or before March 15 following the calendar year during which the payments were made or credited. At the time this return is filed the aggregate amount shown thereby to have been deducted and withheld shall be paid.

\section{Information at the Source.}

Returns of information, as distinguished from returns of tax withheld, are to be made in the case of resident taxpayers to whom under subdivision 10 , section 350 of the Tax Law " interest, rents, salaries, wages, premiums, annuities, compensa- 
THE STATE COMPtroller'S REgULATIONS - (CONT'D) 475

tions, remunerations, emoluments or other fixed or determinable gains, profits and income" are paid. . This includes not only payments to the salaried or wage-earning classes, who are residents, but to the landlords, lessees, mortgagees, annuitants, cestuis que trustent, wards, heirs, or legatees.

Interest Coupons Exempted.-Interest coupons payable to bearer are specifically exempted from returns of information under subdivision 2, section 266 .

We may divide the payors, or those who must file information returns, into the following classes (article 281):

\section{Who Must File Information Returns.}

1. Municipal corporations and state departments, including the disbursing officers of such corporations and departments.

2. Domestic corporations and registered foreign corporations.

3. Unregistered foreign corporations.

4. Individuals, partnerships, associations.

In every case, the taxable income paid must be $\$ 1,000$ or more. There must be a return of information where no withholding is required, under the first paragraph of section 366 of the Tax Law, and there should be no return of information where there is actual withholding (articles 282, 283). The returns of withholding are made on Forms 102 and 103 hereinbefore referred to and set forth. Such returns for 1919 will include all payments made or earned during the year, even if earned before the passage of the act (article 284), the law being retroactive. Payments of income need not be in cash. They may be credited as, for example, interest or salary earned and credited, but not paid. Each payment need not amount to $\$ 1,000$ or more, nor need the payments be of a single kind; thus, $\$ 300$ in commission, $\$ 400$ in interest and $\$ 300$ for personal services paid to one individual will be sufficient to require a return of information (article 285). 
A special bulletin to the heads of State departments relating to withholding and information at the source is given below.

Information and Withholding in the Case of State and Municipal Employees.-Special Bulletin No. 2 and Regulation No. 2, relating to withholding and information required by State departments, is given below in full.

Special Bulletin No. 3 and Regulation No. 1 for the use of fiscal officers of municipalities is practically a duplicate of the regulation for the State departments and is, therefore, not presented at length.

BULLETIN No. 2

\section{STATE OF NEW YORK \\ Office of State Comptroller \\ INCOME TAX BUREAU}

AlbaNy

To the Heads of Alr. State Departments:

Your attention is called to the provisions of the State income tax (chapter 627 , laws of 1919) relating to (a) withholding agents, (b) information at source, and (c) withholding at the source with respect to salaries and wages paid to State officers and employees. (Tax law, section 350, subdivision 10, and section 366.)

Put simply, the law requires all officers and employees of the State having the receipt, custody, control, disposal or payment of compensation to officers or employees, to report to the State Comptroller all payments of personal service compensation of $\$ 1,000$ or more during a calendar year to any one individual resident of the State of New York, and to deduct a tax from the personal service compensation of every nonresident individual who receives $\$ 1,000$ or more during the year, and to pay the tax so deducted to the State Comptroller.

The law gives the State Comptroller the power to prescribe regulations to enforce these provisions. It is my desire to assist State officers in the exercise of their duties under the personal income tax law and to impose no requirement not absolutely necessary for the successful administration of the law. In order to carry out the provisions with respect to State officers and employees, the following special regulation is promulgated: 


\section{SPECIAL REGULATION NUMBER 2}

\section{Information and withholding at the source respecting state officers and employces}

1. In view of the fact that residence within the State of New York is generally a prerequisite to employment by the State or any of its departments or institutions, the employment of non-residents being exceptional in each case, it will be assumed that every State officer and employee is a resident of the State of New York unless the head of the department in which he is employed has reasonable grounds for believing him to be a non-resident. In such a case the head of the department or institution shall request such officer or employee to execute a certificate of residence (Form 101) if a resident of the State, and if he neglects or fails to do so, consider him, for the purposes of the income tax law, a non-resident, and deduct and withhold a tax as provided in paragraph 3 hereof. No certificate of residence need be secured in other cases and no tax deducted and withheld.

2. There shall be attached to, or indorsed on, every payroll presented to the State Comptroller for audit, or to the treasurer or fiscal officer of all State departments or institutions making payments of salaries and compensations to officers and employees, a certificate to be signed by the head of the department, reading as follows:

I hereby certify that to the best of my knowledge, information and belief, every person named on this payroll, receiving compensation of $\$ 1,000$ or more per annum, is a resident of the State of New York, except the following:

(Here list the names of those employees established to be non-residents in the manner provided in paragraph one above.)

Signature

Title

3. After the payrolls have been audited by the State Comptroller, the State Treasurer will be instructed to withhold the tax on all payments for compensation to those persons listed on the payrolls as being nonresidents. No report will be required from the head of any State department with respect to the amount so deducted and withheld by the State Treasurer. The amount so deducted and withheld will be charged to the apporpriation out of which the salaries are paid in the same manner as if the amounts were paid to the employee, and will be withdrawn by the Comptroller monthly or at other stated intervals.

4. The head of each State department shall keep and maintain a record showing the amount of compensation paid during each calendar year to every 
person receiving compensation of $\$ 1,000$ or more during the calendar year. As soon as possible after January 1 of each year, but no later than March 15 of each year, the head of each State department shall file with the State Comptroller (Income Tax Bureau), Albany, N. Y., a return of information with respect to every person from whose income no tax was deducted, who has received $\$ 1,000$ or more of compensation during the preceding calendar year. The returns shall be made on Form 105 and shall be accompanied by a verified letter of transmittal on Form 106. There shall be reported on such forms the information therein called for.

5. The treasurers of all State departments and institutions making direct payments of salaries and other compensation to officers and employees, are required to deduct and withhold a tax of 1 per cent on the first $\$ 10,000$ and 2 per cent on sums in excess of $\$ 10,000$, from all payments of compensation to persons determined to be nonresidents as outlined in paragraph one hereof. In all cases where withholding is required, the treasurer or the fiscal officer of the department or institution shall, as soon as possible after January 1 of each year, but no later than March 15 of each year, make a verified return to the State Comptroller (Income Tax Bureau), Albany, N. Y., on Form 103, accompanied by separate reports, one for each individual, on Form 102, showing the compensation paid and the amount of tax withheld for the preceding calendar year. The aggregate amount shown to have been withheld on Form 103 shall accompany the return and shall be charged to the appropriation out of which the compensation was paid. Furthermore, he shall make a return of information as prescribed in paragraph four in respect of payments where there has been no actual withholding as required by paragraph three of this ruling.

6. The provisions of the Comptroller's regulations relating to information at the source with respect to reporting payments of income other than salaries on Forms 105 and 106 apply to the heads of State departments in the same manner as to all other withholding agents. Reports will be required for all payments to individuals of rent or other fixed and determinable taxable income of $\$ 1,000$ or more during the calendar year. See articles 281 to 290 inclusive of Comptroller's regulations.

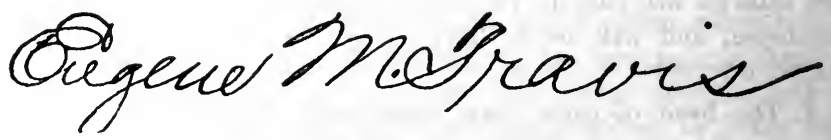

November 18, 1919. 
THE STATE COMPTROLLER'S REgULATIONS - (CONT'D) 479

Returns by Contractors and Subcontractors. - (Art. 286.) Where work is let by contract, which in turn is subcontracted and the subcontractor keeps a complete record of the payment of wages, salaries, etc., the duty devolves upon him to make the return. So also with branch offices, when complete returns are kept by them instead of by the main office. Where the employee is moved from one job to another by different contractors or subcontractors, so that it is difficult to obtain a complete record of his annual income, the average monthly payment for two representativa months on the basis of $\$ 1,000$ per year or more, may be taken for the purpose of making a return of information (article 286). Article 287 only requires information returns from domestic or foreign registered corporations, of interest payments on registered bonds, when the interest aggregates $\$ 1,000$ or over and when the address of the registered payee is known. Nonresident payees are exempt from a tax on income of this class under section 359 of the Tax Law. By a "registered foreign corporation," under article 287, is meant a foreign corporation that has filed a certificate with the Secretary of State permitting it to do business in the State, under section 15 of the General Corporation Law. Presumptively, unregistered foreign corporations are not doing business in the State and their omission from those required to file information returns may be due, therefore, to the inability of the State to claim jurisdiction over this class of corporations. Fiscal officers of the State of New York and of municipal corporations are not required to make information returns under article 287 because payments of interest on State bonds and municipal securities of the cities of the State are exempt from tax. For the reason that securities issued by other divisions of the State are exempt from income tax, information returns need not be made by fiscal officers of counties and villages of the State of New York. Other States and foreign governments 
are not required to make information returns of such interest under article 287, for the same reasons as apply to unregistered foreign corporations.

Return of Information as to Payment of Dividends.-Article 288 a special regulation calling for information returns, in the case of dividends distributed to resident stockholders, applies to domestic or registered foreign corporations. This regulation seems to follow article 1074 of Regulations 45 of the Treasury Department of the United States. It was evidently not intended to place upon corporations generally the burden of making information returns for dividends paid to stockholders, but to call upon them in case it was specially required. Sufficient information would be gathered from the individual taxpayer's own return and his reconciliation of Federal income with State income, shown by his State return.

Art. 289. Payments of Which No Return of Information is Required.- Article 289 provides that the following payments need not be reported on returns of information:

a. Dividends. (See article 288.)

b. Interest coupons payable to bearer. (See article 287.)

c. Income exempt from taxation under section 359 , subdivision 2, of the Tax Law.

d. Bills for merchandise, telegrams, telephone, freight, storage and similar charges.

e. Payments to employees for board and lodging while traveling in the course of their employment.

f. Annuities representing the return of capital.

g. Payments of rent made to real estate agents (but the agent must report payments to landlord if they equal or exceed $\$ 1,000$ annually).

h. To nonresident employees for services rendered entirely without the State. 
i. To nonresidents, of annuities, including pensions, interest on bank deposits, interest on bonds or other interest-bearing obligations or dividends.

j. Fees for professional services, except retainers on an annual or periodical basis.

k. To corporations, to partnerships and fiduciaries, and distributions by partnerships to partners and by fiduciaries to beneficiaries.

Forms of Information Returns.- The following Forms 105, 105 -a and 106 are required in cases of information at the source.

NEW YORK STATE

INCOME TAX
RETURN OF INFORMATION FORM

105

AT SOURCE

Report of Income of $\$ 1000$ or More Paid During the Calendar Year 19

See Instructions on Form 105=A

Do Not Fold or Mar This Card

Name in full TO WHOM PAID

\section{Address}

Name in full BY WHOM PAID

Address

Is Payee Married?
If Not, Is He the

Head of a Family?

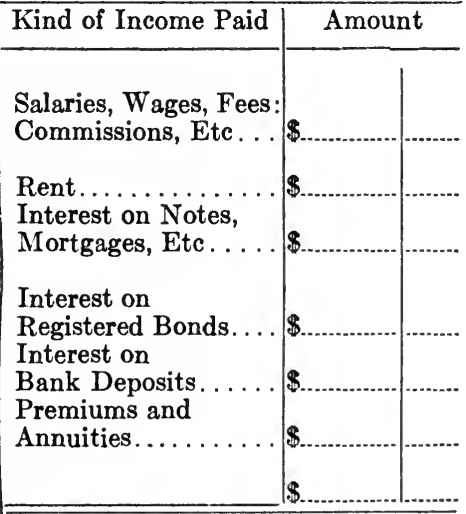

On the blank line above, enter the kind and amount of any other income except as noted on instructions. 


\section{NEW YORK STATE INCOME TAX RETURN OF INFORMATION AT SOURCE}

\section{INSTRUCTIONS FOR USE ON RETURN OF INFORMATION - FORM 105}

1. A separate return on Form 105 must be made for each.individual taxpayer to whom any taxable income aggregating $\$ 1,000$ or more was paid during the calendar year.

2. These returns must be forwarded with summary and letter of transmittal on Form 106 to the State Gomptroller (Income Tax Bureau), Albany, N. Y., on or before March 15 next following the calendar year for which the return is made.

3. Returns of information are not required of the following classes of payments:

(a) Dividends. .

(c) Income exempt from taxation under \$35, subdivision 2 of the Tax Law.

(d) Bills paid for merchandise telegrams, telephone, freight, storage and similar charges.

(e) To employees for board and lodging while traveling in the course of their employment.

(f) Annuities, representing the return of capital.

(g) Of rent. made to real estate agents (but the agent must report payments to the landlord if they equal or exceed $\$ 1,000$ annually.)

Form 106. 11-11-19-45,000 (5-3523) (h) To nonresident employees, for services rendered entirely without the State.

(i) To nonresidents, of annuities including pensions, interest on bank deposits, interest on bonds, or other interest-bearing obligations.

(j) Fees for professional services except retainers on an annual or periodical basis.

(k) To corporations, to partnerships and fiduciaries; and distributions by partnerships to partners and by fiduciaries to beneficiaries.

\section{NEW YORK STATE INCOME TAX \\ ANNUAL SUMMARY AND LETTER OF TRANSMITTAL \\ RETURN OF INFORMATION AT THE SOURCE}

FOR THE CALENDAR YEAR 19

of Payments of

Raəd instructions carefully

Interest, rent, salaries, wages, premiums, annuities, compensations, remunerations, emoluments, or other fixed or determinable gains, profits and income of $\$ 1,000$ or more during the calendar year.

This summary and letter of transmittal accompanied by the returns on Form 105, must be filed with the State Comptroller, (Income Tax Bureau), Albany, N. Y., on or before March'15 following the calendar year for which this return is made.

\section{Name. .}

(Person, Firm, Corporation, Organization, etc., making payments)

Address

(Street and number or rural route)

(Post office and state)
Do not write in this space

Receiving stamp

No.

Examined by reported. 


\section{INSTRUCTIONS}

1. Every individual, corporation or other organization, in whatever capacity acting, making payment to an individual of taxable income, except as shown below, of $\$ 1,000$ or more during the calendar year, must make a return of information thereon on Form 105 to the State Comptroller on or before March 15 following the calendar year during which payments were made or credited.

2. This form must be accompanied by returns on Form 105 showing in each case the name and business address of the person or organization by whom the payments were made, and the name and home address of the person to whom the payments were made, the kind of income and the amount.

3. Returns of information are not required of the following classes of payments:

(a) Dividends.

(b) Interest coupons payable to bearer.

(c) Income exempt from taxation under section 359, subdivision 2 of the Tax Law.

(d) Bills paid for merchandise, telegrams, telephone, freight, storage and similar charges.

(e) To employees for board and lodging while traveling in the course of their employment.

(f) Annuities representing the return of capital

(g) Of rent, made to real estate agents (but the agent must report payments to the landlord if they equal or exceed $\$ 1,000$ annually).

(h) To nonresident employees, for services rendered entirely without the State.

(i) To nonresidents, of annuities, including pensions, interest on bank deposits, interest on bonds, or other interest-bearing obligations or dividends.

(j) Fees for professional services, except retainers on an annual or periodical basis.

(k) To corporations, to partnerships and fiduciaries, and distributions by partnerships to partners and by fiduciaries to beneficiaries.

State of. County of. ss.:

I swear (or affirm) that the foregoing and the accompanying returns constitute a true and complete statement of all payments of income as described on this form, made by the person or organization named at the head of this form during the calendar year 19 .

Sworn to and subscribed before me this

day of

19.

(Signature)

(Signature)

(Title)
(Capacity in which acting)

(State address of person signing if different from that given at head of return) 


\section{CHAPTER XXXVII}

\section{The Comptrollers Regulations (continued)}

Nonresident Section.-The general principles governing the taxation of nonresidents for State income tax purposes, "residence" and nonresident estates and trusts have been set forth in Chapters XXIV, XXV and XXVIII. Articles 401 and subse quent provisions of the nonresident section contain the State Comptroller's rules- defining gross income, deductions allowed, and the method of apportionment of nonresidents' income derived from sources within and without the State. The application of some of these regulations will depend to some extent upon the cases now pending in the United States Supreme Court hereinbefore referred to, in which the right of the State to tax a nonresident's income has been made an issue.

The taxation of nonresidents under the New York Personal Income Tax Law may be divided into three parts:

1. Taxation of a nonresident not engaged in business or occupation, on his own account, upon income derived from personal services in the State, such as salary, wages, or earnings, paid on a weekly, monthly or periodical basis.

2. Taxation of a nonresident whose income is derived from personal or business service, the earnings of which may be ascribed to the activities of the taxpayer, and in which the employment of capital is only incidental; or in which merchandizing or trading is done for the account of others. This will include auction, agency, brokerage or commission business strictly on the basis of commission for personal services. 
THE STATE COMPTROLLER'S REGULATIONS - (CONT'D) 485

It will also include professional occupations carried on for one's own account, such as that of a lawyer, architect, engineer, physician, editor, etc. Under the head of business service may be included income from transportation, laundry, hotel, restaurant and businesses of this character, which, while not merchandizing or manufacturing, involve the employment of more or less capital.

3. The third classification under which nonresidents are taxed may be termed the mercantile and manufacturing class, involving the manufacture or purchase and sale, of property. It also includes those who derive income from real estate as well as those who deal in securities as a business, from which they either derive a profit or a commission in the purchase and sale thereof.

Pensions of Nonresidents Not Taxable.- The State Comptroller has ruled that income in the form of a pension received in the case of a nonresident employee is not taxable (see article 413). The evident basis for this is that the pensioner is not engaged in any profession or occupation in the State, nor does he derive any income from capital employed here, and that the pension is in the nature of an annuity which is expressly exempted by subdivision 3, section 359. If the recipient is a resident, such pension will be regarded as taxable income, except in the case of a teacher's pension in New York City, which is exempt from tax under section 1092-w of the New York charter (see article 41 of regulations for status of resident pensions).

Nonresident Defined.- Under the section entitled "Withholding," a certificate is required from residents in all cases where without it there would be a withholding of tax on income derived from salaries. In such instances the status of nonresidents is determined by the absence of these certificates. It has also been 
said that the status of residents, or nonresidents, becomes established or fixed at the end of the taxable period when the income is earned, or at the end of the calendar year. This corresponds to the determination of status for purposes of local taxation (Matter of Babcock, 115 N. Y. 450) which is also fixed at the end of the assessment period. Likewise do the Federal requirements fix the end of the taxable period, or the end of the calendar year, as the time at which the taxable status of residents or nonresidents shall be determined.

Income in Case of Nonresidents. - Article 414 provides that gross income, in case of a nonresident, shall be determined in the same manner as in the case of a resident. The gross income as well as the net income of a resident is governed by the provisions of the Income Tax Law (sec. 353 to 363). In the case of a nonresident entirely engaged in business in the State deriving all his income from property or business located in the State, the computation of net income would be reached in substantially the same manner as in the case of a resident, with the exception of the personal exemption, and, with the exception of income received in the form of annuities, interest on bank deposits, interest on bonds, notes, or other interest-bearing obligations or dividends referred to in subdivision 3, section 359. It is in the case of a nonresident who is doing business within and without the State that the question arises, first as to what shall be deemed income within the State, and, second, what shall be allowed to a nouresident in the form of deductions.

\section{Definition of "Business Carried on Within the State." -} Article 415 of the regulations defines what is meant by the words "Business, trade, profession or occupation carried on within the State," as used in section 351 of the Tax Law. This definition has reference to a nonresident engaged in business on his own 
The STATE COMPTROLLER'S REgUlations - (CONT'D) 487

account rather than to a salaried employee working for others, and is given below in full:

"A business, trade, profession or occupation (as distinguished from personal service as employee) is carried on within the State by a nonresident, when he occupies, has, maintains or operates desk room, an office, a shop, a store, a warehouse, a factory, an agency or other place where his affairs are systematically and regularly carried on notwithstanding the occasional consummation of isolated transactions without the State. Business is being carried on if it is here with a fair measure of permanency and continuity. Its regularity or continuity need not be for a long period; the life of the business is not a material factor."

The construction to be placed on this regulation is predicated on the meaning of section 351 of the Tax Law, which, in so far as it seeks to tax nonresidents, imposes such tax on the income "from every business, trade, profession or occupation carried on in this State by natural persons not residents of the State." It therefore becomes essential to note what is meant by these words as applied to "natural persons not residents of the State."

The courts of this State and the Federal courts have repeatedly defined what was meant by "doing business," "transacting business." Comparatively few of these cases had reference to "natural persons not residents of the State." Most of these cases arose out of :

1. Liability of foreign corporations to taxation.

2. Maintenance of actions by foreign corporations.

3. Jurisdiction over foreign corporations in the service of process.

Each of these classes of cases required a different state of facts upon which to determine jurisdiction.

For the purpose of holding a nonresident taxable on personal property, he should not only be engaged in business in the State, but capital must be employed, and it has been held even where a foreign corporation has been authorized to do business in the 
State and has an office here for the purpose of holding directors' meetings and paying dividends, that this did not constitute "doing business" in the State under section 7 of the Tax Law. (People ex rel. Dives Pelican Co. v. Feitner, 77 App. Div. 190.)

For State tax purposes, it has also been held that a foreign corporation must employ capital within the State, as well as do business in the State, and it was decided in this connection that where a foreign corporation solicited orders through agents in the State, which were filled from the factory at the home office without the State, even though it leased offices and kept samples and a bank account in New York State, it was not taxable here. (People ex rel. Washington Mills v. Roberts, 8 App. Div. 201.)

The new franchise tax law (article 9-a), taxing corporations on their net income as returned to the Federal government, does not require that capital be employed in order that such corporations may be held liable. Personal service corporations who may or may not employ capital, are taxable under article 9-a upon their net income earned within the State, based on an allocation or apportionment of services or tangible property within and without the State. Such corporations, however, must file a certificate under section 15 of the General Corporation Law, before they are permitted to do business within the State. Otherwise, they will be unable to sue upon any contract rights arising out of business done in the State. The new Personal Income Tax Law goes a step further than either the requirements for jurisdiction for local tax purposes in the assessment of personal property (section 7 of the Tax Law) or the franchise tax based on net income (article 9-a). No capital need be employed, no certificate need be obtained to do business in the State, and there is no criterion or guide as to the number of transactions or amount or volume of business done, which will show that the person is engaged in a continuous business, nor is there any statement in the law, except 
regulation 417, that such tax may not be imposed on income from interstate business, or the income from business temporarily or transiently within the State.

The language of article 415 of the regulations is largely taken from Tauza v. Susquehanna Coal Co., in which the question arose as to what facts were sufficient to constitute jurisdiction for service of process on a foreign corporation not transacting business in the State, within the meaning of section 15 of the General Corporation Law. The court held in that case that while the nonresident might not be within the State for the purpose of the General Corporation Law, it still might be amenable to the service of process. The court used this language, $220 \mathrm{~N}$. Y. 267 :

"But activities insufficient to make out the transaction of business, within the meaning of those statutes may yet be sufficient to bring the corporation within the state so as to render it amenable to process (International Text Book Co. v. Tone, decided herewith (220 N. Y. 313). In construing statutes which license foreign corporations to do business within our borders, we are to avoid unlawful interference by the state with interstate commerce. The question in such case is not merely whether the corporation is here, but whether its activities are so related to interstate commerce that it may, by a denial of a license, be prevented from being here (International Text Book Co. v. Pigg, 217 U. S. 91). * * But the problem which now faces us is a different one.

We are to say not whether the business is such that the corporation may be prevented from being here, but whether its business is such that it is here. If, in fact, it is here, if it is here, not occasionally or casually, but with a fair measure of permanence or continuity, then, whether its business is interstate or local, it is within the jurisdiction of our courts (International Harvester Co. v. Kentucky, supra, at p. 587).

Elsewhere, at page 266, the court said:

"Yet because their activities were systematic and regular, the corporation was held to have been brought within Kentucky and therefore, to be subject to the process of Kentucky courts."

It will be noticed that in this case the court used the language which is now contained in the regulation, but that it makes a 
distinction between jurisdiction which enables process to be served on a nonresident defendant and jurisdiction required for tax purposes.

In International Text Book Co. v. Tone, supra, it was held that a foreign corporation maintaining no office in the State, but employing division superintendents and assistants with an agency in New York City, soliciting orders and fulfilling its contracts by transmitting information through the mails, was doing nothing in New York except in furtherance of interstate commerce, and cannot be subjected to a license tax by reason thereof. The court said here, page 318:

"Business may be sufficient to subject the foreign corporation that does it to the service of process, and yet insufficient to require it to take out a license. In Tauza v. Susquehana Coal Co., (220 N. Y. 259) decided herewith, this distinction is emphasized. * * * We have steadily upheld the right of foreign corporations, without the aid of any license, to engage in activities incidental to commerce between the states."

\section{Corporation Status Differs from Individual Taxpayer.- Attention} has been called to the franchise tax on foreign corporations, based on net income derived from doing business in the State, but incidental to such business, there must be the authority to do such business, and the maintaining of a place of business. The maintaining of such business may be evidenced by " a desk room, an office, a shop, a store, a warehouse, a factory, an agency, or other place where its affairs are systematically or regularly carried on."

A corporation differs from an individual citizen because it is in possession of a franchise, and to exercise the rights under that franchise within the State, it must obtain a certificate from the Secretary of State. No such limitations apply to the individual nonresident. He carries his franchise "under his hat," so to speak, and he need not maintain any regular place of business or even maintain a desk room. 
THE STATE COMPTROLLER'S REgulations - (CON'T'D) 491

The right of a citizen to come and go from one State to another is not limited like that of a foreign corporation and he may transact business in the State while he is coming and going.

How far the Federal courts will go to uphold the tax on net income imposed by a State on a nonresident individual and derived from interstate commerce, in whole or in part, it is impossible to predict. It was held in $U$. S. Glue Co. v. Town of Oxk Creek, 247 U. S. 321, that such a tax may be imposed as an income on a domestic corporation, even if the net income is derived from interstate commerce, provided the method of apportioning the net income earned within and without the State was a reasonable one. Whether the court will apply the same reasoning to a foreign corporation and then again to a nonresident individual is another question.

Sales of Stocks, Bonds and 0ther Securities- (Art. 416.) We have seen that the tax imposed on income from securities owned by a nonresident is not taxable because so expressly provided in section 359, subdivision 3. The underlying reason for this exemption was not to discourage the investment of capital in stocks and securities in domestic corporations which otherwise might be diverted to other States.

There is no express provision in the statute exempting profits arising from sale of stocks, bonds and securities belonging to nonresidents. On the other hand, there is an express provision for the taxation of such profits in the hands of a resident (sections 353, 354, 355, Tax Law). A resident, of course, is taxed on income from all sources. Aside from the reason mentioned for expressly exempting income from securities belonging to a nonresident, the basis for the Comptroller's regulation which is hereinafter quoted in full, may be that in the case of a nonresident, the sale is necessarily brought about through the agency of interstate commerce either by the government 
mails or railroads or express companies as the demium through which the exchange is effected. It may also be said that the source of this income is not derived from property within the State, since the property is of an intangible character. The Comptroller's regulation as to the sale of stocks is as follows:

Sale of Stocks, Bonds and Other Securities.-Art. 416. Gains and profits of a nonresident from the sale, exchange or other disposition of stocks, bonds and other securities are not taxable and should not be included in gross income, except to the extent to which the same shall be a part of the income from a business carried on in the state of New York, even though the sale or other disposition thereof may have been made within the state of New York or consummated on the exchange located within such state. Likewise, losses sustained from the sale, exchange or or other disposition of stocks, bonds and other securities under like conditions, are not deductible, except to the extent that there may be losses incurred in, because forming a part of a business carried on within the state."

Sale of Property 0ther Than Securities. - Article 417 deals with profits arising from the sale of property other than securities when belonging to nonresidents. Such property, when personal, should have an actual situs within the State, but not form part of the assets of a business carried on within the State. Goods in transit or goods shipped here for sale do not appear to come within this requirement. The profits resulting from the occasional sale of a piece of real estate by a nonresident would be subject to tax unless the ownership of the real estate is incorporated. There seems to be no escape from this conclusion. In some States where there is an income tax, the profits arising from the sale of real estate are exempt.

Rents and Royalties. - (Art. 418.) The taxation of a landlord residing without the State on income derived from property located within the State, proceeds on a theory of jurisdiction over the property. The withholding provisions of the statute do not apply to deduction of rent, although the definition of with- 
holding agent includes a person having the control or payment of rent.

The question as to whether income from royalties due to a nonresident is taxable, involves a somewhat different conception than income derived from pensions referred to in article 413 of the regulations. Royalties, in one sense of the term, may be equivalent to rent from property in the State, viz., royalties received by the grantor of a patent, lease of a mine or quarry, and payable proportionately to the use made of the right by the grantee. In this sense, royalty will be taxable to a nonresident. On the other hand, a royalty might refer to a payment made to an author or composer by an assignee or licensee in respect to each copy of the work sold. In the case of the author or composer, the payment is in the nature of a commission for the sale of a literary or musical composition, the original work being in the form of personal service rendered without the State. . In such case there is neither property located, business or occupation carried on, nor salary earned, in the State.

Tax Not Imposed on Income from Securities Owned by Nonresident.-Some misconception has arisen as to what is meant by gross income excluded from taxation in the case of nonresidents under subdivision 3 , section 359 . That subdivision reads as follows:

" 3 . In case of taxpayers other than residents, gross income includes only the gross income from sources within the state, but shall not include annuities, interest on bank deposits, interest on bonds, notes or other interest bearing obligations, or dividends from corporations, except to the extent to which the same shall be a part of income from any business, trade, profession or occupation carried on in this state subject to taxation under this article."

An example of what is meant by income from interest-bearing obligations in the last sentence would be that a nonresident will 
494 THE STATE COMPTROLLER'S REGULATIONS - (CONT'D)

not be taxed on the income from stock and securities in which he may have invested the surplus of his business. On the other hand, if a man is engaged in the business of a security broker, buying and selling on commission, and also obtaining a profit from the enhancement in the value of such securities, such income will be taxable.

Deductions.- (Art. 431.) It may be said at the outset that a nonresident will be entitled to no deductions unless his return discloses his total gross income from sources both within and without the State. (Section 367, Tax Law; article 481, regulations.) Thus in the nonresident form it is necessary to state the income from within and without the State, whether from rents or property located within or without the State, or from business so located. In any event, the nonresident only receives a proportionate deduction, that is to say, in the proportion that his gross taxable income bears to his total gross income. The latter is arrived at by adding to the gross taxable income the nontaxable income.

Taxes Deductible by a Nonresident.-(Art. 433.) Income taxes and assessments for local improvements are not deductible by a nonresident, nor are they deductible by a resident; neither are estate and inheritance taxes which are chargeable against capital and not against income. If a nonresident owns a piece of real estate outside of the State which he uses for a factory from which goods are shipped to his New York warehouse, and he pays taxes on that factory, they should be deducted as an expense of the business in the State.

Interest Deductible by a Nonresident.-(Art. 434.) A nonresident may deduct from his gross income only the proportion of interest paid or accrued in the state which the amount of his gross income within the State bears to his total gross income. By 
THE STATE COMPTROLLER'S REgULATIONS - (CONT'D)

total gross income is included his gross income plus income exempt from taxation, including all his income from sources within the State. This would include net income that the nonresident receives from bonds, securities or annuities otherwise nontaxable.

Losses.- (Art. 435.) A nonresident may only deduct losses arising out of business in the State, or on property located in the State which would yield an income tax to the State. Thus, losses on sales of realty in the State would be deductible, but not losses from the sale of securities. If, on the other hand, his house in New Jersey be destroyed by fire, for which there was no insurance compensation, he could not deduct this loss.

Apportionment of Nonresident Income- (Art. 451.) Salesmen's salaries, etc.-This article deals with the apportionment of income from sales made in and out of the State, where the receipts inure directly to the employer. The basis of apportionment is the volume of business, but the volume of business may not in the case of a salesman on salary be the fairest test. For example, the volume of business transacted in the State may produce a smaller income than the same volume of business without the State and disproportionate to the cost price. A salesman receiving a salary of $\$ 50,000$ a year may sell three or four commodities, some of which may be sold readily at large sums with small profits. The other commodities may be sold at greater effort at lower prices with proportionately greater profits. In such cases a special rule of apportionment may be offered in accordance with article 470 , infra.

Apportionment of Salaries. - In the apportionment of nonresidents' salaries and commissions, whether of salesmen or of other employees, the question whether the service is rendered within 
the State is very often doubtful. For example, a nonresident salesman or agent assigned to certain territory, in and out of the State, may offer goods for sale from New York by telegraph, telephone, letters, etc., to customers outside the State, and these offers may be accepted outside the State. It would seem that in such cases the contracts being made outside the State the services would be rendered outside the State. On the other hand, the sales were negotiated from the New York office. Article 456 may have been framed with such a situation in mind. This article refers to a business, but the same principle applies to the apportionment of salaries as to business.

Article 452 covers the apportionment of salaries of nonresident employees and officers, other than salesmen, on the basis of time. Here again time may not be a fair test of apportionment. If, for instance, an artist residing in Connecticut receives $\$ 150,000$ a year for fifty performances in New York, shall we say that the hours employed in practise in Connecticut are not of value to the New York performance, and hence subject to apportionment.

Income from Vessels. - Article 454 provides that charter moneys are not taxable to a nonresident for freights on vessels operated between New York and foreign ports or ports of other States, if the person maintains no agency in New York and is carrying on no business here. The maintenance of a regular office would not itself be sufficient to prove income earned in New York, if the freight was earned on the high seas beyond the three-mile limit. Only a small proportion would, in any event, go to the State of New York.

Under the heading of "withholding" attention has already been called to such services as may be considered to be rendered without the State by a nonresident, although the income may be derived from a source within the State. References have been 
THE STATE COMPTROLLER's REgULATIONS - (CONT'D) 497

made to a reporter, collector or professional man paid from a New York source, but engaged outside of the State, the service within the State being purely incidental and minor to the work done without the State. This is covered by article 456 of the Regulations.

Apportionment of Business Income-Article 457 provides for the apportionment of business income " on a fair and equitable basis, in accordance with approved methods of accounting." Few business concerns keep their records in such form so that the business attributable to New York State and that done elsewhere can be correctly ascertained. It will, therefore, be found necessary to adopt the artificial basis of apportionment required by article 457 , which depends upon the relative proportion that the New York Factors as defined in this article, bear to the total aggregate of factors as so defined.

The New York factors include the following:

(1) The average tangible real and personal property used in the business within the State, which is obtained by halving the sum of these.items for the beginning and end of the year.

(2) The total wages, salaries and sums paid for personal services in the business carried on within the State during the year.

(3) The gross sales or charges for services performed by or through any agency located within the State.

The Total Factors. - Include the sum of the same items, viz., tangible, real and personal property in and out of the State, plus the total wages and salaries paid in and out of the State, plus the total gross sales or charges for services performed in and out of the State. 
Illustration.- The following is an example showing the method of computing the proportion for taxation:

Take a nonresident engaged in the automobile business, owning garages and shops in New York and in New Jersey and also doing repair work in both States.

New York Factors:
FJan. 1 Dec. 31

$\$ 60,000 \$ 140,000$

$150,000 \quad 170,000$

Tangible personal property (autos, parts,

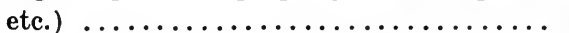

Total wages, etc. in New York.........

Total gross sales in $\mathbf{N} . \mathrm{Y} \ldots \ldots \ldots \ldots \ldots$

Total gross charges for services in N. Y. .
FAverage $\$ 100,000$

160,000 .

60,000

200,000

40,000

$\$ 560,000$

Total Factors:

Real estate in and out of the state......

Tangible personal property in and out of

state

Total wages in and out of $N . Y$

Total gross sales ................

Total gross charges for services in and out

of N. Y

\begin{abstract}
$160,000 \quad 220,000$
$250,000 \quad 320,000$
\end{abstract}

190,000

285,000

145,000

500,000

80,000

$\$ 1,200,000$

The proportion of income taxable in New York would be 560,000

$1,200,000$

If the total income were $\$ 300,000$ the taxable income would be $300,000 \times 7 / 15=\$ 140,000$.

Credit for Taxes.- (Arts. 482-484.) Article 482 provides for credit for taxes on the basis of net income taxed in other States or countries, derived from sources in New York State "provided such credit shall be allowed only if the laws of such state or 
The STATE COMptrolleR's REgUlations - (CONT'D) 499

country grant a substantially similar credit to residents of New York State." This implies in effect that if a resident of New Jersey does all his business in New York and derives all his income from that business, and pays an income tax in New Jersey on all that income, if he is taxable under the present New York Income Tax Law on that same income he will pay no tax to this State, provided New Jersey allows a similar credit to residents of New York doing business in New Jersey.

The proviso in this reciprocal provision is the fly in the ointment. There is no State or country at the present time that has such a reciprocal provision. The Federal government has a reciprocal provision in the present Income Tax allowing credit for taxes paid or accrued during the taxable year, by a resident alien, who is a citizen or subject of a foreign country, "upon income derived from sources therein, if such country, in imposing such taxes, allows a similar credit to citizens of the United States residing in such country. It should be noted that the federal provision does not apply to citizens of states of the Union, and also that the State of New York does not allow any credit, or even a deduction as against income, for income taxes paid to the United States. (See Art. 433.)

Powers of Comptroller; Revision of Taxes; Certiorari; Refunds.(Arts. 481-484.) These subjects have already been discussed in detail in chapters XX, XXI and XXII of the body of the book, and will only be briefly referred to here.

Article 571 of the Comptroller's regulations treats only of the Comptroller's power to revise an erroneous tax in terms, by reference to the statute, sections 373, 374, Tax Law. Those sections do not, however, give the Comptroller any discretionary power in these matters, except, perhaps, where the error or omission comes to the attention of the Comptroller, or his deputies and assistants, and they act ex parte. It is in such case, that under section 373 , 
Tax Law, he may revise the return if, "in his opinion," the same appears to be incorrect. In other cases, where the taxpayer discovers overpayment, or an erroneous assessment or additional assessment made by the Comptroller, the taxpayer may apply for a revision under section 374, Tax Law, and " the Comptroller shall grant a hearing thereon." A prima facie case for a hearing need only be shown in such cases, if this section is construed in conformity with the former practice of the Comptroller applied to corporations, under section 198 (formerly 195) of the Tax Law. This is also the practice of the State Tax Commission under section 218 of the Tax Law. Section 374 of the Personal Income Tax Law was taken from the sections of the Business Corporations Law referred to, and the practice in such cases will be found in chapters XX, XXI and XXII, supra.

Claim for Refund.- No forms of claim for refund have yet been issued, but a refund application may be made by setting forth the facts as to overpayment and other facts required by the statute and regulations, and filing such application duly executed and verified with the State Comptroller.

Certiorari. - The practice in certiorari is set forth in detail in chapter XXII, supra. 
THE STATE COMPTROLLER'S REGULATIONS - (CONT'D) 501

\section{DISTRICT OFFICES OF NEW YORK STATE INCOME TAX BUREAU AND DISTRICT DIREGTORS}

\section{Office}

1. Albany

Location

42 North Pearl st

120 Broadway

180 Montague st.

3. Brooklyn

4. The Bronx

5. Jamaica

6. White Plains.... Court House

7. Buffalo.

8. Rochester

9. Syracuse

10. Utica.

11. Elmira

12. Binghamton

13 Kingston.
Director

Roy H. Palmer

John E. Dempsey

Henry B. Cochen

Thomas W. Whittle

Frederic E. Knauss

Courtney D. Whittemore

Henry Seilheimer

James M. Mangan

Daniel T. Leo

Fred J. Graff

Louis C. Andrews

Henry B. Mulford

J. De Puy Hasbrouck 



\section{INDEX TO SUPPLEMENT TO "TAXATION OF COR- PORATIONS AND PERSONAL INCOME"}

PAGE

Accounts outstanding, when free from personal tax...........402

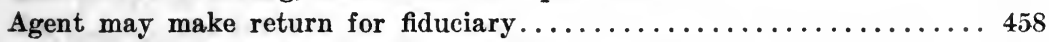

Annual summary and letter of transmittal accompanying information. . 482

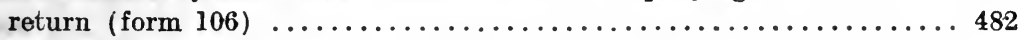

Annuities representing return of capital, need not be returned on informa-

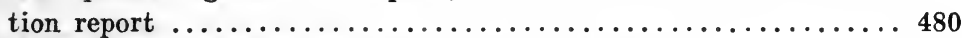

Application must be filed for relief from erroneous assessment. . . . . . 405

Apportionment of deductions in the case of non-residents . . . . . . . 494

of interest in the case of non-residents................. 494

Apportionment of business income.................. 497

of income, of non-resident employees................ 469

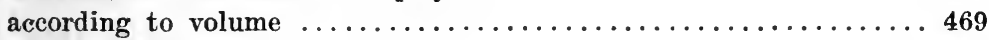

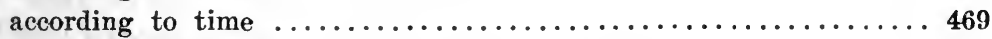

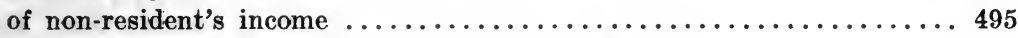

of income under Connecticut corporation $\operatorname{tax}$ law............ 418

Attorney-General's opinions as to school tax.............413

Average monthly payment to be taken if employee has moved from job

to job $\ldots \ldots \ldots \ldots \ldots \ldots \ldots \ldots \ldots \ldots \ldots \ldots \ldots \ldots \ldots \ldots \ldots \ldots \ldots \ldots$

Bad debts, charged off, when deductible............... 437

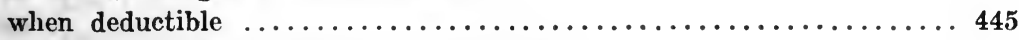

Bank deposits, when free from personal tax ............... 402

Beneficiary, when $\operatorname{tax}$ paid by, or by fiduciary $\ldots \ldots \ldots \ldots \ldots \ldots \ldots$

Bequest, sale of property acquired by ................ 450

Bills for merchandise, telegrams, telephones, freight, storage, etc., no

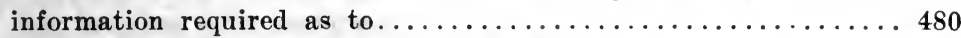

Bonds in default, are they taxable as personalty .............405

and stocks must be owned and controlled by holding corporation.... 424

stocks, securities, when income from, taxable to non-resident.......491

Branch offices in some cases to make return ................479

[The references in this index are to pages. On page $64 \gamma$ et seq. there is a separate index to the text of the Comptroller's Regulations. On pages 373 et seq. will be found an index to the Corporation Tax Articles 9 and 9a.] 
Bulletin No. 2, special, as to state employees............... 476

No. 3, as to municipal employees....................476

to local assessors by State Tax Commission................ 403

Burden of Proof, presumption that Comptroller's assessment is correct.. . 460

Business carried on in the state, definition of . . . . . . . . . . . . 487

corporation, exempt from personal tax................. 409

income from, how apportioned..................... 497

Calendar year, information return required for payments in........ 452 Capital stock defined in relation to exemption from personal tax..... 408 Carrying on business, what is not (International Text Book Co. v. Tone) . 489 Certiorari . . . .............................. 500

Certificate of residence, how long retained................. 470

to be attached to payrolls of State and Municipal departments..... 470

Charter moneys not taxable to non-resident, for freights on vessels to foreign ports ..............................496

Coupons and interest exempt...................... 475

City of New York ( See New York City)

Comptroller's powers ............................497

Contractors and sub-contractors, return by...............479

Commissions of insurance agent, when withheld............. 467

Connecticut's corporation tax, Underwood Typewriter Co. v. Chamberlain. 418

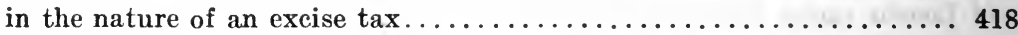

Constitutionality of Connecticut's corporation income tax law.......4 418

of New York State Income Tax Act.................. 426

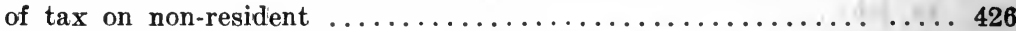

Corporation status differs from status of individual taxpayer....... 489

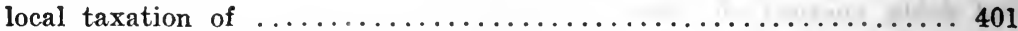

Credit for taxes, and reciprocal provision................. 498

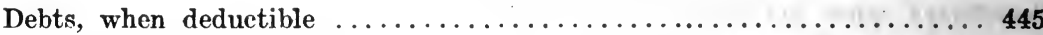

Decision in Yale v. Travis.............................428

in Peo. ex rel. Gen. Chemical Co. v. Cantor, exempting machinery....425

in Peo. ex rel. Barcalo v. Knapp, as to exemption from personal tax. . 410

as to deduction of excess profits tax.................. 42:1

in Peo. ex rel. Franklin Mill v. Collin, as to exemption from personal

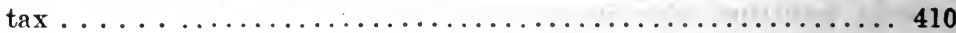

[The references in this index are to pages. On page 6/7 et seq. there is a separate indrx to the text of the Comptroller's Regulations. On pa.ges 373 ct seq. will be found an index to the Corporation Tax Articles 9 and 9a.] 
Decision in Gale v. Travis - Continued PAGE

in U. S. Glue Co. v. Town of Oak Creek................. 419

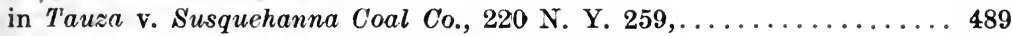

in International Textile Co. v. Tone, 220 N. Y. 313........... 489

of Court of Appeals in Peo. ex rel. Barcalo v. Knapp...........4 419

in Peo. $\epsilon x$ rel. Franklin Mill v. Collin on school tax exemption.......413

Deductions claimed for assessment of personal property...........404

when non-resident entitled to........................494

of bad debts previously charged off, when allowed............ 437

of tax at source (See Withholding)

Definition of business carried on in the state............... 487

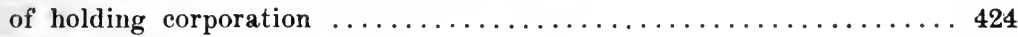

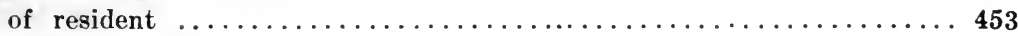

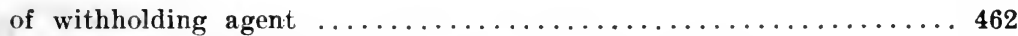

Depreciation and depletion in case of estates and trusts..........451

Difference in taxation, between state and federal law........... 439

Disclosure of Federal information not unconstitutional.......... 418

District offices and District Directors of N. Y. Income Tax Bureau.... 501

Dividends, when income from, taxable to non-residents...........493

declared, prior to January 1,1919 , not taxable to residents. . . . . . . 438

when return of information required as to ................. 480

Doing business in the state (See Business carried on)

Educational Law, assessments under, of personal property, do not apply

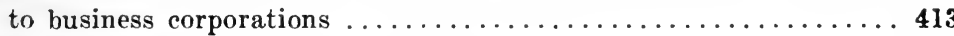

Emerson Act, its application to the Educational Law............ 415

Employees, non-resident, how salaries are apportioned.......... 495

Estates and trusts, only taxed once upon income.............448

how beneficiaries, resident and non-resident, are taxed..........448

depreciation and depletion in case of ..................451

executors and administrators shall file return of income on final

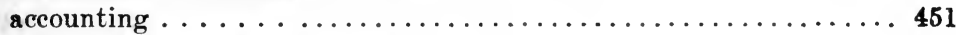

(See also Fiduciaries and Trusts)

Exces profits tax not deductible....................... 419

decision by Court of Appeals....................... 419

Exemption of intangibles ........................... 401

money on hand, on deposit, at interest................. 401

of choses in action from personal tax.................... 401

of shares of stock, from personal tax.................. 401

[The references in this index are to pages. On page 647 et seq. there is a separate index to the text of the Comptroller's Regulations. On pa.ges 373 et seq. will be found an index to the Corporation Tax Articles 9 and 9a.] 
Exemption - Continued

of personal property on $\operatorname{tax}$ day....................... 405

of business corporation from personal tax................ 408

of foreign corporation from personal tax.................. 408

no personal, to non-resident $\ldots \ldots \ldots \ldots \ldots \ldots \ldots \ldots \ldots \ldots \ldots \ldots \ldots \ldots \ldots$

of interest coupons ................................ 475

of business corporations from school tax.................4 413

personal, of resident, when deductible ...................445

of machinery and fixtures of business corporations taxable under Article 9a ............................. 425

of holding corporation from business corporation $\operatorname{tax} \ldots \ldots \ldots \ldots \ldots 423$

Exempt income, no return of information required as to ...........480

Factors, definition of New York factors and total..............497

Fair Market Value, January 1, 1919, includes sales immediately follow-

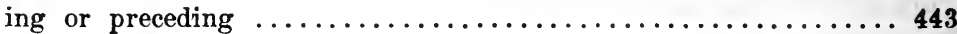

Federal taxes, not deductible ........................ 445

Fees for professional service need not be reported on information return.. 481

Fiduciary may make return by agents. . . . . . . . . . . . . . . 458

income may be taxed to the, or to the beneficiary............447

when $\operatorname{tax}$ payable by, or by beneficiary.................447

Fixtures of business corporation exempt..................425

Foreign corporation taxed under Article 9-a exempt from personal tax. . 409 taxed in New York City ..........................411

when taxable for state or local purposes.................. 488

may not maintain action unless tax is paid................ 488

letter from Counsel to State Tax Commission on taxation of....... 412

(unregistered) is not presumed to be doing business in state.......479

Form of residence cerfificate (Form 101) ................470

return of tax withheld at source (Forms 102, 103)......472, 473, 474

instructions accompanying Form 102 (Form 102-a).......... 472

bulletin to State Municipal Departments................476,478

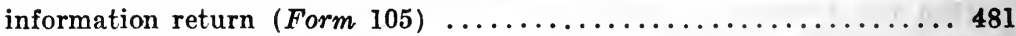

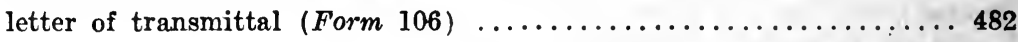

Gift, as "closed transaction" resulting in taxable profit..........452 sale of property acquired by........................442, 450 Griggs, Hon. J. W., as amicus curice for New Jersey in Travis v. Yale... 427 Gross income, how determined in case of non-residents...........427

[The references in this index are to pages. On page 647 et seq. there is a separate index to the text of the Comptroller's Regulations. On pages 373 et seq. will be found an index to the Corporation Tax Articles 9 and 9a.] 
Holding corporation, what is......................... 423

must own and control securities.....................423

Husband and wife's personal exemption, apportionment of . . . . . . 448

returns may be separate or joint.................... 457

Impairment of obligation of contract claimed in Yale v. T'ravis......431

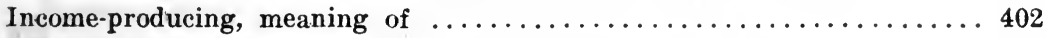

Indebtedness for deductions in assessment of personal property ......44 404

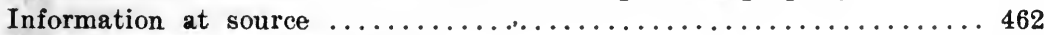

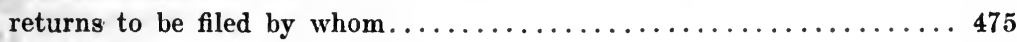

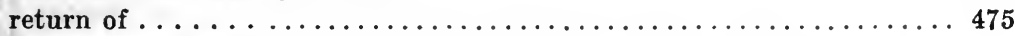

returns not required for interest due other states, foreign countries or municipalities . . . . ..................... 480

return when required as to payments of dividends............ 480

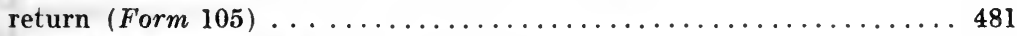

returns not required when $\operatorname{tax}$ withheld................... 451

Insurance agents, when $\operatorname{tax}$ on commissions withheld...........467

Intangible property, should bear interest on tax day ........... 405

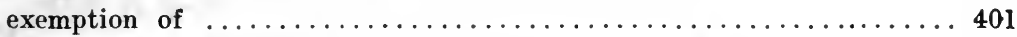

Interest producing intangible property, free from $\operatorname{tax} \ldots \ldots \ldots \ldots \ldots 402$

on bonds, bank deposits, etc., when taxable to non-resident.......493

accrued prior to January 1,1919 , not taxable.............. 438

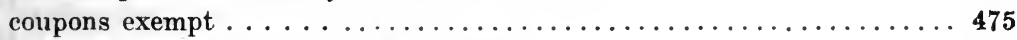

Interstate Commerce clause (Yale v. Travis) ............... 431

not $\operatorname{tax}$ under Connecticut Corporation Tax law.............. 419

Inventory valuations, three methods applied to illustration determining

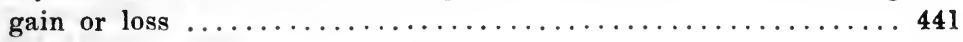

Jurisdiction to assess for personal property may be questioned....... 411

Knox Justice, decision of, in Travis v. Yale \& Towne.......... 426

Letter from Counsel to State Tax Commission as to exemption of intangibles ..................................406

on taxation of foreign corporations................... 412

of transmittal accompanying information return (Form 106)..... 482

Limitations, statute of, in connection with right of state to recover taxes. 460

Local taxation of persons and corporations................4 401

Losses, when non-resident entitled to deduction for............ 495

[The references in this index are to pages. On page 6.7 et seq. there is a separate index to the text of the Comptroller's Regulations. On pages 373 et seq. will be found an index to the Corporation Tax Articles 9 and 9a.] 
Machinery and Fixtures of business corporation exempt from taxation. . 425 Manufacturing and mercantile corporations exempt from personal tax. . 408 Market Value (See Fair Market Value) .................443 Money on hand, on deposit, at interest, exempt from personal tax....401 Mortgage, tax on income from, is not a $\operatorname{tax}$ on ............. 437 Movable machinery and fixtures, exempt from taxation.........425

New Jersey, state of, represented in Travis v. Yale . . . . . . . . 426

New York factors, definition of .....................497

and total factors, definition of ................. 497

New York City, assessment of foreign corporations in...........411 assessments of personal property in ................. 404

Non-resident feature of State Income Tax attacked as unconstitutional. . 420 receives no personal exemption................... 458 taxed on income in Oklahoma.................... 428 section, of State Comptroller's Regulations..............484 when taxable on personal property for local purposes.......... 488

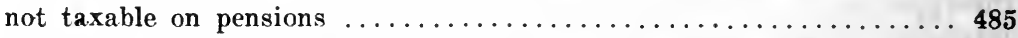
listed on payrolls of state and municipal departments subject to with-

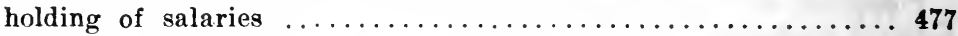

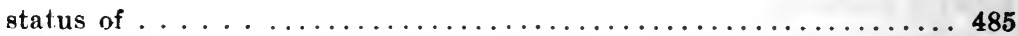
gross income of, how determined $\ldots \ldots \ldots \ldots \ldots \ldots \ldots \ldots \ldots \ldots$ when taxable on income from rents and royalties............ 492

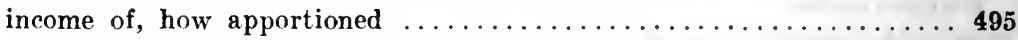
when taxable for charter moneys received from freights of vessels. . . 496 when entitled to deduction for interest, taxes, losses........... 494 taxable on income from sale of property having situs in state...... 492 not taxable for dividends, interest on notes, bonds, bank deposits, etc. 493 when taxable on income from sale of stocks, bonds, securities, etc... 491

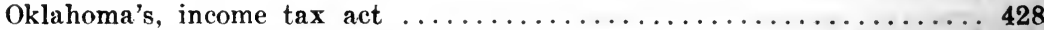

income tax act case (Shaffer $\mathbf{v}$. Carter) . . . . . . . . . . 428

Outstanding accounts, when free from personal tax............402

Partnership earnings, withdrawals of, are not taxable..........446

Payment for professional service on annual basis.............466

for which no return of information is required............ 480

Payrolls audited by State Comptroller require certificates of fiscal offices of departments...

[The references in this index are to pages. On page 647 et seq. there is a separate index to the text of the. Comptroller's Regulations. On pages 373 et seq. will be found an index to the Corporation Tax Articles 9 and 9a.] 
Penalties, failure to make return on time creates............. 460

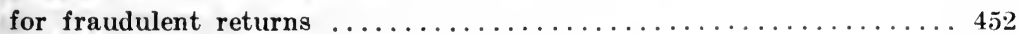

Pensions of, teachers, not taxable.................... 485

to non-residents need not be reported on information return.......481

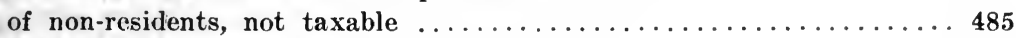

Persons, local taxation of .......................... 401

Personal exemption, of residents, when deductible............ 445

apportionment of, between husband and wife............. 446

Personal property tax, exemption of intangibles from........... 401

of non-resident, when taxable $\ldots \ldots \ldots \ldots \ldots \ldots \ldots \ldots \ldots \ldots \ldots \ldots . \ldots \ldots$

defined in relation to exemption of business corporations........408

Personal service, income only deductible and withheld........... 462

Personal tax, on bonds, defaulting in interest............... 405

exemption of corporation from.................... 408

cannot be collected from non-resident by supplementary proceedings... 411

Powers of Comptroller .......................... 499

Presumption that distributions made ratably from taxable and non-tax-

able income . . . . . . . . . . . . . . . . 448

that state and municipal employees are residents............477

Privilege and residents immunity clause, in Yale v. Travis........ 431

Privilege tax, corporate income $\operatorname{tax}$ is a .................419

Process, service of, when corporations are doing business in state....488

Professional service, fees for, need not be reported on information return. 481

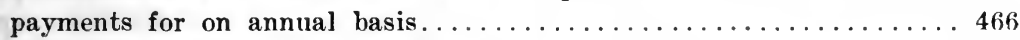

Proportionate deductions only allowed to non-residents..........494

Property having situs in the state, when income from, is taxable to nonresident . . . . . . . . . . . . . . . . . . . . . . 492

Reciprocal provision of credit for taxes.................. 499

Record to he maintained by heads of state departments as to compensation

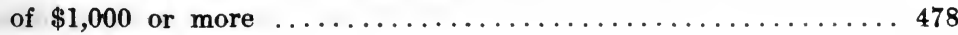

Refunds ................................... 400

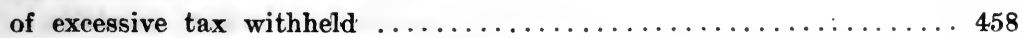

Regulation No. 1 information as to income of municipal employees... 476 special No. 2 as to state employees, information as to income of.... 476

Relief from erroneous assessment, requires previous application for relief. 406

Rents paid to real estate agents, need not be reported on information return .............................. 480

and royalties, when income from taxable to non-residents........492

[The references in this index are to pages. On page 6.17 et seq. there is a separate index to the text of the Comptroller's Regulations. On pages 373 et seq. will be found an index to the Corporation Tax Articles 9 and 9a.] 
Re-organization profits, when taxable $\ldots \ldots \ldots \ldots \ldots \ldots \ldots \ldots \ldots \ldots 44$

shareholders receiving greater aggregate for value of stock........444

Report (See Return)

Resident defined . . . ............................453

personal exemption of, when deductible...................445

Residence, facts establishing intent for purposes of ........... 454

presumption of as to state and municipal employees........... 477

largely a question of intent......................... 454

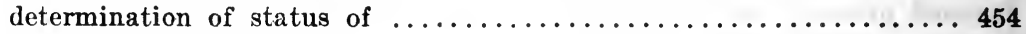

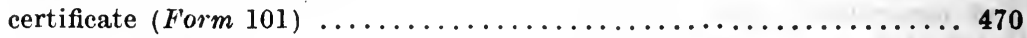

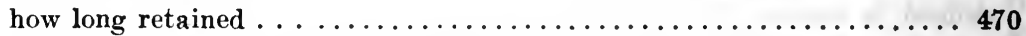

of married woman how determined $\ldots \ldots \ldots \ldots \ldots \ldots \ldots \ldots \ldots \ldots \ldots+\ldots \ldots \ldots$

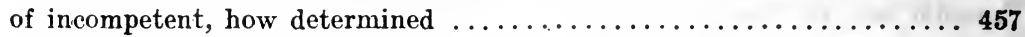

of emancipated minor, how determined................. 457

Return of information as to payment of dividends.............480

of husband and wife, may be separate or joint.............457

penalties for fraudulent ............................. 453

of tax withheld at source $($ Form 102, 102a) ............... 452

of information at source (See Information) .............472, 475

by contractors and sub-contractors $\ldots \ldots \ldots \ldots \ldots \ldots \ldots \ldots \ldots \ldots \ldots$

of information (See Information) ..................... 451

by branch offices instead of main offices................. 479

Revision of taxes .......................... 500

Royalties, when income from, taxable to non-resident.......... 492

Sales of stocks, bonds and other securities, when income from taxable to non-resident ................................491

Sale of property acquired by gift or bequest...............450

Salaries, income of non-resident, from, withheld............. 462

of salesmen, clerks, etc., how apportioned............... 495

School tax, exemption of business corporations from............ 413

opinion of attorney-general as to..................... 413

Securities of municipalities, and of other states and foreign countries,

income from not subject to information returns...........480

income from, when taxable to non-residents................ 493

Service of process, when corporations are doing business for purposes of . 487

Source (See Withholding at source information at source)

State Tax Commission's directions to local assessors as to personal taxes. 403

letter from counsel as to exemption of intangibles............. 406

[The references in this index are to pages. On page 647 et seq. there is a separate index to the text of the Comptroller's Regulations. On pages 373 et seq. will be found an index to the Corporation Tax Articles 9 and 9a.] 
Status of residence, how determined.................. 454 of corporation differs from individual taxpayer ............4490 of non-resident fixed by absence of certificate ..............485

Stocks and bonds must be owned and controlled by holding corporation. . 424 bonds, securities, income from, when taxable to non-resident.......491

Stocks, dividends, income under Federal law of $1913 \ldots \ldots \ldots \ldots \ldots . . \ldots 44$ when taxable . . . . ............................ 444 difference between state and Federal law in taxing.............444 Sub-contractors, return by $\ldots \ldots \ldots \ldots \ldots \ldots \ldots \ldots \ldots \ldots \ldots \ldots . \ldots \ldots 79$

Supplementary proceedings cannot be brought to collect a personal tax from non-residents . . . . . . . . . . . . . . . . . . . 411

Tanzer, Laurence Arnold, as amicus curice for cities in New York in Travis v. Yale .............................. 427

Tax day, its relation to exemptions of personal property......... 405

Taxes, credit for . . . ............................. 452

when deductible by a non-resident $\ldots \ldots \ldots \ldots \ldots \ldots \ldots \ldots \ldots \ldots . \ldots 49$

credit for, reciprocal provision ...................... 499

Federal income or business, license, privilege, excise or stamp, not deductible ............................... 445

Tax Commission (See State Tax Commission)

Teachers' pensions, not taxable ...................... 485

Treasurers of State Departments required to withhold tax on non-resident

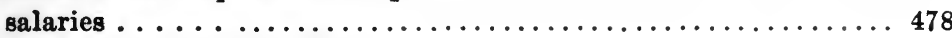

Trusts (See Estates and Trusts)

Vessels, income from, when taxable to non-resident............ 496

Wife and husband's personal exemption, apportionment of .........446

Wisconsin Income Tax Law referred to in Yale v. Travis............431

Withholding of tax when no certificate of resident is filed......... 459

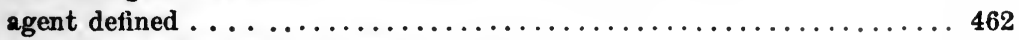

of not more than two per cent of income................ 463

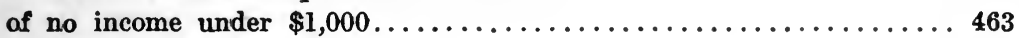

Attorney-General's letter as to......................464

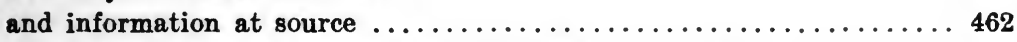

of salaries, wages, commissions, gratuities, emoluments, perquisites of non-residents . . . . .......................462

[The references in this index are to pages. On page 6/7 et seq. there is a separate index to the text of the Comptroller's Regulations. On pages 373 et seq. will be found an index to the Corporation Tax Articles 9 and 9a.] 
Withholding of tax, etc.-Continued $\quad$ PAGE

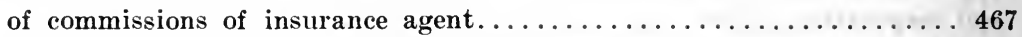
information returns not required, when there is ............ 45 i

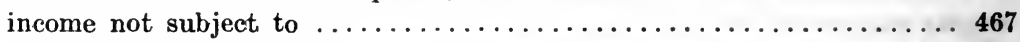
of apportionable income of non-resident employees...........468 of salaries or commissions of non-resident collector or agent......4 468 of salaries of non-residents, State and municipal empiozees........47i Yale v. Travis, decision in ........................ 429

[The references in this index are to pages. On page 647 et seq. there is a separate index to the text of the Comptroller's Regulations. On pages 373 et seg. will be found an index to the Corporation Tax Articles 9 and 9a.] 


\section{RULES AND REGULATIONS}

OF THE

\section{STATE GOMPTROLLER}

FOR THE PURPOSE OF ENFORCING

CHAPTER 627 OF THE LAWS OF 1919

(ARTICLE 16 OF THE TAX LAW)

THE TAX ON PERSONAL INCOMES

WITH THE TEXT OF THE AGT 


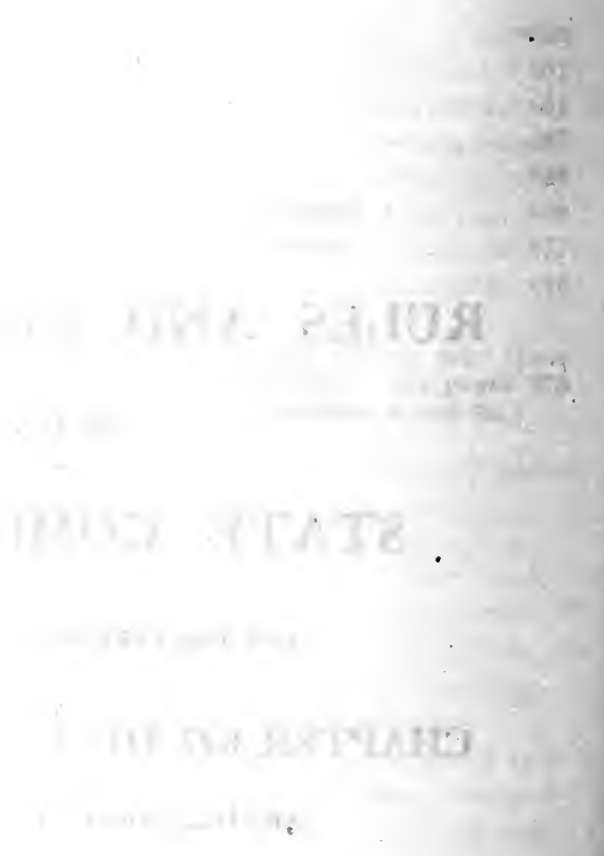

4at y y p 1147.

wh nerle 


\section{THE TAX}

Article 1. Scope of the law.- The statute imposes an income tax on individuals and on certain estates and trusts. (Tax Law, section 351.) The tax is upon net income, as defined in the statute, after deducting from gross income, as defined in the statute, the allowable deductions. (Tax Law, sections 357, 358, 359, 360 and 361.) In certain cases exemptions are allowed against net income and in certain other cases credits against the amount of the tax. (Tax Law, sections 362 and 363.) Special provisions of the statute deal with the effect of the tax on nonresident individuals, partnerships, estates and trusts. (Tax Law, sections 351,364 and 365.) The tax is payable upon the basis of returns rendered by the taxpayers liable thereto, except that in some instances it is to be paid at the source of the income. (Tax Law, sections 366, 367, 368, 369, 370 and 371.)

Art. 2. Tax rate.-For the calendar year 1919, or for any fiscal year ending during the year 1919 and for each taxable year thereafter, an income tax is imposed at the rate of one per centum (1\%) upon the first $\$ 10,000$ of taxable income (net income after subtracting exemptions); two per centum (2\%) upon the amount of taxable income in excess of $\$ 10,000$ and not in excess of $\$ 50,000$; three per centum $(3 \%)$ upon the amount of taxable income in excess of $\$ 50,000$.

ART. 3. Who are taxpayers.- The word "taxpayer" includes

(1) Every resident of the State of New York,

(2) Every estate and trust resident of the State of New York, whose income is in whole or in part subject to the State income tax and

(3) Individuals and estates and trusts, nonresident of the State of New York, receiving taxable income from property owned or from business, trade, profession or occupation carried on or followed within the State of New York. 


\section{NET INCOME DEFINED}

ART. 11. Meaning of net income.- The tax imposed by the statute is upon income. In the computation of the tax various classes of income must be considered: (a) Income (in the broad sense), meaning all wealth which flows into the taxpayer other than as a mere return of capital. It includes the forms of income specifically described as gains and profits, including gains derived from the sale, exchange or other disposition of capital assets. It is not limited to cash alone, for the statute recognizes as incomedetermining factors other items, among which are inventories, accounts receivable, property exhaustion and accounts payable for expenses incurred. (Tax Law, sections 353, 354, 355 and 356.) (b) Gross income, meaning income (in the broad sense) less income which is by statutory provision or otherwise exempt from the tax imposed by the statute. (Tax Law, section 359.) (c) Net income, meaning gross income less statutory deductions. The statutory deductions are in general, though not exclusively, expenditures, other than capital expenditures, connected with the production of income. (Tax Law, sections 360 and 361.) (d) Net income less exemptions. Though taxable net income is wholly a statutory conception, it follows, subject to certain modifications as to exemptions and as to some of the deductions and as to nonresidents, the lines of commercial usage. Subject to these modifications statutory "net income" is commercial "net income." This appears from the fact that ordinarily it is to be computed in accordance with the method of accounting regularly employed in keeping the books of the taxpayer. As to net income of nonresidents, see Tax Law, section 359.

Art. 12. Computation of net income.- Net income must be computed with respect to a fixed period. Usually that period is twelve months and is known as the taxable year. Items of income and expenditure which as gross income and deductions are elements in the computation of net income need not be in the form of cash. It is sufficient that such items, if otherwise properly included in the computation, can be valued in terms of money. The time as of which any item of gross income or any deduction 
is to be accounted for must be determined in the light of the fundamental rule that the computation shall be made in such a manner as clearly reflects the taxpayer's income. If the method of accounting regularly employed by him in keeping his books clearly reflects his income, it is to be followed with respect to the time as of which items of gross income and deductions are to be accounted for. If the taxpayer does not regularly employ a method of accounting which clearly reflects his income, the computation shall be made in such manner as in the opinion of the Comptroller clearly reflects it.

ART. 13. Bases of computation.-Approved standard methods of accounting will ordinarily be regarded as clearly reflecting income. A method of accounting will not, however, be regardet as clearly reflecting income unless all items of gross income and all deductions are treated with reasonable consistency. See section 350 of the Tax Law for definitions of "paid," "paid or accrued" and "paid or incurred." All items of gross income shall be included in the gross income for the taxable year in which they are received by the taxpayer, and deductions taken accordingly, unless in order clearly to reflect income such amounts are to be properly accounted for as of a different period. For instance, in any case in which it is necessary to use an inventory, no accounting in regard to purchases and sales will correctly reflect income except an accrual method. (Tax Law, section 359.) A taxpayer is deemed to have received items of gross income which have been credited to $n \mathrm{r}$ set apart for him without restriction. (Article 44.) On the other hand, appreciation in value of property is not even an accrual of income to a taxpayer prior to the realization of such appreciation through conversion or other disposition of the property. A taxpaver who changes the method of accounting employed in keeping his books for the taxable year 1920 or thereafter, shall before computing his ineome upon such new basis for purposes of taxation secure the consent of the Comptroller. Application for permission to change the basis of the return shall be made at least 30 days in advance of the date of filing return and shall be accompanied by a statement specifying the classes of items differently treated under the two systems and all amounts which would be duplicated or entirely omitted as a 
result of the proposed change. A taxpayer subject to Federal tax shall file with his application a copy of the consent of the Commissioner of Internal Revenue, to change the basis of the return for Federal tax purposes. The requirement of notice to the Comptroller will be modified in such cases with respect to time, and where a change is authorized, it will be made effective at the same date as that authorized by the Commissioner of Internal Revenue.

ART. 14. Methods of accounting.-- It is recognized that no uniform method of accounting car be prescribed for all taxpayers, and the law contemplates that each taxpayer shall adopt such forms and systems of accounting as are in his judgment best suited to his purpose. Each taxpayer is required by law to make a return of his true income. He must, therefore, maintain such accounting records as will enable him to do so. Among the essentials are the following:

(1) In all cases in which the production, purchase or sale of merchandise of any kind is an income-producing factor, inventories of the merchandise on hand (including finished goods, work in process, raw materials and supplies) should be taken at the beginning and end of the year and used in computing the net income of the year;

(2) Expenditures made during the year should be properly classified as between capital and income, that is to say, that expenditures for items of plant, equipment, etc., which have a useful life extending substantially beyond the year should be charged to a capital account and not to an expense account;

(3) In any case in which the cost of capital assets is being recovered through deductions for wear and tear, depletion or obsolescence any expenditure (other than ordinary repairs) made to restore the property or prolong its useful life should be charged against the property account or the appropriate reserve and not against current expenses.

A taxpayer must make his return on the basis on which his books are kept; so that in making his State return, as in making his Federal return, he must use the basis on which his books are kept, if that basis reflects his true income. 


\section{GROSS INCOME DEFINED: INCLUSIONS}

Art. 21. What included in gross income-Gross income includes in general compensation for personal and professional services, business income, profits from sales of and dealings in property, interest, rent, dividends, and gains, profits and income derived from any source whatever, unless exempt from tax by law. Profits derived from sales in foreign commerce are taxable. Income may be in the form of cash or of property. The amount of Federal or State income tax paid for or to a bondholder by an obligor pursuant to a tax-free covenant in its bonds is in the nature of additional interest paid the bondholder and must be included in his gross income. He is not, however, entitled to deduct such income tax paid on his behalf. As to the basis for determining gain or loss from sales and exchanges see Tax Law, sections 353, 354 and 355 and article 91 .

Art. 22. Income from Federal, State and Municipal contracts.Any profit received from the United States, a State or political subdivision thereof by an independent contractor is taxable income.

Art. 23. Compensation for personal services.- Where no determination of compensation is had until the completion of the services, the amount received is income for the taxable year of its determination. Commissions paid salesmen, compensation for services on the basis of a percentage of profits, commissions on insurance premiums, tips, retired pay, pensions and retiring allowances paid by States and political subdivisions or private persons, are income to the recipients; as are also marriage fees, baptismal offerings, sums paid for saying masses for the dead, and other gifts and contributions received by a clergyman, evangelist or religious worker for services rendered. The salaries, wages and other compensation received from the United States by officials and employees are not subject to tax. See articles 41 and 210 . (Tax Law, section 359.)

Art. 24. Compensation of State officers. - Compensation paid its officers and employees by the State of New York or any other state, or any political subdivision thereof, including fees re- 
ceived by notaries public commissioned by states and the commissions of receivers appointed by State courts, and including amounts paid to officers and employees while in the military or naval service, is taxable. Employees of universities receiving salaries paid in part or in whole from funds available under the Smith-Lever Act of May 8, 1914, who are officers or employees of a State, are required to return as taxable income the salaries so received. This is also true with respect to the Act of August 30,1890 , relating to colleges for the benefit of agriculture and the mechanic arts, and to the Act of March 2, 1887, relating to agricultural experiment stations in such colleges.

ArT. 25. Compensation paid other than in cash.- Where services are paid for with something other than money, the fair market value of the thing taken in payment at the time such payment is made is the amount to be included as income. If the services were rendered at a stipulated price, in the absence of evidence to the contrary such price will be presumed to be the fair value of the compensation received. Compensation paid an employee of a corporation in its stock is to be treated as if the corporation sold the stock for its market value and paid the employee in cash. When living quarters such as camps are furnished to employees for the convenience of the employer, the rental value need not be added to the cash compensation of the employee, but where a person receives as compensation for services rendered a salary and in addition thereto living quarters, the value to such person of the quarters furnished constitutes income subject to tax. Premiums paid by an employer on life, accident or health policies in favor of his employees as additional compensation of such employees are income to the employees. Contributions to retirement or pension funds accomplished by deduction from the compensation otherwise payable to the employees are income to the employees.

ÁrT. 26. Compensation paid in notes- Promissory notes received in payment for services, and not merely as security for súch payment, constitute income to the amount of their fair market value. A taxpayer receiving as compensation a note regarded as good for its face value at maturity, but not bearing interest, may properly treat as income as.of the time of receipt 
the fair discounted value of the note at such time. Thus, if it appears that such note is or could be discounted, the recipient may include such note in his gross income to the amount of its face value less discount computed at the prevailing rate for such transactions. If the payments due on a note so accounted for are met as they become due, there should be included as income in respect of each such payment so much thereof as represents recovery for the discount originally deducted.

ART. 27. Payments received in warrants or securities.- Where warrants are issued by, or in behalf of, a state, city, town, or other political subdivision of a state, and are accepted, in payment, the fair market value of such warrants at the time of receipt must be returned as income. When a contractor receives payment in stock, bonds or other obligations of a corporation other than as stated above, such securities shall, for the purpose of determining gain or loss be treated as the equivalent of cash to the amount of their fair market value. If upon conversion of the warrants or securities into cash or other property, the contractor receives an amount or value greater or less than the value so returned, the profit or loss so realized or sustained shall be reported in the return for the year in which such warrants or securities are converted.

Art. 28. Gross income from business. - In the case of a manufacturing, merchandising or mining business "gross income" means the total sales, less the cist of goods sold, plus any income from investments and from incidental or outside operations or sources. In determining the gross income subtractions should not be made for depreciation, depletion, selling expenses or losses, or for items not ordinarily used in computing the cost of goods sold. Any allowance made to a taxpayer by a contracting department of the Government or by any other contractor for amortization or fall in the value of property, either as a part of the cost of production or as a part of the price of the product, shall be included in gross income, but unlike the Federal Income Tax Law, no deduction for amortization is allowable under the state law.

ART. 29. Long term contracts.-- Persons engaged in contracting operations, who have uncompleted contracts, in some cases 
perhaps running for periods of several years, will be allowed to prepare their returns so that the gross income will be arrived at on the basis of completed work; that is, on jobs which have been finally completed any and all moneys received in payment will be returned as income for the year in which the work was completed. If the gross income is arrived at by this method, the deduction from gross income should be limited to the expenditures made on account of such completed contracts. In arriving at the gross income by this method the receipts and expenditures relating to jobs commenced prior to 1919 must be included if completed in 1919 or subsequent years. Or the percentage of profit from the contract may be estimated on the basis of percentage of completion, in which case the income to be returned each year during the performance of the contract will be computed upon the basis of the expenses incurred on such contract during the year; that is to say, if one-half of the estimated expenses necessary to the full performance of the contract are incurred during one year, onehalf of the gross contract price should be returned as income for that year. Upon the completion of a contract if it is found that as a result of such estimate or apportionment the income of any year or years has been overstated or understated, the taxpayer should file amended returns for such year or years. (Tax Law, sections 358 and $37 \%$ and article 5\%4.)

ArT. 30. Gross income of farmers.-All gains, profits and income derived from the sale or exchange of farm products, whether produced on the farm or purchased and resold, shall be included in the return of income for the year in which the products were actually marketed and sold, unless an inventory is used. In the case of the sale of machinery, and of animals purchased as draft or work animals or solely for breeding purposes and not for resale, any excess over the cost thereof reduced by all sums theretofore deducted for depreciation shall be included as gross income in preparing the taxpayer's return. Where farm produce is exchanged for merchandise, groceries or mill products, the market value of the article or product received in exchange is to be returned as income. Rents received in crop shares shall be returned as of the year in which the crop shares are 
reduced to money or a money equivalent. If a farmer is ensaged in producing erops which take more than a year from the time of planting to the time of gathering and disposing, the income therefrom nay be computed upon the arop basis; but in any such case the entire cost of producing the crop must tre taken as a dediction in the rar in which the gross income from the crop is realized. Then live stock purchased is sold, its $\cos ^{2}$ is to be deducted from the sales price in ascertaining the amount of gain or profit to be returned for tax purposes. If, howerer, an inventory is used the cost price of the article sold must not be taken as an additional deduction in the return of income, as such cost price will be reflected in the inventory. As herein used the term "farm" embraces the farm in the ordinarily accepted sense and includes stock, dairy, poultry, fruit and truck farms, also plantations, ranches and all land used for farming operations. All taxpayers that cultivate, operate or manage farms for gain or profit, either as owners or tenants, are desigaator farmers. A person cultivating or operating a farru for recreation or pleasure, the result of which is a continual loss from year to vear, is not rexarded as a farmer. (See further, waticles 192 and 181.)

ArT. 31. Sale of stock and rights.- When shares of stock in a corporation are sold from lots purchased at different times and at different prices and the identity of the lots can not be determined, the stock sold shall be charged against the earliest purchase of such stock. The excess of the amount realized on the sale over the cost of the stock. or its fair market value as of January 1, 1919, if purchased before that date, will be the profit to be accounted for as income. In the case of stock re ceived as a stock dividend, and in the case of stock in respect of which ary stch dividend was paid, the cost of each share of such stock shall be ascertained as specified in article 64 . Where common stock is received as a bonus with the purchase of preferved stock or bonds, the total purchase price shall be fairly apportioned between the stock and securities purchased for the prupose of determining the portion of the consideration nttriantalk to each class of stock or securities and so representing its cost, but if that should be impracticable in any case, 
no profit on any subsequent sale of any part of the stock or securities will be realized until out of the proceeds of sales shall have been recovered the total cost. (Article 96.) The entire amount realized from the sale of rights to subscribe for stock by a stockholder to whom such rights are issued, is income.

ArT. 32. Sale of patents and copyrights.-A taxpayer disposing of patents or copyrights by sale should determine the profit or loss arising therefrom by computing the difference between the selling price and the value as of January 1, 1919, if ac: quired prior to that date, or between the selling price and the cost, if acquired subsequent to that date. The profit or loss thus determined should be increased or decreased, as the case may be, by the amounts deducted on account of depreciation of such patents or copyrights since December 31, 1918, or since the date of acquisition if acquired subsequent thereto. (See article 17\%.)

ArT. 33. Sale of good will.-Any profit or loss resulting from an investment in good will can be taken only when the business, or a part of it, to which the good will attaches is sold, in which case the profit or loss will be determined upon the basis of the cost of the assets, including good will, or their fair market value as of January 1, 1919, if acquired prior thereto. If nothing was paid for good will acquired on or after January 1, 1919, no deductible loss is possible, although, on the other hand, upon the sale of the business there may be a profit. It is immaterial that good will may never have been carried on the books as an asset, but the burden of proof is on the taxpayer to establish the cost or fair market value on January 1, 1919, of the good will sold.

\section{ART. 34. Sale of personal property on installment plan.-} Dealers in personal property ordinarily sell either for cash, or on the personal credit of the buyer, or on the installment plan. Occasionally a fourth type of sale is met with, in which the buyer makes an initial payment of such a substantial nature (for example, a payment of more than 25 per cent) that the sale, though involving deferred payments, is not one on the installment plan. In sales on personal credit, and in the 
substantial payment type just mentioned, obligations of purchasers are to be regarded as the equivalent of cash, but a different rule applies to sales on the installment plan. Dealers in personal property who sell on the installment plan usually adopt one of four ways of protecting themselves in case of default: (a) through an agreement that title is to remain in the seller until the buyer has completely performed his part of the transaction; (b) by a form of contract in which title is conveyed to the purchaser immediately, but subject to a lien for the unpaid portion of the purchase price; (c) by a present transfer of title to the purchaser, who at the same time executes a reconveyance in the form of a chattel mortgage to the seller; or (d) by conveyance to a trustee pending performance of the contract and subject to its provisions. The general purpose and effect being the same in all of these plans, it is desirable that a uniformly applicable rule be established. The rule prescribed is that in the sale or contract for sale of personal property on the installment plan, whether or not title remains in the vendor until the property is fully paid for, the income to be returned by the vendor will be that proportion of each installment payment which the gross profit to be realized when the property is paid for bears to the gross contract price. Such income may be ascertained by taking that proportion of the total payments received in the taxable year from installment sales (always including payments received in the taxable year on account of sales effected in earlier years as well as those effected in the taxable year) which the gross profit to be realized on the total installment sales made during the taxable year bears to the gross contract price of all such sales made during the taxable year. Where a change is made to this method of computing net income the taxpayer's balance sheet should be adjusted conformably as of the date when the change is effected. If for any reason the vendee defaults in any of his installment payments and the vendor repossesses the property, the entire amount received on installment payments, less the profit already returned, will be income of the vendor for the year in which the property was repossessed, and the property repossessed must be included in the inventory at its original cost to himself, less proper allowance for damage and use, if any. 
If the rendor chooses as a matter of consistent practice to treat the obligations of purchasers as the equivalent of eash, such a course is permissible. If sales during prior years contain a different percentage of profit than those of the taxable year, or if for any other reason corrections are required to produce a more accurate result, they can be made as of the end of the taxable year.

Alir. 35. Sale of real estate in lots... Where a traet of land is Furchased with at riew to dividing it into lots or pareels of ground to be sold as such, the entire fair market value as of January $\mathbf{1}$, 1919 , or the cost, if acquired subsequent to that date, shall be equitably apportioned to the several lots or parcels and made a matter of record in the books of the taxpayer, to the end that iny gain derived from the sale of any such lots or parcels may be returned as income for the year in which the sale was made. This rule contemplates that there will be a measure of gain or loss in every lot or parcel sold, and not that the capital invested in the entire tract shall be extinguished before any taxable income shall be returned. The sale of each lot or parcel will be treated as a separate transaction and the gain or loss will be accounted for accordingty.

ArT. 36. Sale of real estate involving deferred payments.Deferred parment sales of real estate ordinarily fall into two classes when considered with respect to the terms of sale, as follows :

(1) Installment transactions, in which the initial payment is relatively small (generally less than one-fourth of the purchase price) and the deferred payments usually numerous and of small amount. They include (a) sales where there is immediate transfer of title when a small initial payment is made, the seller being protected by a mortgage or other lien as to deferred payments, and (b) agreements of purchase and sale which contemplate that a conveyance is not to be made at the outset, but only after all or a substantial portion of the agreed installments have been paid.

(2) Deferred payment sales not on the installment plan, in which there is a substantial initial payment (ordinarily not less 
than onefourth of the purehase price), deferred payments being secured by a mortgage or other lien. Such sales are distinguished from sales on the installment plan by the substantial character of the initial payment and also usnally by a relatively small number of deferred payments.

In determining how these classes shall be treated in levving the income tax, the question in each case is whether the income to be reported for taxation shall be based only on amounts actually reeeived in a taxable year, or on the entire consideration made up in part of agreements to pay in the future.

ART. 37. Sale of real estate on installment plan.- In the two kinds of transactions included in class (1) in the foregoing article, installment obligations assumed by the buyer are not ordinarily to be regarded as the equivalent of cash, and the vendor may report as his income from such transactions in any year that proportion of each payment actually received in that yeur which the gross profit to be realized when the property is paid for bears to the gross contract price. If the return is made on this basis and the vendor repossesses the property after default by the buyer, retaining the previous parments, the entire amount of such payments, less the profit previously returned, will be income to the vendor and will be so: returned for the year in which the property was repossessed, and the property repossessed must be included in the inventory at its original cost to himself (less any depreciation as defined in articles 171 and 172). If the taxpayer chooses as a matter of settled practice consistently followed to treat the obligations of the purchaser as equivalent to cash and to report the profit derived from the entire consideration, cash and deferred payments, as income for the year when the sale is made, this is permissible. If so treated the rnle prescribed in article 38 will apply.

ART. 38. Deferred payment sales of real estate not on installment plan.- In class (2) in article 36 the obligations assumed by the buyer are much better secured becanse of the margin afforded by the substantial first payment, and experience shows that the greater number of such sales are eventually carried out according to their terms. These obligations for deferred payments are therefore to be regarded as equivalent to cash, and the profit 
indicated by the entire consideration is taxable income for the year in which the initial payment was made and the obligations assumed. If the buyer defaults and the seller regains title to the land by agreement or process of law, retaining payments previously made, he may deduct from his gross income as a loss in the year of repossession any excess of the amount previously reported as income over the amount actually received, and must include such real estate in his inventory at its original cost to himself (less any depreciation as defined in articles 171 and 172).

ARт. 39. Isolated installment transactions. - The provisions of articles 34 to 38 , both inclusive, are applicable only to transactions by taxpayers who regularly deal in personal or real property upon the installment or deferred payment plan. Isolated transactions are not within the scope of these provisions.

Art. 40. Annuities and insurance policies.-Annuities paid under an annuity contract are subject to tax to the extent that the aggregate amount of the payments to the annuitant exceeds any amounts paid by him as consideration for the contract. An annuity charged upon devised land is income taxable to the annuitant, whether paid by the devisee out of the rents of the land or from other sources. The devisee is not required to return as taxable income the amount of rent paid to the annuitant, and he is not entitled to deduct from his taxable income any sums paid to the annuitant. Where an insured receives under life insurance, endowment or annuity contracts sums in excess of the premiums paid therefor, such excess is income for the year of its receipt. (Article 72.) Distributions on paid-up policies which are made out of earnings of the insurance company are in the nature of corporate dividends and as such are income of an individual subject to the tax.

Art. 41. Pension receipts.- - Pensions are classified as follows:

(1) Periodical payments made to persons retired from service (a) after reaching a specified age, or (b) after a stated period of employment, or (c) on account of disability.

(2) Compensation for personal injuries or sickness.

Both classes of pensions may be paid out of funds to which the recipient has contributed, or out of funds to which the recipient has made no contribution. 
First.- When received by a nonresident, a pension of any kind is not taxable income, as it is an annuity and, therefore, exempt from taxation against a nonresident under section 359 , subdivision 3 of the Tax Law.

Second.-When received by a resident, a pension is not taxable (a) when received from the United States Government, or (b) if received as compensation for personal injuries or sickness, or for accident or health insurance, or under workmen's compensation acts, or through war risk insurance, or under any law for the benefit or relief of injured or disabled members of the military or naval forces of the United States. Pensions arising upon retirement for disability are not regarded as compensation for personal injuries within the meaning of this paragraph. Pensions received from the New York City Teachers' R'tirement Fund are exempt from taxation. (New York City Charter, section 1092-W.)

Third.-All other pensions received by residents are taxable. Fourth.-If the recipient has contributed to the fund out of which the pension is paid, the pension receipts are taxable only when, and to the extent that, they exceed the aggregate amount of all payments or contributions made by him to the fund.

ArT. 42. Rents and royalties. - When improvements made by a lessee become part of the real estate, the value of such improvements upon the expiration of the existing term of the lease is income to the lessor.' In general, sums paid by a tenant for the use of property, although to another than the landlord, are properly to be regarded as rent and constitute income of the landlord. See further article 120. Royalties on patents and copyrights are income.

AirT. 43. Forgiveness of indebtedness.- The cancellation and forgiveness of indebtedness is dependent upon the circumstances for its effect. It may amount to a payment of income or to a gift or to a capital transaction. If, for example, an individual performs services for a creditor, who in consideration thereof cancels the debt, income to that amount is realized by the debtor as compensation for his services and a corresponding amount is deductible by the creditor. If, however, a creditor merely desires to benefit a debtor and without any consideration therefor cancels the debt, the amount of the debt is a gift from the creditor to the 
debtor and need not be included in the latter's gross income and may not be dedueted by the ereditor. If a corporation to which a stockholder is indebted forgives the debt, the transaction has the effect of the payment of a dividend.

ArT. 44. When inchded in gross income.-Gains, profits and income are to be included in the gross income for the taxable year in which they are received by the taxpayer, unless they are included when they accrue to him in accordance with the approved method of accounting followed by him. (Articles 11-14.) Lands which are received as compensation for services in one year, the title to which is disputed and in a later year adjudged to be valid, constitute income to the grantee in the former year. On the other hand, a person may sue in one year on a pecmiary elaim or for property, but money or property recovered on a judgment therefor rendered in a later year would be income in the year in which receiced assuming that it would have been income in the earlier year if then received. This is true of a recovery for patent infringement. Bad debts or accounts charged of because of the fact that they were determined to be worthless, which are subsequently recovered, whether or not by suit, constitute income for the year in which recovered, regardless of the date when the amounts were charged off. (Articles 123 and 161.)

ART: 45. Income not reduced to possession. - Income which is credited to the account of or set apart for a taxpayer and which may be drawn upon by him at any time is subject to tax for the year during which so credited or set apart (unless previously accrued by the taxpayer and included in his return of income), although not then actually reduced to possession. To constitute receipt in such a case the income must be eredited to the taxpayer without any substantial limitation or restriction as to the time or manner of payment or condition upon which payment is to be made. A book entry, if made, should indicate an absolute transfer from one account to another. If the ineome is not credited, but is set apart, such ineome must be unqualifiedly: subject to the demand of the taxpayer. For example, where a corporation contingently credits its employees with bonus stock, but the stoek is not available to such employees until the termination of five years of employment, the mere crediting on the books of the corporation 
does not constitute receipt. The distinction between receipt and accrual must he lopt in mind. Income may accrue to the taxpayer and yet not be subject to his demand or capable of being drawn on or against by him.

ArT. 46. Examples of constructive receipt.- Where interest coupons have matured, but have not been cashed, such interest, though not collected when due and payable, is nevertheless available to the taxpayer and should therefore be included in his gross income for the year during which the coupons matured unless the debtor be in default. This is so although the coupons are exchanged for other property instead of eventually being cashed. Dividends on corporate stock are subject to tax in the year in which made pavable, although not yet collected by the stockholder. (Tax Law, section 359 and articles 14 and 61.) The distributive share of the profits of a partncr in a partnership is regarded as received at the close of the partnership's fiscal year. (Tax Law, section 364, and articles 229 and 230.) Interest credited on savings bank deposits, even though the bank nominally has a rule, seldom or never enforced, that it may require a stipulated number of days' notice in advance of cashing depositors' shecks, is income to the depositor when credited. An amount credited to shareholders of a building and loan association, when such credit passes without restriction to the shareholder has a taxable status as income for the year of the credit. Where the anrount of such accumulation does not become available to the shareholder until the maturity of a share, the amount of any share in excess of the aggregate amount paid in by the shareholder (or value on January 1, 1919, plus subsequent payments) is insome for the year of the maturity of the share. 


\section{GROSS INCOME DEFINED : INCLUSIONS: DIVIDENDS}

ArT. 61. Dividends.-Dividends for the purpose of the statute comprise any distribution in the ordinary course of business, even though extraordinary in amount, made by a domestic or foreign corporation to its shareholders out of its earnings or profits. The mere declaration of a dividend is not a distribution. Dividends are income for the year in which payable, regardless of when the earnings or profits out of which they were paid were accumulated, except that dividends declared payable to stockholders of record prior to January 1, 1919, are to be excluded from gross income even if received on or after January 1, 1919. (Article 79.) Although interest on United States bonds and certain other obligations is not taxable when received by a corporation, upon amalgamation with other funds of the corporation such income loses its identity and when distributed to stockholders in dividends is taxable to the same extent as other dividends. See further article 46.

Arт. 62. Dividends paid in property-_-Dividends paid in securities or other property (other than its own stock), in which the earnings of a corporation have been invested, are income to the recipients to the amount of the fair market value of such property when receivable by the stockholders. A dividend paid in stock of another corporation is not a stock dividend. Where a corporation declares a dividend in stock of another corporation, setting aside the stock to be so distributed and notifying the stockholders of its action, the income arising to the recipients of such stock is its fair market value at the time the dividend becomes payable. Scrip dividends are subject to tax in the year in which the warrants are issuable to the stockholders.

ART. 63. Stock dividends.-A dividend paid in stock of the corporation is income to the amount of the fair market value of the stock received as a dividend. But stock distributions made out of surplus when there are no earnings or profits are free from tax as dividends. (See article 66.) Stock dividends paid from earnings or profits received by a fiduciary and retained as an 
accretion to the estate under the terms of the will or trust are income to the estate.

Art. 64. Sale of stock received as a dividend.-For the purpose of ascertaining the gain or loss derived from the sale of stock of a corporation received subsequent to December 31, 1918, as a dividend or from the sale of the stock in respect of which such dividend was paid, the cost of each share of new stock is the quotient of the sum of (a) the cost of the old stock or its value on January 1, 1919, if acquired prior thereto, plus (b) the valuation at which the new stock was returnable as income, divided by the number of old and new shares.

ART. 65. Distribution in liquidation.- So-called liquidation or dissolution dividends by corporations during dissolution are not dividends within the meaning of the statute, and amounts so distributed are to be regarded as payments for the stock of the dissolved corporation. Any excess so received over the cost of his stock to the stockholder, or over its fair market value as of January 1,1919 , if acquired prior thereto, is a taxable profit. A distribution in liquidation of the assets and business of a corporation, which is a return to the stockholder of the value of his stock upon a surrender of his interest in the corporation, is distinguishable from a dividend paid by a going corporation out of current earnings or accumulated surplus when declared by the directors in their discretion, which is in the nature of a recurrent return upon the stock.

Art. 66. Distribution from depletion or depreciation reserve.A reserve set up out of gross income by a corporation and maintained for the purpose of making good any loss of capital assets on account of depletion or depreciation is not a part of its surplus out of which ordinary dividends may be paid. A distribution made from such a reserve will be considered a liquidating dividend and will constitute taxable income to a stockholder only to the extent that the amount so received is in excess of the cost or fair market value as of January 1, 1919, of his shares of stock. No distribution, however, will be deemed to have been made from such a reserve except to the extent that the amount paid exceeds the surplus and undivided profits of the corporation. In general, any distribution made by a corporation other than out 
of eamings or profits is to be regarded as a return to the sstockholder of part of the capital represented by his shares of stock, and upon a subsequent sale of such stock his profit will be the excess of the selling price over the cost of the stock or its fair market value as of January 1, 1919, after applying on such cost or xalue the amount of any such eapital distribution. 


\section{GROSS INCOME DEFINED: EXGLUSIONS}

ART. 71. What excluded from gross income- - Gross income excludes the items specifically exempted by scetion 359 of the Tax Law: Such tax-fiee income should not be included in the return of income and need not be mentioned in the return, except where information regarding it is specifically called for. The exclusion of such income should not be confused with the reduction of income by the application of allowalle deductions or exemptions. (Tax Law, sections 360 and 362 and article 11.)

Arv: 72. Proceeds of insurance- - (a) Upon the death of an insured the proceeds of his life-insurance policies, whether paid to his estate or to individual beneficiaries, directly: or in trust, are exeluded from the gross income of the beneficiary. (Tax Enak; section, 359.), (b) During his life only so mueh of the amount received by an insured under life, endowment ar annuity contracts as: represents a return, without interest, of the value thereof on January 1, 1919, plus the preminms pail by him thereafter, is excluded from his gross income. (.lrticle 40.) (c), The amounts reeeived by an insured or his estate or other beneficiaries through aceident or health insumenes or miler wonkmen's compensation acts as compensation for personal injuries: or sickness are excluded from the gross income of the insured, his estate and other beneficiaries. Any damige recovered by suit or agreement on account of such injuries or sickness are similarly excluded from the gross ineome of the individual injured or sick, or of his estate or other beneficiaries entitled to reccive such damages. Amounts, received from any allotments, family allowances, compensation, or death or disability insurance pavable under the War Risk Insurance Act of September 2, 1917, as: amended, are excluded from gross. income.

Ant. $7 \%$ Gifts and bequests.- Money and real or personal property receired as gifts, or received under a will or under statutes of descent and distribution, are exempt from tax, althøugh the ineome thenefrom derived from investment, sale or otherwice is not. (Tax Law, section 359, and articles 23, 4.3 and 93.) An amount of principal paid under a marriage settle- 
ment is a gift. Neither alimony nor an allowance based on a separation agreement is included in gross income, nor are they allowable deductions. (Article 125.)

Ant. 74. Interest exempt from tax.-Among income exempt from tax is interest upon the obligations of the United States or its possessions; or securities issued under the provisions of the Federal Farm Loan Act of July 17, 1916; or bonds issued by the war finance corporation; or the obligations of the State of New York or of any municipal corporation or political subdivision thereof; or investments upon which the tax provided for in section 331 of the Tax Law has been paid between June 1, 1917, and May 14, 1919, during the period of years for which such tax shall have been paid. (Tax Law, section 359.) However, the income from securities (1) upon which the investment tax was paid after May 14, 1919, or (2) upon which the secured debt tax or the mortgage tax was paid, is not exempt. The term "political subdivision" denotes any division of the State made by the proper authorities thereof acting within their constitutional powers for the purpose of carrying out a portion of those functions of the State which by long usage and the inherent necessities of government have always been regarded as public. Political subdivisions of the State, within the meaning of the exemption, include special assessment districts so created, such as road, water, sewer, gas, light, drainage, school and similar districts and divisions. The purchase by the State or any political subdivision thereof of property subject to a mortgage does not render the debt an obligation of the State, or of such political subdivision, and the interest upon it does not become exempt from taxation, whether or not the purchaser assumes the payment of the debt.

ArT. 75. Dividends and interest from Federal land bank and national farm loan association.- The income derived from dividends on stock of Federal land banks and national farm loan associations and from interest on farm loan bonds is excluded from gross income. (Tax Law, section 359.)

ART. 76. Dividends from federal reserve banks. - The dividends received on the stock of federal reserve banks are excluded from gross income. Dividends paid by member banks, however, are treated like dividends of ordinary corporations. 
ART. 77. Income of foreign consular officers. - The income of foreign ambassadors and ministers from investments in bonds and stocks and from interest on bank balances, and the fees of foreign consuls-general, consuls, vice-consuls-general, vice-consuls, deputy consuls-general, deputy consuls and consular agents, who are not citizens of the United States, are excluded from gross income, but income of such foreign officials from any business carried on by them in the State of New York would be taxable. The compensation of citizens of the United States who are officers or employees of a foreign government is, however, not exempt from tax.

Art. 78. Compensation received from the United States.Salaries, wages and other compensation received from the United States by officials or employees thereof, whether in a civilian capacity or in the military or naval service, including the fees and commissions of receivers and referees appointed by Federal courts, are exempt from taxation and should be excluded from gross income. The salaries, wages and other compensation of persons engaged in the operation of railroads, telegraphs, telephones and cables during the period of federal control and operation are regarded as paid by the United States, and likewise exempt from taxation. The amount received must, however, be reported on the return of income, and must be subtracted from the personal exemption. (Article 210, and Tax Law, section 359, subdivision 1-f, and 362, subdivision 3.)

ArT. 79. Income accruing prior to January 1, 1919. - Property held by the taxpayer on January 1, 1919, is capital. Included in this capital are all claims, whether cvidenced by writing or not, and all interest which had accrued thereon before that date. Interest accruing on or after that date is taxable income. Where an interest-bearing claim contracted prior to January 1, 1919, is paid in whole or in part after that date, any gain derived from the conversion of the claim into money is taxable. The amount of such gain is the excess of the proceeds of the claim (both principal and interest), exclusive of any interest accrued since December 31, 1918 (but such interest must be returned as income), over the fair market value of the claim as of January 1 , 1919 (both principal and interest then accrued). In the case 
of an insurance policy its surrender value: as of Jaunary 1,1212 , may be used as a basis for the purpose of ascertaining the gain derived from the sale or other disposition of such policy. Where: services were rendered prior to January 1, 1919, but paid for thereafter, the amount received for such services ordinarily should not be included in gross income. If, however; the value of such. a elaim on January 1, 1919, was less than the amount received subsequent to that date, the difference-should be included in gross income. $\Delta$ elaim for the puriose of this article means a right. existing uneonditionally on January 1,1919 , and then assignable, whether presently pavable or not. Interest does not, of course, include dividends on corporate stock. (Tax Law, section 350, and article 61.) Dividends declared payable to stockholders of record prior to January 1, 1919, are to be excluded from gross. income even if received on or after January $1,1919$.

ART. 80. Subtraction for redemption of trading stamps.-Whenea taxpayer for the purpose of promoting his business, issues with sales trading stamps or premium coupons redeemable in mexchandise or cash, he should in computing the ineome from such sales. subtract only the amount received or receivable which will be required for the redemption of such part of the total issue of trading stamps or premium coupons issued during the taxable: year as will eventually be presented for redemption. This amount will be determined in the light of the experience of the taxpayer in his particular business and of other users engaged in similar businesses. The taxpayer shall file for each of the five preceding: years, excluding the taxable year, or such number of these years as stamps or coupons have been issued by him, a statement showing (a) the total issue of stamps during each year, (b) the total stamps redeemed in each year; and (c): the percentage for each year of the stamps redeemed to the stamps issued in such year. A similar statement shall also be presented showing the: experience of other users of: stamps or: coupons: whose experience is relied upon by the taxpayer to determine the amount to be: subtracted from the proceeds of sales. The Comptroller widl examine the basis used in each return, and in any case in which the amount subtracted in respect of such stamps or coupons is: 
found to be excessive an amended return or amended returns will be required.

In the case of an individual furnishing a coroperative or other trading stamp system for others, he shall conpute his income in aceordance with the same principles and submit similar statements with his return. 


\section{GROSS INCOME DEFINED: BASIS FOR DETER- MINING GAIN OR LOSS}

ART. 91. Basis for determining gain or loss from sale, gift or other disposition.-For the purpose of ascertaining the gain or loss from the sale, gift, exchange, or other disposition of property the basis is (a) its fair market price or value as of January 1, 1919 , if acquired prior thereto, or (b) if acquired on or after that date, its cost or its approved inventory value. In both cases proper adjustment must be made for any depreciation or deplo tion sustained. Gifts, whether charitable contributions or otherwise, constitute a disposition of property which may result in a profit or loss to be measured by the difference between the cost (or the value on January 1, 1919, if acquired prior thereto) and the value at the date of the gift.

Art. 92. Fair market value January 1, 1919.- What the fair market price or value of property was on January 1,1919 , is a question of fact to be established by any evidence which will reasonably and adequately make it appear.

In the case of securities dealt in on a recognized exchange, the fair market value on January 1, 1919, will ordinarily be determined by the average of the bid and asked prices after closing on December 31, 1918. In all other cases other evidence of value is necessary and bona fide sales nearest January 1, 1919, of securities publicly or privately dealt in, or appraisals for inheritance or similar purposes, will be considered.

ArT. 93. Sale of property acquired by gift or bequest.- In the case of property acquired by gift, bequest, devise or descent the basis for computing gain or loss on a sale is the fair market price or value of the property at the date of acquisition or as of January 1, 1919, if acquired prior thereto. For the purpose of determining the profit or loss from the sale of property acquired by bequest, devise, or descent since December $31 ; 1918$, its value as appraised for the purpose of the New York transfer tax, or in the case of estates not subject to that tax its value as appraised in a State court for the purpose of State inheritance tax, should be deemed to be its fair market value when acquired. If there 
has been no judicial determination of the fair market value as of the date of acquisition, such value is a matter of fact to be proved by the taxpayer. (Tax Law, section 353.)

ART. 94. Exchange of property.-- Gain or loss arising from the acquisition and subsequent disposition of property is realized when as the result of a transaction between the owner and another person the property is converted into cash or into property (a) that is essentially different from the property disposed of and (b) that has a market value. In other words, both (a) a change in substance and not merely in form, and (b) a change into the equivalent of cash, are required to complete or close a transaction from which income may be realized. By way of illustration, if a man owning ten shares of listed stock exchanges his stock certificate for a voting trust certificate, no income is realized, because the conversion is merely in form; or if he exchanges his stock for stock in a small, closely held corporation, no income is realized if the new stock has no market value, although the conversion is more than formal; but if he exchanges his stock for a liberty bond, income may be realized, because the conversion is into independent property having a market value. The property received in exchange may be real estate, personal property, or a chose in action. The exchange of a so-called convertible bond for stock pursuant to such a privilege granted in the bond will produce income if the stock received in exchange has a fair market value in excess of the cost or fair market value as of January 1, 1919, of the bond. (Tax Law, section 354.)

Art. 95. Determination of gain or loss from exchange of property. - (a) The amount of income derived in the case of an exchange of property, as of stock for a bond, is the excess of the fair market value at the time of exchange of the bond received in exchange over the original cost of the stock exchanged for it, or over the fair market price or value of such stock as of January 1, 1919, if acquired before that date. The anount of income derived from a subsequent sale of the bond for cash is the excess of the amount so received over the fair market value of such bond when acquired in exchange for the stock. (b) On the other hand, if the property received in exchange is substantially the same property or has no market value, then no gain or loss is 
realized, but the new property is to be regarded as substitinted for the old and upon a sale of the new property the amount of income derived is the excess of the amount so received over the cost or fair market value as of January 1, 1919, of the old. (Tax Law, section 3.5.5.)

ART. 96. Exehange for different. kinds of property.- (a) If property is exchanged for two different kinds of property, such as bonds and steck, the bonds having a market value and the stoek none, the value of the bonds is to be compared with the cast: or fair market vilne as of January 1, 1919, of the origiaal property, as the ease may be. If the market value of the bonds is less that such cost or value, the difference represents the cost of the stock. If the market value of the bonds is greater than such cost or value:the difference is, taxible ineome at the time: of the exchange: and whenever sold the entire proceeds of the stock will be taxable. (b) If property is exchanged for two different kinds of property, such as bonds and stock, neither having a market value, the cost or fair market value as of January 1,1919 , of the original property should he apportioned, if possible, between the bonds; and stoek for the purpose of determining gain or loss on subsequent sales. If no fair apportionment is practicable, no profit on arry suberquent sale of any part of the bonds or stock is realized watil out of the procects of sale there shall have been recovered the entire cost or fair market value as of Janumr 1, 1919, of the original preperty.

ArT. 97. Exchange of property and stock:- Where property is transferred to a corporation in exchange for its stock, the exchange constitutes a closed transaction and the former owner of the property realizes a gain or loss if the fair market value of the stock is greuter or less than the cost or the fair market value as of January 1, 1919 (if acquired prior thereto), of the property given in exchange. For the rule applicable where a corporation, in conncetion with a reorganization, merger or consolidation, exchanges property for stock, see article 98 .

ART. 98: Exchange of stock for other stock of no greater par value.-In general, where two (or more) corporations unite their properties by either (a) the dissolution of corporation $B$ 
and the sale of its assets to corporation $A$, or (b) the sale of its property by $B$ to $A$ and the dissolution of $B$, or (c) the sale of the strock of $B$ to $A$ and the dissolution of $B$, or (d) the merger of $B$ into A or (e) the consolidation of the corporations, no taxable income is received from the transaction by $\mathrm{A}$ or $\mathrm{B}$ or the stockholders of either, provided the sole consideration received by $B$ and its istockholders in (a), (b), (c) and (d) is stock or securities of $A$, and by $\Lambda$ and $B$ and their stockholders in (e) is stock or speurities of the consolidated corporation, in any case of no greater aggregate par or face value than the old stock and securities swurrendered. The term "reorganization," as used in section :54 of the statute, includes cases of corporate readjustment where stockholders exchange their stock for the stock of a holding corperation, provided the holling corporation and the original corperation, in which it holds stock, are closely related and affiliated. So-called "no-par-value stock" issued under a statute or statutes which require the eorporation to fix in a certificate or on its books cof account or otherwise an amomt of capital or an amount of stock issued which may mot he impaired by the distribution of dividends, will for the purpose of this section be deemed to have a par xalue representing an aliquot part of such amount, proper account being taken of any preferred stock issued with a prefenence as to principal. In the case (if any) in which no such amounit of capital or issued stock is so required, "no-par-value stoek" received in exchange will be regarded for purposes of this section as having in fret no par or face value, and consequently as having "no greater agrgregate par or frce value" than the stack or securities exchanged therefor.

ArT. 99. Determination of gain or loss from subsequent saleThe new stock and somurities received as described in the precoding article take the place of the old stock and securities. For the purpose, therefore, of ascertaining the grain derived or loss sustained from the subsequent sale of any stock or securities so received, the original cost to the taxpayer or the fair market value as of Jamuary 1, 1919, of the stock or securities in respect of which the new stock and securities were issucd, less any untaxed distribution made to the taxpayer by $\mathrm{A}$ out of the former capital or surplus of $B$, or by the consolidated corporation out of the 
former capital or surplus of $\mathrm{A}$ or $\mathrm{B}$, is the basis for determining the amount of such gain or loss.

Art. 100. Exchange of stock for other stock of greater par value. - If in the case of any reorganization, merger or consolidation the aggregate par or face value of the new stock or securities received is in excess of the aggregate par or face value of the stock and securities exchanged, income will be realized from the transaction by the recipients of the new stock or securities to an amount limited by (a) the excess of the par or face value of the new stock or securities over the par or face value of the old and (b) the excess of the fair market value of the new stock or securities over the cost or fair market value as of January 1 , 1919 , of the old. In other words, the taxable profit will be (a) or (b) whichever is less. Upon a subsequent sale of the new stock or securities their cost to the taxpayer will be the cost or fair market value as of January 1, 1919, of the old stock and securities, plus the profit taxed on the exchange.

ArT. 101. Readjustment of partnership interests.-When a partner retires from a partnership, or it is dissolved, he realizes a gain or loss measured by the difference between the price received for his interest and the cost to him or (if acquired prior thereto) the fair market value as of January 1, 1919, of his interest in the partnership, including in such cost or value the amount of his share in any undistributed partnership net income earned since December 31, 1918, on which the income tax has been paid. If, however, the partnership distributes its assets in kind and not in cash, the partner realizes no gain or loss until he disposes of the property received on distribution. Whenever a new partner is received into a partnership, or any existing partnership is reorganized, the facts as to such change or reorganization should be fully set forth in the next return of income, in order that the Comptroller may determine whether any gain or loss has been realized by any partner. But see also article 94 . 


\section{DEDUCTIONS ALLOWED: BUSINESS EXPENSES}

Arr. 111. Business expenses.-Business expenses (whether subtracted from total receipts in computing gross income or deducted from gross income in computing net income) include all items entering into what is ordinarily known as the cost of goods sold, together with selling and management expenses, except such classes of items as are treated in articles 136-190 under "Deductions Allowed." Among the items to be treated as business expenses are material, labor, supplies and repairs in the case of a manufacturer, while a merchant would include his purchases of goods bought for resale. In either case the amount to be taken as a deduction in any year should be determined by taking into consideration the inventory at the beginning and end of the year. Other items that may be included as business expenses are reasonable compensation for the services of officers and employees, advertising and other selling expenses. A taxpayer is entitled to deduct all the ordinary and necessary expenses paid in carrying on his business from his gross income from whatever source. Expenses in earning income which is not taxable do not constitute allowable deductions in computing net income from other sources which are taxable under the law. In the ease of a nonresident taxpayer the ordinary and necessary expenses which may be deducted are those paid in connection with income arising from sources within the state only. (Tax Law, section 360, and articles 482 and 481.)

AR'T. 112. Cost of materials.- Taxpayers carrying materials and supplies on hand should include in expenses the charges for materials and supplies only to the amount that they are actually consumed and used in operation during the year for which the return is made, provided that the cost of such material and supplies has not been taken into account in determining the net income for any previous year. If a taxpayer carries materials or supplies on hand for which no record of consumption is kept or of which physical inventories at the beginning and end of the year are not taken, it will be permissible for the taxpayer to include in his expenses and deduct from gross income the total cost of 
such supplies and materials as were purchased during the year for which the return is made, pmovided the net income is sclearly reflected by this method.

Art. 113. Repairs. - The cost of incidental repairs which neither materially add to the value of the property nor appreciably frolong its life, but keep it in an ordinarily efficient operating rondition, may be deducted as expense, provided the plant or property account is not increased by the amount of such expenditures. Repairs in the nature of replacements, to the exten't that they arrest deterioration and anpreciably prolong the life of the fropertr, should be charged against the depreciation reserve.

Arr. 11t. Professional expenses.- - t professional man may *haim as deductions the cost of supjplies used by him in the practice of his profession, expenses paid in the operation and repair of an automobile used in making professional calls, dues to professional societies and subscriptions to professional journals, the rent paid for office rooms, the expense of the fuel, light, water, telephone, etc., used in such ofices, and the hire of office assistants. Anounts expended for books, furniture and professional instruments and equipment of a permanent character are not allowable decluetions, but a preper allowance for the depreciation of such capital assets may be doducted. (Tax Law, section -361. and article 125.)

Art. 115. Compensation for personal services.-Among the ordinawy and meessary expenses paid or incurred in carrying on any trade or business may be inciuded a reasonable allowance for salaries or other compensation for personal services actnally rendered. The test of deductibility in the case of compensation payments is whether they are reasonable and are in faet payments purely for servioes. This test and its practical application may he further stated and illustrated as follows:

(1) Any amount paid in the form of compensation, but not in faet as the purchase price of services, is not deductible. An nstmsible salary may be in part parment for property. For example, an oxner may sell a business to another, the seller agreeing to continue in the service of the purchaser. In such a case it may be found that the salary of the seller is not merely for 
services, but in part eonstitutes payment for the transfer of the business.

(2) The form or method of fixing compensation is not decisive as to deduetibility. While any form of contingent compensation invites serutiny as a possible distribution of earnings of the enterprise, it does not follow that payments on a contingent basis are to be treated fundamentally on any basis different from that applying to compensation at at flat rate. Generally speaking, if contingent compensation is paid pursuant to a free bargain between the enterprise and the individual made before the services are rendered, not influenced by any consideration on the part of the employer other than that of securing on fair and advantageous terms the services of the individual, it should be allowed as a deduction even though in the aetual working out of the entract it may prove to be greater than the amount which would ordinarily be paiel.

(3) In any event the allowance for compensation paid, to be deduetible, may not exceed what is reasonable in all the circumstances. It is in general just to assume that reasonable and true compensation is only sueh amerunt as would ordinarily be paid for like services by like enterprises in like circumstances. The cireumstances to be taken into consideration are those existing at the date when the eontract for services was made, not those existing at the date when the contract is questioned. (Article 23.) The father, is legally entitled to the services of his unemancipated minor ehildren and allowances which he gires them, whether such be in eonsideration of services or otherwise, are not allowable decluctions in his return of income.

Art. 116. Treatment of excessive compensation.- In the case of excessive payments by partnerships, the amounts disallowed should ordinarily be treated as shares of the profits of a partnership, exeept that a payment for property by an indiridual or a partnership should be treated by the individual or partnership as a eapital expenditure and by the recipient as part of the purehase price.

Arrt. 117. Bontses to employees.-Gifts or bonuses to employees will constitute allowable deductions from gross income when such payments are made in good faith and as additional eompensation for services actually rendered by the employees, 
provided such payments, when added to the stipulated salaries, do not exceed a reasonable compensation for the services rendered. Donations made to employees and others, which do not have in them the element of compensation or are in excess of reasonable compensation for services, are considered gratuities and are not deductible from gross income.

Art. 118. Traveling expenses. - Traveling expenses, as ordinarily understood, include railroad fares and meals and lodging. If the trip is undertaken for other than business purposes, such railroad fares are personal expenses and such meals and lodging are living expenses. If the trip is on business, the traveling expenses including railroad fares, meals and lodging become business instead of personal expenses. (a) If, then, an individual whose business requires him to travel receives a salary as full compensation for his services, without reimbursement of traveling expenses, his traveling expenses are deductible from gross income. (b) If such individual receives a salary and is also repaid his actual traveling expenses, no part of such expenses is deductible from gross income and no part of such repayment is returnable as income. (c) If such an individual receives a salary and also an allowance for meals and lodging, as, for example, a per diem allowance in lieu of subsistence, any excess of the cost of such meals and lodging over the allowance is not deductible, but any excess of the allowance over the actual expenses is taxable income. Any person who receives a mileage allowance for railroad fares should return as income any excess of such allowance over his actual expenses for such fares. A payment for the use of a sample room at a hotel for the display of goods is a business expense.

Art. 119. Pension payments.-Amounts paid for pensions to retired employees or to their families or others dependent upon them, or on account of injuries received by employees, and lump sum amounts paid as compensation for injuries, are proper deductions as ordinary and necessary expenses. Such deductions are limited to the amount not compensated for by insurance or otherwise. No deduction shall be made for contributions to a pension fund held by the taxpayer, the amount deductible in such case being the amount actually paid to the employee. When the amount of the salary of an officer or employee is paid for a 
limited period after his death to his widow or heirs in recognition of the services rendered by the individual, such payments may be deducted. Salaries paid by employers during the continuance of the war to employees who are absent in the military or naval service or are serving the Government in other ways at a nominal compensation, but who intend to return at the conclusion of the war, are allowable deductions. (See article 41.)

ART. 120. Rentals.-- Rent for the use of business property is a deductible expense. In the case of a professional man who rents a property for residential purposes but incidentally receives there clients, patients or callers in connection with his professional work (his place of business being elsewhere) no part of the rent is deductible as a business expense. If, however, he uses part of the house for his office, such portion of the rent as is properly attributable to such office is deductible.

Where a leasehold is acquired for a specified sum, the purchaser may take as a deduction in his return an aliquot part of such sum each year, based on the number of years the lease has to run. Taxes paid by a tenant to or for a landlord for business property are additional rent and constitute a deductible item to the tenant and taxable income to the landlord, the amount of the tax being deductible by the latter. The cost of erecting buildings or permanent improvements on ground leased by a taxpayer is additional rental and is, therefore, a proper deduction from gross income, provided such buildings and improvements under the terms of the lease revert to the owner of the ground at the expiration of the lease. In such a case, the cost will be prorated according to the number of years constituting the term of the lease. The lessee will not be permitted to deduct from gross income any depreciation with respect to such buildings, but the cost of incidental repairs necessary to keep them in an efficient condition for the purposes of their use may be deducted. If, however, the life of the improvement is less than the life of the lease, depreciation may be taken by the lessee instead of treating the cost as rent. (Article 42.)

Art. 121. Insurance premiums.-Premiums for insurance against fire, storm, theft, accident or other similar losses in the case of a business, including employer's liability and work- 
men's eompensation insurance, are deductible business expenses. Insurance paid on a dwelling owned and occupied by the taxpayer, is a personal expense, and not deductible. Premiums paid for life insurance by the insured are not deductible:

Where the taxpayer pays premiums on an insurance policy on the life of an employee or individual finaneially interested in the taxpayer's business, for the purpose of protecting himself from loss in the event of the death of any such person, such premiums are not deductible from his gross income. But if the taxpayer is in no sense a benefieiary under sueh a policy, except as he may derive adrantage from the increased effieiency of the employee, and pays the premiums purely as reasonable additional compensation of such employee, they are allowable deductions. (Articles 115 and 11\%.)

ArT. 122. Expenses of farmers. $-\Lambda$ farmer who operates a farm for profit is entitled to deduct from gross income as necessary expenses all amounts actually expended in carrying on the business of farming. The cost of ordinary tools, of short life or small cost, such as hand tools, including shovels, rakes, ete. may be included. The cost of feeding and raising live stock may be treated as an expense decluction, in so far as such cost represents actual outlay, but not including the value of farm produce grown upon the farm or the labor of the taxpayer. Where a farmer is engaged in producing crops which take more than a year from the time of plauting to the process of gathering and disposal, expenses derlucted may he determined upon the crop basis, and such deductions must be taken in the year in which the gross ineome from the crop has been realized. If a farm is operated for recreation or pleasure and not on a commercial basis, and if the expenses incurred in connection with the farm are in excess of the receipts therefrom, the entire receipts from the sale of products may be ignored in rendering a return of ineome, and the expenses incurred, being regarded as personal expenses, will not constitute allowable deductions. The cost of farm machinexy and farm buildings represents a eapital investment and is not an allowable deduction as an item of expense. Amounts expended in the development of farms, orchards and ranches prior to the time when the productive 
state is reached may be regarded as investments of capital. The amount expended in purchasing draft or work animals or live stock either for resale or for breeding purposes is regarded as an investment of capital. The purchase price of an automobile even when wholly used in carrying on farming operations, is not deductible, but is regarded as an investment of capital. The cost of gasoline, repairs and upkeep of an automobile if used wholly in the business of farming is deductible as an expense; if used partly for business purposes and partly for the pleasure or convenience of the taxpayer or his family, such cost may be apportioned according to the extent of the use for purposes of business and pleasure or convenience, and only the proportion of such cost justly attributable to business purposes is deductible as a necessary expense. (Article 30.)

ARr. 123. When charges deductible.- Each year's retum, so far as practicable, both as to gross income and deductions therefrom, should be complete in itself, and taxpayers are expected to make every reasonable effort to ascertain the facts necessary to make a correct return. (Articles 11-14 and \%1.) The expenses, liabilities or deficit of one year can not be used to reduce the income of a subsequent year. A person making returns on an accrual basis has the right to deduct all authorized allowances, whether paid in cash or set up as a liability, and it follows that if he does not within any year pay or accrue certain of his expenses, interest, taxes or other charges, and makes no deduction therefor, he can not deduct from the inccme of the next or any subsequent year any amounts then paid in liquidation of the previous year's liabilities. A loss from theft or embezzlement occurring in one year and discovered in another is deductible only for the year of its occurrence. Any amount paid pursuant to a judgurent or otherwise on account of damages for personal injuries, patent infringement or otherwise, is deductible from gross income when the claim is put in judgment or paid, less any amount of such damages as may have been compensated for by insurance or otherwise. If subsequent to its occurrence, however, a taxpayer first ascertains the amount of a loss sustained during a prior taxable year which has not been deducted from the gross income, he may render an amended 
return for such preceding taxable year, and may file a claim for refund of the excess tax paid by reason of the failure to deduct such loss in the original return. (Tax Law, section 374 and article 5\%4.)

Art. 124. Payments by public utilities.- In the case of a public utility acquired, constructed, operated or maintained by a taxpayer under contract with any State, Territory or political subdivision thereof, or with the District of Columbia, containing an agreement that a portion of the net earnings of such public utility shall be paid to the State, Territory or political subdivision thereof, or the District of Columbia, the amount so paid may be deducted by the taxpayer as a necessary expense in transacting business. (Tax Law, section 360.)

ART. 125. Items not deductible.-Amounts paid for increasing the capital value or for restoring the depreciated value of property are not deductible from gross income. (Article 171.) Amounts expended for securing a copyright and plates, which remain the property of the person making the payments, are investments of capital. The cost of defending or perfecting title to property constitutes a part of the cost of the property and is not a deductible expense. The amount expended for architect's services is part of the cost of the building. Commissions paid in purchasing securities are a part of the cost price of such securities. Commissions paid in selling securities are an offset against the selling price. Expenses of the administration of an estate, such as court costs, attorney's fees and executor's commissions, are chargeable against the corpus of the estate and are not allowable deductions. Amounts to be assessed and paid under an agreo ment between bondholders or stockholders of a corporation, to be used in a reorganization of the corporation, are investments of capital and are not deductible for any purpose in returns of income. An assessment paid by a stockholder of a national bank on account of his statutory liability is similarly not deductible.

Expenses incurred by a legatee to sustain or attack the validity of a will are not deductible expenses.

Alimony and an allowance paid under a separation agreement are not deductible from gross income. Personal and living expenses are not deductible. (Article 73.) 


\section{DEDUCTIONS ALLOWED: INTEREST}

$A_{R T}$. 136. Interest.-A resident is entitled to deduct from gross income that proportion of the total interest paid or accrued as the amount of his gross income, as defined in the Tax Law, section 359, bears to his total gross income. His total gross income is his gross income, as defined by the Tax Law, section 359, plus his income exempt from taxation. A taxpayer shall not be entitled to any deduction for interest paid or accrued unless his return discloses his total gross income, whether taxable or exempt. See article 434 for interest deductions allowable to nonresidents.

ART. 137. Interest on capital_-_ Interest calculated as being a charge against income on account of capital invested in the business, but which does not represent a payment on an interestbearing obligation, is not an allowable deduction from gross income; that is to say, the interest which the money might earn if otherwise invested is not a deductible charge against income. 


\section{DEDUGTIONS ALLOWED: TAXES}

ArT. 141. Taxes. - Taxes other than income taxes paid or accrned within the taxable year imposed, first, by the authority of the United States, or of any of its possessions, or, second, by the authority of any State or Territory, or any county, school district, municipality or other taxing subdivision of any State or "Teritory, not including those assessed against local benefits of a kind tending to increase the value of the property assessed, 01. third, by the authority of any foreign government, are deductible from gross income. (T'ax Law, section 360.) Postage is not a tax. Amounts paid to States under secured debts laws in order to render securities tax exempt are deductible. Automobile license fees are ordinarily taxes.

Art. 142. Federal duties and excise taxes. - Import or tariff duties paid to the proper customs officers, and business, license, privilege, excise and stamp taxes paid to internal revenue collectors, are deductible as taxes imposed by the authority of the United States, provided they are not added to and made a part of the expenses of the business or the cost of articles of merchandisf with respect to which they are paid, in which case they camot be separately deducted.

Art. 143. Taxes for local benefits. - So-called taxes, more properly assessments, paid for local benefits, such as street, sidewalk and other like improvements, imposed because of and measured by some benefit inuring directly to the property against which the assessment is levied, do not constitute an allowable deduction from gross income. A tax is considered assessed against local benefits when the property subject to the tax is limited to the property benefited. Special assessments are not deductible, even though an incidental benefit may inure to the public welfare. The taxes deductible are those levied for the general public welfare by the proper taxing authorities at a like rate against all property in the territory over which such authorities have jurisdiction. Assessments under the statutes of California relating to irrigation and of Iowa relating to drainage, and under certain statutes of Tennessee relating to levees, are 
limited to property benefited, and when it is clear that the assessments are so limited, the amounts paid thereunder are not deductible as taxes. When assessments are made for the purpose of maintenance or repair of local benefits, the taxpayer may deduct the assessments paid as an expense incurred in business, if the payment of such assessments is necessary to the conduct of his business. When the assessments are made for the purpose of constructing local benefits, the payments by the taxpayer are in the nature of capital expenditures and are not deductible. Where assessments are made for the purpose of both construction and maintenance or repairs, the burden is on the taxpayer to show the allocation of the amounts assessed to the different purposes. If the allocation cannot be made, none of the amounts so paid is deductible.

ART. 144. Inheritance taxes. - State inheritance taxes paid by the executor or administrator of an estate of a deceased person, which are provided by law to be deducted from the respective legacies or distributive shares, are not allowable deductions in computing the net income of such estate subject to tax, even though the will contains a direction to pay inheritance taxes out of the residue. An inheritance tax is upon the transfer of the property and not upon the estate of the decedent or upon the executor or administrator, although the latter is required to pay it. In general, taxes paid or accrued within the year imposed by the authority of any State, or otherwise, are limited to those imposed upon the taxpayer and do not include taxes paid by him on behalf of another, even though he is required by law to make such payment. Since, moreover, the tax is imposed upon the transfer before the property reaches the legatee or distributee, and merely diminishes the capital share of the estate received by him, such tax is not imposed upon the legatee or distributee and is not an allowable deduction from his income. Similarly, Federal estate taxes are not deductible. 


\section{DEDUCTIONS ALLOWED: LOSSES}

ARt. 151. Losses.- Losses sustained during the taxable year and not compensated for by insurance or otherwise are fully deductible (except by nonresidents) if (a) incurred in the taxpayer's trade or business, or (b) incurred in any transaction entered into for profit, or (c) losses of property arising from fires, storms, shipwreck or other casualty, or from theft. They must usually be evidenced by closed and completed transactions. In the case of the sale of assets the loss will be the difference between the cost thereof, less depreciation sustained since acquisition, or the fair market value as of January 1, 1919, if acquired before that date, less depreciation since sustained, and the price at which they were disposed of. (Tax Law, section 355 and articles 31-39 and 91.) When the loss is claimed through the destruction of property by fire, flood or other casualty, the amount deductible will be the difference between the cost of the property or its fair market value as of January 1, 1919, if acquired prior thereto, and the salvage value thereof, after deducting from the cost (or value as of January 1, 1919,) the amount, if any, which has been or should have been set aside and deducted in the current year and previous years from gross income on account of depreciation and which has not been paid out in making good the depreciation sustained. But the loss should be reduced by the amount of any insurance or other compensation received. A loss in the sale of an individual's residence is not deductible. Losses in illegal transactions are not deductible. See article 435 for deductions for losses allowable to nonresidents.

ART. 152. Voluntary removal of buildings.- Loss due to the voluntary removal or demolition of old buildings, the scrapping of old machinery, equipment, ete, incident to renewals and replacements will be deductible from gross income in a sum representing the difference between the cost of such property demolished or scrapped (or its fair market value on January 1, 1919, if acquired prior thereto) and the amount of a reasonable allowance for the depreciation which the property had undergone prior to its demolition or scrapping; that is to say, the deductible loss is anly so much of the original cost (or value as of January 1 , 
1919) of the property, less salvage, as would have remained unextinguished had a reasonable allowance been charged off for depreciation during each year prior to its destruction. When a taxpayer buys real estate upon which is located a building which he proceeds to raze with a view to erecting thereon another building, it will be considered that the taxpayer has sustained no deductible loss by reason of the demolition of the old building, and no deductible expense on account of the cost of such removal, the value of the real estate, exclusive of old improvements, being presumably equal to the purchase price of the land and building plus the cost of removing the useless building.

Art. 153. Loss of useful value.- When through some change in business conditions the usefulness in the business of some or all of the capital assets is suddenly terminated, so that the taxpayer discontinues the business or discards such assets permanently from use in the business, he may claim as a loss for the year in which he takes such action the difference between the cost or the fair market value as of January 1, 1919, of any asset so discarded (less any depreciation allowances) and its salvage value remaining. This exception to the rule requiring a sale or other disposition of property in order to establish a loss requires proof of some unforeseen cause by reason of which the property must be prematurely discarded, as, for example, where machinery or other property must be replaced by a new invention, or where an increase in the cost of or other change in the manufacture of any product makes it necessary to abandon such manufacture, to which special machinery is exclusively devoted, or where new legislation directly or indirectly makes the continued profitable use of the property impossible. This exception does not extend to a case where the useful life of property terminates solely as a result of those gradual processes for which depreciation allowances are authorized. It does not apply to inventories or to other than capital assets. The exception applies to buildings only when they are permanently abandoned or permanently devoted to a radically different use, and to machinery only when its use as such is permanently abandoned. Any loss to be deductible under this exception must be charged off on the books and fully explained in returns of income. But see article 28. 
ART. 154. Shrinkage in value of securities and stocks. - A person possessing securities, such as stocks and bonds cannot deduct from gross income any amount claimed as a loss on account of the shrinkage in value of such securities through fluctuation of the market or otherwise. The loss allowable in such cases is that actually suffered when the securities mature or are disposed of. See, however, article 161 . In the case of individual bankers or private bankers who are subject to supervision by State authorities, and who in obedience to the orders of such supervisory officers charge off as losses, amounts representing an alleged shrinkage in the value of property, the amounts so charged off do not constitute allowable deductions. The foregoing applies only to owners and investors, and not to dealers in securities, as to whom see article 220. However, if stock of a corporation becomes worthless, its cost or its fair market value as of January 1, 1919, if acquired prior thereto, may be deducted by the owner in the taxable year in which the stock was ascertained to be worthless and charged off, provided a satisfactory showing of its worthlessness be made as in the case of bad debts. (Article 161.)

ART. 155. Losses of farmers. - Losses incurred in the operation of farms as business enterprises are deductible from gross income. If farm products are held for favorable markets, no deduction on account of shrinkage in weight or physical value or by reason of deterioration in storage shall be allowed. The total loss by frost, storm, flood or fire of a prospective crop, or of a crop which has not been sold, is not a deductible loss in computing net income. A farmer engaged in raising and selling stock, cattle, sheep,. horses, etc., is not entitled to claim as a loss the value of animals that perish from among those animals that were raised on the farm. If live stock has been purchased for any purpose, and afterward dies from disease, exposure or injury, or is killed by order of the authorities of a State or the United States, the actual purchase price of such stock, less any depreciation which may have been previously claimed with respect to such perished live stock, and less also any insurance or indemnity recovered, may be deducted as a loss. The actual cost of other property, less depreciation already allowed, ilestroyed by order of the authorities of a State or of the United States, may in like manner be 
claimed as a loss; but if reimbursement is made by a State or the United States in whole or in part on account of stock killed or property destroyed, the amount received shall be reported as income for the year in which reimbursement is made. In determining the cost of stock for the purpose of ascertaining the deductible loss there shall be taken into account only the purchase price, and not the cost of any feed, pasturage or care which has been deducted as an expense of operation. If gross income is ascertained by inventories, no deduction can be made for live stock or products lost during the year, whether purchased for resale or produced on the farm, as such losses will be reflected in the inventory by reducing the amount of live stock or products on hand at the close of the year. If an individual owns and operates a farm, in addition to being engaged in another trade, business or calling, and sustains a loss from such operation of the farm, then the amount of loss sustained may be deducted from gross income received from all sources, provided the farm is not operated for recreation or pleasure. (Articles 30, 122 and 181.) 


\section{DEDUGTIONS ALLOWED: BAD DEBTS}

ArT. 161. Bad debts.-An account merely written down or a debt recognized as worthless prior to the beginning of the taxable year is not deductible. Where all the surrounding and attendant circumstances indicate that a debt is worthless and uncollectible and that legal action to enforce payment would in all probability not result in the satisfaction of execution on a judgment, a showing of these facts will be sufficient evidence of the worthlessness of the debt for the purpose of deduction. Bankruptcy may or may not be an indication of the worthlessness of a debt, and actual determination of worthlessness in such a case is sometimes possible before and at other times only when a settlement in bankruptcy shall have been had. Where a taxpayer ascertained a debt to be worthless and charged it off in one year, the mere fact that bankruptey proceedings instituted against the debtor are terminated in a later year confirming the conclusion that the debt is worthless will not authorize shifting the deduction to such later year. In the case of debts existing prior to January 1, 1919, only their value on that date may be deducted upon subsequently ascertaining them to be worthless. But see article 44. If a taxpayer computes his income upon the basis of valuing his notes or accounts receivable at their fair market value when received, which may be less than their face value, the amount deductible. for bad debts in any such case is limited to such original valuation.

Art. 162. Examples of bad debts.- Worthless debts arising from unpaid wages, salaries, rents and similar items of taxable income will not be allowed as a deduction unless the income such items represent has been included in the return of income for the year in which the deduction as a bad debt is sought to be made or in a previous year. Only the difference between the amount received in distribution of the assets of a bankrupt and the amount of the claim may be deducted as a bad debt. The difference between the amount received by a creditor of a decedent in distribution of the assets of the decedent's estate and the amount of his claim may be considered a worthless debt. A purchaser of accounts receivable which cannot he collected and are conse- 
quently charged off the books as bad debts is entitled to deduct them, the amount of deduction to be based upon the price he paid for them and not upon their face value.

ART. 163. Worthless mortgage debt.- Where under foreclosure a mortgagee buys in the mortgaged property and credits the indebtedness with the purchase price, the difference between the purchase price and the indebtedness will not be allowable as a deduction for a bad debt, for the property which was security for the debt stands in the place of the debt. The determination of loss in such a situation is deferred until the property is disposed of, except where a purchase money mortgage is foreclosed by the vendor of the property. (See article 38.) Only where a purchaser for less than the debt is another than the mortgagee may the difference between the debt and the net proceeds from the sale be deducted as a bad debt.

ART. 164. Worthless securities. - Where bonds purchased before January 1, 1919, depreciated in value between the date of purchase and that date, and were in a later year ascertained to be worthless and charged off, the owner is entitled to a deduction in that year equal to the value of the bonds on January 1, 1919. Bonds purchased since December 31, 1918, when ascertained to be worthless may be treated as bad debts to the amount actually paid for them, but not exceeding their amortized value if purchased at a premium. Bonds of an insolvent corporation secured only by a mortgage from which on foreclosure nothing is realized for the bondholders are regarded as ascertained to be worthless not later than the year of the foreclosure sale, and no deduction for such bad debt is allowable in computing the bondholder's income for a subsequent year. To authorize a deduction for a bad debt on account of notes held prior to January 1, 1919, their value on that date must be established. (See articles 154 and 220.) 


\section{DEDUGTIONS ALLOWED: DEPREGIATION}

ArT. 171. Depreciation.-A reasonable allowance for the exhaustion, wear and tear and obsolescence of property used in the trade or business may be deducted from gross income. For convenience such an allowance will usually be referred to as covering depreciation, excluding from the term any idea of a mere reduction in market value not resulting from exhaustion, wear and tear or obsolescence. The proper allowance for such depreciation of any property used in the trade or business is that amount which should be set aside for the taxable year in accordance with a consistent plan by which the aggregate of such amounts for the useful life of the property in the business will suffice, with the salvage value, at the end of such useful life to provide in place of the property its cost, or its value as of January 1, 1919, if acquired by the taxpayer before that date.

ART. 172. Depreciable property.-- The necessity for a depreciation allowance arises from the fact that certain property used in the business gradually approaches a point where its usefulness is exhausted. The allowance should be confined to property of this nature. In the case of tangible property, it applies to that which is subject to wear and tear, to decay or decline from natural causes, to exhaustion, and to obsolescence due to the normal progress of the art or to becoming inadequate to the growing needs of the business. It does not apply to inventories or to stock in trade; nor to land apart from the improvements or physical development added to it. It does not apply to bodies of minerals which through the process of removal suffer depletion, other provision for this being made in the statute. (Section 360, subdivision 9, of the Tax Law, and article 190.) Property kept in repair may, nevertheless, be the subject of a depreciation allowance. (Article 113.) The deduction of an allowance for depreciation is limited to property used in the taxpayer's trade or business. No such allowance may be made in respect of automobiles or other vehicles used chicfly for pleasure, a building used by the taxpayer solely as his residence, nor in respect of furniture or furnishings therein, personal effects, or clothing; but properties and costumes used exclusively in a business, such 
as a theatrical business, may be the subject of a depreciation allowance.

ART. 173. Depreciation of intangible property.- Intangibles, the use of which in the trade or business is definitely limited in duration, may be the subject of a depreciation allowance. Examples are patents and copyrights, licenses and franchises. Intangibles, the use of which in the business or trade is not so limited, will not usually be a proper subject of such an allowance. If, however, an intangible asset acquired through capital outlay is known from experience to be of value in the business for only a limited period, the length of which can be estimated from experience with reasonable certainty, such intangible asset may be the subject of a depreciation allowance, provided the facts are fully shown in the return or prior thereto to the satisfaction of the Comptroller. No depreciation is allowable with respect to good will, secret formulae or processes, trade names, trademarks or trade brands.

ART. 174. Capital sum recoverable through depreciation allowance.- The capital sum to be replaced by depreciation allowances is the cost of the property in respect of which the allowance is made, except that in the case of property acquired by the taxpayer prior to January 1, 1919, the capital sum to be replaced is the fair market value of the property as of that date. In the absence of proof to the contrary, it will be assumed that such value as of January 1,1919, is the cost of the property less depreciation up to that date. To this sum should be added from time to time the cost of improvements, additions and betterments, the cost of which is not deducted as an expense in the taxpayer's return, and from it should be deducted from time to time the amount of any definite loss or damage sustained by the property through casualty, as distinguished from the gradual exhaustion of its utility which is the basis of the depreciation allowance. In the case of the acquisition after December 31, 1918, of a combination of depreciable and nondepreciable property for a lump price, as for example, land and buildings, the capital sum to be replaced is limited to that part of the lump price which represents the value of the depreciable property at the time of such acquisition. 
Aкт. 175. Miethod of computing depreciation allowance.-The capital sum to be replaced should be charged off over the useful life of the property either in equal anmual installments or in accordance with any other recognized trade practice, such as an apportionment of the capital sum over units of production. Whatever plan or method of apportionment is adopted must be reasonable and should be described in the return.

ART. 176. Modification of method of computing depreciation.If it develops that the useful life of the property has been underestimated, the plan of computing depreciation should be modified and the balance of the cost of the property, or its fair market value as of Jamuary 1, 1919, not already provided for through a depreciation reserve or deducted from book value, should be spread over the estimated remaining life of the property. No modification of the method should be made on account of fluctuations in the market value of the property from time to time, such as, on the one hand, loss in rental value of buildings due to deterioration of the neighborhood, or, on the other hand, appreciation due to increased demand. The conditions affecting such market value should be taken into consideration only so far as they affect the estimate of the useful life of the property.

ArT. 17\%. Depreciation of patent or copyright.- In computing a depreciation allowance in the case of a patent or copyright, the capital sum to be replaced is the cost (not already deducted as current expense) of the patent or copyright or its fair market value as of January 1, 1919, if acquired prior thereto. The allowance should be computed by an apportionment of the cost of the patent or copyright or of its fair market value as of January 1,1919 , over the life of the patent or copyright since its grant, or since its acquisition by the taxpayer, or since December 31,1918 , as the case may be. If the patent or copyright was acquired from the government, its cost consists of the various government fees, cost of drawings, experimental models, attorney's fees, etc., actually paid. Depreciation of a patent can be taken on the basis of the fair market value as of January 1, 1919, only when affirmative and satisfactory evidence of such value is offered. Such evidence should whenever practicable be submitted with the return. If the patent becomes obsolete prior to its expiration such proportion of the amount on which its deprecia- 
tion may be based as the number of year's of its remaining life bears to the whole number of years intervening betwern the date when it was acquired and the date when it legally expires may be deducted, if permission so to do is specifically secured from the Comptroller. Owing to the difficulty of allocating to a particular year the obsolescence of a patent, such permission will be granted only if affirmative and satisfactory evidence that the obsolescence occurred in the year for which the return is made is submitted to the Comptroller. The fact that depreciation has not been taken in prior years does not entitle the taxpayer to deduct in any taxable year a greater amount for depreciation than would otherwise be allowable. (See articles 32 and 123.)

ART. 178. Depreciation of drawings and models.-A taxpayer who has incurred expenses in his business for designs, drawings, patterns, models, or work of an experimental nature calculated to result in improvement of his facilities or his product, may at his option deduct such expenzes from gross income for the taxable year in which they are incurred or treat such articles as a capital asset to the extent of the amount so expended. In the latter case, if the period of usefulness of any such asset may be estimated from experience with reasonable accuracy, it may be the subject of depreciation allowances spread over such estimated period of usefulness. The facts must be fully shown in the return or prior thereto to the satisfaction of the Comptroller. Except for such depreciation allowances no deduction shall be made by the taxpayer against any sum so set up as an asset except on the sale or other disposition of such assets at a loss or on proof of a total loss thereof.

ART. 179. Charging off depreciation.- If regular books of account are kept, a depreciation allowance, in order to constitute an allowable deduction from gross income, should be regularly charged off thereon. The particular manner in which it shall be charged off is not material, except that the amount measuring a reasonable allowance for depreciation must be either deducted directly from the book value of the assets or preferably credited to a depreciation reserve account, which must be reflected in the annual balance sheet. If regular books of account are not kept by the taxpayer, a permanent record must be kept of the facts on which the claim for depreciation is based. The allowance 
should be computed and charged off with express reference to specific items, units or groups of property, each item or unit being considered separately or specifically included in a group with others to which the same factors apply. The taxpayer should keep such records as to each item or unit of depreciable property as will permit the ready verification of the factors used in computing the allowance for each year for each item, unit or group.

ART. 180. Closing depreciation account.- If the use of any property in the business is permanently discontinued, although no sale or other disposition of the property has taken place, a determination of any gain or loss may be made; but any deduction in respect of any loss thereon must be disclosed in the taxpayer's return for the year in which the determination is made and a full statement of the facts and the basis upon which the computation is calculated must be attached to the return. Upon a sale or other disposition of the property, the consideration received shall be compared with the amount of the estimated salvage value used in computing the gain or loss as above provided, and the amount of the difference shall be treated as a gain or loss, as the case may be, of the year in which the sale or other disposition was made. (See articles 151-153.)

Art. 181. Depreciation in the case of farmers.-A reasonable allowance for depreciation may be claimed on farm buildings (other than a dwelling occupied by the owner), farm machinery and other physical property including live stock purchased for draft, dairy or breeding purposes, but no claim for depreciation on live stock raised, or purchased for resale, will be allowed. Live stock purchased for draft, breeding or dairy purposes, or for any purpose other than resale, may be included in the inventory for each year at a figure which will reflect the reduction in value estimated to have occurred during the year through increase of age or other causes. Such a reduction in value should be based on the cost and estimated life of the live stock. If an inventory is not used, a reasonable allowance for depreciation may be claimed based upon the cost of draft and work animals and animals kept solely for breeding purposes and not for resale. (See articles 30, 120 and 155.) 


\section{DEDUGTIONS ALLOWED: DEPLETION}

Art. 190. Depletion of mines, oil and gas wells, natural deposits and timber.-Until specific regulations on the subject of depletion are issued and promulgated by the State Comptroller, deductions for depletion will be allowed in accordance with the principles and rules adopted by the Commissioner of Internal Revenue in regulations 45 , except that the fair market value as of January 1, 1919, is the basis for claims of depletion with respect to property acquired prior to that date, and except also that claims for depletion based upon discovery must relate to discoveries by the taxpayer on or after January 1, 1919.

\section{DEDUCTIONS ALLOWED: GHARITABLE CON- TRIBUTIONS}

ART. 201. Charitable contributions.-Contributions or gifts within the taxable year are deductible to an aggregate amount not in excess of 15 per cent of the taxpayer's net income as computed without the benefit of this deduction, if made (a) to corporations or associations incorporated by or organized under the laws of the State of New York and operated exclusively for religious, charitable, scientific or educational purposes, or for the prevention of cruelty to children or animals, no part of the net earnings of which inures to the benefit of any private stockholder or individual, or (b) to the special fund for vocational rehabilitation under the Vocational R'ehabilitation Act of June 27, 1918. A gift to a common agency (as a war chest) for several such corporations or associations is treated like a gift directly to them. In connection with claims for this deduction there shall be stated on returns of income the name and address of each organization to which a gift was made, and the approximate date and the amount of the gift in each case. Where the gift is other than money, the basis for calculation of the amount of the gift shall be the fair market value of the property at the time given, but the difference between such value and cost (or fair market value on January 1, 1919, if acquired before that date) shall be returned as profit or loss by the donor. (Article 91.) A gift of real estate to a city to be maintained perpetually as a public 
park is not an allowable deduction. This article does not apply to gifts by partnerships or estates and trusts. (Tax Law, section 360, subdivision 10, and sections 364 and 365, and articles 233 and 251.)

Art. 202. Definition of religious, charitable, scientific and educational corporations and associations.- In order to be deductihle, contributions must be to a corporation or association: (a) incorporated by or organized under the laws of the State of New York; (b) organized and operated exclusively for one or more of the specified purposes; (c) no part of its income must inure to the benefit of any private stockholder or individual.

Charitable corporations include an association for the relief of the families of clergymen, even though the latter make a contribution to the fund established for this purpose; or for furnishing the services of trained nurses to persons unable to pay for them; or for aiding the general body of litigants by improving the efficient administration of justice. Educational corporations may include an association whose sole purpose is the instruction of the public. This is true of an association to promote acquaintance with the Spanish language and literature, although it has incidental amusement features; of an association to increase knowledge of the civilization of another country; and of a Chautauqua association whose primary purpose is to give lectures on subjects useful to the individual and beneficial to the community and whose amusement features are incidental to this purpose. But associations formed to disseminate controversial or partisan propaganda are not educational within the meaning of the statute. Scientific corporations include an association for the scientific study of law, to the end of improvement in its administration. 


\section{PERSONAL EXEMPTIONS}

Ar's. 205. Personal exemption of resident individual. - An unmarried individual, or a married individual not living with husband (or wife), and who is not the head of a family, is entitled. to a personal exemption of $\$ 1,000$, if he is a resident of the State of New York.

ArT. 206. Personal exemption of head of family.-A head of a family (resident of the State of New York) is entitled to a personal exemption of $\$ 2,000$. A head of a family is a person who actually supports and maintains in one household one or more individuals who are closely connected with him by blood relationship, relationship by marriage, or by adoption, and whose right to exercise family control and provide for these dependent individuals is based upon some moral or legal obligation. In the absence of continuous actual residence together, whether or not a person with dependent relatives is the head of a family within the meaning of the statute must depend on the character of the separation. If a father is absent on business or at war, or a child or other dependent is away at school or on a visit, the common home being still maintained, the additional exemption applies. If, moreover, through force of circumstances a parent is obliged to maintain his dependent children with relatives or in a boarding house while he lives elsewhere, the additional exemption may still apply. A resident alien with children abroad is not entitled to the exemption of a head of a family.

ART. 207. Personal exemption of married person.-A married person (resident of the State of New York) living with husband (or wife), is entitled to a personal exemption of $\$ 2,000$ against the aggregate net income of both husband and wife. In the case of a married man or married woman the joint exemption replaces the individual exemption only if the man lives with his wife or the woman lives with her husband. In the absence of continuous actual residence together, whether or not a man or woman has a wife or husband living with him or her within the meaning of the statute must depend on the character of the separation. If merely occasionally and temporarily a wife is away on a visit 
or a husband is away on business, the joint home being maintained, the additional exemption applies. The unavoidable absence of a wife or husband at a sanatorium or asylum on account of illness does not preclude claiming the exemption. If, however, the husband voluntarily and continuously makes his home at one place and the wife hers at another, they are not living together for the purpose of the Tax Law, irrespective of their personal relations. A resident alien with a wife residing abroad is not entitled to the joint exemption.

ART. 208. Exemption for dependents. A resident taxpayer receives an exemption of $\$ 200$ for each person (other than husband or wife), whether related to him or not and whether living with him or not, dependent upon and receiving his chief support from the taxpayer, provided the dependent is either (a) under eighteen years of age or (b) incapable of self-support because defective. The exemption is based upon actual financial dependency and not mere legal dependency and may accrue to a taxpayer who is not the head of a family. But a father whose children receive half or more of their support from a trust fund or other separate source is not entitled to the exemption.

Art. 209. Date determining exemption. - The status of the taxpayer during the taxable year determines his right to an additional exemption and to exemption for dependents. If at any time during the taxable year he is the head of a family, the personal exemption of $\$ 2,000$ may be taken. If he is the chief support of a dependent who is under eighteen years of age, or incapable of self-support because mentally or physically defective, the exemption of $\$ 200$ may be taken. A husband and wife living together during the taxable year may receive but one personal exemption of $\$ 2,000$, divisible as they please, against their aggregate net income. If an individual dies during the taxable year, his executor or administrator in making a return for him is entitled to claim his full personal exemption according to the status of the decedent. If a husband or wife so dies and the joint personal exemption is used by the executor or administrator in making a return for the decedent, an undiminished personal exemption according to the status of the survivor during his (or her) taxable year subsequent to such death, may be claimed in the survivor's return. 
Art. 210. Personal exemption of officer or employee of the United States.-A taxpayer receiving salary, wages, or other compensation from the United States, whether as civilian or in the military or naval service, exempt from taxation under the tax law shall be entitled to only so much of the personal exemption provided for in this section as is in excess of the aggregate amount of such salaries, wages or other compensation. If the compensation received from the United States is in excess of the personal exemption, no personal exemption is allowable. (Tax Law, section 362, subdivision 3.) 


\section{INVENTORIES}

ArT. 216. Need of inventories. - In order to reflect the net income correctly, inventories at the beginning and ending of each year are necessary in every case in which the production, purchase or sale of merchandise is an income-producing factor. The inventory should include raw materials and supplies on hand that have been acquired for sale, consumption or use in productive processes, together with all finished or partly finished goods. Title to the merchandise included in the inventory should be vested in the taxpayer and goods merely ordered for future delivery and for which no transfer of title has been effected should be excluded. The inventory should include merchandise sold only if title has not passed to the purchaser; but if title has passed to the purchaser and such goods have been included in the sales of the taxable year, they should not be taken in the inventory. It should also include merchandise purchased, although not actually received, to which title has passed to the purchaser. In this regard care should be exercised to take into the accounts all invoices or other charges in respect of merchandise properly included in the inventory, but which is in transit or for other reasons has not been reduced to physical possession.

ART. 217. Valuation of inventories. - Inventories should be valued at (a) cost or (b) cost or market whichever is lower. Whichever basis is adopted must be applied to each item and not merely to the total of the inventory; that is, if for instance basis (b) is aclopted, the value of each item in the inventory will be measured by market if that is lower than cost, or by cost if that is lower than market. Whichever of the above methods is adopted for 1919, changes can be made thereafter only after permission is secured from the Comptroller. Inventories should be recorded in a legible manner and properly computed and summarized, and should be preserved as a part of the accounting records of the taxpayer. Goods taken in the inventory which have been so intermingled that they cannot be identified with specific invoices will be deemed to be the goods most recently purchased.

$\bar{A}_{\text {RT. }}$ 218. Inventories at cost.- Cost means:

(1) In the case of merchandise purchased, the invoice price 
less trade or other discounts except strictly cash discounts approximating a fair interest rate, which may be deducted or not at the option of the taxpayer provided a consistent course is followed. To this net invoice price should be added transportation or other necessary charges incurred in acquiring possession of the goods.

(2) In the case of merchandise produced by the taxpayer, (a) the cost of raw materials and supplies entering into or consumed in connection with the product, (b) expenditures for direct labor, (c) indirect expenses incident to and necessary for the production of the particular article, including in such indirect expenses a reasonable proportion of management expenses, but not including any cost of selling or return on capital whether by way of interest or profit. In any industry in which the usual rules for computation of cost of production are inapplicable, costs may be approximated upon such basis as may be reasonable and in conformity with established trade practice in the particular industry.

ArT. 219. Inventories at market.- Market means the current bid price prevailing at the date of the inventory for the particular merchandise, and is applicable to goods purchased and on hand and to basic materials in goods in process of manufacture and in finished goods on hand, exclusive, however, of goods on hand or in process of manufacture for delivery upon firm sales contracts at fixed prices entered into before the date of the inventory. Where no open market quotations are available the taxpayer must use such evidence of a fair market price at the date or dates nearest the inventory as may be available to him, such as specific transactions in reasonable volume entered into in good faith, or compensation paid for cancellation of contracts for purchase commitments. The burden of proof will rest upon the taxpayer in each case to satisfy the Comptroller of the correctness of the prices adopted.

ArT. 220. Inventories by dealers in securities. - A dealer in securities, who in his books of account regularly inventories unsold securities on hand either (a) at cost or (b) at cost or market value, whichever is lower, may make his return upon the basis upon which his accounts are kept; provided that a description of the 
method employed shall be included in or attached to the return, that all the securities must be inventoried by the same method, and that such method must be adhered to in subsequent years, unless another be authorized by the Comptroller. For the purpose of this rule a dealer in securities is a merchant of securities, whether an individual or partnership, with an established place of business, regularly engaged in the purchase of securities and their resale to customers, that is, one who as a merchant buys securities and sells them to customers with a view to the gains and profits that may be derived therefrom. If such business is simply a branch of the activities carried on by such person, the securities inventoried as here provided may include only those held for purposes of resale and not for investment. Taxpayers who buy and sell or hold securities for investment or speculation, and not in the course of an established business, and officers of corporations and members of partnerships, who in their individual capacities buy and sell securities, are not dealers in securities within the meaning of this rule. 


\section{PARTNERSHIPS}

Art. 226. Partnerships.- Partnerships as such are not subject to taxation under the Tax Law, but are required to make returns of income. (Tax Law, section 368, and articles 230 and 231.) Individuals carrying on business in partnerships, are, however, taxable upon their distributive shares of the net income of such partnerships, whether distributed or not, and are required to include such distributive shares in their returns. The net income of a partnership shall be computed in the same manner and on the same basis as the net income of an individual, except that the deduction of charitable contributions is not permitted. Resident individuals who are members of partnerships may be required by the Comptroller to make a return stating the gross receipts and the net gains or profits of the partnership for the taxable year. (Tax Law. section 36\%, and articles 11-14.)

A resident member of a partnership must include in his return his distributive share of the profits of such partnership even though it do no business within the State of New York and derive no income from sources within the State.

Every distribution (or credit) shall be deemed to be a ratable distribution of income of each kind received during the year.

ART. 227. Limited partnerships.-All limited partnerships, whether of the type authorized by the statutes of New York and Illinois or of Pennsylvania and Michigan and most other states, are partnerships and not corporations within the meaning of the statute.

ArT. 228. Association distinguished from partnership.-An organization, the partnership interests in which are not transferable without the consent of the members, is a partnership and not an association. Any so-called association or organization not taxable under article 9-a of the Tax Law and not exempted under such article, will be regarded as a partnership within the meaning of the Income Tax Law. The members of such partnerships will be required to include in their returns their share of the profits of such partnerships, whether distributed or undistributed. Such partnerships will be required to file returns in the same manner as all other partnerships.

ART. 229. Distributive shares of partners. - The distributive share of the net income of a partnership which a partner is 
required to include in his return is his proportionate share of the net income of the partnership, either (a) for the taxable year upon the basis of which the partner's net income is computed, or (b) if the partner's net income is computed upon the basis of a taxable year different from that upon the basis of which the net income of the partnership is computed, for the taxable year of the partnership ending within the taxable rear upon the basis of which the partner's net income is computed. Amounts earned and distributed to a partner by a partnership after the end of its taxable year and before the end of his corresponding taxable year should be accounted for both by the partnership and by the partners in their returns for their next succeeding taxable years.

ART. 230. Partnership returns.-- Every partnership deriving income (a) from property owned within the State of New York, or (b) from a business, trade, profession or occupation carried on within the State of New York must make a return of income, regardless of the amount of its gross or net income and regardless of the residence of the partners. The return shall be on Form 204 and shall be swom to by one of the partners. If the partnership (a) has a nonresident member, and (b) carries on business (as "business carried on" is defined in article 415) both within and without the State of New York, its return shall be accompanied by a schedule of apportionment on Form 204a. Such return shall be made for the fiscal year of the partnership, that is, for its annual accounting period (fiscal year or calendar year as the case may be), irrespective of the taxable years of the partners. (Tax Law, section 368.) If the partnership makes any change in its accounting period it shall make its return in accordance with the provisions of the Tax Law, section 370, and article 529.

Arт. 231. Contents of partnership return. - The return of a partnership shall state specifically (a) the items of its gross income enumerated in section 359 of the Tax Law; (b) the deductions enumerated in section 360 other than the deductions provided in paragraph 10 of that section; (c) the names and adilresses of the individuals who would be entitled to share in the net income of the partnership if distributed; (d) the amount of the distributive share of such net income of each such individual; and (e) such other facts as are required by Form 204. (See also Tax Law, section 371, and articles 541-544.) 
ART. 232. Taxation of partners in partnership with fiscal year ending in 1919.- If the fiscal year of a partnership began in the calendar year 1918 and ended in the calendar year 1919, the tax for the calendar year 1919 applies to the amount of each partner's distributive share of such net income of the partnership attributable to the calendar year 1919. The amount of each partner's distributive share of the net income of the partnership for such fiscal year attributable to the calendar vear 1919 is found by determining the net income of the partnership for its entire fiscal year in accordance with the law and the distributive share thereof of each partner, and then taking such proportion of that distributive share as the part of the fiscal year falling within the calendar year 1919 bears to the full fiscal year. (Tax Law, section 364, and article 527.)

Art. 233. Charitable contributions by partnerships. - In computing the net income of partnerships, charitable contributions may not be deducted. Each partner may, however, take as a deduction on his personal return his proportionate share of the charitable.contributions made by the partnership, subject to the limitations contained in article 201 . 


\section{ESTATES AND TRUSTS}

ART. 240. Fiduciary. - "Fiduciary" is a term which applies to all persons that occupy positions of peculiar confidence and trust toward others, such as guardians, trustees, executors, administrators, receivers, conservators or any other person, whether individual or corporate, acting in any fiduciary capacity for any person, trust or estate. A committee of the property of an incompetent person is a fiduciary. (Tax Law, section 365.)

Art. 241. Fiduciary distinguished from agent.- There may be a fiduciary relationship between an agent and a principal, but the word "agent" does not denote a fiduciary. A fiduciary relationship cannot be created by a power of attorney. An agent having entire charge of property, with authority to effect and execute leases with tenants entirely on his own responsibility and without consulting his principal, merely turning over the net profits from the property periodically to his principal by virtue of authority conferred upon him by a power of attorney, is not a fiduciary within the meaning of the statute. In cases where no legal trust has been created in the estate controlled by the agent and attorney the liability to make a return rests with the principal.

ArT. 242. Classification of income of estates and trusts.- For the purpose of the income tax, income of estates and trusts may be divided into two classes:

First.- Income, the tax upon which is imposed upon the estate or trust and the tax paid by the fiduciary, consisting of

(a) Income received by estates of deceased persons during the period of administration or settlement except as provided in " $f$ " below;

(b) Income accumulated in trust for the benefit of unborn or unascertained persons or persons with contingent interests;

(c) Income held in trust for future distribution under the terms of the will or trust.

Second.- Income, the tax upon which is imposed upon and paid by the beneficiaries, consisting of

(d) Income which is to be distributed to beneficiaries periodically whether or not at stated intervals; 
(e) Income collected by the guardian of an infant to be held or distributed as the court may direct;

(f) Income of the estate of any deceased person which during the period of administration or settlement is properly paid or credited to any legatee, heir or other beneficiary.

ART. 243. Resident and nonresident estates and trusts distinguished.-For the purpose of the income tax estates and trusts are (a) resident estates and trusts or (b) nonresident estates and trusts. If the decedent was at the time of his death a resident of New York State, his estate is a resident estate and any trust created by his will is a resident trust. If the decedent was at the time of his death a nonresident, his estate is a nonresident estate and any trust created by his will is a nonresident trust. If the creator of a trust was at the time the trust was created a resident of New York State, the trust is a resident trust. Conversely, if the creator of a trust was at the time the trust was created a nonresident of the State, the trust is a nonresident trust. The residence or situs of the fiduciary does not in any sense control in the classification of estates and trusts as resident or nonresident.

ART. 244. Income of estates and trusts taxed to fiduciary.- In the case of estates or trusts falling within subdivisions $a, b$ and $c$ of article 242, the fidueiary is required to make return on Form 200 or 201 as prescribed in article 246 and pay the tax on the taxable income of such estate or trust. The imposition of the tax is not affected by the fact that an ultimate beneficiary may be a person not subject to tax. Where under the terms of the will or deed, the trustee may in his discretion distribute the income or accumulate it, the amount actually distributed is taxable to the beneficiaries and only the amount accumulated is taxable to the fiduciary.

A statutory allowance paid a widow out of the corpus of the estate is not deductible from gross income. As an. intestate's real estate does not pass to his administrator, upon a sale by the heirs, whether before or after settlement of the estate, each heir is taxed individually on any profit derived. If such an estate or trust is a resident as defined in article 243 its income from all sources both within and without the State is taxable. If the estate or trust is a nonressident as defined in article 243 , only its 
income from sources within the State (exclusive of annuities, interest on bank deposits, interest on bonds, notes or other interest-bearing obligations or dividends from corporations, except to the extent to which the same shall be a part of income of any business, trade, profession or occupation carried on in this State subject to taxation) is taxable. In the case of a resident estate or trust taxed as provided in this article, a personal exemption of $\$ 1,000$ is allowed against income subject to tax. If the estate or trust is a nonresident, no personal exemption is allowed.

\section{ArT. 245. Income of estates and trusts taxed to beneficiaries.-} In the case of estates and trusts falling within subdivisions $\mathrm{d}$, e and $f$ of article 242 , the fiduciary is required to make a return on Form 205 as prescribed in article 246. The fiduciary is not required to pay any tax, the income being taxable directly to the beneficiary or beneficiaries. Each beneficiary must include in his return his distributive share whether distributed or not, of the net income of the estate or trust for the taxable year, or, if his net income for such taxable year is computed upon the basis of a period different from that upon the basis of which the net income of the estate or trust is computed, then his distributive share of the net income of the estate or trust for any accounting period of such estate or trust ending within the fiscal or calendar year upon the basis of which such beneficiary's net income is computed. 'For the purpose of the imposition and collection of taxes under this article the residence of the beneficiary is controlling. A resident beneficiary is taxable on the income of an estate or trust regardless of whether such income is derived from sources within or without the State and without consideration as to whether or not the estate or trust is a resident or nonresident estate or trust. A nonresident beneficiary is taxable only on such part of his income from the estate or trust as arises from sources within the State of New York (exclusive of annuities, interest on bank deposits, interest on bonds, notes or other interest-bearing obligations or dividends from corporations, except to the extent to which the same shall be a part of income from any business, trade, profession or occupation carried on in this State subject to taxation). The regulations governing partnerships are generally applicable to such an estate or trust. 
Art. 246. Fiduciary returns._- Every fiduciary or at least one of joint fiduciaries (except receivers appointed by authority of law, in possession of part only of the property of the taxpayer) is required to make a return of income of the estate or trust for which he acts (either (1) a tax return or (2) an information return) as follows:

\section{TAX RETURNS-}

A. The fiduciary of every resident trust or estate must make a tax return on Form 200 or 201 and pay the tax on the taxable income of each estate or trust taxed as an entity having a net income of $\$ 1,000$ or over during the taxable year in the case of :

(a) Ineome received by estates of deceased persons during the period of administration or settlement;

(b) Ineome aceumulated in trust for the benefit of unborn or unascertained persons or persons with contingent interests ;

(c) Ineome held for future distribution under the terms of a will or trust.

In (a) the fiduciary is entitled to deduet the amount of ineome properly paid or credited to any beneficiary.

The fiduciary of a resident estate or trust is entitled to the personal exemption of $\$ 1,000$ in ascertaining the tax liability of the estate or trust.

B. The fidueiary of every nonresident estate or trust must make a tax return on Form 200a or 201a and pay the tax on the taxable income of each estate or trust taxed as an entity having taxable income of $\$ 1,000$ or over during the taxable year from sources within the State of New York, as defined in article 401, in the case of :

(a) Income received by estates of deceased persons during the period of administration or settlement;

(b) Income accumulated in trust for the benefit of unborn or unascertained persons or persons with contingent interests ;

(c) Income held for future distribution under the terms of a will or trust.

In (a) the fiduciary is entitled to deduct the amount of ineome properly paid or credited to any beneficiary.

In the absence of any specific allocation of income under the will or deed of trust, every distribution shall be deemed to apply ratably to taxable and non-taxable ineome of the estate or trust. 
The fiduciary of a nonresident estate or trust is not entitled to any personal exemption whatever on account of the estate or trust.

2. INFORMATION RETURNS-

The fiduciary of every estate or trust (resident or nonresident) must make an information return on Form 205 if any beneficiary receives or is entitled to a distributive share of taxable income of $\$ 1,000$ or over during the taxable year in the following cases:

(a) Income which is to be distributed to beneficiaries periodically, whether or not at stated intervals;

(b) Income collected by the guardian of an infant, to be held or distributed as the court may direct;

(c) Income of the estate of any deceased person, which during the period of administration or settlement, is properly paid or credited to any legatee, heir or other beneficiary.

In the absence of any specific allocation of income, under the will or deed of trust, every distribution shall be deemed to apply ratably to taxable and non-taxable income of the estate or trust and the beneficiary must be guided by the same allocation.

No tax is to be paid by the fiduciaries on these returns as the income is taxable to the beneficiaries, but there shall be included in computing the net income of each beneficiary his distributive share, whether distributed or not, of the net income of the estate or trust for the taxable vear.

If the estate or trust (a) has a nonresident beneficiary and (b) carries on business (as "business carried on" is defined in article 415) both within and without the State of New York, the fiduciary shall accompany his return with a schedule of apportionment on Form 205a.

A RT. 247. Tax returns for beneficiaries.-Every fiduciary must make a return of income on Form 200 or 201 for every individual whose entire income is in charge of such fiduciary, if such individual is a resident and his net income is $\$ 2,000$ or over, if living with husband or wife, or $\$ 1,000$ or over in other cases. If such individual is a nonresident, the fiduciary must make a return of the income of such individual on Form 200a or 201a, regardless of the amount of his taxable income. In such cases, the fiduciary must pay the tax shown by the return to be due.

ArT. 248. Return by guardian or committee. - A fiduciary acting as the guardian of a resident minor having a net income of $\$ 1,000$ or $\$ 2,000$, according to the marital status of such person, 
must make a return for such minor on Form 200 or 201 and pay the tax, unless such minor himself makes a return or causes it to be made. A fiduciary acting as the committee of a resident incompetent person having an income of $\$ 1,000$ or $\$ 2,000$, according to the marital status of such person, must make a return for such incompetent on Form 200 or 201 and pay the tax. Such return must be made on Form 200-a or 201-a in the case of a nonresident minor or nonresident incompetent, regardless of the amount of the taxable income.

ArT. 249. Returns where more than one trust.- In the case of two or more trusts the income of which is taxable to the beneficiaries, which were created by the same person and are in charge of the same trustee, the trustee may at his option make a single return on Form 205 for all such trusts, notwithstanding that they may arise from different instruments. When, however, a trustee holds trusts created by different persons for the benefit of the same beneficiary he shall make a return on Form 205 for each trust separately.

ART. 250. Return by receiver.-A receiver who stands in the stead of an individual must render a return of income on Form 200 or 201 and pay the tax for his trust, but a receiver of only part of the property of an individual need not do so. A receiver in charge of the business of a partnership shall render a return on Form 204. A receiver appointed to hold and operate a mortgaged parcel of real estate, to whom rents and profits are paid, but who is not in control of all the property or business of the mortgagor, and a receiver in partition proceedings, are not required to render returns of income. In general statutory receivers and common law receivers of all the property or business of an individual must make returns. (See also Tax Law, section 366, and article 24\%.)

ArT. 251. Computation of income of estates and trusts. - The net income of an estate or trust shall be computed in the same manner and on the same basis as the net income of an individual, except that there shall also be allowed as a deduction from the gross income any part of it which during the taxable year is, pursuant to the will or trust deed, paid to or permanently set aside for the United States, a State, a Territory or any political 
subdivision thereof, the District of Columbia, or any corporation or association organized and operated exclusively for religious, charitable, scientific or educational purposes or for the prevention of cruelty to children or animals, no part of the net earnings of which inures to the benefit of any private stockholder or individual. The gross income of a revocable trust must be included in the gross income of the grantor. No taxable income is realized from the passage of property to the executor or administrator on the death of the decedent, even though it may have appreciated in value since the decedent acquired it. In the event of delivery of property in kind to a legatee or distributee, no income is realized. Where, however, the executor sells property of the estate for more than its fair market value at the death of the decedent, (or on January 1, 1919, if the decedent's death occurred prior thereto) the cxcess is taxable income. (See article 252.)

ArT. 252. Losses and gains from the sales by fiduciaries of property included in the original trust or estate.-The profit or loss from the sale or other disposition of property included in the original trust or estate is the difference between the sales price and the fair market value of the property at the time of decedent's death or at the date of the creation of the trust, unless the decedent's death occurred or the trust was created prior to January 1, 1919, in which case the fair market value upon that date is the basis for determining loss or gain. Profit derived from the sale or other disposal of assets of estates or trusts even though considered as a capital asset of the trust or estate, is taxable income, and taxable to the beneficiaries, if paid or credited to them, or to the estate or trust as an entity, if not so paid or credited; likewise, losses from the sale of capital assets are allowable deductions from the gross income of the estate or trust.

ArT. 253. Decedent's estate during administration. - The "period of administration or settlement of the estate" is the period required by the executor or administrator to perform the ordinary duties pertaining to administration, in particular the collection of assets and the payment of debts and legacies. It is the time actually required for this purpose, whether longer or 
shorter than the period specified in the local statute for the settlement of estates. Where an executor, who is also named as trustee, fails to obtain his discharge as executor, the period of administration continues up to the time when the duties of administration are complete and he actually assumes his duties as trustee, whether pursuant to an order of the court or not.

ArT. 254. Deductions allowed estates and trusts.-Distinction is made between (1) expenses which are charges against the corpus of an estate or trust and (2) expenses which are incident to the business management of the estate or trust. Items falling under (1) are not proper deductions in computing net income, whereas items which fall under (2) are proper deductions in computing net income.

In accordance with the foregoing, executor's commissions, court costs and attorney's fees in connection with the settlement of an estate or the creation of a trust which are directly chargeable to the corpus of the estate or trust, are not proper deductions in determining net income. Likewise, expenses incurred by a fiduciary in litigation to sustain a will are not proper deductions in determining net income. On the other hand, if trustees' commissions are deducted from the income of the estate or trust distributable among the beneficiaries, the amount of such commission should be entered as legitimate and necessary expenses properly deductible by the fiduciary for income tax purposes.

Expenses necessary to carrying on the business of the trust or estate by the fiduciary are deductible in the same manner as similar expenses of an individual; likewise interest, taxes, losses, depreciation and depletion are subject to the same rules relating to these deductible items as apply to individuals.

Art. 255. Liability for payment of the tax.-Liability for payment of the tax attaches to the person of an executor or administrator up to and after his discharge, where prior to distribution and discharge he had notice of his tax obligation or failed to exercise due diligence in determining whether or not such obligation existed. Liability for the tax also follows the estate itself, and when by reason of the distribution of the estate and the discharge of the executor or administrator it appears that collection of the tax cannot be made from the executor or administrator, 
the legatees or distributees must account for their proportionate share of the tax due and unpaid. The same considerations apply to other trusts. Where the tax has been paid on the net income of an estate or trust by the fiduciary, such income is free from tax when distributed to the beneficiaries. 


\section{WITHHOLDING AT SOURGE}

ArT. 261. Deducting and withholding tax at source.-Under the opinion of the Attorney-General (Income Tax Letter No. 1, May 29, 1919), deducting and withholding is required of one per cent $(1 \%)$ on the first $\$ 10,000$ and of two per cent (2\%) on all sums in excess of $\$ 10,000$ from all salaries, wages, commissions, gratuities, emoluments, perquisites and other fixed and determinable annual or periodical compensation earned for personal services in a business, trade, profession or occupation carried on within the State, if the aggregate amount thereof in any calendar year on account of any individual equals or exceeds $\$ 1,000$, unless there shall be filed with the withholding agent a certificate of residence, on Form 101, to the effect that the recipient is a resident of the State and setting forth his residence address within the State.

ArT. 262. Deducting and withholding in 1919.- Withholding agents shall deduct and withhold, as set forth in article 261, in respect of personal service compensation paid or credited to the payee at any time on or after January 1, 1919, except that if the employee left the service of the withholding agent prior to May 14, 1919 (the date of the enactment of chapter 627 of the Laws of 1919), and was fully paid prior to that date, no duty or obligation in respect to such payments rests on the withholding agent, unless the status of employer and employee is again created during 1919 and further payments of compensation for personal services are made or credited in 1919. In other words, the provisions for deducting and withholding are effective from January 1,1919 , except as stated in this article.

Art. 263. Fixed or determinable annual or periodical income.Only income earned for personal services is subject to deducting and withholding. The statute specifies that every withholding agent shall deduct from all salaries, wages, commissions, gratuities, emoluments and perquisites. But other kinds of personal service income may be included if fixed or determinable, annual or periodical. Income is fixed when it is to be paid in amounts definitely predetermined. It is determinable whenever there is 
a basis of calculation by which the amount to be paid may be ascertained. The income need not be paid annually or at an annual rate. It may be paid periodically. The word "periodical" is used in opposition to "annual" and means from time to time, whether or not at regular intervals. That the length of time during which the payments are to be made may be increased or diminished in accordance with someone's will or with the happening of an event, does not make the payments any the less determinable or periodical.

The following shall be deemed to be fixed and determinable annual or periodical compensation within the meaning of section 360 of the Tax Law:

Any payment made by way of salary, wage, commission, gratuity, emolument, perquisite or otherwise for personal services rendered, if the amount thereof shall be

(a) determined prior to, concurrent with or subsequent

to the rendering of the service, and is

(b) based on personal services rendered by the hour, week, month, year or other period of time,

whether such personal service consists of

(c) the performance of specified or unspecified duties, or of

(d) work done on or in connection with one or more of certain articles or parts thereof;

irrespective of whether payment be made

(e) in cash,

(f) in board or lodging, or both,

(g) in the stock of a corporation,

(h) by promissory note or other obligation, or

(i) in property, service or otherwise.

If payment shall be made otherwise than in cash, it shall be considered and treated as payment in cash to the fair market value (determinable usually by understanding or agreement existing between the payor and the payee) of such medium, other than cash, as may be employed.

Fees for professional services are not subject to withholding unless contracted for or paid on an annual or periodical basis.

ART. 264. Year, for purposes of deducting and withholding.Deducting and withholding of personal service compensation by 
withholding agents shall be on the basis of a calendar year, irrespective of the basis of reporting adopted by the payee-taxpayer. Personal service compensation shall be deemed to have been paid by the withholding agent and received by the payee-taxpayer only if and to the extent actually paid or credited to the payee and thus made reducible to possession by him. Commissions and all other forms of personal service compensation determined and paid or credited to a payee-taxpayer after the close of a calendar year, shall, for the purpose of deducting and withholding the tax and of returning information with respect thereto, be treated as payments made in the calendar year when paid or credited, but for such purposes only. The approved method of accounting employed by the payee-taxpayer shall govern in so far as he may be called upon to account for such payments for income tax purposes.

ART. 265. Income not subject to deducting and withholding.Deducting and withholding from income is not required in the following cases:

(a) In respect of personal service compensation income when there shall have been filed with the withholding agent a resident's certificate on Form 101, to the effect that the person receiving the compensation is a resident of this State and setting forth his residence address within the State.

(b) If of a character other than compensation for personal services.

(c) Where the personal services are rendered entirely without the State, by a nonresident, whether payment be made from within or without the State, irrespective of the status of the withholding agent. The occasional entry into the State of a nonresident employee who performs the duties for which he is employed entirely without the State, but enters the State for the purpose of reporting, receiving instructions, accounting, etc., incidental to his duties without the State, shall not be deemed to take such employee out of the class of those rendering their services entirely without the State. 
(d) Where the personal services are rendered within the State, if rendered for, and delivery of payment is made without the State by, a nonresident individual or partnership having no office or place of business or paying agent within the State, or a foreign corporation that (1) is not registered in New York and (2) has no office or place of business or paying agent within the State. (Nothing in subparagraph " $d$ " shall be construed to relieve the recipient from liability to make return and pay the tax on such income.)

Art. 266. (Revised.) Income of a nonresident for services performed partly within and partly without the State.- In case a nonresident receives compensation for personal services rendered or performed partly within and partly without the State, the withholding agent shall deduct and withhold on that portion of the compensation which is earned within the State of New York in accordance with the following rules of apportionment:

(a) If the nonresident is a salesman, drummer, agent or other employee through whose services receipts or remuneraiton inure directly to the employer, the deducting and withholding shall attach to the portion of the entire salary which the volume of business transacted by the employee within the State of New York bears to the total volume of business transacted within and without the State by such employee.

(b) If the nature of the employment of the nonresident is such that receipts or remuneration for services rendered do not inure directly to the employer, as in the case of clerks, bookkeepers, laborers or other like classes of employees, the deducting and withholding shall attach to the portion of the personal service compensation income of such employee which the time employed within the State bears to the time employed both within and without the State. 
(c) If it is not possible to apportion the income as above provided, because of the peculiarities of the service of the employee, the apportionment shall be made in accordance with the facts and the tax deducted and withheld accordingly. In such a case a full statement of the facts shall be made to the Comptroller.

Art. 267. Form of residence certificate.-Form 101 shall be used by residents of the State of New York for the purpose of claiming the benefit of such residence for income tax purposes. Withholding agents shall retain, preserve and keep available for examination and inspection by the Comptroller or his authorized representative all residence certificates for a period of one year next following the close of the calendar year for which such certificates shall have been given. Blanks (Form 101) will be furnished by the Comptroller on the application of withholding agents. Withholding agents may, if they choose to do so, use blanks acquired from other sources, provided, however, that the form and wording thereof shall comply exactly with Form 101.

Art. 268. (Revised.) Renewal of residence certificates.-A certificate of residence shall be effective only for the calendar year in which it is filed. New certificates shall be required by withholding agents for each succeeding calendar year.

ART. 269. Deducting and withholding where residence is established.-When a withholding agent shall have deducted and withheld from the personal service compensation of an employee and such employee shall thereafter, before return of the amount so withheld is made by the withholding agent but not later than March 15 in the year following, file with the withholding agent a residence certificate on Form 101, the withholding agent shall thereupon pay over to the employee the entire amount of income so deducted and withheld for such calendar year.

ArT. 270. Return of tax withheld.- Every withholding agent shall, for each calendar year, on or before March 15 next following, make a verified return to the New York State Income 
Tax Bureau of all sums deducted and withheld from the personal service compensation of employees during that calendar year, in accordance with articles 261 and 262 . The return shall be made on Form 103, accompanied by separate reports, one for each individual, on Form 102. There shall be reported on such reports the items of information therein called for. The aggregate amount of tax shown to be withheld by the return on Form 103 shall accompany the return. 


\section{INFORMATION AT SOURCE}

Art. 281. Who shall make returns of information.- The following shall make returns of information to the New York State Tncome Tax Bureau, Albany, N. Y. Every

(a) resident of the State,

(b) officer and employee of the State,

(c) officer and employee of a municipal corporation or political subdivision of the State,

(d) domestic corporation,

(e) foreign corporation registered within the State,

(f) individual, corporation, association and partnership maintaining an office or place of business within the State, whether or not a paying agency be maintained within the State,

making payment to a taxpayer of fixed or determinable taxable income of $\$ 1,000$ or more in a calendar year.

ART. 282. Return of information where no actual withholding. - Returns of information shall be made for the calendar year and shall be filed with the New York State Income Tax Bureau, Albany, N. Y., on or before March 15 next following. The return shall be made on Form 105. The return or returns of information shall be accompanied by a verified letter of transmittal on Form 106. There shall be reported on such forms the items of information therein called for. Whether the recipient is single, married or the head of a family, is to be stated if possible. Where no present address is available, the last known postoffice address must be given.

Art. 283. No return of information where there has been actual withholding. - No return or report shall be made on Forms 105 and 106 , of payments of personal service compensation, where there has been actual withholding and report made thereof on Forms 102 and 103 as provided in article 270 .

ART. 284. Return of information for payments in 1919.-Returns of information for the calendar year 1919 shall include all payments made during that year, the Income Tax Law being retroactive in this regard to January 1, 1919. 
ART. 285. What is included in calculating $\$ 1,000$ for the purpose of reporting information.- Returns of information are required of all amounts paid or credited to the same payee by one payor (except as provided in article 289) if they aggregate $\$ 1,000$ or more during the calendar year, irrespective of the basis of reporting by the payee or by the payor. The necessity of reporting is not limited to payments of income of a single kind equalling or exceeding $\$ 1,000$, but information returns are required if the aggregate payments of income of all kinds, of which returns of information are generally required, equal or exceed $\$ 1,000$. For example, if a payor pays to a payee $\$ 600$ for personal services, $\$ 250$ for rent and $\$ 150$ for interest, he is required to report the payments on Form 105, the aggregate of these sums equalling $\$ 1,000$.

ART. 286. Returns of information as to payments for personal service.-Payments for personal service, equalling or exceeding $\$ 1,000$ for the calendar year, whether such total sum is made up of wages, salaries, commissions or any other compensation, however paid, must be reported. Heads of branch offices and subcontractors employing labor, who keep the only complete record of payments therefor, should file returns of information in regard to such payments directly with the Income Tax Bureau. When both main office and branch office have adequate records the return should be filed by the main office. In the case of an employer having a large number of employees who are moved from place to place as the exigencies of the service require, and who has no complete record of annual payments to them at any one place, the average monthly compensation of two representative months may be taken to establish a fair monthly wage and, unless the yearly payment based on this estimate in the case of an employee amounts to $\$ 1,000$ or more, no return of information respecting such payments is required.

Art. 287. Return of information as to payments of interest on registered bonds. - Every (a) domestic corporation and (b) registered foreign corporation, making payment to a resident of the State, of interest on registered bonds or other obligations, shall make returns of information thereon if the amount, either of itself or in connection with other payments of income to the same 
payee, equals or exceeds $\$ 1,000$ in a calendar year. Any such corporation may make returns through its fiscal or paying agent. In case the payee is known to be a nonresident of the State no return need be made in respect of him. If the residence of the payee is not known to the corporation or its fiscal or paying agent, it need report only such payments as are made to payees with registered addresses withiu the State.

Fiscal or other paying agents of (a) States, (b) municipal corporations or political subdivisions of States, (c) foreign governments, or (d) unregistered foreign corporations, are not required to make returns of interest payments.

ART. 288. Return of information as to payment of dividends.When directed by the State Comptroller, either specially or by general regulation, every domestic or registered foreign corporation shall render a return of its payments of dividends and distributions to resident stockholders, if the amount paid or distributed equals or exceeds $\$ 1,000$ in a calendar year, for such period as may be specified, stating the name and address of each stockholder, the number and class of shares owned by him and the date and amount of each dividend paid him. If the residence of the payee is not known to the corporation, or its fiscal or paying agent, it need report only such payments as are made to payees with registered addresses within the State.

ART. 289. Payments of which no return of information is required.-Payments of the following classes need not be reported on returns of information:

(a) Dividends (see article 288),

(b) Interest coupons payable to bearer (see article 287 for reports of payments of interest on registered bonds),

(c) Income exempt from taxation under section 359 , subdivision 2, of the Tax Law,

(d) Bills paid for merchandise, telegrams, telephone, freight, storage and similar charges,

(e) To employees for board and lodging while traveling in the course of their employment,

(f) Annuities representing the return of capital,

(g) Of rent, made to real estate agents (but the agent must report payments to the landlord if they equal or exceed $\$ 1,000$ annually), 
(h) To nonresident employees, for services rendered entirely without the State,

(i) To nonresidents, of annuities, including pensions, interest on bank deposits, interest on bonds or other interestbearing obligations or dividends,

(j) Fees for professional services, except retainers on an annual or periodical hasis,

(k) To corporations, to partnerships and fiduciaries, and distributions by partnerships to partners and by fiduciaries to beneficiaries.

ART. 290. Information as to actual owner.- When the person receiving a payment or credit, with respect to which information at the source is required, is not the actual owner of the income received, the name and address of the actual owner shall be furnished upon demand of the State Comptroller, and in default of a compliance with such demand, the payee becomes liable to the penalties provided. (See subdivision 1, section 376, of the statute.) 


\section{NONRESIDENT SECTION}

\section{TAX ON NONRESIDENTS}

ArT. 401. Tax on nonresidents. - In the case of a nonresident, the tax is imposed upon his entire net income from sources within the State; that is, (a) from all property owned and (b) from every business, trade, profession or occupation carried on in the State of New York. It is not imposed upon income arising from annuities, interest on bank deposits, interest on bonds, notes or other interest-bearing obligations or dividends from corporations, except to the extent to which the same shall be a part of the taxable income from any business, trade, profession or occupation carried on in this State. (Tax Law, sections 351 and 359.) (See article 415.)

\section{GROSS INCOME DEFINED}

Art. 411. Gross income.-With respect to every business, trade, profession or occupation carried on within the State of New York by a nonresident, the gross income therefrom is determined in the same manner as in the case of a resident, and includes and excludes the same elements. The articles in the resident section of these regulations under the titles of "Gross Income Defined: Inclusions," "Gross Income Defined: Exclusions" and "Gross Income Defined: Basis for Determining Gain or Loss," apply equally to nonresidents except as stated in the following articles, 412 to 419 . A nonresident member of a partnership is taxable on his distributive share of that portion of the partnership profits which is derived from sources within the State. With respect to the apportionment of the income of a nonresident (or a partrership with a nonresident member) derived from sources both within and without the State, see articles 451-470.

ArT. 412. Compensation for personal services.-The gross income of a nonresident (not engaged in the practice of a trade, profession or occupation on his own account, but employed and receiving compensation for his services) includes compensation for personal services only if; and to the extent that, the services were rendered within the State of New York. Compensation for personal services rendered by a nonresident wholly without 
the State is excluded from gross income regardless of the fact that payment may be made from a point within the State or that the employer is a resident individual, partnership or corporation. See articles 451 and 452 for apportionment of compensation for services rendered by a nonresident partly within and partly without the State.

Art. 413. Pensions received.-When received by a nonresident, a pension of any kind is not taxable income as it is an annuity and, therefore, exempt from taxation against a nonresident. (See Tax Law, section 359, subdivision 3, and article 41.)

Art. 414. Gross income from business. - In the case of a nonresident (other than one who is employed by another, as distinguished from doing business on his own account) gross income from a business, trade, profession or occupation is determined in the same manner as is the gross income of a resident, from a business, trade, profession or occupation, but includes only income from a business, trade, profession or occupation carried on within the State of New York. (See article 45\%.)

- ART. 415. Definition of "business carried on" within the State. - A business, trade, profession or occupation (as distinguished from personal service as employee) is carried on within the State by a nonresident when he occupies, has, maintains or operates desk room, an office, a shop, a store, a warehouse, a factory, an agency or other place where his affairs are systematically and regularly carried on notwithstanding the occasional consummation of isolated transactions without the State. Business is being carried on if it is here with a fair measure of permanency and continuity. Its regularity or continuity need not be for a long period; the life of the business is not a material factor.

ART. $4 \overline{16}$. Sale of stocks, bonds and other securities.-Gains and profits of a nonresident from the sale, exchange or other disposition of stocks, bonds and other securities are not taxable and should not be included in gross income, except to the extent to which the same shall be a part of the income from a business carried on in the State of New York, even though the sale or other disposition thereof may have been made within the State of New York or consummated on an exchange located within such State. Likewise, losses sustained from the sale, exchange or other dis- 
position of stocks, bonds and other securities under like conditions are not deductible, except to the extent that they may be losses incurred in, because forming a part of a business carried on within the State.

Art. 417. Sale of property other than securities.-Gross income of a nonresident shall include all the profits derived from the sale, exchange or other disposition of real property located within the State of New York. It also includes all the profits derived from the sale, exchange or other disposition of personal property (other than stocks, bonds or other securities) having an actual situs within the State but not forming part of the assets of a business carried on within the State. Gross income from the sale, exchange or other disposition of real or personal property is determined in the same manner as gross income from similar sales by a resident. (See articles 3.1-39.)

Art. 418. Rents and royalties. - The gross income of a nonresident from rents and royalties includes all rents and royalties received from property. located within the State of New York and excludes all other rents and royalties. Such gross income is determined in the same manner as is the gross income of a resident from rents and royalties. (See articles 42 and 120.) Rent received by a nonresident for property located without the State is excluded from gross income regardless of the fact that payments may be made from a point within the State by a resident individual, partnership or corporation.

ART. 419. Interest and dividends. - Except to the extent to which interest and dividend income shall be part of the taxable income from any business, trade, profession or occupation, carried on within the State of New York, a nonresident shall exclude interest and dividends from gross income.

\section{DEDUCTIONS ALLOWED}

Art. 431. Allowable deductions. - In general, the deductions from gross income allowable to a nonresident are the same as allowed to a resident, except that they are allowed only if, and to the extent that, they are connected with income arising from sources within the State of New York, that is, in connection with property owned or with a business, trade, profession or occupation carried on within the State.

(See article 45\%.)

A taxpayer 
shall not be entitled to any deductions unless his return discloses his total gross income from sources both within and without the State to the extent required by the form of return. (Tax Law, section 367; article 481.)

Art. 432. Business expenses.-Articles 111 to 125, inclusive, under the title of "Deductions Allowed: Business Expenses" in the resident section, apply equally to a nonresident to the extent that the business expenses are connected with a business, trade, profession or occupation carried on within the State of New York, but not otherwise. (See articles 415, 457 and 481.)

ArT. 433. Taxes.- Income taxes and taxes and assessments for benefits of a kind tending to increase the value of the property assessed, paid or accrued within the taxable year, are not deductible. Estate and inheritance taxes are not deductible. All other taxes paid or accrued by a nonresident are deductible to the extent that they are connected with sources of income derived from property owned or a business, trade, profession or occupation carried on within the State. (See articles 415, 457 and 481.)

ART. 434. Interest.-A nonresident is entitled to deduct from gross income the proportion of the total interest paid or accrued in connection with taxable income from sources within the State of New York, which the amount of his gross income, as defined in the Tax Law, section 359, and as provided by these regulations, from all sources within the State, bears to his total gross income from all sources within and without the State. His total gross income is his gross income, as defined by the Tax Law, section 359, and these regulations, plus his income exempt from taxation, including all of his income from sources without the State. (See Tax Law, section 367, and article 481.)

ART. 435. Losses.-A nonresident taxpayer may dëduct from gross income on account of losses sustained during the taxable year and not compensated by insurance or otherwise, as follows:

(a) If incurred in a trade or business carried on within the State.

(b) If incurred in any transaction within the State entered into for profit though not connected with a trade or business, but only if and to the extent that, they are connected with property located within the State of such a character that the 
income flowing from, or by virtue of the transaction, if a profit had been realized, would have been included in the gross income of a nonresident.

(c) If arising from fire, storm, shipwreck or other casualty or from theft, but only if and to the extent that, they are connected with property located within the State of such a character, that the income flowing from $i t$, or by virtue of it, if any, would be included in the gross income of a nonresident. (See article 481.)

\section{APPORTIONMENT OF INCOME FROM SOURCES WITHIN AND WITHOUT THE STATE OF NEW YORK}

Art. 451. Earnings of salesmen.- The gross income from commissions and salaries earned by nonresident salesmen, drummers, agents or others, through whose services receipts or remuneration. inure directly to the employer, for services performed or sales made within and without the State of New York, includes that proportion of the commissions and salaries received which the volume of business transacted by such employee within the State of New York bears to the total volume of business transacted by him within and without the State. (See article 266.) Allowable deductions must be apportioned on the same basis.

ART. 452. Salaries and wages of nonresident employees and officers.- If the nature of the employment of the nonresident is such that receipts or remuneration for services rendered do not inure directly to the employer, as in the case of corporate officers, clerical employees, laborers or other like classes of employees, gross income includes that proportion of the total amount received for services which the time employed within the State bears to the total time employed both within and without the State of New York. (See article 266.) Allowable deductions must be apportioned on the same basis.

ART. 453. Wages of nonresident seamen.-Resident seamen, like all other residents of the State of New York, are taxable on their entire net income as defined by the law and these regulations from whatever sources derived. Nonresident seamen, however, are taxable only on income derived from sources within the State of New York. The wage of a nonresident seaman 
earned on a vessel operating exclusively within the State of New York is regarded as income received from sources within the State of New York, and as such, is taxable income. The wage earned by a nonresident seaman on a ship which is operated exclusively between ports of the State of New York and foreign ports, or ports of other states is not to be regarded as from sources within the State of New York, even though at times the ship touches at a port within the State of New York and remains there a reasonable time for the transaction of its business. The presence within the State of a seaman aboard a ship which enters a port for the purpose of foreign or interstate trade is merely transitory and the wages earned during that period by a nonresident seaman are not taxable. Seamen employed on vessels operating between the States of New Jersey and New York within the port of New York, are regarded as earning income from sources partly within and partly without the State of New York. Onehalf of the compensation earned aboard such a vessel by a nonresident is held to be taxable income. Withholding at the source applies with respect to all compensation of nonresident seamen, which in accordance with this article, constitutes taxable income.

ArT. 454. Income from vessels. - The tax does not apply to charter money or freight or passage payments, received by a nonresident owner or lessee in regard to a vessel which is operated exclusively between ports of the State of New York and foreign ports, or ports of other states, if the person receiving the income maintains no regular agency in the State of New York and is not carrying on business in the State of New York. (See article 415.)

Art. 455. Business carried on wholly within the State.-The entire net income of a nonresident from a business, trade, profession or occupation, carried on within the State (as "business carried on" is defined in article 415), and not carried on elsewhere, as so defined, is income from a source within the State of New York and taxable as such.

This is so, even though the nonresident or his representatives travel without the State for the purposes of the trade or business, 
that is for the purpose of buying, selling, financing or performing any duties in connection with the business, and even though sales may be made to, or services performed for, or on behalf of, persons or corporations located without the State.

ARt. 456. Business carried on wholly without the State--No part of the net income of a nonresident from a business, trade, profession, or occupation, carried on without the State of New York, (as "business carried on" is defined in article 415, ) and not carried on as so defined within this State, is taxable.

This is so, even though the nonresident or his representatives may enter the State for the purpose of buying, selling, financing, or performing any other duty in connection with the business; and even though sales may be made to, or services performed for, or on behalf of, persons or corporations located within the State.

ART. 457. Apportionment of business income from business carried on both within and without the State.-If a nonresident, or a partnership with a nonresident member, carries on business, (as business carried on" is defined in article 415 ,) both within and without the State, the net business income therefrom must be apportioned so as to allocate to the State of New York a proportion of such income on a fair and equitable basis, in accordance with approved methods of accounting.

If the books of the taxpayer are so kept as regularly to disclose the proportion of his business income, which is earned from sources within the State, the return of the taxpayer shall disclose both the total income, and the part apportioned to the State of New York, and the basis upon which such apportionment is made. If such basis is approved by the Comptroller, the return will be accepted.

If the books of the taxpayer do not disclose the proportion of his net income from sources within the State of New York, his return, or if the basis of apportionment used by him shall not be approved by the Comptroller, his amended return shall disclose his net income from business both within and without the State, and the tax will be calculated and collected upon the portion of his total net income from business which the aggregate of the New York State factors bears to the aggregate of the total FACTORS as herein defined. 
The "New York State factors" include the following:

(1) The average of the value of his real property and tangible personal property within the State, (a) at the beginning of the taxable year and (b) at the end of the taxable year, but only of property connected with the business.

(2) The total wages, salaries, and other personal service compensation paid during the taxable year to employees in connection with the business carried on (as defined in article 415) within the State.

(3) The gross sales or charges for services performed, by or through an agency (of the kind enumerated in article 415) located within the State. The sales or charges to be allocated to New York shall include all sales negotiated or consummated by salesmen, or services performed by other representatives, attached to or sent from offices, or other agencies, situated within the State of New York.

The "тотад Factors" include the following:

(1) The average of the value of all his real property and tangible personal property (a) at the beginning of the taxable year, and (b) at the end of the taxable year, both within and without the State, but only of property connected with the business.

(2) The total wages, salaries, and other personal service compensation paid by him during the taxable year, to employees connected with the business, whether within or without the State.

(3) The gross sales, or charges for services performed, whether within or without the State.

"Business Income" as used in this article excludes profits (or losses) from the sale, exchange or other disposition of real property, and income from rents and royalties, income from these sources being taxable only if the property from which the income was derived was located within the State of New York, and in such case the entire net income from these sources is taxable. (See articles 417 and 418.)

ArT. 470. Alternative basis of apportionment.-The provisions of articles 451 to 470 dealing with the apportionment of income of nonresidents earned from sources both within and without the 
State of New York are designed to allocate to the State of New York on a fair and equitable basis a proportion of such income carned from sources both within and without the State. Any nonresident may submit an alternative basis of apportionment with respect to his own income and explain that basis in full in his return. If approved by the Comptroller, that methorl will be accepted instead and in place of the one herein prescribed.

\section{ALLOWANCE OF DEDUCTIONS AND CREDIT}

ART. 481. Allowance of deductions to a nonresident.-Unless a nonresident individual shall render a return of income as required in article 523, the tax shall be collected on the basis of his gross income (not his net income) from sources within the State of New York. Where a nonresident has income from sources within the State of New York, and a return of income shall not be filed by him or on his behalf, the Comptroller will cause an estimate of the taxable income of such nonresident taxpayer to be made, such estimate to include the income of such nonresident from all sources within the State of New York concerning which he has information, and for such purpose may examine or cause to be examined the books, accounts and records of such taxpayer and he will then compute the tax of such nonresident taxpayer without allowance for deductions or credit and with penalties and interest. (Tax Law, sections 367 and 373 and article 556.)

$A_{R^{\prime} T}$. 482. Allowance of credit for taxes.-A taxpayer not a resident of the State of New York who has become liable to income tax to the State or country wherein he resides, upon his net income for the taxable year derived from sources within the State of New York, shall be credited with such proportion of the tax payable by him to the State or country wherein he resides as his income subject to taxation under the New York State Income Tax Law bears to his entire income upon which the tax so payable to such other State or country was imposed; provided such credit shall be allowed only if the laws of such State or country grant a substantially similar credit to residents of New York State subject to income tax under such laws.

(Tax Law, section 363.) 
Amount of "taxes payable" means taxes only (no credit being given for amounts representing interest or penalties) paid or accrued during the taxable year on behalf of the individual claiming credit. "Other State or country" includes within its meaning territories, possessions, states (other than New York State) and any foreign sovereignty.

Art. 483. Conditions of allowance of credit.-When credit is sought for income taxes paid to other States or countries pursuant to the Tax Law, section 363, (See article 482) the Income Tax return form of the individual must be carefully filled ont with all the information called for therein, the calculation of credit indicated, and executed as provided therein. When the Comptroller receives proof that any other State or country allows a substantially similar credit to residents of this State within the meaning of section 363 of the Tax Law, that fact will be announced from time to time by amendment to this article.

ART. 484. Redetermination of tax when credit proves incorrect. - In case credit has been taken and allowed for taxes accrued, or a proportionate share thereof, and the amount that is actually paid on account of such taxes, or a proportionate share thereof, is not the same as the amount of such credit, or in case any tax payment credited is refunded in whole or in part, the taxpayer shall immediately notify the Comptroller. The Comptroller will thereupon redetermine the amount of the income tax of such taxpayer for the year or years for which such incorrect credit was granted. The amount of tax, if any, due upon such redetermination shall be paid by the taxpayer upon notice and demand by the Comptroller. The amount of tax, if any, shown by such redetermination to have been overpaid shall be immediately refunded to him. (Tax Law, section $37 \%$ and articles 571-574.) 


\section{GENERAL PROVISIONS}

\section{RESIDENCE}

Art. 501. Who is a resident.-For the purpose of the Income Tax Law, a resident of New York State is a natural person, who has a fixed and settled abode in this State to which he returns from incidental and temporary absences and from which he has no present intention of removing. Such residence may not be, nor be intended to be, of long riuration if it be fixed and settled and to continue for the time necessary to accomplish some business or other purpose and is not merely transient. A taxpayer's residence for purposes of taxation is not necessarily his domicile for election purposes, as he may be domiciled outside the State and still be taxable as a resident of the State. As the question of residence is largely determined by the intent of the taxpayer and by the facts in each case, the Comptroller may require a statement of the circumstances to aid him in determining whether the individual be a resident or nonresident.

ArT. 502. Who is a nonresident._. "Nonresident" means an individual whose residence is not within the State of New York. Any individual living in the State of New York who is not a mere transient is a resident of the State of New York for purposes of the Income Tax. Whether he is a transient or not is determined by his intentions with regard to his stay. If he lives in the State of New York and has no definite intention to leave or reside elsewhere, he is a resident. The best evidence of his intention is afforded by the conduct, acts and declarations of the individual. The typical transient is one who stops for a short time in the course of a journey through the State of New York, sometimes performing labor, sometimes not, or one who enters such State intending only to stop long enough to carry out some purpose, object or plan not involving an extended stay. A mere floating intention, indefinite as to time, to return to another State or country, is not sufficient to constitute him a transient.

Art. 503. Proof of residence.-An individual's statements as to his intention with regard to residence are not conclusive, but 
when unequivocal will determine the question of his intention, unless his conduct, acts or other surrounding circumstances contradict the statements. It sometimes occurs that an individual who genuinely intends his stay to be transient may put off his departure from time to time by reason of changed conditions, remaining a transient though living in the State of New York for a considerable time. The fact that an individual's family is without the State does not necessarily indicate that he is a transient rather than a resident. An individual who enters this State intending to make his home elsewhere as soon as he has accumulated a sum of money sufficient to provide for his journey to a point without the State is not to be considered a transient eren though his expectation in this regard may reasonably, considering the rate of his saving, be fulfilled within a comparatively short time.

ART. 504. Loss of residence.-It will be presumed that an individual who has established a residence in the State of New York, as outlined above, continues to be a resident until he or his family establish a residence without the State. (Articles 501 and 502.)

\section{INDIVIDUAL RETURNS}

ART. 521. Resident individual returns.-Every resident individual (including a head of a family) whose net income as defined in the Tax Law, sections 357 and 358, and articles 11-14, is $\$ 1,000$ or over for the taxable year must make a return of income unless married and living with husband or wife as defined in article 207 . The return shall be for his taxable year, whether calendar or fiscal. Whether or not an individual is the head of a family or has dependents is immaterial in determining his liability to render a return. If an individual is a married person living with husband or wife, no return need be made where their aggregate net income is less than $\$ 2,000$; but a separate return must be made by each of them, regardless of the amount of the individual income of each, where their aggregate net income is $\$ 2,000$ or over, unless they join in a single return. The husband shall include in his return the income derived from services rendered by the wife or from the sale of products of her labor if she does not file a separate return or join with him in a return 
setting forth her income separately. For returns by partnerships see Tax Law, section 368 , and articles 230 and 231 ; by fiduciaries, see Tax Law, section 369 , and articles 246-250. When specifically directed by the Comptroller an individual must file the return of his income whether or not such income is subject to taxation under this law. (Tax Law, section 373.)

Art. 522. Form of return for residents. - The return shall be on Form 201 unless the taxpayer's entire gross income is derived from personal services, interest and dividends or from partnerships, estates and trusts. The return shall be on Form 200 if the taxpayer's gross income is derived from personal services, interest and dividends or from partnerships, estates and trusts, but any taxpayer may make a return of his income on Form 201. Forms are provided by the Comptroller and may be had at any office of the State Comptroller. When by reason of illness, absence, minority, nonresidence or otherwise the person liable for the return is unable to make it, the return may be made by an agent, guardian or other person charged with the care of the person or property of such taxpayer, the agent assuming the responsibility for making the return and incurring liability to the specific penalties provided for erroneous, false or fraudulent returns. (Tax Law, section 376, and article 556.)

ArT. 523. Nonresident individual returns.-Every nonresident individual (including the head of a family) whose net income, as defined in the Tax Law, sections 357 and 358, articles 11-14, from sources within the State of New York as defined in article 401 , is $\$ 1,000$ or more for the taxable year, must make a return of income unless married and living with husband or wife as defined in article 207. The returns shall be for the taxable year, whether calendar or fiscal. Whether or not an individual is the head of a family or has dependents is immaterial in determining his liability to render a return. If a nonresident individual is a married person living with husband or wife, no return need be made where the aggregate net income from sources within the State is less than $\$ 2,000$, but a separate return must be made by each of them, regardless of the amount of the individual income of each, where the aggregate net income from sources within the State is $\$ 2,000$ or over, unless they join in a single return. 
The return shall be on Form 201a unless the entire gross income from sources within the state, of the nonresident taxpayer, is derived from personal services and from partnerships, estates and trusts. The return shall be on Form 200a if the nonresident taxpayer's gross income from sources within the State is derived from personal services, and from partnerships, estates and trusts.

The responsible representatives of taxpayers not resident within the State in connection with any sources of income which such taxpayers may have within the State of New York shall make a return of such income, and shall pay any and all tax, imposed upon the income received by them in behalf of their taxpayer principals, in all cases. The agent of a nonresident is responsible for a correct return of all income accruing to his principal within the purview of the agency. The agency appointment will determine how completely the agent is substituted for the principal for tax purposes.

Where upon filing a return of income it appears that a nonresident taxpayer is not liable for tax, but nevertheless a tax shall have been withheld at the source, or where the amount withheld is in excess of his tax liability, in order to obtain a refund on the basis of the showing made by the return there shall be attached to it a statement showing accurately the amounts of tax withheld, with the names and post-office addresses of all withholding agents. (Article 574.)

ART. 524. Return of income of minor.-An individual under twenty-one years of age is required to render a return of income if he has a net income of his own of $\$ 1,000$ or over for the taxable year. If he is married, see article 521. If the aggregate of the net income of a minor from any property which he possesses, and from any funds held in trust for him by a trustee or guardian, and from any earnings for his own use, is at least $\$ 1,000$, a return as in the case of any other individual must be made by him or by his guardian or some other person charged with the care of his person or property for him. (Article 248.) If, however, a minor is dependent upon his parent, who appropriates or may appropriate his earnings, such earnings are income of the parent and not of the minor for the purpose of the tax. In the absence of proof to the contrary a parent will be assumed 
not to have emancipated his minor child and must include in his return any earnings of the minor. (See article 115.) Nonresident minors must make return in the same manner and of the same classes of income as other nonresidents. The provisions of article 523 are equally applicable to nonresident minors.

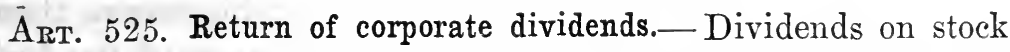
of domestic corporations or resident foreign corporations are prima facie income of the record owner of the stock, and such record owner will be liable for any tax based thereon, unless a disclosure of the actual ownership is made to the Comptroller, which shall show that the record owner is not the actual owner and who the owner is and his address.

Art. 526. Accounting period-- The return of a taxpayer is made and his income computed for his taxable year, which means his fiscal year, or the calendar year if he has not established a fiscal year. The term "fiscal year" means an accounting period of twelve months ending on the last day of any month other than December. No fiscal year will, however, be recognized unless before its close it was definitely established as an accounting period by the taxpayer and the books of such taxpayer were kept in accordance therewith. The taxable year 1919 is the calendar year 1919 or any fiscal year ending during the calendar year 1919 . (Tax Law, section 350.) A taxpayer having an existing accounting period which is a fiscal year within the meaning of the statute not only needs no permission to make his return on the basis of such a taxable year, but is required to do so. A person having no such fiscal year must make return on the basis of the calendar year.

A taxpayer must make his return for the accounting period on the basis of which his books are kept; so that his State return, like his Federal return, must be for a fiscal year if his books are kept on a fiscal year basis.

ART. 527. Fiscal year ending in 1919. - The method provided for computing the tax for a fiscal year beginning in 1918 and ending in 1919 is as follows: The tax attributable to the calendar year 1919 is found by computing the income of the taxparer in accordance with the statute for the fiscal year and determining the proportion of such income which the portion of such fiscal 
year falling within the calendar year is of the full fiscal year, and computing the tax on such amount. The personal exemption must be correspondingly apportioned.

ArT. 528. Change in accounting period.-If a taxpayer changes his accounting period he shall as soon as possible give to the Comptroller written notice of such change and his reasons there for. The Comptroller will not approve a change of the basis of computing net income unless such notice is given at a time which is both (a) at least thirty days before the date of the taxpayer's return on the basis of his existing taxable year and (b) at least thirty days before the close of the proposed taxable year. If the change in the basis of computing the net income of the taxpayer is approved by the Comptroller the taxpayer shall thereafter make his returns upon the basis of the new accounting period in accordance with the requirement of section 370 of the statute and his net income shall be computed as therein provided. A taxpayer subject to Federal tax shall file with his application a copy of the consent of the Commissioner of Internal Revenue to change the basis of his return for Federal tax purposes. The requirement of notice to the Comptroller will be modified in such cases with respect to time, and where a change is authorized, it will be made effective at the same date as that authorized by the Commissioner of Internal R'evenue.

ART. 529. Returns when accounting period changed.-No return may be made for a period of more than twelve months. A separate return for a fractional part of a year is, therefore, required whenever there is a change with the approval of the Comptroller in the basis of computing net income from one taxable year to another taxable year, and the exemptions allowed shall be reduced respectively to amounts which bear the same ratio to the full exemptions provided for as the number of months in such period bears to twelve months. The separate returns shall be filed for the period from the close of the old taxable year to the beginning of the new taxable year. See article 527 with reference to first returns for fiscal year ending in 1919. (Tax Law, sections 370 and 371, and articles 541-544 and 551.) The tax on net income shall be computed on the basis of the period for which a separate return is made. 
ArT. 530. Verification of returns.-All income tax returns must be verified under oath or affirmation before an officer duly authorized to administer oaths either by the laws of the United States or the laws of the state or territory where such officer resides. Persons in the naval or military service of the United States may verify their returns before any official authorized to administer oaths for the purpose of those services. Income tax returns executed abroad may be attested before United States consular officers.

Ar'r. 531. Use of prescribed forms.-- Copies of the prescribed return forms will so far as possible be furnished taxpayers by the Comptroller. Failure on the part of any taxpayer to receive a blank form will not, however, excuse him from making a return. Taxpayers not supplied with the proper forms should make application therefor to the Comptroller, or at any district office, in ample time to have their returns prepared, verified and filed on or before March fifteenth following the close of the taxable year. Each taxpayer should carefully prepare his return so as to fully and clearly set forth the data therein called for. Imperfect or incorrect returns will not be accepted as meeting the requirements of the statute. In lack of a prescribed form a statement made by a taxpayer disclosing his gross income and the deductions therefrom may be accepted as a tentative return, and if filed within the prescribed time a return so made will relieve the taxpayer from liability to penalties, provided that without unnecessary delay such a tentative return is replaced by a return made on the proper form. The forms and the instructions contained therein have the force and effect of regulations. Each question must be answered and each direction complied with in the same manner as if the forms and instructions were embodied in these regulations.

\section{TIME AND PLACE FOR FILING RETURN}

ART. 541. Time for filing return.-A return of income must be made on or before the fifteenth day of March following the close of the taxpayer's taxable year, and must include the taxpayer's net income for such taxable year. (Tax Law, section 3\%1.) The last due date is the last day upon which a return is required to be filed in accordance with the provisions of the statute or the last 
day of the period covered by an extension of time granted by the Comptroller. When the last due date falls on Sunday or a legal holiday, the last due date for filing returns will be the day following such Sunday or legal holiday. If placed in the mails the return should be posted in ample time to reach the Comptroller's office or any district office of the Income Tax Bureau, under ordinary handling of the mails, on or before the date on which the return is required to be filed. Mailed returns should be addressed: "N. Y. State Income Tax Bureau;" and the address of the district office to which it is sent. If a return is made and placed in the mails in due course, properly addressed and postage paid, in ample time to reach the office of the Comptroller or a district office on or before the last due date, no penalty will attach should the return not be actually received by such officer until subsequent to that date. Where a question may be raised as to whether or not the return was posted in ample time to reach the Comptroller's office or a district office on or before the due date, the envelope in which the return was transmitted will be preserved by the Comptroller with the return.

ART. 542. Time for filing returns upon death or termination of trust.-As soon as possible after his appointment and qualification, without waiting for the close of the taxable year, an executor or administrator may file a return of income for the decedent. Upon the completion of the administration of an estate and final accounting an executor or administrator shall file a return of income of the estate for the portion of the taxable year in which the administration was closed. An ancillary administrator need make no separate return if the domiciliary administrator includes in his return the entire income of the estate. Similarly, upon the termination of any other trust the trustee may make a return without waiting for the close of the taxable year. In any such case the tax must be paid at the time the return is filed. The payment of the tax before the end of the taxable year in such circumstances does not relieve the taxpayer from liability for any additional tax which may subsequently be imposed upon income of the taxable year.

ArT. 543. Extension of time by Comptroller.-It is important that the taxpayer render on or before the return due date a return 
as complete and final as it is possible for him to prepare. However, whenever good cause exists by reason of sickness, absence or otherwise, the Comptroller is authorized to grant an extension of time in which such return may be filed where in his judgment such further time is actually required for the making of an accurate return, not however, in any case exceeding six month, except in cases of taxpayers who are abroad. (Tax Law, section 371.) If the time for filing the return shall be extended the taxpayer shall pay, in addition to the tax, interest thereon at the rate of 6 per centum per annum from the time when the return was originally required to be filed, to the time of actual payment. (Tax Law, section 37\%.) The application for each extension must be made prior to the expiration of the period for which the extenision is desired. As a condition of granting an extension of time for filing a return the Comptroller may require the submission of a tentative return and payment of the tax based on such tentative return.

ArT. 544. Place for filing returns.-- Returns of income must be delivered or mailed to any one of the district offices of the Income Tax Bureau. The following are the addresses of the district offices of the Income Tax Bureau:

District No. 1. Albany.

District No. 2. Borough of Manhattan, New York City.

District No. 3. Borough of Brooklyn, New York City.

District No. 4. Borough of The Bronx, New York City.

District No. 5. Jamaica.

District No. 6. White Plains.

District No. 7. Buffalo.

District No. 8. Rochester.

District No. 9. Syracuse.

District No. 10. Utica.

District No. 11. Elmira.

District No. 12. Binghamton.

District No. 13. Kingston.

Partnership returns (Form 204) and fiduciary returns (Form 205) should be sent to the office of the New York State Income Tax Bureau at Albany, N. Y. 


\section{PAYMENT OF TAXES}

ART. 551. Time for payment of tax.-The tax, unless paid at the source, is to be paid to the Comptroller at the time of filing the return. (Tax Law, section 371, and articles 541-544.) An unconditional extension of time for filing a return will postpone the date for payment of the tax, but see article 543 with reference to tentative returns. Upon computation of the tax, if the amount paid exceeds the correct amount of the tax, the excess shall be refunded to the taxpayer. If the amount paid is less than the correct amount of the tax then due, the difference shall be paid within thirty days after notice of the correct tax as computed by the Comptroller is mailed to the taxpayer. (Tax Law, section 377 and articles 5\%1-5\%4.)

ArT. 552. Receipts for tax payments. - The Comptroller will issue a cash register receipt for every tax which is paid in cash. In the case of payments in cash, the taxpayer should in every instance require a cash register receipt. In the case of payments made by check, the cancelled check is usually a sufficient receipt, but the Comptroller will on request issue an additional receipt.

Art. 553. Interest on tax.- Where the time for the payment of any tax is postponed at the request of the taxpayer, interest at the rate of 6 per centum per annum is added from the original due date to the date of payment. If any tax be not paid when required by the provisions of the statute or in the case of additional taxes at the time designated by the Comptroller, the taxpayer shall pay 5 per centum of such tax plus 1 per centum per month for each month or fraction thereof such tax remains unpaid after such required or designated time, in addition to the amount of such tax. (Tax Law, section 379, subdivision 2.)

Art. 554. Payment of tax by uncertified checks.- The Comptroller will accept uncertified checks in payment of income taxes, provided such checks are collectible at par, that is, for their full amount without any deduction for exchange or other charges. The day on which the Comptroller receives the check will be considered the date of payment so far as the taxpayer is concerned unless the check is returned dishonored. If one check is remitted to cover two or more persons' taxes, the remittance must 
be accompanied by a letter of transmittal stating (a) the name of the drawer of the check; (b) the amount of the check; (c) the amount of any cash, money order or other instrument included in the same remittance; (d) the name of each person whose tax is to be paid by the remittance; and (e) the amount of the payment on account of each person.

ART. 555. Procedure with respect to dishonored checks.-If any check is returned unpaid, all expenses incident to collection of such a check will be charged to the taxpayer. If any taxpayer whose check has been returned uncollected by the depositary bank should fail at once to make the check good, the Comptroller will proceed to collect the tax as though no check had been given. A taxpayer who tenders a certified check in payment for taxes is also not released from his obligation until the check has been paid.

Art. 556. Penalties.- 1. A person who intentionally fails to make a return is guilty of a misdemeanor punishable by a fine not exceeding $\$ 1,000$ or imprisonment not exceeding one year, or both, and in addition is liable to taxation at twice the ordinary rate.

2. If any person, liable to taxation under the law, makes any false or fraudulent return or statement, with intent to evade any tax imposed by the law, he is guilty of a misdemeanor punishable by a fine not exceeding $\$ 1,000$ or imprisonment not exceeding one year, or both, and in addition is liable to taxation at twice the ordinary rate upon the additional amount of income discovered to be taxable.

3. A person who fails to make a return within the required time, but who voluntarily makes a correct return within sixty (60) days is subject to a penalty of 5 per centum of the tax (in no case less than $\$ 2$ ) and an additional 1 per centum for each month or fraction of a month during which the tax remains unpaid.

4. A person who, without intent to defraud, fails to make a return within the required time or a voluntary return within sixty (60) days thereafter, is liable to taxation at twice the ordinary rate, in addition to the penalty referred to in the following paragraph. 
5. A person who fails to pay the tax when due is subject to a penalty of 5 per centum of the amount due but not paid, plus 1 per centum for each month or fraction of a month during which the tax remains unpaid. (Tax Law, sections 376, 377 and 379.)

\section{CORRECTION OF RETURNS}

Art. 571. Comptroller's power of revision.-If, in the opinion of the Comptroller, the return of any taxpayer in any essential respect is incorrect the Comptroller may revise such return and may audit and state an account according to such revised return for the amount due from such taxpayer for taxes, penalties and interest. If any taxpayer fails to make a return the Comptroller may make an estimate of the taxable income of such taxpayer from any information in his possession and for this purpose may examine or cause to be examined, the books and records of such taxpayer, and may take testimony and require proof material for his information, and may audit and state an account according to such information of the amount due from the taxpayer for taxes, penalties and interest. (Tax Law, section 373.)

ART. 5\%2. Authority for abatement and refund of tax.Authority for the refund or abatement of taxes erroneously collected or assessed is contained in section 377 of the Tax Law.

ArT. 573. Claim for abatement.- Where the Comptroller has made an additional assessment, the amount of such additional assessment is payable within thirty days from the date of notice thereof. However, the taxpayer will be afforded opportunity to offer proof as to the incorrectness of all or any part of the additional assessment and may during the thirty-day period file claim for abatement of all or any part thereof. The application must be sustained by the affidavit of the party against whom the tax was assessed, or of other parties cognizant of the facts. When a tax has been audited and stated by the Comptroller the presumption is that the assessment is correct, and the additional assessment must be paid when due, unless the Comptroller has in the meantime ahated all or a part of it. The burden of proof in rebutting the presumption and showing that it was improperly or illegally assessed, or that relief should be given under sec- 
tion 374 of the statute, rests upon the applicant for abatement. The affidavits must, therefore, contain full and explicit statements of all the material facts relating to the claim in support of which they are offered and to the proper consideration of which they are essential. The legality of the claim is to be determined by the Comptroller upon the facts presented by the affidavits. The filing of a claim for abatement does not operate as a suspension of the collection of the tax. The tax must be paid within the thirty-day period, except as to any part thereof which the Comptroller has advised the taxpayer has been abated.

Art. 574. Claim for refund.-Claims by the taxpayer for the refunding of taxes and penalties erroneously or illegally collected shall be made on Form 110. In this case, as in that of claims for abatement, the burden of proof rests upon the claimant. All the facts relied upon in support of the claim should be clearly set forth under oath. It should be accompanied by the Comptroller's receipt or the cancelled check showing payment of the tax. The affidavit may be made by an agent of the person assessed. Checks in payment of claims allowed will be drawn in the names of the persons entitled to the money and shall unless otherwise directed be sent by the Comptroller directly to the proper persons or their duly authorized attorneys or agents. In the case of mere overpayments by taxpayers the Comptroller may repay the excess. The Comptroller has no authority to refund on equitable grounds penalties legally collected. 


\section{RETURNS TO BE PUBLIC RECORDS}

ART. 581. Inspection of returns.-Subdivision 1 of the Tax Law, section 384, provides as follows: "Except in accordance with proper judicial order or as otherwise provided by law, it shall be unlawful for the Comptroller, any agent, clerk or other officer or employee to divulge or make known in any manner the amount of income or any particulars set forth or disclosed in any report or return required under this article. Nothing herein shall be construed to prohibit the publication of statistics so classified as to prevent the identification of particular reports or returns and the items thereof, or the inspection by the AttorneyGeneral or other legal representative of the State of the report or return of any taxpayer who shall bring action to set aside or review the tax based thereon, or against whom an action or proceeding has been instituted in accordance with the provisions of sections 380 and 381 of this chapter. Reports and returns shall be preserved for three years and thereafter until the Comptroller orders them to be destroyed."

ART. 582. Penalties for disclosure of returns.-Subdivision 2 of the Tax Law, section 384, provides as follows: "Any offense against subdivision one of this section shall be punished by a fine not exceeding one thousand dollars or by imprisonment not exceeding one year, or both, at the discretion of the court, and if the offender be an officer or employee of the state he shall be dismissed from office and be incapable of holding any public office in this state for a period of five years thereafter."

\section{PROMULGATION OF REGULATIONS}

Pursuant to the authority conferred by chapter 627 of the Laws of 1919, the foregoing regulations are hereby made and promulgated, and any regulations and rulings inconsistent therewith are hereby revoked.

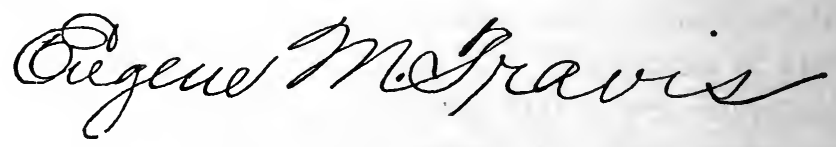

Albany, N. Y.

Comptroller. 


\section{APPENDIX I}

Table showing where subjects covered by Federal Regular tions 45 are considered in these regulations.

\begin{tabular}{|c|c|c|c|}
\hline $\begin{array}{c}\text { U. S. } \\
\text { Regulations } \\
\text { No. 45 } \\
\text { Article No. } \\
1\end{array}$ & $\begin{array}{c}\text { Subject } \\
\text { considered in } \\
\text { Comptroller's } \\
\text { Regulations } \\
\text { Article No. } \\
1\end{array}$ & $\begin{array}{l}\text { U. S. } \\
\text { Regulations } \\
\text { No. 45 } \\
\text { Article No. } \\
83\end{array}$ & $\begin{array}{c}\text { Subject } \\
\text { considered in } \\
\text { Comptroller's } \\
\text { Regulations } \\
\text { Article No. } \\
77\end{array}$ \\
\hline 2 & 2 & 84 & 124 \\
\hline 3 & 3 & 85 & 24 \\
\hline 4 & 501 & 86 & 78 \\
\hline 21 & 11 & 87 & 79 \\
\hline 22 & 12 & 88 & 80 \\
\hline 23 & 13 & 91 & 411 \\
\hline 24 & 14 & & $(412$ \\
\hline 25 & 526 & 92 & 418 \\
\hline 26 & 528 & & 456 \\
\hline 31 & 21 & 93 & 419 \\
\hline 32 & 23 & 101 & 111 \\
\hline 33 & 25 & 102 & 112 \\
\hline 34 & 26 & 103 & 113 \\
\hline 35 & 28 & 104 & 114 \\
\hline 36 & 29 & 105 & 115 \\
\hline 37 & $\int 22$ & 106 & 116 \\
\hline & $\{27$ & 107 & 117 \\
\hline 38 & 30 & 108 & 119 \\
\hline 39 & 31 & 109 & 120 \\
\hline 40 & 32 & 110 & 122 \\
\hline 41 & 33 & 111 & 123 \\
\hline 42 & 34 & 121 & 136 \\
\hline 43 & 35 & 122 & 137 \\
\hline 44 & 36 & 131 & 14] \\
\hline 45 & 37 & 132 & 142 \\
\hline 46 & 38 & 133 & 143 \\
\hline 47 & 40 & 134 & 1.44 \\
\hline 48 & 42 & 141 & 151 \\
\hline 51 & 43 & 142 & 152 \\
\hline 52 & 44 & 143 & 153 \\
\hline 53 & 45 & 144 & 154 \\
\hline 54 & 46 & 145 & 155 \\
\hline 71 & 71 & 151 & 161 \\
\hline 72 & 72 & 152 & 162 \\
\hline 73 & 73 & 153 & 163 \\
\hline 74 & 74 & 154 & 164 \\
\hline 75 & 75 & 161 & 171 \\
\hline 76 & 76 & 162 & 172 \\
\hline 77 & 74 & 163 & 173 \\
\hline
\end{tabular}




\begin{tabular}{|c|c|c|c|}
\hline $\begin{array}{l}\text { U. S. } \\
\text { Regulations } \\
\text { No. 45 } \\
\text { Article No. } \\
\quad 164\end{array}$ & $\begin{array}{c}\text { Subject } \\
\text { considered in } \\
\text { Comptroller's } \\
\text { Regulations } \\
\text { Article No. } \\
174\end{array}$ & $\begin{array}{c}\text { U. S. } \\
\text { Regulations } \\
\text { No. 45 } \\
\text { Article No. } \\
407\end{array}$ & $\begin{array}{c}\text { Subject } \\
\text { considered in } \\
\text { Comptroller's } \\
\text { Regulations } \\
\text { Article No. } \\
\mathbf{5 3 1}\end{array}$ \\
\hline 165 & 175 & 411 & 230 \\
\hline 166 & 176 & 412 & 231 \\
\hline 167 & 177 & 421 & 246 \\
\hline 168 & 178 & 422 & 248 \\
\hline 169 & 179 & 423 & 249 \\
\hline 170 & 180 & 424 & 250 \\
\hline 171 & 181 & 425 & 247 \\
\hline 201 & 190 & 431 & 529 \\
\hline 251 & 201 & 441 & 541 \\
\hline 271 & 431 & 442 & 542 \\
\hline \multirow{4}{*}{291} & $\int 121$ & 444 & 543 \\
\hline & 120 & 447 & 551 \\
\hline & 115 & 448 & 544 \\
\hline & 125 & 1001 & 551 \\
\hline 292 & 118 & 1003 & 553 \\
\hline 293 & 125 & 1004 & 556 \\
\hline 294 & 121 & 1005 & 556 \\
\hline 302 & 206 & 1006 & 556 \\
\hline 303 & 207 & 1021 & 552 \\
\hline 304 & 208 & 1031 & 572 \\
\hline 305 & 209 & 1032 & 573 \\
\hline 311 & 481 & 1036 & 574 \\
\hline 312 & 502 & 1041 & 556 \\
\hline 313 & 503 & 1051 & 288 \\
\hline 314 & 504 & 1071 & 281 \\
\hline 321 & 226 & 1072 & 286 \\
\hline 322 & 229 & 1074 & 289 \\
\hline 341 & 251 & 1075 & 287 \\
\hline 342 & 244 & 1080 & 290 \\
\hline 343 & 253 & 1091 & 581 \\
\hline 344 & 255 & 1094 & 582 \\
\hline 345 & 245 & 1503 & 228 \\
\hline 361 & 261 & 1505 & 227 \\
\hline 362 & 263 & 1521 & 240 \\
\hline 370 & 270 & 1522 & 241 \\
\hline 381 & 482 & 1541 & 61 \\
\hline 382 & 482 & 1544 & 62 \\
\hline 383 & 483 & 1545 & 63 \\
\hline 384 & 484 & 1547 & 64 \\
\hline 401 & 521 & 1548 & 65 \\
\hline 402 & 522 & 1549 & 66 \\
\hline 403 & 524 & 1561 & 91 \\
\hline 404 & 523 & 1562 & 93 \\
\hline 405 & 525 & 1563 & 94 \\
\hline 406 & 530 & 1564 & 95 \\
\hline
\end{tabular}




\begin{tabular}{cc|cc}
$\begin{array}{c}\text { U. S. } \\
\text { Regulations }\end{array}$ & $\begin{array}{c}\text { Subject } \\
\text { considered in } \\
\text { Comptroller's } \\
\text { Regulations } \\
\text { Article No. }\end{array}$ & $\begin{array}{c}\text { U. S. } \\
\text { Regulations } \\
\text { No. 45 } \\
\text { Article No. }\end{array}$ & $\begin{array}{c}\text { Subject } \\
\text { considered in } \\
\text { Comptroller's } \\
\text { Regulations } \\
\text { Article No. }\end{array}$ \\
1565 & 96 & 1582 & 217 \\
1566 & 97 & 1583 & 218 \\
1567 & 98 & 1584 & 219 \\
1568 & 99 & 1585 & 220 \\
1569 & 100 & 1625 & 527 \\
1570 & 101 & 1733 & 554 \\
1581 & 216 & 1734 & 555
\end{tabular}




\section{APPENDIX II}

\section{THE TAX LAW}

\section{ARTICLE $16^{1}$}

Taxes Upon and With Respect to Personal Incomes.

Section 350. Definitions.

351. Imposition of income tax.

352. Exemption of certain personal property.

353. Ascertainment of gain and loss.

354. Exchange of property.

355. Gain through exchange.

356. Inventory.

357. Net income defined.

358. Computation of net income.

359. Gross income defined.

360. Deductions.

361. Items not deductible.

362. Exemptions.

363. Credit for taxes in case of taxpayers other than residents of the state.

364. Partnerships.

365. Estates and trusts.

366. Information and payment at source.

367. Taxpayers' returns.

368. Partnership returns.

369. Fiduciary returns.

370. Returns when accounting period changed.

371. Time and place of filing returns.

372. Administration of income tax law.

373. Powers of comptroller.

374. Revision and readjustment of accounts by comptroller.

375. Review of determination of comptroller by certiorari and regulations as to writ.

376. Penalties.

1 Added by Laws of 1919, Chapter 627, in effect May 14, 1919. 
Section 377. When payable.

378. Notice of assessment.

379. Collection of taxes; penalties and interest.

380. Warrant for the sollection of taxes.

381. Action for recovery of taxes.

382. Distribution of the income tax.

383. Comptroller to make regulations and collect facts.

384. Secrecy required of officials; penalty for violation.

385. Contract to assume income tax illegal.

Section 350. Definitions. For the purpose of this article and unless otherwise required by the context:

1. The word "comptroller" means the state comptroller.

2. The word "taxpayer" includes any person, trust or estate subject to a tax imposed by this article, or whose income is in whole or in part subject to a tax imposed by this article, and does not include corporations.

3. The words "military or naval forces of the United States" include the marine corps, the coast guard, the army nurse corps, female, and the navy nurse corps, female, but this shall not he deemed to exclude other units otherwise included within such words.

4. The words "taxable year" mean the calendar year, or the fiscal year ending during such calendar year, upon the basis of which the net income is computed under this article. The words "fiscal year" mean an accounting period of twelve months, ending on the last day of any month other than December.

5. The word "fiduciary" means a guardian, trustee, executor, administrator, receiver, conservator, or any person, whether individual or corporate, acting in any fiduciary capacity for any person, trust or estate.

6. The word "paid" for the purposes of the deductions and credits under this article, means "paid or accrued" or "paid or incurred:" and the terms "paid or incurred" and "paid or accrued" shall be construed according to the method of accounting upon the basis of which the net income is computed. under this article. The term "received" for the purpose of the computation of net income under this article. means "received or 
accrued" and the term "received or accrued" shall be construed according to the method of accounting upon the basis of which the net income is computed under this article.

7. The word "resident" applies only to natural persons and includes for the purpose of determining liability to the tax imposed by this article upon or with reference to the income of any taxable year, commencing with the year nineteen hundred and nineteen, any person who shall, at any time on or after January first and not later than March fifteenth of the next succeeding calendar year, be or become a resident of the state.

8. The word "dividend" means any distribution made by a corporation out of its earnings or profits to its shareholders or members, whether in cash or in other property or in stock of the corporation.

9. The words "foreign country" or "foreign government" mean any jurisdiction other than one embraced within the United States. The words "United States" include the states, the territories of Alaska and Hawaii and the District of Columbia.

10. The words "withholding agent" include all individuals, corporations, associations and partnerships, in whatever capacity acting, including lessees, or mortgagors of real or personal property, fiduciaries, employers, and all officers and employees of the state, or of any municipal corporation or political subdivision of the state, having the control, receipt, custody, disposal or payment, of interest, rent, salaries, wages, premiums, annuities, compensation, remunerations, emoluments or other fixed or determinable annual or periodical gains, profits and income taxable under this article.

$\S 351$. Imposition of income tax. A tax is hereby imposed upon every resident of the state, which tax shall be levied, collected and paid annually upon and with respect to his entire net income as herein defined at rates as follows: One per centum of the amount of net income not exceeding ten thousand dollars; two per centum of the amount of net income in excess of ten thousand dollars but not in excess of fifty thousand dollars; three per centum of the amount of net income in excess of fifty thousand dollars. A like tax is hereby imposed and shall be levied, 
collected and paid annually, at the rates specified in this section, upon and with respect to the entire net income as herein defined, except as hereinafter provided, from all property owned and from every business, trade, profession or occupation carried on in this state by natural persons not residents of the state. Such tax shall first be levied, collected and paid in the year nineteen hundred and twenty upon and with respect to the taxable income for the calendar year nineteen hundred and nineteen, or for any taxable year ending during the year nineteen hundred and nineteen.

$\S 352$. Exemption of certain personal property from taxation. The taxes imposed by this article are in addition to all other taxes imposed by law, except that money on hand, on deposit or at interest, bonds, notes and choses in action and shares of stock in corporations other than banks and banking associations, owned by any individual or constituting a part of a trust or estate subject to the income tax imposed by this article, and from which any income is derived, shall not after July thirty-first, nineteen hundred and nineteen, be included in the valuation of the personal property included in the assessment-rolls of the several tax districts, villages, suhool districts and special tax districts of the state.

$\S 353$. Ascertainment of gain and loss. For the purpose of ascertaining the gain derived or loss sustained from the sale or other disposition of property, real, personal or mixed, the basis shall be first, in case of property acquired before January first, nineteen hundred and nineteen, the fair market price or value of such property, as of January first, nineteen hundred and nineteen, and, second, in case of property acquired on or after that date, the cost thereof; or the inventory value, if the inventory is made in accordance with this article.

$\S 354$. Exchange of property. When property is exchanged for other property, the property received in exchange shall for the purpose of determining gain or loss be treated as the equivalent of cash to the amount of its fair market value, if any; but when in connection with the reorganization, merger or consolidation of a corporation a taxpayer receives, in place of stock or securities owned by him, new stock or securities of no greater aggregate 
par or face value, no gain or loss shall be deemed to occur from the exchange, and the new stock or securities received shall be treated as taking the place of the stock, securities or property exchanged.

$\S 355$. Gain through exchange. When in the case of any such reorganization, merger or consolidation the aggregate par or face value of the new stock or securities received is in excess of the aggregate par or face value of the stock or securities exchanged, a like amount in par or face value of the new stock or securities received shall be treated as taking the place of the stock or securities exchanged, and the amount of the excess in par or face value shall be treated as a gain to the extent that the fair market value of the new stock or securities is greater than the cost of the stock or securities exchanged, if acquired on or after January first, nineteen hundred and nimeteen, and its fair market price or value as of January first, nineteen hundred and nineteen, if acquired before that date.

$\S 356$. Inventory. Whenever in the opinion of the comptroller the use of inventories is necessary in order clearly to determine the income of any taxpayer, inventories shall be taken by such taxpayer upon such basis as the comptroller may prescribe, conforming as nearly as may be to the best accounting practice in the trade or business and most clearly reflecting the income, and conforming so far as may be to the forms and methods prescribed by the United States commissioner of internal revenue under the act of congress known as the revenue act of nineteen hundred and eighteen.

$\S 357$. Net income defined. The term "net income" means the gross income of a taxpayer less the deductions allowed by this article.

$\S 358$. Computation of net income. 1. The net income shall be computed upon the basis of the taxpayer's annual accounting period (fiscal year or calendar year as the case may be) in accordance with the method of accounting regularly employed in keeping the books of such taxpayer; but if no such method of accounting has been so employed, or if the method employed does not clearly reflect the income, the computation shall be made upon such basis and in such manner as in the opinion of the comptroller 
does clearly reflect the income. If the taxpayer's annual accounting period is other than a fiscal year as defined in this article, or if the taxpayer has no annual accounting period or does not keep books, the net income shall be computed on the basis of the calendar year.

2. If a taxpayer changes his accounting period from fiscal year to calendar year, from calendar year to fiscal year, or from one fiscal year to another, the net income shall, with the approval of the comptroller, be computed on the basis of such new accounting period, subject to the provisions of section three hundred and seventy.

$\S 359$. Gross income defined. The term "gross income":

1. Includes gains, profits and income derived from salaries, wages or compensation for personal service, of whatever kind and in whatever form paid, or from profession, vocations, trades, businesses, commerce, or sales, or dealings in property, whether real or personal, growing out of the ownership or use of or interest in such property; also from interest, rent, dividends, securities, or the transaction of any business carried on for gain or profit, or gains or profits and income derived from any source whatever. The amount of all such items shall be included in the gross income for the taxable year in which received by the taxpayer, unless, under the methods of accounting permitted in this article, any such amounts are to be properly accounted for as of a different period; but

2. Does not include the following items which shall be exempt from taxation under this article:

a. The proceeds of life insurance policies and contracts paid upon the death of the insured to individual beneficiaries or to the estate of the insured.

b. The amount received by the insured as a return of premium or premiums paid by him under life insurance, endowment or annuity contracts, either during the term or at the maturity of the term mentioned in the contract or upon surrender of the contract.

c. The value of property acquired by gift, bequest, devise or descent (but the income from such property shall be included in gross income). 
d. Interest upon the obligations of the United States or its possessions; or securities issued under the provisions of the federal farm loan act of July seventeen, nineteen hundred and sixteen; or bonds issued by the war finance corporation; or the obligations of the state of New York or of any municipal corporation or political subdivision thereof; or investments upon which the tax provided for in section three hundred and thirty-one of this chapter has heretofore been paid since June first, nineteen hundred and seventeen, during the period of years for which such tax shall have been paid.

e. Any amount received through accident or health insurance or under workmen's compensation acts, as compensation for personal injuries or sickness, plus the amount of any damages received whether by suit or agreement on account of such injuries or sickness, or through the war risk insurance act or any law for the benefit or relief of injured or disabled members of the military or naval forces of the United States.

f. Salaries, wages and other compensation received from the United States of officials or employees thereof, including persons in the military or naval forces of the United States.

g. Income received by any officer of a religious denomination or by any institution, or trust, for moral or mental improvement, religious, bible, tract, charitable, benevolent, fraternal, missionary, hospital, infirmary, educational, scientific, literary, library, patriotic, historical or cemetery purposes, or for the enforcement of laws relating to children or animals, or for two or more of such purposes, if such income be used exclusively for carrying out one or more of such purposes; but nothing herein shall be construed to exempt the fees, stipends, personal earnings or other private income of such officer or trustee.

3. In the case of taxpayers other than residents, gross income includes only the gross income from sources within the state, but shall not include annuities, interest on bank deposits, interest on bonds, notes or other interest-bearing obligations or dividends from corporations, except to the extent to which the same shall be a part of income from any business, trade, profession or occupation carried on in this state subject to taxation under this article. 
$\S 360$. Deductions. In computing net income there shall be allowed as deductions :

1. All the ordinary and necessary expenses paid or incurred during the taxable year in carrying on any trade or business, including a reasonable allowance for salaries or other compensation for personal services actually rendered, and including rentals or other payments required to be made as a condition to the continued use or possession, for purposes of the trade or business, of property to which the taxpayer has not taken or is not taking title or in which he has no equity.

2. In the case of a resident of the state such a proportion of the total interest paid or accrued during the taxable year on indebtedness, as the net income of the taxpayer taxable under this article bears to his total income from all sources; or in case of an individual not a resident of the state, the same proportion of interest paid or accrued within the taxable year on indebtedness which the amount of such gross income, as herein defined, bears to the gross amount of his income from all sources within and without the state.

3. Taxes other than income taxes paid or accrued within the taxable year imposed, first, by the authority of the United States, or of any of its possessions, or, second, by the authority of any state, or territory, or any county, school district, municipality, or other taxing subdivision of any state or territory, not including those assessed against local benefits of a kind tending to increase the value of the property assessed, or, third, by the authority of any foreign government.

4. Losses sustained during the taxable year and not compensated for by insurance or otherwise, if incurred in trade or business.

5. Losses sustained during the taxable year and not compensated for by insurance or otherwise, if incurred in any transaction entered into for profit, though not connected with the trade or business; but in the case of a taxpayer other than a resident of the state, only as to such transactions within the state.

6. Losses sustained during the taxable year of property not connected with the trade or business (but, in the case of a taxpayer other than a resident, only of property within the state) if 
arising from fires, storms, shipwrecks, or other casualty or from theft, and not compensated for by insurance or otherwise.

7. Debts ascertained to be worthless and charged off within the taxable year.

8. A reasonable allowance for the exhaustion, wear and tear of property used in the trade or business, including a reasonable allowance for obsolescence.

9. In the case of mines, oil and gas wells, other natural deposits and timber, a reasonable allowance for depletion and for depreciation of improvements, according to the peculiar conditions in each case, based upon cost including cost of development not otherwise deducted; provided, that in the case of such properties acquired prior to January first, nineteen hundred and nineteen, the fair market value of the property (or the taxpayer's interest therein) on that date shall be taken in lieu of cost up to that date; provided, further, that in the case of mines, oil and gas wells, discovered by the taxpayer on or after January first, nineteen hundred and nineteen, and not acquired as the result of a purchase of a proven tract or lease, where the fair market value of the property is materially disproportionate to the cost, the depletion allowance shall be based upon the fair market value of the property at the date of the discovery or within thirty days thereafter; such reasonable allowance in all the above cases to be made under rules and regulations to be prescribed by the comptroller. In the case of leases the deductions allowed by this paragraph shall be equitably apportioned between the lessor and lessee.

10. Contributions or gifts made within the taxable year to corporations incorporated by, or associations organized under, the laws of this state and operated exclusively for religious, charitable, scientific or educational purposes, or for the prevention of cruelty to children or animals, no part of the net earnings of which inures to the benefit of any private stockholder or individual, or to the special fund for vocational rehabilitation authorized by section seven of the act of congress known as the vocational rehabilitation act, to an amount not in excess of fifteen per centum of the taxpayer's net income as computed without the benefit of this subdivision. Such contributions or gifts shall be allowable as deductions only if verified under rules and regula- 
tions prescribed by the comptroller. In the case of a taxpayer other than a resident of the state this deduction shall be allowed only as to contributions or gifts made to corporations or associations incorporated by or organized under the laws of this state or to the vocational rehabilitation fund above mentioned.

11. In the case of a taxpayer other than a resident of the state the deductions allowed in this section shall be allowed only if, and to the extent that, they are connected with income arising from sources within the state; and the proper apportionment and allocation of the deductions with respect to sources of income within and without the state shall be determined under rules and regulations to be prescribed by the comptroller.

$\S 361$. Items not deductible. In computing net income no deduction shall in any case be allowed in respect of:

1. Personal, living, or family expenses;

2. Any amount paid out for new buildings or for permanent improvements or betterments made to increase the value of any property or estate;

3. Any amount expended in restoring property or in making good the exhaustion thereof for which an allowance is or has been made; or

4. Premiums paid on any life insurance policy, covering the life of any officer or employee, or of any person financially interested in any trade or business carried on by the taxpayer, when the taxpayer is directly or indirectly a beneficiary under such policy.

$\S 362$. Exemptions. The following exemptions shall be allowed to any resident taxpaver:

1. In the case of a single person, a personal exemption of one thousand dollars, or in the case of the head of a family or a married person living with husband or wife, a personal exemption of two thousand dollars. A husband and wife living together shall receive but one personal exemption of two thousand dollars against their aggregate net income; and in case they make separate returns, the personal exemption of two thousand dollars may be taken by either or divided between them.

2. Two hundred dollars for each person (other than husband or wife) dependent upon and receiving his chief support from 
the taxpayer, if such dependent person is under eighteen years of age or is incapable of self-support because mentally or physically defective.

3. A taxpayer receiving salary, wages, or other compensation from the United States as an official thereof, exempt from taxation under this article, shall be entitled to only so much of the personal exemption provided for in this section as is in excess of the aggregate amount of such salaries, wages, or other compensation.

$\S 363$. Credit for taxes in case of taxpayers other than residents of the state. Whenever a taxpayer other than a resident of the state has become liable to income tax to the state or country where he resides upon his net income for the taxable year, derived from sources within this state and subject to taxation under this article, the comptroller shall credit the amount of income tax payable by him under this article with such proportion of the tax so payable by him to the state or country where he resides as his income subject to taxation under this article bears to his entire income upon which the tax so payable to such other state or country was imposed; provided that such credit shall be allowed only if the laws of said state or country grant a substantially similar credit to residents of this state subject to income tax under such laws.

$\S$ 364. Partnerships. Individuals carrying on business in partnerships shall be liable for income tax only in their individual capacity. There shall be included in computing the net income of each partner his distributive share, whether distributed or not, of the net income of the partnership for the taxable year, or, if his net income for such taxable year is computed upon the basis of a period different from that upon the basis of which the net income of the partnership is computed, then his distributive share of the net income of the partnership for any accounting period of the partnership ending within the fiscal or calendar year upon the basis of which the partner's net income is computed. Taxpayers who are members of partnerships may be required by the comptroller to make a return stating the gross receipts and net gains or profits of the partnership for any taxable year. The net income of the partnership shall be computed in the same 
manner and on the same basis as provided in computing the net income of individuals except that the deduction provided in subdivision ten of section three hundred and sixty shall not be allowed and the personal exemptions provided for in section three hundred and sixty-two shall be allowed only to the individual partners.

$\S 365$. Estates and trusts. 1. The tax imposed by this article shall apply to the income of estates or of any kind of property held in trust, including:

a. Income received by estates of deceased persons during the period of administration or settlement of the estate;

b. Income accumulated in trust for the benefit of unborn or unascertained persons or persons with contingent interests;

c. Income held for future distribution under the terms of the will or trust; and

d. Income which is to be distributed to the beneficiaries periodically, whether or not at regular intervals, and the income collected by a guardian of an infant to be held or distributed as the court may direct.

2. The fiduciary shall be responsible for making the return of income for the estate or trust for which he acts. The net income of the estate or trust shall be computed in the same manner and on the same basis as provided in this article for individual taxpayers, except that there shall also be allowed as a deduction any part of the gross income which pursuant to the terms of the will or deed creating the trust, is during the taxable year paid to or permanently set aside for the United States, any state, territory, or any political subdivision thereof, or the District of Columbia, or any corporation or association organized and operated exclusively for religious, charitable, scientific or educational purposes, or for the prevention of cruelty to children or animals, no part of the net earnings of which inures to the benefit of any private stockholder or individual; and in cases under paragraph $d$ of subdivision one of this section, the fiduciary shall include in the return a statement of each beneficiary's distributive share of such net income, whether or not distributed before the close of the taxable year for which the return is made. 
3. In cases under paragraphs $\mathrm{a}, \mathrm{b}$, and $\mathrm{c}$ of subdivision one, of this section, the tax shall be imposed upon the net income of the estate or trust and shall be paid by the fiduciary, except that in determining the net income of the estate of any deceased person during the period of administration or settlement there may be deducted the amount of any income properly paid or credited to any legatee, heir or other beneficiary. In such cases, the estate or trust shall be allowed the same exemptions as are allowed to single persons under section three hundred and sixty-two, and in such cases an estate or trust created by a person not a resident and an estate of a person not a resident shall be subject to tax only to the extent to which individuals other than residents are liable under section three hundred and fifty-nine, subdivision three.

4. In cases under paragraph $d$ of subdivision one of this section and in the case of any income of an estate during the period of administration or settlement permitted by subdivision three to be deducted from the net income upon which tax is to be paid by the fiduciary, the tax shall not be paid by the fiduciary, but there shall be included in computing the net income of each beneficiary his distributive share whether distributed or not, of the net income of the estate or trust for the taxable year, or, if his net income for such taxable year is computed upon the basis of a period different from that upon the basis of which the net income of the estate or trust is computed, then his distributive share of the net income of the estate or trust for any accounting period of such estate or trust ending within the fiscal or calendar year upon the basis of which such beneficiary's net income is computed. In such cases the income of a beneficiary of such estate or trust not a resident shall be taxable only to the extent provided in section three hundred and fifty-nine, subdivision three, for individuals other than residents.

$\S 366$. Information and payment at source. 1. Every withholding agent shall deduct and withhold two per centum from all salaries, wages, commissions, gratuities, emoluments, perquisites and other fixed and determinable annual or periodical compensation of whatever kind and in whatever form paid or received, earned for personal services and taxable under this article, of which he shall have control, receipt, custody, disposal or payment, 
if the amount paid or received or to be paid or received in any taxable. year on account of any individual equals or exceeds one thousand dollars, unless there shall be filed with the withholding agent, before the time when he is required to make return and payment thereof, a certificate in such form as shall be prescribed by the comptroller to the effect that the person entitled to such salary, wage, commission, gratuity, emolument, perquisite or other compensation is a resident and setting forth his residence address within the state.

2. Every withholding agent shall make return to the comptroller of complete information concerning the amount of all interest, rent, salaries, wages, premiums, annuities, compensations, remunerations, emoluments or other fixed or determinable gains, profits and income, except interest coupons payable to bearer, of any taxpayer taxable under this article of one thousand dollars or more in any taxable year under such regulations and in such form and manner and to such extent as may be prescribed by the comptroller.

3. Every withholding agent required to deduct and withhold any tax under subdivision one of this section shall make return thereof on or before the fifteenth day of March in each year and shall at the same time pay the tax to the comptroller. Every such individual corporation or partnership is hereby made liable for such tax and is hereby indemnified against the claims and demands of any individual, corporation or partnership for the amount of any payments made in accordance with the provisions of this section.

4. Income upon which any tax is required to be withheld at the source under this section shall be included in the return of the recipient of such income, but any amount of tax so withheld shall be credited against the amount of income tax as computed in such return.

5. If any tax required under this section to be deducted and withheld is paid by the recipient of the income, it shall not be recollected from the withholding agent; nor in cases in which the tax is so paid shall any penalty be imposed upon or collected from the recipient of the income or the withholding agent for 
failure to return or pay the same, unless such failure was fraudulent and for the purpose of evading payment.

$\S$ 367. Taxpayers' returns. Every taxpayer having a net income for the taxable year of one thousand dollars or over if single or if married and not living with husband or wife, or of two thousand dollars or over if married and living with husband or wife, shall make under oath a return stating specifically the items of his gross income and the deductions and credits allowed by this article. If a husband and wife living together have an aggregate net income of two thousand dollars or over, each shall make such a return unless the income of each is included in a single joint return. If the taxpayer is unable to make his own return the return shall be made by a duly authorized agent or by the guardian or other person charged with the care of the person or property of such taxpayer. A taxpayer other than a resident shall not be entitled to the deductions authorized by section three hundred and sixty unless he shall make under oath a complete return of his gross income both within and without the state.

$\S$ 368. Partnership returns. Every partnership shall make a return for each taxable year, stating specifically the items of its gross income and the deductions allowed by this article, and shall include in the return the names and addresses of the individuals who would be entitled to share in the net income if distributed and the amount of the distributive share of each individual. The return shall be sworn to by any one of the partners.

$\S 369$. Fiduciary returns. Every fiduciary (except receivers appointed by authority of law in possession of part only of the property of a taxpayer) shall make under oath a return for the taxpayer for whom he acts, first, if the net income of such taxpayer is one thousand dollars or over if single, or if married and not living with husband or wife, or two thousand dollars or over if married and living with husband or wife, or second, if the net income of such taxpayer, if an estate or trust, is one thousand dollars or over or if any beneficiary is a taxpayer other than a resident of the state, which return shall state specifically the items of the gross income and the deductions, exemptions and credits allowed by this article. Under such regulations as 
the comptroller may prescribe, a return made by one of two or more joint fiduciaries and filed in the office of the comptroller or collector in the district where such fiduciary resides shall be a sufficient compliance with the above requirement. The fiduciary shall make oath that he has sufficient knowledge of the affairs of such individual, estate or trust to enable him to make the return, and that the same is, to the best of his knowledge and belief, true and correct.

Fiduciaries required to make returns under this article shall be subject to all the provisions of this article which apply to taxpayers.

$\$ 370$. Returns when accounting period changed. If a taxpayer, with the approval of the comptroller, changes the basis of computing net income from fiscal year to calendar year, a separate return shall be made for the period between the close of the last fiscal year for which return was made and the following December thirty-first. If the change is made from calendar year to fiscal year, a separate return shall be made for the period between the close of the last calendar year for which return was made and the date designated as the close of the last fiscal year. If the change is from one fiscal year to another fiscal year, a separate return shall be made for the period between the close of the former fiscal year and the date designated as the close of the new fiscal year. If a taxpayer making his first return for income tax keeps his accounts on the basis of a fiscal year, he shall make a separate return for the period between the beginning of a calendar year in which such fiscal year ends and the end of such fiscal year.

In all of the above cases the net income shall be computed on the basis of such period for which separate return is made, and the tax shall be paid thereon at the rate for the calendar year in which such period is included; and the exemptions allowed in this article shall be reduced respectively to amounts which bear the same ratio to the full exemptions provided for as the number of months in such period bears to twelve months.

$\S 371$. Time and place of filing returns. Returns shall be made to the comptroller on or kafore the fifteenth day of March in each year of the taxpayer's net income for his last preceding taxable year. The comptroller may grant a reasonable extension 


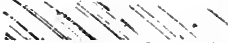

ii time for filing returns whenever in its judgment good cause exists and shall keep a record of every such extension and the reason therefor. Except in the case of taxpayers who are abroad, no such extension shall be granted for more than six months. Such returns shall, so far as may be, set forth the same or similar items called for in the blank forms of return prescribed by the United States commissioner of internal revenue for the enforcement of the act of congress known as the revenue act of nineteen hundred and eighteen, together with such other facts as the comptroller may deem necessary for the proper enforcement of this article. There shall be annexed to such roturn the affidavit or affirmation of the person making the return, to the effect that the statements contained therein are true. Blank forms of return shall be furnished by the comptroller upon application, but failure to secure the form shall not relieve any taxpayer from the obligation of making any return herein required.

$\S 372$. Administration of income tax law. The comptroller shall administer and enforce the tax herein imposed for which purpose he may divide the state into districts in each of which a branch office of the comptroller may be maintained; provided that in no cases shall a county be divided in forming a district.

$\$ 373$. Powers of comptroller. If in the opinion of the comptroller any return of a taxpayer is in any essential respect incorrect he shall have power to revise such return, or if any taxpayer fails to make return as herein required, the comptroller is authorized to make an estimate of the taxable income of such taxpayer from any information in his possession, and to audit and state an account according to such revised return or the estimate so made by him for the taxes, penalties and interest due the state from such taxpayer. The comptroller shall also have power to examine or cause to have examined, in case of failure to report the books and records of any such taxpayer, and may take testimony and require proof material for his information.

$\S 374$. Revision and readjustment of accounts by comptroller. If an application for revision be filed with the comptroller by a taxpayer within one year from the time of the filing of the return, or if the tax of such taxpayer shall have been recomputed, then from the time of such recomputation, the comptroller shall grant 
a hearing thereon and if it shall be made to appear, upon any such hearing by evidence submitted to him or otherwise, that any such computation includes taxes or other charges which could not have been lawfully demanded, or that payment has been illegally made or exacted of any such amount so computed, the comptroller shall resettle the same according to law and the facts, and adjust the computation of taxes accordingly, and shall send notice of his determination thereon to the taxpayer.

$\S 375$. Review of determination of comptroller by certiorari an a regulations as to writ. The determination of the comptroller upon any application made to him by any taxpayer for revision and resettlement of any computation of tax, as prescribed by this article, may be reviewed in the manner prescribed by and subject to the provisions of section one hundred and ninety-nine of this chapter. No certiorari to review any statement of a computation or any determination by the comptroller under this article shall be granted unless notice of application therefor is made within thirty days after the service of the notice of such determination. Eight days' notice shall be given to the comptroller of the application for such writ. Before making the application an undertaking must be filed with him, in such amount and with such sureties as a justice of the supreme court shall approve, to the effect that if such writ is dismissed or the determination of the comptroller affirmed, the applicant for the writ will pay all costs and charges which may accrue against him in the prosecution of the writ, including costs of all appeals.

$\S$ 376. Penalties. 1. Any person required by this article to make, render, sign or verify any return, who fails to make, render, sign or verify such return within the time required by or under a provision of law, or who makes any false or fraudulent return or statement, with intent to evade any tax imposed by this article, shall be guilty of a misdemeanor and shall, upon conviction, be fined not to exceed one thousand dollars, or be imprisoned not to exceed one year, or both, at the discretion of the court.

2. If any such person shall fail or refuse to make a return of income at the time or times hereinbefore specified, but shall voluntarily make a correct return of income within sixty days 
thereafter, there shall be added to his tax five per centum of the amount otherwise due, but such additional amount shall in no case be less than two dollars.

3. If any person liable to taxation under this article fails to make a return as herein required, the amount of income of such person discovered to be taxable shall be subject to twice the ordinary rate of taxation. If any person liable to taxation under this article makes any false or fraudulent return or statement, with intent to evade any tax imposed by this article, and an additional amount is discovered to be taxable, such additional amount shall be subject to twice the ordinary rate of taxation. Such tax shall be collected at such time and in such manner as may be designated by the comptroller. This penalty shall be additional to all other penalties in this or any other section provided.

$\S 377$. When payable. 1. Each taxpayer shall, at the time of filing his return, pay to the comptroller the amount of tax payable hereunder as the same shall appear from the face of the return. If the time for filing the return shall be extended, he shall pay in addition interest thereon at the rate of six per centum per annum from the time when the return was originally required to be filed to the time of payment.

2. As soon as practicable after the return is filed, the comptroller shall examine it and compute the tax.

3. If the amount of tax as compuied shall be greater than the amount theretofore paid, the excess shall be paid by the taxpayer to the comptroller within thirty days after the amount of the tax as computed shall be mailed by the comptroller.

4. If the amount of tax as computed shall be less than the amount theretofore paid, the excess shall be refunded by the comptroller out of the proceeds of the tax retained by him as provided in this article.

$\S 378$. Notice of assessment. Notice of tax assessment shall be sent by mail to the post office address given in the report, and the record that such notice has been sent shall be presumptive evidence of the giving of the notice and such record shall be preserved by the comptroller. 
$\S 379$. Collection of taxes; penalties and interest. 1. The comptroller is authorized at his discretion to designate agents for the purpose of collecting income taxes and shall require from them reasonable bond.

2. If the tax imposed by this article or any part of such tax be not paid at the time when required to be paid under the provisions of this article or in the case of additional taxes, at the time designated by the comptroller, the taxpayer liable to pay such tax shall pay to the comptroller, in addition to the amount of such tax, or part thereof, five per centum of said amount, plus one per centum for each month, or fraction of a month, the tax, or part thereof. remains unpaid.

$\S 380$. Warrant for the collection of taxes. If any tax imposed by this article or any portion of such tax be not paid within sixty days after the same becomes due, the comptroller shall issue a warrant under his hand and official seal directed to the sheriff of any county of the state commanding him to levy upon and sell the real and personal property of the person owning the same, found within his county, for the payment of the amount thereof, with the added penalties, interest and the cost of executing the warrant, and to return such warrant to the comptroller and pay to him the money collected by virtue thereof by a time to be therein specified, not less than sixty days from the date of the warrant. The sheriff shall within five days after the receipt of the warrant, file with the clerk of his county a copy thereof, and thereupon the clerk shall enter in the judgment docket, in the column for judgment debtors, the name of the taxpayer mentioned in the warrant, and in appropriate columns the amount of the tax or portion thereof and penalties for which the warrant is issued and the date when such copy is filed, and thereupon the amount of such warrant so docketed shall become a lien upon the title to and interest in real property or chattels real of the person against whom it is issued in the same manner as a judgment duly docketed in the office of such clerk. The said sheriff shall thereupon proceed upon the same in all respects, with like effect, and in the same manner, prescribed by law in respect to executions issued against property upon judgments of a court of record, and shall be entitled to the same fees for his services in executing the warrant, to be collected in the same manner. In the dis- 
cretion of the comptroller a warrant of like terms, force and effect may be issued and directed to any agent authorized to collect income taxes, and in the execution thereof such agent shall have all the powers conferred by law upon sheriffs, but shall be entitled to no fee or compensation in excess of actual expenses paid in the performance of such duty. If a warrant be returned not satisfied in iull, the comptroller shall have the same remedies to enforce the cloim for taxes against the taxpayer as if the people of the state had recovered judgment against the taxpayer for the amount of the tax.

$\S 381$. Action for recovery of taxes. Action may be brought at any time by the attorney-general of the state at the instance of the comptroller, in the name of the state to recover the amount of any taxes, penalties and interest due under this article.

$\S 382$. Distribution of the income tax. Of the revenue collected under this article the comptroller shall retain in his hands sufficient to provide at all times a fund in his hands in the sum of two hundred and fifty thousand dollars out of which he shall pay any refunds to which taxpayers shall be entitled under the provisions of this article. Of the remainder, fifty per centum shall be paid into the state treasury to the credit of the general fund. The remaining fifty per centum thereof shall, not later than the first day of July, and in case of moneys subsequently collected at least quarterly thereafter, be distributed and paid to the treasurers of the several counties of the state, in the proportion that the assessed valuation of the real property of each county bears to the aggregate assessed valuation of the real property of the state. As to any county included in the city of New York such payment shall be made to the receiver of taxes in such city and be paid into the general fund for the reduction of taxation of the city of New York. The county treasurer shall apportion the amount so received among the several towns and cities within the county in proportion that the assessed valuation of the real property of each town or city bears to the aggregate assessed valuation of the real property of the county, and shall credit the amount apportioned to each town against the county tax payable by it, and shall pay the amount apportioned to each city to the chief fiscal officer of the city to be paid into the 
general fund for city purposes. If the amount of the credit to a town exceeds the county tax from such town, the excess shall be paid to the supervisor of the town and be by him credited to general town purposes.

$\S 383$. Comptroller to make regulations and to collect facts. The comptroller is hereby authorized to make such rules and regulations, and to require such facts and information to be reported, as it may deem necessary to enforce the provisions of this article.

$\S 384$. Secrecy required of official; penalty for violation. 1. Except in accordance with proper judicial order or as otherwise provided by law, it shall be unlawful for the comptroller, any agent, clerk, or other officer or employee to divulge or make known in any manner the amount of income or any particulars set forth or disclosed in any report or return required under this article. Nothing herein shall be construed to prohibit the publication of statistics so classified as to prevent the identification of particular reports or returns and the items thereof, or the inspection by the attorney-general or other legal representatives of the state of the report or return of any taxpayer who shall bring action to set aside or review the tax based thereon, or against whom an action or proceeding has been instituted in accordance with the provisions of sections three hundred and eighty and three hundred and eighty-one of this chapter. Reports and returns shall be preserved for three years and thereafter until the comptroller orders them to be destroyed.

2. Any offense against subdivision one of this section shall be punished by a fine not exceeding one thousand dollars or by imprisonment not exceeding one year, or both, at the discretion of the court, and if the offender be an officer or employee of the state he shall be dismissed from office and be incapable of holding any public office in this state for a period of five years thereafter.

$\S 385$. Contract to assume income tax illegal. It shall be unlawful for any person to agree or contract directly or indirectly to pay or assume or bear the burden of any tax payable by any taxpayer under the provisions of this article. Any such contract or agreement shall be null and roid and shall not be enforced or given effect by any court. 



\section{NDE X}

Abatement of taxes..................... $374, \quad 573$

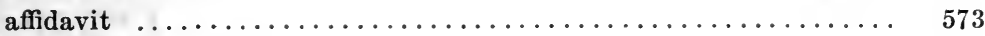

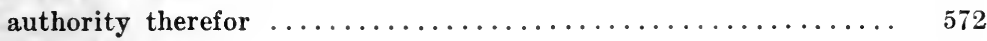

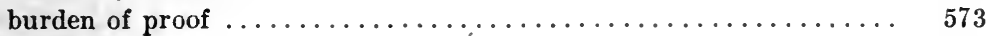

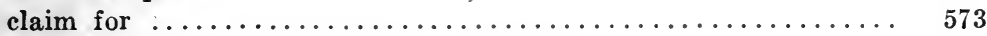

does not operate as suspension of collection............ 573

Absence

cause for securing extension of time for filing return......... 543

of wife or husband, effect on joint exemption............ 207

return by agent when taxpayers are absent............ 522

Accident insurance

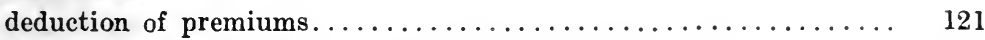

premiums paid by employer as taxable income to employee...... 25

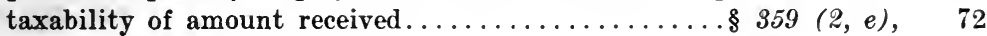

Accounting methods

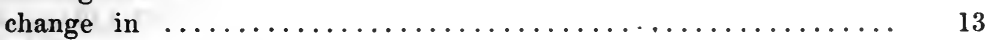

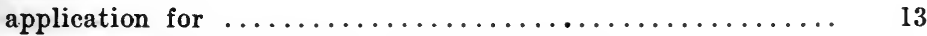

consent of Commissioner of Internal Revenue.......... 13

return to conform to..................... 14

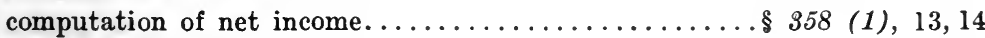

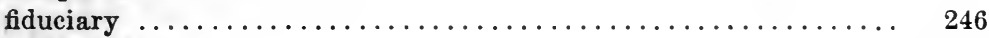

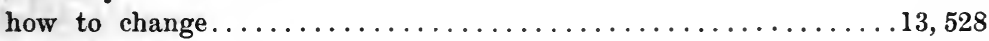

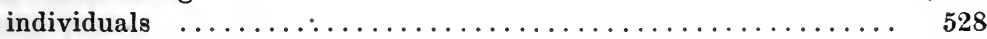

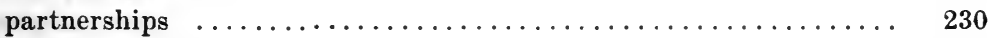

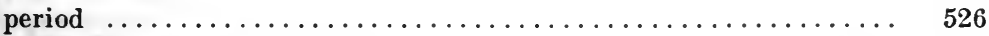

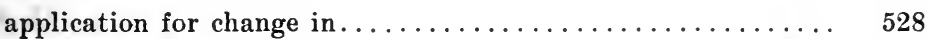

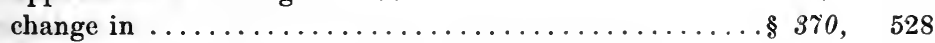

consent of Commissioner of Internal Revenue........ 528

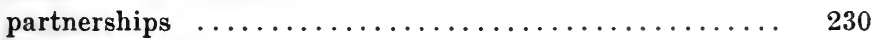

returns to conform to ............. 358 (2), $\quad 529$

returns to conform to $\ldots \ldots \ldots \ldots \ldots \ldots \ldots \ldots \ldots \ldots 858,14,526,529$

Accounting records to be maintained.................. 14

Accrual basis in determining net income............... 123

change from cash to accrual and vice versa............ 13

Action for recovery of taxes........................ $\$ 381$

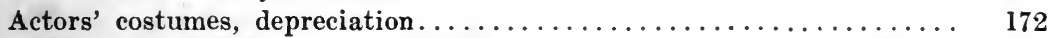

Additional assessment of income tax.............

Additions and betterments, made by tenant.............. 42

Administration of estates

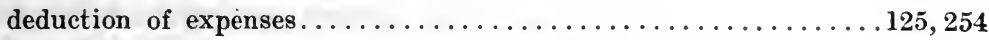

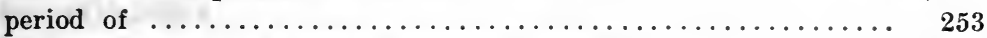

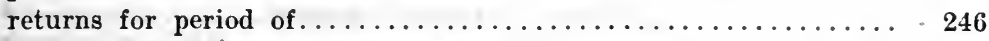

[References in italics are to sections of the law; other references are to articles of the regulations.] 
Administrative provisions

information at the source................ 366 (2), 281, 290

payment of taxes $\ldots \ldots \ldots \ldots \ldots \ldots \ldots \ldots \ldots \ldots \beta 377$ (1), 551-556

returns $\ldots \ldots \ldots \ldots \ldots \ldots \ldots \ldots \ldots \ldots \ldots \ldots \ldots \ldots \ldots .371,521-582$

correction of $\ldots \ldots \ldots \ldots \ldots \ldots \ldots \ldots \ldots \ldots \ldots \ldots$ 374, 571-574

estates and trusts...................... 365,246

fiduciary $\ldots \ldots \ldots \ldots \ldots \ldots \ldots \ldots \ldots \ldots \ldots \ldots \ldots \ldots \ldots \ldots \ldots \ldots \ldots$

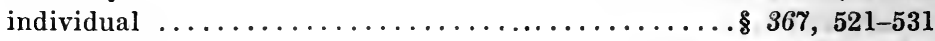

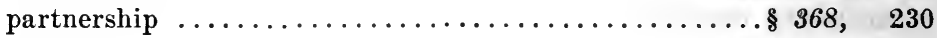

secrecy of $\ldots \ldots \ldots \ldots \ldots \ldots \ldots \ldots \ldots \ldots \ldots \ldots \ldots$ 384, 581-582

withholding at source..................... 261-270

Administrator, see fiduciary

Advertising, deductions, business expenses............... 111

Affidavits

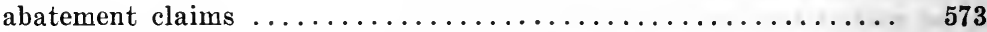

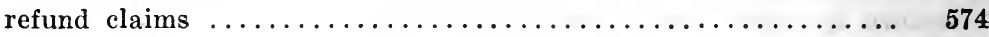

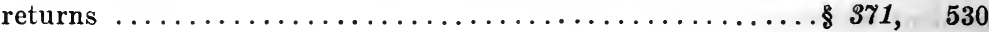

Agent

distinguished from fiduciary.................... 241

making return $\ldots \ldots \ldots \ldots \ldots \ldots \ldots \ldots \ldots \ldots \ldots \ldots \ldots \$ 67,522-523$

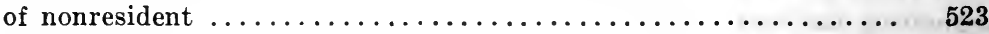

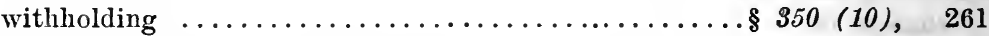

Alien, resident, personal exemption of . . . . . . . . . . . 206-207

Alimony

not deductible .............................. 125

not included in gross income.................... 73

Allotments under war risk insurance............\& 359 (2-e), 72

Allowable deductions, nonresidents.............\& $\$ 60$ (11), 431-435 see also deductions

Allowance

for amortization $\ldots \ldots \ldots \ldots \ldots \ldots \ldots \ldots \ldots \ldots \ldots \ldots \ldots \ldots \ldots \ldots \ldots, 28$

of credit for taxes to nonresidents. . . . . . . . . .

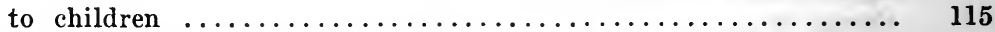

Alternative basis of apportionment by nonresidents........... 470

Ambassadors, exemption of income.................. 77

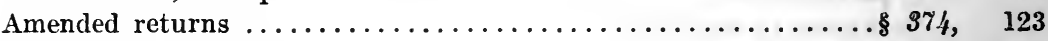

Amortization allowance $\ldots \ldots \ldots \ldots \ldots \ldots \ldots \ldots \ldots \ldots \ldots \ldots \ldots \ldots \ldots \ldots, 28$

Amount deducted and withheld

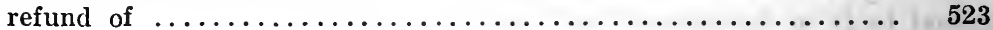

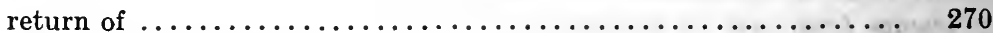

Annual or periodical income......................... 263

Annuities ......................................... 40

nonresident, nontaxable ................ $\$ 59$ (3), 413

representing return of capital - information at source......., 289

Apportionment

business income of nonresident from business carried on both within and without the state............. 360 (11), 457

income of partnerships having nonresident member.......... 457

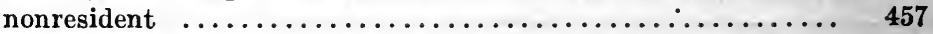

alternative basis of $\ldots \ldots \ldots \ldots \ldots \ldots \ldots \ldots \ldots \ldots, 470$

[References in italics are to sections of the law; other references are to articles of the regulations.] 
Apportionment - continued

personal services of nonresident, withholding at source....... 266

wages of nonresident seamen ....................... 454

Appraisal, property acquired by gift or inheritance.......... 73,93

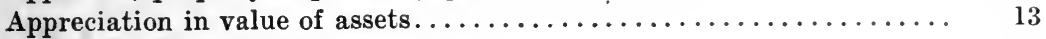

Architect's services, deduction of fees.................. 125

Assessments

local benefits $\ldots \ldots \ldots \ldots \ldots \ldots \ldots \ldots \ldots \ldots \ldots \ldots 60 \ldots \ldots$ (3), 143

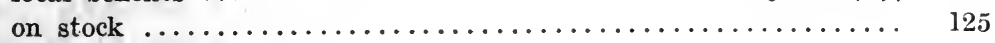

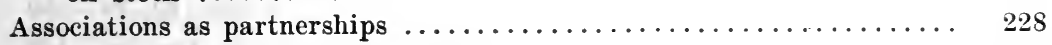

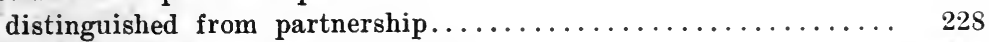

Assumption of tax, contract for, illegal.............. $\$ 385$

Attorney's fees of estates or trusts.................. 254

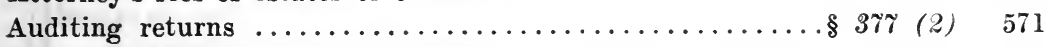

Authority of Comptroller for abatement and refund of tax.... $\$ 3 \% 3, \quad 572$

Automobiles

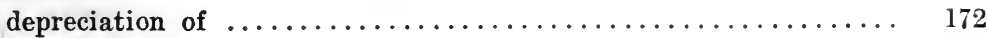

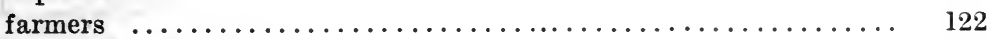

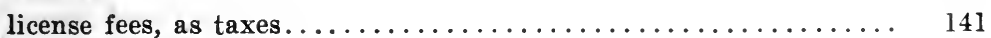

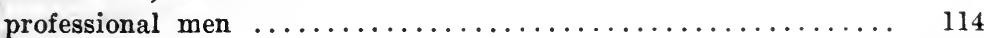

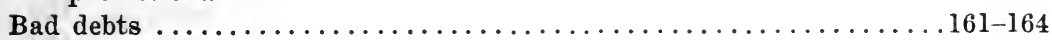

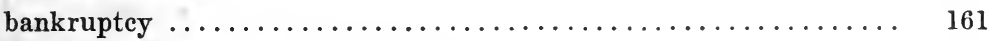

bonds ascertained to be worthless................. 164

collected after being charged off and deducted............. 44

deductions, in general ................. 360 (y) 161-164

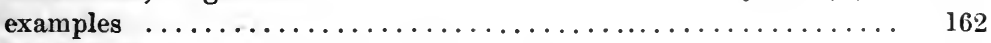

existing prior to January 1, 1919, deductions for.......... 161

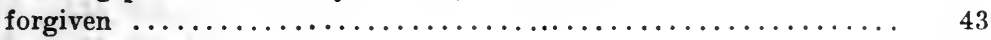

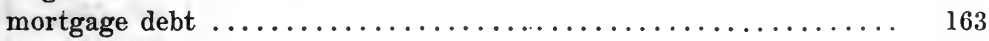

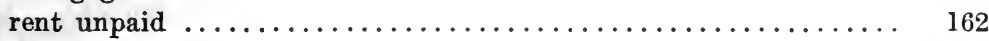

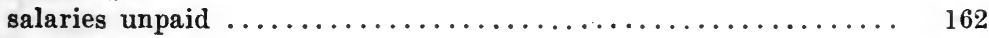

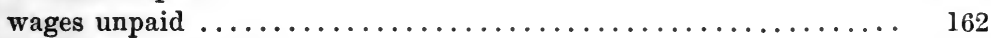

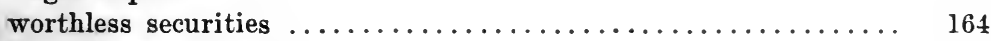

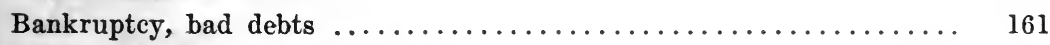

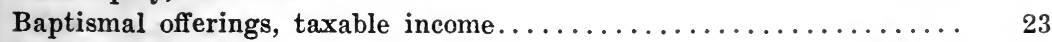

Basis for computation of net income.............

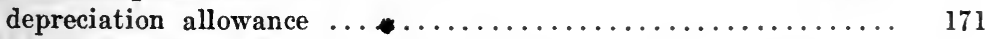

determining gain or. loss from sale, gift or other disposition of

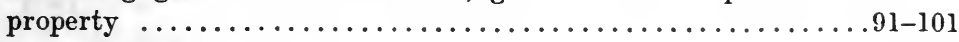

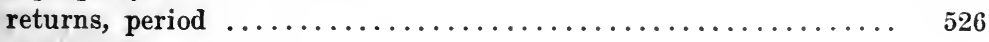

Beneficiaries

distributive income of estate or trust, to be accounted for by.....

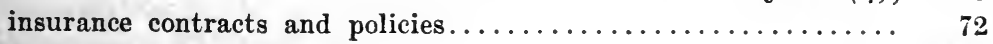

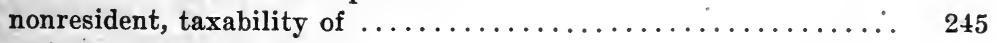

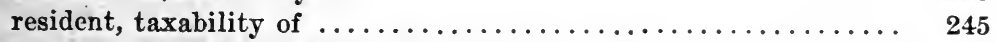

taxable year differing from that of trust or estate......... 245

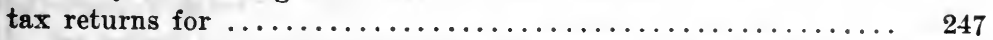

[References in italics are to sections of the law; other references are to articles of the regulations.] 
Bequests, see gifts

Betterments, made by lessee, income to lessor............... 42

Bills paid for merchandise, information at source............. 289

Bonds

exemption from personal property tax, extent of ........... $\$$ \$52

interest on, accrued prior to $1919 \ldots \ldots \ldots \ldots \ldots \ldots \ldots \ldots \ldots \ldots .79$

constructive receipt of .......................... 46

exemptions $\ldots \ldots \ldots \ldots \ldots \ldots \ldots \ldots \ldots \ldots 59(2-d), \quad 74$

information at source $\ldots \ldots \ldots \ldots \ldots \ldots \ldots \ldots 66$ (2), 2S7-289

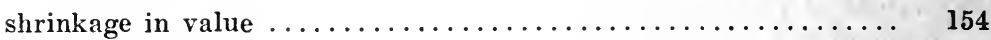

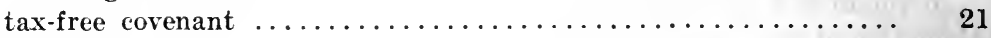

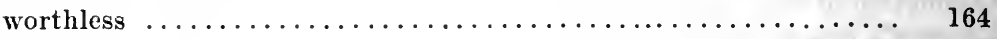

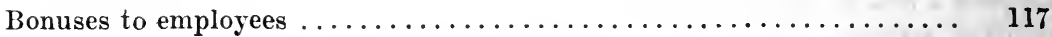

Bonus stock, sale of, determination of cost.............. 31

Bookkeeping, approved methods $\ldots \ldots \ldots \ldots \ldots \ldots \ldots \ldots \ldots 58, \quad 13$

see also accounting methods

Books of professional men $\ldots \ldots \ldots \ldots \ldots \ldots \ldots \ldots \ldots \ldots \ldots \ldots, 114$

Building

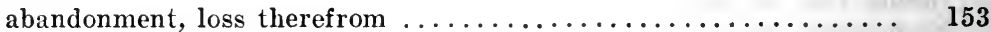

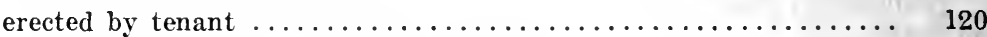

voluntary removal of, deduction of loss............... 152

Business

expenses

deductions .................... 360 (1), 111-125

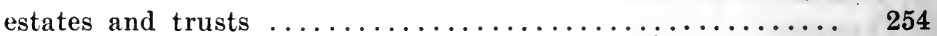

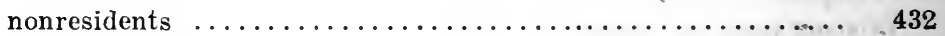

gross income from .................. 359 (1), 28

income of nonresident, taxability............. 359 (3), 414

losses, deductions .................. 360 (4), 151

Business of nonresident

carried on

defined ............................... 415

wholly within the state................... 455

within and without the state................. 457

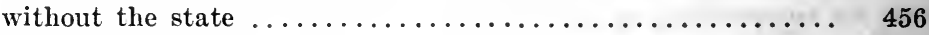

Calendar year, see accounting period

basis of

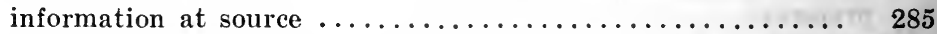

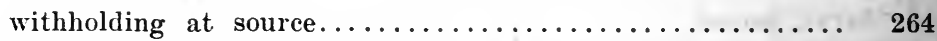

Cancellation of debt, as producing income................. 43

Capital

accrual of income prior to January $1,1919 \ldots \ldots \ldots \ldots \ldots \ldots \ldots .79$

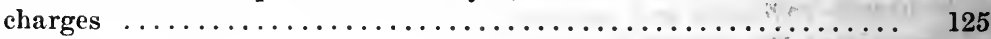

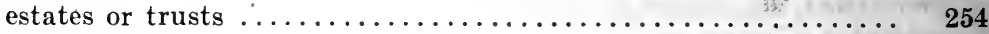

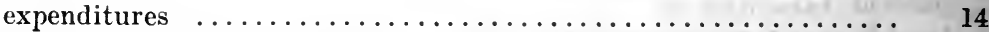

farmers' expenses ............................. 122

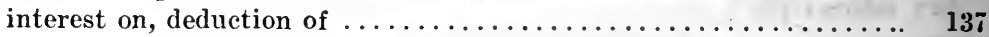

recovery of, through depreciation allowance............. 174

[ References in italics are to sections of the law; other references are to articles of the regulations.] 
Cash basis, see accounting methods

Cash, form of items of, as gross income and deductions.

Casualty

deduction of losses $\ldots \ldots \ldots \ldots \ldots \ldots \ldots \ldots \ldots \ldots \ldots \ldots \ldots \ldots$ (j)

losses from

deduction

nonresidents

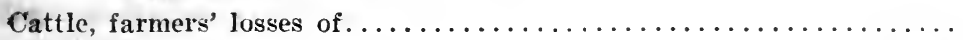

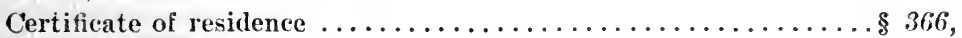

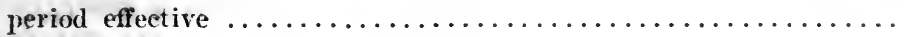

renewal $\ldots \ldots \ldots \ldots \ldots \ldots \ldots \ldots \ldots \ldots \ldots \ldots \ldots \ldots \ldots . \ldots \ldots . \ldots \ldots$

Certified checks not required in payment of taxes............ 55 5

Certiorari to review determination of Comptroller............ $\$ 3 \% 5$

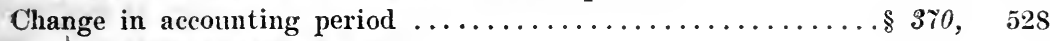

see also accounting period

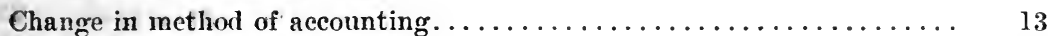

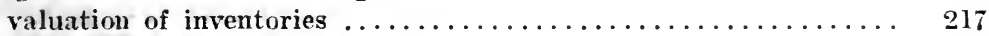

see also accounting methods

Charges deductible, when

see also deductions

to capital account $\ldots \ldots \ldots \ldots \ldots \ldots \ldots \ldots \ldots \ldots \ldots \ldots \ldots \ldots \ldots$

see also capital charges

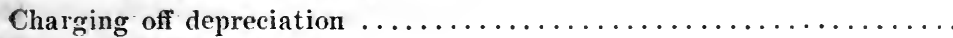

see also depreciation

Charitable contributions

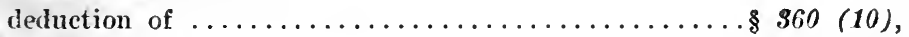

201

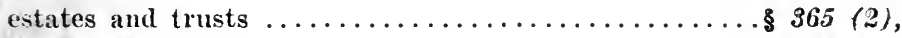

251

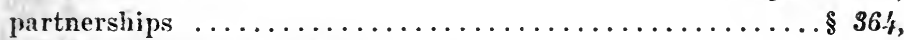

Charitable corporations, defined $\ldots \ldots \ldots \ldots \ldots \ldots \ldots \ldots \ldots \ldots . \ldots 2$

Checks

dishonored, given in payment of $\operatorname{tax} \ldots \ldots \ldots \ldots \ldots \ldots \ldots \ldots \ldots \ldots$

urcertified, in payment of $\operatorname{tax} \ldots \ldots \ldots \ldots \ldots \ldots \ldots \ldots \ldots \ldots \ldots \ldots \ldots$

\section{Children}

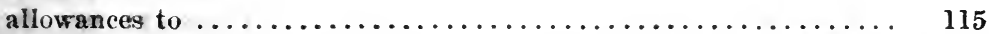

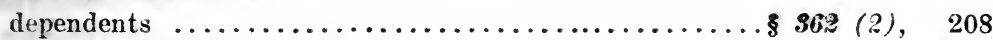

Choses in action, exemption from personal property tax, extent of ... \& 352

Claims

abatement of taxes.

see also abatement of taxes

defined

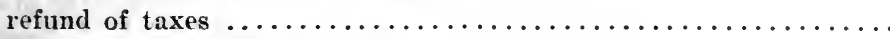

see also refund of taxes.

Classification of income of estates and trusts.............. 242

Clergymen's compensation $\ldots \ldots \ldots \ldots \ldots \ldots \ldots \ldots \ldots \ldots \ldots \ldots, 23$

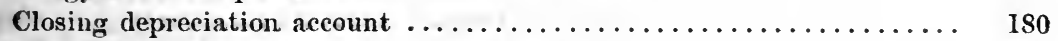

Clothing, depreciation of . . . . . . .

Collection of taxes

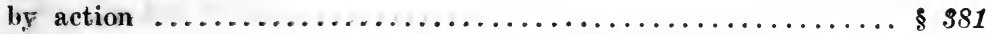

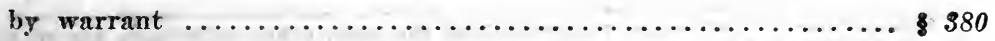

[References in italies are to sections of the law; other references are to articles of the regulations.] 


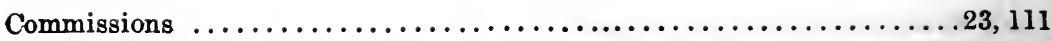

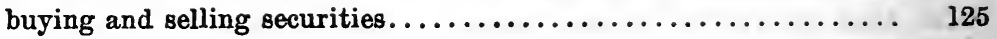

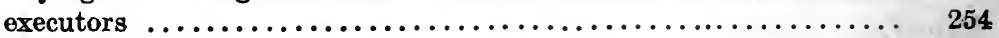

referees and receivers, Federal courts................. 78

withholding at the source...................... 264

Committee of property of incompetent

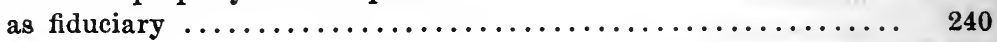

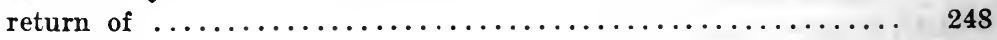

Compensation

deducting and withholding at source............ \& $\$ 66$ (1), 261

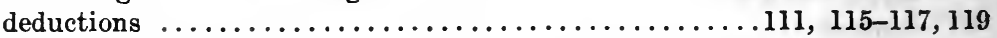

information at source $\ldots \ldots \ldots \ldots \ldots \ldots \ldots \ldots \ldots$ s66 (2), 286

injuries ........................ $\$ 59$ (2-e), 41

paid

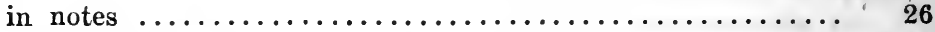

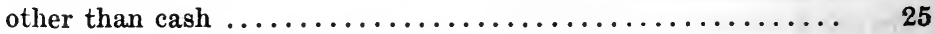

to widow of employee, deduction................ 119

personal services, taxable income............. $\$ 59$ (1), 23

federal employees and officers............ \& 359 (2-f), 78

included in gross income $\ldots \ldots \ldots \ldots \ldots \ldots \ldots \ldots \ldots \ldots . \ldots \ldots . \ldots \ldots$

nonresidents, taxability ................ \$ $\$ 59$ (\$), 412

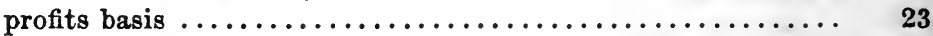

receivers of state courts..................... 24

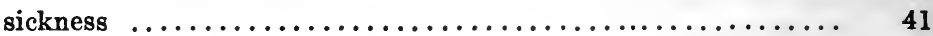

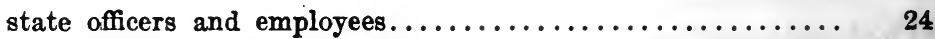

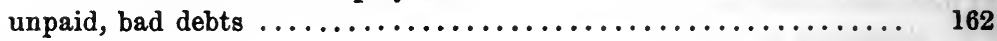

Comptroller

definition of $\ldots \ldots \ldots \ldots \ldots \ldots \ldots \ldots \ldots \ldots \ldots \ldots \ldots \ldots \ldots \ldots \ldots \ldots \ldots$

power to make regulations...................... \& $88 s$

Computation

amount of gifts to charity....................... 201

gross income of nonresident ............... $\$ 59$ (\$), 411

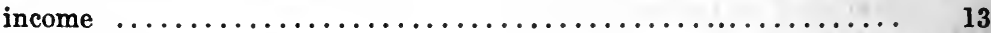

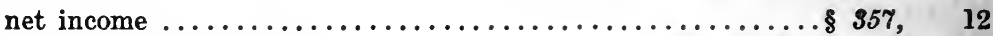

estates and trusts $\ldots \ldots \ldots \ldots \ldots \ldots \ldots \ldots \$ \$ 65$ (2), 251, 252, 254

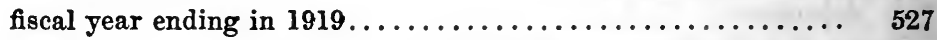

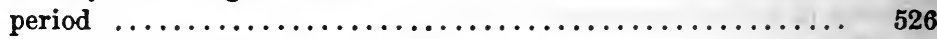

Conditions of allowances of credit to nonresidents............. 483

Constructive receipt

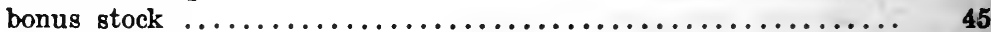

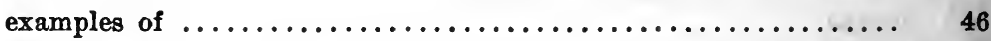

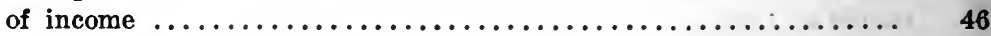

Consular officers, exemption of income.................. 77

Contents of partnership return................. 2368 , 231

Contract to assume tax illegal. ...................... $\$ 385$

Contracts, long term, ascertainment of income............... 39

Contributions by employees to pension fund.............. 25, 41

charitable deductions ................. $\$ 60$ (10), 201

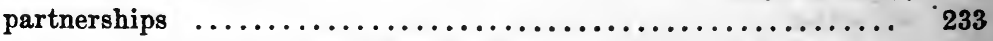

[References in italics are to sections of the law; other references are to articles of the regulations.] 
Cooperative trading stamp system................... 80

\section{Copyrights}

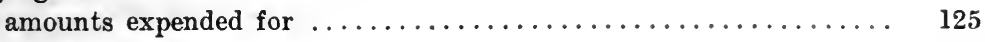

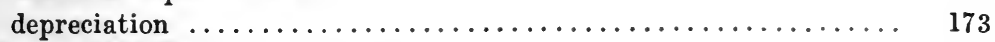

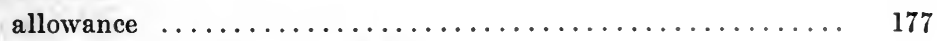

sale, determination of gain or loss................. 32

Corporate dividends

inclusions in income $\ldots \ldots \ldots \ldots \ldots \ldots \ldots \ldots \ldots 59$ (1), 61-66

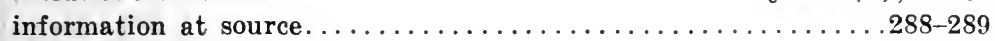

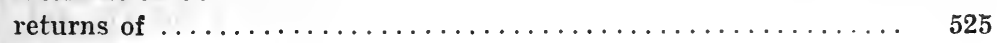

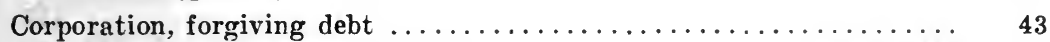

Corrected returns, when payable............... $\$ 77$ (\$), 551

Correction of returns $\ldots \ldots \ldots \ldots \ldots \ldots \ldots \ldots \ldots \ldots \ldots$. $\ldots \ldots \ldots, 571-574$

Cost

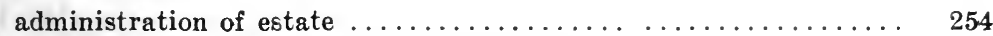

defending or perfecting title to real estate............ 125

feeding cattle, expenses of farmers.................. 122

improvements, depreciation deduction................ 174

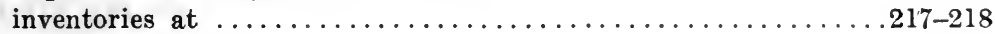

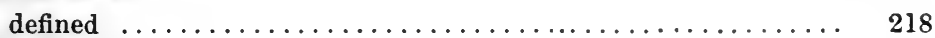

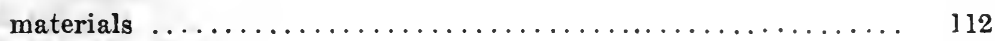

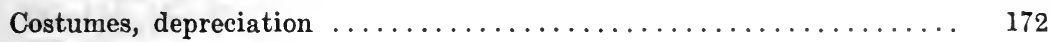

Coupons, interest

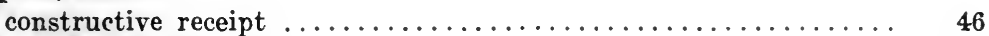

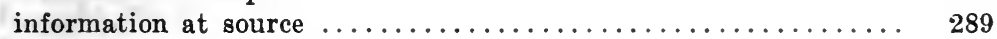

Credits of income $\ldots \ldots \ldots \ldots \ldots \ldots \ldots \ldots \ldots \ldots \ldots \ldots \ldots \ldots \ldots \ldots$

Crops

deduction of cost of producing by farmer............... 122

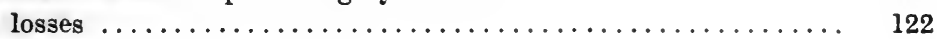

destruction of loss by, deduction. . . . . . . . . . . . 155

harvested in following year....................... 30

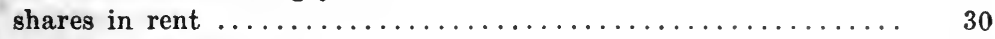

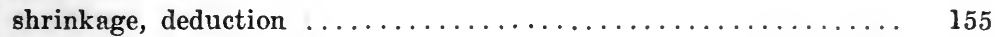

Customs duties, deduction ................ $\$ 60$ (\$), 142

Dairy animals, depreciation allowance................ 30

Damages

deductible, as of what time......................... 123

for personal injuries or sickness...........\& $\$ 59$ (2-e), 72

Date, determining personal exemption................ 209

Dealers in securities

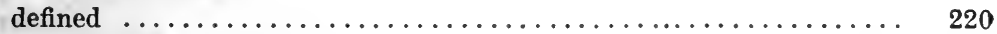

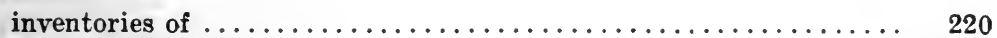

on installment plan $\ldots \ldots \ldots \ldots \ldots \ldots \ldots \ldots \ldots \ldots \ldots \ldots \ldots \ldots \ldots$

\section{Debts}

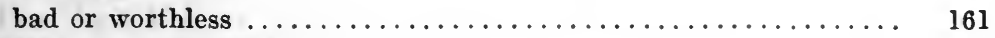

forgiven or canceled ........................ 43

see also bad debts

[References in italics are to sections of the law; other references are to articles of the regulations.] 
Decedent's estate during administration.............. \& $365, \quad 253$

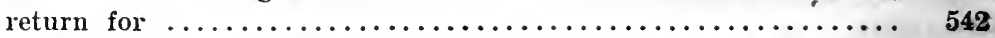

Deducting and withholding at source, see withholding at the source

Deductions

apportionment of nonresident $\ldots \ldots \ldots \ldots \ldots \ldots \ldots \$ \$ 60$ (11), 457

alternative basis ...................... 470

employees and oflicers $\ldots \ldots \ldots \ldots \ldots \ldots \ldots \ldots \ldots \ldots \ldots .452$

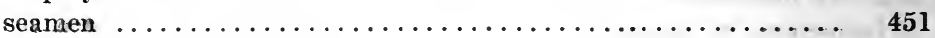

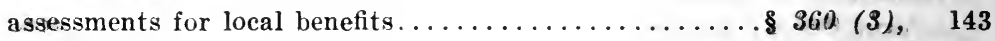

bad debts $\ldots \ldots \ldots \ldots \ldots \ldots \ldots \ldots \ldots \ldots \ldots \ldots \ldots \ldots \& 360$ (7), 161-164

bonuses to employees.......................... 117

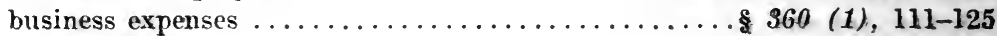

nonresident $\ldots \ldots \ldots \ldots \ldots \ldots \ldots \ldots \ldots \ldots \ldots \$ 360(11), 432$

charitable contributions ................ $\$ 60$ (10), 201

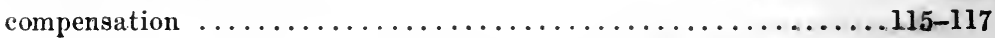

computation of net income...................... 12

customs duties ...................... \& 360 (\$), 142

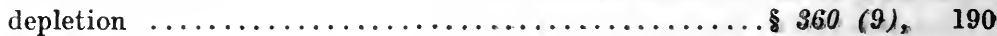

depreciation $\ldots \ldots \ldots \ldots \ldots \ldots \ldots \ldots \ldots \ldots \ldots \ldots \ldots \ldots \ldots \ldots \ldots \ldots$ (8), 171-181

see also depreciation deductions

estates and trusts................... \& $\$ 65$ (2), 251, 254

expenses, business $\ldots \ldots \ldots \ldots \ldots \ldots \ldots \ldots \ldots \ldots \ldots$ \& 360 (1), 111-125

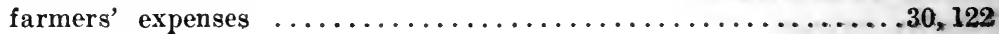

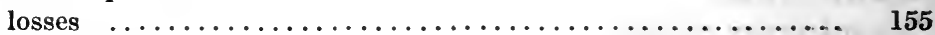

import duties .................... $\$ 60(3), \quad 142$

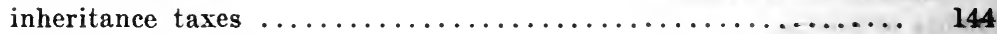

interest $\ldots \ldots \ldots \ldots \ldots \ldots \ldots \ldots \ldots \ldots \ldots \ldots \ldots 60$ (2), 136-137

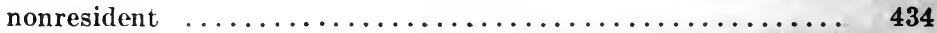

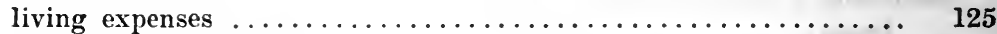

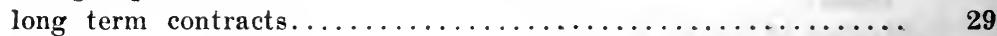

losses $\ldots \ldots \ldots \ldots \ldots \ldots \ldots \ldots \ldots \ldots \ldots 60(4,5,6), 151-155$

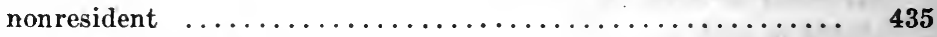

sale of copyrights............................ 32

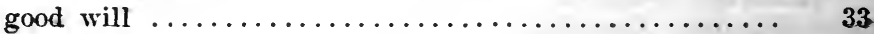

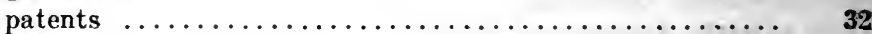

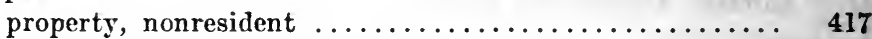

securities, nonresident $\ldots \ldots \ldots \ldots \ldots \ldots \ldots \ldots \ldots \ldots, 416$

nonresidents $\ldots \ldots \ldots \ldots \ldots \ldots \ldots \ldots \ldots \ldots \ldots \ldots \$ 960$ (11), 431-435, 481

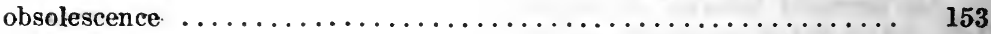

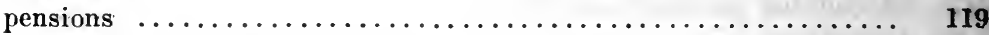

personal and family expenses...................... 125

services, compensation for................115-117

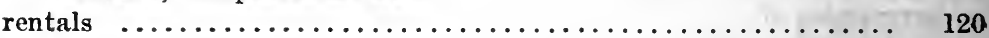

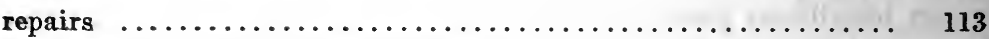

shrinkage in securities and stocks................. 154

tariff duties $\ldots \ldots \ldots \ldots \ldots \ldots \ldots \ldots \ldots \ldots \ldots \ldots \ldots$ s6. (3), 142

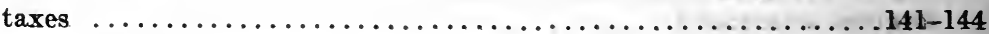

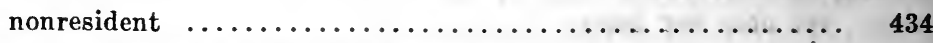

[References in italics are to sections of the law; otber references are to articles of the regulations.] 
Deductions - continued

traveling expenses

trusts $\S 365(2), 251,254$

uncollectible accounts 161

unpaid rents, as bad debts...................... 162

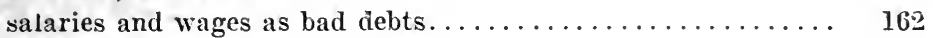

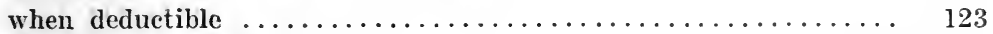

Default in installment payments....................... 34 , 3 S

Deferred payments, sales of real estate............... 36,38

Definitions

annual or periodical income. . . $2 \ldots \ldots \ldots \ldots \ldots \ldots \ldots \ldots \ldots$

business carried on ...................

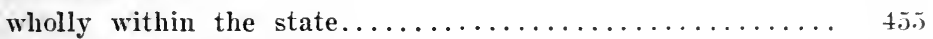

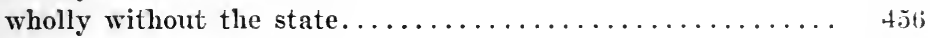

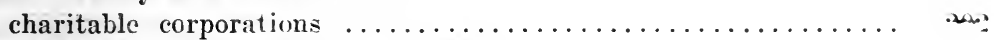

claim existing on January $1,1919 \ldots \ldots \ldots \ldots \ldots \ldots \ldots \ldots \ldots \ldots$ i!)

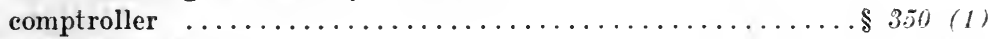

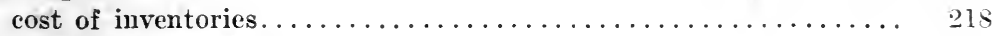

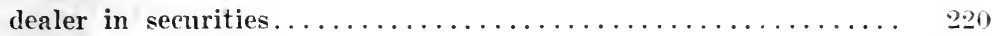

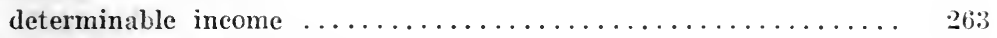

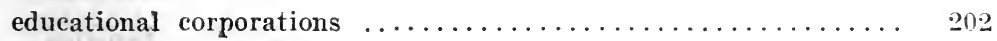

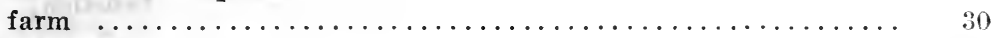

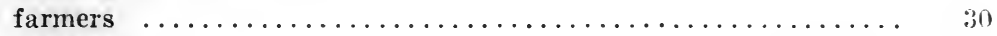

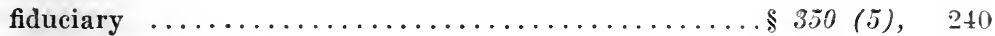

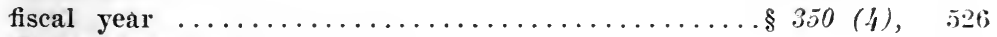

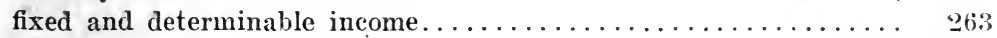

gross income $\ldots \ldots \ldots \ldots \ldots \ldots \ldots \ldots \ldots \ldots \ldots \ldots \ldots \ldots \ldots \ldots \ldots \ldots \ldots \ldots \ldots$

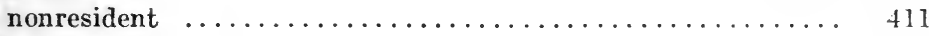

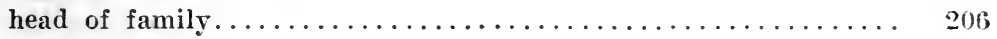

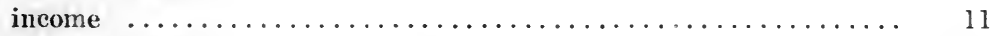

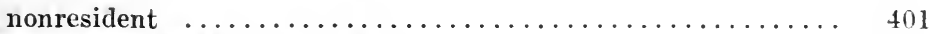

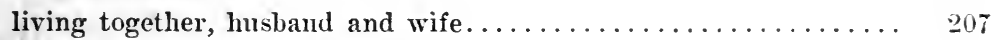

market value of inventories.................... 219

need not be in form of cash....................... 12

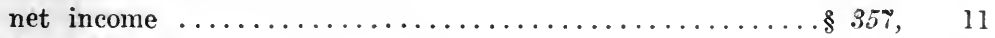

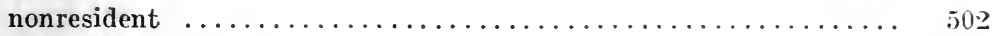

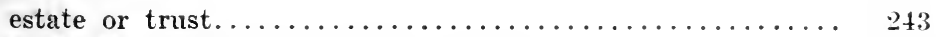

period of administration of estate and trust........... 253

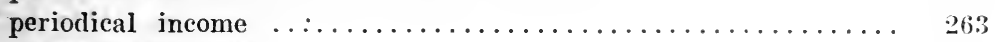

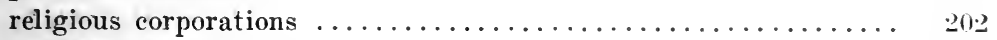

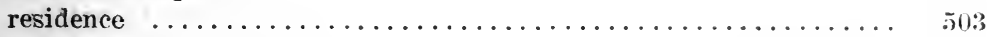

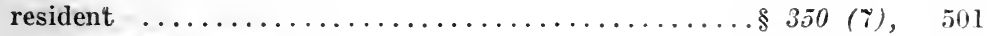

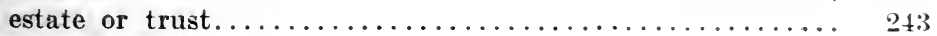

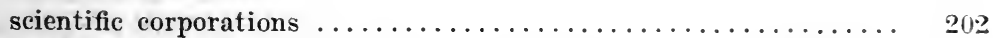

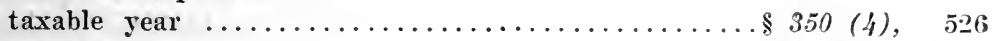

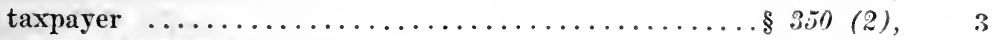

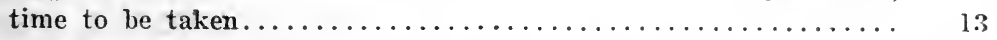

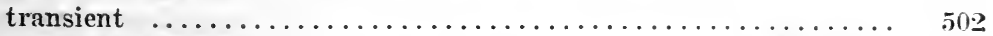

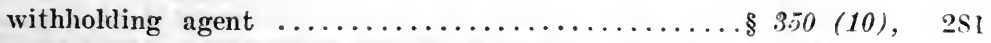

[References in italies are to sections of the law; other references are to articles of the regulations.] 
Demolition, buildings, deduction of loss................ 152 Dependents, exemption for................. 362 (2), 208 Depletion of mines, oil and gas wells, natural deposits and timber...28, 190 deductions ....................... 360 (9), 190

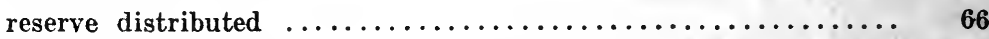

Depreciation deductions $\ldots \ldots \ldots \ldots \ldots \ldots \ldots \ldots \ldots \ldots 860$ (8), 28, 171-181

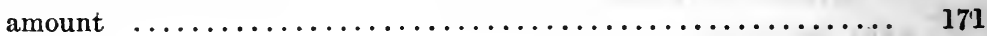

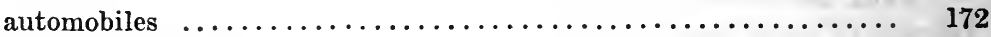

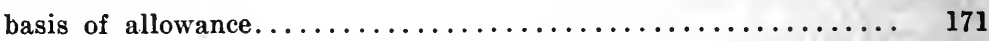

capital sum recoverable through depreciation allowances........ 174

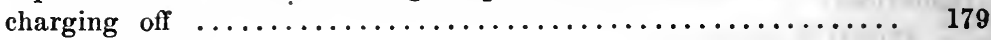

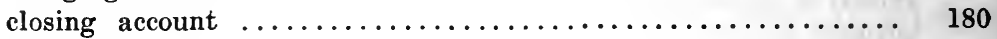

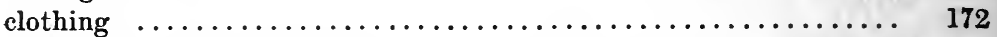

computation of allowances...........................

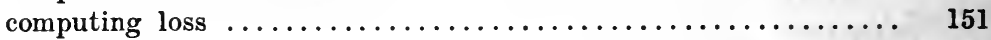

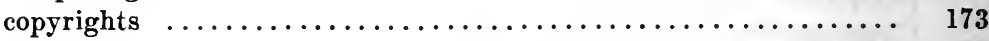

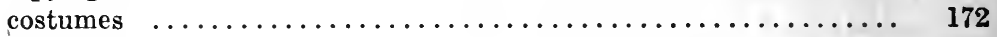

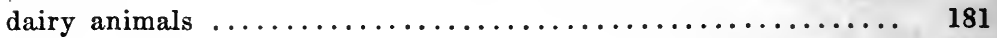

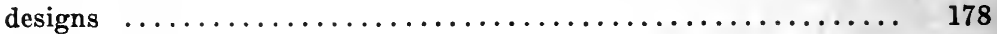

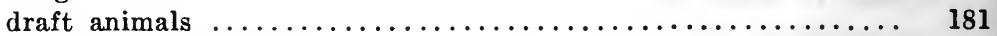

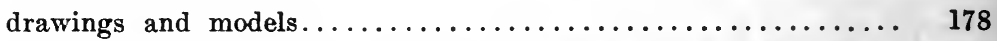

expenditures in restoring property or making good the exhaustion. 174

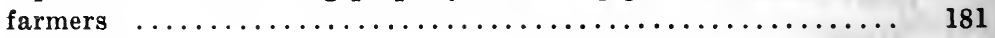

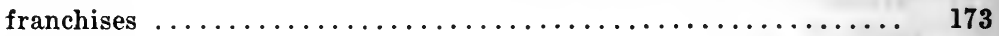

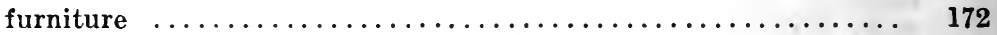

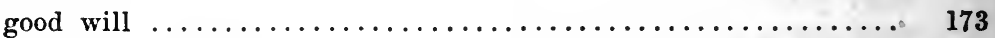

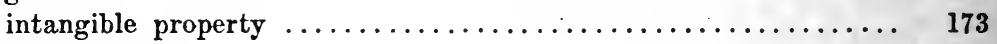

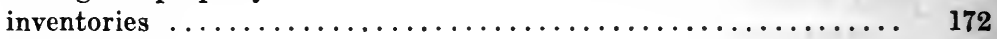

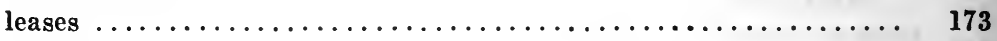

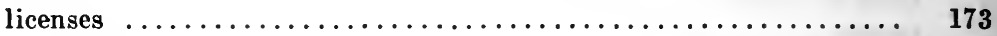

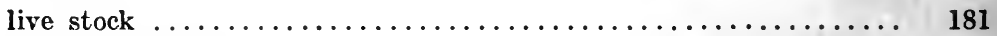

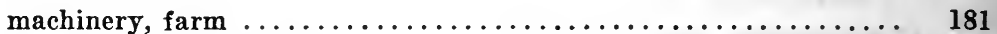

methods of computing......................

minerals, not allowable............................. 172

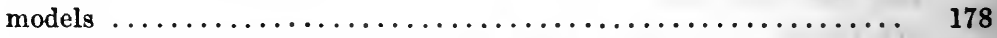

modification of method of computing allowances............ 176

natural resources, not allowable.................... 172

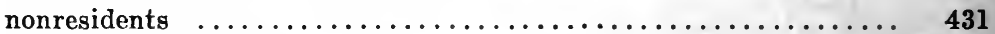

patent or copyright........................... 177

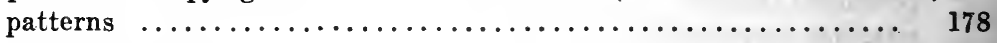

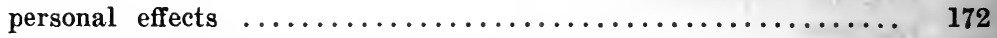

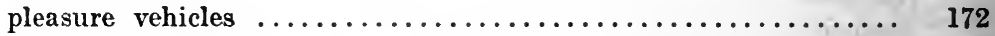

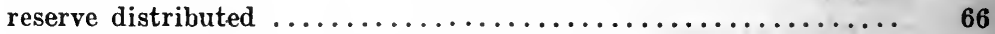

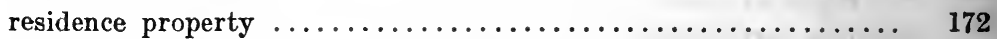

secret formulae or processes........................ 173

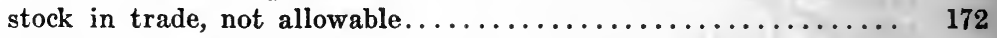

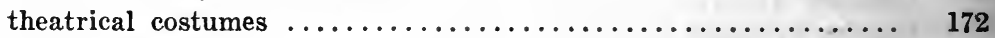

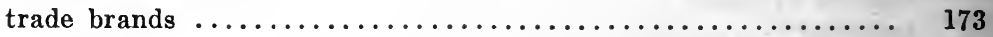

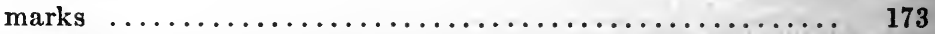

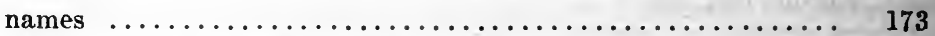


Depreciation reserve

distribution from $\ldots \ldots \ldots \ldots \ldots \ldots \ldots \ldots \ldots \ldots \ldots \ldots \ldots \ldots . \ldots \ldots$

expenditures to restore depreciation as charge against........ 14

Designs, depreciation, deduction.................... 178

Determinable income

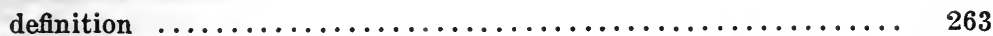

information at source................ \& 366 (2), 281-290

Determination of gain or loss from exchange of property.....\& $354,91-101$

Devises, annuities charged upon devised land................ 40

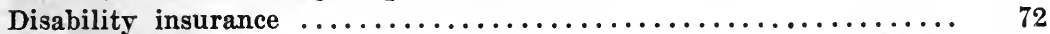

Disclosure of returns, penalties therefor............ \$84, 582

Discounted value of notes received as compensation............ 26

Diseased stock, loss of farmers', deductions............... 155

Dishonored checks given in payment of tax............... 555

Distribution from depletion or depreciation reserve............. 66

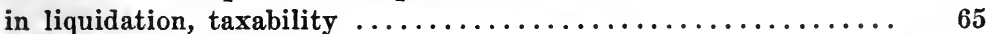

Distribution of income $\operatorname{tax}$ revenue.................. \& 382

Distributive shares of partners, taxability............46, 226, 229

Dividends

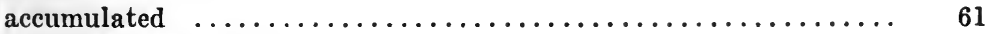

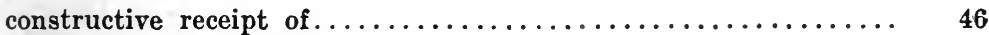

declaration merely, does not constitute distribution.......... 61

declared prior to January 1, 1919, excluded from gross income... $\quad 79$

farm loan association.................. $\$ 59$ (2d), 75

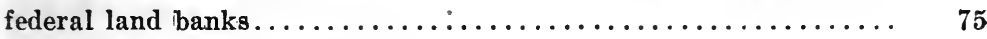

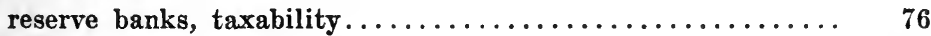

from depletion reserve.......................... 66

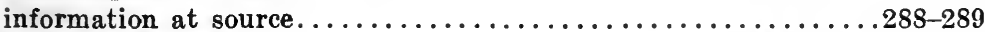

in gross income..................... $\$ 59$ (1), 61-66

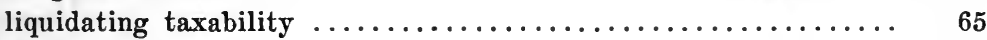

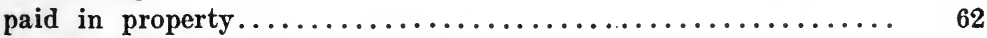

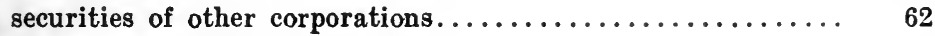

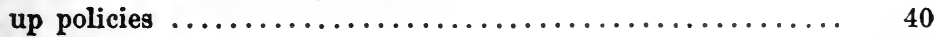

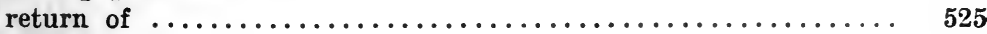

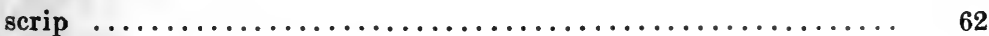

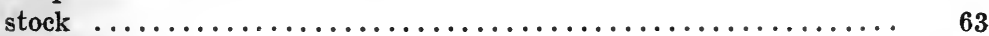

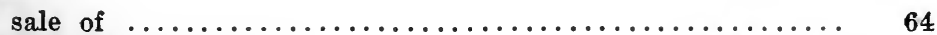

taxability of nonresident's............... 359 (3), 419

Donations, employees $\ldots \ldots \ldots \ldots \ldots \ldots \ldots \ldots \ldots \ldots \ldots \ldots \ldots \ldots \ldots \ldots \ldots \ldots$

Draft animals

deduction of cost by farmer..................... 122

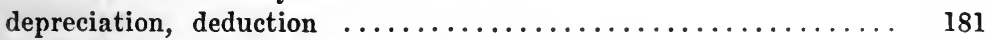

profit from sale by farmers, as taxable income............ 30

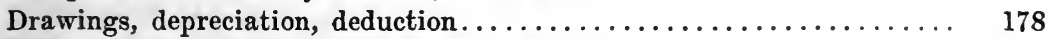

Drummer, nonresident, withholding at source.............. 266

Due date of return......................

Dues to professional societies......................... 114

Duties of withholding agent................... $366, \quad 262$

[References in Italics are to sections of the law; other references are to articles of the regulations.] 
Dwelling

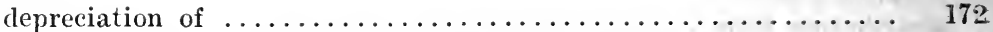

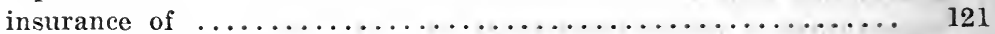

Earnings of salesmen, nonresident, taxable income.......... 451

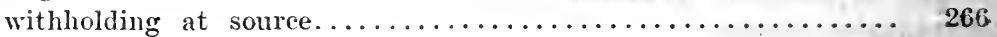

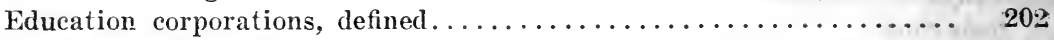

Effect of instruction on forms........................ 531

Emancipated children, return in case of................ 524

Employees

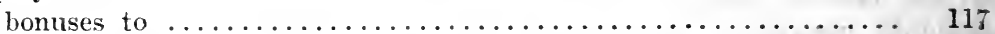

compensation, as taxable income............. $359(1), 23$

constructive receipt of bonus stock................. 45

federal, taxability of salaries.............. 35.9 (2f), 23

information at source as to payments to.........\$ 366 (2), 286

leaving employer, withholding at source.............. 262

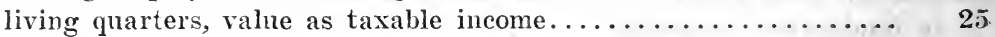

premiums on insurance, paid by employer, deduction......... 121

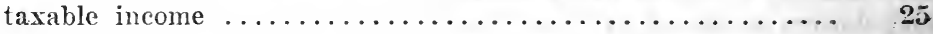

promissory notes in payment for services, taxable income...... 26

retired, payments to, deduction.................... 119

state, taxability of compensation from ................ 24

Employers

duties as withholding agent................. 366,262

liability insurance, deduction of premiums.............. 121

Endowments, sums in excess of premiums, taxable income. \& $\$ 399(2 b), \quad 72$

Estate taxes, deduction......................... 144

Estates and trusts.................. 365, 240-255

Estates

closed, return on final accounting................. 542

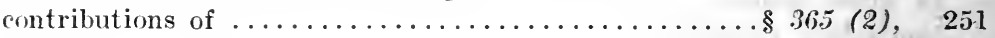

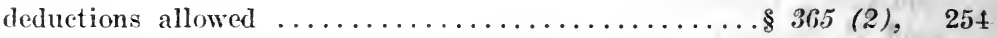

exemptions allowed $\ldots \ldots \ldots \ldots \ldots \ldots \ldots \ldots \ldots, \ldots \ldots \$ 365$ (3), 244

expenses of administration deductible............125, 253, 254

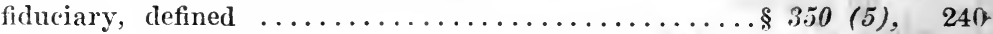

income of, computation ............ 365 (9), 251, 252, 254

income of, accumulated by fiduciaries. ..........242, 245, 246

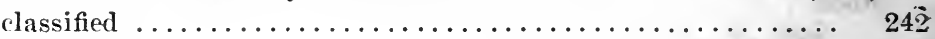

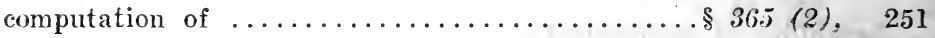

held for future distribution...............242, 244, 246

taxed to beneficiaries..................

fiduciary ................... 36.5 (3), 244

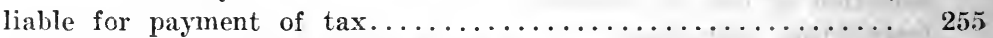

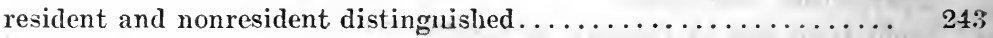

returns where more than one trust................ 249

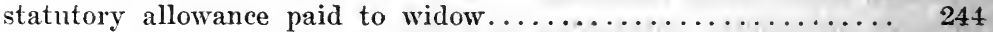

Evangelists, gifts or contributions to, as taxable income......... 23

Example of bad debts................................ 162

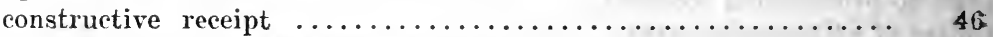

Excessive compensation, deductions........................ 116

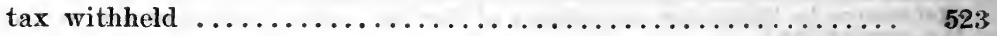

[References in italics are to sections of the law; other references are to articles: of the regulations.] 
Fxchange of property $\ldots \ldots \ldots \ldots \ldots \ldots \ldots \ldots \ldots \ldots \ldots \ldots$ 35!, $\quad 94$ basis for determining gain or loss............... \& 355, 91-101

determination of gain or loss from ............... 74-91

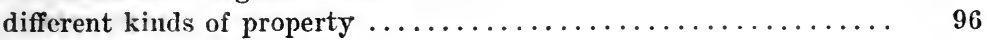

farm produce for merchandise..................... 30

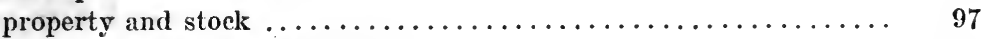

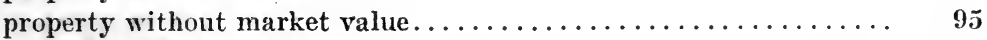

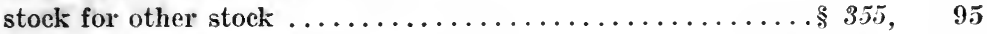

Excise taxes and federal duties, deductions.........\$ 360 (3), 142

Executors, commissions

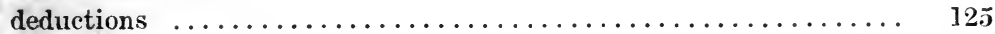

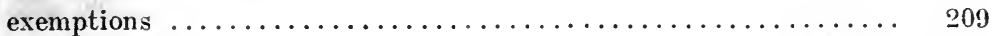

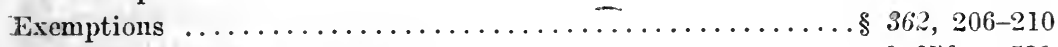

accounting period changed.................. $3 \% 0, \quad 529$

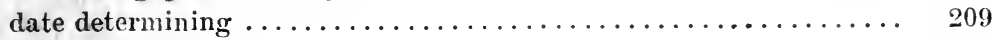

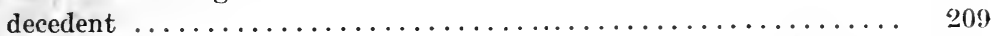

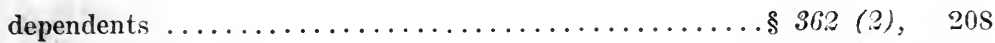

estates and trusts .................. 365 (3), 244

head of family ................... 362 (1), 206

husband or wife dying $\ldots \ldots \ldots \ldots \ldots \ldots \ldots \ldots \ldots \ldots \ldots \ldots \ldots \ldots$

married persons .................... 207

officer or einployee of United States............\$ 362 (3), 210

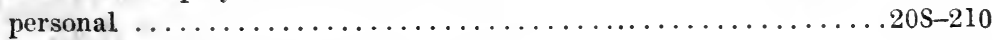

personal property, from taxation, extent of ............. $\$ 352$

prorating between husband and wife................ 209

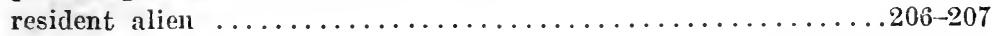

single persons $\ldots \ldots \ldots \ldots \ldots \ldots \ldots \ldots \ldots \ldots \ldots \ldots \ldots 362(1), \quad 205$

trusts $\ldots \ldots \ldots \ldots \ldots \ldots \ldots \ldots \ldots \ldots \ldots \ldots \ldots \ldots \ldots \ldots \ldots \ldots \ldots$ (3), 244

Exhaustion of property, deduction...........

Expense

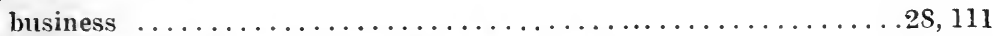

classification as between capital and income............ 125

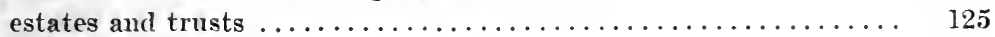

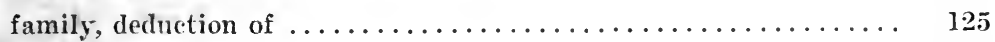

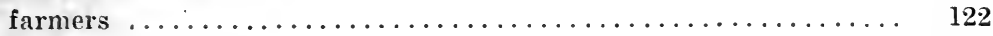

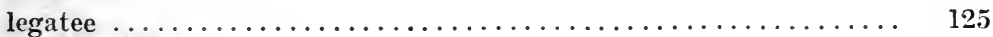

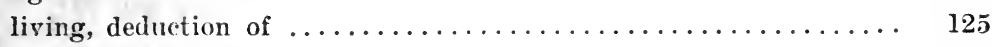

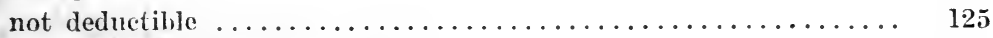

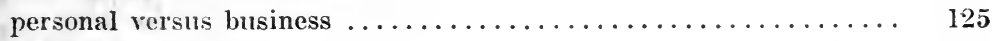

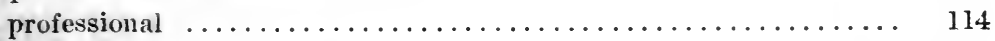

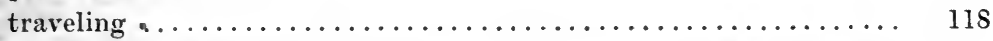

Extension of time, for filing return ...........

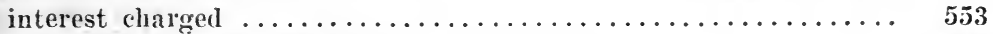

Factor used in apportioning income of nonresident........... 457

Failure to file return, penalties................

Failure to pay tax, penalties............. 379 (2), 556

[References in italics are to sections of the law; other references are to articles of the regulations.] 
Fair market value

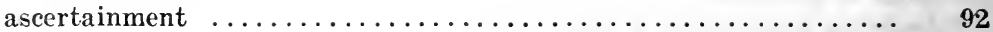

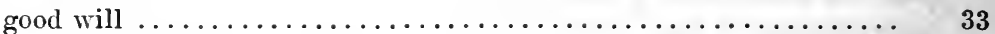

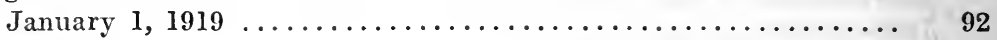

False returns

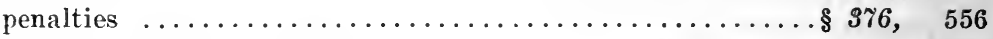

understatement of income...................... 571

Family allowances under war risk insurance........ $\$ 59$ (2-e), 72

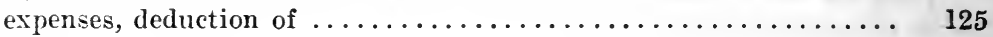
Farm

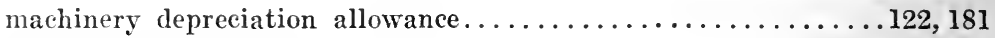

operated for pleasure $\ldots \ldots \ldots \ldots \ldots \ldots \ldots \ldots \ldots \ldots \ldots \ldots, 122,155$

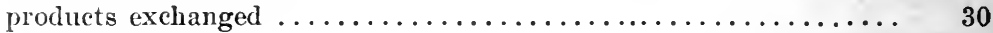

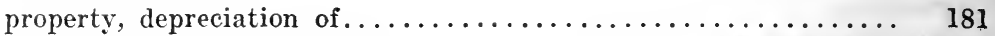

Farm loan association, dividends............. 359 (2-d), 75

Farms and farmers ................................. 122, 181

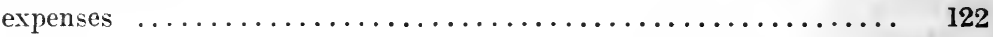

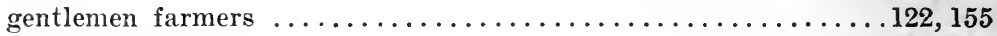

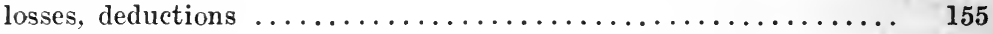

Federal estate taxes

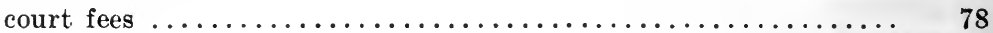

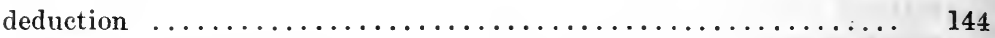

duties and excise taxes................. $\$ 60$ (\$), 142

farm loan securities .................. 359 (2-d), 74

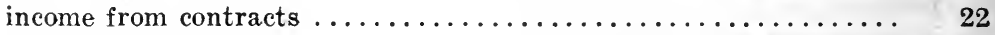

land bank dividends ................. $\$ 59$ (2-d), 75

reserve bank dividends, taxability................ 76

salaries ..................... $\$ 59$ (2-f), 23

Feeding live stock $\ldots \ldots \ldots \ldots \ldots \ldots \ldots \ldots \ldots \ldots \ldots \ldots \ldots \ldots \ldots, 122$

Fees

federal officers, taxability ............... $\$ 59$ (2-f), 78

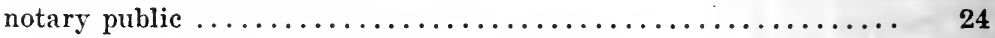

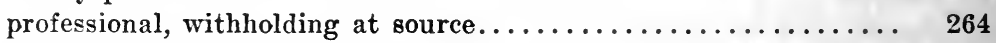

receivers, federal courts ................. \& $\$ 59$ (2-f), 78

referees, federal courts............... 359 (2-f), 78

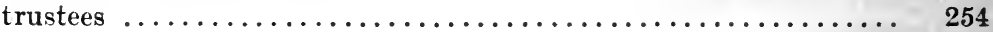

Fiduciary

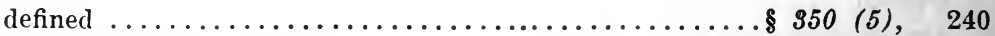

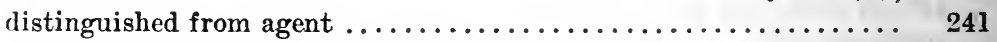

$\begin{array}{ll}\text { having entire charge of income of individual, must make return. . } 247 & 247\end{array}$

liable for payment of taxes...................... 255

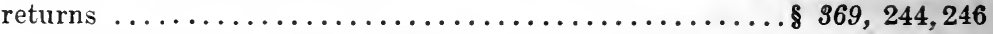

more than one trust or estate................... 249

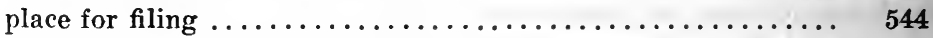

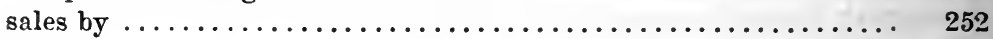

Filing

claim for abatement.................... $\$$ \$74, 573 returns

extension of time..................... $\$ \$ \mathbf{s 7 1}, \quad 543$

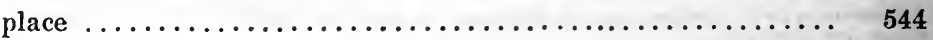

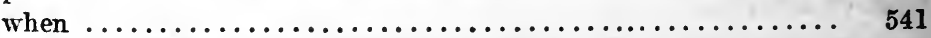

[References in italics are to sections of the law; other references are to articles of the regulations.] 
Fire insurance

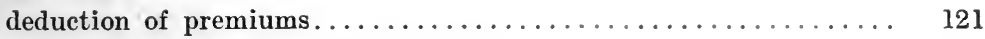

on residence, premiums not deductible............... 121

Fire losses, deduction $\ldots \ldots \ldots \ldots \ldots \ldots \ldots \ldots \ldots . \ldots \ldots 6$ (6), 151, 155

Fiscal year

defined .......................... $\$ 50$ (4), 526

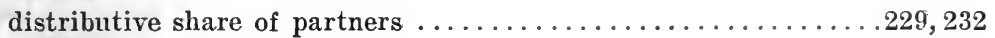

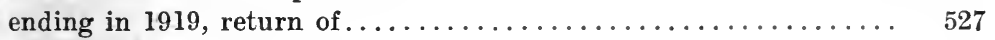

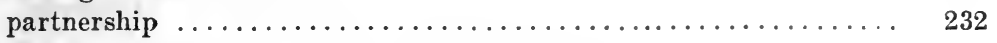

Fixed or determinable annual or periodical income

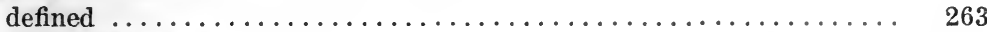

information at source $\ldots \ldots \ldots \ldots \ldots \ldots \ldots \ldots 66$ (2), 281-290

withholding at source ................... $\$ 66$ (1), 261

Flood losses, deduction ................... 360 (6), 151, 155

Fluctuation in values of stocks and bonds................ 154

Foreign commerce

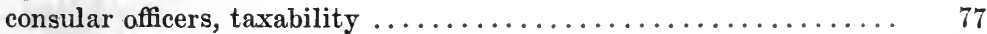

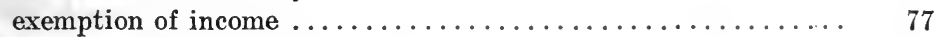

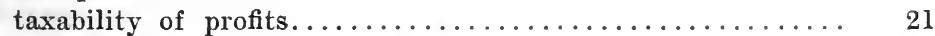

Forgiveness of indebtedness, taxable income.............. 43

Forms

certificate of residence ................ 366 (1), 267

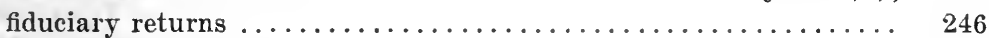

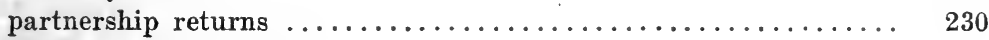

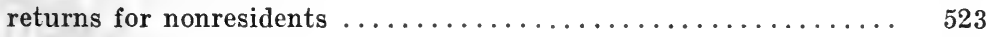

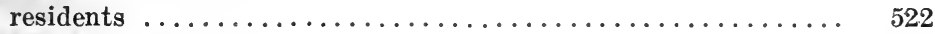

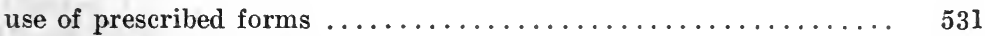

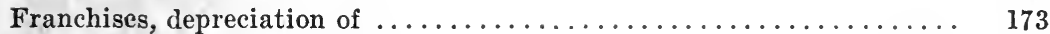

Fraudulent returns, penalties ................ $376, \quad 556$

Furniture

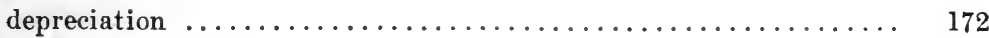

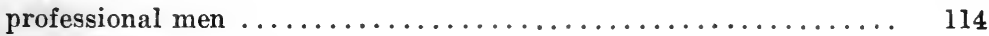

Gain or loss from sales

basis for determining $\ldots \ldots \ldots \ldots \ldots \ldots \ldots \ldots \ldots \ldots 59,91-101$

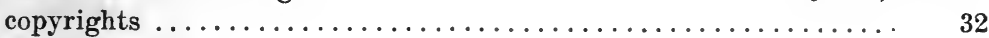

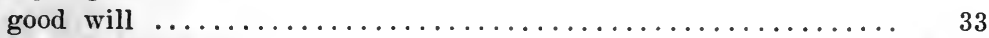

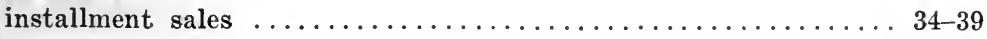

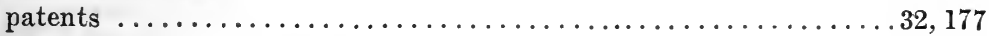

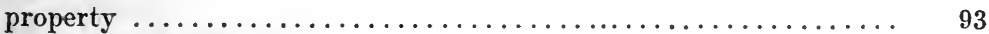

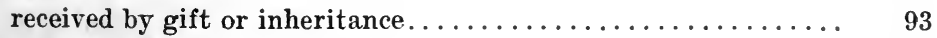

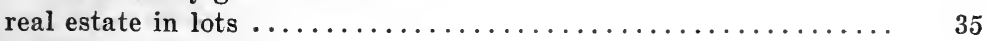

sales

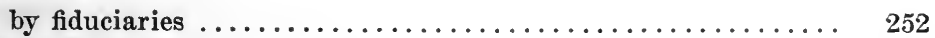

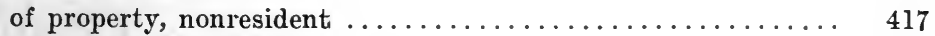

securities, nonresident ...................... 416

Gas wells, depletion ................. 360 (9), 190

Gifts

charitable, allowable deductions............. 360 (10), 201

clergymen, etc., taxable income.................... 23

estates and trusts, allowable deductions.......... 365 (2), 251 
Gifts - continued

exchuded from gross income .............. 359 (2-c), 73

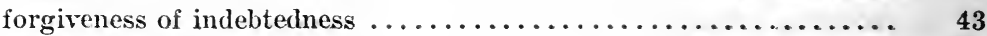

gain or loss on disposal by ....................... 91

partnership, not allowable deductions.................226, 233

sales of property acquired by ...................... 93

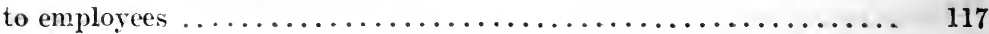

additional compensation $\ldots \ldots \ldots \ldots \ldots \ldots \ldots \ldots \ldots \ldots \ldots \ldots \ldots$

Good will depreciation

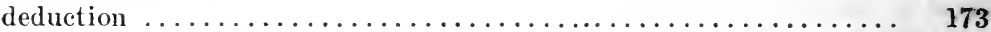

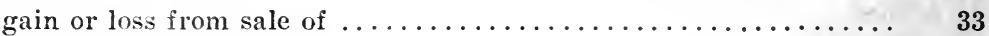

Government bonds

taxability of interest on............... §"359 (2-d), 74

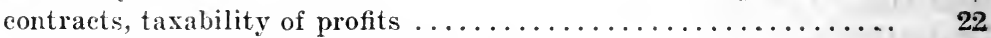

incone from, taxable income $\ldots \ldots \ldots \ldots \ldots \ldots \ldots \ldots \ldots . \ldots \ldots 22$

employees, taxability of compensation......... 359 (2-f), 78

Gross income .........................

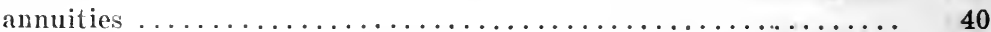

appreciation in value of property $\ldots \ldots \ldots \ldots \ldots \ldots \ldots \ldots \ldots, 13$

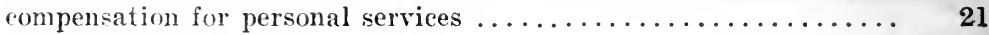

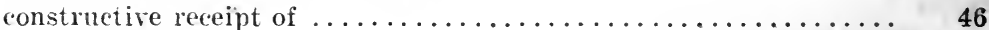

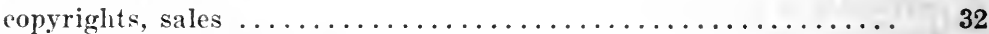

deductions, see deductions

deferred payment, sales of real estate............... 36, 38

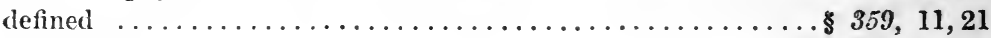

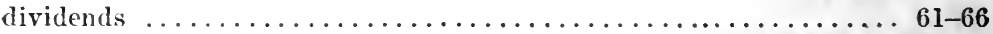

estates and trusts .................... $\$ 365$ (2), 251

exchange of property ................... \$54, 91

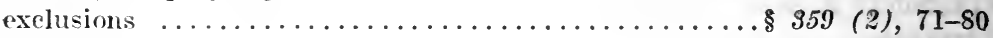

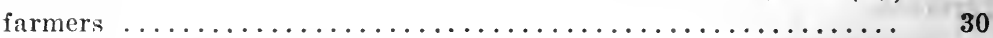

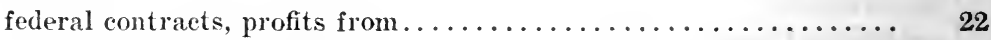

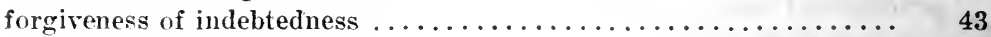

from business, nonresident .................... 414

gifts of property $\ldots \ldots \ldots \ldots \ldots \ldots \ldots \ldots \ldots \ldots \ldots \ldots$ (2-c), 91

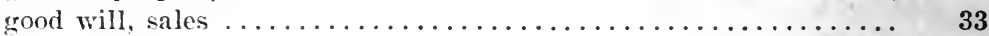

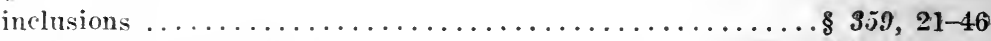

installment plan sales

of personal property.................... 34, 39

real estate ........................... 35-39

insurance policies, proceeds of ............ \& $959(?-a), \quad 40$

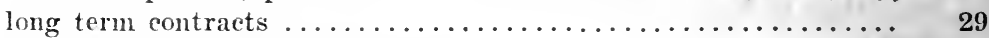

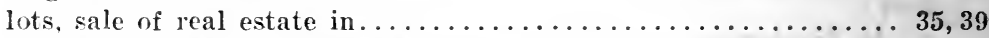

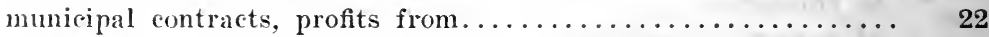

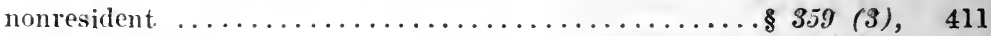

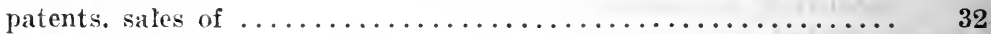

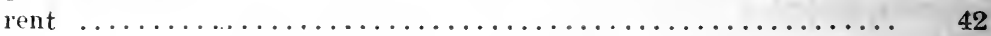

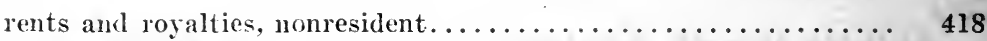

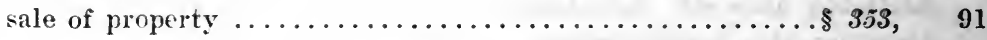

[References in italies are to sections of the law; other references are to articles of the regulations.] 
Gross income - continued

state contracts, profits from ............... 2 ב

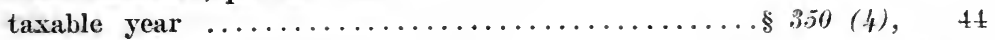

time as of which to be accounted for......... \& 35.9 (1), 13, 44, 46

Guardian, returns for infants..................... 248

Head of family

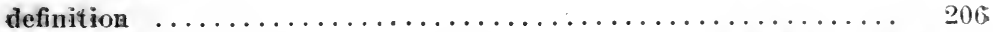

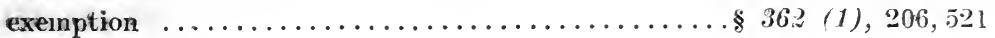

Health insurance

premiums paid by employers as taxable income to emploxec..... 25

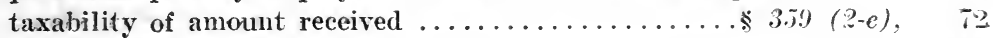

Holiday, due date for filing return................. 541

Husband and wife

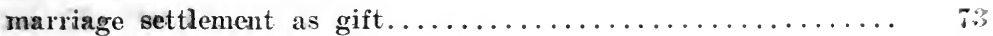

one dying, exemption of survivor................. 209

personal exemption $\ldots \ldots \ldots \ldots \ldots \ldots \ldots \ldots \ldots \ldots 36.2$ (1), 207,209

what constitutes living together....................... 207

Hlegal transactions, deduction of losses............ 1;

Illness

insurance or damages received on account of ...... $359(2-c), \quad 72$

return by agent where taxpayer is ill...........

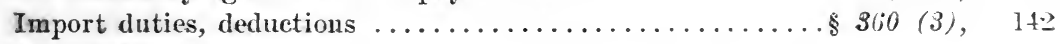

Improvements, by tenant

cost of, added in determining depreciation allowance......... 17t

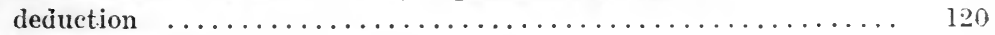

lessee, income to lessor..................... 42

Inclusion in gross income, see gross income

in inventory, see inventories

Income

accruing prior to January $1,1919 \ldots \ldots \ldots \ldots \ldots \ldots \ldots \ldots \ldots$

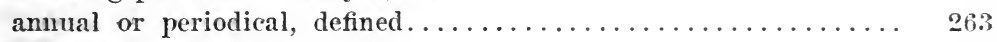

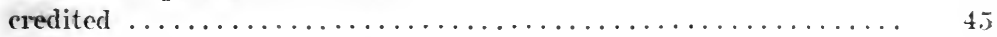

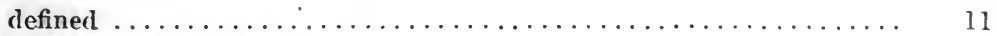

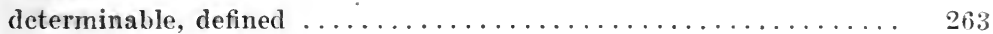

estates and trusts

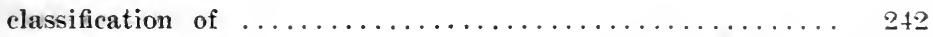

computation of $\ldots \ldots \ldots \ldots \ldots \ldots \ldots \beta 36.5$ (2), 251, 252, 254

taxed

to beneficiaries $\ldots \ldots \ldots \ldots \ldots \ldots \ldots \ldots .365$ (1), 245

fiduciary ................... $\$ 6.5(3), \quad 241$

exeupt from taxation $\ldots \ldots \ldots \ldots \ldots \ldots \ldots \ldots \ldots 59$ (2), il

federal, state and municipal contracts............... $\mathbf{2} 2$

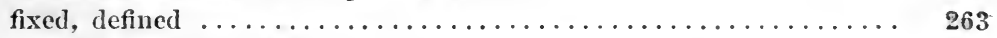

foreign consular officers..................... 7

from ressels, nonresident, taxability.............. 454

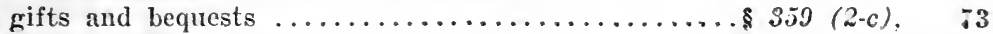

information at source $\ldots \ldots \ldots \ldots \ldots \ldots \ldots \ldots \ldots \$ 66$ (2), 281, 290

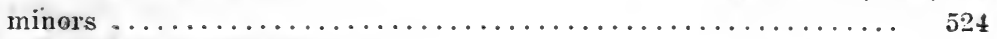

nonresident, see nonresident

[References in italics are to sections of the law; other references are to articles of the regulations.] 
Income - continued

not reduced to possession. ....................... 45

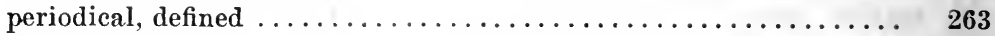

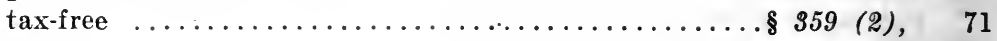

trusts

classification of ........................ 242

computation of $\ldots \ldots \ldots \ldots \ldots \ldots \ldots \ldots \$ 365$ (2), 251,252, 254

withholding at the source................ $\$ 66$ (1), 261-270

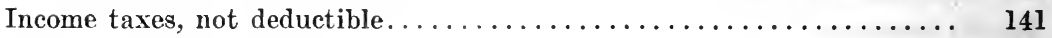

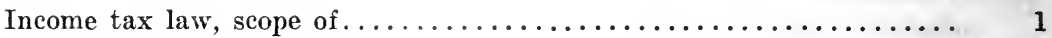

Indebtedness, forgiveness of ....................... 43

Individual returns, see returns

Information as to actual owner, information at the source...... 290

Information at the source $\ldots \ldots \ldots \ldots \ldots \ldots \ldots \ldots \ldots .366$ (2), 281-290

annuities representing return of capital............... 289

bills paid for merchandise, telephone, etc.............. 289

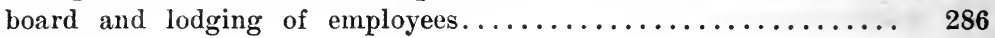

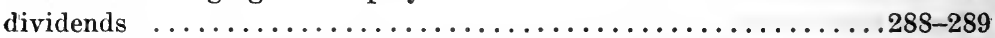

fiscal agents of governments, estates and municipalities, no return

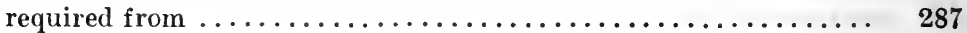

information as to actual owner................... 290

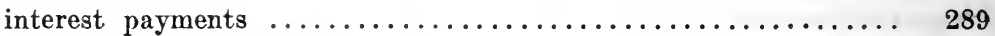

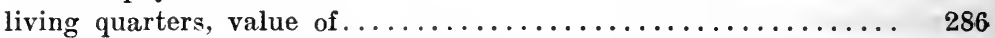

no returns where tax was withheld................. 283

payments

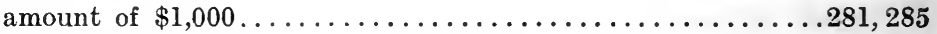

corporations, return of, not required............. 289

fiduciary, return of, not required ............... 289

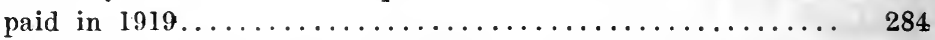

partnership, return of, not required............... 289

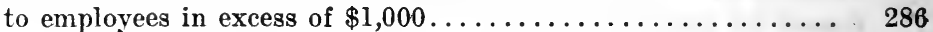

no returns required, which..................... 2839

professional fees, no returns of, required.............. 289

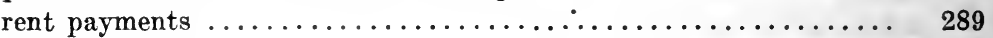

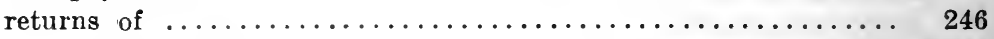

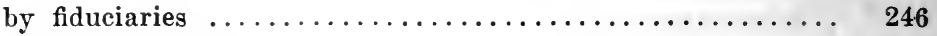

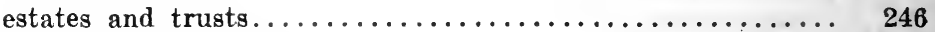

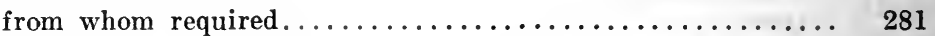

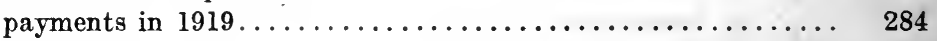

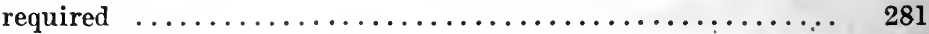

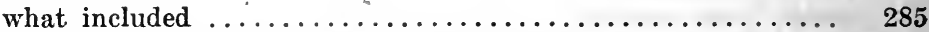

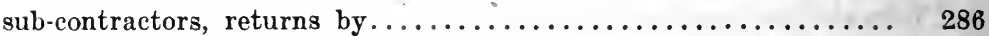

Infringement of patent, recovery for .................. 44

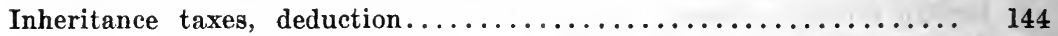

Injuries, compensation paid on account of ..........\& 359 (2-e), 41

Insane person, committee of, as fiduciary............... 240

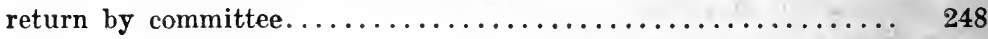

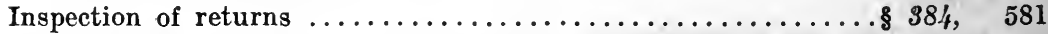


Installment plan

real estate

sales of personal property.......................... 39

Instructions with forms, have effect of, regulations............ 531

Insurance

allotments and allowances under war risk insurance, taxability.

$\S 359(2-e)$,

annuity policies, taxability.

policy value as of January 1, 1919, excluded from gross income. . premiums

business insurance, deduction..................111, 121

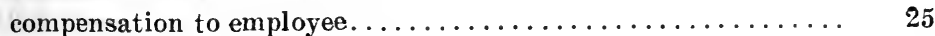

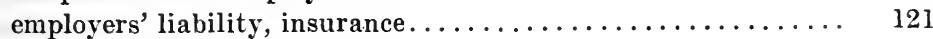

fire insurance ............................ 121

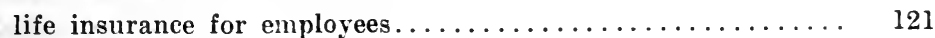

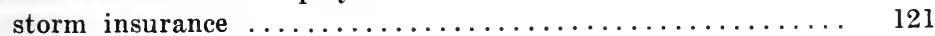

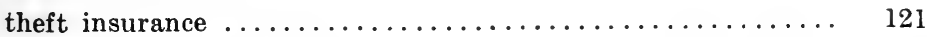

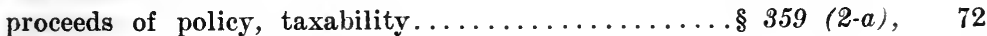

Intangible property, depreciation. . . . . . 173

Interest

accrued prior to January 1, 1919, excluded from gross income... 79

bank deposits, constructive receipt when credited.......... 46

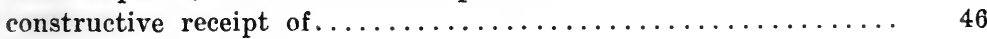

deduction of

nonresidents ................... $\$ 60$ (2), 434

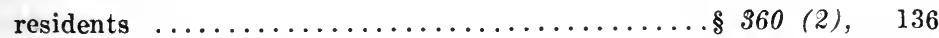

included in gross income................. $\$ 59$ (1), 21, 74

municipal obligations, taxability............ 359 (2-d), 74

national farm loan association, obligations of ..... \& 359 (2-d), $\quad 75$

nonresidents, taxability of ............... 359 (3), 419

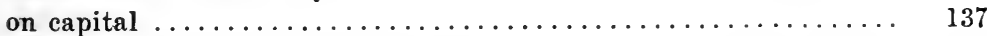

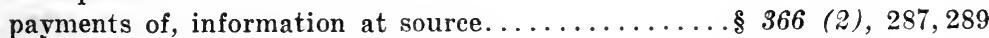

state and municipal obligations, taxability ....... \& 359 (2-d). 74

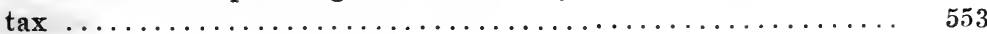

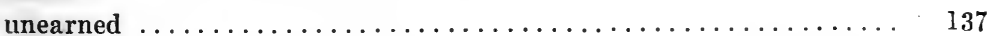

United States bonds, taxability............ 359 (2-d), 74

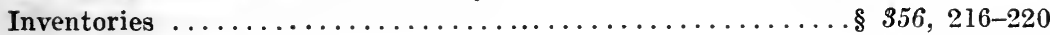

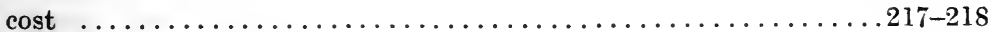

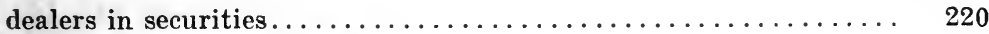

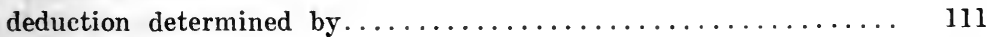

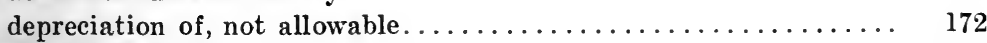

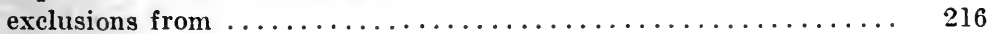

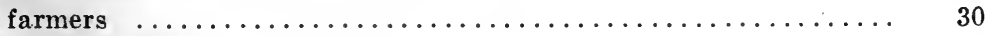

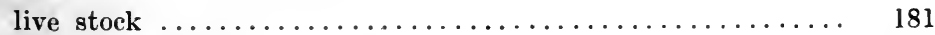

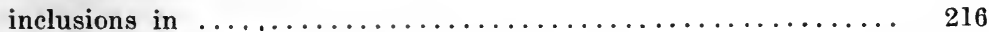

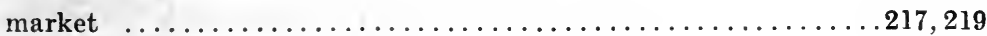

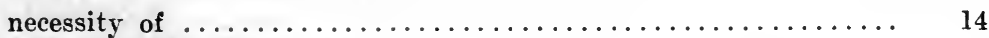

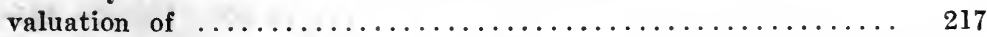

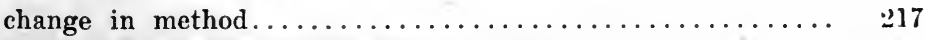

[References in italies are to sections of the law; other references are to articles of the regulations.] 
Investment tax paid, exemption of interest on bonds on which..... \$ $359(2-d), \quad 74$

Isolated installment transactions..................... 39

Isolated transactions without the state, nonresident........... 415

Items not deductible. .............................. 125

Joint exemption of husband and wife............. 362 (1), 207

return of husband and wife...................... 521

Judgment paid

recovered when included in income................... 44

when deductible $\ldots \ldots \ldots \ldots \ldots \ldots \ldots \ldots \ldots \ldots \ldots \ldots \ldots \ldots \ldots . \ldots \ldots$

Laborers, nonresident, withholding at source from....... 366 (1), 266

Land bank, dividends of, taxability ............ 359 (2-d), 75

Landlord and tenant

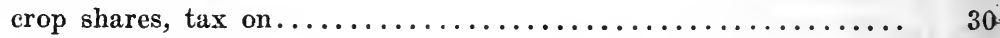

improvements by lessee......................... 120

rent, see rent

Last due date for filing return.................. $371, \quad 541$

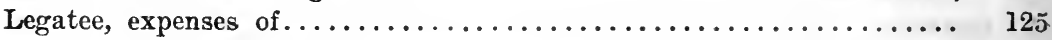

Lessee, improving property...................... 42

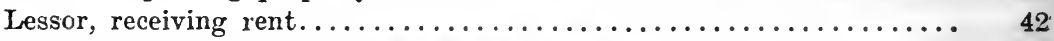

Liability of fiduciary for payment of the tax.............. 255

License

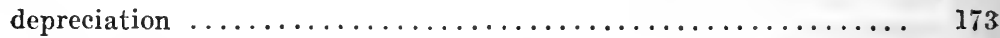

taxes, deductions .................................. 142

Life insurance premiums

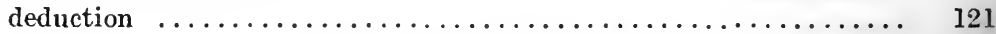

paid by employer as taxable income to employee............ 25

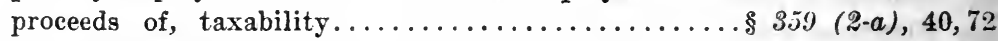

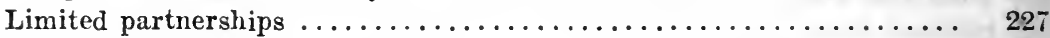

Liquidating dividend, taxability ................. 65-66

Live stock

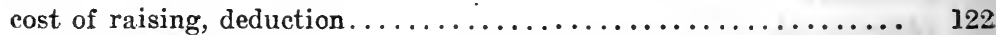

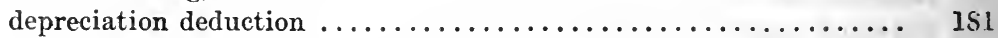

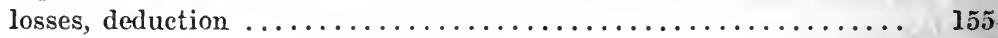

profit from sale of, as taxable income............... 30

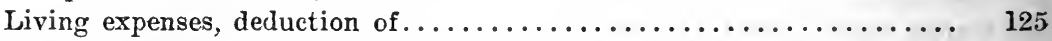

Living quarters, furnished to employees as taxable income........ 25

Living together, husband and wife, defined............... 207

Local benefits, taxes and assessments for, deduetion...... 360 (3), 141, 143

Long term contracts, ascertainment of gross income from......... 29

Losses

basis for determining $\ldots \ldots \ldots \ldots \ldots \ldots \ldots \ldots \ldots \ldots \ldots$ 353, 91-101

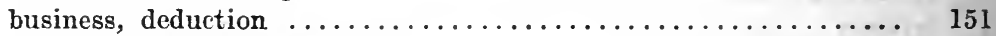

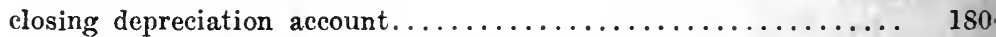

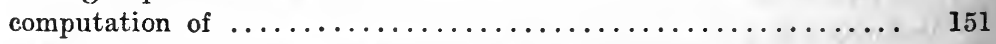

conversion of municipal warrants or securities into eash...... 27

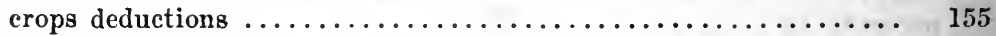

deductions for $\ldots \ldots \ldots \ldots \ldots \ldots \ldots \ldots \ldots \ldots \ldots \ldots \ldots \ldots \ldots \ldots \ldots \ldots, 5,6), 151-155$

depletion, see depletion 


\section{Losses - continued}

\section{depreciation, see depreciation}

destruction of property, deduction

.151-15:5

embezzlement, discovery of, when deductible.......\$ 360 (6), 123

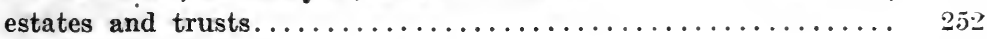

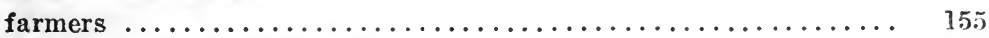

fiduciaries, on sale of property....................... 25

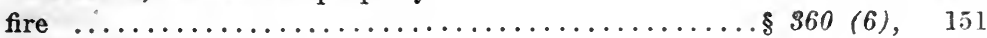

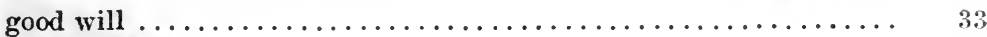

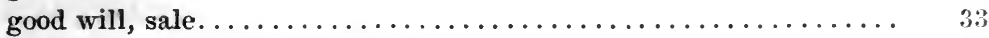

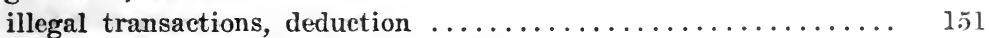

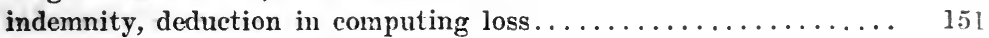

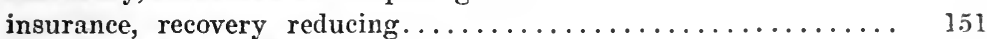

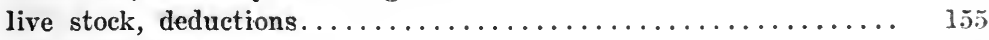

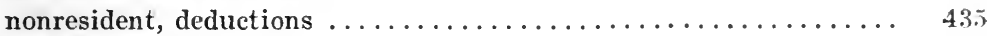

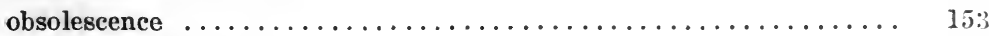

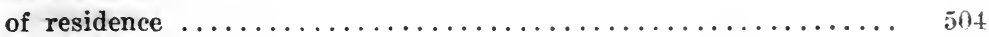

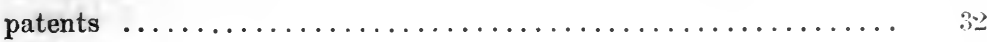

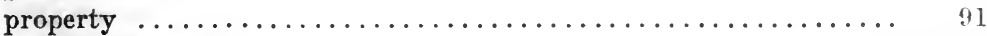

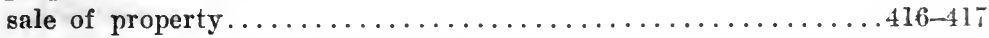

sale of stock received as dividend................. 99

or other disposition of property........... $353,91-101$

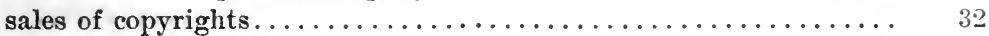

scrapping of machinery, deduction................. 152

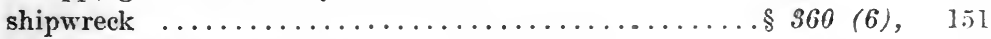

shrinkage in securities and stock, deduction............ 154

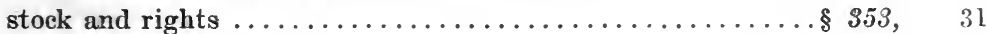

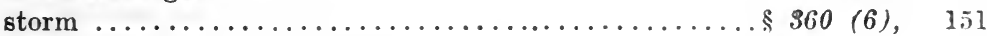

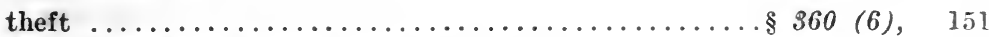

discovery of, when deductible................ 123

transactions entered into for profit, deduction....... 360 (5), 151

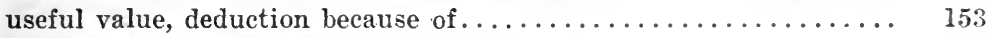

voluntary removal or demolition of buildings............ 152

\section{Machinery}

deduction of losses due to obsolescence.............. 15.3

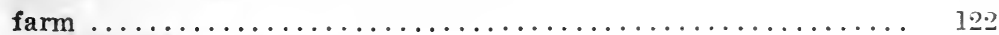

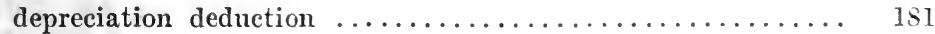

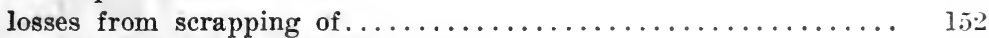

profit from sale, as taxable income................ 30

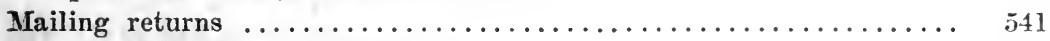

Management expenses, deductible...................... 111

Market value

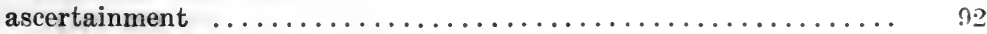

fluctuations, deduction of losses due to.............. 15t

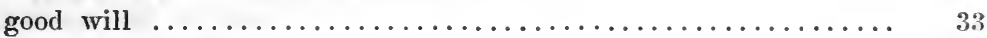

inventories $\ldots \ldots \ldots \ldots \ldots \ldots \ldots \ldots \ldots \ldots \ldots \ldots \ldots \ldots \ldots \ldots \ldots \ldots \ldots \ldots \ldots \ldots \ldots . .217,219$

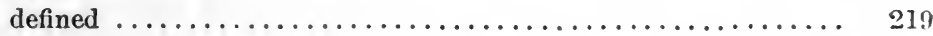

[References in italics are to sections of the law; other references are to articles of the regulations.] 
Market value - continued

modification of method of computing depreciation allowance because

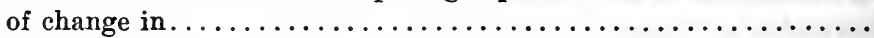
product received in exchange for farm produce, as income....... thing paid as compensation for personal services............

Marriage fees

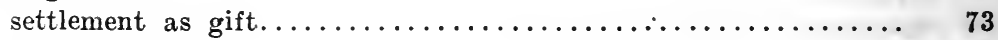

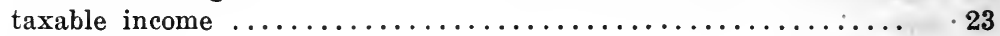

Married persons

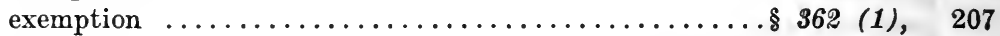

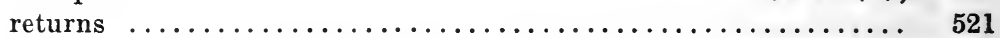

Materials, cost of business deduction.................111-112

Meaning of net income, see net income

Method of computing depreciation allowance, see depreciation

Methods, accounting, see accounting method

Mileage, excess over actual traveling expenses as income...........

Military service, allotments and allowances under war risk insurance

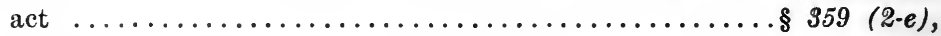

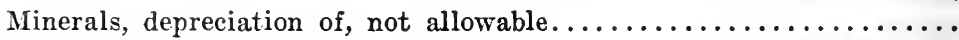

Mines, depletion .................... \$60, (9),

Ministers

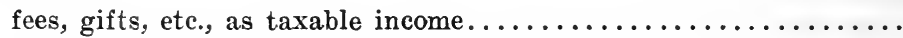

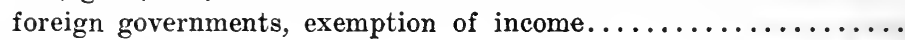

Minors

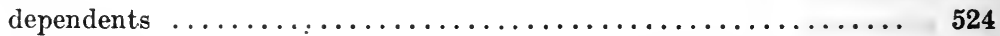

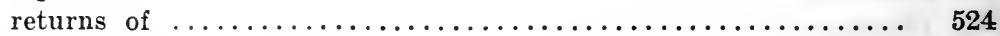

Models, depreciation deduction....................... 178

Modification method of computing depreciation, see depreciation

Money on hand or on deposit, exemption from personal property tax,

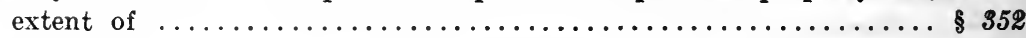

Mortgaged property, purchased by mortgagor............... 163

Mortgages

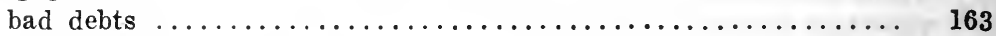

tax paid, income taxable..................... 74

Municipal bonds

contracts, income from, taxable income................. 22

interest on, taxability ................. 859 (2-d), 74

taxes, deduction ..................... 360 (\$), 141

National farm loan association, dividends and interest, taxability..... 75

Natural deposits

depletion $\ldots \ldots \ldots \ldots \ldots \ldots \ldots \ldots \ldots \ldots \ldots \ldots \ldots \ldots \$ 60$ (9), 190

resources, depreciation of, not allowable............... 172

Naval service, allotments and allowances under war risk insurance

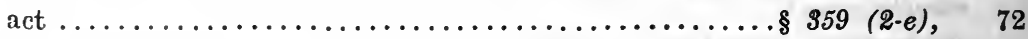

Need of inventories...................... $356, \quad 216$

Net income

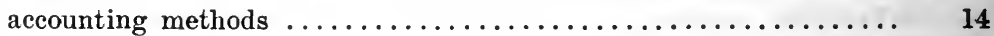

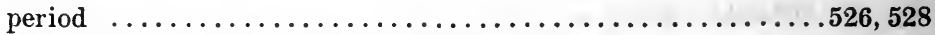

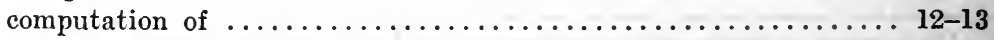

[References in italics are to sections of the law; other references are to articles of the regulations.] 
Net income - continued

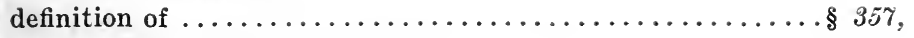

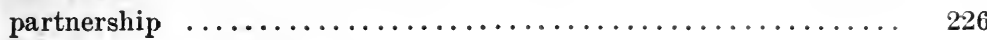

\section{see also deductions}

New York State and municipal bonds, interest on...... 8359 (2-d), 74

New York stock exchange, sales on, by nonresident........... 416

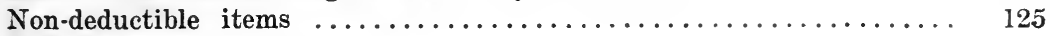

Nonresident

agents acting for.

allowable deductions ............... 360 (11), 431, 435, 481

allowance of credit for taxes................ $363,482-484$

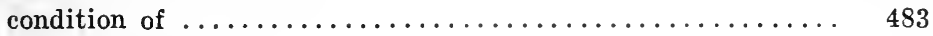

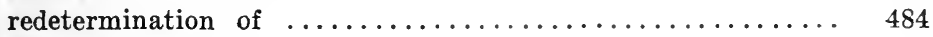

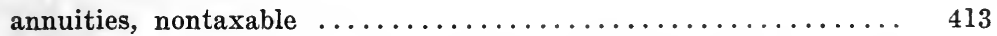

apportionment of business income from business carried on both

within and without the state............. 360 (11),

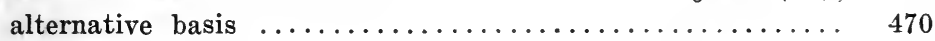

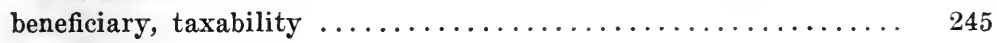

business carried on

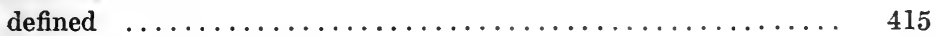

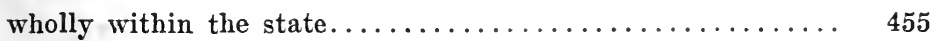

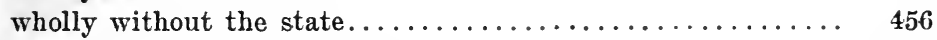

compensation for personal services................. 412

computation of gross income of ............. 359 (3), 411

conditions of allowance of credit for taxes.......... $\$ 363,483$

deductions ................... 360 (11), 431-435, 481

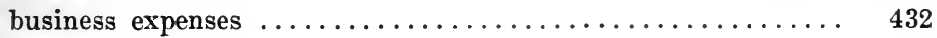

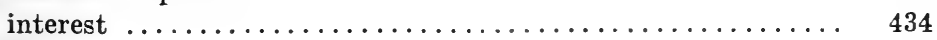

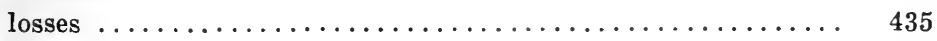

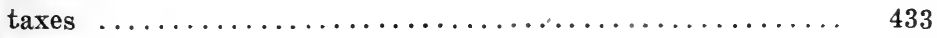

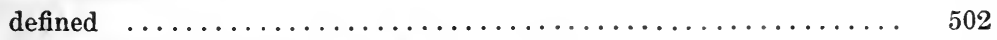

definition of income sources within the state............ 401

disposition of property.................... 417

dividends, when included in gross income......... \& 359 (3), 419

estates and trusts, distinguished as to residence............ 243

gross income of

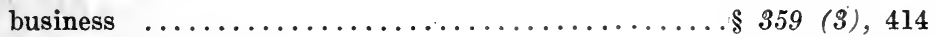

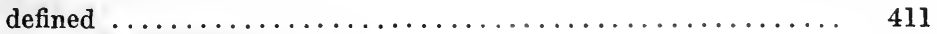

interest and dividends.................... 419

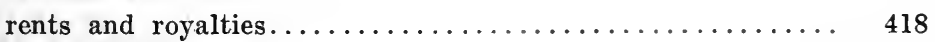

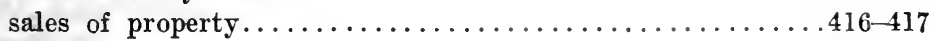

inclusions in gross income of . . . . . . . . . . . . . 401,411

income of

from vessels, taxability.................... 454

sources within the state, defined................ 401

interest and dividends

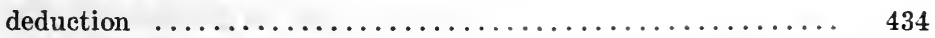

when included in gross income............ $\$ 559$ (3), 419

losses, deductions .................... 8360 (11), 435

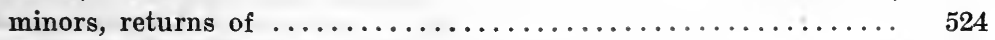

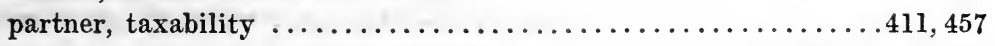

[References in italics are to sections of the law; other references are to articles of the regulations.] 
Nonresident - continued

pensions, received, nontaxable..................41, 413

redetermination of $\operatorname{tax}$ when credit proves incorrect........ 484

rents and royalties as income.................... 418

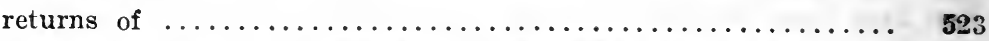

salaries and wages of nonresident employees and officers..... 452 sale of bonds

property, gain or loss, taxability and deductions........ 417

stocks, bonds, and other securities, gain or loss......... 416

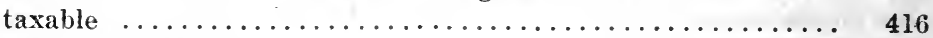

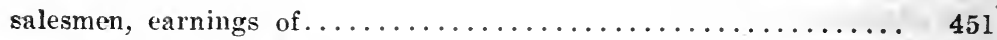

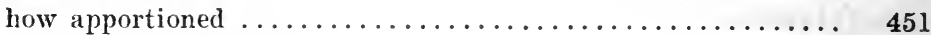

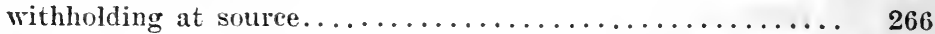

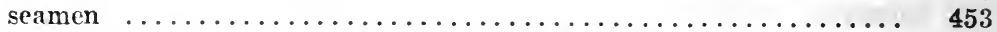

services performed wholly without the state, not taxable income. 412

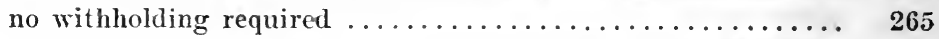

taxability of business income................ 359 (3), 414

taxes deductible .......................... 433

wages of seamen.......................... 453

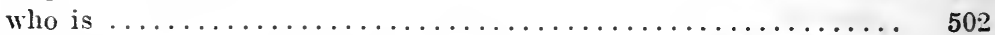

withholding at source on payments to $\ldots \ldots \ldots \ldots \ldots 366$ (1), 261-270 see also withholding at source

No par value stock

received in exchange of other stock................ 9s

subsequent sale of, determination of, gain or loss.......... 99

Notaries public, taxability of fees of .................. 24

Notes

compensation paid in, taxable income................ 26

exemption from personal property tax, extent of.......... \& 352

Notice of change in accounting period............... 5 \%

Obsolescence

copyrights .............................. 177

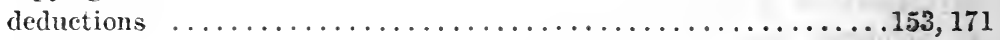

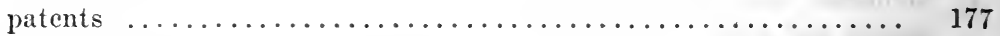

Office expenses of a professional man.................. 114

Oil wells, depletion.................... $\$ 60$ (9), 190

Operation of automobile by professional men, deductible.......... 114

Orchards, deductions of amounts expended in development of...... 122

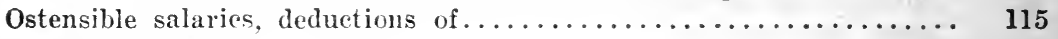

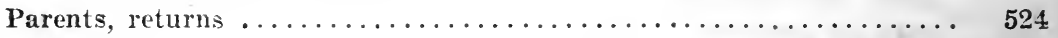

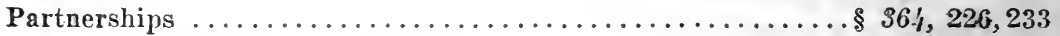

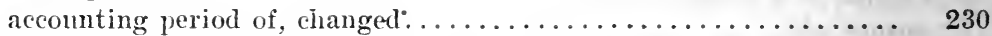

charitable contributions by ..................... 226, 233

computation of net income of .................... 226

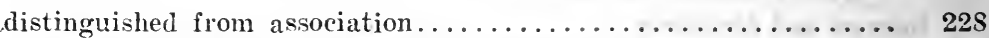

having nonresident member, apportionment of income.......411,457

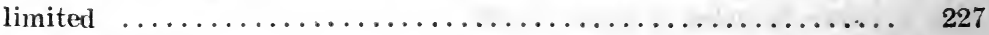

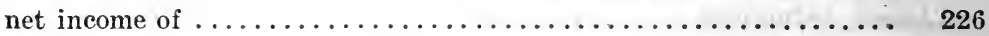


Partnerships - continued

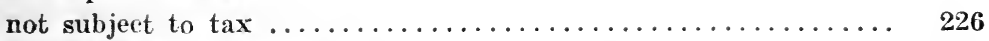

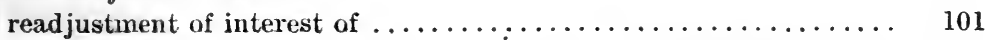

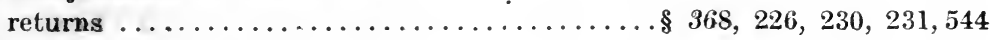

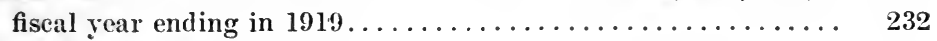

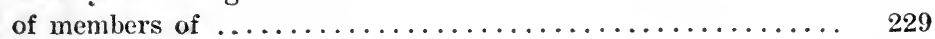

\section{Patent}

place for filing ......................... 544

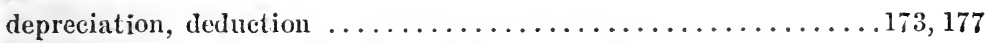

infringement, recovery for, when included in gross income...... 44

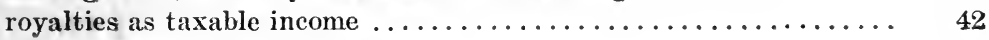

sale of, determination of gain or loss................ 32

Patterns, depreciation, deduction $\ldots \ldots \ldots \ldots \ldots \ldots \ldots \ldots \ldots \ldots \ldots$

Payment as to which no return of information is required......... 289

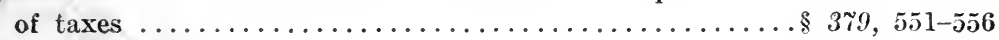

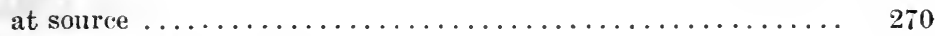

by public utilities, deduction $\ldots \ldots \ldots \ldots \ldots \ldots \ldots \ldots \ldots \ldots .124$

dishonored checks, procedure ................ 5 55

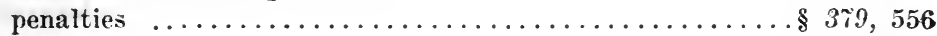

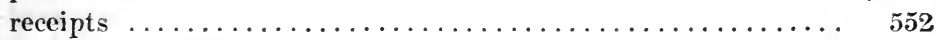

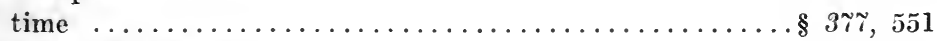

uncertified checks $\ldots \ldots \ldots \ldots \ldots \ldots \ldots \ldots \ldots \ldots \ldots \ldots \ldots \ldots \ldots \ldots \ldots \ldots \ldots$

Payments

interest on coupon bonds, information at source........... $\mathbf{2 8 9}$

received in warrants or securities .................. 27

registered bonds, information at source............... 287

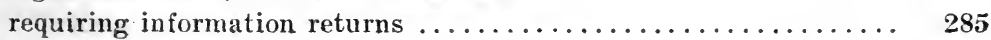

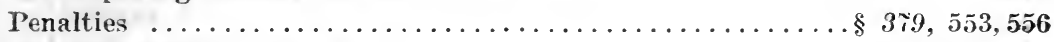

disclosure of returns $\ldots \ldots \ldots \ldots \ldots \ldots \ldots \ldots \ldots \ldots \ldots \ldots \ldots \ldots \ldots \ldots$

Pension fund, contributions to, taxable income............. 25

Pensions

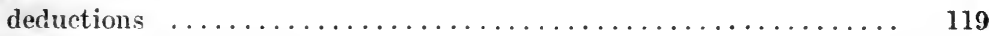

nonresident, taxability ........................ 413

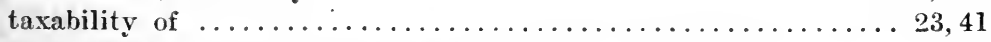

Per diem allowance in lieu of subsistence, excess as taxable income... $11 \mathrm{~S}$

Period, accounting, see accounting period

covered by returns ........................526,529

of administration, of estate or trust, defined............ 253

Periodical income, defined $\ldots \ldots \ldots \ldots \ldots \ldots \ldots \ldots \ldots \ldots \ldots \ldots . \ldots \ldots$

Personal

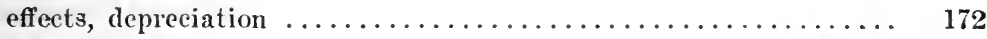

exemptions .......................... $362,205-210$

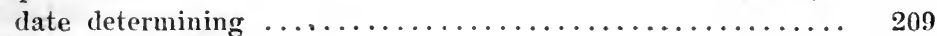

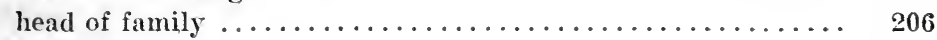

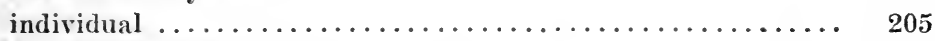

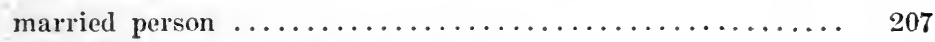

officer or employee of the United States............ 210

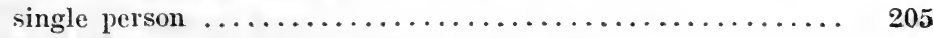

[References in italics are to sections of the law; other references are to articles of the regulations.] 
Personal - continued

injuries

deductibility of damages $\ldots \ldots \ldots \ldots \ldots \ldots \ldots \ldots \ldots \ldots . \ldots \ldots$

insurance or damages received, taxability.....\$ 359 (2-e), 72

property

exemption from personal property tax, extent of........ \$ 352 service

sales on installment plan.

compensation, see compensation

place of payment, withholding at source........... 265

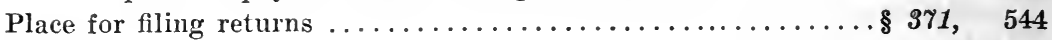

Pleasure

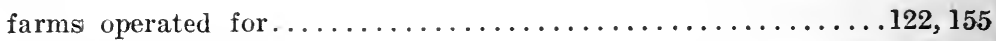

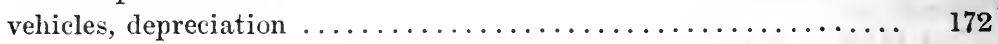

Policies, proceeds of, taxability............. 359 (2-a), 72

Possession, income reduced to ................... 45-46

Power of revision by Comptroller................ $373, \quad 571$

Premium coupons, basis of deductions for redemption of ......... 80

Premiums, insurance $\ldots \ldots \ldots \ldots \ldots \ldots \ldots \ldots \ldots \ldots \ldots \ldots \ldots \ldots$

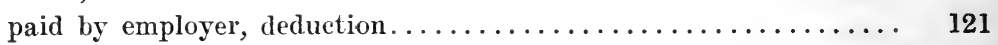

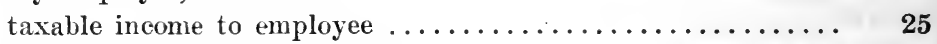

sums in excess of, taxable income........... \& 359 (2-b), 40

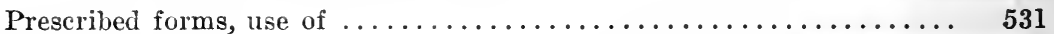

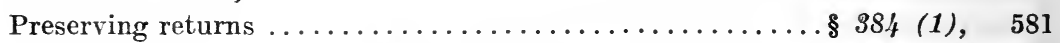

Procedure with respect to dishonored checks.............. 555

Proceeds of insurance, taxability $\ldots \ldots \ldots \ldots \ldots \ldots \ldots \ldots \ldots \ldots \ldots, \quad 72$

Professional

fees, return of, information at source, not required........ 289

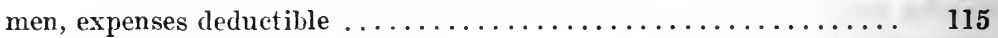

fees of, withholding at source.................. 263

Profit and loss

sale of property, nonresident . .................. 417

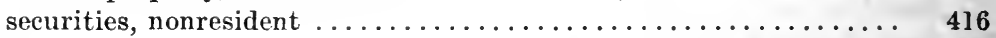

Profits

deferred payment sales of real estate................ 38

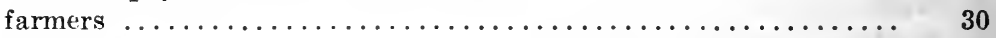

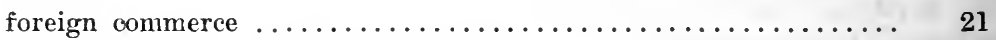

installment plan, sales of real estate.............. 35-39

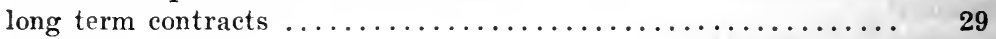

sales of

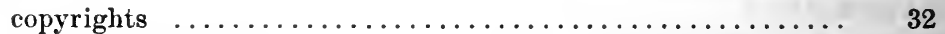

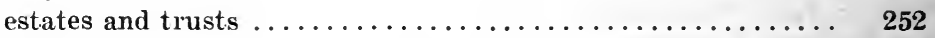

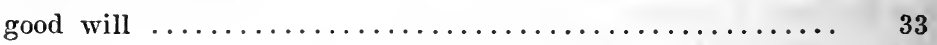

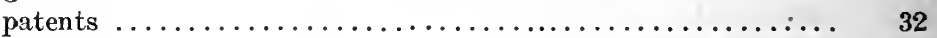

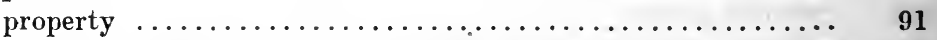

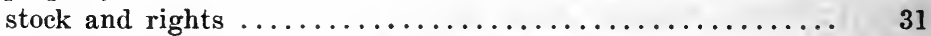

Promissory notes, compensation paid in, as taxable income........ 26

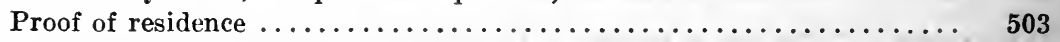

Propaganda associations, contributions to, not deductible....... 202

[References in italics are to sections of the law; other references are to articles of the regulations.] 
Property acquired prior to January 1, 1919

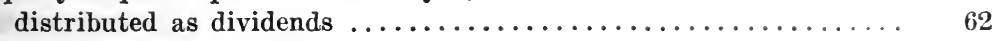

exchanged

determination of gain or loss from $\ldots \ldots \ldots \ldots \ldots \ldots \ldots . \ldots 94$

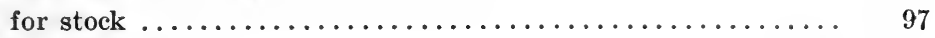

sale or disposal of $\ldots \ldots \ldots \ldots \ldots \ldots \ldots \ldots \ldots \ldots \ldots \ldots \ldots \ldots \ldots \ldots \ldots \ldots$

Public park

gift of real estate to city for, not allowable deduction........ 201

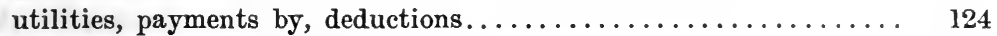

Purchase money mortgage, bad debt................. 163

Railroad employees, taxability of compensation during period of federal control

Rate used in deducting and withholding $\ldots \ldots \ldots \ldots \ldots \ldots \ldots \ldots \ldots \ldots \ldots \ldots \ldots \ldots \ldots \ldots \ldots \ldots \ldots \ldots \ldots \ldots \ldots \ldots \ldots \ldots \ldots$
Rates of $\operatorname{tax} \ldots \ldots \ldots \ldots \ldots \ldots \ldots \ldots \ldots$

Readjustment of partnership interests .................. 101

Real estate

installment transactions $\ldots \ldots \ldots \ldots \ldots \ldots \ldots \ldots \ldots \ldots \ldots \ldots \ldots$

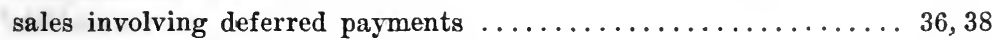

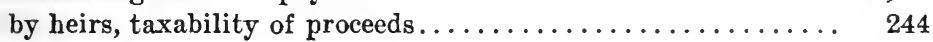

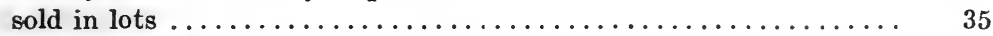

Reasonable cause, delay in filing returns............. $371, \quad 543$

Receipt basis of computation of net income............... 13

Receipts for tax payments ...................... $\quad 552$

Receivers

commissions, taxability, federal courts.............. 78

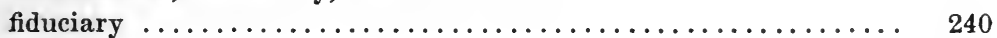

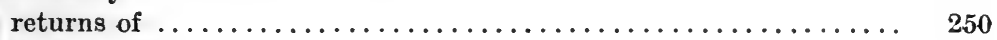

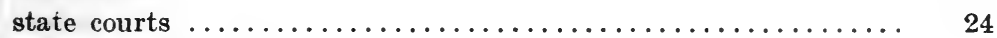

Records

accounting, necessity of maintaining........................ 14

\section{Recovery}

depreciable property $\ldots \ldots \ldots \ldots \ldots \ldots \ldots \ldots \ldots \ldots \ldots \ldots \ldots$

for infringement of patent.................... 44

of judgment, when included in gross income............. 44

of taxes by action ........................ $\$ 881$

Redemption of trading stamps ..................... 80

Redetermination of $\operatorname{tax}$ when credit proves incorrect........... 484

Referee, fees of, federal court, taxability............... 78

Refunds

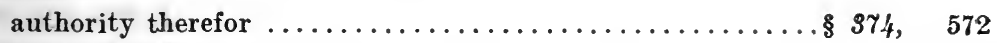

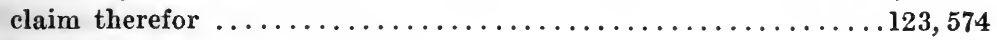

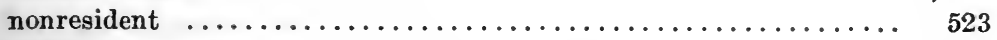

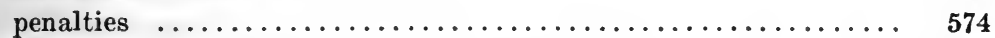

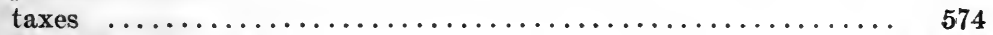

Regulations, power of comptroller to make.............. $\$ \$ 8 s$

Religious corporations

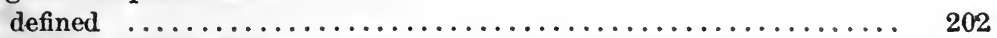

workers, gifts and contributions to, taxable income........ 23

[References in italics are to sections of the law; other references are to articles of the regulations.] 
Removal of buildings, deduetion of loss.............. 152

Renewal of residence certificate..................... 268

lient

erop shares, taxable ineome..................... 30

deductions ................................... 120

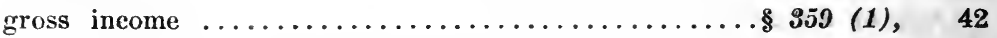

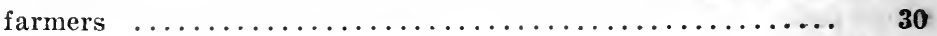

landlord, where paid by tenant. ................ 120

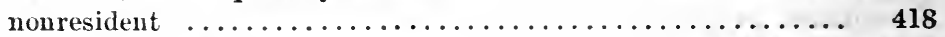

information at source................... 366 (2), 289

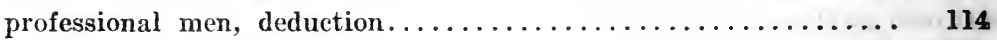

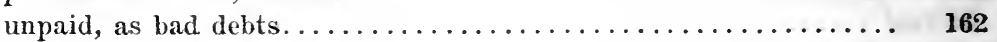

Rents and royalties........................... 42

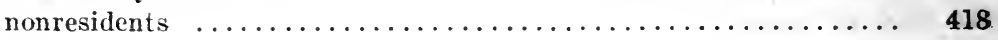

Repairs

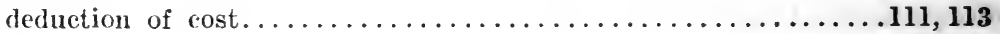

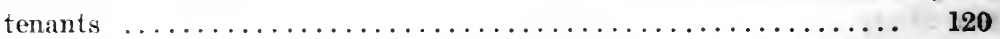

Replacements, addition of cost, in determining capital sum to be

replaced by depreciation allowance..................113, 174

Residence

certificate of ..................... 366 (1), 267

defined ................................ 503

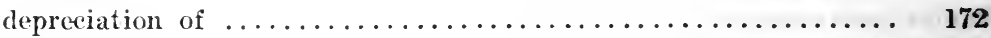

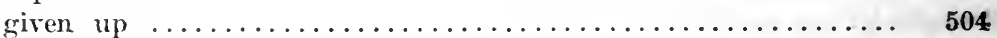

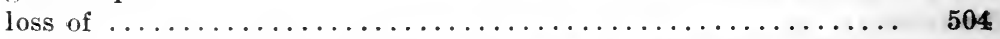

New York State, acquired after deducting and withholding, effeet of 269

sale of, deduction of loss in ...................... 151

Resident

alien

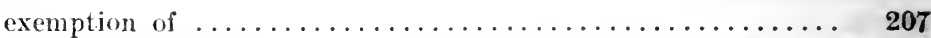

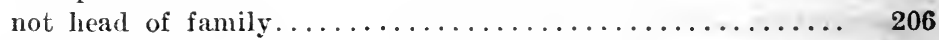

beneficiary, taxability of ........................... 245

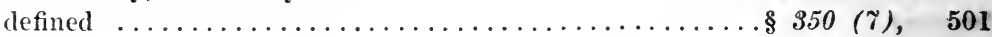

estate and trust, defined........................ 243

pension receipts of, taxability .................... 41

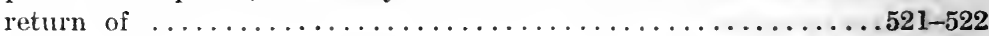

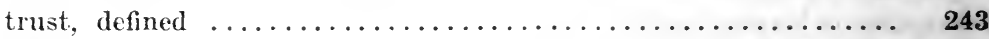

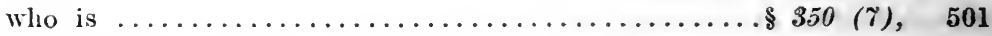

Fetired pay of employees, taxability................ 23, 41

Returus

accounting period changed................ \$ \$ 70 , 525-529

corporate dividends ......................... 525

corrected, when payable...................... 551

disclosure of, penalties therefor.................. $581-582$

extension of time for filing.................... 543

failure to file, penalties..................

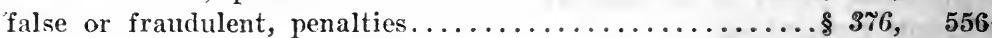

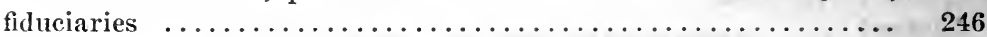

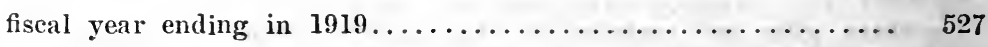

[References in italies are to sections of the law; other references are to articles of the regulations.] 
Returns - continued

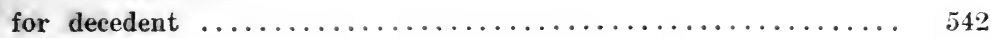

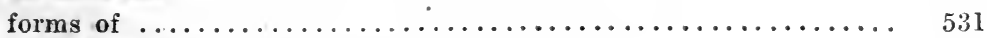

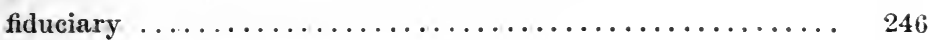

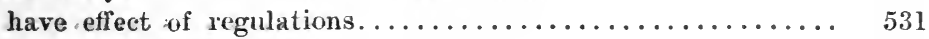

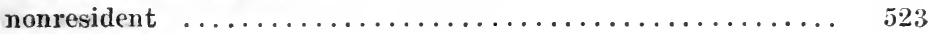

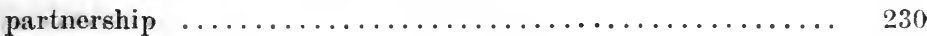

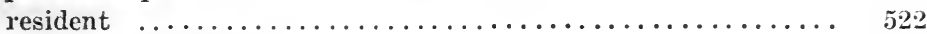

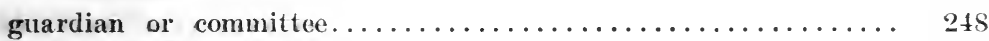

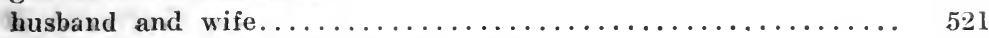

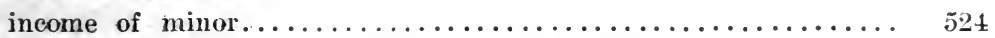

information at source, see information at source

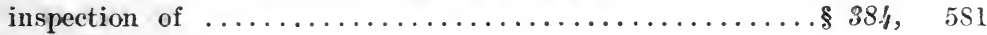

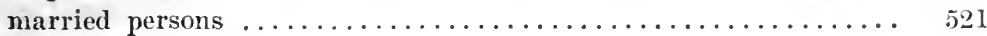

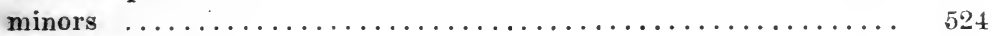

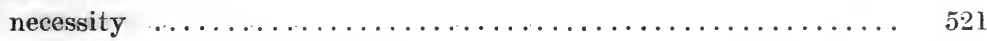

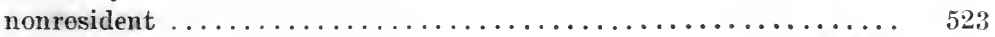

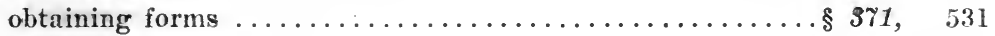

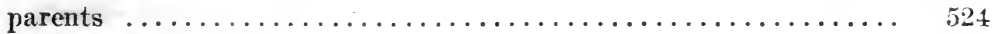

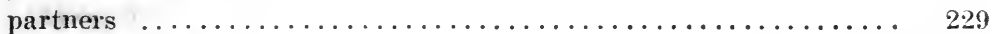

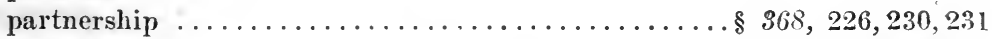

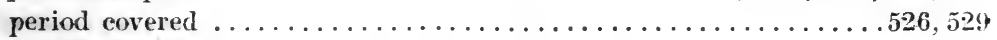

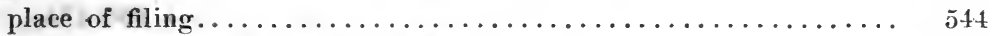

prescribed forms of, must be used................. 531

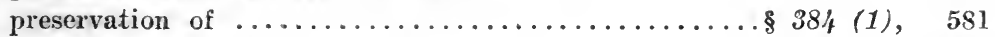

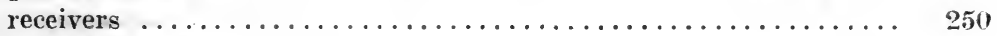

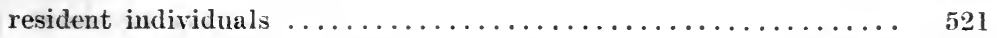

secrecy $\ldots \ldots \ldots \ldots \ldots \ldots \ldots \ldots \ldots \ldots \ldots \ldots \ldots \ldots \ldots \ldots$ 384, 582

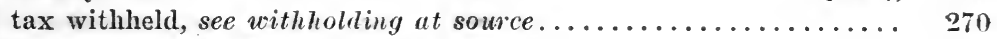

termination of estate or trust.................. 542

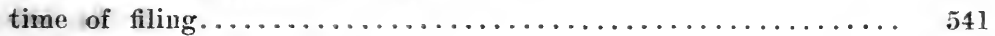

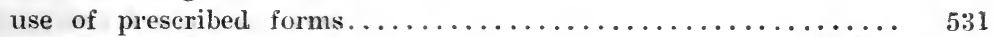

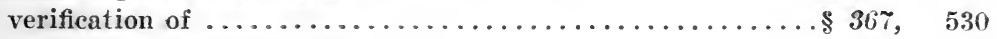

voluntarily made after lue date............ $3 \% 6$ (2), 556

where more than one trust..................... 249

Review of determination of comptroller, by certiorari.......... $\$ 37.5$

Revision of returns by comptroller............... $3 \%$, 571

Revocable trust, income of ......................... 2.5

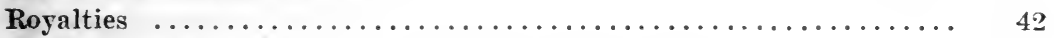

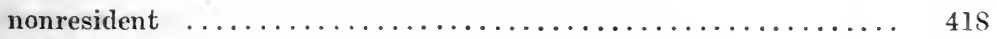

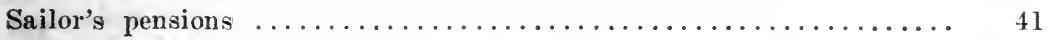

Salaries and wages of nonresident employees and officers

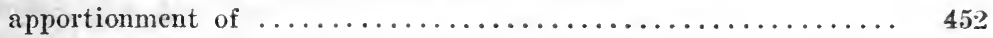

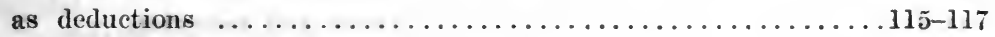

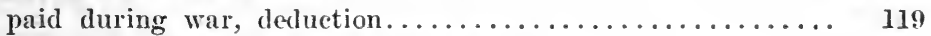

paid to widow, of employee, deduction............ 119

unpaid, as bad debts.......................... 162

[References in italies are to sections of the law; other references are to articles of the regulations.] 
Sales

basis for determining gain or loss............. s5s, 91-101

bonds and other securities, nonresident................ 416

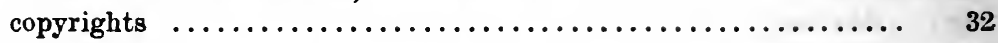

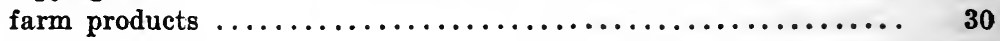

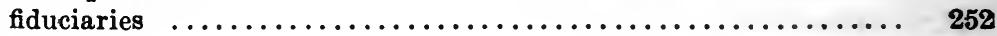

$\operatorname{good}$ will $\ldots \ldots \ldots \ldots \ldots \ldots \ldots \ldots \ldots \ldots \ldots \ldots \ldots \ldots \ldots \ldots \ldots \ldots \ldots \ldots, 33$

installment plan

personal property $\ldots \ldots \ldots \ldots \ldots \ldots \ldots \ldots \ldots \ldots \ldots \ldots \ldots \ldots, 34$

real estate $\ldots \ldots \ldots \ldots \ldots \ldots \ldots \ldots \ldots \ldots \ldots \ldots \ldots \ldots \ldots \ldots \ldots$ 35-39

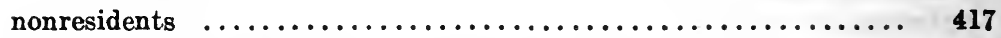

patents and copyrights...................................... 32

property acquired by gift or inheritance.............. 93

real estate

involving deferred payments.................. 36-38

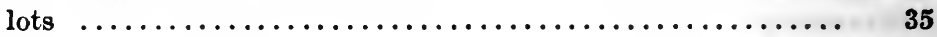

residence, loss by deduction. ..................... 151

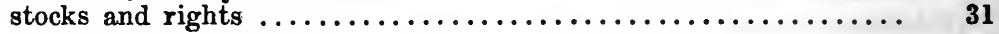

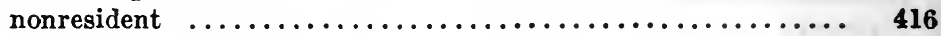

received as dividend $\ldots \ldots \ldots \ldots \ldots \ldots \ldots \ldots \ldots \ldots \ldots, 64$

Salesmen

deduction of, traveling expenses.................. 118

nonresident, withholding at source from......... $\$ 66$ (2), 266

Salvage value, in computing depreciation................ 180

Sample room, traveling men....................... 118

Savings bank deposits, constructive receipt of interest......... 46

Scientific corporations, defined $\ldots \ldots \ldots \ldots \ldots \ldots \ldots \ldots \ldots \ldots \ldots \ldots . \ldots \ldots 2$

Scope of the law.................................... 1

Scrapping machinery, deduction of loss................. 152

Scrip, dividends paid in.......................... 62

Secrecy of returns........................ $384,581-582$

Secret formulae or processes, depreciation deduction........... 173

Secured debt tax, paid, income taxable................. 74

Securities

dealers in, definition.......................... 220

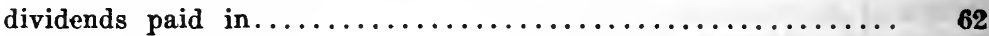

inventory of dealers.......................... 220

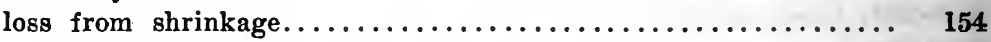

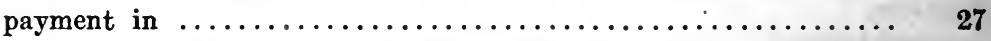

value on January' 1, 1919, h'ow determined.............. 92

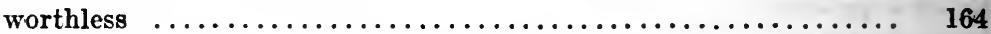

Selling expense, deduction $\ldots \ldots \ldots \ldots \ldots \ldots \ldots \ldots \ldots \ldots \ldots \ldots \ldots, 111$

Separate returns by married persons................... 521

Separation agreement, payments under, as income and deduction.....73, 125

Shareholders

building and loan association, constructive receipt of distributive

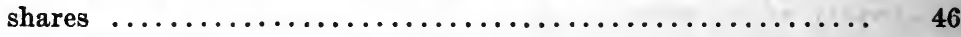

forgiveness of indebtedness........................ 43

[References in italics are to sections of the law; other references are to articles of the regulations.] 
Shares, partners .............................. 229

Shipwreck, losses from, deduction............ \& 360 (6), 151

Shrinkage

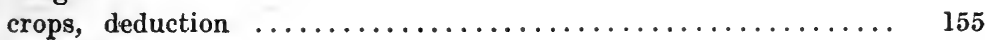

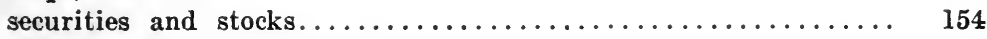

Sickness

compensation paid during...................... 41

insurance and damages received, taxability....... 359 (2-e), 72

pensions, on account of ................. 8359 (2-e), 41

Sidewalk assessments, deduction of ............ \& 360 (3), 143

Smith-Lever Act, taxability of salaries, paid under........... 24

Soldiers' pensions, taxability.................. 359 (2-e), 41

Special assessments, deductions..............\$ 360 (3), 143

State Comptroller, see comptroller

State

contracts, income from, taxable income.............. 22

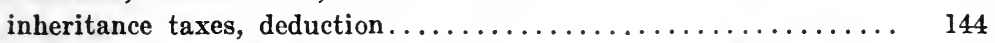

interest upon obligations of, taxability........\& 359 (2-d), 74

afficers of, compensation, taxability................ 24

taxes, deductions ................... $\$ 60$ (\$), 141

Statutory allowance paid to widow from estate or trust......... 244

Stock

amount received from sale of rights to subscribe for, taxability.. 31

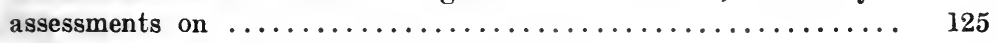

bonus, constructive receipt by employee.............. 45

compensation paid employee in, as taxable income......... 25

dividends, gross income.............. \& 359 (1), 31, 46, 63, 64

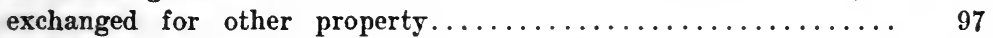

exchanged for stock............................. 100

subsequent sale of, determination of gain or loss........ 99

exemption from personal property tax, extent of ......... § 352

profits from sale of ............................. 31

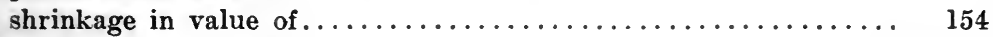

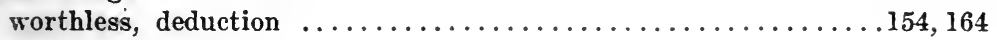

Storm

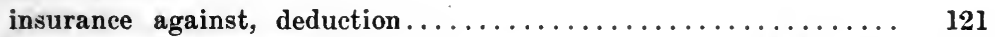

losses by, deduction.................... 360 (6), 151

Street assessment, not deductible.............. 360 (3), 143

Subcontractors, information at source as to payments to employees... 286

Subscription for stock, amount received from sale of right to, as taxable

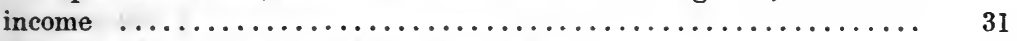

Subtraction for redemption of trading stamps.............. 80

Sunday, due date for filing return................... 541

Supplies

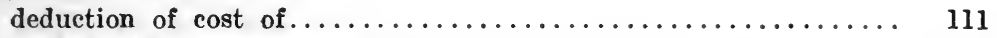

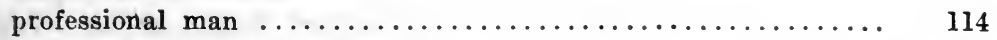

Surrender value of insurance policy................. 79

Tariff duties, deductions.................. 360 (\$), 142

[References in italics are to sections of the law; other references are to articles of the regulations.] 
Taxable year

computation of net income....................... 12

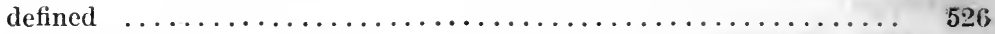

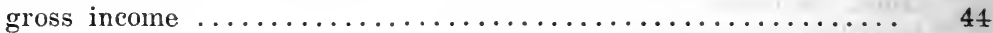

Taxes

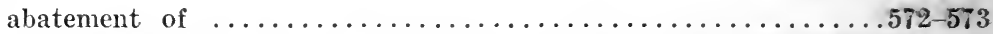

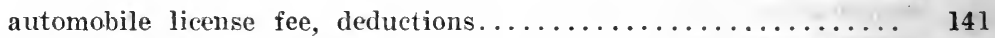

customs duties, deductions................ 360 (马), 142

deductions for ................... 360 (3), 141-144

ronresidents .......................... 433

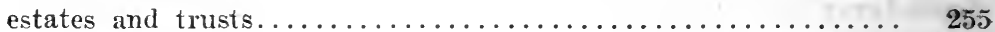

deductions ............................ 144

excise, deductions $\ldots \ldots \ldots \ldots \ldots \ldots \ldots \ldots \ldots \ldots \ldots \ldots \ldots \ldots$ (3), 142

Federal, deductions $\ldots \ldots \ldots \ldots \ldots \ldots \ldots \ldots \ldots \ldots 360$ (3), 141, 142

import duties, deductions.................\$ 360 (3), 142

inheritance, deductions ...................... 144

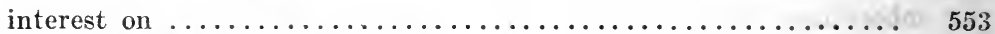

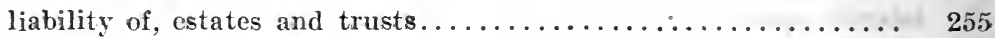

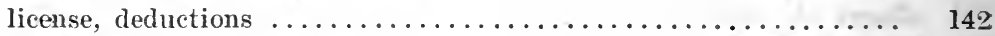

local benefits, deductions................ 360 (3), 141, 143

nonresidents ............................. 401

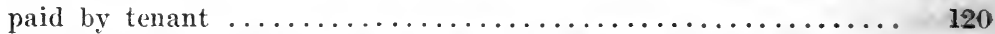

partners in partnership with fiscal year ending in $1919 \ldots \ldots \ldots .232$

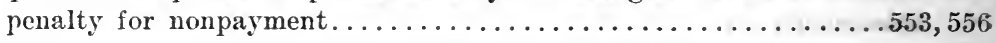

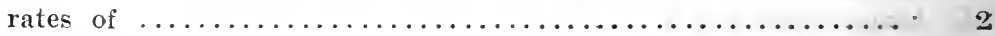

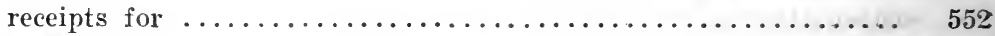

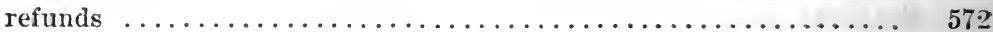

repairs, assessments, deductions........... 360 (3), 143, 574

sidewalk assessments ................. 360 (3), 143

special assessments, deductions............. 360 (3), 143

stamp, deductions ........................... 142

street assessments, deductions.............. \$ 360 (3), 143

tariff duties, deductions................ 360 (3), 142

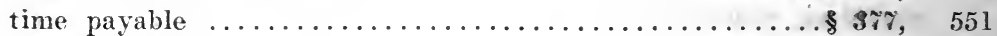

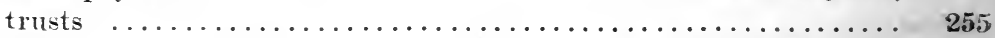

withholding at source................. 366 (1), 261

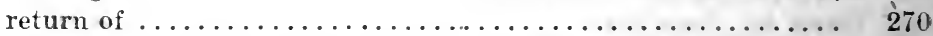

Tax-free covenant clause in bonds, tax as gross income......... 21

Tax-free income $\ldots \ldots \ldots \ldots \ldots \ldots \ldots \ldots \ldots \ldots \ldots \ldots \ldots \ldots \ldots \ldots$

Taxpayers

definition $\ldots \ldots \ldots \ldots \ldots \ldots \ldots \ldots \ldots \ldots \ldots \ldots \ldots \ldots \ldots \ldots \ldots \ldots \ldots \ldots$ (2),

returns

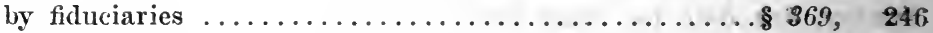

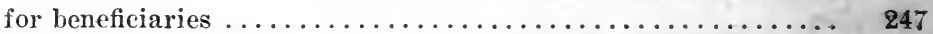

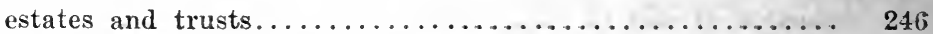

Telégraph employees, taxability of compensation during period of Federal control .................................. $7 \mathrm{f}$

Telephone employees, taxability of compensation during period of

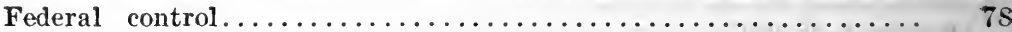

[References in italics are to sections of the law; other references are to articles of the regulations.] 


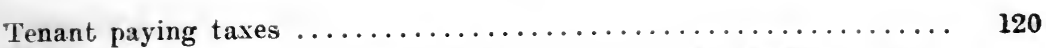

Tentative returns may be required as condition of extension of time. $\quad 543$

Termination of estate or trust, return to be filed on ........... 542

Theatrical costumes, depreciation, deductions............ 172

Theft $\cdots$

insurance premiums against loss by................. 121

losses by, deductions.................... 360 (6), 151

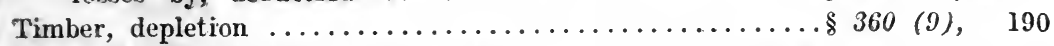

rime as of which item of gross income or deduction is to be accounted

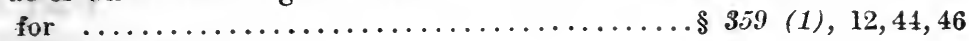

for filing returns............................. 541

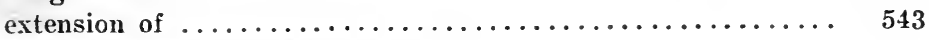

on death or termination of trust............... 542

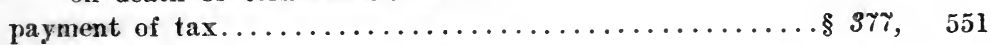

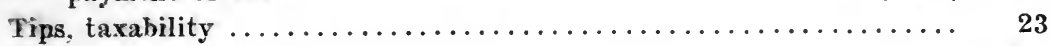

Title, deduction of cost of defending or perfecting ........... 125

Tools, ordinary, farmers'...................... ${ }^{2} 122$

Trade brands

depreciation, deductions $\ldots \ldots \ldots \ldots \ldots \ldots \ldots \ldots \ldots \ldots \ldots \ldots$

losses

deductions $\ldots \ldots \ldots \ldots \ldots \ldots \ldots \ldots \ldots \ldots \ldots \ldots \ldots \ldots \ldots \ldots$ (4),

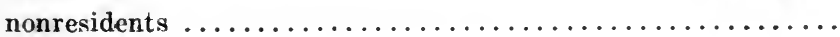

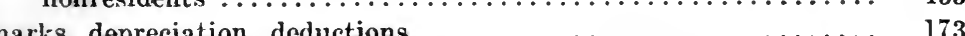

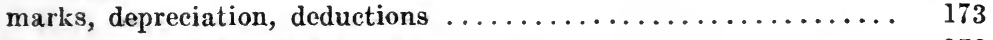

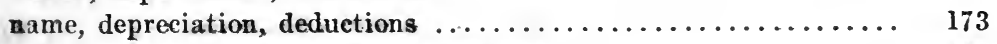

Trading stamps, subtraction for redemption............... 80

Transfer $\operatorname{tax}$ deductions........................... 144

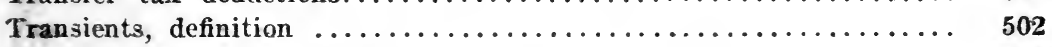

Traveling expenses, deduction....................... 118

Treatment of excessive compensation................. 116

Trusts, see estates and trusts

Uncertified checks, parment of tax................. 554

Uncompleted contracts, ascertainment of gross income......... 29

Understatement of income in return.................. 571

\section{United States}

employees and officers, taxability of salaries......\& $\$ 59$ (2-f), 78 exemption of employees.................. 362 (3), 210

interest on obligations of, taxability.......... 359 (2-d), 74

officer and employee of, personal exemption........ $\$ 62$ (\$), 210

pensions from, taxability..................... 41

taxes, deductions $\ldots \ldots \ldots \ldots \ldots \ldots \ldots \ldots \ldots \ldots \$ 360$ (3), 141

Universities, employees of, taxability of salaries paid from Smith-

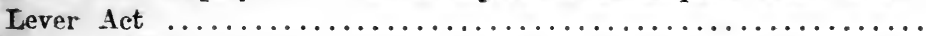

Unpaid rents

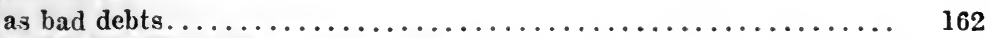

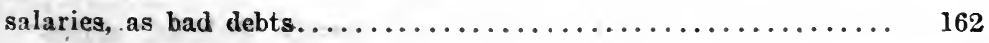

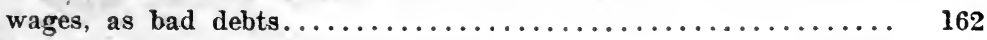

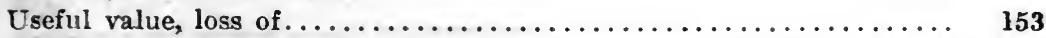

Use of prescribed forms....................

[References in italics are to sections of the law; other references are to articles of the regulations.] 
Valuation

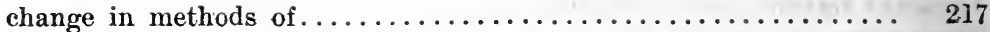

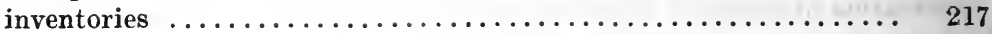

Value

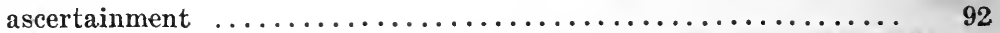

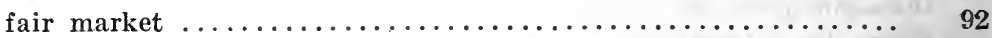

product received in exchange for farm produce, return as income. $\quad 30$

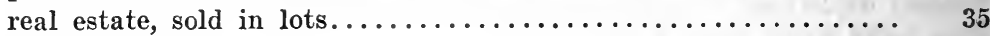

Verification of returns..................... $36 \%$, 530

Vocational rehabilitation fund, deduction of contribution to....... 201

Voluntary absence

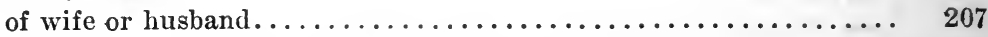

removal of buildings, deduetion of loss............... 152

returns after due date....................... 556

Wages

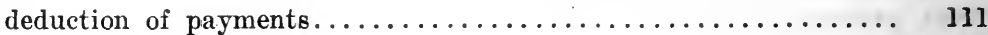

nonresident seamen ........................... 453

paid to widow or employee, deduction................ 119

unpaid, as bad debts.......................... 162

War chest gifts

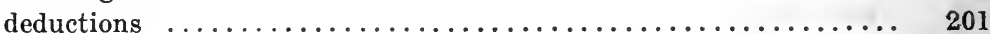

finance bonds, taxability ..................... 74

risk insurance, taxability of allotments and allowances......4 41,72

Warrant for collection of taxes, has effect of judgment.......... \& $\$ 80$

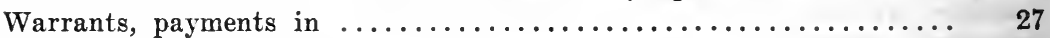

Wear and tear of property, deductions.................. 171

When charge is deductible......................... 123

Who is a resident................................... 501

Withholding at the source................ $\$ 66$ (1), 261-270

agent, defined $\ldots \ldots \ldots \ldots \ldots \ldots \ldots \ldots \ldots \ldots \ldots$ \&50 (10), 281

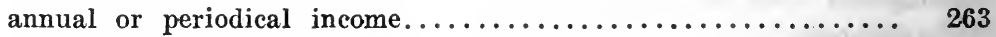

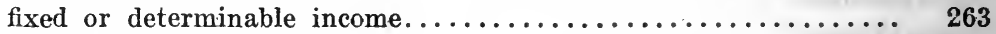

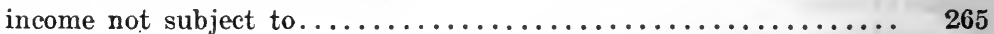

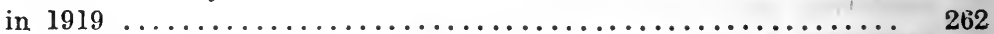

no return of information respecting payments on which there

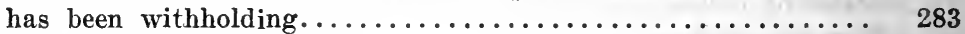

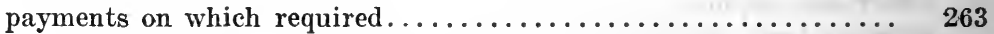

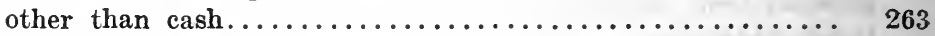

period of time covered........................... 264

refund of excessive amount withheld................ 523

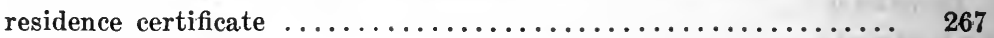

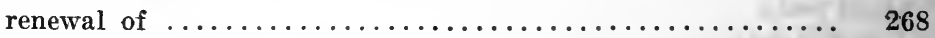

return of tax withheld.............................. 270

services performed partly within and partly without, appor-

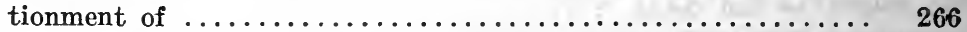

[References in italics are to sections of the law; other references are to articles of the regulations.] 
Withholding at the source-continued

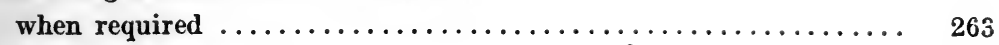

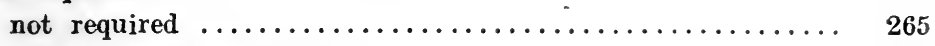

where residence is established...................... 269

withholding agent, defined......................... 281

year for purpose of $\ldots \ldots \ldots \ldots \ldots \ldots \ldots \ldots \ldots \ldots \ldots \ldots \ldots, 264$

Workmen's compensation, taxäbility of amount received..\& 359 (2-d), 41

Worthless mortgage debt

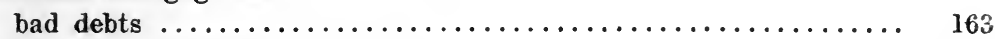

securities, deduction of losses.......................154, 164

Year, for purpose of deducting and withholding.............. 264 

THIS BOOK IS DUE ON THE LAST DATE STAMPED BELOW

AN INITIAL FINE OF 25 CENTS WILL BE ASSESSED FOR FAILURE TO RETURN THIS BOOK ON THE DATE DUE. THE PENALTY WILL INCREASE TO 50 CENTS ON THE FOURTH DAY AND TO $\$ 1.00$ ON THE SEVENTH DAY OVERDUE.

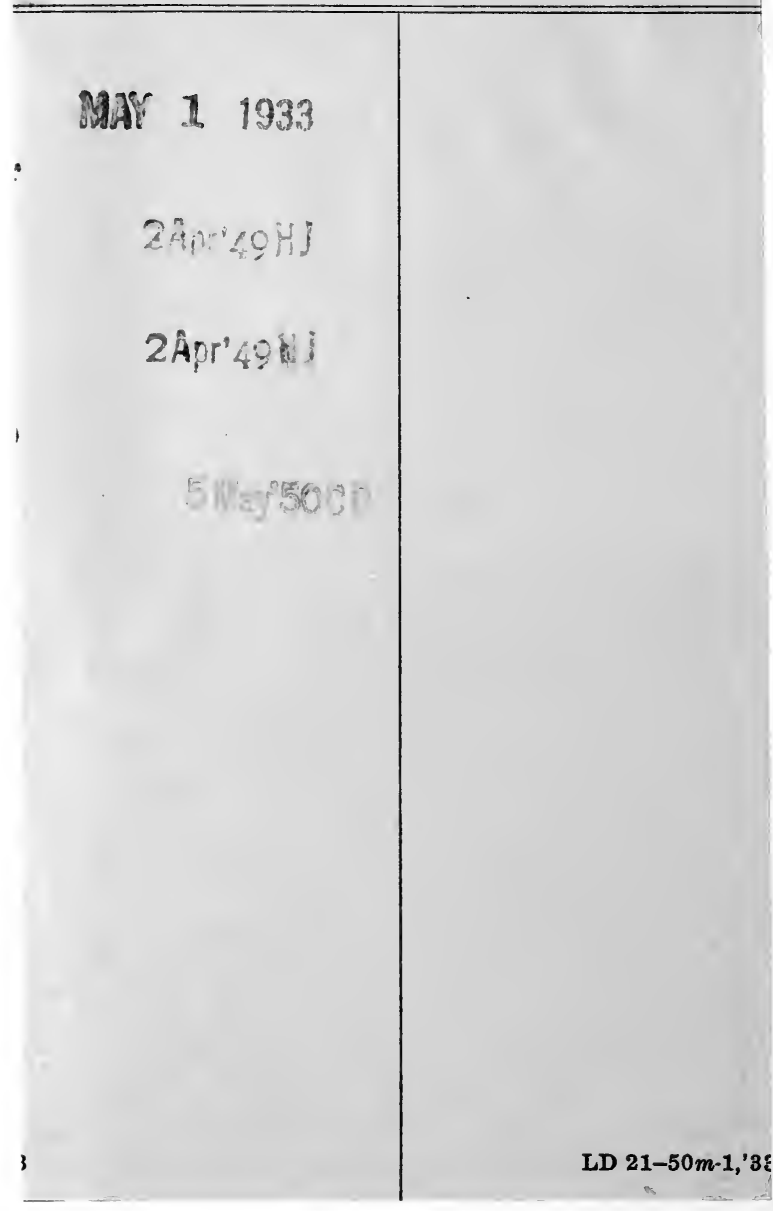




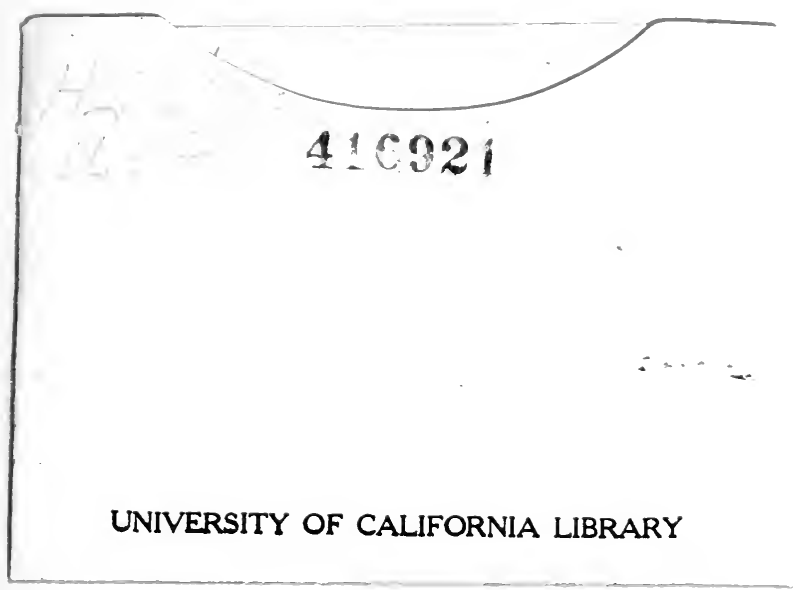


